\title{
Influence of the West Virginia Dome on paleocurrent patterns in the Upper Devonian-Lower Mississippian Price Formation in the Central Appalachians
}

Sheldon James Murphy

West Virginia University

Follow this and additional works at: https://researchrepository.wvu.edu/etd

\section{Recommended Citation}

Murphy, Sheldon James, "Influence of the West Virginia Dome on paleocurrent patterns in the Upper Devonian-Lower Mississippian Price Formation in the Central Appalachians" (2001). Graduate Theses, Dissertations, and Problem Reports. 1316.

https://researchrepository.wvu.edu/etd/1316

This Thesis is protected by copyright and/or related rights. It has been brought to you by the The Research Repository @WVU with permission from the rights-holder(s). You are free to use this Thesis in any way that is permitted by the copyright and related rights legislation that applies to your use. For other uses you must obtain permission from the rights-holder(s) directly, unless additional rights are indicated by a Creative Commons license in the record and/ or on the work itself. This Thesis has been accepted for inclusion in WVU Graduate Theses, Dissertations, and Problem Reports collection by an authorized administrator of The Research Repository @ WVU. For more information, please contact researchrepository@mail.wvu.edu. 


\title{
INFLUENCE OF THE WEST VIRGINIA DOME ON PALEOCURRENT PATTERNS IN THE UPPER DEVONIAN-LOWER MISSISSIPPIAN PRICE FORMATION IN THE CENTRAL APPALACHIANS
}

\begin{abstract}
Sheldon J. Murphy
Thesis submitted to the College of Arts and Sciences at West Virginia University in partial fulfillment for the degree of
\end{abstract}

\author{
Master of Science \\ in \\ Geology
}

Thomas Kammer, Ph.D., Chair

Richard Smosna, Ph.D.

Ronald McDowell, Ph.D.

Department of Geology and Geography

Morgantown, West Virginia

2001 


\title{
ABSTRACT \\ INFLUENCE OF THE WEST VIRGINIA DOME ON PALEOCURRENT PATTERNS IN THE UPPER DEVONIAN-LOWER MISSISSIPPIAN PRICE FORMATION IN THE CENTRAL APPALACHIANS
}

\author{
Sheldon J. Murphy \\ Upper Devonian-Lower Mississippian sedimentation was influenced by a
} positive area known as the West Virginia Dome located in the Central Appalachians of West Virginia. Paleocurrent data collected from the Price Formation demonstrates the significance of the dome on paleoflow patterns. Exposures in West Virginia are located along the Allegheny Front and include the lowermost marine Oswayo Member, Riddlesburg Shale Member, unnamed Upper Member and the uppermost non-marine Rockwell Member. These units overlie the Devonian Hampshire Formation or Greenland Gap Formation and underlie the Mississippian Greenbrier Limestone or Maccrady Formation. At the center of the dome the Price Formation is absent with the Mississippian Greenbrier Limestone unconformably overlying the Devonian Hampshire Formation.

Paleocurrent data were grouped into the Hampshire Formation and into the members of the Price Formation into regions that were analyzed to determine if the West Virginia Dome was tectonically active during the Late Devonian-Early Mississippian, or during the Middle Mississippian. Outcrop locations were chosen around the West Virginia Dome to get a widespread distribution of paleocurrent data. Numerous samples of paleocurrent data were collected from the Rockwell Member because it was well exposed. Sedimentary structures revealed unidirectional 
paleoflow patterns probably the result of syndepositional tectonics suggesting the dome was active during the Late Devonian-earliest Mississippian.

The lower and upper Rockwell Member contains two different, statistically significant paleoflow patterns and lateral grain size distributions around the eastern portion of the West Virginia Dome. The lower Rockwell consists of coarse-grained sediment with southward paleoflow directions along the eastern flank of the West Virginia Dome with northwest paleoflow in the north and southwest paleoflow in the south. The upper Rockwell consists of fine-grained sediment with northward paleoflow along the eastern flank of the West Virginia Dome and southwest paleoflow patterns to the north. Paleocurrent patterns from upper and lower Rockwell were different during Rockwell deposition and suggest that sediment coming from the Acadian Highlands was influenced by tectonic activity that caused the divergence of paleostreams around the West Virginia Dome during the early Mississippian. 


\section{ACKNOWLEDGEMENTS}

I would like to express my deepest appreciation to my research advisor Dr. Thomas Kammer for his support and enthusiasm along with his great interest in this study. He truly understands the great effort it takes to work and attend graduate school. I would like to thank my committee members Dr. Ronald McDowell and Dr. Richard Smosna for their advice and cooperation. Special thanks is extended to David Matchen from the West Virginia Geological Survey who provided the financial support for fieldwork and lodging expenses for which I am sincerely grateful.

I am especially thankful for the support from many people at the West Virginia Geological Survey. Nick Fedorko permitted fieldwork, time and encouragement while allowing time for my research. Dave Jones and Barnes Nugent helped with fieldwork and without their help this study would not have been possible. Pat Bowman helped with photocopying and Betty Schleger provided computer support. Dan Barker provided drafting advice and suggestions. I am grateful for the help from Jim Britton, Dave Matchen, and Anne Oldham for their review of the manuscript and provided helpful suggestions and discussions.

I would like to thank Chuck Gover, Anne and Dave Oldham, and Susan and Steve Kite for their valuable friendship, encouragement, and enthusiasm to which I am truly grateful.

I am especially grateful to Tracy Oleyar for her patience, encouragement, and understanding during the final stages of this project and I am sincerely blessed that she is a part of my life. I would like to express my sincere thanks to my family James and Freeda Murphy, Mark, Kevin, and Annemarie for their encouragement and support. 


\section{TABLE OF CONTENTS}

$\underline{\text { Page }}$

\section{TITLE PAGE}

\section{ABSTRACT}

ACKNOWLEDGEMENTS iv

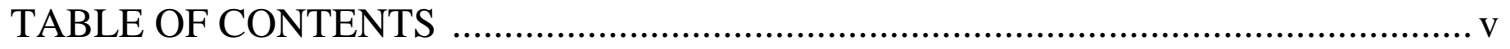

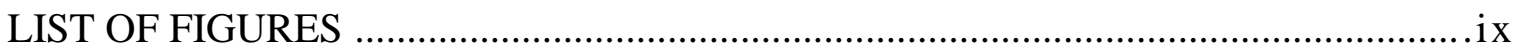

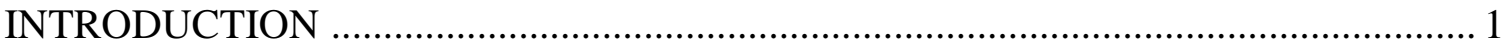

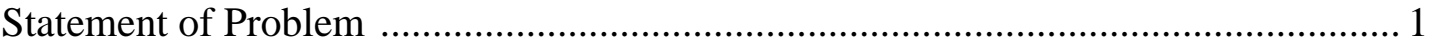

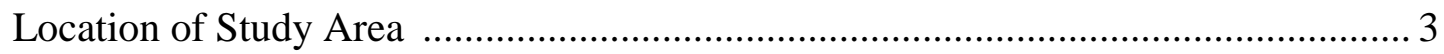

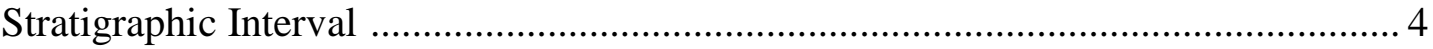

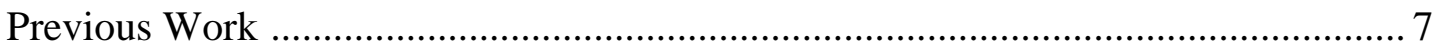

Origin of the name Price Formation in Pennsylvania, Virginia, and West Virginia .................................................................................... 7

Pocono Paleocurrents .................................................................... 9

Price Formation Paleocurrents ........................................................ 10

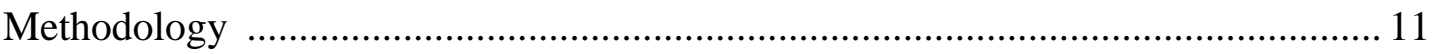

Primary and Secondary Localities ............................................... 11

Grain Size, Texture, and Color ....................................................... 12

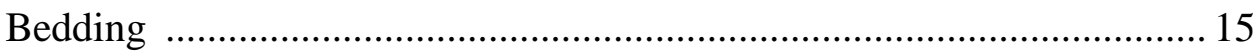

Types of Paleocurrent Indicators …................................................. 15

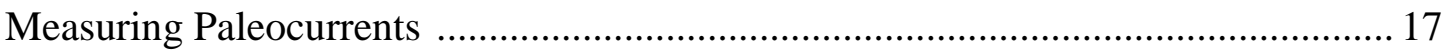

Planar Crossbed Paleocurrent Strike and Dip Orientation ..................... 17

Trough Crossbed Paleocurrent Strike and Dip Orientation .................... 18 


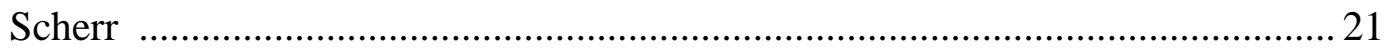

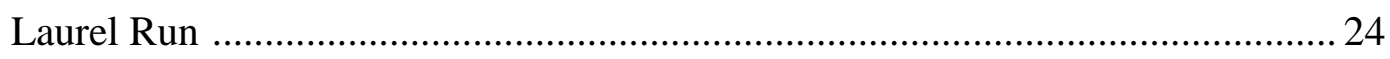

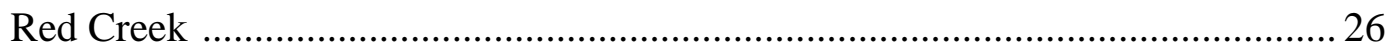

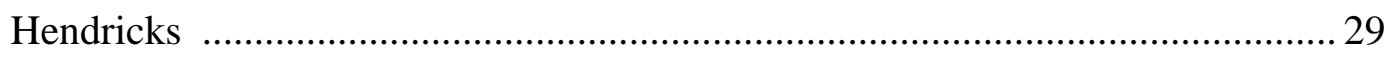

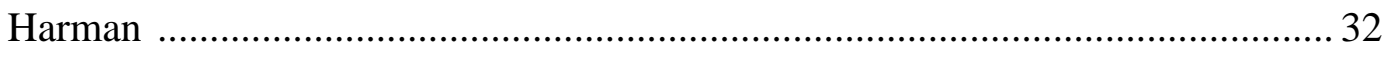

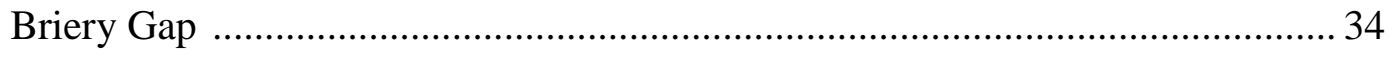

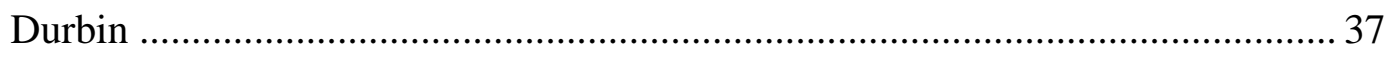

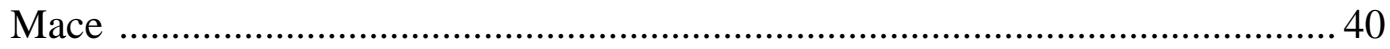

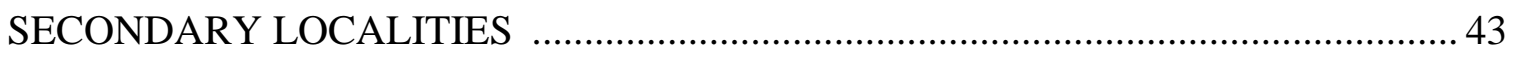

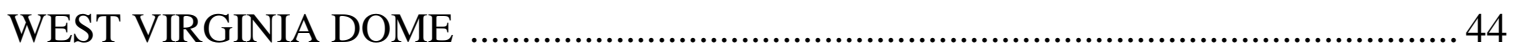

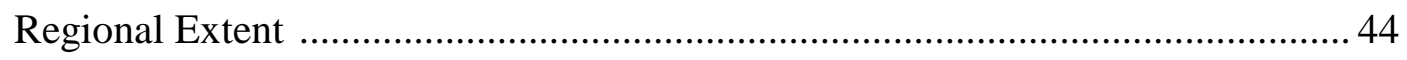

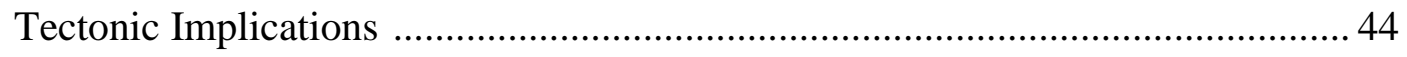

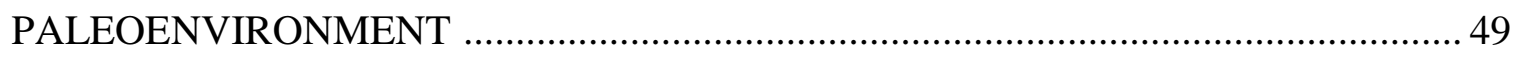

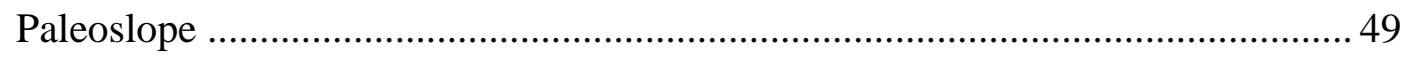

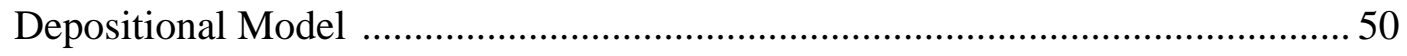

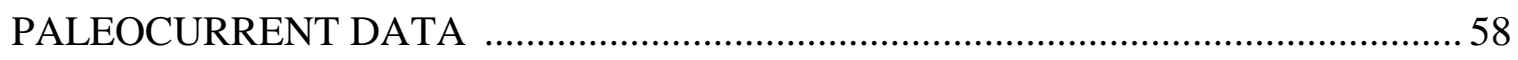

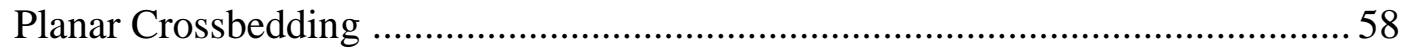

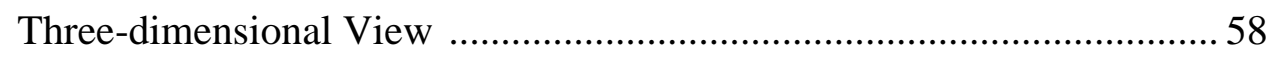

Planar Crossbedding Strike and Flow Directions ...................................... 60

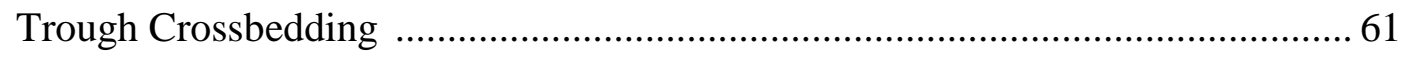

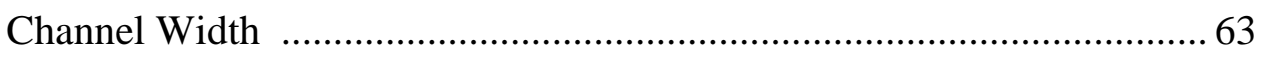

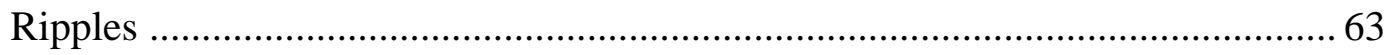




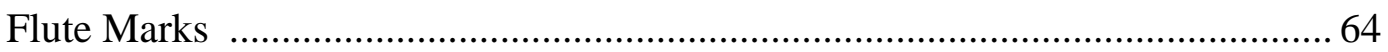

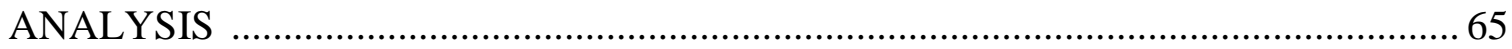

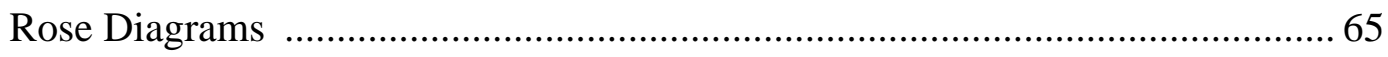

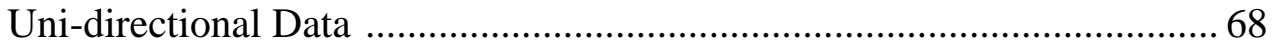

Mean Azimuth Paleoflow Directions ........................................ 69

Trough Height …........................................................... 70

Grain Size ................................................................. 71

Bi-directional Data .................................................................... 72

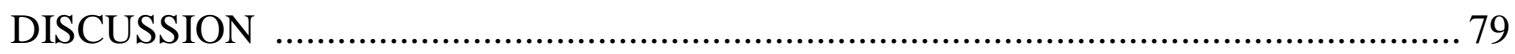

Influence of West Virginia Dome on Channel Patterns ................................... 79

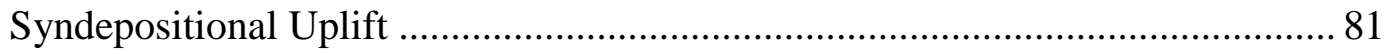

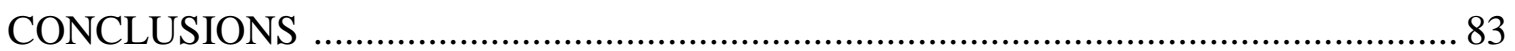

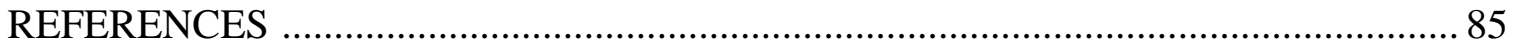

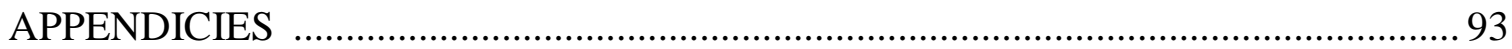

Appendix I Principal localities ............................................................. 93

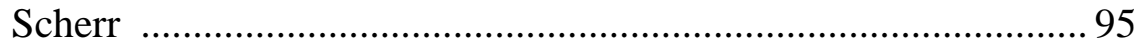

Laurel Run ................................................................. 114

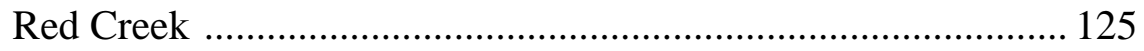

Hendricks ................................................................. 139

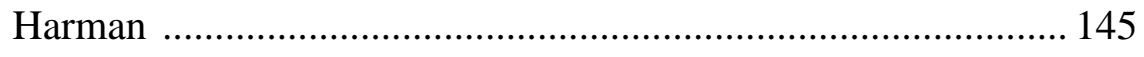

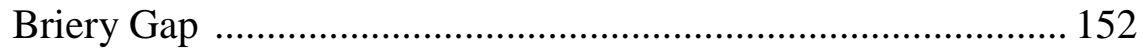

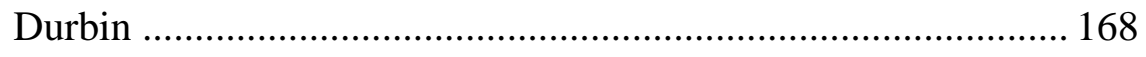

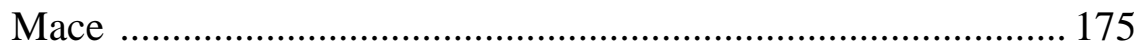


Appendix II Secondary Localities ..................................................... 185

Appendix III Rose diagrams of paleocurrent data from primary and secondary localities ...................................................... 191

Hampshire Formation ..................................................... 191

Oswayo Member .............................................................. 197

Riddlesburg Shale Member ................................................ 198

Rockwell Member ............................................................ 206

Appendix IV Grouped data from the lower Rockwell Member .....................269

Appendix V Grouped data from the upper Rockwell Member ..................... 280

Appendix VI Randomly generated standard deviations for observations ranging from 1-360 degrees ............................. 292

Appendix VII Cross-section of the Price Formation in West Virginia .............. 315 


\section{LIST OF FIGURES}

Figure 1: $\quad$ Isopach of the Price Formation ....................................................... 2

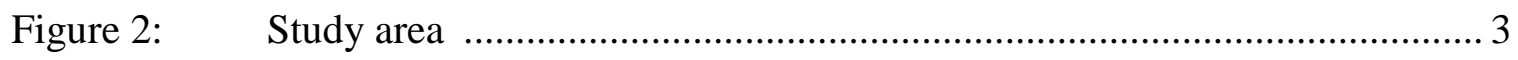

Figure 3: $\quad$ Stratigraphic nomenclature north of the

West Virginia Dome ...................................................................... 5

Figure 4: $\quad$ Stratigraphic nomenclature south of the

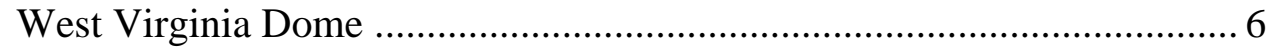

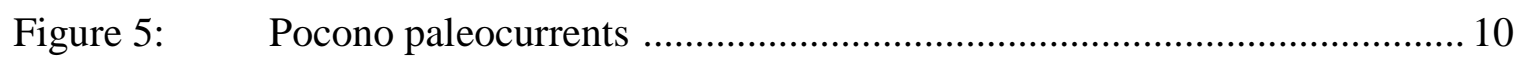

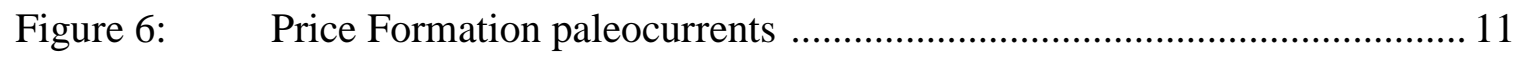

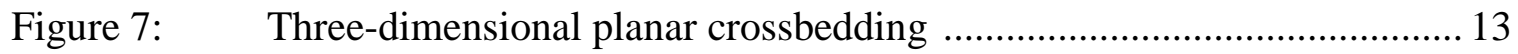

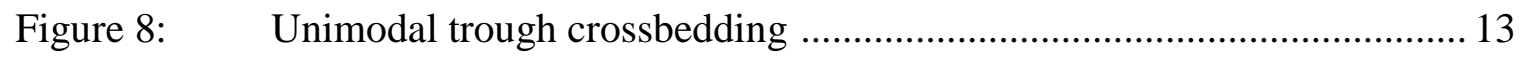

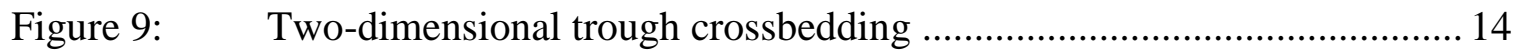

Figure 10: Board technique for planar crossbedding ......................................... 19

Figure 11: $\quad$ Plan view and cross-sectional view of trough crossbedding $\ldots . . . \ldots \ldots \ldots . . . . .20$

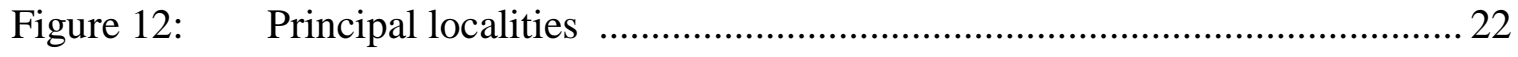

Figure 13: The Rockwell Member at Scherr ..................................................... 24

Figure 14: $\quad$ Riddlesburg Shale Member at Red Creek ....................................... 28

Figure 15: Quartz pebbles within the Rockwell Member at Red Creek .................. 28

Figure 16: Medium scale trough crossbedding in the Hampshire

Formation at Hendricks .................................................................... 30

Figure 17: Riddlesburg Shale Member at Hendricks ....................................... 30

Figure 18: $\quad$ Orbiculoid brachiopods from Hendricks ....................................... 31

Figure 19: Large channel sandstone in the Rockwell Member

at Hendricks ............................................................................... 32

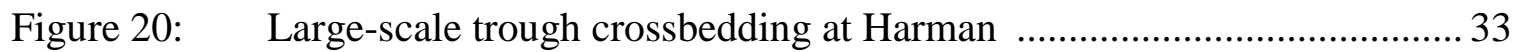


Figure 21: New exposure at Briery Gap …………….......................................... 35

Figure 22: Hampshire Formation at Briery Gap ……………………………...... 36

Figure 23: Riddlesburg Shale Member at Briery Gap ………………………….... 36

Figure 24: Uppermost red sandstones in the Rockwell Member

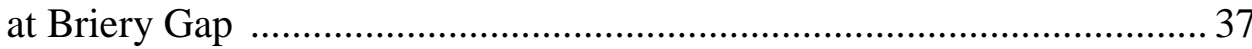

Figure 25: Schuchertella macensis brachiopods in the unnamed

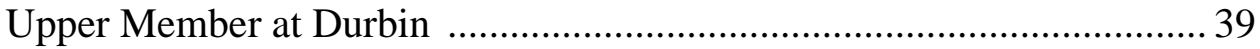

Figure 26: Planar crossbedding in the Hampshire Formation at Mace ...................... 41

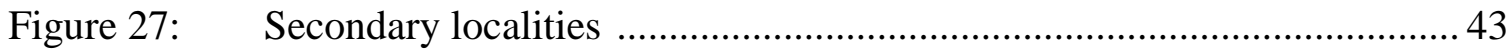

Figure 28: Lower Rockwell paleoflow associated with Lewis'

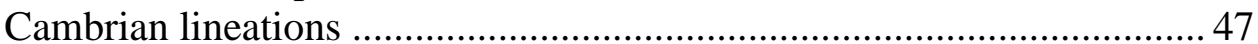

Figure 29: Upper Rockwell paleoflow associated with Lewis'

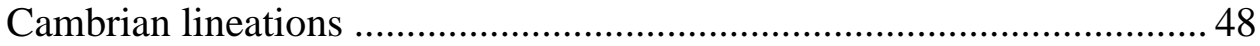

Figure 30: Facies distribution during Oswayo time …………………………..... 54

Figure 31: Facies distribution during Riddlesburg Shale time ……........................... 55

Figure 32: Facies distribution during lower Rockwell time ……………………......56

Figure 33: Facies distribution during upper Rockwell time ……………………..... 57

Figure 34: Two-dimensional planar crossbedding indicating

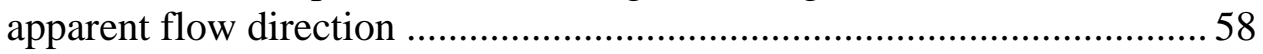

Figure 35: Two-dimensional vs. three-dimensional crossbedding ……………......... 59

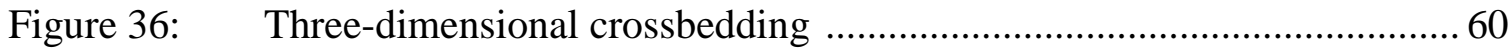

Figure 37: Transverse-vertical and oblique-vertical trough crossbedding ................ 62

Figure 38: Transverse-oblique and oblique-oblique trough crossbedding ................ 62

Figure 39: Longitudinal cuts through trough crossbedding ……………………...... 63

Figure 40: Resolved unimodal paleocurrent data from the Rockwell

Member 
Figure 41: Unresolved unimodal paleocurrent data from the Rockwell

Member

Figure 42: $\quad$ Unimodal paleoflow patterns in the lower Rockwell ............................ 73

Figure 43: $\quad$ Unimodal paleoflow patterns in the upper Rockwell ............................ 74

Figure 44: Modal heights of trough crossbedding in the lower Rockwell

Figure 45: Modal heights of trough crossbedding in the upper Rockwell 76

Figure 46: Grain size distribution in the lower Rockwell ....................................... 77

Figure 47: Grain size distribution in the upper Rockwell .................................... 78

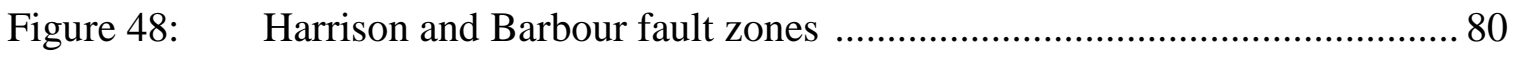

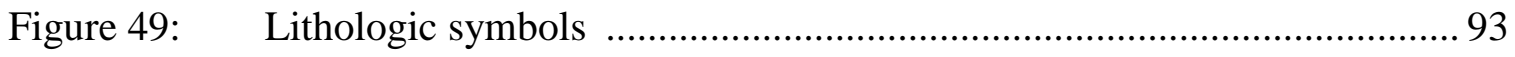

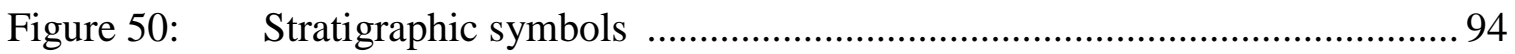

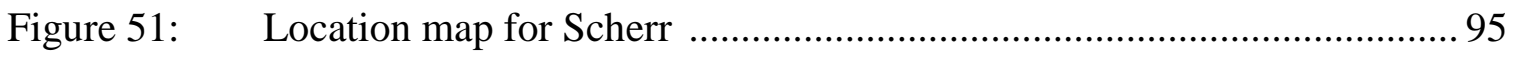

Figure 52: $\quad$ Units 1-9 from the Scherr stratigraphic section .................................... 107

Figure 53: $\quad$ Units 10-17 from the Scherr stratigraphic section ............................... 108

Figure 54: Units 17-23 from the Scherr stratigraphic section .............................. 109

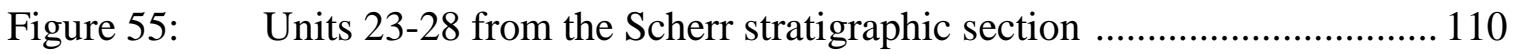

Figure 56: Units 28-37 from the Scherr stratigraphic section .............................. 111

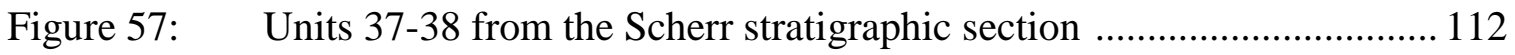

Figure 58: $\quad$ Unit 38 from the Scherr stratigraphic section ................................. 113

Figure 59: $\quad$ Location map for Laurel Run ........................................................... 114

Figure 60: $\quad$ Units 1-2 from the Laurel Run stratigraphic section ........................... 119

Figure 61: $\quad$ Units 2-4 from the Laurel Run stratigraphic section ........................... 120

Figure 62: $\quad$ Units 5-7 from the Laurel Run stratigraphic section ............................ 121 
Figure 63: Units 7-9 from the Laurel Run stratigraphic section 122

Figure 64: Units 9-10 from the Laurel Run stratigraphic section ........................... 123

Figure 65: Units 10-13 from the Laurel Run stratigraphic section ........................ 124

Figure 66: Location map for Red Creek ………….............................................. 125

Figure 67: Units 1-14 from the Laurel Run stratigraphic section .......................... 135

Figure 68: Units 15-27 from the Laurel Run stratigraphic section ........................ 136

Figure 69: Units 28-36 from the Laurel Run stratigraphic section ........................ 137

Figure 70: $\quad$ Units 36-39 from the Laurel Run stratigraphic section ......................... 138

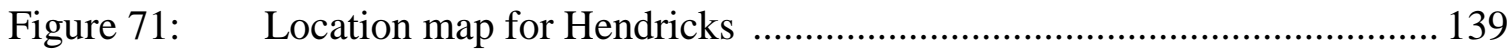

Figure 72: Units 1-8 from the Hendricks stratigraphic section .............................. 143

Figure 73: Units 8-11 from the Hendricks stratigraphic section ............................. 144

Figure 74: Location map for Harman …………………............................... 145

Figure 75: Units 1-9 from the Harman stratigraphic section .................................. 150

Figure 76: Units 9-10 from the Harman stratigraphic section …………………... 151

Figure 77: $\quad$ Location map for Briery Gap ……………......................................... 152

Figure 78: Units 1-7 from the Briery Gap stratigraphic section ............................. 161

Figure 79: Units 7-9 from the Briery Gap stratigraphic section ............................ 162

Figure 80: Units 9-12 from the Briery Gap stratigraphic section ........................... 163

Figure 81: Units 12-20 from the Briery Gap stratigraphic section ......................... 164

Figure 82: Units 20-24 from the Briery Gap stratigraphic section ......................... 165

Figure 83: Unit 24-27 from the Briery Gap stratigraphic section ........................... 166

Figure 84: Unit 27 from the Briery Gap stratigraphic section ................................. 167

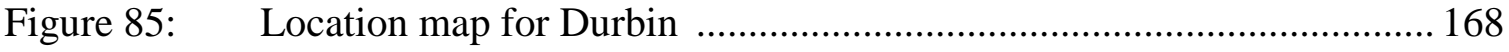


Figure 86: Units 1-4 from the Durbin stratigraphic section 172

Figure 87: Units 4-6 from the Durbin stratigraphic section .................................... 173

Figure 88: Unit 6 from the Durbin stratigraphic section ...................................... 174

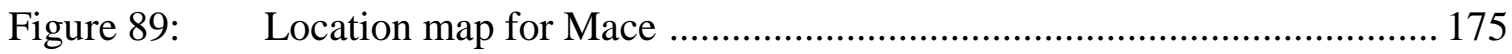

Figure 90: Units 1-5 from the Mace stratigraphic section ……………………..... 181

Figure 91: Units 5-10 from the Mace stratigraphic section ……………………... 182

Figure 92: Units 10-16 from the Mace stratigraphic section …………………..... 183

Figure 93: Units 16-19 from the Mace stratigraphic section …………………...... 184

Figure 94: Uni-directional rose diagram for secondary locality 14 in the Hampshire Formation

Figure 95: Uni-directional rose diagram for secondary locality 15 in the Hampshire Formation

Figure 96: Bi-directional rose diagram for secondary locality 15

in the Hampshire Formation

Figure 97: Bi-directional rose diagram for secondary locality 20 in the Hampshire Formation

Figure 98: Bi-directional rose diagram for secondary locality 28

in the Hampshire Formation

Figure 99: Uni-directional rose diagram for secondary locality 9 in the Hampshire Formation

Figure 100: Uni-directional rose diagram for secondary locality at

Rowlesburg in the Oswayo Member

Figure 101: Bi-directional rose diagram for secondary locality at Durbin in the Riddlesburg Shale Member

Figure 102: Uni-directional rose diagram for secondary locality at Rowlesburg in the Riddlesburg Shale Member

Figure 103: Uni-directional rose diagram for secondary locality 8 in the Riddlesburg Shale Member 200 
Figure 104: Uni-directional rose diagram for secondary locality 11

in the Riddlesburg Shale Member

Figure 105: Bi-directional rose diagram for secondary locality 11

in the Riddlesburg Shale Member

Figure 106: Bi-directional rose diagram for secondary locality 22

in the Riddlesburg Shale Member 203

Figure 107: Bi-directional rose diagram for secondary locality 27

in the Riddlesburg Shale Member

Figure 108: Bi-directional rose diagram for secondary locality 40

in the Riddlesburg Shale Member

Figure 109: Uni-directional rose diagram for secondary locality at

Briery Gap in the lower Rockwell Member 206

Figure 110: Uni-directional rose diagram for secondary locality at

Briery Gap in the upper Rockwell Member

Figure 111: Uni-directional rose diagram for secondary locality 1 in the upper Rockwell Member 208

Figure 112: Bi-directional rose diagram for secondary locality 1 in the upper Rockwell Member

Figure 113: Uni-directional rose diagram for secondary locality 2

in the lower Rockwell Member

Figure 114: Uni-directional rose diagram for secondary locality 3 in the lower Rockwell Member

Figure 115: Uni-directional rose diagram for secondary locality 4 in the upper Rockwell Member

Figure 116: Uni-directional rose diagram for secondary locality 5

in the upper Rockwell Member

Figure 117: Uni-directional rose diagram for secondary locality 6 in the upper Rockwell Member

Figure 118: Uni-directional rose diagram for secondary locality 7

in the lower Rockwell Member

Figure 119: Bi-directional rose diagram for secondary locality 7 
in the lower Rockwell Member

Figure 120: Uni-directional rose diagram for secondary locality 10

in the lower Rockwell Member

Figure 121: Bi-directional rose diagram for secondary locality 10

in the lower Rockwell Member

Figure 122: Uni-directional rose diagram for secondary locality 12

in the lower Rockwell Member

Figure 123: Uni-directional rose diagram for secondary locality 12

in the upper Rockwell Member

Figure 124: Bi-directional rose diagram for secondary locality 13

in the upper Rockwell Member

Figure 125: Uni-directional rose diagram for secondary locality 16

in the lower Rockwell Member

Figure 126: Uni-directional rose diagram for secondary locality 16

in the upper Rockwell Member

Figure 127: Uni-directional rose diagram for secondary locality 17

in the upper Rockwell Member

Figure 128: Bi-directional rose diagram for secondary locality 17

in the upper Rockwell Member

Figure 129: Uni-directional rose diagram for secondary locality 18

in the lower Rockwell Member

Figure 130: Bi-directional rose diagram for secondary locality 18

in the lower Rockwell Member

Figure 131: Uni-directional rose diagram for secondary locality 19

in the lower Rockwell Member

Figure 132: Bi-directional rose diagram for secondary locality 19

in the lower Rockwell Member

Figure 133: Uni-directional rose diagram for secondary locality 21

in the upper Rockwell Member

Figure 134: Bi-directional rose diagram for secondary locality 21

in the upper Rockwell Member 
Figure 135: Uni-directional rose diagram for secondary locality 22

in the lower Rockwell Member

Figure 136: Uni-directional rose diagram for secondary locality 23

in the upper Rockwell Member

Figure 137: Bi-directional rose diagram for secondary locality 24

in the upper Rockwell Member

Figure 138: Bi-directional rose diagram for secondary locality 25

in the upper Rockwell Member

Figure 139: Uni-directional rose diagram for secondary locality 26

in the upper Rockwell Member

Figure 140: Uni-directional rose diagram for secondary locality 29

in the upper Rockwell Member

Figure 141: Uni-directional rose diagram for secondary locality 30

in the lower Rockwell Member

Figure 142: Uni-directional rose diagram for secondary locality 31

in the lower Rockwell Member

Figure 143: Bi-directional rose diagram for secondary locality 31

in the lower Rockwell Member

Figure 144: Uni-directional rose diagram for secondary locality 32

in the lower Rockwell Member

Figure 145: Bi-directional rose diagram for secondary locality 32

in the lower Rockwell Member

Figure 146: Uni-directional rose diagram for secondary locality 33

in the lower Rockwell Member

Figure 147: Uni-directional rose diagram for secondary locality 34

in the upper Rockwell Member

Figure 148: Uni-directional rose diagram for secondary locality 35

in the lower Rockwell Member

Figure 149: Uni-directional rose diagram for secondary locality 36

in the upper Rockwell Member 246 
Figure 150: Bi-directional rose diagram for secondary locality 36

in the upper Rockwell Member

Figure 151: Bi-directional rose diagram for secondary locality 37

in the lower Rockwell Member

Figure 152: Uni-directional rose diagram for secondary locality 38

in the upper Rockwell Member

Figure 153: Bi-directional rose diagram for secondary locality 38

in the upper Rockwell Member

Figure 154: Bi-directional rose diagram for secondary locality 39

in the upper Rockwell Member

Figure 155: Bi-directional rose diagram for secondary locality 43

in the upper Rockwell Member

Figure 156: Uni-directional rose diagram for secondary locality 44

in the lower Rockwell Member

Figure 157: Bi-directional rose diagram for secondary locality 44

in the lower Rockwell Member

Figure 158: Uni-directional rose diagram for secondary locality 45

in the lower Rockwell Member

Figure 159: Bi-directional rose diagram for secondary locality 45

in the lower Rockwell Member

Figure 160: Uni-directional rose diagram for secondary locality 46

in the upper Rockwell Member

Figure 161: Bi-directional rose diagram for secondary locality 46

in the upper Rockwell Member 258

Figure 162: Uni-directional rose diagram for secondary locality 47

in the lower Rockwell Member

Figure 163: Bi-directional rose diagram for secondary locality 48

in the upper Rockwell Member 260

Figure 164: Bi-directional rose diagram for secondary locality 49

in the upper Rockwell Member

Figure 165: Bi-directional rose diagram for secondary locality 50 
in the lower Rockwell Member

Figure 166: Uni-directional rose diagram for secondary locality 51

in the lower Rockwell Member

Figure 167: Bi-directional rose diagram for secondary locality 51

in the lower Rockwell Member 264

Figure 168: Uni-directional rose diagram for secondary locality 52

in the lower Rockwell Member

Figure 169: Uni-directional rose diagram for secondary locality 53

in the lower Rockwell Member 266

Figure 170: Uni-directional rose diagram for secondary locality 54

in the lower Rockwell Member

Figure 171: Bi-directional rose diagram for secondary locality 54

in the lower Rockwell Member

Figure 172: Uni-directional rose diagram from area 1

in the lower Rockwell Member

Figure 173: Bi-directional rose diagram from area 1

in the lower Rockwell Member

Figure 174: Uni-directional rose diagram from area 2

in the lower Rockwell Member

Figure 175: Uni-directional rose diagram from area 3

in the lower Rockwell Member

Figure 176: Bi-directional rose diagram from area 3

in the lower Rockwell Member

Figure 177: Uni-directional rose diagram from area 4

in the lower Rockwell Member

Figure 178: Bi-directional rose diagram from area 4

in the lower Rockwell Member

Figure 179: Uni-directional rose diagram from area 5

in the lower Rockwell Member

Figure 180: Bi-directional rose diagram from area 5

in the lower Rockwell Member 277 
Figure 181: Uni-directional rose diagram from area 6 in the lower Rockwell Member

Figure 182: Uni-directional rose diagram from area 7 in the lower Rockwell Member

Figure 183: Uni-directional rose diagram from area 1 in the upper Rockwell Member

Figure 184: Uni-directional rose diagram from area 2

in the upper Rockwell Member 281

Figure 185: Bi-directional rose diagram from area 2

in the upper Rockwell Member

Figure 186: Uni-directional rose diagram from area 3

in the upper Rockwell Member

Figure 187: Bi-directional rose diagram from area 3

in the upper Rockwell Member

Figure 188: Uni-directional rose diagram from area 4

in the upper Rockwell Member

Figure 189: Bi-directional rose diagram from area 4

in the upper Rockwell Member .286

Figure 190: Uni-directional rose diagram from area 5

in the upper Rockwell Member

Figure 191: Bi-directional rose diagram from area 5

in the upper Rockwell Member

Figure 192: Uni-directional rose diagram from area 6

in the upper Rockwell Member

Figure 193: Bi-directional rose diagram from area 6

in the upper Rockwell Member

Figure 194: Bi-directional rose diagram from area 7

in the upper Rockwell Member

Figure 195: North-south cross-section of the Price Formation

along the West Virginia Dome 


\section{INTRODUCTION}

\section{$\underline{\text { Statement of Problem }}$}

Upper Devonian-Lower Mississippian sedimentation within the Appalachian foreland basin was affected by a positive area known as the West Virginia Dome (Figure 1). Two distinct basins were created that influenced sedimentation in the Upper Devonian-Lower Mississippian Price Formation in West Virginia (Kammer and Bjerstedt, 1986). Northern lithologic members include the Devonian Oswayo and the Mississippian Riddlesburg Shale and Rockwell Member (Figure 3). Lithologic members south of the Dome consist of the Mississippian Riddlesburg Shale, Rockwell, and the unnamed Upper Member (Figure 4). The purpose of this study is to determine if uplift of the West Virginia Dome during the Early Mississippian can be recognized based on paleocurrent data collected from outcrop and used to reconstruct paleoflow patterns, depositional environments, and paleoslopes.

Origin of the Dome is debatable, yet tectonic activity is suggested from paleoflow patterns and stratigraphy. Tectonic control that influenced the West Virginia Dome is apparent from facies relationships, large interval isopach patterns, and stacked shoreline and fluvial sandstones from the Devonian and Mississippian (Kammer and Bjerstedt, 1986; Boswell, 1988). Lithologies within the northern and southern depositional basins (Figure 1) contain different facies patterns identified in outcrop studies. Rapid lithologic thickening along the exterior of the Dome is apparent from regional isopach maps and Boswell (1988) suggested this thickening corresponds to fault boundary zones identified in the subsurface (Boswell, 1988). Furthermore, stacked shoreline sandstones parallel to 
this boundary zone support tectonic control of the West Virginia Dome because stacked shoreline sandstone are not typical of clastic deposition (Boswell, 1988).

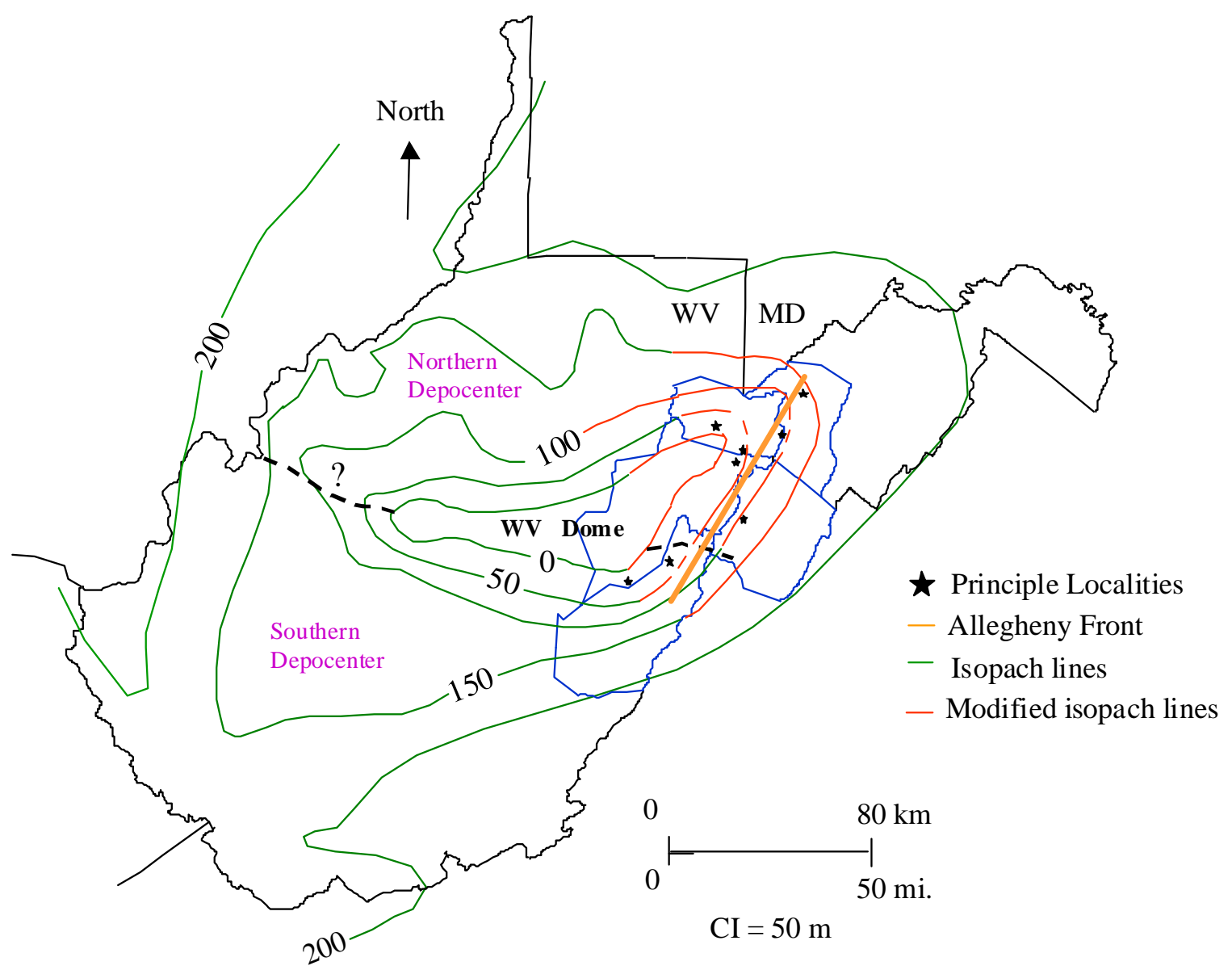

Modified from Bjerstedt (1986) and Dally (1956)

Figure 1. Isopach of the Price Formation redrawn from Bjerstedt (1986) and Dally (1956). The "bullseye" pattern indicates thinning over the West Virginia Dome and the red lines represent the new isopach lines determined from this study. 


\section{Location of Study Area}

Upper Devonian-Lower Mississippian rocks in West Virginia are exposed along the Allegheny Front within the central Appalachians. Eight principal road and stream exposures of these rocks were measured and described in Grant, Pendleton, Pocahontas, Randolph, and Tucker counties (Figure 2). Principal localities contain measurements and descriptions of the Late Devonian Hampshire Formation along with northern stratigraphic members and one southern stratigraphic member of the Price Formation along the West Virginia Dome. The study area encompasses approximately 7022 square kilometers largely within the Monongahela National Forest.

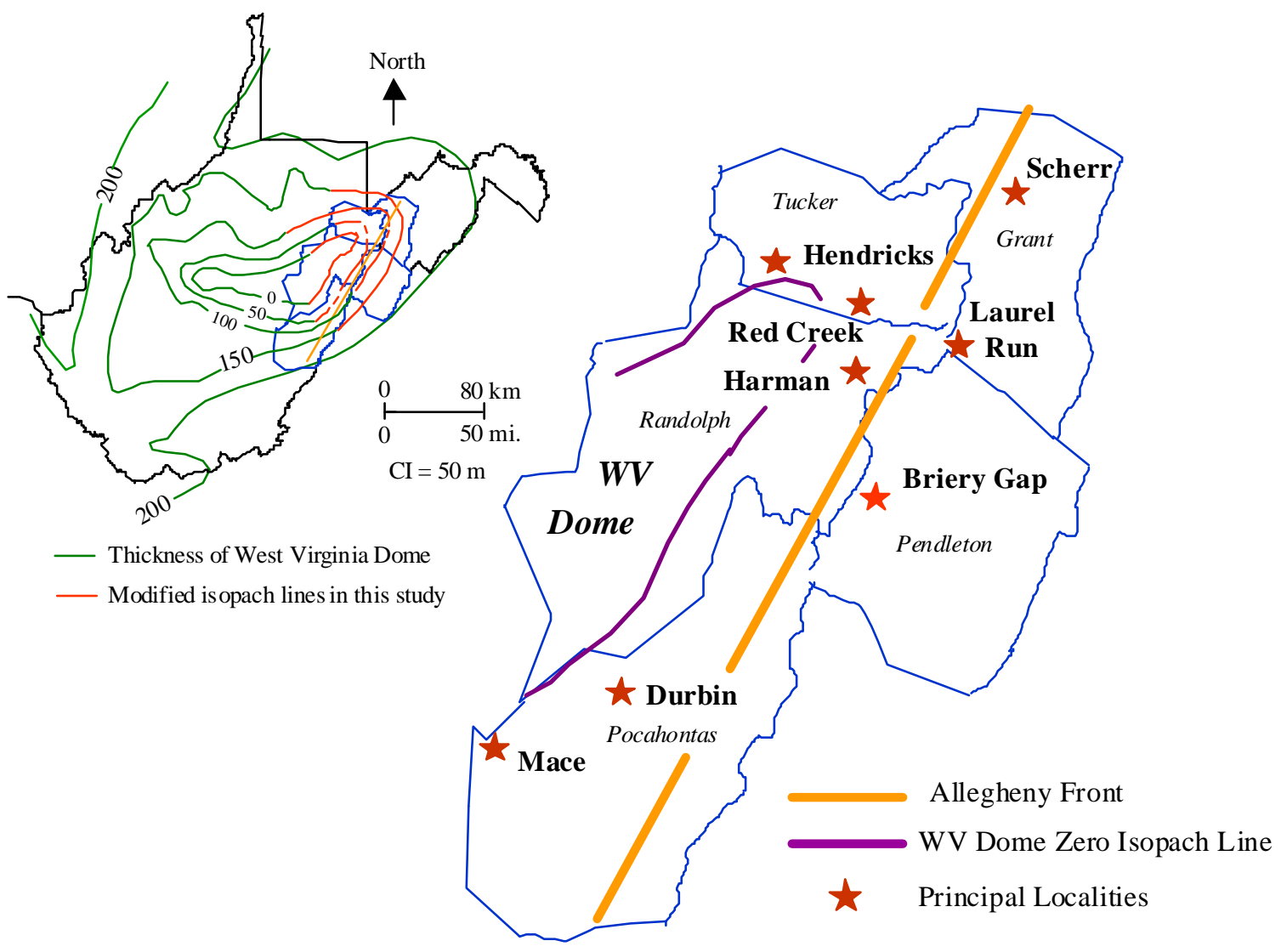

Figure 2. Study Area 


\section{$\underline{\text { Stratigraphic Interval }}$}

The West Virginia Dome influenced the creation of two distinct sedimentary depocenters in northern and southern West Virginia during the late Devonian-early Mississippian (Figure 1). Seven members of the Price Formation were deposited and contain different lithologic units due to a north-south facies change (Kammer and Bjerstedt, 1986). Measured sections were taken primarily within northern stratigraphic members, however the Mace locality includes the unnamed member from the southern stratigraphic basin (Figures 3 and 4).

Oldest to youngest northern stratigraphic units include the Devonian Oswayo Member and the Mississippian Riddlesburg Shale, and Rockwell members (Figure 3). The Oswayo Member consists of fine to medium-grained marine sandstones with interbedded siltstones, mudstones, and claystones. The Riddlesburg Shale Member consists of fine- to medium-grained marine sandstones, siltstones, shales, and mudstones. The Rockwell Member contains non-marine, fine, medium, and coarse-grained sandstones interbedded with siltstones, mudstones, and claystones. The unnamed upper member at Mace (Figure 4) consists of marine sandstones and siltstones with numerous brachiopod body fossils and ichnofossils. 

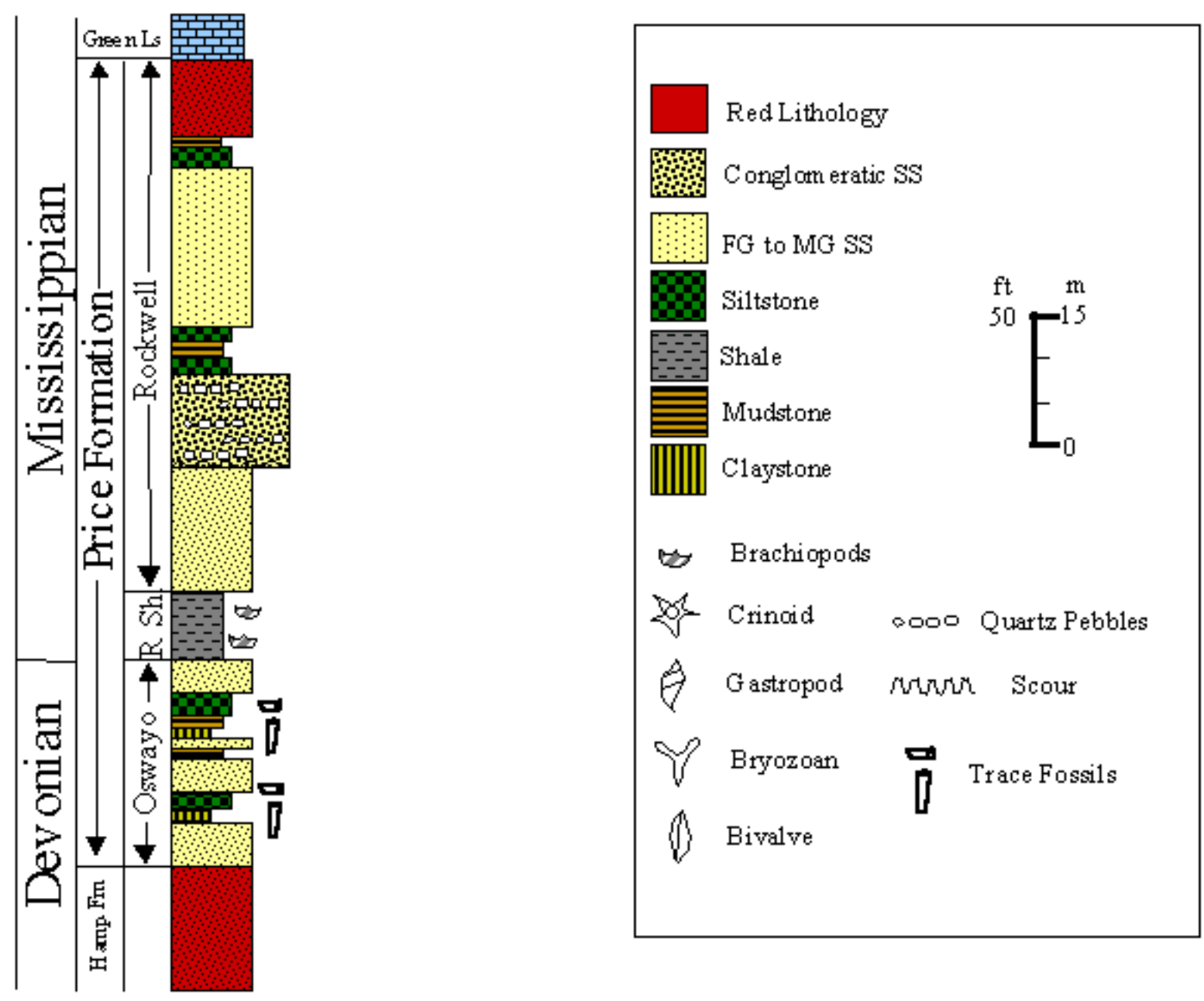

Figure 3. Stratigraphic nomenclature of the Price Formation north of the West Virginia Dome; location is beneath the Greenbrier Limestone and above the Hampshire Formation. R. Sh. = Riddlesburg Shale. 

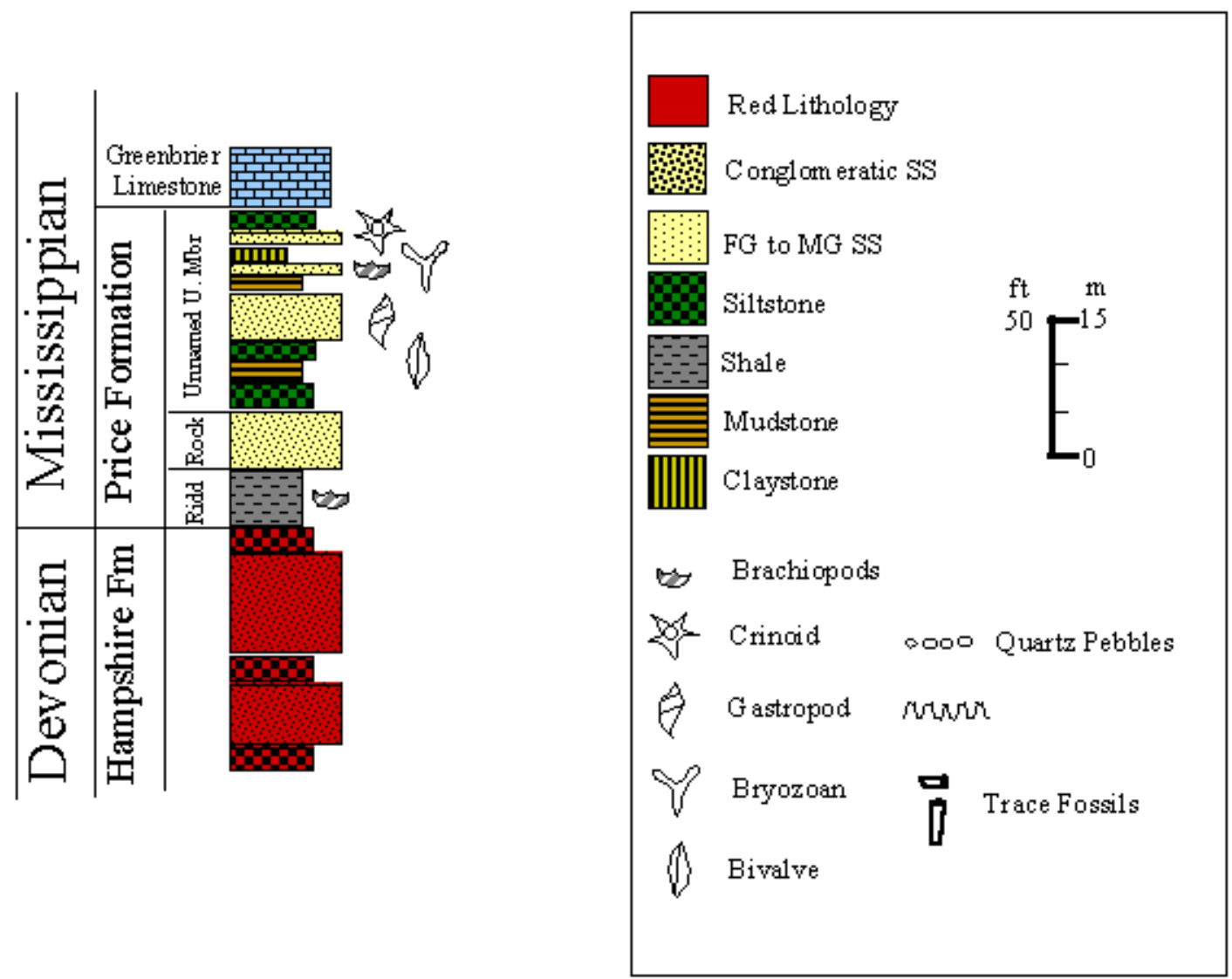

Figure 4. Stratigraphic nomenclature of the Price Formation south of the West Virginia Dome; location is beneath the Greenbrier Limestone and above the Hampshire Formation. Ridd. = Riddlesburg Shale, Rock. $=$ Rockwell, and Unnamed U. Mbr. = Unnamed Upper Member. 


\section{Previous Work}

Origin of the name Price Formation in Pennsylvania, Virginia, and West Virginia

The stratigraphic interval now termed the Price Formation in West Virginia was termed Pocono and was formalized by Rodgers (1836) of the First Pennsylvania Geological Survey (Kammer and Bjerstedt, 1986). Rodgers (1836) identified buff colored sandstones stratigraphically located between the red beds of the Devonian Catskill Formation and the Mississippian Mauch Chunk and assigned these sandstones a Formation number 10 (Kammer and Bjerstedt, 1986). In 1838, Rodgers (1836) changed all of his Formation numbers to Roman numerals at the same time his brother W. B. Rodgers (1838), of the Virginia Geological Survey, identified what's now the Price Formation at Caldwell and Marlinton, West Virginia (then Virginia). W. B. Rodgers (1838) assigned the Price Formation rocks the Formation number 10 (Kammer and Bjerstedt, 1986) and in 1884 H. D. Rodgers changed his formations to the hours of the Roman day and Formation X became the Vespertine Formation (Kammer and Bjerstedt, 1986).

Lesley of the Second Pennsylvania Geological Survey (1876) mapped what he thought was the Vespertine formation in the Pocono Plateau. Lesley decided that it was appropriate for all Formations to bear the name of geographic locations (Kammer and Bjerstedt, 1986). The Vespertine Formation became the Pocono Formation. Although I. C. White disagreed with Lesley (Kammer and Bjerstedt, 1986) saying that the Vespertine was not exposed in the Pocono Plateau, the name prevailed. The false interpretation by Lesley of the Pocono led to disputes about the true age of the Pocono. In spite of these disputes, the name was used by other geologists (Kammer and Bjerstedt, 1986). 
Darton $(1892 ; 1894)$ used the name Pocono in West Virginia and Virginia at the same time Campbell (1894) was naming the Price Formation for outcrops on Price Mountain in Montgomery County, Virginia (Kammer and Bjerstedt, 1986). All rocks between the red beds of the Hampshire Formation and the Mauch Chunk were chronostratigraphically grouped together in Pennsylvania and it made sense to extend this same interval into the Virginias. The term Pocono used by Darton in West Virginia had priority over Campbell's Price Formation in Virginia (Kammer and Bjerstedt, 1986).

Various workers in West Virginia researching the Pocono had divided this interval into separate lithologic units. Stose and Swartz (1912) identified five distinct lithologic units at Hancock, Maryland referred to as the Pinkerton Sandstone, Meyers Shale, Hedges Shale, Purslane Sandstone, and the Rockwell Formation; the Pinkerton Sandstone and the Meyers Shale are actually part of the Mauch Chunk (Kammer and Bjerstedt (1986).

The West Virginia Geological Survey's County Reports used the common drillers terms "Big Injun", "Squaw", and "Weir" for sandstones in this stratigraphic interval. Dally (1956) lists the Matoaka, Marlinton, and Manheim formations in his Pocono Group and Reger and Price (1926) list the Lindside sandstone and Broad Ford sandstone (Kammer and Bjerstedt, 1986). Kammer and Bjerstedt (1986) suggested these names be abandoned because all the names used by the authors were not formal stratigraphic names.

Mapping of the Pocono Formation in West Virginia, Maryland, and Pennsylvania was lithostratigraphically correct, however it was assumed this stratigraphic interval was contemporaneous with earliest Mississippian sedimentation which implied that time and 
lithologic boundaries were equivalent (Bjerstedt, 1988). Kammer and Bjerstedt (1986) suggested the name "Pocono" be abandoned because the Price Formation in northern and southern West Virginia contains distinct lithologies and genetic events that differ greatly from Pennsylvania to West Virginia. Carter and Kammer (1990) further supported the need for replacement of the term "Pocono" in West Virginia with the identification of Mississippian and Devonian brachiopods within the Price Formation.

\section{Pocono Paleocurrents}

Paleocurrent studies of the Price Formation in West Virginia have been few in the past. Although Kammer and Bjerstedt (1986) undertook detailed lithologic and stratigraphic analysis, not much consideration was given to paleocurrent data. Conversely, a large-scale paleocurrent study has been done for this same stratigraphic interval in Maryland and Pennsylvania (Pelletier, 1958).

An extensive study of the Pocono Formation was conducted by Pelletier (1958) across most of Pennsylvania and western Maryland (Figure 5). Crossbed measurements at 254 localities, including grain size, petrography, and stratigraphy, were compiled to determine paleocurrent systems, source area, and paleogeography. His analysis revealed a source area near the vicinity of present-day Atlantic City, New Jersey, with an overall mean paleoflow toward the northwest. Decreasing grain size and sand-shale ratios toward the northwest further confirmed this flow direction (Pelletier, 1958). 


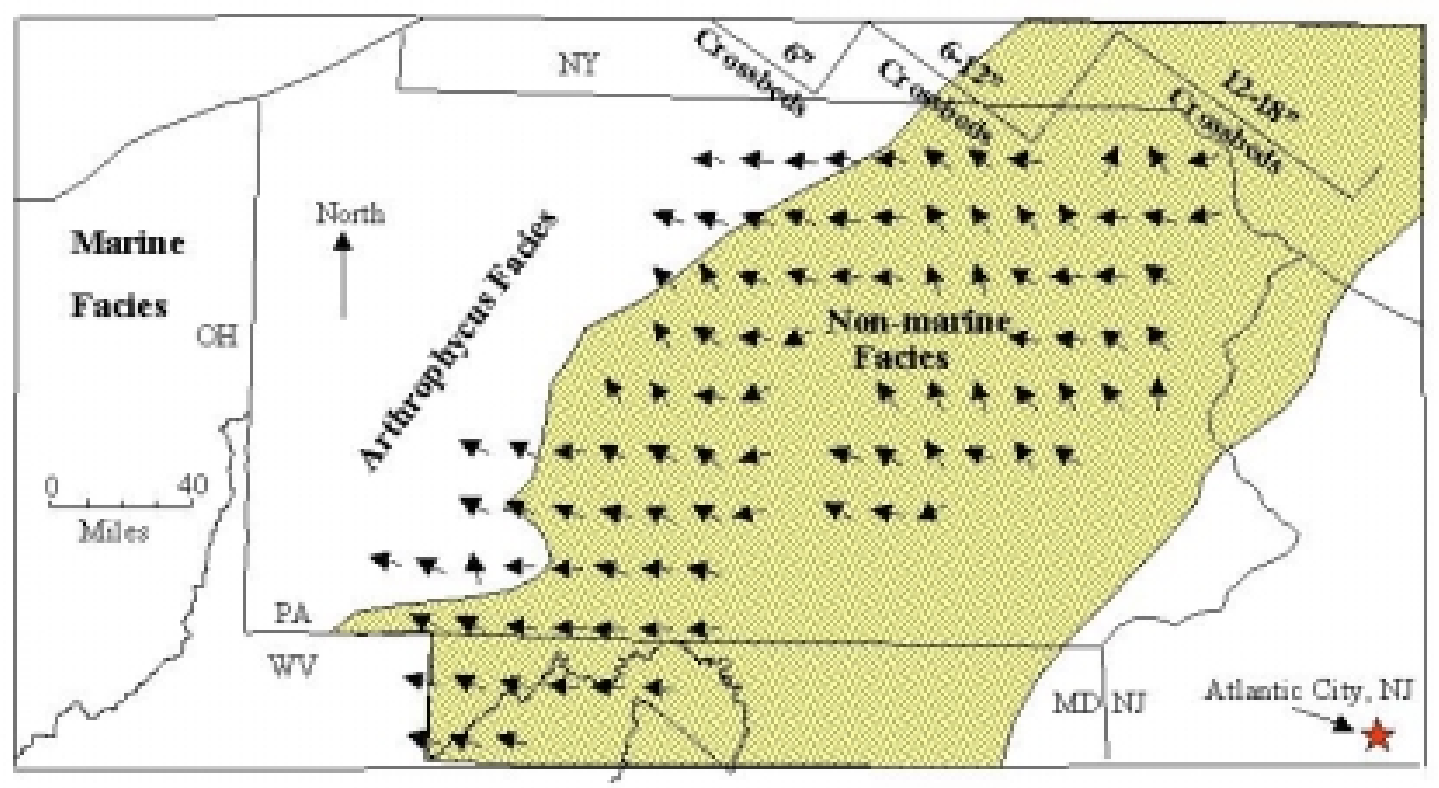

Figure 5. Pocono paleocurrents from Pelletier (1958).

Price Formation Paleocurrents

Bjerstedt (1986) collected paleocurrent data from the Price Formation at nine measured and described stratigraphic sections in West Virginia. Measurements were reported from six stratigraphic members in northern and southern West Virginia and these paleocurrent data were separated and grouped by member. Paleocurrent indicators were recorded from fluvial and marine facies with a total of twenty-seven crossbed readings. A map showing mean paleoflow directions was created from oscillation ripple trends and averaged unidirectional indicators (Figure 6). The paleocurrent data indicated a westward flow direction, however Bjerstedt (1986) noted that the number of readings taken at each locality did not represent a statistically significant sample size. 


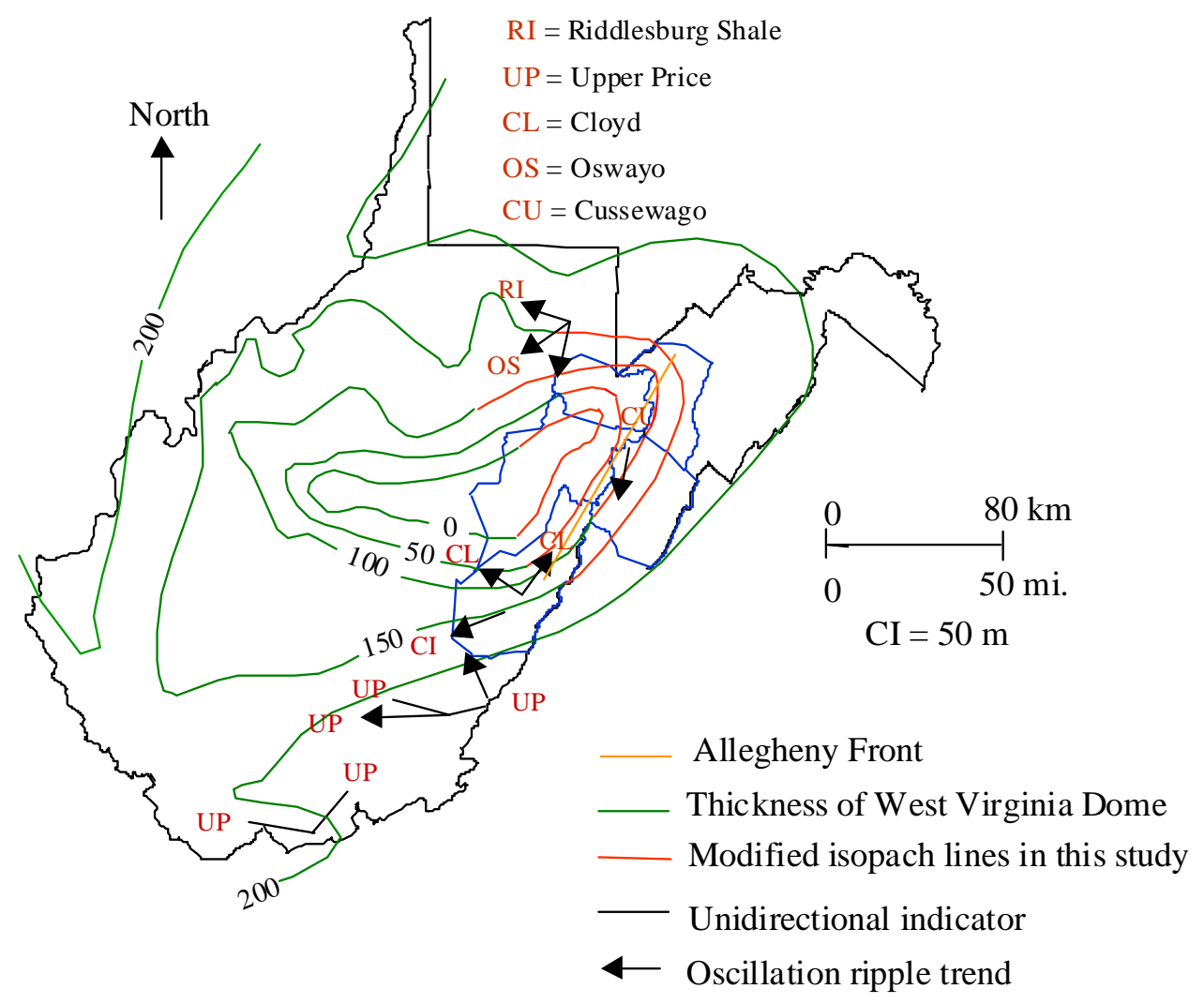

Figure 6. Price Formation paleocurrents from Bjerstedt (1986).

\section{$\underline{\text { Methodology }}$}

Principal and Secondary Localities

Principal localities (Figure 2) consist of thick stratigraphic sequences that were described and measured to identify units and members of the Price Formation. Vertical sections were measured with a tape and compass. Detailed descriptions included grain size, texture, color, bedding, sedimentary structures, paleocurrent measurements, fossils, nature of contacts, strike and dip, and thickness. Exposures were often limited therefore 
the contacts with the underlying Devonian Hampshire Formation and the overlying Mississippian Greenbrier Limestone define the boundaries of the Price Formation.

Secondary localities (Appendix II) were thinner stratigraphic sections located along roads and in streambeds that contained some useful paleocurrent indicators. All lithologic units were described because their bedding contained sedimentary structures useful for paleocurrent analysis. Descriptions included grain size, texture, color, bedding, sedimentary structures, paleocurrent measurements, fossils, nature of contacts, strike and dip and thickness. Paleocurrent measurements recorded from planar crossbeds were included in three-dimensional block diagrams with a north arrow (Figure 7). Trough crossbedding was sketched in three-dimensions with the azimuth reading recorded as a unimodal vector along with the width and height of the bedding and a north arrow (Figure 8). Indeterminate flow directions were sketched in two-dimensions and recorded as bimodal (Figure 9). Localities were assigned a paleocurrent location number and grouped by members of the Price Formation.

Grain Size, Texture, and Color

Sedimentary grains were evaluated based on size, shape, orientation, configuration, and sorting. Generally, size indicates the level of kinetic energy during transport and deposition (Compton, 1985) along with the distance from the source area. The angularity or roundness of grains is related to the transport energy and current strength; grain shape was recorded as very angular, angular, sub-angular, sub-rounded, rounded or well rounded. Grain orientations were noted because imbricated grains could 


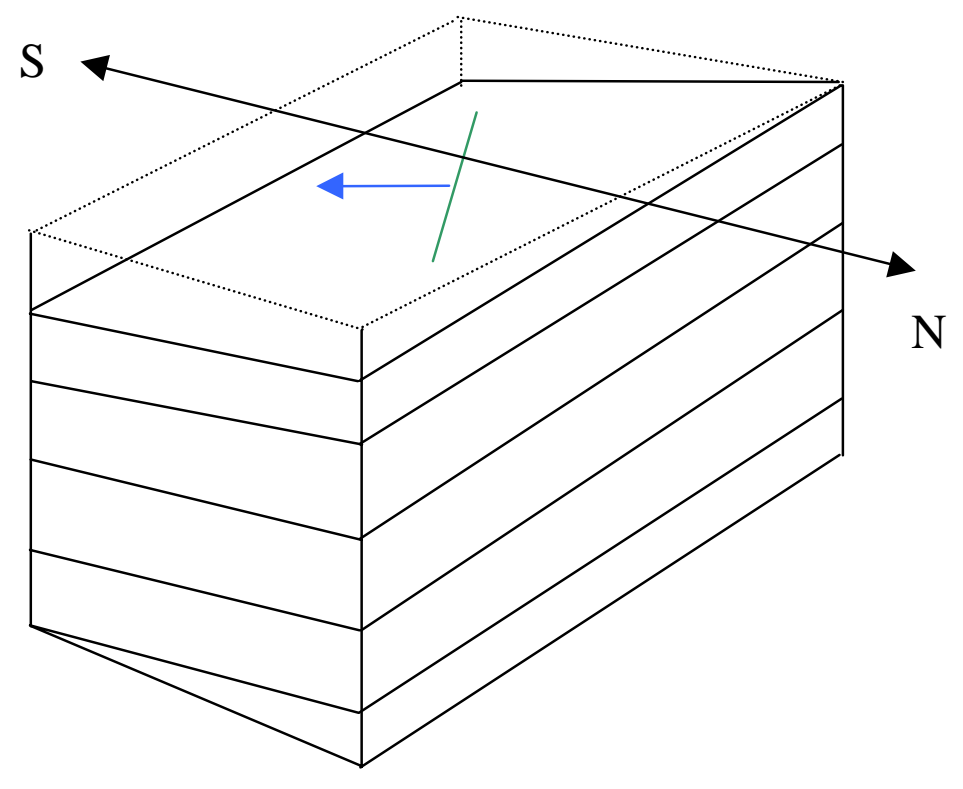

Figure 7. Three-dimensional block diagram of planar crossbedding indicating the strike of the crossbed (green), the current direction (blue), and the north arrow

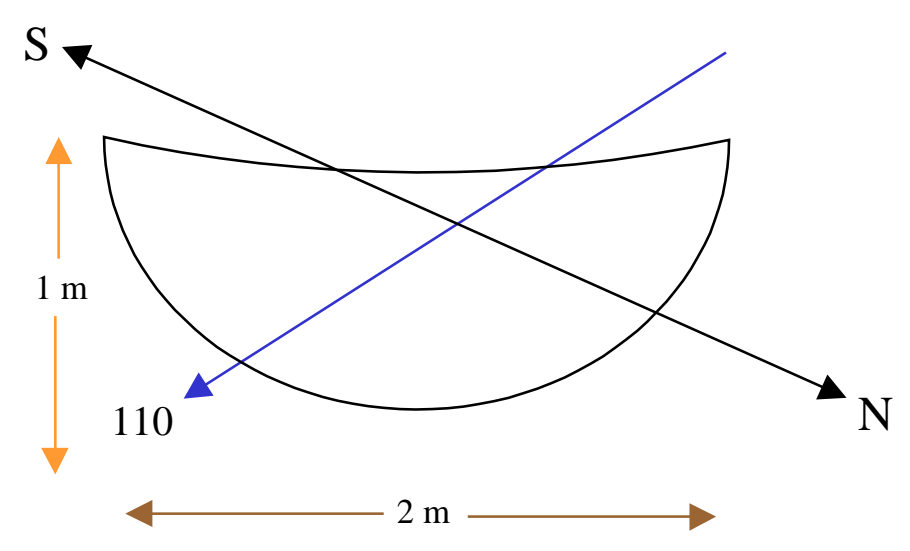

Figure 8. Example of a unimodal diagram of trough crossbedding looking directly at the trough; arrows were sketched to indicate the unimodal current direction (blue arrow), height (orange arrow), width (brown arrow), and north arrow. 


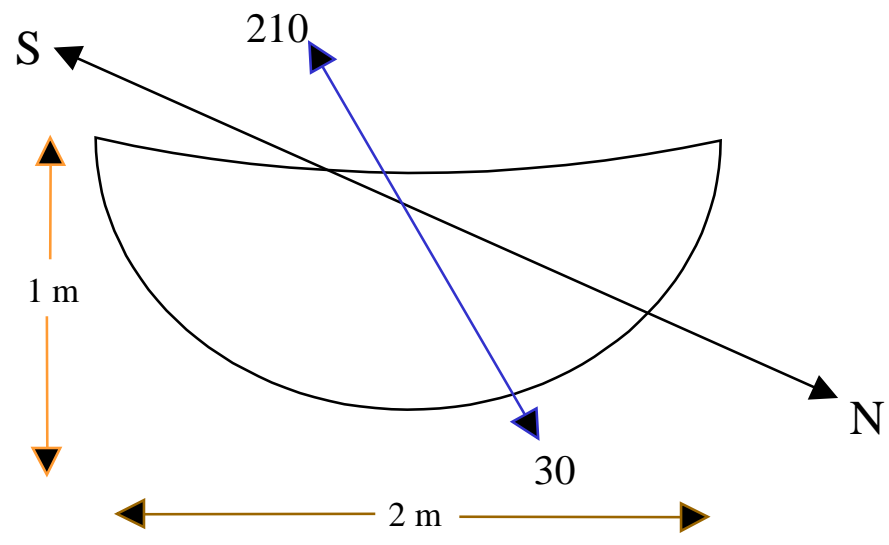

Figure 9. Example of a two-dimensional diagram of trough crossbedding looking directly at the trough; arrows were sketched to indicate the bimodal current direction (blue arrow), height (orange arrow), width (brown arrow), and north arrow.

reveal flow direction; size grading may reflects cyclic changes in the energy of transporting currents (Compton, 1985). Sorting provides a measure of uniformity and persistence of currents or waves and was classified as very poor, poor, poorly, moderately, well sorted, or very well sorted.

Color was noted because it reflects the paleoenvironment in which beds were deposited. A red color suggests non-marine conditions whereas dark grey to black can imply deep-water marine conditions. Red sandstones and shales at the top of the Rockwell Member were interpreted by the author as a subaerially exposed fluvial deltaic sequence. The lower portion of the Rockwell Member at Snowy Mountain, West Virginia contains red colored lithologies (personal communication with Thomas Kammer). 


\section{Bedding}

Individual beds were recognized based on lithology, color, shape, and grain size within each member of the Price Formation. Terminology adopted from Reineck and Singh (1975) was used to characterize the thickness of beds as laminated, very thin, thin, medium or thick. Bed shapes were described as parallel or nonparallel and continuous or non-continuous (Reineck and Singh, 1975).

Regional structural strike, dip angle, and dip direction were recorded for individual beds because the degree of dip was necessary to obtain the true bed thickness. Calculating unit thickness required measuring bedding and laminae with a Jacob staff or measuring tape. Obtaining structural dip for each unit was important because dips greater than ten degrees distort paleocurrent measurements and azimuth directions (Miall, 1984). Seven localities out of the 58 principal and secondary locations contained dipping beds greater than ten degrees. Five out of seven were just over 10 degrees and two were higher than 15 degrees. These values were plotted on rose diagrams, however were not corrected on a steronet.

\section{Types of Paleocurrent Indicators}

Paleocurrent indicators useful for paleocurrent analysis were represented by primary inorganic sedimentary structures formed by currents or current born tools. Mechanical and chemical processes create secondary sedimentary structures, whereas burrowing or crawling organisms form organic sedimentary structures. Secondary and organic sedimentary structures are generally not useful for paleocurrent analysis (Miall, 1984). 
Depositional sedimentary structures useful for paleocurrent analyses include planar and trough crossbedding, asymmetrical ripple and cross laminations, imbricated clasts, oriented fossils, and flute marks. Erosional sedimentary structures consist of channels, flute marks and scours and scoops. The most frequently utilized sedimentary structures for this study included planar and trough crossbedding although one flute mark and two asymmetrical ripples were incorporated. Four symmetrical ripples were recorded, but were not used because they represent bimodal paleoflow.

Planar crossbedding is classified as low-angle ( $<20$ degrees) or high-angle $(>20$ degrees), tabular beds. Low-angle planar crossbeds are generally long and concave up (High and Picard, 1974). In contrast, high-angle crossbeds are relatively short in length and truncate abruptly against the lower boundary surface (High and Picard, 1974). Highangle crossbedding is generally made up of coarse-grained sediment with alternating fine- and coarse-grained beds with coarse-grained lags concentrated at the base of each laminae.

Trough crossbedding is classified as micro cross stratification and festoon or medium scale trough crossbedding (High and Picard, 1974). Micro cross stratification are small-scale ripples that are less than six centimeters tall. Festoon crossbedding is megaripples that are greater than six centimeters tall. Measurements for trough crossbeds include channel depth and width, scale, thickness, maximum clast size, strike and dip, and indicated current directions (Miall, 1984). Precise and accurate measurements are important because the magnitudes of these directional structures can be an indication of current velocity. 
Crossbedding is used to calculate the mean paleocurrent direction and used to reconstruct paleocurrent patterns and shifts in paleoflow. Analyzing directional structures in vertical profiles can determine the stability or frequency of alternation of currents (Pettijohn, Potter, and Siever, 1973). Plotting directional data alongside stratigraphic columns reveals stream flow variations throughout an entire formation or within an individual member. Uniformity or variability of current flow determined from sedimentary structures within a particular bed or unit reflects water depth and velocity.

\section{Measuring Paleocurrents}

Paleocurrent indicators were identified from primary sedimentary structures that included planar and trough crossbedding, asymmetrical ripples, and flute marks. The most common type of sedimentary structures was current features and included crossbedded trough axes and planar bed sets. The long dimension and orientation of flute marks and grooves plus the steep, downstream slope of asymmetrical ripples were recorded because these structures provided accurate current directions. Azimuth readings were recorded within individual beds and the directional variability of sedimentary structures within each bed determined the total number of readings to be taken at each outcrop. It is generally best to have more outcrops with fewer readings than a small number of outcrops with numerous reading (Pettijohn, Potter, and Siever, 1973).

Planar Crossbed Paleocurrent Strike and Dip Orientation

Paleoflow directions from planar crossbedding were calculated by determining the strike of the bed from a three-dimensional surface. This was important because two- 
dimensional surfaces reveal apparent flow directions rather than true ones (Compton, 1985). A board was aligned parallel to the bedding surface on the three-dimensional plane and the strike of the bed was determined by leveling and orienting the compass on top of the board (Figure 10). The board represented an extension of the bedding surface; this procedure was incorporated when the top of crossbedded surfaces was not accessible.

Three-dimensional surfaces are crucial because the three-dimensional surface indicates the orientation of the planar crossbedded surface. Once the strike of the planar crossbed was calculated, the paleocurrent direction was aligned ninety degrees to the strike of the bed in the direction of the dipping, three-dimensional bed. Planar crossstratification must be used with caution because unimodal and bimodal patterns show large degrees of scatter and require a large number of measurements for reconstruction of paleocurrent systems (High and Picard, 1974).

\section{Trough Crossbed Paleocurrent Strike and Dip Orientation}

Paleoflow directions determined from trough crossbedding were calculated by aligning the compass with the trough axes. Measurements of paleoflow from twodimensional trough crossbedded surfaces were obtained by using the mirror to align the compass to the trough axes to calculate azimuth direction. Error arises in this procedure, however unimodal trough cross-stratification of all sizes contains only a small degree of scatter relative to the overall channel direction and fewer readings are required to reconstruct the "true" channel direction (High and Picard, 1974).

Three-dimensional trough crossbedding was measured by standing directly on top of the upper bedding surface and aligning the compass in the downstream direction 
(Figure 11). Reliable and accurate azimuth readings were obtainable because the true directions of the channel were observable as compared to oblique, two-dimensional trough crossbeds. Observing the plan view of multiple trough crossbeds can indicate the direction of movement of current at a specific point within streams and demonstrates the meandering or non-meandering nature of the stream.

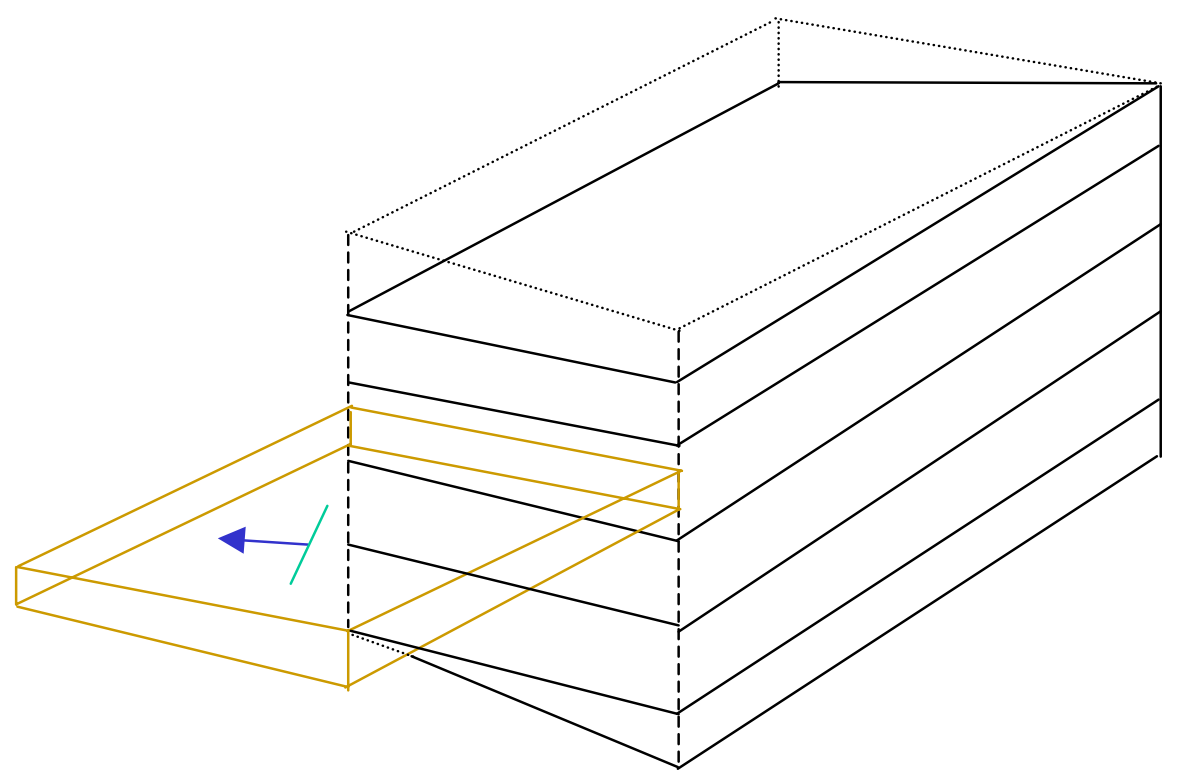

Figure 10. Board (brown) alignment on the three-dimensional surface of a planar crossbed with the strike (green) and paleocurrent direction (blue). 


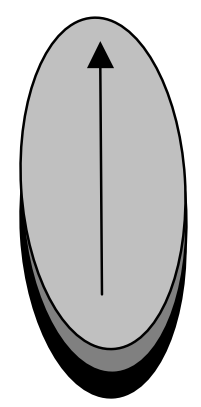

(A)

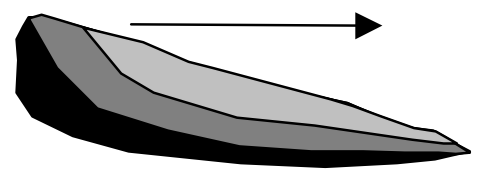

(B)

Figure 11. Three-dimensional trough crossbedding in plan view (a) and side view (b) with downstream flow direction (black arrow). 


\section{PRINCIPAL LOCALITIES}

The principal localities consisted of eight measured and described sections that were used to create the regional cross-section (Appendix VII). The outcrop exposures were located at Scherr, Laurel Run, Red Creek, Hendricks, Harman, Briery Gap, Durbin, and Mace (Figure 12). Stratigraphy was described and measured by the author except for Scherr, Red Creek, Harman, and Mace. Measured and described sections at Scherr, Harman, and Mace were taken from Bjerstedt and Kammer (1986) whereas Red Creek was taken from Nick Fedorko (1994).

\section{$\underline{\text { Scherr }}$}

Outcrop exposures at Scherr were located, described, and measured by Thomas Bjerstedt and Thomas Kammer (Bjerstedt, 1986). Members of the Price Formation recognized here included the Oswayo, Riddlesburg Shale, and the Rockwell. The exposed section, beginning in the underlying Hampshire Formation and ending at the overlying Greenbrier Limestone contact, was 143 meters thick of which $125.6 \mathrm{~m}$ was Price Formation.

Lithologies within the Hampshire Formation consisted of grey-yellow claystone, mudstone, shale, red and grey siltstone, and grey-orange sandstones. Sandstones were fine- to medium-grained with scattered shale pebbles. Bedding was thin, medium, or thick. Sedimentary structures consisted of medium scale trough crossbedding, ripple marks, root mottling, and planar crossbed sets with tangential bases or scour surfaces. No fossils were observed except for scattered plant debris. The contact was covered at the base and sharp at the top. The Hampshire Formation was interpreted as a fluvial deposit 


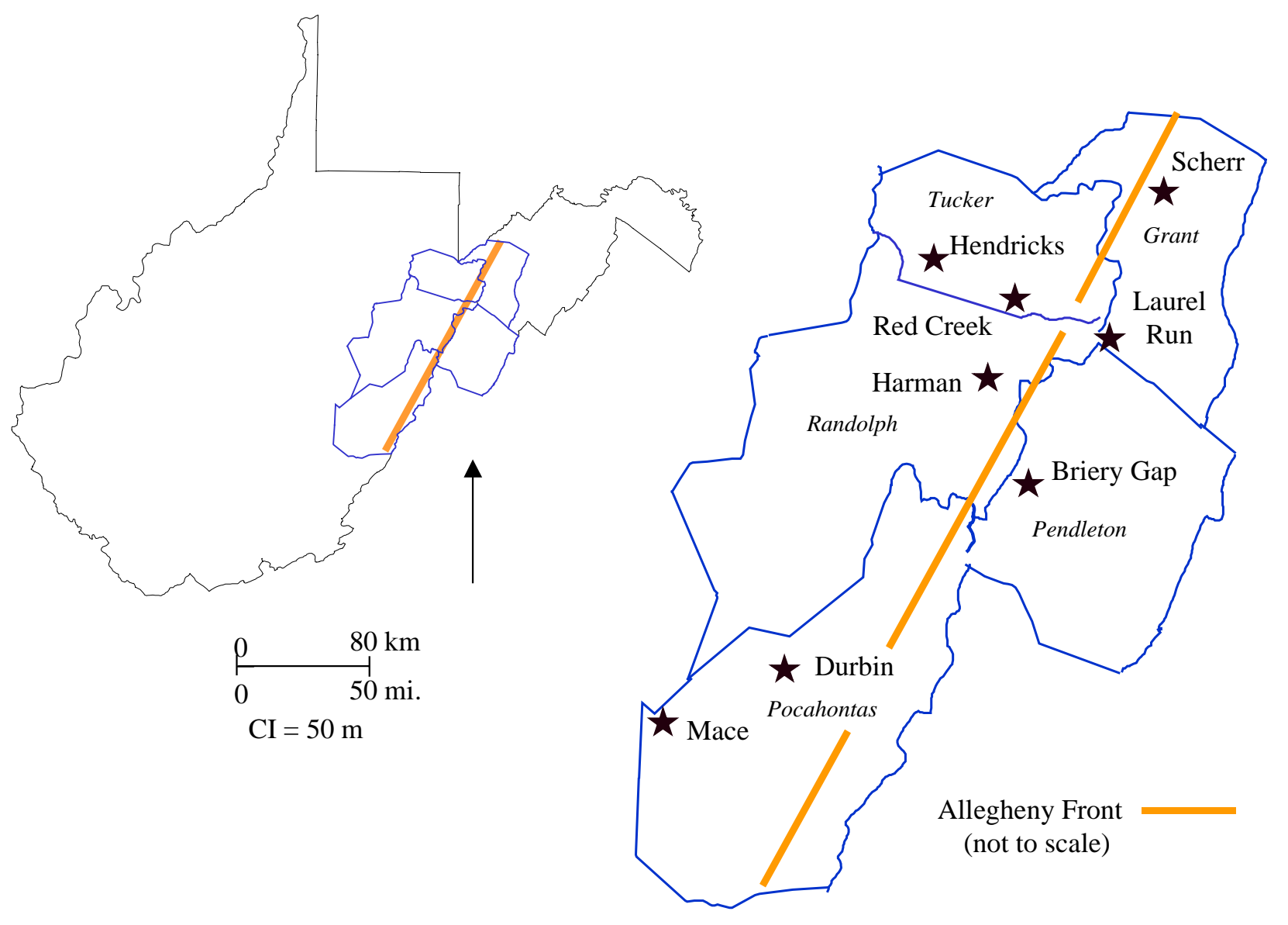

Figure 12. Principal Localities 
based on sedimentary structures and absence of fossils.

Lithologies within the Oswayo Member consisted of light olive grey claystone, mudstone, shale, siltstone, and grey-yellow sandstone. Sandstones were fine- and medium-grained that were poorly to well-sorted with rounded, quartz pebbles. Rock type was described as lithic, feldspatholithic, quartz sublitharenite, and quartz arenite from thin section. Bedding is laminated, very thin, thin, medium, or thick.

Sedimentary structures consisted of medium-scale trough crossbedding, planar crossbed sets, ripple marks, scour and fill surfaces and bioturbation. Fossils consisted of vertical and horizontal burrows identified as Skolithos and Planolites. The lower contact was sharp and top of section was concealed. The Oswayo Member was interpreted as a shallow marine deposit based on ichnofossils and sedimentary structures.

Lithologies within the Riddlesburg Shale Member consisted of light olive grey siltstone interbedded with yellowish silty mudstone and yellowish sandstone. This section was entirely covered except at the base. Grain size was not recorded and bedding was very thin to thin. There were no apparent sedimentary structures, body fossils, or ichnofossils. Basal contact was gradational and upper contact was concealed. The Riddlesburg Shale Member was interpreted as a shallow marine deposit based on Bjerstedt's (1986) interpretation.

Lithologies within the Rockwell Member consisted of grey-brown claystone, mudstone, grey and red shale, siltstone, and sandstone (Figure 13). Sandstones were fine, medium-, and coarse-grained and moderately sorted with a few small quartz pebbles; they were identified as a sublitharenite in thin section. Abundant siderite nodules and shale pebble conglomerates were present throughout the section. Bedding was very thin, 
thin, or medium. Sedimentary structures included medium- to large-scale trough crossbedding, ripple marks, and scoured bases. Fossils were not observed except for scattered plant debris. Contact was concealed at the base and sharp at the top. The Rockwell Member was interpreted as a fluvial deposit based on sedimentary structures and absence of marine fossils.

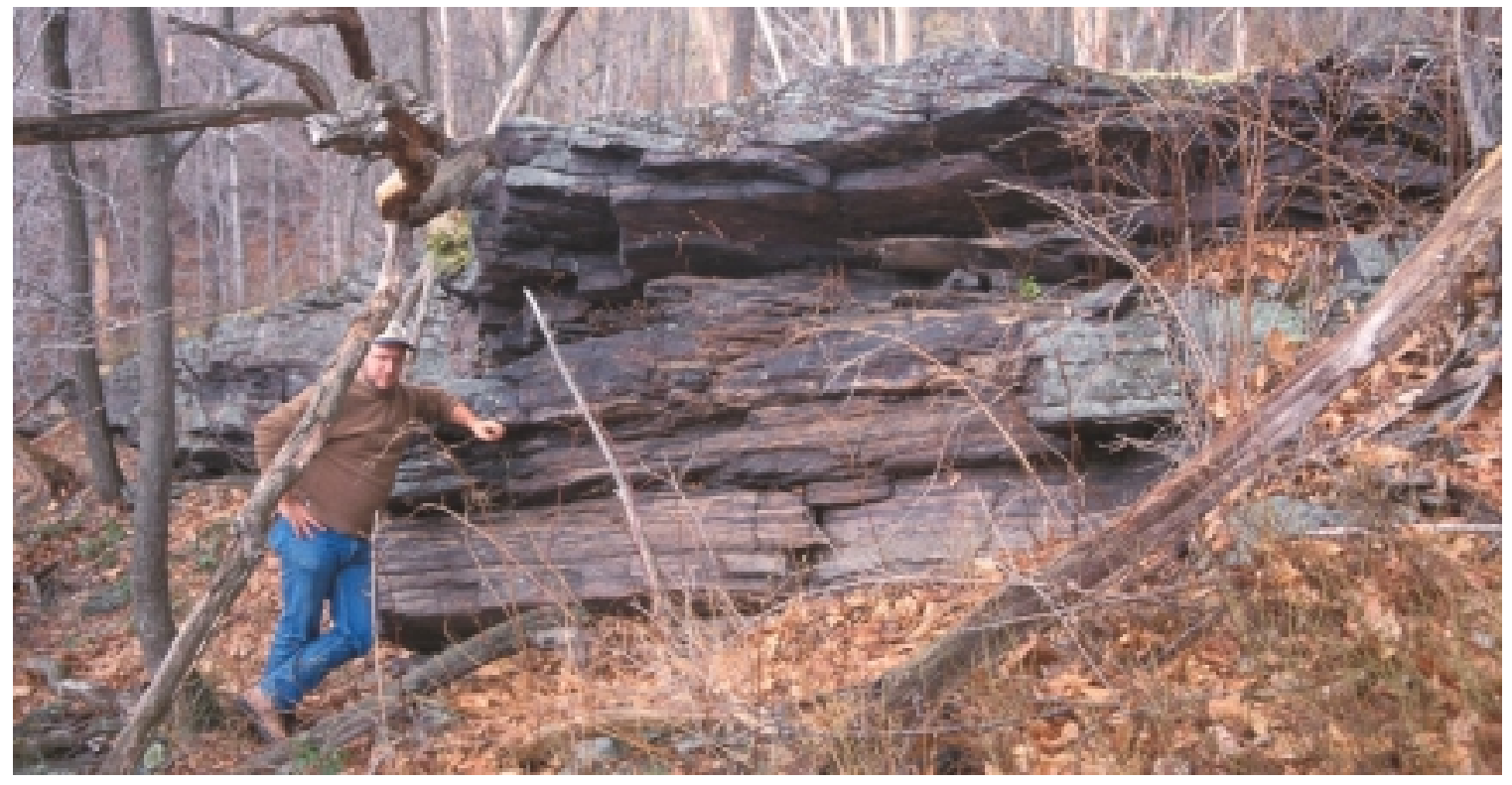

Figure 13. Unit 38 of the Rockwell Member at Scherr in Figure 38 (1.8 meter tall person for scale).

\section{Laurel Run}

Outcrop exposures at Laurel Run are situated along the Allegheny Front. Members of the Price Formation there included the Oswayo, Riddlesburg Shale, and the Rockwell. The exposed section, beginning in the underlying Hampshire Formation and ending with the overlying Greenbrier Limestone contact, was 120 meters thick of which 95.5 m was Price Formation. 
Lithologies within the Devonian Hampshire Formation consisted of buff and red sandstones, shales and mudstones. Sandstones were very fined-grained with subangular and subrounded grains that were tightly packed and well-sorted. Bedding was very thin, thin, or contorted. Sedimentary structures consisted of planar crossbedding. The section was devoid of fossils. Scattered plant debris was present in the middle of the section. Contacts were sharp at the top and bottom of the section. The Hampshire Formation is interpreted as a fluvial deposit based on red color, sedimentary structures, and absence of marine fossils.

Lithologies within the Oswayo Member consisted of buff sandstones and grey siltstone interbedded with dark grey mudstone. Sandstones were very fine-grained with subrounded grains that were tightly packed and well sorted. Siltstones were fine-grained and exhibited a mottled appearance. Bedding was laminated, very thin, thin, medium, or contorted. Sedimentary structures included bioturbation and planar and epsilon crossbedding. Paleocurrent measurements were not attainable; ichnofossils consisted of Skolithos located within the lowermost sandstone and siltstone. The section contained sharp upper and lower contacts. The Oswayo Member was interpreted as a shallowmarine deposit based on ichnofossil identification.

Lithologies within the Riddlesburg Shale consisted of dark grey to black shales interbedded with sandstone, siltstone, and mudstone. Shale was silty and poorly bedded with no apparent sedimentary structures. No ichnofossils or body fossils were not seen. The section contained a gradational lower contact and an upper sharp contact. The Riddlesburg Shale Member was interpreted as a shallow-marine deposit based on the dark grey shales. 
Lithologies within the Rockwell Member consisted of buff and red sandstones and dark grey siltstones. Sandstones are very fined-grained with subangular, angular, subrounded, or rounded grains that are tightly packed and well-sorted. The bottom of the section contained quartz pebbles that were two to three centimeters in diameter as well as ferruginous nodules. Siltstones were fine-grained and had a mottled appearance.

Bedding was laminated, very thin, thin, or wavy. Sedimentary structures consisted of high-angle planar crossbedding and trough crossbedding. The section was devoid of fossils and contained a sharp upper contact and a concealed base. The Rockwell Member was interpreted as a fluvial deposit based on sedimentary structures and absence of marine fossils.

\section{$\underline{\text { Red Creek }}$}

Outcrop exposures at Red Creek were located, described, and measured by Nick Fedorko (WVGES, 1996). Members of the Price Formation there included the Oswayo, Riddlesburg Shale, and the Rockwell. The exposed section, beginning in the underlying Hampshire Formation and ending with the overlying Greenbrier Limestone contact, was 86 meters thick of which 47.23 meters was Price Formation.

Lithologies within the Hampshire Formation consisted of red and buff mudstone, shale, siltstone and sandstone. Sandstones were very fine-, fine-, medium-, or coarsegrained with a few quartz pebbles. Bedding was thin, tabular, or blocky containing abundant slickensided surfaces. Sedimentary structures included planar crossbed sets, scour surfaces, and root traces. Basal contact was covered whereas the upper contact was sharp. The Hampshire Formation was interpreted as a fluvial deposit based on 
sedimentary structures and the absence of marine fossils. Mudstones were interpreted as paleosols based on root structures.

Lithologies within the Oswayo Member consisted of grey-green shale and siltstone with light grey sandstones. Sandstones were fine- or medium-grained with quartz pebbles at the top of the section. Bedding was not described except for thick bedding interbedded with thin, planar laminae. Sedimentary structures included scour surfaces and bioturbation. Fossils consisted of vertical and lateral burrows and a few scattered plant fossils. The lower contact was sharp and upper contact concealed. The Oswayo Member was interpreted as a shallow-marine deposit based on ichnofossils.

Lithologies within the Riddlesburg Shale Member consisted of grey shale interbedded with light grey silty sandstone (Figure 15). Sandstones were fine-grained with scattered quartz pebble horizons. Bedding was lenticular to thin in sandstone and fissile to slightly blocky in shales. Sedimentary structures consisted of horizontal bioturbation. Fossils included horizontal ichnofossils with scattered plant debris. The lower contact was concealed and the upper contact was erosional. The Riddlesburg Shale Member was interpreted as a shallow marine deposit based on ichnofossils.

Lithologies within the Rockwell Member consisted of grey to dark grey shales and light grey to brown sandstones. Sandstones are very fine-, fine-, medium-, or coarsegrained with quartz pebbles (Figure 15). Bedding was thin, medium, thick, or tabular and the section was interpreted as a fining upward sequence. Sedimentary structures included planar crossbeds and erosional scour surfaces. Contacts were sharp at the bottom and top. The Rockwell Member was interpreted as a fluvial deposit based on sedimentary structures and absence of marine fossils. 


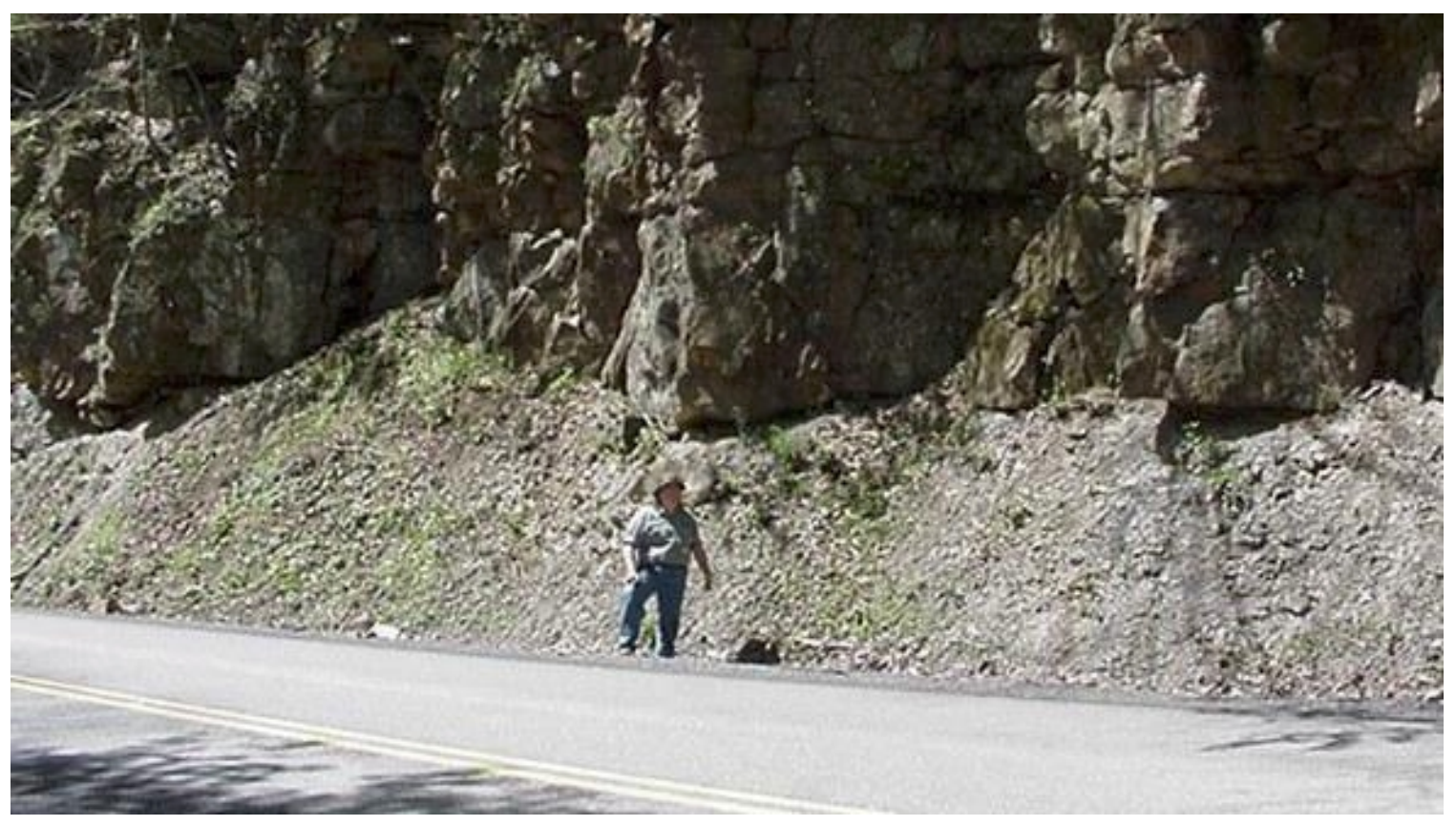

Figure 14. Units 32-35 of the Riddlesburg Shale Member at Red Creek in Figure 69 (1.7 meter tall person for scale).

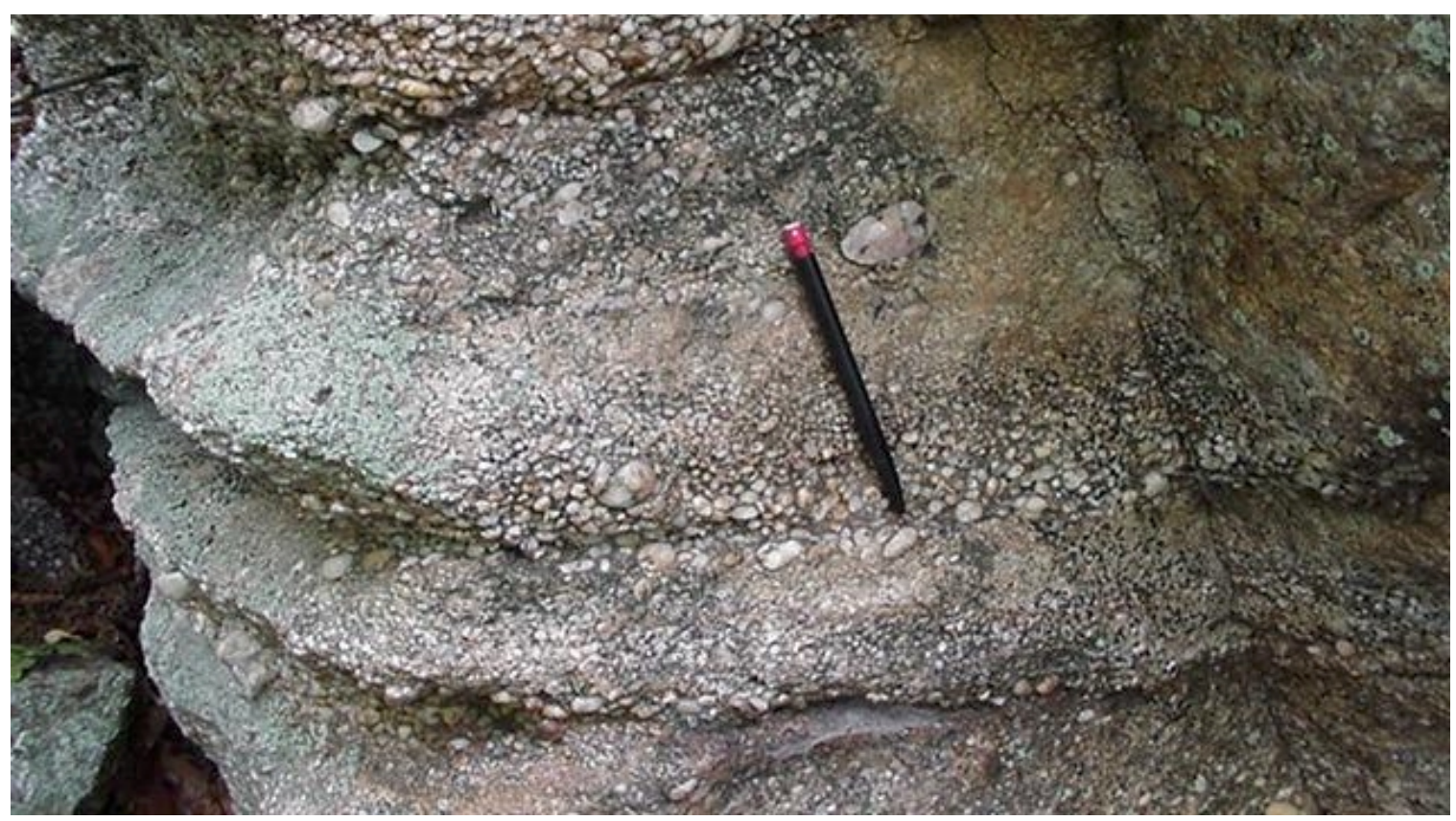

Figure 15. Unit 36 of the Rockwell Member at Red Creek in Figure 70 (mechanical pencil for scale). 


\section{$\underline{\text { Hendricks }}$}

Outcrop exposures at Hendricks lie along the road and in a nearby stream. Members of the Price Formation here included the Oswayo, Riddlesburg Shale, and the Rockwell. The exposed section, beginning in the underlying Hampshire Formation and ending at the overlying Greenbrier Limestone contact, was 35 meters thick of which 32 meters was Price Formation. The Oswayo Member was concealed therefore lithologic descriptions were not recorded for it.

Lithologies within the Upper Devonian Hampshire Formation include buff to grey sandstones interbedded with mottled, red and green mudstones. Sandstones were very fine- to fine-grained with angular grains that were tightly packed and well-sorted. Mudstones were fine-grained with a few scattered sand lenses. Bedding was very thin, thin, medium, or thick and consisted of parallel and continuous bed sets.

Sedimentary structures included small- and medium-scale trough crossbedding in the upper sandstones (Figure 16) and soft sediment deformation. Fossils were not observed; this interval was partially concealed and contained a gradational lower contact and a sharp upper contact. The Hampshire Formation was interpreted as a fluvial deposit based on sedimentary structures and absence of fossils.

Lithologies within the Riddlesburg Shale Member consisted of dark grey shale (Figure 17). Shale is fine-grained and poorly bedded. Sedimentary structures included mudcracks with soft-sediment deformation below overlying sandstone channel. Body fossils included orbiculoid brachiopods (Figure 18). The well-exposed section had sharp upper and lower contacts. The Riddlesburg Shale Member was interpreted as a shallowmarine deposit based on the orbiculoid body fossil. 


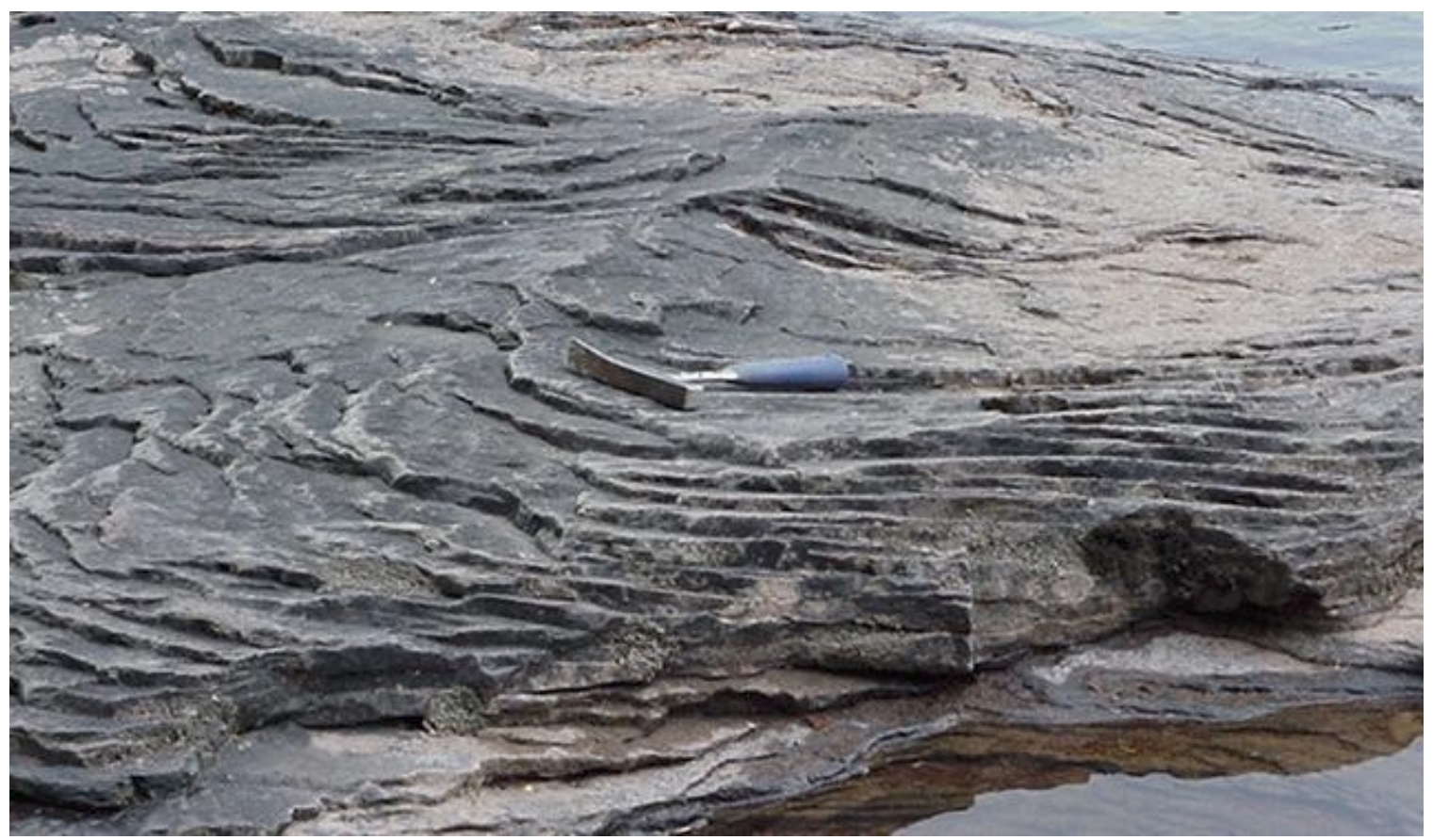

Figure 16. Unit 2 of the Hampshire Formation at Hendricks in Figure 72 (rock hammer for scale). Medium-scale trough crossbedding with the paleoflow direction to the right.

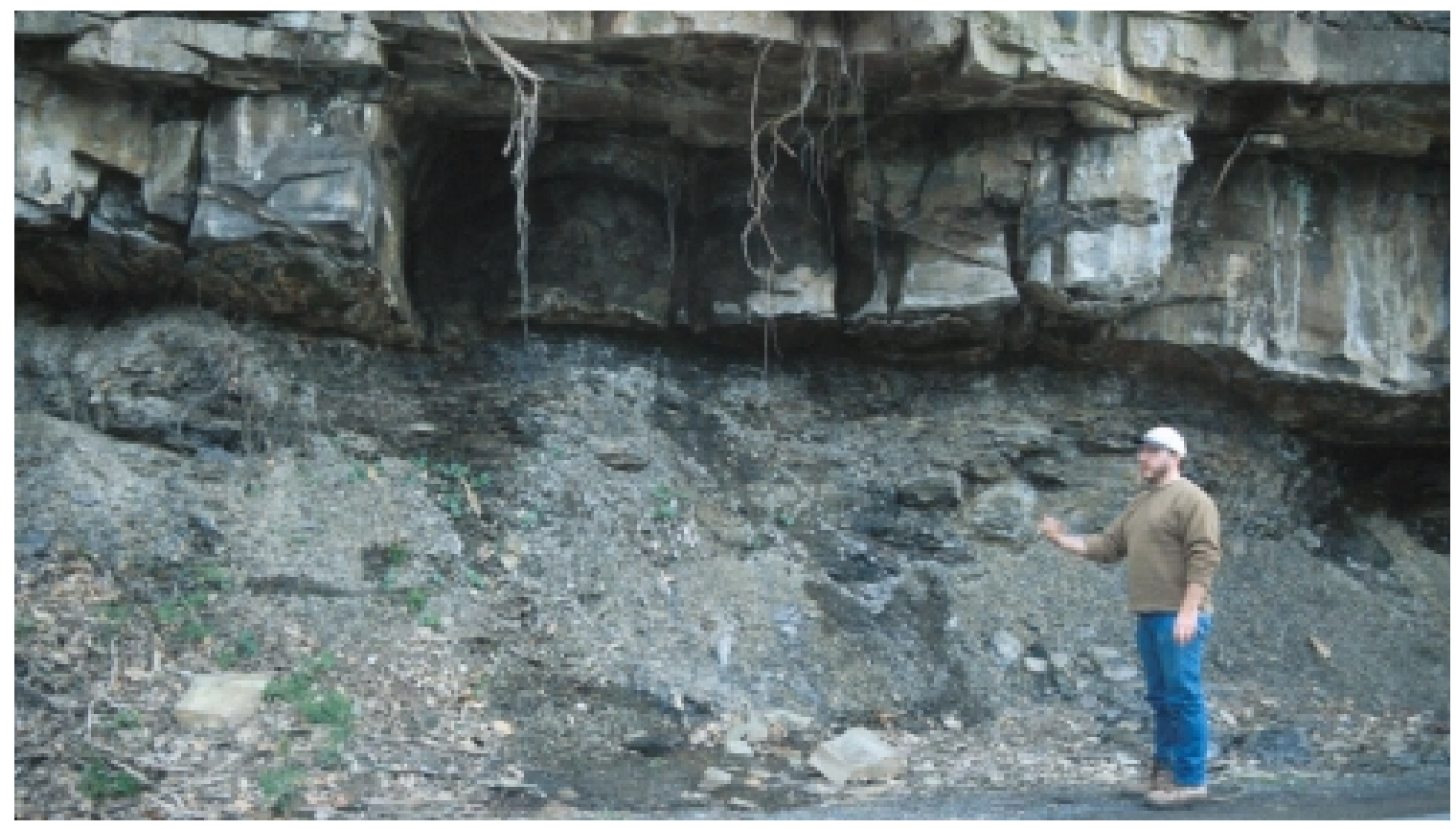

Figure 17. Unit 8 of the Riddlesburg Shale Member at Hendricks in figures 72 and 73 (1.7 meter tall person for scale). 


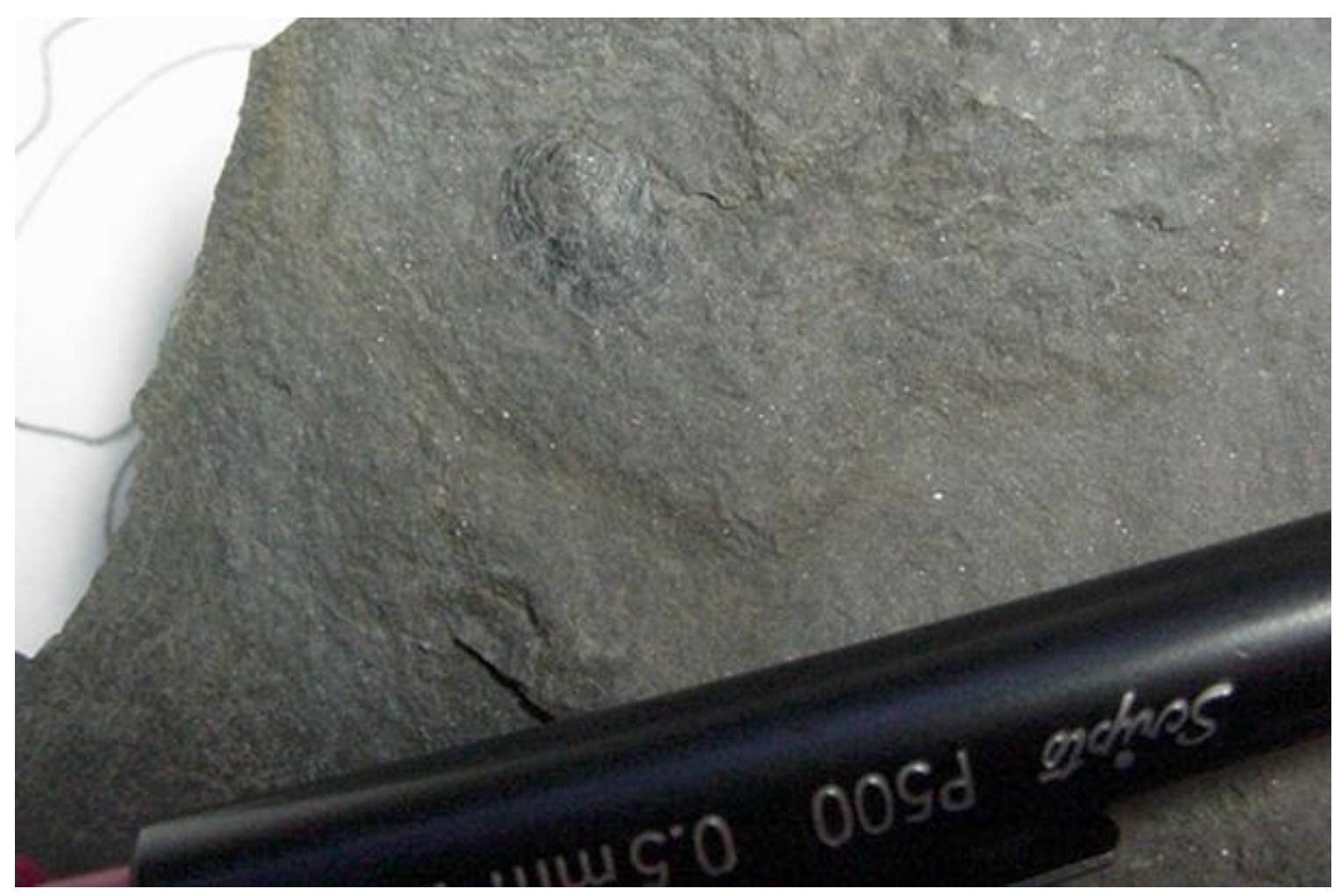

Figure 18. Unit 8 of the Riddlesburg Shale Member at Hendricks in Figures 72 and 73 (mechanical pencil for scale).

Lithologies within the Rockwell Member included buff, grey, and white sandstone. Sandstones were fine-, medium-, or coarse-grained and were well-sorted and tightly packed. Quartz pebbles were well-rounded with diameters measuring up to $6 \mathrm{~cm}$. Bedding was thin with parallel and continuous bed sets. Primary sedimentary structures included low-angle planar crossbedding and trough crossbedding (Figure 19). Fossils were not observed; this interval was well exposed with a gradational lower contact and a sharp upper contact. The Rockwell Member was interpreted as a fluvial deposit because of sedimentary structures and absence of marine fossils. 


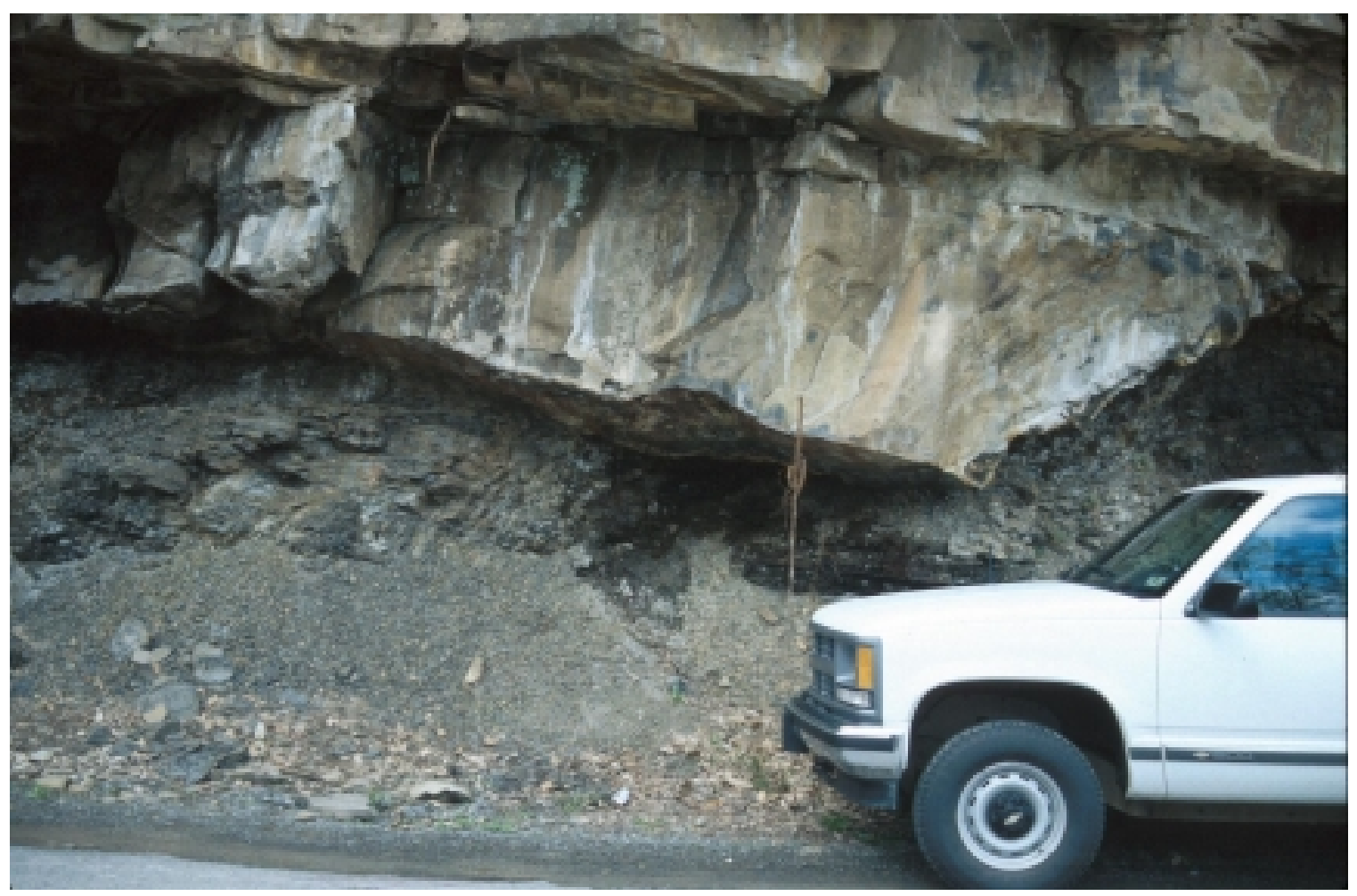

Figure 19. Unit 9 of the Rockwell Formation at Hendricks in Figure 73 (1.8 meter tall truck for scale).

\section{$\underline{\text { Harman }}$}

Outcrop exposures at Harman were located, measured, and described by Thomas Bjerstedt and Thomas Kammer (Bjerstedt, 1986). Members of the Price Formation here included the Riddlesburg Shale and the Rockwell. The exposed section, beginning in the Riddlesburg Shale and ending with the overlying Greenbrier Limestone contact, was 35 meters thick. The overlying Mississippian Greenbrier Limestone was present at a nearby limestone quarry approximately 152 meters away.

Lithologies within the Riddlesburg Shale Member include sandstones, siltstones, silty shales, and medium to dark grey mudstones. Sandstones were very fine-grained. Bedding was thin, medium, and wavy with fissle shales. Sedimentary structures included wave ripples, load balls and casts, and scour surfaces. This unit contained abundant 
ichnofossils that included Scalarituba, Helminthopsis, Phycosiphon, Pelecypodichnus, and Bifungites. The lower contact was covered and the upper contact was gradational . The Riddlesburg Shale was interpreted as a shallow-marine deposit based on ichnofossils.

Lithologies within the Rockwell Member include conglomeratic sandstones, sandstones, siltstones, and silty shales. Grains were moderately well-sorted and were composed of 1.5 centimeter quartz pebbles. Bedding was laminated, very thin, thin, medium, or thick. Sedimentary structures included small- and medium-scale planar crossbeds and trough crossbedding (Figure 20); fossils were not observed. The outcrop was well exposed with sharp upper and lower contacts. The Rockwell Member is interpreted as a fluvial deposit based on sedimentary structures and absence of marine fossils.

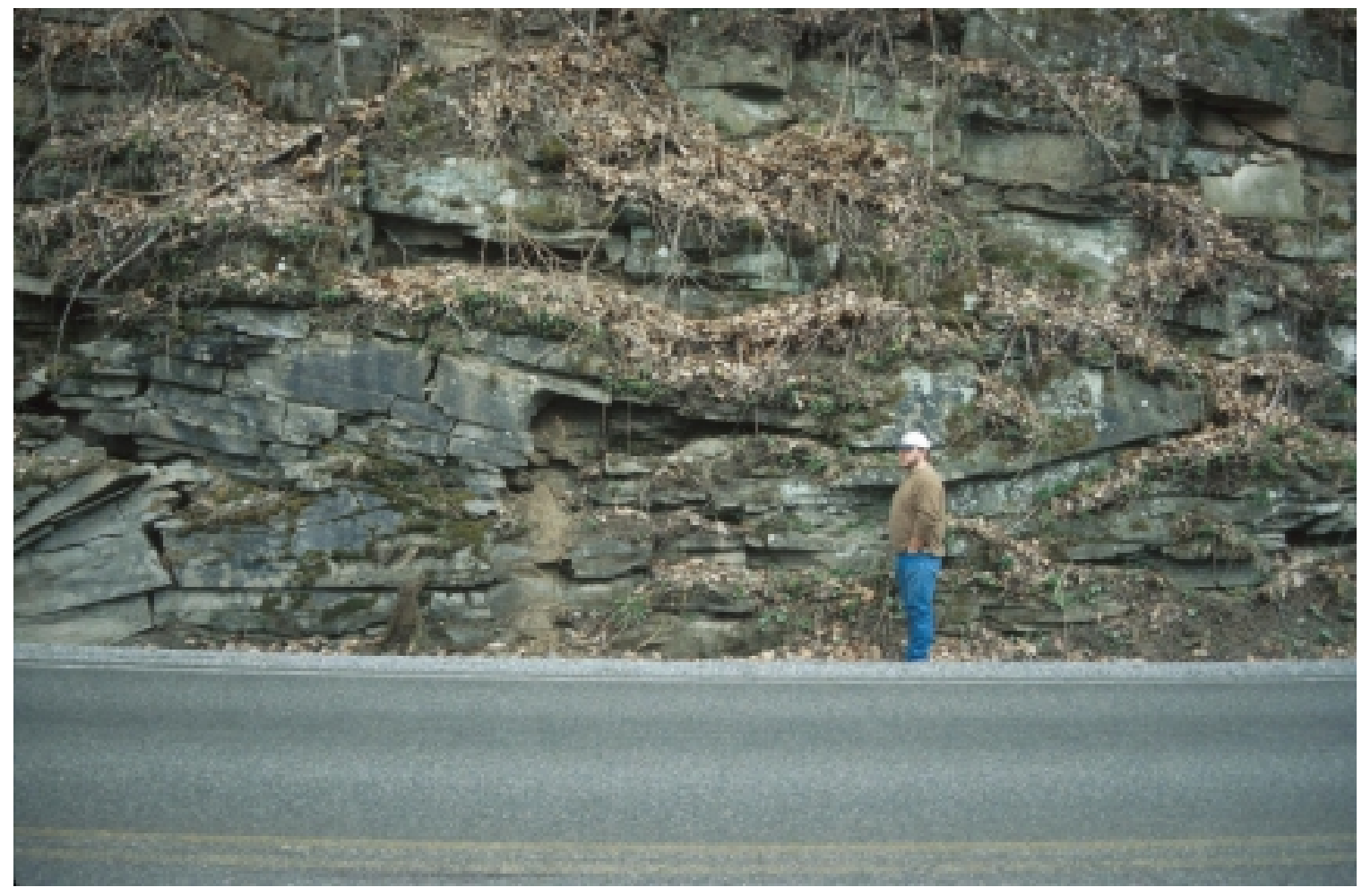

Figure 20. Unit 8 in the Rockwell Member at Harman in Figure 76 (1.7 meter tall person for scale). 


\section{Briery Gap}

New outcrop exposures were located along the road at Briery Gap (Figure 21). Members of the Price Formation included the Riddlesburg Shale and the Rockwell. The exposed section, beginning in the underlying Hampshire Formation and ending with the overlying Greenbrier Limestone contact, was 136.5 meters thick of which $106.3 \mathrm{~m}$ was Price Formation. These new exposures confirmed the absence of the Oswayo Member in this region and defined the Upper Devonian-Mississippian contact.

Lithologies within the Hampshire Formation consisted of red and buff sandstones interbedded with red shales and buff siltstones and mudstones (Figure 22). Sandstones are very fine-grained to fine-grained with subangular grains that are well sorted. Bedding was very thin, thin, medium, or thick in sandstones; siltstones and shales were thinly bedded. Sedimentary structures included high-angle planar crossbedding. Zones of plant debris were identified in the middle of the section; unit contacts were sharp. The Hampshire Formation was interpreted as a fluvial deposit based on sedimentary structures and absence of marine fossils.

Lithologies within the Riddlesburg Shale Member consisted of interbedded buff to grey sandstones, siltstones, shales and mudstones (Figure 23). Sandstones were very fine-grained and well-sorted. Bedding in the sandstones and mudstones was medium; siltstones were thinly bedded. Physical sedimentary structures were not observed; this unit contained horizontal and vertical worm burrows near the top of the section. Unit contacts were sharp. This Riddlesburg Shale was interpreted as a fining-upward marine sequence based on ichnofossils. 
Lithologies within the Rockwell Member consisted of buff and red sandstones and white to pink conglomeratic sandstones. The upper 3.5 meters of the section consisted entirely of red sandstone (Figure 24). Sandstones were fine to very coarsegrained with angular to sub-rounded grains that were tightly packed. Conglomeratic sandstones were coarse-grained with very well-rounded quartz pebbles up to 5 or 6 centimeters in diameter. Bedding was laminated, very thin, thin, medium, or wavy.

Sedimentary structures included low- and high-angle planar crossbeds plus epsilon and trough crossbedding. Paleocurrent readings recorded from two conglomeratic channel sandstones indicated a west to southwest paleoflow direction. The unit was devoid of ichnofossils or body fossils. The lower contact was covered; the upper contact was sharp. Large portions of the section were covered. The Rockwell Member was interpreted as a fluvial deposit because of sedimentary structures and the absence of marine fossils.

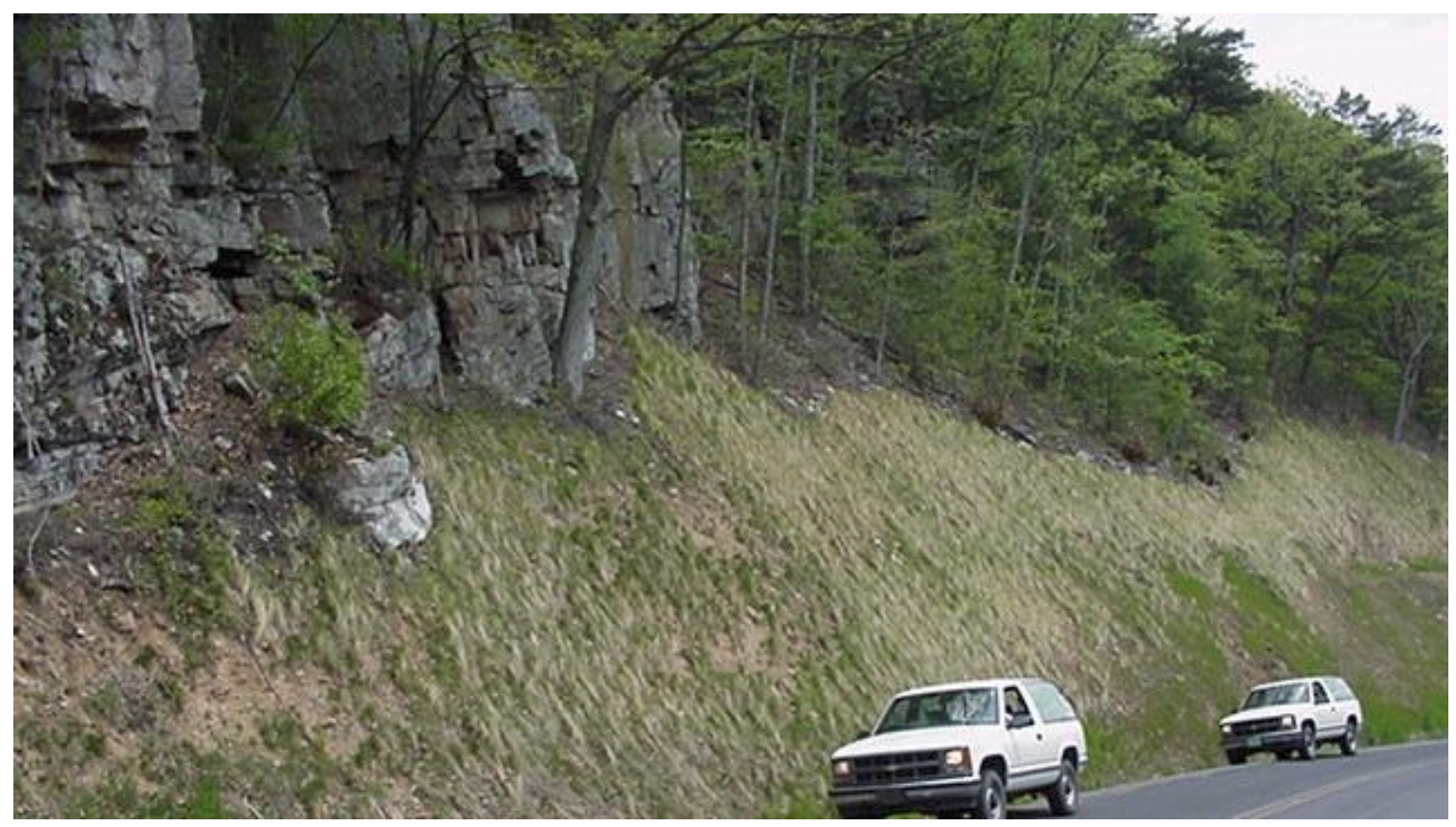

Figure 21. Units 9-14 of the Rockwell Member at Briery Gap in Figures 80 and 81 (1.8 meter tall truck for scale). 


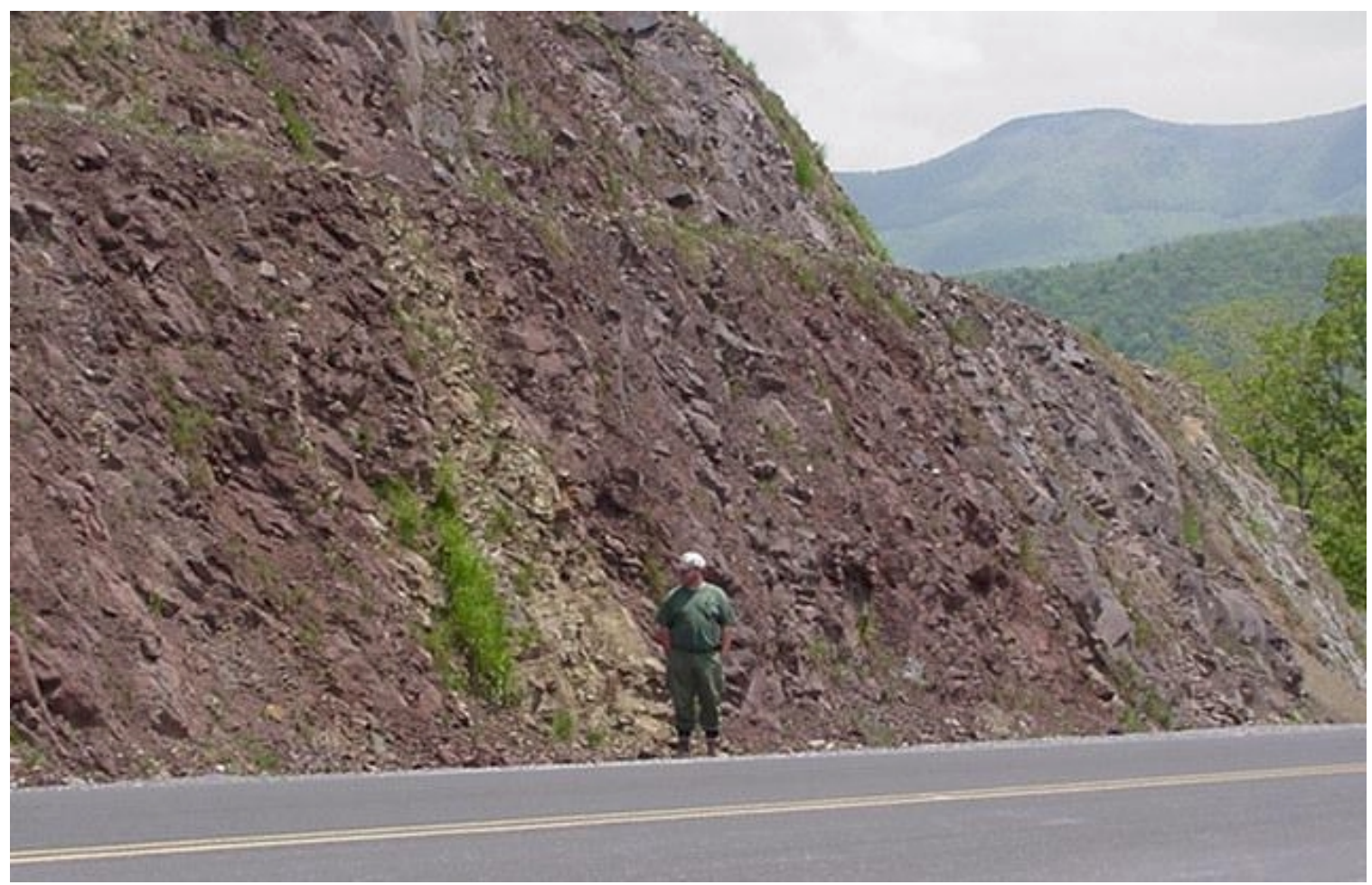

Figure 22. Unit 1 of the Hampshire Formation at Briery Gap in Figure 78 (1.7 meter person for scale).

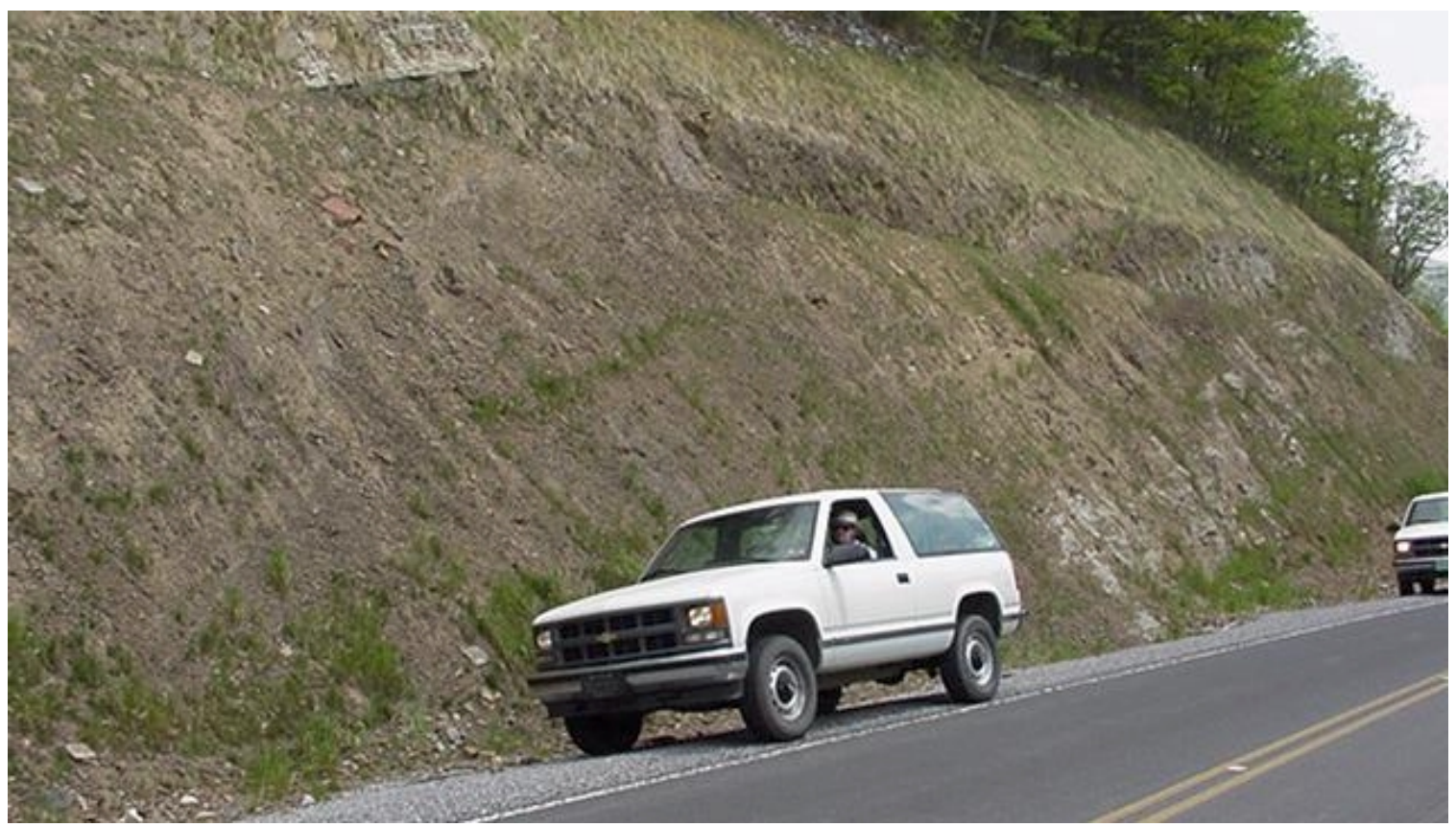

Figure 23. Unit 8 of the Riddlesburg Shale Member at Briery Gap in Figure 79 (1.8 meter tall truck for scale). 


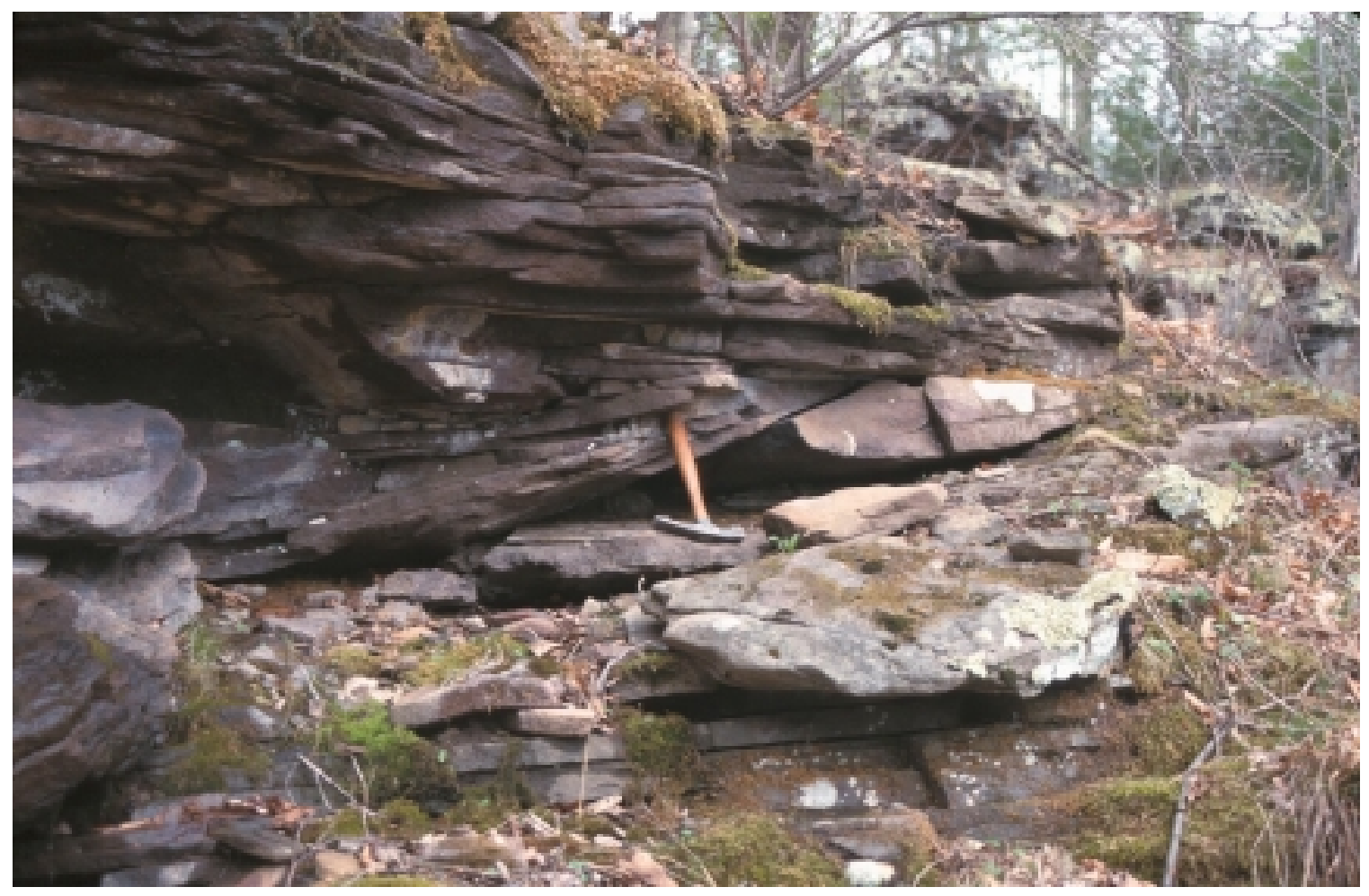

Figure 24. Unit 27 of the Rockwell Member at Briery Gap in Figure 83 (rock hammer for scale).

\section{$\underline{\text { Durbin }}$}

Outcrop exposures were located along the road at Durbin. Members of the Price Formation here included the Riddlesburg Shale, Rockwell and the Unnamed Upper Member. The exposed section, beginning in the underlying Hampshire Formation and ending with the overlying Greenbrier Limestone contact, was 44.5 meters thick of which $35 \mathrm{~m}$ was Price Formation. This exposure is the last outcrop of the Rockwell Member in the southernmost portion of the study area.

Lithologies within the Upper Hampshire Formation consisted of buff sandstones with mottled, red and green siltstones and mudstones. Sandstones were fine-grained with subangular grains that were moderately well-sorted. Bedding was mostly planar and consisted of continuous and parallel bed sets and contorted beds. Sedimentary structures 
consisted of laminated crossbedding and large scour surfaces at the top and bottom of unit containing rip-up clasts. Scattered plant debris was located in the middle and the upper portions of the section; lower contacts were gradational. The Hampshire Formation is interpreted as a fluvial deposit based on sedimentary structures and absence of marine fossils. The lowermost unit is interpreted as a sandy paleosol indicated by root mottling.

Lithologies within the Riddlesburg Shale Member consisted of buff to grey sandstones, siltstones, and mudstones. Sandstones were very fine-grained to coarsegrained with sub-rounded grains that were well-sorted. A few, well-rounded quartz pebbles, one to two-centimeters in diameter, were located at the top of the section. Sandstones contained parallel and continuous beds that were laminated or very thin with some small shaly units and ferruginous concretions. Siltstones and mudstones were thickly bedded.

Sedimentary structures consisted of lateral, vertical, and u-shaped ichnofossils. Ushaped ichnofossils were identified as Diplocraterion and Arenocolites. This section was well exposed and contained a sharp lower contact and upper gradational contact. This Riddlesburg Shale was interpreted as a shallow-marine deposit located within the littoral zone based on ichnofossils.

Lithologies within the Rockwell Member consisted of white to brown sandstones and grey siltstones, shale, and mudstones. Sandstones were fine-grained or coarsegrained with well-rounded one- to two-centimeter quartz pebbles. Grains were subrounded and well sorted. Bedding was laminated or thin and consisted of parallel and continuous bed sets. Sedimentary structures and fossils were not observed; this interval was predominantly covered with a concealed gradational lower contact and a concealed 
upper contact. This Rockwell Member was interpreted as a fluvial deposit based on sedimentary structures and absence of marine fossils.

Lithologies within the Upper Unnamed Member consisted of grey sandstones interbedded with siltstones, shales and mudstones. Sandstones were very fine-grained with sub-rounded grains that were well-sorted and tightly packed. Bedding was laminated, thin, or thick with a few conchoidal fractures zones. Sedimentary structures were restricted to trough crossbedding. There were no ichnofossils observed; body fossils were abundant and consisted of crinoid stems, Schuchertella macensis brachiopods, and bryozoans (Figure 25). The Unnamed Upper Member was interpreted as a shallowmarine deposit based on body fossils.

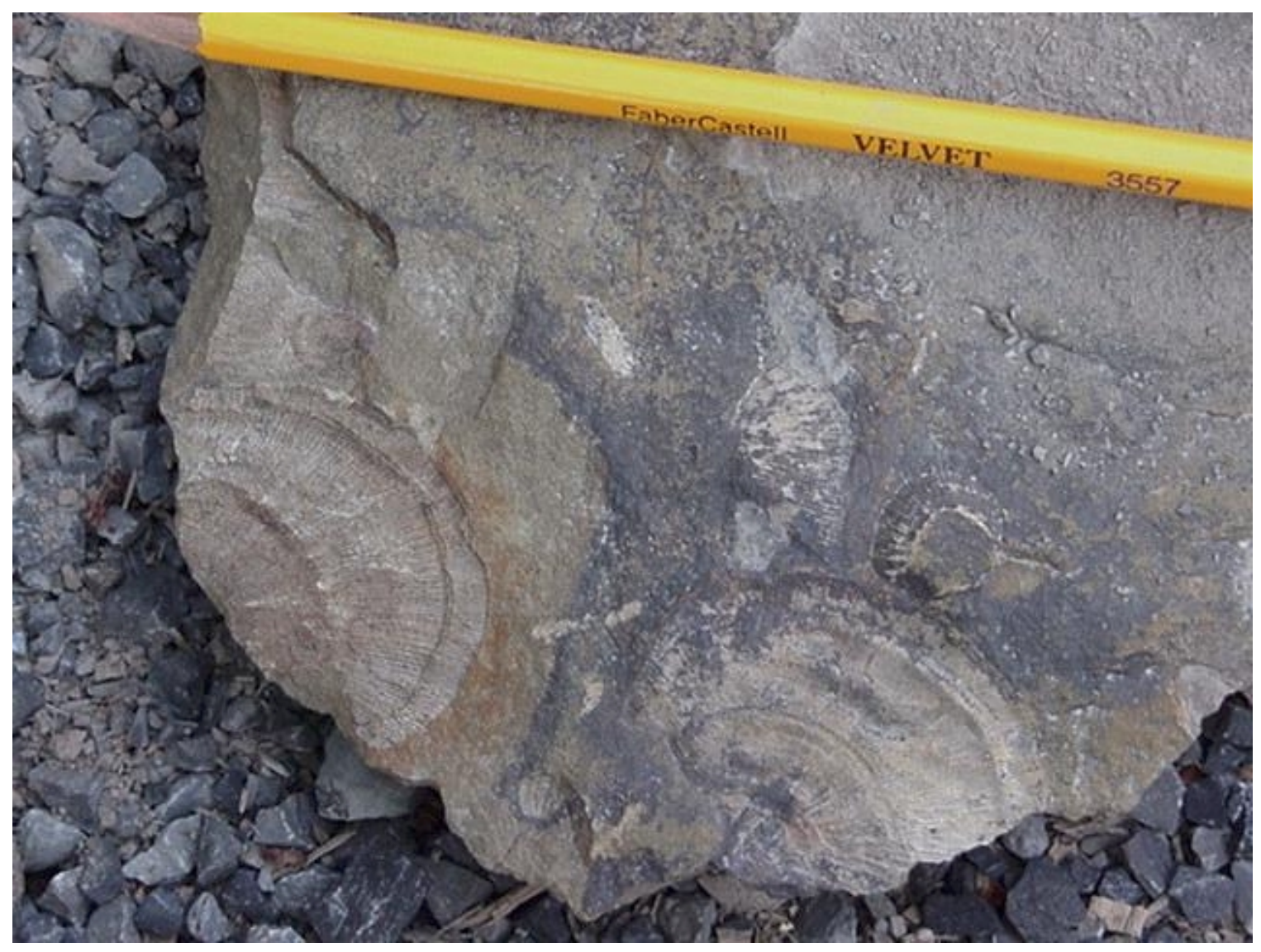

Figure 25. Unit 6 of the Unnamed Upper Member at Durbin in Figure 87 (pencil for scale). 


\section{$\underline{\text { Mace }}$}

Outcrop exposures at Mace were located, described, and measured by Thomas Bjerstedt and Thomas Kammer (Bjerstedt, 1986). Members of the Price Formation here included Riddlesburg Shale and the Unnamed Upper Member. The exposed section, beginning in the underlying Hampshire Formation and ending at the overlying Greenbrier Limestone contact, was 70.5 meters thick of which 26 m was Price Formation.

Lithologies within the Devonian Hampshire Formation consisted of buff, grey and red shaly and silty sandstones. Sandstones were very fine-, fine- or coarse-grained with scattered shale clasts and fine- to medium-sized quartz pebbles. Bedding was laminated, thin, medium, or thick. Sedimentary structures included trough and planar crossbedding (Figure 26). Trough crossbeds contained basal lags of plant debris and light grey shale pebbles. The bottom of section was not entirely measured; the upper contact was concealed. The Hampshire Formation was interpreted as a fluvial deposit based on sedimentary structures and absence of marine fossils.

Lithologies within the Riddlesburg Shale Member included light olive grey sandstones with interbeds of silty shale and siltstone in the basal two-thirds of the section. Sandstones were fine-grained and well-sorted. They were identified as a sublitharenite in thin section by Bjerstedt (1986). Bedding was rhythmic, laminated, very thin, thin, medium, thick, or massive and consisted of a series of at least 15 fining-upward sequences.

Sedimentary structures consisted of low-angle cross stratification, trough crossbeds and hummocky stratification. Ichnofossils included Helminthopsis and Planolites that appeared as hyporeliefs. Body fossils were abundant and disarticulated 
forming shelly lags containing Syringothyrsis angulata, bivalves, planispiral gastropods, and crinozoan columnals. The lower and upper contacts were concealed. The Riddlesburg Shale Member was interpreted as a near shore, shallow-marine deposit based on ichnofossils and body fossils.

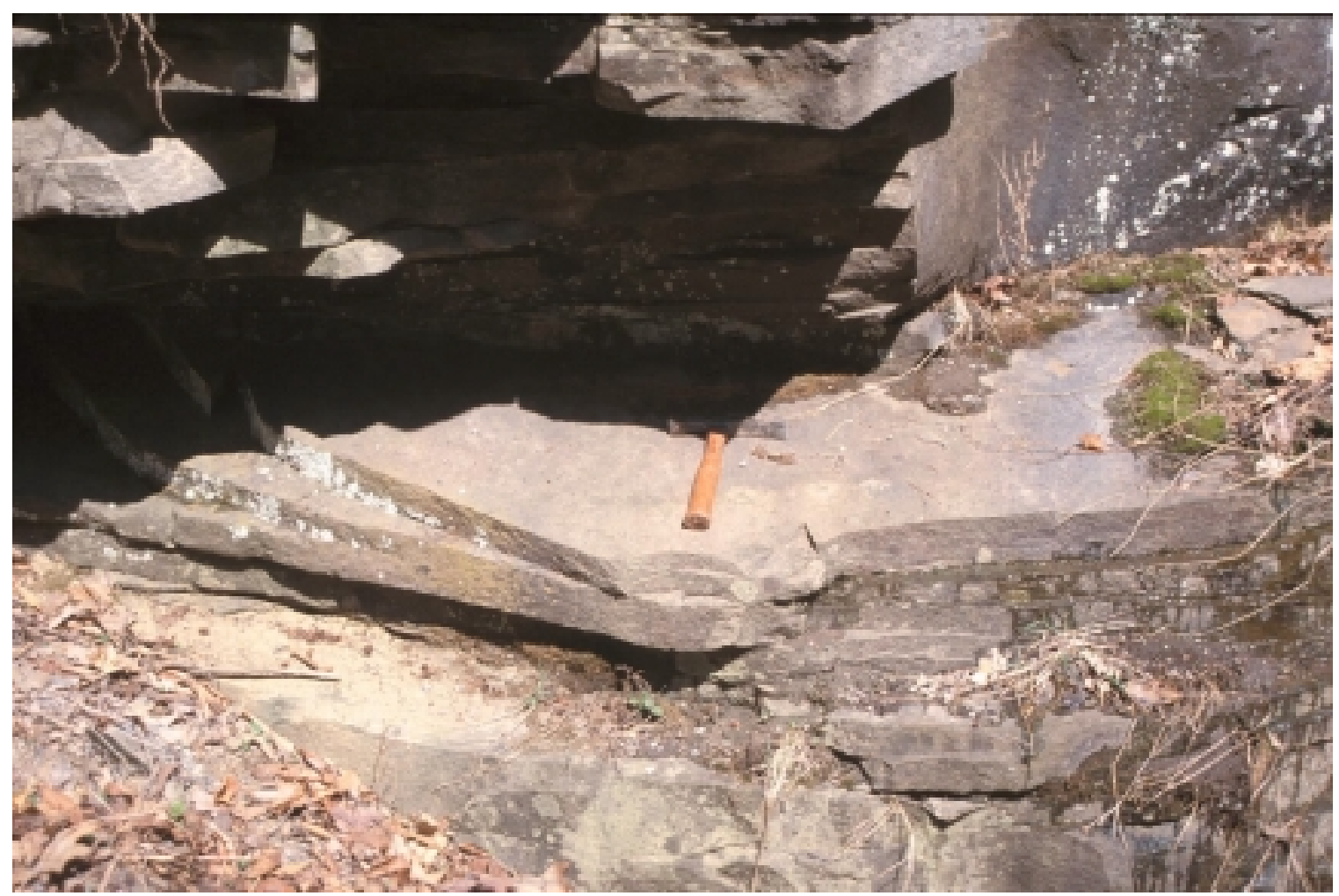

Figure 26. Unit 1 of the Hampshire Formation at Mace in Figure 90 (rock hammer for scale).

Lithologies within the Unnamed Upper Member consisted of sandstones and siltstones in largely covered interval. Sandstones were very fine- to fine-grained with scattered shale pebbles. Bedding was laminated, thin, medium, or thick. Sedimentary structures included flute marks and abundant bioturbated zones. Fossils were abundant and consisted of body and ichnofossils. 
Body fossils included orbiculoid brachiopods. The ichnofossils Scalarituba, Isopodichnus, Planolites and Phycodes were present. Planolites and Phycodes appeared at the base of the section with Scalarituba and Isopodichnus at the top. The upper contact was sharp and the lower contact was concealed. The Unnamed Upper Member was interpreted as a shallow marine deposit based on ichnofossils and body fossils. 


\section{SECONDARY LOCALITIES}

Secondary localities were exposures of the Price Formation within the study area that contained sedimentary structures useful for paleocurrent analysis (Figure 27). Stratigraphic measurements, descriptions, and paleocurrent azimuths were recorded from 53 locations (Appendix II) and each location was assigned a number and grouped into members of the Price Formation (Appendix III). The localities were used in conjunction with the principal locations to plot rose diagrams for paleocurrent analysis.

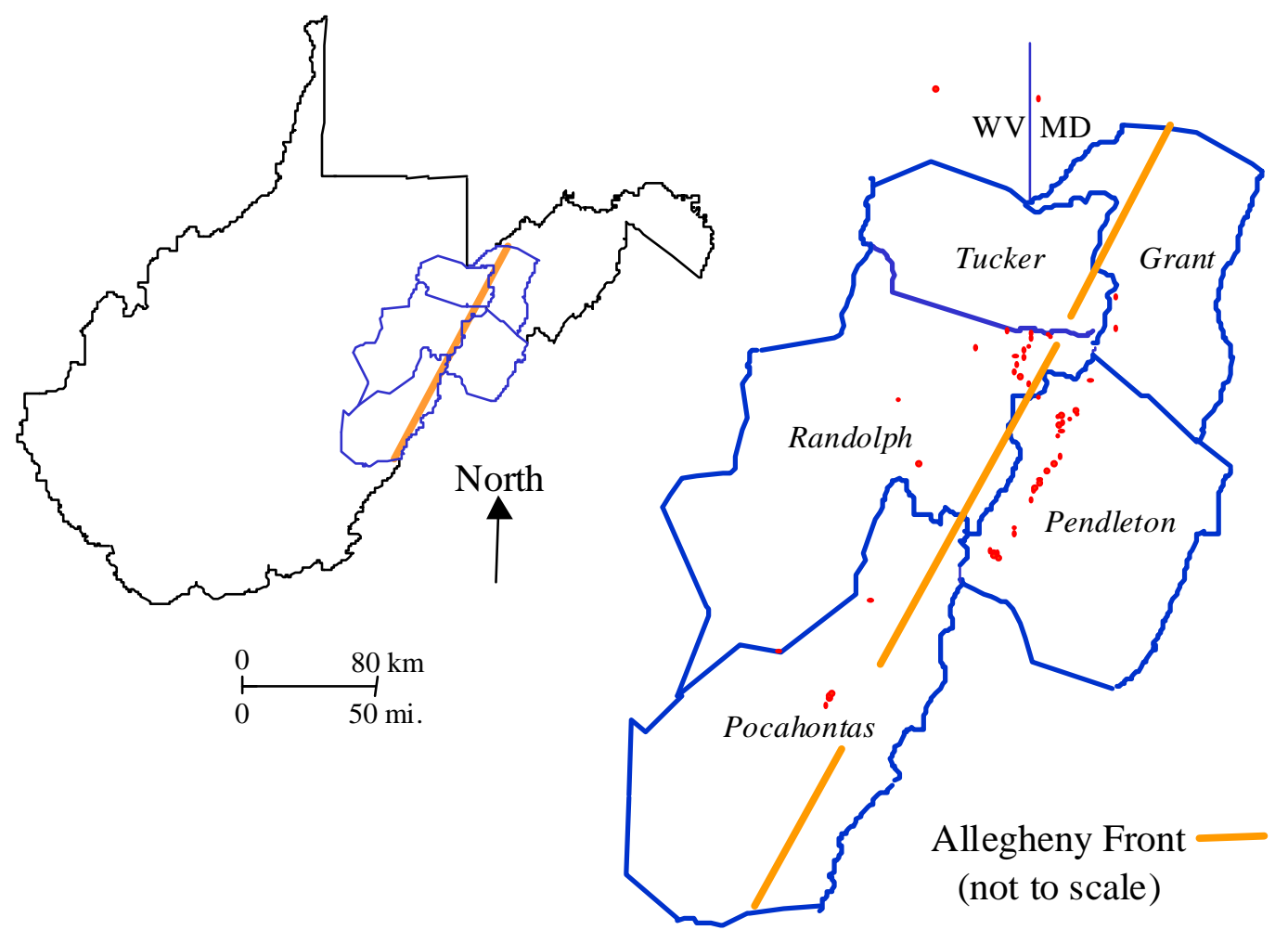

Figure 27. Secondary Localities 


\section{WEST VIRGINIA DOME \\ $\underline{\text { Regional Extent }}$}

The West Virginia Dome was a topographic high during the early Mississippian that formed the northern and southern basins in West Virginia. The original Pocono isopach map created by Dally (1956) and modified by Bjerstedt (1986) was redrafted for this study (Figure 1). The West Virginia Dome is a syndepositional fold or dome created by tectonism in the Appalachian basin that is apparent from a regional angular unconformity, facies relationships, and paleoflow patterns. The fluvial channels of the Rockwell Member indicate shifting paleoflow patterns associated with tectonism around the West Virginia Dome.

\section{$\underline{\text { Tectonic Implications }}$}

Evidence of tectonic control related to the origin the West Virginia Dome is seen in facies relationships (Appendix VI), widely spaced isopach patterns (Figure 1) and stacked shoreline and fluvial sandstones (Boswell, 1988). Changes in lithology in eastern- southeastern West Virginia reveals a north-south facies shift associated with variable water depths along depositional strike (Boswell, 1988; Kammer and Bjerstedt, 1986). Regional isopach maps indicated vertical sandstone stacking and shifting from shoreline and fluvial-distributary systems along the West Virginia Dome that is explained by different subsidence rates. Vertical sandstone stacking of shoreline facies was identified parallel and perpendicular to depositional strike and is not characteristic of clastic deposition (Boswell, 1988). Additionally, rapid lithologic thickening observed in the subsurface suggests boundary zones related to tectonic activity (Boswell, 1988). 
Boundary zones suggested by Boswell (1988) are probably related to unequal subsidence rates corresponding to movement along the Harrison and Barbour fault zones. Boswell (1988) suggested that the Harrison and Barbour fault zones are associated with Cambrian basement normal faulting. The Barbour fault is perpendicular to strike and was recognized by the vertically stacked fluvial sandstones within the Devonian Hampshire Formation, facies patterns in the Price Formation, and the sub-Greenbrier unconformity. Boswell (1988) proposed the Barbour fault zone as the northern edge of the West Virginia Dome.

Facies variations within the Mississippian Greenbrier Limestone reveal stratigraphic thinning across a topographic high during earliest Greenbrier deposition (Yeilding and Dennison, 1986). The West Virginia Dome, termed the Beverly Uplift by Yeilding and Dennison (1986), is covered by sandy carbonates, siltstones and supratidal to inter-tidal sediments. Lithologies grade into high-energy, shallow-water oolitic shoals consisting of oolites, bioclastic packstones, and wackestones (Yeilding and Dennison, 1986). Further evidence for the influence of the West Virginia Dome is the angular unconformity surface and reworked Price Formation sediments at the base of the overlying Greenbrier Limestone.

Yeilding and Dennison (1986) suggested the West Virginia Dome is associated with tectonism at the east end of the $38^{\text {th }}$ parallel fracture zone during the middle Mississippian. The West Virginia Dome is situated north of the $38^{\text {th }}$ parallel fracture zone, related to the Kentucky rift system (Bjerstedt and Kammer, 1988). Donaldson and Shumaker (1981) suggested the thick Mississippian sequence in southern West Virginia is related to subsidence associated with the $38^{\text {th }}$ parallel fracture zone. A northern-tilted, 
basement sub-block, subjected to thrust loading, is responsible for the West Virginia Dome.

Structural models presented by Slingerland and Beaumont (1989) for the Appalachian foreland basin illustrated how the superposition of peripheral bulges created broad intracratonic arches or domes. Peripheral bulges are lithosphere flexural responses to overthrust loading during continental collision that migrate ahead of thrust sheets and produce basin wide unconformities and differential rates of subsidence (Slingerland and Beaumont, 1989). The superposition of peripheral bulges develops because thrust loading is inconsistent at different localities within foreland basins creating sediment accumulation and subsidence in one locality along with adjacent flexural uplift and erosion zones. Peripheral bulges are parallel to strike whereas the West Virginia Dome is perpendicular to regional strike for the Appalachians.

Lewis (1983) suggested that the West Virginia Dome is associated with the Cambrian, cross-over rift zones, introduced by Donaldson and Shumaker (1981), that is revealed from sediment depositional patterns within the Catskill Delta of northeastern West Virginia. Isopach maps created for the Devonian Bradford, Speechley shale, Hampshire Formation, and the Price Formation correspond with the eastern margin of the Rome Trough and indicate greater than normal thickness associated with the crossover rift zones. These trends correspond to the Barbour and Harrison fault zones and the rapid sediment thickening suggested by Boswell (1988). Altered paleoflow patterns within the lower Rockwell (Figure28) and the upper Rockwell (Figure 29) coincide with the Cambrian crossover rift and lineations. 


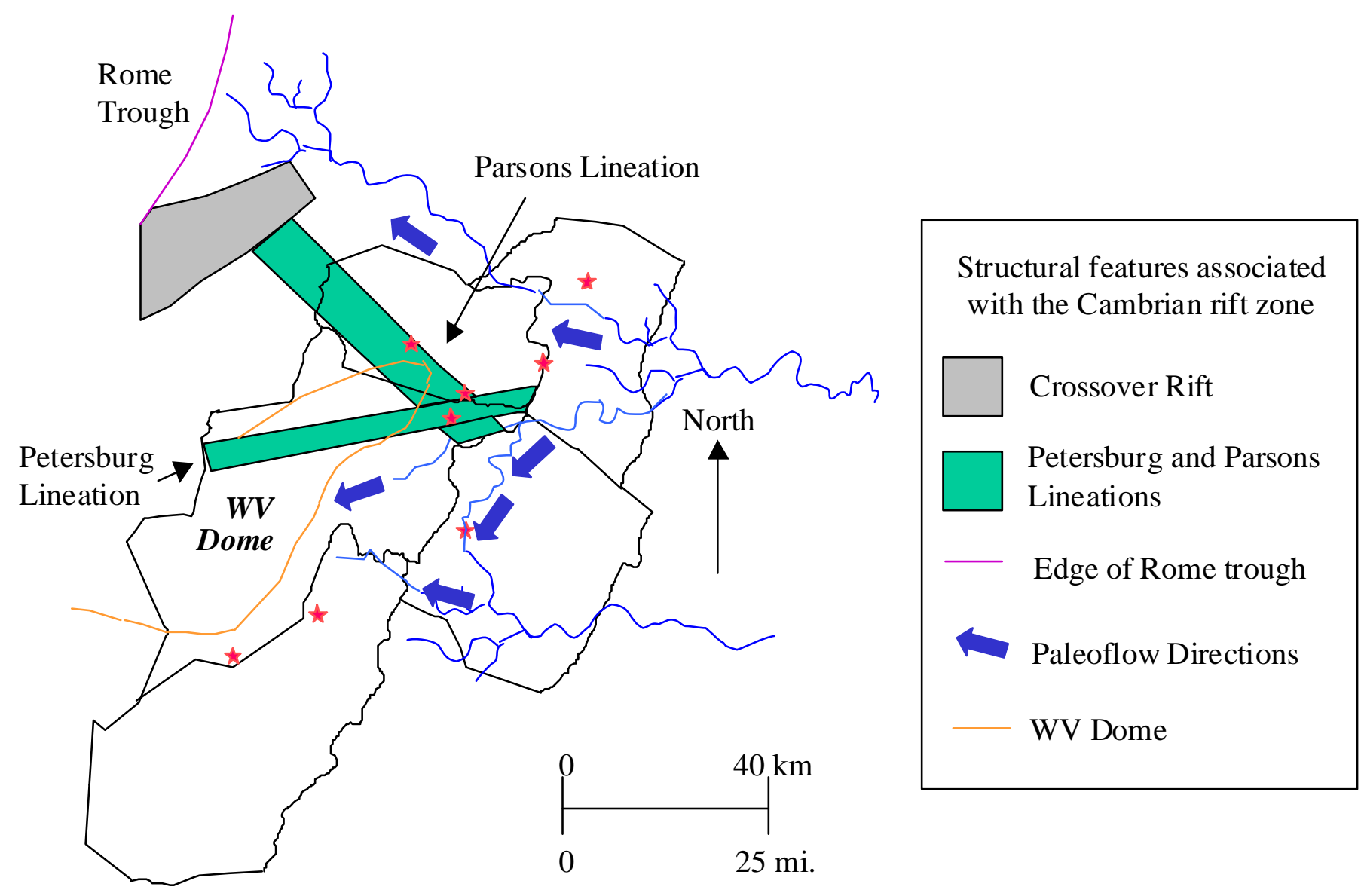

Figure 28. Paleoflow directions in the lower Rockwell associated with the Cambrian crossover rift and lineations modified from Lewis (1983). 


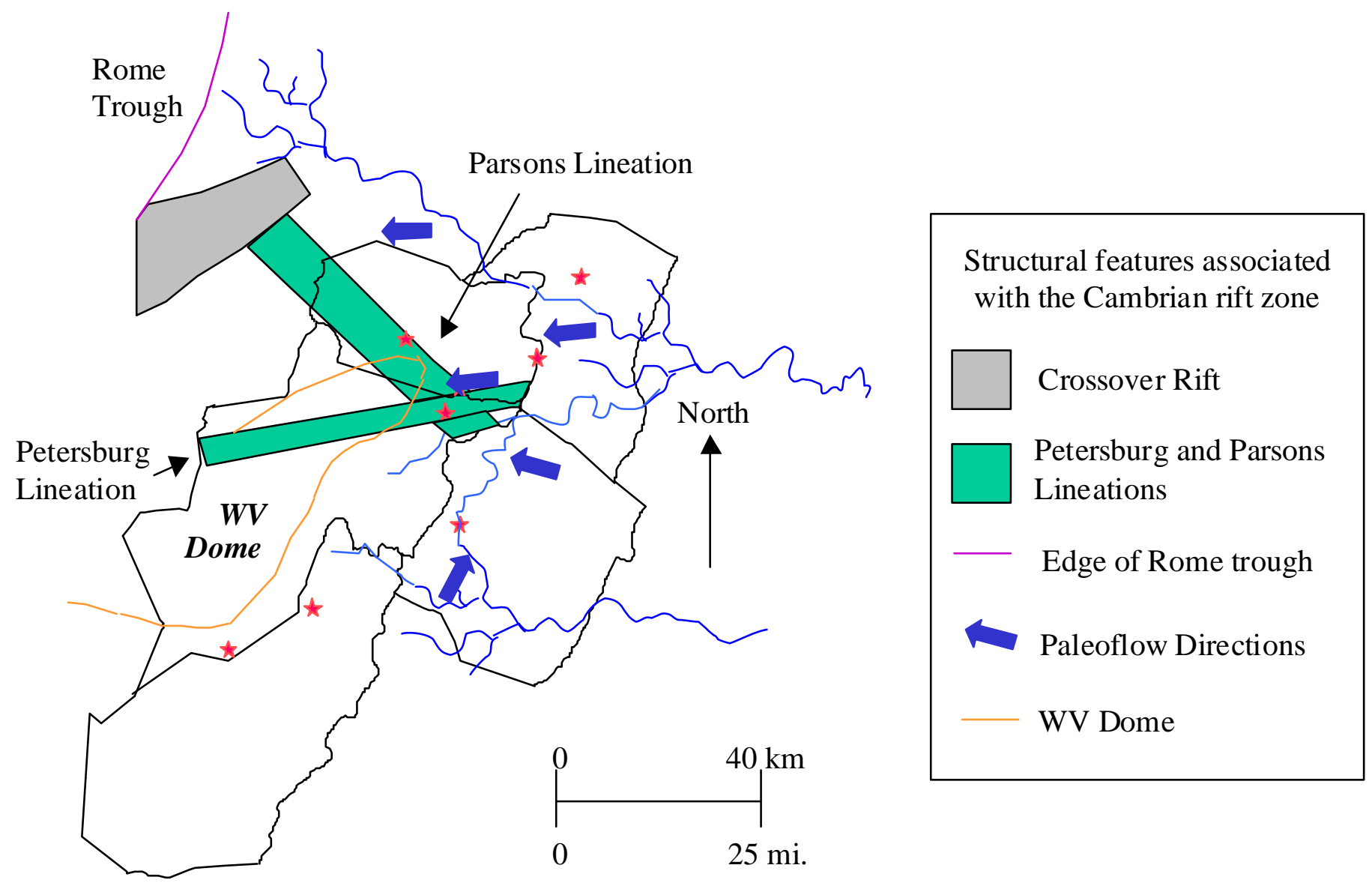

Figure 29. Paleoflow directions in the upper Rockwell associated with the Cambrian crossover rift and lineations modified from Lewis (1983). 


\section{PALEOENVIRONMENTS}

\section{$\underline{\text { Paleoslope }}$}

Meandering channels migrating from the west side of the Acadian Highlands were formed on a relatively shallow sloping landscape. Streams deposited sediment into a shallow marine environment in the northern basin during Oswayo time, while fluvial sediments of the Hampshire Formation prograded westward from the alluvial plain into the southern basin (Figure 30). Tectonism, subsidence, and base-level fluctuations that began in the late Devonian created the depositional basins and helped separate the marine and non-marine environments.

A eustatic rise in sea level caused transgression over the West Virginia Dome during Riddlesburg Shale time and deposited sediment into the northern and southern basins (Figure 31). Shallow-marine ichnofossils and body fossils were identified at the eight principal localities. A relatively shallow paleoslope is suggested because the Riddlesburg Shale transgressed to cover the West Virginia Dome. Fluvial sediments of the Hampshire Formation regressed to produce the alluvial plain that was located at present day Virginia.

Depositional paleoslope along the dome increased during Rockwell regression due to increased tectonism associated with normal faults and lineations (Figures 28 and 29). Increased paleoslope altered fluvial stream patterns flowing from the delta plain that was recorded within the lower and upper Rockwell Member. During the lower Rockwell, paleocurrents flowed southward along the eastern flank of the West Virginia Dome (Figure 32) whereas paleocurrents flowed northward at this same locality during upper Rockwell time (Figure 33). 


\section{Depositional Model}

Paleomagnetic data collected along eastern North America indicates that Upper Devonian-Lower Mississippian sedimentation was deposited at low latitudes near the equator (Kent, 1985). Climatic temperatures were warm to hot with variable rainfall patterns, high evaporation rates, and generally easterly winds (Kent, 1985). The Acadian Mountains were formed as Laurentia and Baltica collided during the Devonian and supplied sediment to the delta complex of the Price Formation. Sedimentation was largely affected by climate, regional and local tectonism, erosion rate, subsidence, and changes in local and eustatic sea level (Dennison, 1985).

The Oswayo Member of the Price Formation (Figure 30) represents a nearshore, shallow-marine environment located in the basin north of the West Virginia Dome that transgressed the alluvial plain of the Catskill delta. Trace fossils identified by the author at Laurel Run included Skolithos whereas Bjerstedt (1986) identified Diplocraterion, Planolites and Skolithos at Scherr. Diplocraterion, Planolites, and Skolithos are identified as belonging to the Skolithos ichnofacies that represents partially restricted shallow water within a lagoonal marine environment (Dodd and Stanton, 1990). The Skolithos ichnofacies appears in the intertidal and shallow shelf environment with daily changes in salinity, temperature, and light (Dodd and Stanton, 1990). Sand waves and tidal currents rework bottom sediments that contain predominantly vertical burrows.

Deeper water trace fossils identified by Bjerstedt (1986) outside this study area included Arthrophycus, Bifungites, Cruziana, Chrondrites, Palaeophycus, Rhizocorallium, Rosselia, Rusochycus, and Skolithos identified as within the Cruziana ichnofacies (Dodd and Stanton, 1990). This represents a transition from shallow to deep 
water into the northern and southern basins. Ichnofossils helped define the depositional environment and were the basis for separating the upper Hampshire Formation and lower Oswayo Member buff colored sandstones. The Hampshire Formation did not contain trace fossils in this study area.

The Riddlesburg Shale of the Price Formation (Figure 31) represents a nearshore, shallow-shelf marine environment that was deposited in the basins north and south of the West Virginia Dome. Ichnofossils and body fossils identified by the author at Durbin included Arenocolites and Diplocraterion (?), unnamed vertical and horizontal burrows at Briery Gap, and the inarticulate brachiopod Orbiculoidea newberryi at Hendricks. Bjerstedt (1986) identified numerous trace fossils and body fossils at Harman and Mace. The Harman locality contained Scalarituba, Helminthopsis, Phycosiphon, Pelecypodichnus, and Bifungites. Mace included the trace fossil Helminthopsis along with bivalues, planispiral gastropods, crizoan columnals, and Syringothyrsis angulata body fossils.

Ichnofossil assemblages and body fossils identified at Durbin, Harman, and Mace represent the Cruziana ichnofacies. Environmental conditions proposed include normal salinity, varying seasonal temperatures, high oxygen content, and a stable bottom setting (Dodd and Stanton, 1990). Horizontal grazing fossils dominates over vertical feeding burrows. Diplocraterion identified at Durbin may have been misidentified because this trace fossil typically is found in the Skolithos ichnofacies representative of higher salinities and less oxygen.

The Rockwell Member of the Price Formation represents an onshore fining upward sequence that is typical in fluvial deposition (Miall, 1981) (Appendix VIII). 
Sediments were probably deposited during regression in the northern basin with a small tongue protruding into the southern basin at Durbin. Meandering rivers flowing across the delta plain from the Acadian Mountains to the east were located in a humid, tropical region with high precipitation and runoff within heavily vegetated areas (personal communication, Mitch Blake, WVGES Geologist 2001). Distributary channels were redirected during tectonic processes associated with the West Virginia Dome and changed the flow patterns and distribution of sediment.

The lower Rockwell facies is a coarsening upward sequence from fine-grained sandstones, shales, mudstones, and claystones to conglomeratic sandstones interpreted as interdistributary overbank deposits. A lower flow regime is indicated at the base by wave or ripple bedding. A higher flow regime is indicated at the top by trough crossbedding. Channel width to depth ratios are low and indicative of laterally migrating channels (Reading, 1978). Flow within the main channel was diverted to the south along the eastern side of the West Virginia Dome (Figure 32).

The upper Rockwell facies is a fining upward sequence from coarse- to mediumgrained sandstones to fine-grained sandstones, shales, mudstone, and claystones interpreted as meandering channel deposits (Figure 33). Channel width to depth ratios are low and indicative of laterally migrating channels or infilling during channel abandonment. Higher flow regimes are apparent from trough crossbedding within the basal conglomeratic sandstones and result in unimodal paleoflows and point bar deposits. The system changed to a lower flow regime at the top with overbank deposits that consisted of siltstones, shales, and mudstones. Flow direction within the main channel was diverted to the north along the eastern side of the West Virginia Dome (Figure 39). 
This sequence represents delta progradation, alternating sand currents or channels, and fine-grained sediment deposition (Reading, 1978). 


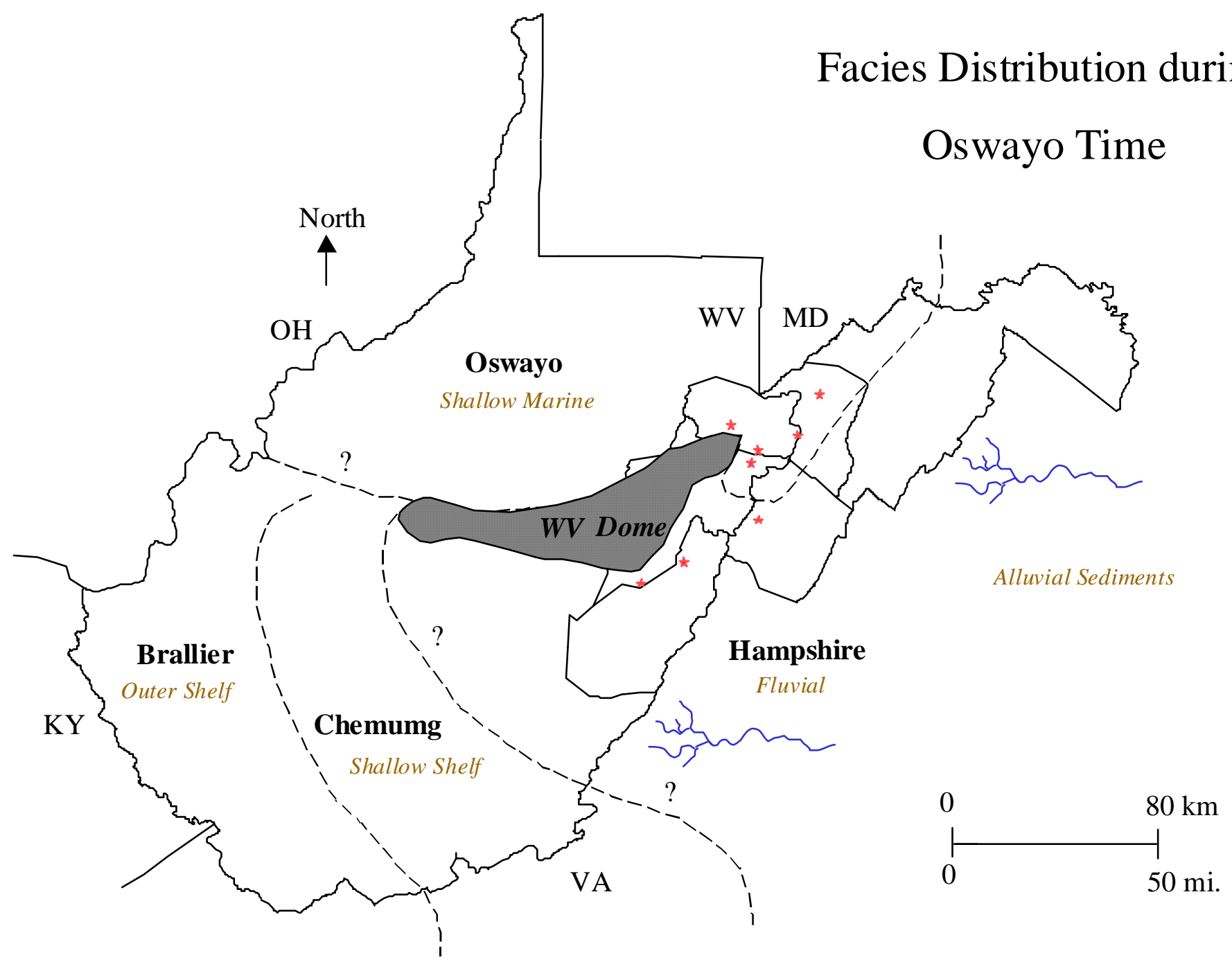

Figure 30. Facies distribution of the Price Formation during Oswayo time, modified from Bjerstedt (1986). 


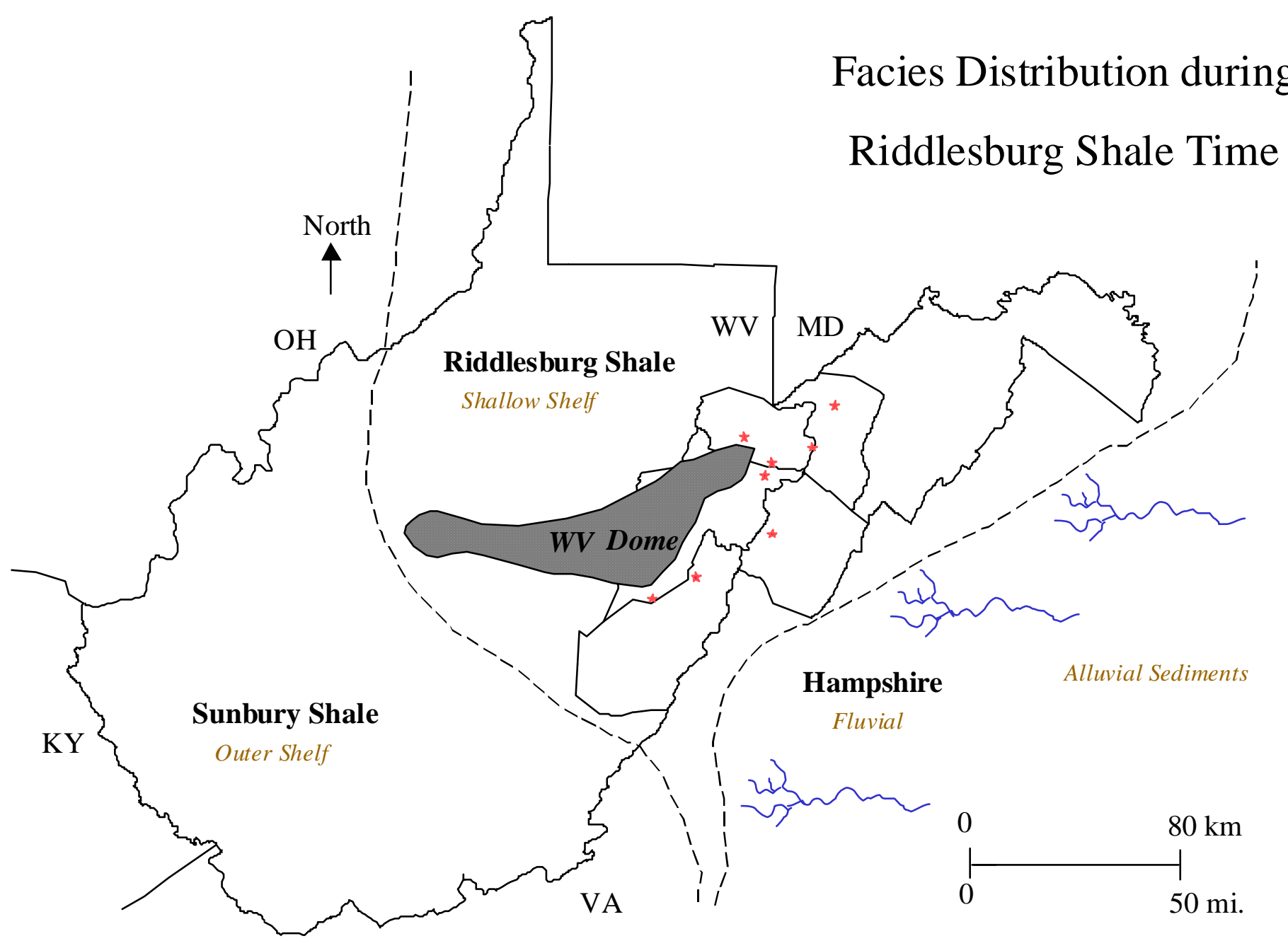

Figure 31. Facies distribution of the Price Formation during Riddlesburg Shale time, modified from Bjerstedt (1986). 


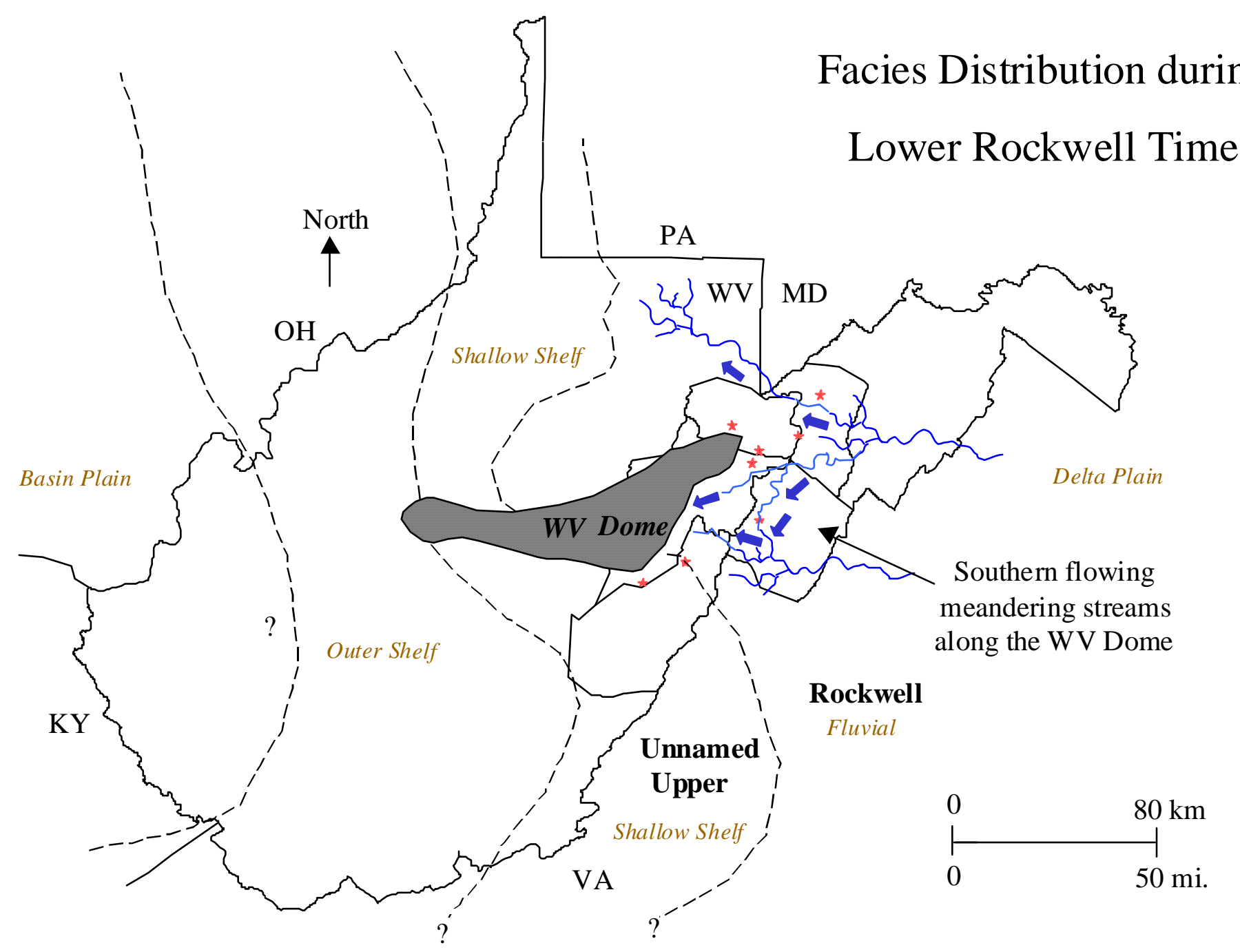

Figure 32. Facies distribution of the Price Formation during the lower Rocwell Member, modified from Bjerstedt (1986). 


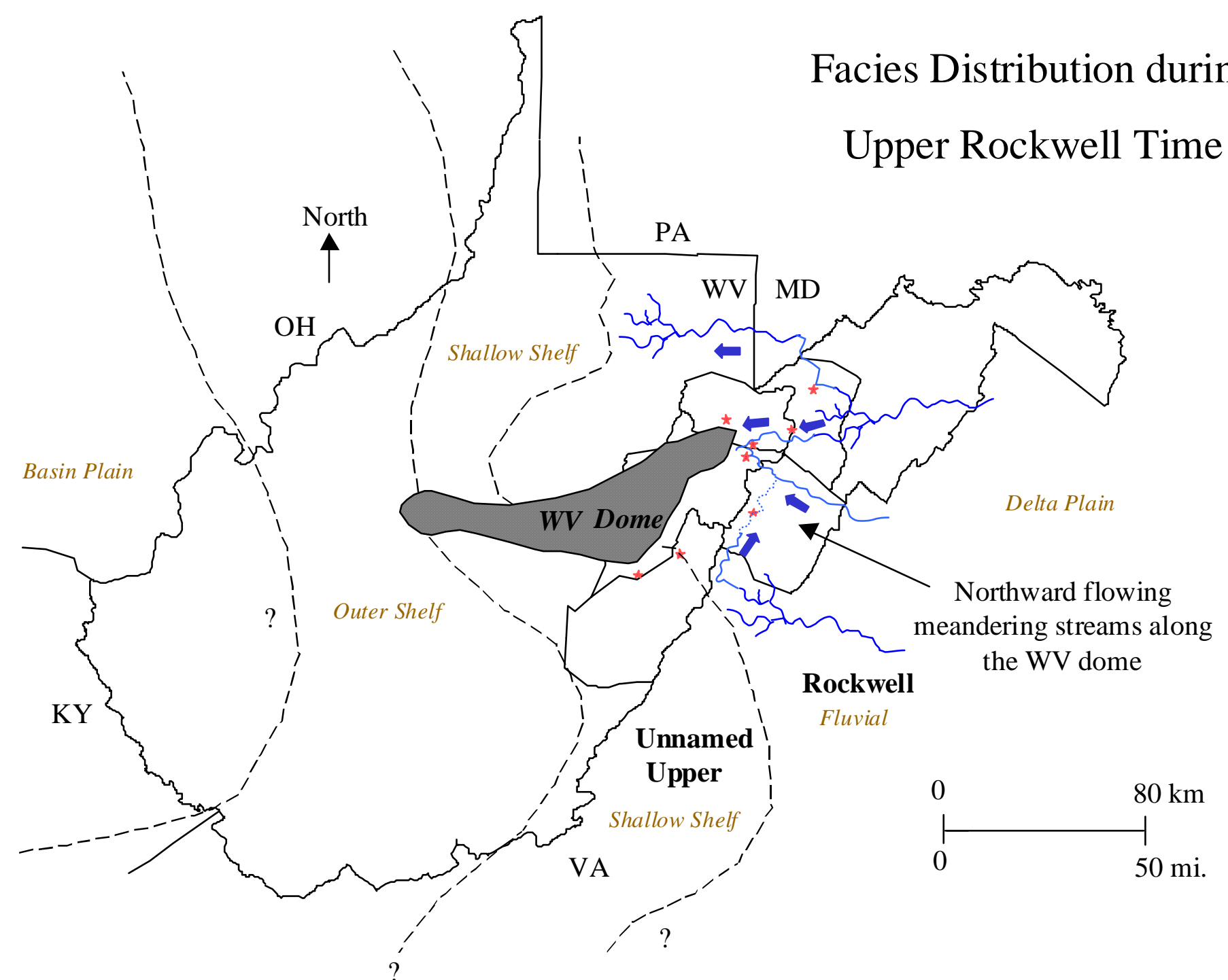

Figure 33. Facies distribution of the Price Formation during the upper Rockwell Member, modified from Bjerstedt (1986). 


\section{PALEOCURRENT DATA \\ Planar Crossbedding}

Three-dimensional View

Calculating paleocurrent directions from planar crossbeds requires clear and attainable three-dimensional surfaces for accurate measurements. Determining flow directions depends on the crossbed orientation, therefore making three-dimensional exposure surfaces essential. Planar crossbedding recognized in this study included lowangle, high-angle, and tabular bed sets. Since outcrop exposures were poor and not always easily accessible, paleocurrent measurements were recorded from the best available three-dimensional surfaces.

Two-dimensional surfaces indicate apparent paleoflow patterns rather than true ones. Paleocurrent measurements taken from two-dimensional unconstrained surfaces will produce inaccurate readings with errors as great as ninety degrees. Planar crossbed sets in two-dimensions appear to suggest flow parallel to the outcrop (Figure 34). Flat, two-dimensional surfaces without any indication about the three-dimensional nature of the bedsets can create significant data collection errors and false paleoflow directions.

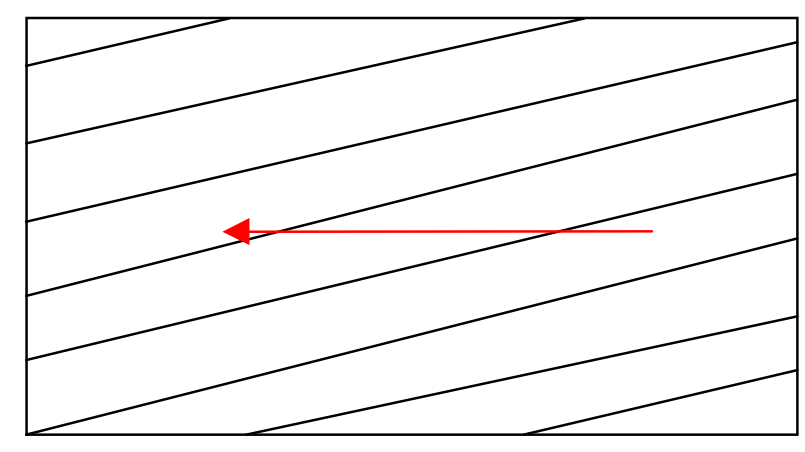

Figure 34. Two-dimensional planar crossbedding indicating apparent flow direction 
Three-dimensional surfaces are necessary to determine the true orientation of flow. A horizontally bedded, third planar surface indicates flow in the direction of twodimensional crossbedded surfaces, however interpretations are inaccurate unless this third surface is revealed (Figure 35). Inclined beds on the third planar surface show flow directions oblique from the two-dimensional cross-stratification (Figure 36).

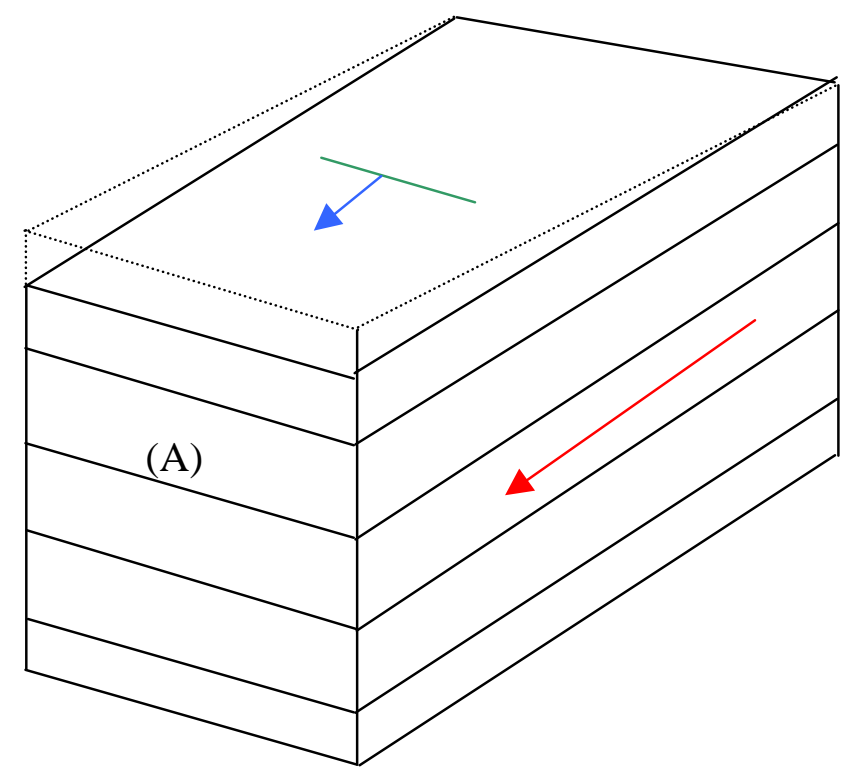

Figure 35. Three-dimensional crossbedding with the strike of the bed (green) and the true flow direction (blue). The two-dimensional and three-dimensional flow directions are the same in this situation, however this would be misleading without an accurate three-dimensional surface labeled (A) in the diagram. 


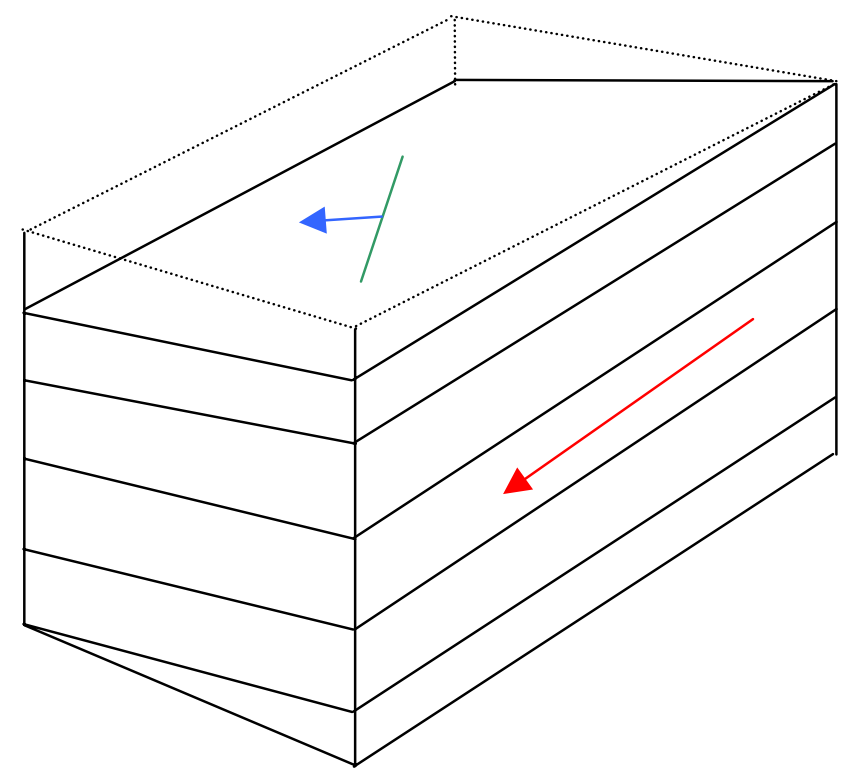

Figure 36. Three-dimensional crossbedding with the strike of the bed (green) and the true flow direction (blue). Red line indicates the apparent flow direction in two dimensions.

\section{Planar Crossbedding Strike and Flow Directions}

Measuring the strike of planar or tabular crossbedding from three-dimensional surfaces is the basis for determining paleoflow directions. Utilizing the board technique (Figure 10) allowed accurate measurements to be recorded because the board acts as an extension of the bedding surface. Paleoflow directions from the dip of the crossbeds on the three-dimensional surface represent sand waves and are oriented 90 degrees to strike in the direction of dip. Paleocurrent readings can vary within about 10-15 degrees of the true flow direction. 


\section{Trough Crossbedding}

Trough crossbedding is one of the most reliable sedimentary structures used to determine paleoflow directions in fluvial systems (DeCelles, Langford, and Schwartz, 1983). Even though fewer readings are required compared with planar crossbedding (Dott, 1974), determining the orientations and true geometry of two-dimensional trough crossbedding from outcrop is difficult. Trough crossbed geometry depends upon the degree of plunge of large-scale trough sets. Gently plunging ( $<10$ degrees), large-scale tough beds are cylindrically shaped and are observed approximately $80 \%$ of the time in random outrop cuts (DeCelles, Langford, and Schwartz, 1983). Steeply plunging (20-25 degrees) a) large-scale tough beds are scoop-shaped and are observed $20 \%$ of the time in random cuts (DeCelles, Langford, and Schwartz, 1983). The observed trough crossbedding in this study were gently plunging.

The trough crossbeds frequently appear in transverse vertical, oblique vertical, transverse oblique, oblique oblique, and longitudinal cuts within planar cuts (Figures 37, 38, and 39). Identifying the type and true trough-crossbed orientation depends upon the symmetry, asymmetry, and truncation of foreset beds within the trough. For the most part, all trough crossbedding observed during this study were symmetrical with low plunge. Trough crossbed geometries were mostly transverse vertical (see Figure 37). This allowed relatively accurate measurements of the paleocurrent direction. 

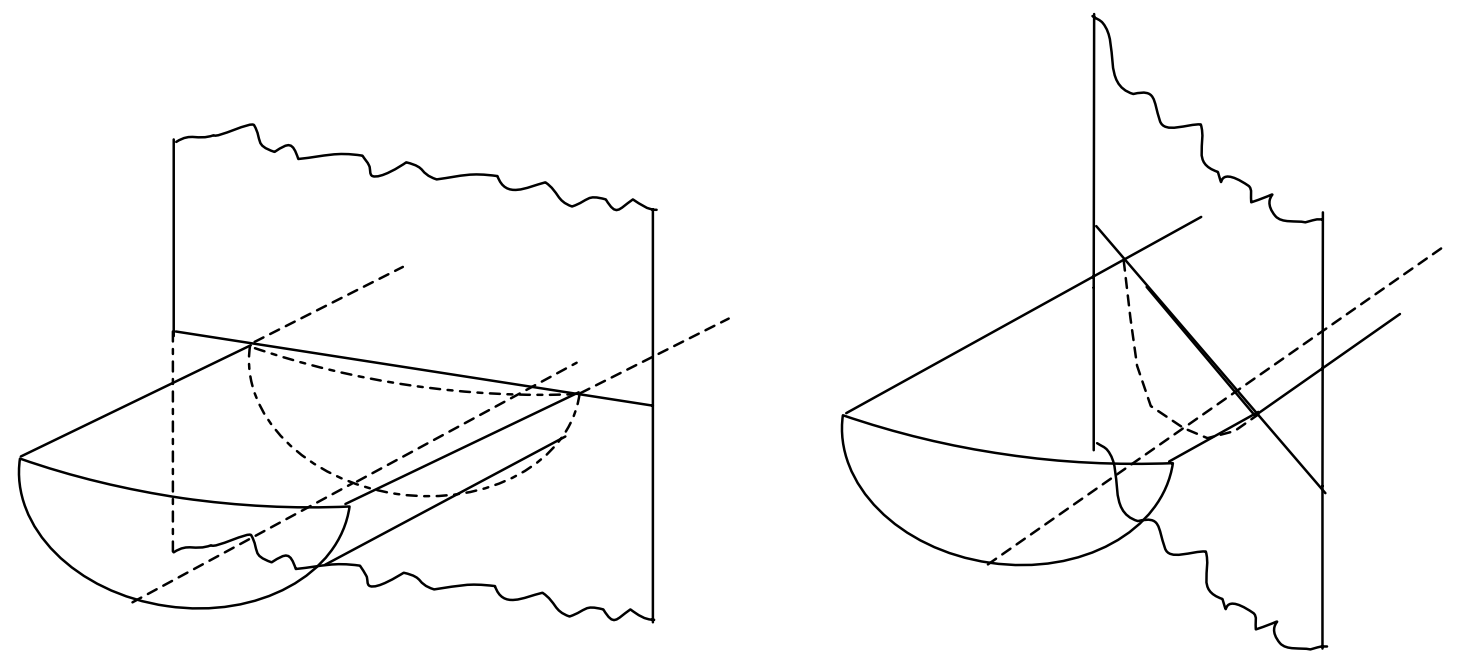

Figure 37. Example of transverse vertical (left) and oblique vertical (right) modified from DeCelles, Langford, and Schwartz (1983).
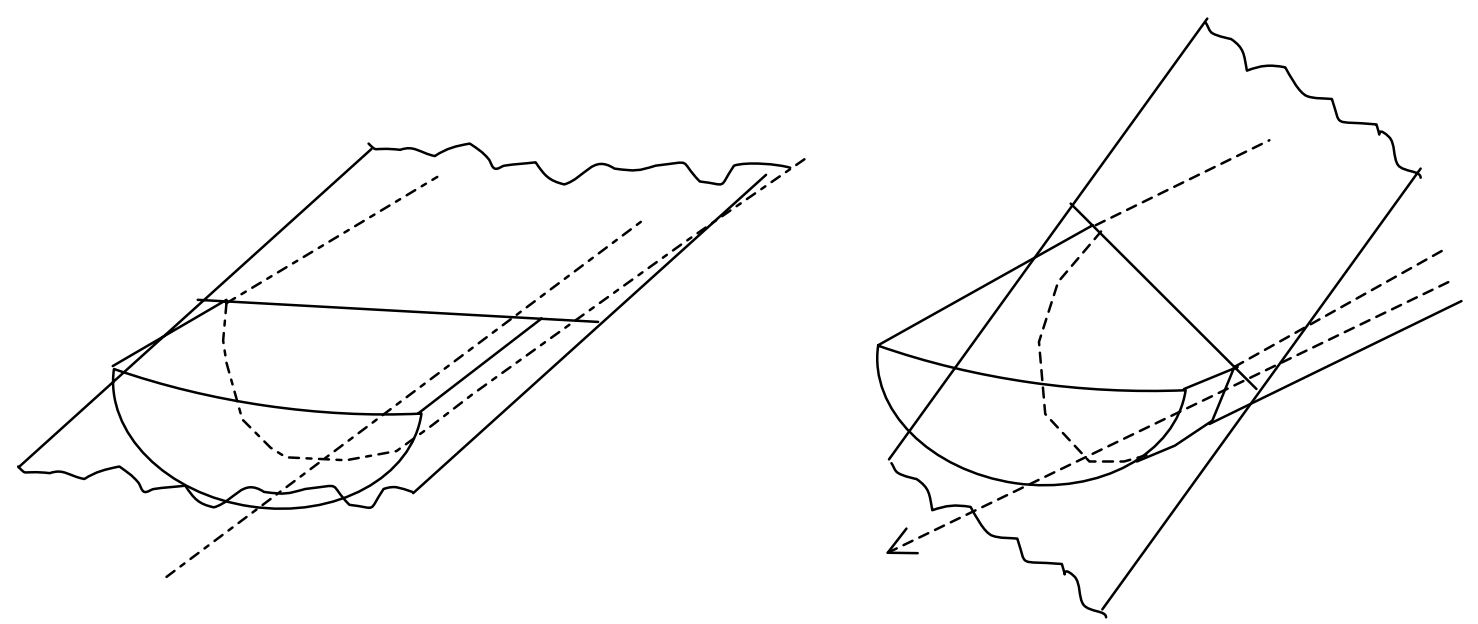

Figure 38. Examples of transverse oblique (left) and oblique oblique (right) modified from DeCelles, Langford, and Schwartz (1983). 


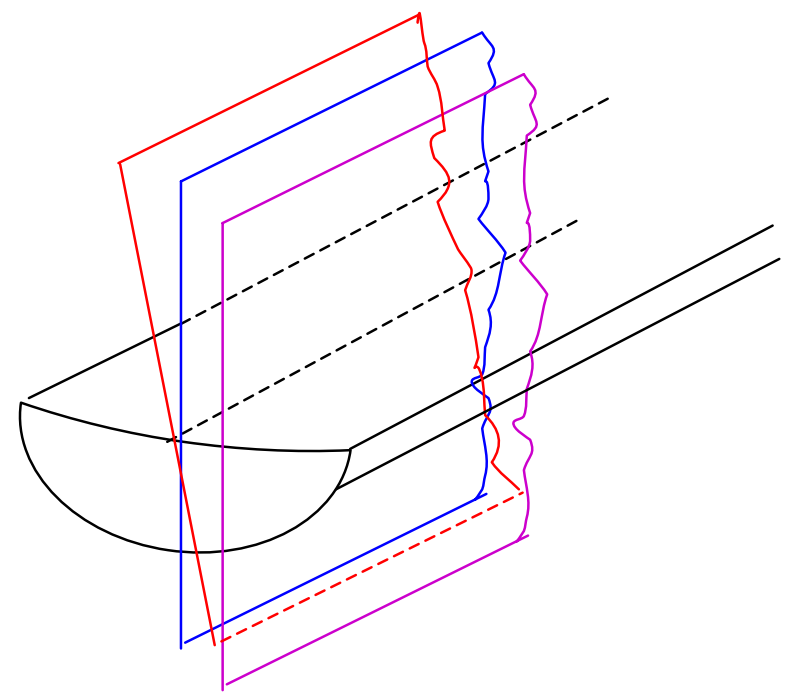

Figure 39. Example of longitudinal cuts through a trough crossbed as centered vertical (blue), off-centered vertical, and centered non-vertical.

\section{Channel Width}

Determining the channel width is important when defining depositional systems in fluvial or marine environments. The morphology of the channel depends upon many factors that include sediment type, the amount discharge, slope, tectonics, vegetation, and climate within the system (Reading, 1978). Channels with higher portions of finegrained sediment and cohesive banks tend to meander whereas streams with coarse sediment and non-cohesive banks tend to be braided (Reading, 1978).

\section{Ripples}

Asymmetrical ripples are reliable paleocurrent indicators because unimodal paleoflow directions are obtainable from the lee side of the ripple. The lee side is 
perpendicular to the crest of the ripple. Two asymmetrical ripples were recorded from secondary localities 12 and 17 with paleocurrent azimuths at 115 and 235 degrees. A diagram was sketched for each that indicated the paleocurrent azimuth, the strike of the ripple, and a north arrow.

Symmetrical ripples are reliable paleocurrent indicators and indicate bimodal paleoflow directions. Four asymmetrical ripples were recorded from secondary localities $22,27,44$, and 54 with bimodal paleocurrent azimuths at 160 or 340,20 or 200,130 or 310 , and 15 or 195 degrees. A diagram was sketched for each that indicated the paleocurrent azimuth, the strike of the ripple, and a north arrow.

\section{Flute Marks}

Flute marks are excellent erosional sedimentary structures used for paleocurrent analysis. The paleoflow direction was recorded away from the rounded head in the long axis direction. One flute mark was recorded from secondary locality number two with a paleocurrent direction of 210 degrees. A diagram of the flute mark was sketched that indicated the shape, current direction, and a north arrow. 


\section{ANALYSES}

\section{$\underline{\text { Rose Diagrams }}$}

Paleocurrent data were separated by members and designated as marine or non-marine within of the Price Formation. Nearly all azimuth readings were collected from the Rockwell Member because this interval is highly resistant to weathering and is well exposed. The Rockwell also preserves numerous fluvial channels with abundant sedimentary structures.

Data were limited in the uppermost Devonian Hampshire Formation, Oswayo Member, and the Mississippian Riddlesburg Shale Member. Eleven paleocurrent readings were collected from the Hampshire Formation at five localities (Figures 94-99). One azimuth reading was collected from the Oswayo Member (Figure 100) whereas 12 readings were recorded from the Riddlesburg Shale at eight localities (Figures 101-108). Individual azimuths were plotted for each formation or member (Appendix III), however the data were not statistically significant because the number of readings was too small; in addition, the Oswayo and Riddlesburg Shale members revealed bimodal distributions within marine environments.

The Rockwell Member was separated into a lower and upper section based on opposing paleoflow directions. Paleocurrent indicators identified in the field were keyed to correct stratigraphic position. Paleocurrent data were grouped according to the section where they were collected. Crossbed data recorded for the Rockwell Member yielded 142 individual azimuth readings with 63 azimuth readings in the upper Rockwell and 79 azimuth readings from the lower Rockwell.

Crossbedding was recorded as either uni-directional (Figure 40) or bi-directional (Figure 41). Planar crossbed sets in three dimensions indicated unimodal current flow directions, therefore only trough crossbeds could contain bi-directional data. Determining the two- 
dimensional azimuth readings from trough crossbedding depends upon the geometry of the trough and the orientation of the foreset beds within the trough (DeCelles and Langford, 1983). Three-dimensional trough crossbeds observed in plan view indicate accurate uni-directional flow because variability in flow direction can be recognized. Flute marks on the bottoms of beds and asymmetrical ripples were also used to determine flow direction. One flute mark was recorded with an azimuth of 210 degrees and two asymmetrical ripples at 115 and 235 degrees.

Rose diagrams were plotted from both primary and secondary localities to determine mean paleoflow directions. Circular histograms display the total number of observations and the mean vector, circular variance, circular standard deviation, and standard mean of error were calculated (Figure 40). The total number of observations refers to the paleocurrent azimuths applied to create the rose diagram and the mean vector is the sum of all observations divided by the number of observations to produce the average paleocurrent direction.

The circular variance is the dispersion about the mean within 360 degrees. The circular standard deviation is the square root of the variance indicating the dispersion on both sides of the mean (Davis, 1986). The standard mean of error is the variability that can be expected in the mean of samples by repeated random collection from the same population (Davis, 1986). Two means were calculated if locations contained uni-directional and bi-directional data. Measurements at certain localities included multiple readings of the same azimuth that were indicated by frequency circles on the diagram. 


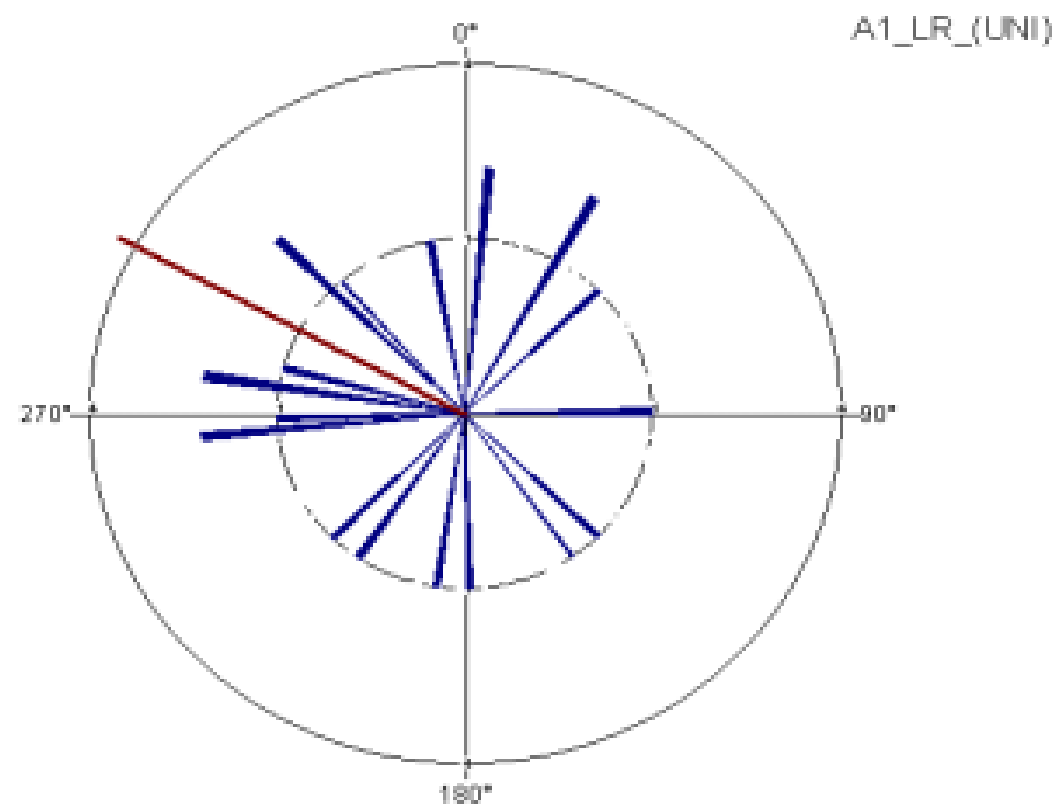

Figure 40. Example of data from planar crossbedding where flow direction could be resolved. Length of vector reflects the number of readings with a particular azimuth. Inner circle on diagram represents one reading. The red line is the mean vector.

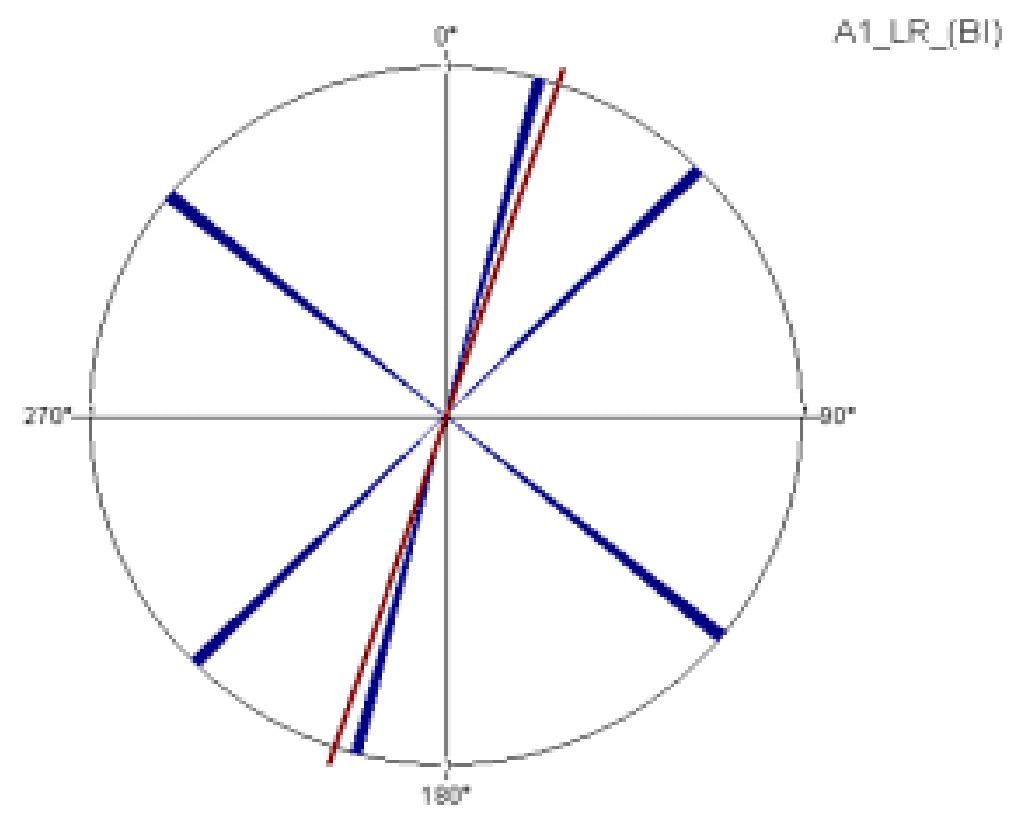

Figure 41. Example of data from trough crossbedding where flow direction could not be resolved. 


\section{Uni-directional Data}

Azimuth data collected from the Rockwell Member were grouped into seven areas to obtain enough azimuth readings for paleocurrent analysis (Figures 42 and 43). The author concluded that six was a desirable cutoff for the number of azimuth readings in each area, however paleocurrent data collected in areas 5, 6, and 7 from the lower Rockwell (Figure 42) and areas 1, 3, 5, 6 in the upper Rockwell (Figure 43) contained less than six azimuth readings per area. Rose diagrams were plotted for this data even though six was the desired cutoff. The Rockwell Member was the only Member of the Price Formation that contained enough data for paleocurrent analysis. Unimodal data was collected from the fluvial Hampshire Formation, but the data were limited and insufficient for generating statistically significant results.

Paleocurrent data were plotted as rose diagrams to ascertain the mean paleoflow direction and circular standard deviation for each area. The grouped areas for the upper and lower Rockwell were the same in order to identify changes in paleoflow. The total number of observations for the lower and upper Rockwell within each area was entered into a statistical program that randomly generated standard deviations for observations ranging from 1-360 degrees (Appendix III). Circular standard deviations calculated from rose diagrams were looked up on the chart in Appendix III to determine the probability of randomness of the data.

The author concluded that a probability of randomness less than $12 \%$ was statistically significant for the paleocurrent data. Area 4 from the lower Rockwell (Figure 42) had a 50\% probability of randomness and area 2 from the upper Rockwell (Figure 43) had a 40\% probability of randomness. Therefore, paleocurrent data from area 4 from the lower Rockwell and area 2 from the upper Rockwell were considered statistically insignificant by the author. Paleocurrent data from areas 1-3 and 5-7 from the lower Rockwell (Figure 42) and areas 1 and 3- 
6 from the upper Rockwell (Figure 43) had probabilities of randomness less than 12\% and were considered statistically significant.

Mean Azimuth Paleoflow Directions

Unimodal paleoflow patterns were significantly different within the Rockwell Member. A vertical change in paleoflow was identified between the lower and the upper Rockwell Member therefore the Rockwell was subdivided into two sections. The lower Rockwell was interpreted as a coarsening-upward sequence whereas the upper Rockwell was interpreted as a fining upward sequence. Bimodal paleoflow was discounted; paleoflow directions could not be further resolved.

Paleocurrent data collected from the lower Rockwell (Figure 42) indicated a southeastern flow direction along the eastern side of the West Virginia Dome at areas 2 and 3. Areas 1, 5, 6, contained paleoflow directions predominantly to the northwest whereas the paleoflow direction at area 7 was to the southwest. The probability of randomness for data at area 4 was $50 \%$ and was considered statistically insignificant; therefore its mean azimuth direction was discounted. The interpretation was that uplift associated with the West Virginia Dome altered the mean paleoflow directions during lower Rockwell.

Paleocurrent data collected from the upper Rockwell (Figure 43) indicated a northeastern flow direction along the eastern side of the West Virginia Dome at area 1. The mean paleoflow direction at area 3 was to the northwest; areas 4 and 5 indicated a southwestern paleoflow and area 6 indicated a westward paleoflow. The probability of randomness at area 2 was $40 \%$ and was considered statistically insignificant; therefore its mean azimuth reading was discounted, even though areas 1 and 2 had similar paleoflow directions. The interpretation was that uplift 
associated with the West Virginia Dome altered the mean paleoflow directions from the lower Rockwell in the upper Rockwell.

\section{Trough Height}

Trough heights remained relatively consistent from the lower to the upper the Rockwell (Figures 44 and 45). The modal height of the paleocurrent data was calculated for each area in the upper or lower Rockwell. Modes in the lower and upper Rockwell were 0.15, 0.30, and 0.91 meters in height. The lower Rockwell modal height at area 7 was 0.15 meters whereas areas 1, 3, 4, and 5 contained modal heights of 0.30 meters. Area 1 in the upper Rockwell at areas 1 contained a modal height of 0.15 meters whereas areas 3,4 , and 6 were 0.30 meters and area 5 was 0.91 meters.

The heights of trough crossbedding the lower and upper Rockwell in this study are interpreted as megaripples because modal heights were greater than $5 \mathrm{~cm}$ and less than 1 meter. Variations in ripple geometry with depth is negligible for flow depths greater than a few times the ripple height, however as depth decreases to a few centimeters, surface waves substantially changes the geometry of the ripples (Harms, Southard, Spearing, and Walker, 1975). Ripples forming in fine sediment during low flow have more angular foreset-toeset contacts than ripples formed at higher velocities which is useful for detailed interpretations of flow conditions (Harms, Southard, Spearing, and Walker, 1975).

The approximate mean flow velocity for megaripples at a mean flow depth of $20 \mathrm{~cm}$ is 35 $\mathrm{cm} / \mathrm{sec}$ although the mean flow depth is dependent upon grain size (Harms, Southard, Spearing, and Walker, 1975). At a flow depth of $20 \mathrm{~cm}$ with a mean flow velocity of $35 \mathrm{~cm} / \mathrm{sec}$, the mean grain size is approximately $0.5 \mathrm{~mm}$. The thickness of the troughs $(0.30 \mathrm{~m})$ suggests a minimum 
flow depth with relatively low flow velocities (Harms, Southard, Spearing, and Walker, 1975). The mean flow depth could not be calculated because only an average grain size was recorded for each unit.

\section{Grain Size}

Grain size was ranked as very fine-, fine, medium, coarse, and very coarse-grained and the average grain size was recorded at each outcrop. Grain size variation and distribution are different in the lower and upper Rockwell (Figures 46 and 47). The lower Rockwell is very coarse grained in areas 2, 3, 4, and 5 (Figure 46). Area 2 and 5 contain four localities that are very coarse-grained. Area 3 has five localities with three locations that are very coarse grained and two locations that are medium grained. Area 4 has a total of six localities with two locations that are very coarse-grained, two locations that are medium-grained, and two locations that are fine-grained. Areas 1 and 6 contain a total of eight localities that are very fine to fine-grained and area 7 has one location that is medium-grained.

The upper Rockwell contains fine-grained lithologies compared to the lower Rockwell (Figure 47). Areas 1 and 5 contain two locations that are very fine-grained, however area 6 has only one location that is very coarse-grained. Areas 3 and 4 contain four locations that are medium-grained and four locations that are fine-grained. Area 2 is very fine and fine-grained and contains one coarse-grained location.

High flow velocities associated with dunes usually consist of coarse-grained sediment at shallow depths, although dunes can appear in deep water (Harms, Southard, Spearing, and Walker, 1975). The grain size distribution in the lower Rockwell (Figure 46) was interpreted as within the lower flow regime at high velocities along the eastern flank of the West Virginia 
Dome whereas the upper Rockwell (Figure 47) was interpreted as within the lower flow regime at low velocities. The average grain size was recorded at both primary and secondary localities, however using thin section point counts or the 10 largest grains would generate more reliable results.

Bi-directional Data

The number of bimodal data collected from trough crossbedding in the Rockwell Member were insignificant compared to the unimodal data and flow directions could not be resolved (Figure 41). Two-dimensional trough crossbedded surfaces may contain the same paleoflow azimuth readings as the unimodal trough crossbeds within the same outcrop, however no assumption was made as to not bias the data set. Non-plunging troughs were more accurately measured compared to plunging beds within each trough-crossbed.

Data collected from the Oswayo and Riddlesburg Shale facies were plotted into rose diagrams (Figures 100-108). The data were limited in number and undesirable for paleocurrent analysis. The Oswayo and Riddlesburg Shale are interpreted as marine environments and the sedimentary structures are related to tidal channels and longshore currents that display unimodal or bimodal distributions. Therefore, marine paleocurrent distributions are unrelated to paleoslope and not applicable to this study (Shelly, 1967). 


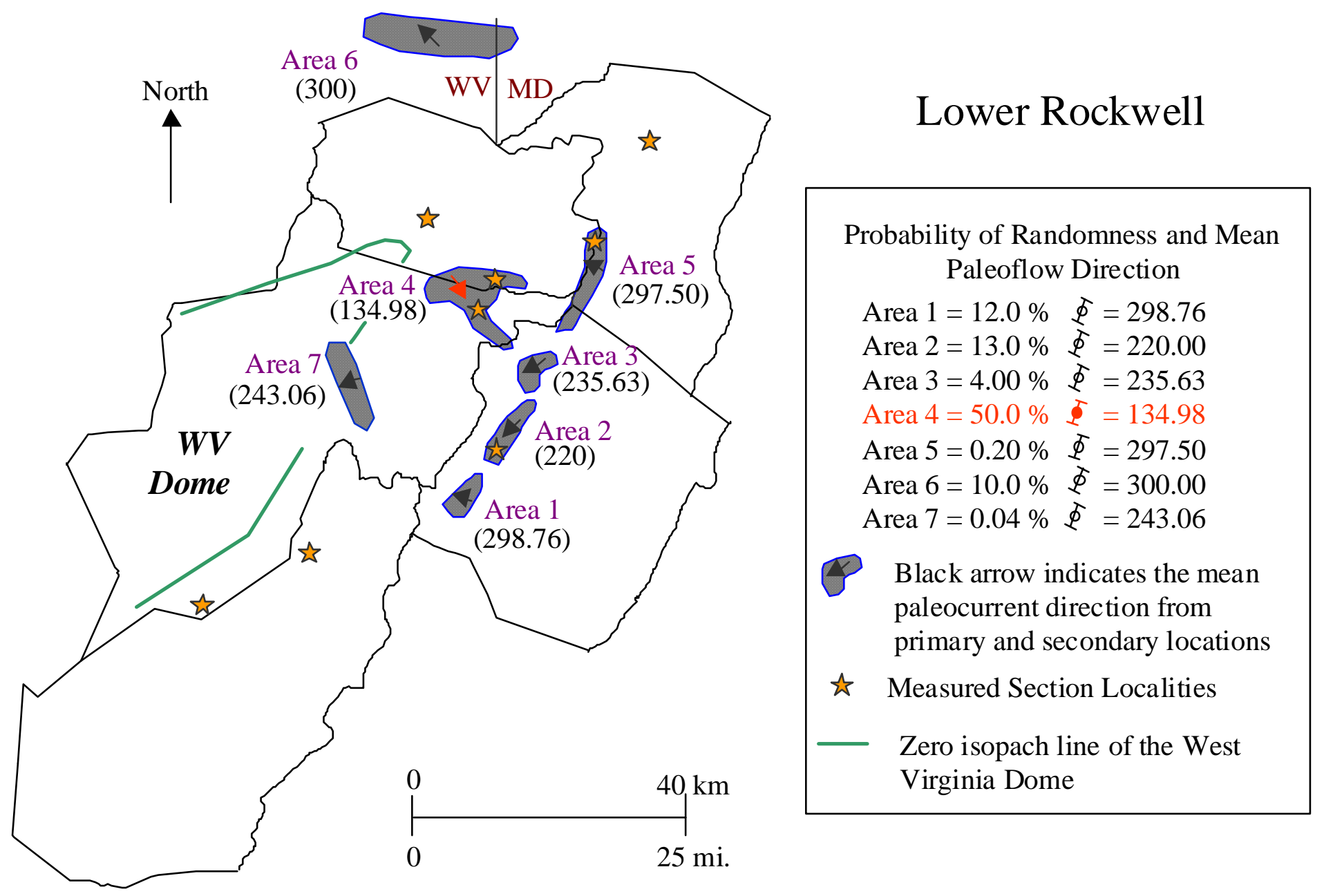

Figure 42. Unimodal paleoflow patterns in the lower Rockwell 


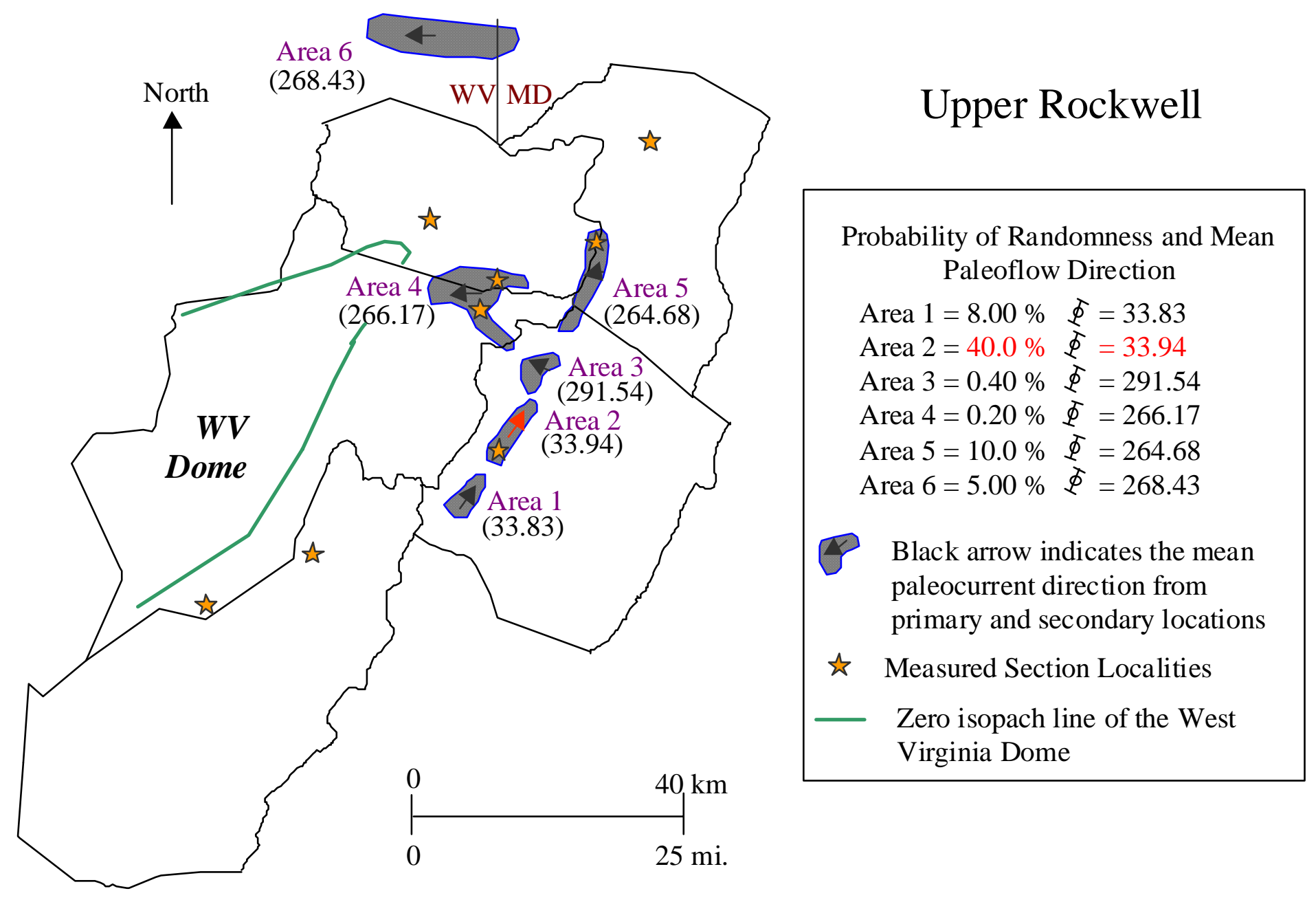

Figure 43. Unimodal paleoflow patterns in the upper Rockwell 


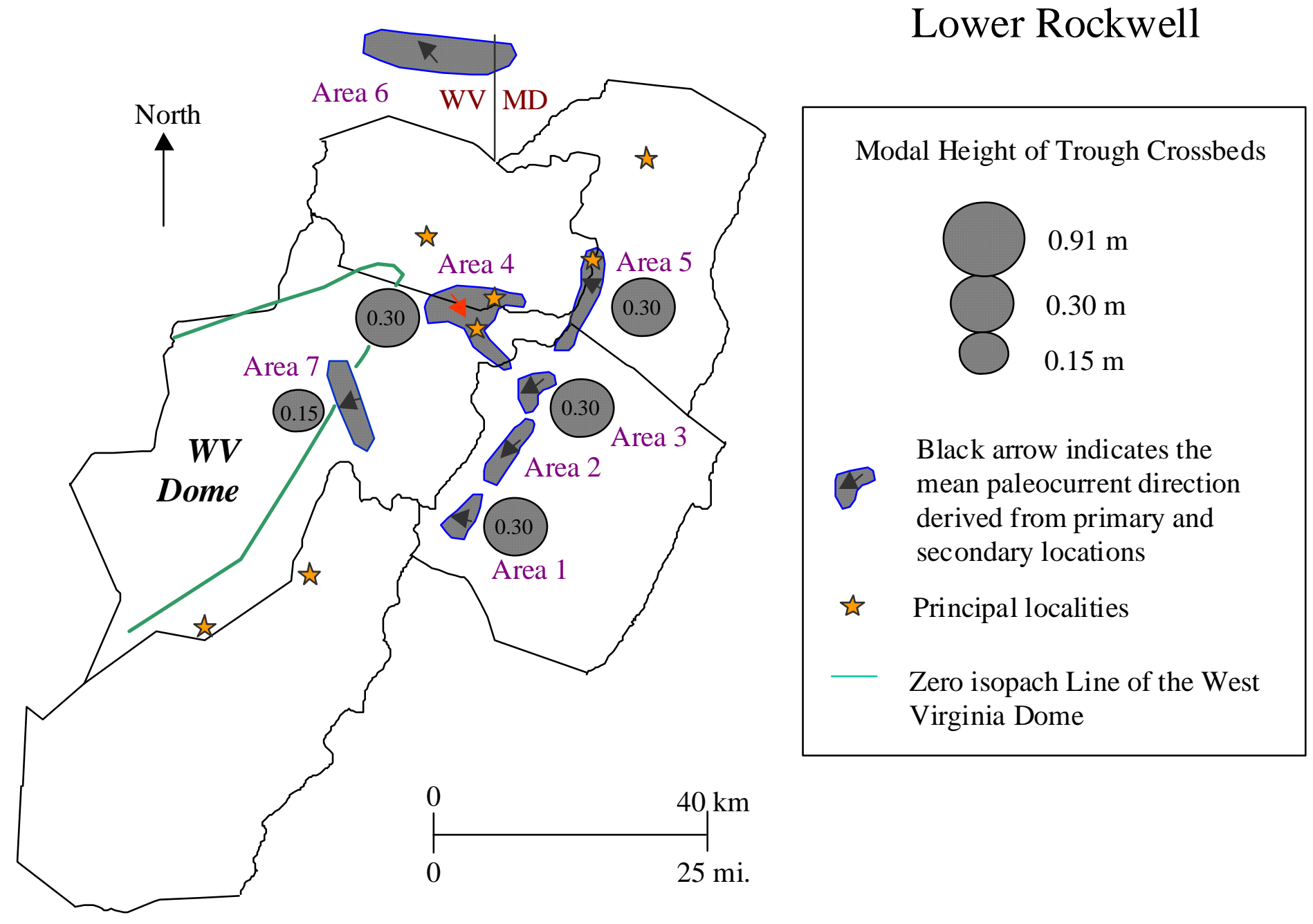

Figure 44. Modal height of trough crossbedding in the lower Rockwell 


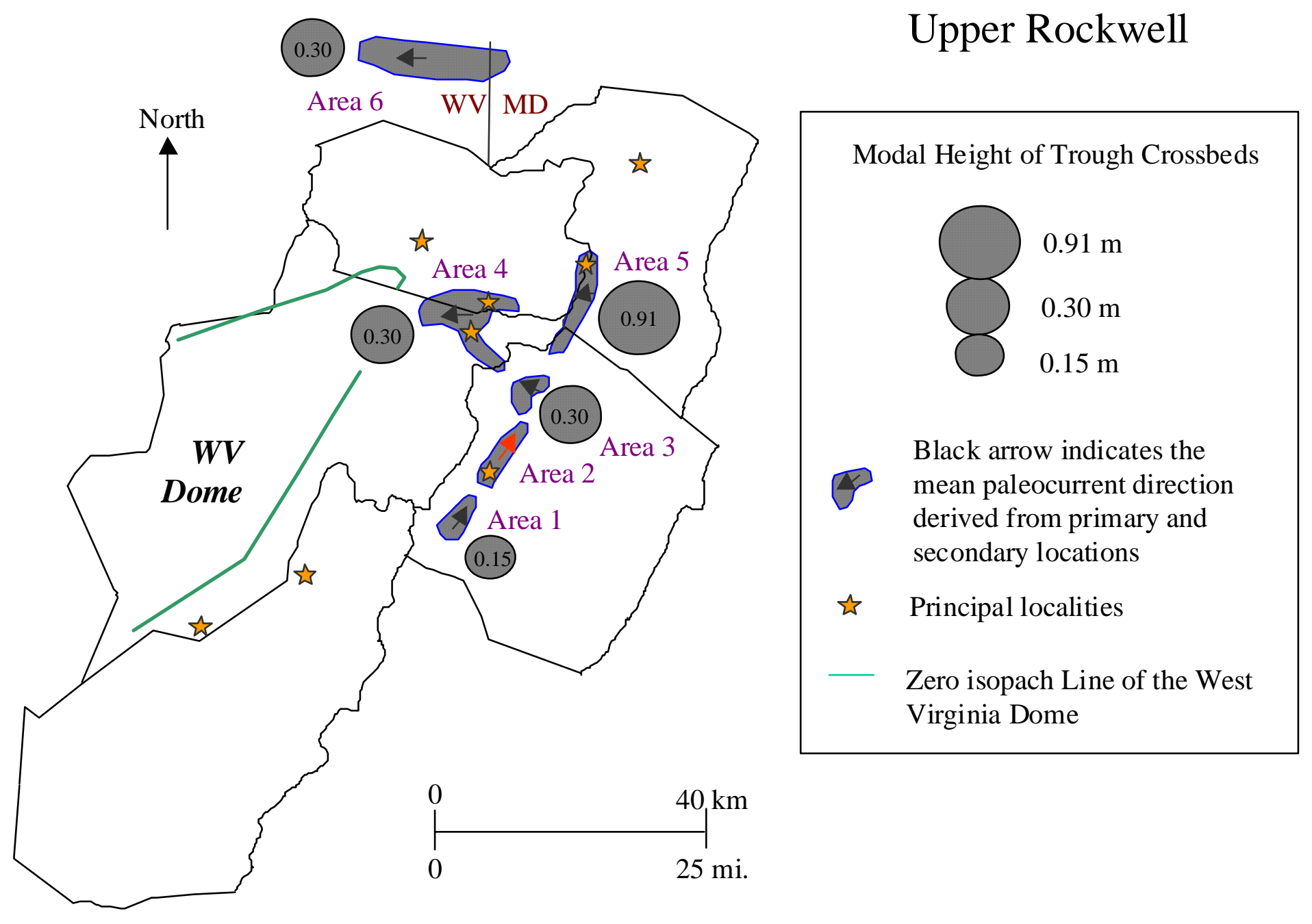

Figure 45. Modal height of trough crossbedding in the upper Rockwell 


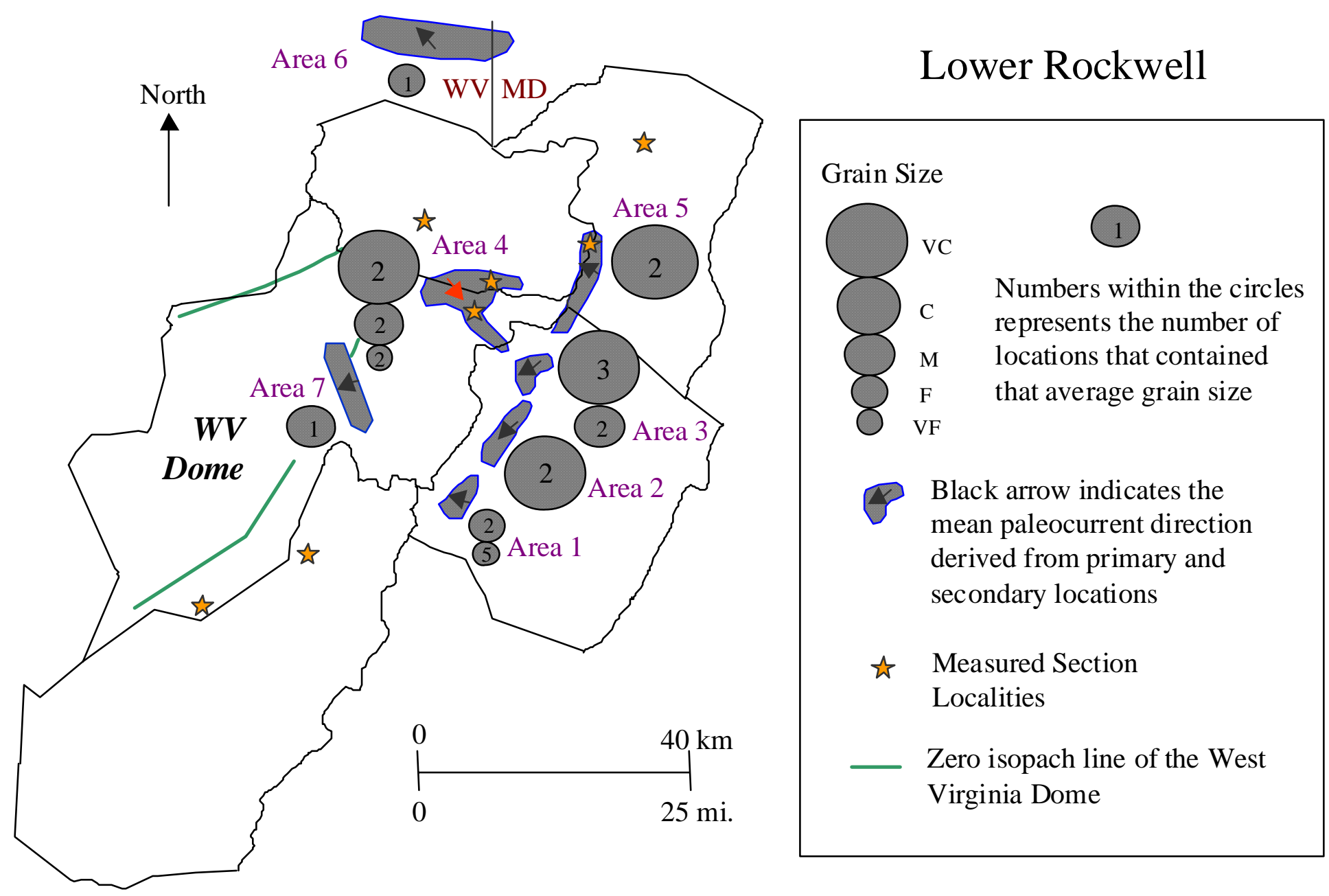

Figure 46. Grain size in the lower Rockwell 


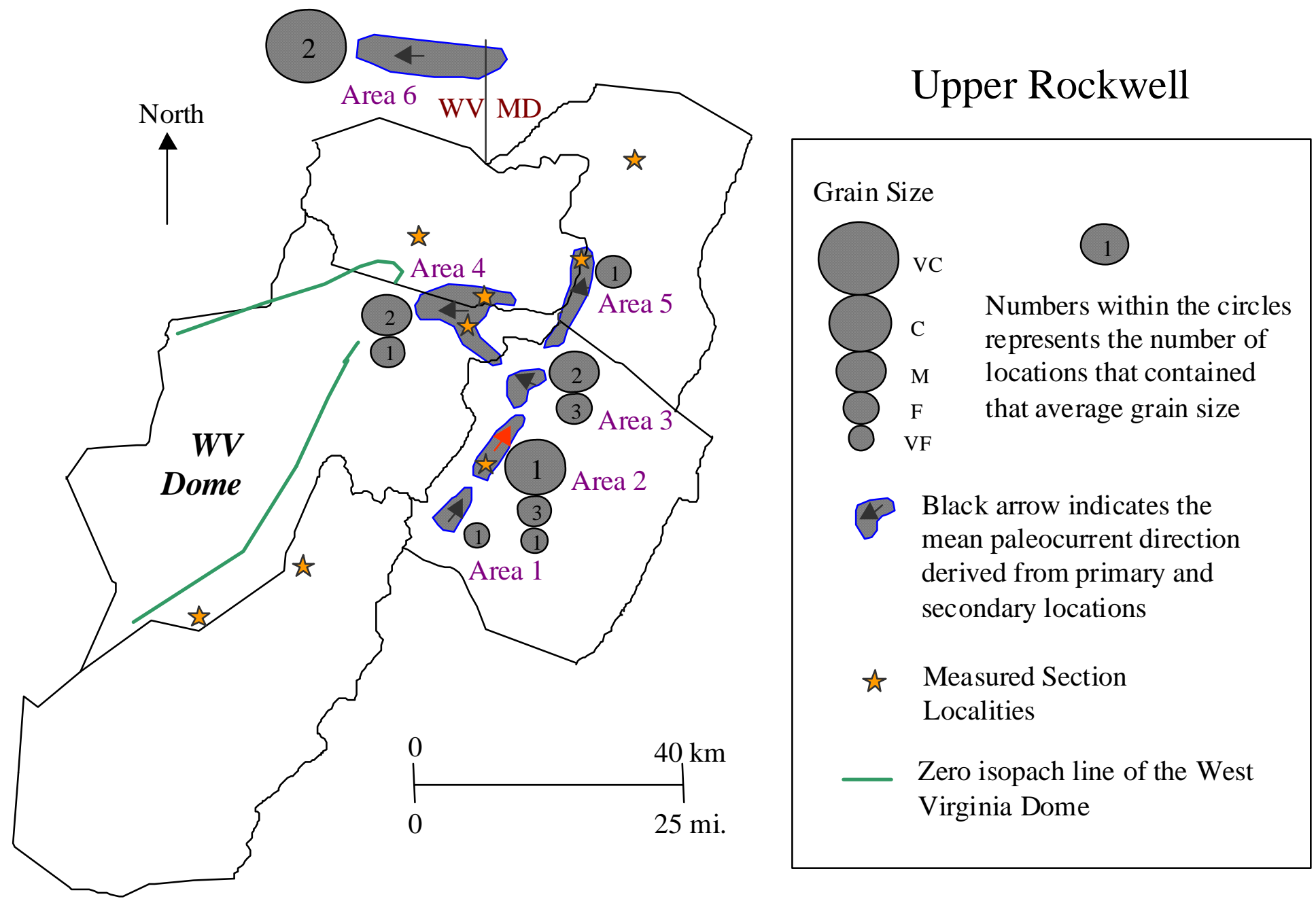

Figure 47. Grain Size in the upper Rockwell 


\section{DISCUSSION}

\section{Influence of West Virginia Dome on Channel Patterns}

The origin of the West Virginia Dome has been considerably debated in past research. Yeilding and Dennison (1986) suggested the east-end of the $38^{\text {th }}$ parallel fracture zone (Donald and Shumaker, 1981) during the middle Mississippian created the West Virginia Dome. Boswell (1988) suggested two normal faults whereas Lewis (1983) inferred the crossover Cambrian rift systems and two lineations for the origin of the West Virginia Dome.

Shifts in paleoflow directions from the lower to the upper Rockwell in this study are significant in relation to the West Virginia Dome and only observed within the Mississippian portion of the Price Formation. Boswell's (1988) two speculated normal fault zones, know as the Harrison and Barbour fault zones, are located around the western and northern ends of the West Virginia Dome. Boswell (1988) suggested that unequal subsidence rates were associated with the Harrison and Barbour fault zones (Figure 48).

Variability of paleocurrent direction in the lower and upper Rockwell Member facies probably are associated with the different subsidence rates suggested by Boswell (1988) and Donaldson and Shumaker (1981). The lower Rockwell facies indicates a southward paleoflow along the east-southeastern portion of the study area. Uplift that occurred during the earliest Mississippian appear to have deflected stream patterns that were emerging from the Acadian Mountains to the east. Areas 2 and 3 of the lower Rockwell (Figure 42) indicate southern flow along the eastern flank of the Dome with only a $13 \%$ and $4 \%$ probability of randomness. Areas 1,5 , and 6 indicate paleoflow toward the northwest with $12 \%, 0.20 \%$ and $10 \%$ probability of randomness while area 7 
indicates a southwest flow with a $4 \%$ probability of randomness. Northwest paleoflow directions correspond to Pelletiers (1958) northwest paleoflow for western Maryland.

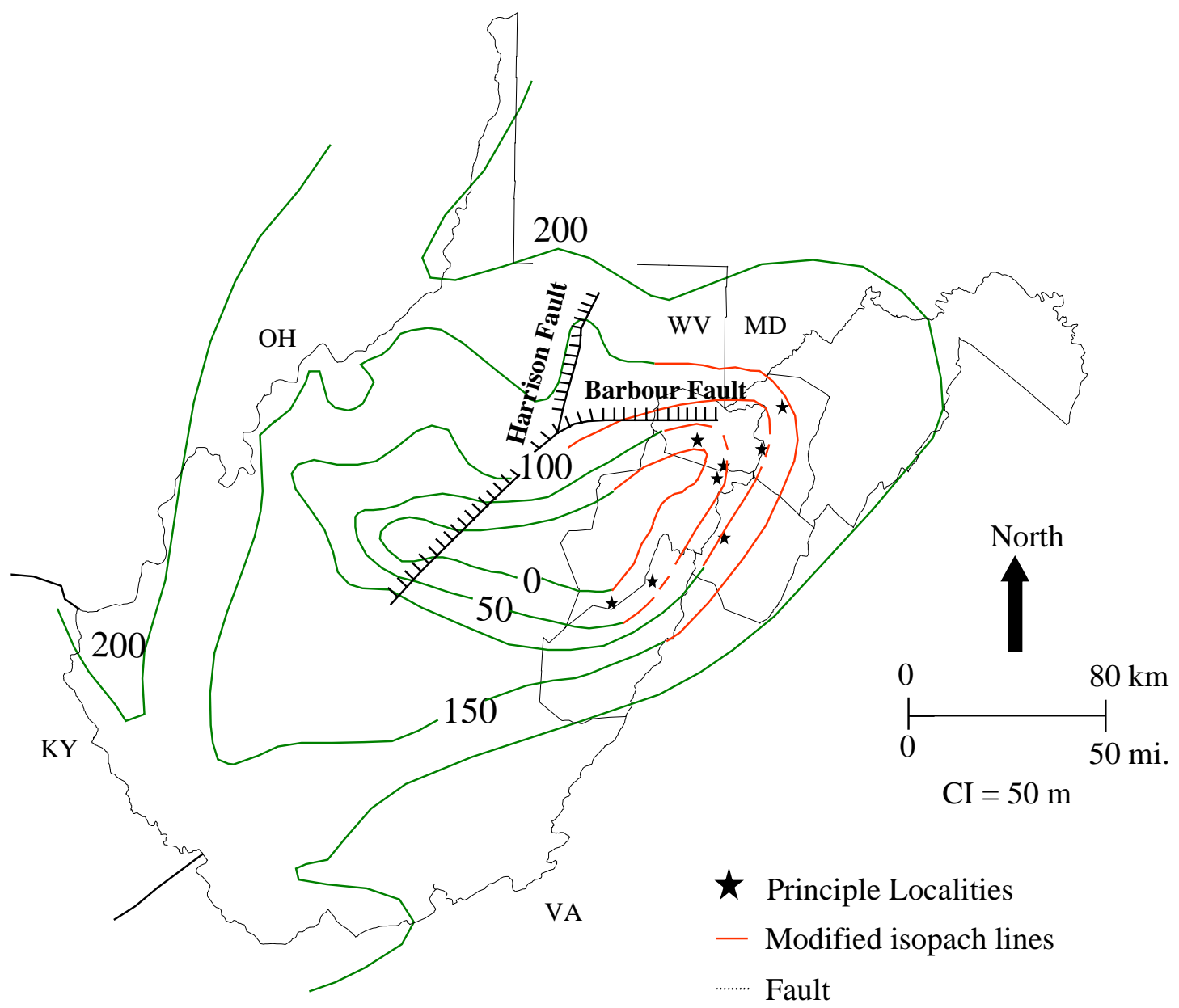

Figure 48. Harrison and Barbour normal faults zones adjacent to the West Virginia Dome redrawn from Boswell (1988).

The upper Rockwell facies indicates a northeast paleoflow direction in area 1 (Figure 43 ) with an $8 \%$ probability of randomness along the east-southeastern portion of the study area. Area 2 indicates northern paleoflow, however the probability of randomness was $40 \%$. Areas 3 indicates a northwest paleoflow with $0.40 \%$ probability of 
randomness, whereas areas 4,5 , and 6 indicate southwest paleoflow with $0.20 \%, 10 \%$, and 5\% probabilities of randomness. Areas 4, 5, and 6 oppose Pelletiers (1958) paleoflow patterns to the northwest for western Maryland.

\section{$\underline{\text { Syndepositional Uplift }}$}

Paleocurrent patterns during deposition of the lower and upper Rockwell indicate syndepositional uplift during the lower Mississippian. Uplifted strata as a result of normal faulting created the West Virginia Dome and separated the Price Formation into the northern and southern depocenters. The interpretation is that uplift associated with the West Virginia Dome altered the mean paleoflow directions during the lower and upper Rockwell.

Evidence supporting this interpretation and typical of syndepositional tectonics includes coarsening and fining upward cycles, faults, and unconformities (Miall, 1981).

The regional cross-section (Appendix VII) of the Price Formation indicates a coarsening upward sequence in the lower Rockwell and a fining upward sequence in the upper Rockwell. The lower Rockwell consists of fine-grained sandstones, siltstones, shales, and mudstones that grade into very coarse-grained channel sandstones (Appendix VII). The upper Rockwell consists of fine-grained sandstones that become interbedded with siltstones and mudstones (Appendix VII). Facies patterns and thickness variations reflect a syndepositional setting as a result of tectonics and large-scale basin subsidence.

Two normal faults identified in the subsurface by Boswell (1988) appear to the west and north of the West Virginia Dome (Figure). The fault zones Uplift of the West Virginia Dome was probably created by the two normal faults. Lewis' (1983) two 
lineations correspond to changing paleoflow patterns in the Rockwell Member. Thickness and lithologic trends correspond to Boswell's (1988) eastern and northern fault.

The appearance of a regional angular unconformity at the base of the overlying Mississippian Greenbrier Limestone indicates interrupted sediment accumulation of the Price Formation identified in cross-section (Appendix VII). Angular unconformities suggest tectonic uplift and erosion of sediment. Considering the relationship between facies that were supplied by two separate sediment sources suggest that an interplay between tectonics and channel morphology controlled sedimentary accumulation within the Appalachian basin in West Virginia. 


\section{CONCLUSIONS}

Combining the interpretations of Boswell (1988) and Lewis (1983) and paleoflow patterns provided the probable origin of the West Virginia Dome. Comparing the paleoflow patterns to Lewis' (1983) Parsons and Petersburg cross rift lineations revealed correlations between the lineations and stream paleoflow. This correlation suggests that stream patterns within the lower and upper Rockwell Member diverged around the two major fault lineations and corresponds to the area of non-deposition of the Price Formation.

Based on the paleocurrent data, outcrop studies, and the depositional model presented in this study, the author suggests that tectonism was active during the early Mississippian which began in the late Devonian. During Oswayo and Riddlesburg Shale time, minimal tectonic uplift began as a result of normal faulting and increased during deposition of the Rockwell Member. Changing paleoflow patterns identified within this study supports the idea of increased tectonism during Rockwell time. The north-south facies change and the rapid thickening indicated by Kammer and Bjerstedt (1986), stacked shoreline sandstones presented by Boswell (1988), and fault lineations presented by Lewis (1983) suggest that tectonism was responsible for the West Virginia Dome and its effects on the sedimentary deposits that overlie it.

Applying unimodal paleocurrent data and facies analysis to the Price Formation in West Virginia revealed opposing paleoflow patterns around the eastern flank of the West Virginia Dome during Rockwell deposition. During the Early Mississippian, stream patterns within the lower Rockwell contained coarse-grained sediment that meandered and diverged to the south on the eastern side whereas paleoflow patterns in the north 
meandered to the northwest. Migrating channels within the upper Rockwell produced fine-grained sedimentary deposits that meandered and diverged to the north on the eastern side whereas paleocurrents in the north meandered toward the southwest. The different paleocurrent patterns in the upper and lower Rockwell Member suggest that sediment coming from the Acadian Highlands was influenced by the tectonic activity that caused the divergence of paleostreams around the West Virginia Dome. 


\section{References}

Allen, J. R. L., 1966, On bed forms and paleocurrents: Sedimentology, v. 6, p. 153-190.

Bjerstedt, T. W., 1986, Stratigraphy and deltaic depositional systems of the Price Formation, Upper Devonian-Lower Mississippian in West Virginia [Ph.D. thesis]: Morgantown, West Virginia, West Virginia University, 459 p.

1988, Trace fossils from the early Mississippian Price Delta, southeast West Virginia: Journal of Paleontology, v. 62, p. 506-519.

Bjerstedt, T. W., and Kammer, T. W., 1988, Genetic stratigraphy and depositional systems of the Upper Devonian-Lower Mississippian Price-Rockwell deltaic complex in the central Appalachians, U.S.A: Sedimentary Geology, v. 54, p. 265301.

Blair, T. C., 1987, Tectonic and hydrologic controls on cyclic alluvial fan, fluvial, and lacustrine rift-basin sedimentation, Jurassic-Lowermost Cretaceous Todos Santos Formation, Chiapas, Mexico: Journal of Sedimentary Petrology, v. 57, p. 845862.

Blatt, H., 1967, Original characteristics of clastic quartz grains: Journal of Sedimentary Petrology, v. 37, p. 401-424.

Boswell, R., 1988, Stratigraphic expression of basement fault zones in northern West Virginia: Geological Society of America, v. 100, p. 1988-1998.

Brett, C. E., 1983, Sedimentology, facies and depositional environments of the Rochester Shale (Silurian; Wenlockian) in western New York and Ontario: Journal of Sedimentary Petrology, v. 53, p. 947-971.

Bridge, J. S., 1985, Paleochannel patterns inferred from alluvial deposits: a critical evaluation: Journal of Sedimentary Petrology, v. 55, p. 579-589.

Buck, S. P., and Bottjer, D. J., 1985, Continental slope deposits from a late Cretaceous, tectonically active margin, southern California: Journal of Sedimentary Petrology, v. 55, p. $843-855$.

Carter, J. L., and Kammer, T. W., 1990, Late Devonian and Early Carboniferous brachiopods (Brachipoda, Articulata) from the Price Formation of West Virginia and adjacent areas of Pennsylvania and Maryland: Annals of Carnegie Museum, v. 59, p. 77-103.

Compton, R. R., 1985, Geology in the Field: John Wiley \& Sons, Inc., p. 22-47, 162-196 and 222-241. 
Curray, J. R., 1956, The analysis of two-dimensional orientation data: Journal of Geology, v. 64, p.117-130.

Daley, B., 1968, Sedimentary structures from a non-marine horizon in the Bembridge Marls (Oligocene) of the Isle of Wright, Hampshire, England: Journal of Sedimentary Petrology, v. 38, p. 114-127.

Dally, J. L., 1954, Sedimentation cycles in the Pocono of West Virginia: Proceedings of the West Virginia Academy of Science, West Virginia University Bulletin, v. 26, p. 51-52.

Davies, D. K., and Ethridge, F. G., 1975, Sandstone composition and depositional framework: American Association of Petroleum Geologists, v. 59, p. 239-264.

Davis, J. C., 1986, Statistics and testing normal populations, in Statistics and data analysis in geology, John Wiley and Sons, p. 28-57.

DeCelles, P. G., Langford, R. P., and Schwartz, R. K., 1983, Two new methods of paleocurrent determination from trough cross-stratification: Journal of Sedimentary Petrology, v. 53, p. 629-642.

Dennison, J. M., 1985, Catskill delta shallow marine strata, in The Catskill Delta, Woodrow, D. L., and Sevon, W. D., ed.: Geological Society of America Special Paper 201, p. 91-106.

Dodd, J.R. and R.J. Stanton, Jr., 1990, Paleoecology, Concepts and Applications, John Wiley and Sons, Chapter 6, Ichnology, p. 191-222.

Donaldson, A. C., 1974, Pennsylvanian sedimentation of the Central Appalachians: Geological Society of America Special Paper, v. 148, p. 47-78.

Donaldson, A. C. and Shumaker, R., 1981, Late Paleozoic molasse of central Appalachians, in Miall, A. D., ed., Sedimentation and tectonics in alluvial basins: Geological Association of Canada Special Paper 23, p. 99-124.

Dott, R. H. Jr., 1973, Paleocurrent analysis of trough cross stratification: Journal of Sedimentary Petrology, v. 43, p. 779-783.

------, 1974, Paleocurrent analysis of severely deformed flysch-type strata, a case study from south Georgia island: Journal of sedimentary Petrology, v. 44, p. 1166-1173.

Edwards, M. B., Eriksson, K. A., and Kier, R. S., 1983, Paleochannel geometry and flow patterns determined from exhumed Permian point bars in north central Texas: Journal of Sedimentary Petrology, v. 53, p. 1261-1270.

Englund, K. J., Brown, S. E., and Dutro, T. Jr., 1988, Pocono Dome, West Virginia; 
Catskill Island or Fantasy Island ?: American Association of Petroleum Geologists, v. 72, 961 p.

Ettonsohn, F. R., 1985, Controls on development of Catskill Delta complex basin-facies: Geological Society of America Special Paper 201, p. 65-77.

Fahnestock, R. K., and Haushild, W. L., 1962, Flume studies of the transport of pebbles and cobbles on a sand bed: Geological Society of America Bulletin, v. 73, p. 1431-1436.

Fedorko, N., 1994, Measured section of the Price Formation units in a series of road cuts along route 32 starting on route 72: West Virginia Geological and Economic Survey, v. 174, p. 49-55.

Faill, R. T., 1985, The Acadian Orogeny and the Catskill Delta, in the Catskill Delta, Woodrow, D. L., and Sevon, W. D., ed.: Geological Society of America Special Paper 201, p. 15-37.

Frederic, R. Van De Graaff, 1972, Fluvial-deltaic facies of the Castlegate sandstone (Cretaceous), east central Utah: Journal of Sedimentary Petrology, v. 42, p. 558571.

Galloway, W. E., 1981, Depositional architecture of Cenozoic gulf coast plain fluvial systems, recent and ancient non-marine depositional environments, models for exploration: Society of Economic Paleontologists and Mineralogist Special Publication 31, p. 127-155.

Gao, D., Shumaker, R. C., and Wilson, T. H., 2000, Along-axis segmentation and growth history of the Rome Trough in the central Appalachian Basin: American Association of Petroleum Geologists, v. 84, p. 75-99.

Gordon, E. A., and Bridge, J. S., 1987, Evolution of Catskill (Upper Devonian) river Systems, intra- and extra basinal controls: Journal of Sedimentary Petrology, v. 57, p. 234-249.

Hand, B. M., 1974, Supercritical flow in density currents: Journal of Sedimentary Petrology, v. 44, p. 637-648.

Harms, J. C., Southard, J. B., Spearing, D. R., and Walker, R. G., 1975, Depositional environments as interpreted from primary sedimentary structures and stratification sequences: Society of Economic Paleontologists and Mineralogist Short Course 2, p. 1-103.

Hatfield, C. B., RohrBacher, T. J., and Floyd, J. C., 1968, Directional properties, 
paleoslope, and source of the Sylvania Sandstone (Middle Devonian) of southeastern Michigan and Northwestern Ohio: Journal of Sedimentary Petrology, v. 38, p. 224-228.

Heckel, P. H., 1972, Recognition of ancient shallow marine environments, recognition of ancient sedimentary environments: Society of Economic Paleontologists and Mineralogists Special Publication 16, p. 226-286.

Hobday, D. K., Woodruff, C. M., and McBride, M. W., 1981, Paleotopographic and structural controls on non-marine sedimentation of the lower Cretaceous Antlers Formation and correlatives, north Texas and southeastern Oklahoma, recent and ancient non-marine depositional environments, models for exploration: Society of Economic Paleontologists and Mineralogist, Special Publication no. 31, p. 71-87.

Hopkins, J. C., 1985, Channel-Fill Deposits formed by aggradation in deeply scoured, superimposed distributaries of the lower Kootenai Formation (Cretaceous): Journal of Sedimentary Petrology, v. 55, p. 42-52.

Howard, J. D., 1972, Trace fossils as criteria for recognizing shorelines in stratigraphic record, recognition of ancient sedimentary environments: Society of Economic Paleontologists and Mineralogists Special Publication 16, p. 215-225.

Hunter, R. E., 1985, Subaqueous sand-flow cross-strata: Journal of Sedimentary Petrology, v. 55, p. 886-894.

Iriondo, M. H., 1973, Volume factor in paleocurrent analysis: American Association of Petroleum Geologists, v. 57, p. 1341-1342.

Jones, M. L., and Clendening, J. A., 1968, A feasibility study for paleocurrent analysis in lutaceous Monongahela-Dunkard Strata of the Appalachian Basin: West Virginia Geological Survey and West Virginia Academy of Science, v. 40, p. 255-260.

Jones, T. A., 1968, Statistical analysis of orientation data: Journal of Sedimentary Petrology, v. 38, p. 61-67.

Kammer, T. W., and Bjerstedt, T. W., 1986, Stratigraphic framework of the Price Formation in West Virginia: Southeast Geology, v. 27, p.13-33.

Kent, D. V., 1985, Paleocontinential setting for the Catskill Delta, in The Catskill Delta, Woodrow, D. L., and Sevon, W. D., ed.: Geological Society of America Special Paper 201, p. 9-13.

Klein, G. D., 1967, Paleocurrent analysis in relation to modern marine sediment dispersion patterns: American Association of Petroleum Geologists, v. 51, p. 366382. 
Krause-Robert, G. F., and Geijer-Theresa A. M., 1987, An improved method for calculating the standard deviation and variance of paleocurrent data: Journal of Sedimentary Petrology, v. 57, p. 779-780.

Le Roux, J. P., 1992, Determining the channel sinuosity of ancient fluvial systems from paleocurrent data: Journal of Sedimentary Petrology, v. 62, p. 283-291.

Lewis, J.S., 1983, Reservoir rocks of the Catskill Delta in northern West Virginia, stratigraphic basin analysis emphasizing deposystems [M. S. Thesis]: Morgantown, West Virginia, West Virginia University, 147 p.

MacDonald, D. I. M., and Tanner, P. W. G., 1983, Sediment dispersal patterns in part of a deformed Mesozoic back-arc basin on South Georgia, South Atlantic: Journal of Sedimentary Petrology, v. 53, p. 83-104.

, and Jefferson, T. H., 1985, Orientation studies of waterlogged wood: A paleocurrent indicator: Journal of Sedimentary Petrology, v. 55, p. 235-239.

Matchen, D. L., and Kammer, T. W., 1994, Sequence stratigraphy of the lower Mississippian Price and Borden Formations in southern West Virginia and eastern Kentucky: Southeastern Geology, v. 34, p.25-41.

Mazzullo, J., and Magenheimer, S., 1987, The original shapes of quartz sand grains: Journal of sedimentary Petrology, v. 57, p. 479-487.

McKee, E. D., and Weir, G. W., 1953, Terminology for stratification and crossstratification in sedimentary rocks: Geological Society of America Bulletin, v. 64, p. 381-390.

Meckel, L. D., 1967, Origin of Pottsville Conglomerates (Pennsylvanian) in the Central Appalachians: Geological Society of America Bulletin, v. 78, p. 223-258.

Michelson, P. C., and Dott, R. H., 1973, Orientation analysis of trough cross stratification in Upper Cambrian Sandstones of western Wisconsin: Journal of Sedimentary Petrology, v. 43, p. 784-794.

Miall, A. D., 1974, Paleocurrent analysis of alluvial sediments: A discussion of directional variance and vector magnitude: Journal of Sedimentary Petrology, v. 4, p. 1174-1185.

------, 1981, in Basin mapping methods, A. D. Miall ed., Principles of Sedimentary Basin Analysis, second edition: New York, Springer-Verlag, p. 315-328.

------, 1981, Analysis of fluvial depositional systems: American Association of Petroleum Geologist Education Fall Education Course Note Series 20, Calgary Canada, 68 p. 
Narayan, J., 1971, Graphical method for calculation vector mean azimuth and magnitude for paleocurrent analysis: Journal of Geology, v. 79, p. 498-500.

Pelletier, B. R., 1958, Pocono paleocurrents in Pennsylvania and Maryland: Geological Society of America Bulletin, v. 69, p. 1033-1064.

Pettijohn, F .J., Potter, P. E., and Siever, R. S., 1973, in Sand and Sandstone, Heidelberg, Springer-Verlag, p. 102-147.

Picard, M. D., 1967, Paleocurrents and shoreline orientations in Green River Formation (Eocene), raven ridge and red wash areas, Northeastern Uinta Basin, Utah: American Association of Petroleum Geologist, v. 51, p. 383-392.

Pulham, A. J., 1989, Deltas: Sites and Traps for Fossil Fuels: Geological Society Special Publication 41, p. 179-203.

Reading, H. G., 1986, Sedimentary environments and facies, alluvial sediments: Blackwell Scientific Publications, p. 20-54.

Reineck, H. E. and Singh, I. B., 1975, Depositional Sedimentary Structures, SpringerVerlag, p. 1-128 and 225-305.

Rocheleau, M., Lajoie, J., 1974, Sedimentary structures in resedimented conglomerate of the Cambrian Flysch, L'islet, Quebec Appalachians: Journal of Sedimentary Petrology, v. 44, p. 826-836.

Rubin, D. M., 1987, Formation of scalloped crossbedding without unsteady flows: Journal of Sedimentary Petrology, v. 57, no. 1, p. 39-45.

Rust, B. R., 1968, Deformed crossbedding in Tertiary-Cretaceous sandstone, Arctic Canada: Journal of Sedimentary Petrology, v. 38, p. 87-91.

Narayan, J., 1971, Graphical method for calculating vector mean azimuth and magnitude for paleocurrent analysis: Journal of Geology, v. 79, p. 498-500.

Sanderson, D. J., 1973, Some inference in paleocurrent analysis: Journal of Sedimentary Petrology, v. 43, p. 1096-1100.

Saunderson, H. C., 1976, Paleocurrent analysis of large scale cross stratification in the brampton esker, Ontario: Journal of Sedimentary Petrology, v. 46, p. 761-769.

Schumm, S. A., 1981, Evolution and response of the fluvial system, sedimentologic implications, recent and ancient non-marine depositional environments, models for exploration: Society of Economic Paleontologists and Mineralogists Special Publication 31, p. 19-29. 
Selley, R. C., 1967, A classification of paleocurrent models: Journal of Geology, v. 76, p. 99-108.

, 1982, An introduction in sedimentology, Sedimentary Structures, p. 241-250.

Seimers, C. T., 1976, Sedimentology of the Rocktown Channel Sandstone, upper part of the Dakota Formation (Cretaceous), Central Kansas: Journal of Sedimentary Petrology, v. 46, p. 97-123.

Shelton, J. W., Burman, R. H., and Noble, R. L., 1974, Directional features in braidedmeandering stream deposits, Cimarron River, North Central Oklahoma: Journal of Sedimentary Petrology, v. 44, p. 1114-1117.

Slingerland R. L., and Williams, E. G., 1979, Paleocurrent analysis in light of trough cross-stratification geometry: Journal of Geology, v. 87, p. 724-732.

Singerland, R., and Beaumont, C., 1989, Tectonics and sedimentation of the Upper Paleozoic Foreland Basin in the Central Appalachians, Sedimentation and basin analysis in siliciclastic rock sequences, Sedimentology and thermal-mechanical history of basins in the Central Appalachian Orogen, v. 2, p. 4-24.

Smith, N. D., 1972, Some sedimentological aspects of planar cross stratification in a sandy braided river: Journal of Sedimentary Petrology, v. 42, p. 624-634.

Smosna, R., and Koehler, B., 1993, Tidal origin of a Mississippian oolite on the West Virginia Dome: American Association of Petroleum Geologists Studies in $\begin{array}{lllll}\text { Geology } & \text { v. } & 35, & \text { p. } & 149-162 .\end{array}$

Sturm, E., 1971, High-resolution paleocurrent analysis by moving vector averages: Journal of Geology, v. 79, p. 222-233.

Tucker, M. E., 1984, Terrigenous Clastic Sediments I: sandstones, conglomerates, and breccias, Sedimentary Petrology: An Introduction, Blackwell Scientific Publications, p. 20-40.

Tucker, M. E., 1996, Paleocurrent Analysis, Sedimentary Rocks in the Field, Blackwell Scientific Publications, p. 118-125.

Visher, G. S., 1972, Physical characteristics of fluvial deposits: Recognition of ancient sedimentary environments: Society of Economic Paleontologists and Mineralogists Special Publication 16, p. 84-97.

Walker, R. G., 1984, Sandy fluvial systems and deltas, in Facies Models, v. 1, p. 71-91 and 105-119.

Wells, J. T., and Ludwick, J. C., 1974, Application of multiple comparisons to grain size 
on sand waves: Journal of Sedimentary Petrology, v. 44, p. 1029-1036.

Whisonant, R. C., 1987, Paleocurrents and petrographic analysis of imbricate intraclasts in shallow marine carbonates, Upper Cambrian, Southwestern Virginia: Journal of Sedimentary Petrology, v. 57, p. 983-994.

Whitaker, J. C., 1955, Direction of Current Flow in Some Lower Cambrian Clastics in Maryland, Bulletin of the Geological Society of America, v. 66, p. 763-766.

Williams, G. E., 1968, Formation of large scale trough cross stratification in a fluvial Environment: Journal of Sedimentary Petrology, v. 38, p. 136-140.

Yeilding, C. A., Dennison, J. M., 1986, Sedimentary response to Mississippian tectonic activity at the east end of the $38^{\text {th }}$ parallel fracture zone: Geology, v. 14, p. 621624. 


\section{Appendix I - Lithologic Symbols}

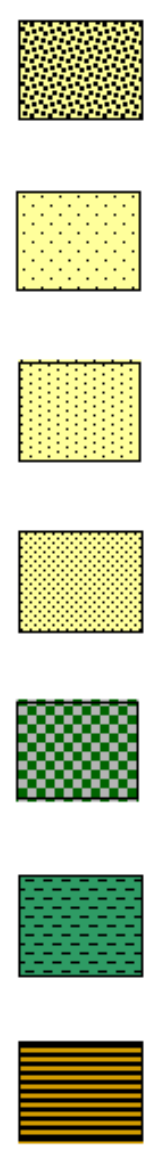

Conglomeratic Sandstone

Coarse-grained Sandstone

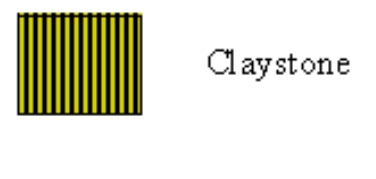

Medium-grained Sandstone

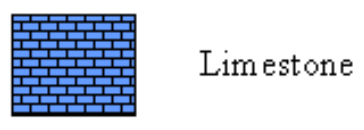

Very fine to fine-grained Sandstone

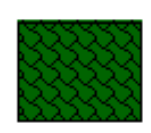

Green and Red Paleosol

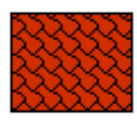

Siltstone

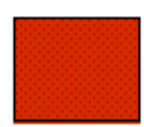

Red color for any lithology

Shale

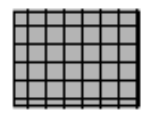

Concealed Interval

Mudstone

Figure 49. Lithologic Symbols 


\section{Appendix I - Stratigraphic Symbols}

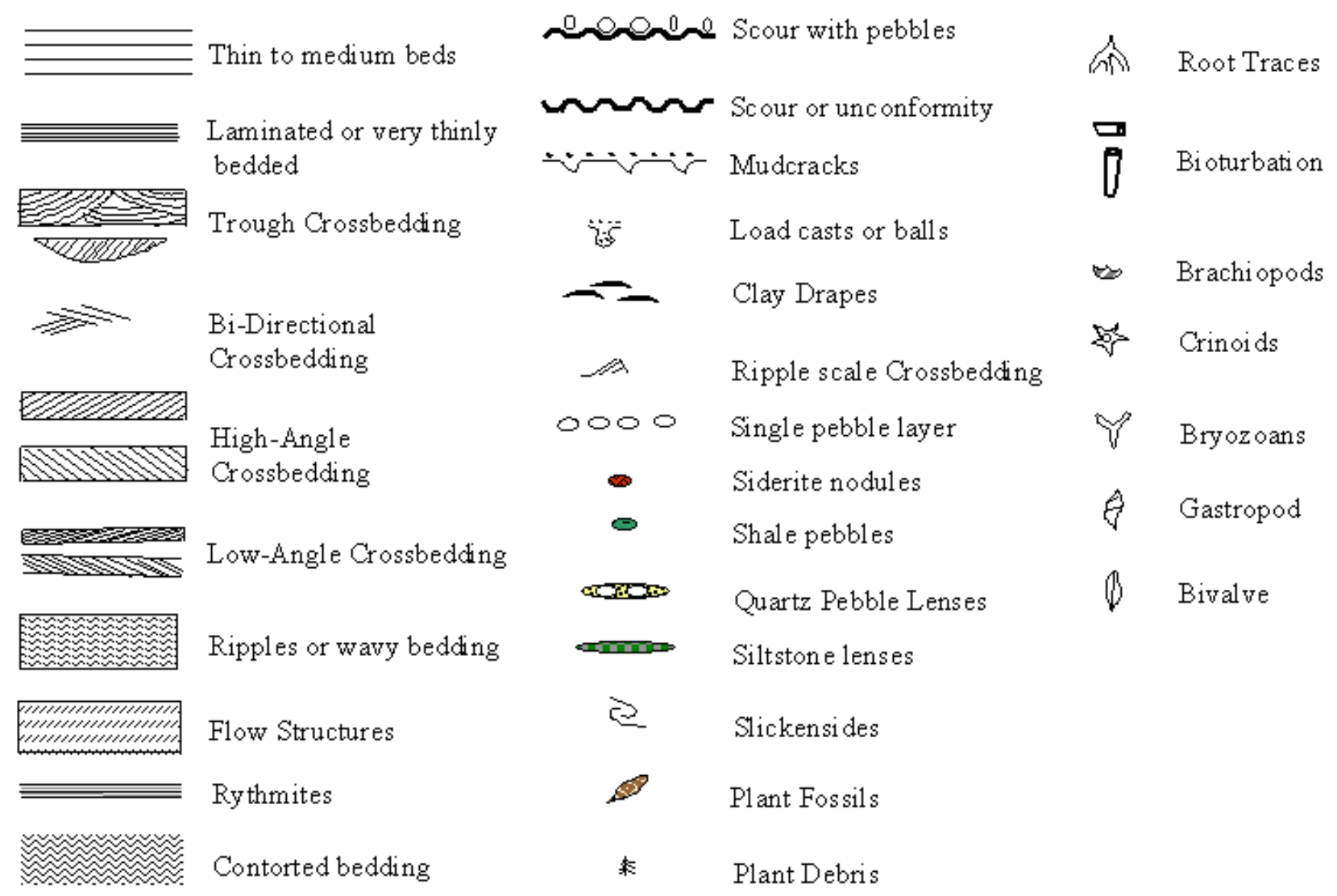

Figure 50. Stratigraphic Symbols 
Measured Section - Scherr, West Virginia

Measured by Tom Bjerstedt and Dr. Tom Kammer

Quadrangle - Greenland Gap 7.5'

Date $-07 / 17 / 84$

Measured section of the Price Formation along WV route 42 at Scherr. Top of section at elevation $2600 \mathrm{ft}$. (792 m) located $1800 \mathrm{ft}$. (548 m) southeast of benchmark 2689. Base of section at elevation $2380 \mathrm{ft}$. (725 m) located $10000 \mathrm{ft}$. (3048 m) northwest of benchmark 2296. Located in Union District within Grant County.

Hampshire Formation (Units 1-6)

Oswayo Member (Units 7-22)

Riddlesburg Shale Member (Units 22-24)

Rockwell Member (Units 24-38)

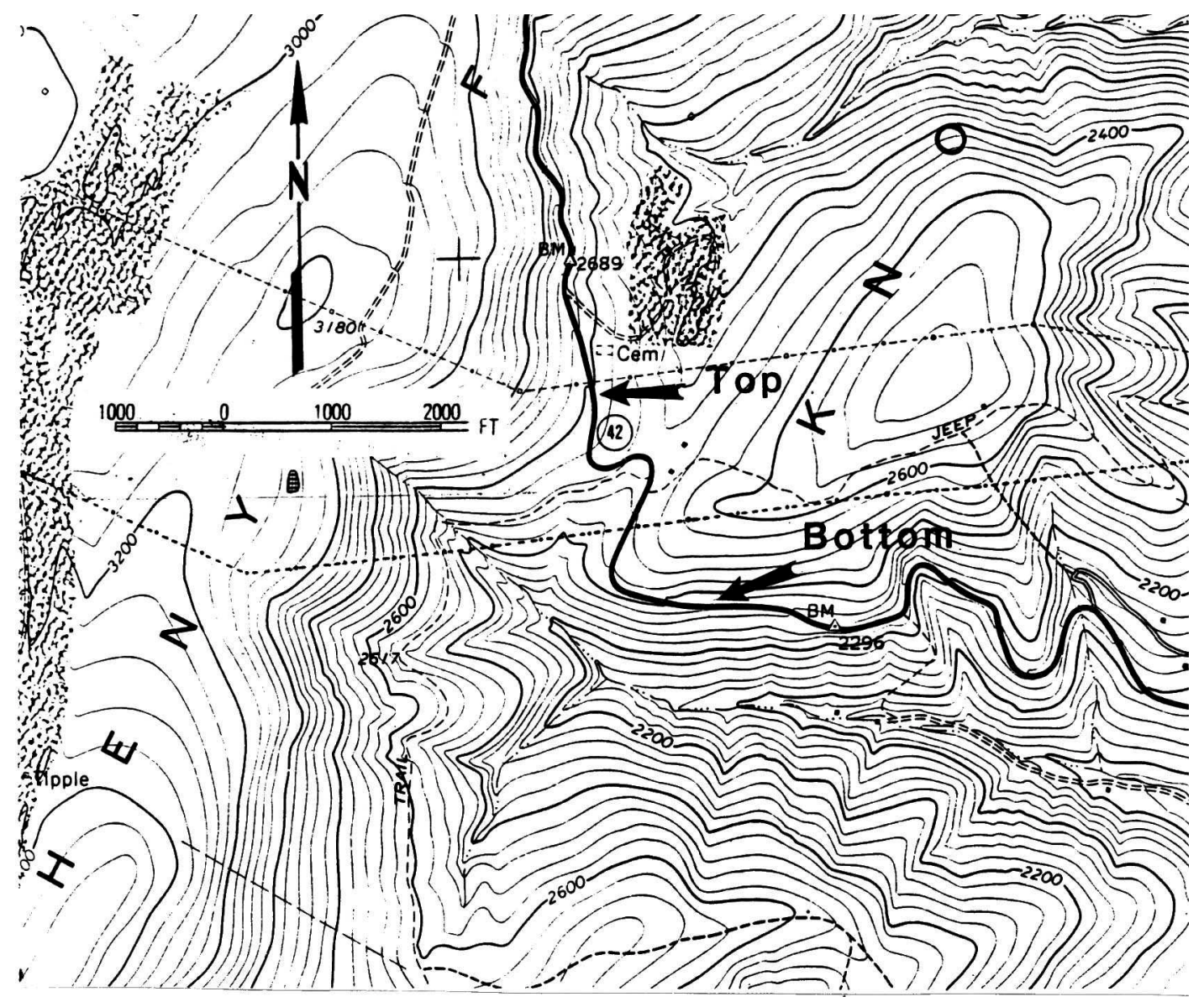

Figure 51. Location map for Scherr section taken from the Greenland Gap 7.5' USGS topographic map 
Measured Section - Scherr, West Virginia

Measured by Tom Bjerstedt and Dr. Tom Kammer

Quadrangle - Greenland Gap 7.5'

Date $-07 / 17 / 84$

\section{UNIT 1: SILTSTONE}

Grain Size and Texture - none recorded

Color - F - greyish red (5R 4/2), W - pale red (5R 6/2)

Bedding - thin-bedded

Sedimentary Structures - none observed

Paleocurrent Measurements - none

Fossils - none

Contact - none recorded

Strike/dip - none recorded

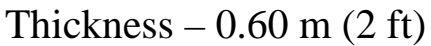

UNIT 2: COVERED INTERVAL

Thickness $-2.3 \mathrm{~m}(7.5 \mathrm{ft})$

\section{UNIT 3: SANDSTONE}

Grain Size and Texture - medium-grained

Color $-\mathrm{F}$ - very pale orange (10YR 8/2), W - moderate brown (5YR 3/4)

Bedding - thin to medium bedded

Sedimentary Structures - medium scale trough crossbed sets, planar crossbed sets

with tangential bases, shale pebbles on bedding planes common

Paleocurrent Measurements - none

Fossils - larger plant debris and macerated organic matter

Contact - none recorded

Strike/dip - N26E/17W

Thickness $-5.4 \mathrm{~m}(18 \mathrm{ft})$

\section{UNIT 4: CLAYSTONE}

Grain Size and Texture - none recorded

Color - F - yellowish grey (5Y 7/2), W - soil bedding - unbedded

Bedding - unbedded

Sedimentary Structures - none observed

Paleocurrent Measurements - none

Fossils - none

Contact - none recorded

Strike/dip - none recorded

Thickness $-3.2 \mathrm{~m}(10.6 \mathrm{ft})$

\section{UNIT 5: SANDSTONE}

Grain Size and Texture - medium-grained

Color $-\mathrm{F}$ - greyish orange (10Y 7/4), $\mathrm{W}$ - moderate brown (5YR 3/4)

Bedding - medium to thick bedded 
Sedimentary Structures - planar crossbed sets with tangential bases, unit has scour base

Paleocurrent Measurements - none

Fossils - none

Contact - none recorded

Strike/dip - none recorded

Thickness $-0.8 \mathrm{~m}(2.6 \mathrm{ft})$

UNIT 6: SANDSTONE WITH INTERBEDDED SILTSTONE, CLAYSTONE, AND MUDSTONE

Grain Size and Texture - fine-grained sandstone, sand/silt/mud/clay - 2/2/1/1

Color - sandstone F - very pale orange (10YR 8/2), W - pale yellowish orange

(10YR 8/6); siltstone - F - dusky yellow (5Y 6/4), W - weathers to soil;

mudstone $\mathrm{F}$ - dark yellowish orange (10YR 6/6), W - weathers to soil; claystone

$\mathrm{F}$ - pale yellowish green (10Y 6/6), W - light brown (5YR 5/6)

Bedding - thin bedded to crumbly

Sedimentary Structures - ripple marks in sandstone and siltstone, probable root mottling

Paleocurrent Measurements - none

Fossils - larger plant debris in mudstone and claystone,

Contact - none recorded

Strike/dip - none recorded

Thickness $-5.1 \mathrm{~m}(16.8 \mathrm{ft})$

\section{UNIT 7: SHALY SANDSTONE}

Grain Size and Texture - medium-grained sandstone

Color - F - greyish yellow green (10GY 7/2), W - moderate brown (5YR 4/4)

Bedding - thin to medium bedded

Sedimentary Structures - bioturbated, clay rich in upper meter

Paleocurrent Measurements - none

Fossils - lower $1.2 \mathrm{~m}$ contains apparent vertical burrows, lower meter bioturbated, larger plant debris and macerated organic matter

Contact - none recorded

Strike/dip - none recorded

Thickness $-2.2 \mathrm{~m}(7.3 \mathrm{ft})$

\section{UNIT 8: SANDSTONE}

Grain Size and Texture - fine-grained

Color $-\mathrm{F}$ - yellowish grey (5Y 7/2), $\mathrm{W}$ - light brown (5YR 5/6)

Bedding - one thick bed, unit thins to almost zero due to scour

Sedimentary Structures - medium scale trough crossbed sets and planar crossbed sets with tangential bases, unit fines upward from medium-grained sand at base to ripple-marked, fine-grained sandstone at top, scour-base causes thinning and thickening of unit

Paleocurrent Measurements - none

Fossils - rare Skolithos 
Contact - none recorded

Strike/dip - none recorded

Thickness $-0.4 \mathrm{~m}(1.5 \mathrm{ft})$

\section{UNIT 9: SANDSTONE}

Grain Size and Texture - medium-grained with interbedded fine-grained sandstone, sand/silty sand $=1 / 1$

Color - sandstone F - dusky red (5R 3/4) and greyish green (10Gy 5/2), W moderate brown (5YR 4/4): very fine-grained sandstone $-\mathrm{F}$ - greyish red $(5 \mathrm{R} 4 / 2)$ and greyish green (10GY 5/2), W - moderate brown (5YR 3/4)

Bedding - very thin to medium bedded

Sedimentary Structures - shale pebbles in medium-grained sandstone, scour and fill, probable root mottling

Paleocurrent Measurements - none

Fossils - unit appears to be bioturbated

Contact - none recorded

Strike/dip - none recorded

Thickness $-0.9 \mathrm{~m}(3 \mathrm{ft})$

\section{UNIT 10: SANDSTONE}

Grain Size and Texture - medium-grained, poorly sorted fine to medium grained quartz arenite in thin section

Color - F - greyish yellow green (5GY 7/2), W - dusky brown (5YR 2/2)

Bedding - thin to medium bedded

Sedimentary Structures - ripple marks common, minor shaly partings

Paleocurrent Measurements - none

Fossils - abundant Skolithos, rate Diplocraterion, all as hyporeliefs and

epireliefs, burrows often filled with green claystone

Contact - none recorded

Strike/dip - none recorded

Thickness - $1.7 \mathrm{~m}(5.6 \mathrm{ft})$

\section{UNIT 11: SHALY SANDSTONE}

Grain Size and Texture - shaly medium-grained sandstone with interbedded medium-grained sandstone, sand/sand $=2 / 1$, moderately sorted medium- to coarse-grained sublitharenite in thin section

Color - shaly sandstone F - dark greenish yellow (10Y 6/6), W - greenish yellow green (5GY 7/2); sandstone - F - greyish yellow green (5GY 7/2), greyish red (5R 4/2), W - light brown (5YR 5/6)

Bedding - thin to medium bedded

Sedimentary Structures - none observed

Paleocurrent Measurements - none

Fossils - Skolithos in both lithologies

Contact - none recorded

Strike/dip - none recorded

Thickness - $1.1 \mathrm{~m}(3.6 \mathrm{ft})$ 


\section{UNIT 12: SANDSTONE}

Grain Size and Texture - medium-grained

Color - shaly sandstone F - dark greenish yellow (10Y 6/6), W - greenish yellow green (5GY 7/2); sandstone - F - greyish yellow green (5GY 7/2), greyish red (5R 4/2), W - light brown (5YR 5/6)

Bedding - thin to medium bedded

Sedimentary Structures - none observed

Paleocurrent Measurements - none

Fossils - Skolithos in both lithologies

Contact - none recorded

Strike/dip - none recorded

Thickness $-1.1 \mathrm{~m}(3.6 \mathrm{ft})$

\section{UNIT 13: CLAY SHALE}

Grain Size and Texture - none recorded

Color - F - light olive grey (5Y 5/2), W - soil bedding - laminated

Bedding - laminated

Sedimentary Structures - none observed

Paleocurrent Measurements - none

Fossils - none

Contact - none recorded

Strike/dip - none recorded

Thickness $-0.3 \mathrm{~m}(1.0 \mathrm{ft})$

\section{UNIT 14: SANDSTONE}

Grain Size and Texture - fine-grained

Color - F - yellow grey (5Y 7/2), W - pale brown (5YR 5/2)

Bedding - medium bedded at base, thinning up section

Sedimentary Structures - none observed

Paleocurrent Measurements - none

Fossils - none

Contact - none recorded

Strike/dip - none recorded

Thickness $-0.8 \mathrm{~m}(2.7 \mathrm{ft})$

\section{UNIT 15: CLAY SHALE WITH INTERBEDDED SANDY MUDSTONE AND} SANDSTONE

Grain Size and Texture - fine-grained sandstone, shale/sandy mud/sand = 3/2/1

Color - shale, mudstone - F - light olive grey (5Y 5/2), dusky yellow green (5GY

5/2), W - soil; sandstone - F - medium light grey (N6), W - light brown

(5YR 5/6)

Bedding - very thin to thin bedded

Sedimentary Structures - none observed

Paleocurrent Measurements - none

Fossils - none 
Contact - none recorded

Strike/dip - none recorded

Thickness $-1.8 \mathrm{~m}(6.0 \mathrm{ft})$

\section{UNIT 16: SANDSTONE}

Grain Size and Texture - fine-grained

Color $-\mathrm{F}$ - yellowish grey (5Y 7/2), $\mathrm{W}$ - moderate brown (5YR 3/4)

Bedding - thin to medium bedded

Sedimentary Structures - bioturbation

Paleocurrent Measurements - none

Fossils - Skolithos common, rare horizontal burrows

Contact - none recorded

Strike/dip - none recorded

Thickness $-0.5 \mathrm{~m}(1.6 \mathrm{ft})$

\section{UNIT 17: SILTY MUDSTONE WITH INTERBEDDED SILTSTONE AND} SANDSTONE (UNIT MOSTLY COVERED)

Grain Size and Texture - fine-grained sandstone, $\mathrm{mud} / \mathrm{silt} / \mathrm{sand}=5 / 2 / 1$

Color - mudstone - F - greyish brown (5YR 3/2), siltstone - W - light olive grey (5YR 5/2)

Bedding - thin to medium bedded

Sedimentary Structures - none

Paleocurrent Measurements - none

Fossils - none

Contact - none recorded

Strike/dip - none recorded

Thickness $-9.8 \mathrm{~m}(64.7 \mathrm{ft})$

\section{UNIT 18: SANDSTONE}

Grain Size and Texture - fine-grained

Color - F - greyish yellowish (5GY 7/2), W - moderate brown (5YR 4/4)

Bedding - medium bedded

Sedimentary Structures - horizontal laminations

Paleocurrent Measurements - none

Fossils - none

Contact - none recorded

Strike/dip - none recorded

Thickness $-0.7 \mathrm{~m}(2.5 \mathrm{ft})$

\section{UNIT 19: CLAY SHALE}

Grain Size and Texture - none recorded

Color - F - light olive grey (5Y 5/2), W - weathers to soil

Bedding - laminated

Sedimentary Structures - none observed

Paleocurrent Measurements - none

Fossils - none 
Contact - none recorded

Strike/dip - none recorded

Thickness $-3.0 \mathrm{~m}(9.7 \mathrm{ft})$

\section{UNIT 20: SANDSTONE}

Grain Size and Texture - fine-grained, well sorted fine - to medium-grained quartz arenite in thin section, quartz pebbles in base

Color - F - light olive grey (5Y 5/2), W - moderate brown (5YR 4/4)

Bedding - thin to medium bedded, dominantly medium

Sedimentary Structures - minor planar crossbed sets with tangential bases, thin

fine quartz pebble conglomerate stringer at base and thin discontinuous stringers

throughout unit, some interference wave-rippled on bedding planes

Paleocurrent Measurements - none

Fossils - Planolites

Contact - none recorded

Strike/dip - none recorded

Thickness $-4.0 \mathrm{~m}(13.3 \mathrm{ft})$

UNIT 21: SILTY SHALE WITH INTERBEDDED FINE-GRAINED SANDSTONE

Grain Size and Texture - fine-grained sandstone, well sorted medium-grained quartz sublitharenite in thin section, sand/shale $=3 / 1$

Color - F - light olive grey (5Y 5/2), W - soil

Bedding - thin to medium bedded

Sedimentary Structures - none

Paleocurrent Measurements - none

Fossils - none

Contact - none recorded

Strike/dip - none recorded

Thickness $-1.2 \mathrm{~m}(4.0 \mathrm{ft})$

UNIT 22: SANSTONE WITH INTERBEDDED SILTSTONE AND SILTY SHALE (UNIT MOSTLY COVERED)

Grain Size and Texture - fine-grained sandstone, well sorted medium-grained lithic feldsarenite in thin section, sand/silt/shale $=4 / 2 / 1$

Color - sandstone - F - light olive grey (5Y 6/1), W - moderate brown (5YR 3/4); siltstone $-\mathrm{F}$ - light olive grey (5Y 5/2), W - weathers to soil

Bedding - thin to medium bedded

Sedimentary Structures - minor ripple marks

Paleocurrent Measurements - none

Fossils - none

Contact - none recorded

Strike/dip - none recorded

Thickness $-2.7 \mathrm{~m}(9.0 \mathrm{ft})$

UNIT 23: SILTSTONE WITH SILTY MUDSTONE AND SHALY SANDSTONE (UNIT MOSTLY COVERED) 
Grain Size and Texture - none recorded

Color - siltstone - F - light olive grey (5Y 5/2), W - weathers to soil; mudstone -

$\mathrm{F}$ - greyish yellow green $(5 \mathrm{GY} 7 / 2), \mathrm{W}$ - weathers to soil; sandstone - F - dusky yellow (5Y 6/4), W - weathers to soil

Bedding - very thin to thin bedded

Sedimentary Structures - none

Paleocurrent Measurements - none

Fossils - none

Contact - none recorded

Strike/dip - none recorded

Thickness $-4.4 \mathrm{~m}(14.5 \mathrm{ft})$

UNIT 24: COVERED INTERVAL

Thickness $-12 \mathrm{~m}(39.7 \mathrm{ft})$

UNIT 25: SANDSTONE (UNIT MOSTLY COVERED)

Grain Size and Texture - fine-grained

Color - F - light olive grey (5Y 6/1), W - light brown (5YR 5/6)

Bedding - thin bedded

Sedimentary Structures - none

Paleocurrent Measurements - none

Fossils - none

Contact - none recorded

Strike/dip - none recorded

Thickness $-0.9 \mathrm{~m}(3.0 \mathrm{ft})$

UNIT 26: COVERED INTERVAL WITH TOP OF UNIT A SHALE PEBBLE CONGLOMERATE

Grain Size and Texture - shale in medium-grained sandstone matrix

Color - medium light grey (N6)

Bedding - none recorded

Sedimentary Structures - none

Paleocurrent Measurements - none

Fossils - none

Contact - none recorded

Strike/dip - none recorded

Thickness $-2.4 \mathrm{~m}$ ( $8.0 \mathrm{ft})$, upper $0.6 \mathrm{~m}$ (2.0 ft) - shale pebble conglomerate

\section{UNIT 27: SANDSTONE}

Grain Size and Texture - fine to medium-grained

Color - F - yellowish grey (5Y 7/2), W - moderate brown (5YR 4/4)

Bedding - thin bedded

Sedimentary Structures - minor trough crossbed sets, shale pebbles at base, minor ripple marks

Paleocurrent Measurements - none

Fossils - none 
Contact - none recorded

Strike/dip - none recorded

Thickness $-1.8 \mathrm{~m}(6.0 \mathrm{ft})$

\section{UNIT 28: SHALY SANDSTONE}

Grain Size and Texture - fine to medium-grained, mica on bedding planes

Color - F - yellowish grey (5Y 7/2), W - light brown (5YR 5/6)

Bedding - very thin to thin bedded, medium-bedded at top of unit

Sedimentary Structures - minor shale pebbles

Paleocurrent Measurements - none

Fossils - none

Contact - none recorded

Strike/dip - none recorded

Thickness - $4.9 \mathrm{~m}(16.2 \mathrm{ft})$

\section{UNIT 29: MUDSTONE WITH INTERBEDDED SILTY SHALE}

Grain Size and Texture - none recorded

Color - F - moderate olive brown (5YR 4/4) and light olive brown (5YR

$5 / 6), \mathrm{W}-$ weathers to soil

Bedding - unbedded

Sedimentary Structures - none

Paleocurrent Measurements - none

Fossils - none

Contact - none recorded

Strike/dip - none recorded

Thickness - $3.2 \mathrm{~m}(10.7 \mathrm{ft})$

\section{UNIT 30: MUDSTONE}

Grain Size and Texture - none recorded

Color - F - moderate brown (5YR 3/4), W - weathers to soil

Bedding - none

Sedimentary Structures - none observed

Paleocurrent Measurements - none

Fossils - none

Contact - none recorded

Strike/dip - none recorded

Thickness $-1.5 \mathrm{~m}(5.0 \mathrm{ft})$

\section{UNIT 31: CLAYSTONE}

Grain Size and Texture - none recorded

Color - F - yellowish grey (5YR 7/2) and light brown (5YR 5/6), W - weathers

to soil

Bedding - unbedded

Sedimentary Structures - none observed

Paleocurrent Measurements - none

Fossils - none 
Contact - none recorded

Strike/dip - none recorded

Thickness $-0.3 \mathrm{~m}(1.0 \mathrm{ft})$

\section{UNIT 32: SANDSTONE}

Grain Size and Texture - coarse-grained, moderately sorted, medium to coarsegrained sublitharenite in thin section, few fine quartz pebbles

Color - F - pale brown (5YR 5/2), W - moderate brown (5YR 4/4)

Bedding - medium bedded

Sedimentary Structures - scour base, medium-scale trough crossbed sets, shale pebbles from unit 30 commonly in trough axes

Paleocurrent Measurements - none

Fossils - none

Contact - none recorded

Strike/dip - none recorded

Thickness $-2.2 \mathrm{~m}(7.3 \mathrm{ft})$

\section{UNIT 33: CLAYSTONE WITH UNIT MOSTLY COVERED}

Grain Size and Texture - none recorded

Color - F - moderate yellow (5YR 7/6), W - weathers to soil

Bedding - none

Sedimentary Structures - none observed

Paleocurrent Measurements - none

Fossils - none

Contact - none recorded

Strike/dip - none recorded

Thickness $-2.7 \mathrm{~m}(9.0 \mathrm{ft})$

\section{UNIT 34: SANDSTONE}

Grain Size and Texture - coarse-grained, well-sorted, medium grained sublitharenite in thin section

Color - F - dark grey (N3), W - greyish brown (5YR 3/4)

Bedding - thin to medium bedded, dominantly medium

Sedimentary Structures - scour base, medium-scale trough crossbed sets, brown and light grey shale pebbles from unit 33 in trough axes

Paleocurrent Measurements - none

Fossils - none

Contact - none recorded

Strike/dip - none recorded

Thickness $-1.8 \mathrm{~m}(6.0 \mathrm{ft})$

UNIT 35: MUDSTONE

Grain Size and Texture - none recorded

Color - F - light brown (5YR 5/6), W - weathers to soil

Bedding - none

Sedimentary Structures - none observed 
Paleocurrent Measurements - none

Fossils - none

Contact - none recorded

Strike/dip - none recorded

Thickness - $2.4 \mathrm{~m}(8.0 \mathrm{ft})$

\section{UNIT 36: SANDSTONE}

Grain Size and Texture - medium-grained, well sorted, medium grained sublitharenite in thin section

Color - F - light brownish grey (5YR 6/1), W - light brownish grey (5YR 6/1)

Bedding - thin to medium bedded

Sedimentary Structures - abundant large-scale trough crossbed sets, $10 \mathrm{~cm}$ thick ironstone (siderite?) and shale pebble conglomerate at base light grey (N7)

Paleocurrent Measurements - none

Fossils - plant debris and macerated organic matter

Contact - none recorded

Strike/dip - none recorded

Thickness - $5.2 \mathrm{~m}(17 \mathrm{ft})$

UNIT 37: COVERED INTERVAL

Thickness - $16.7 \mathrm{~m}(55 \mathrm{ft})$

\section{UNIT 38: COVERED INTERVAL AND SILTY SHALE WITH INTERBEDDED} MUDSTONE

Grain Size and Texture - shale $/$ mud $=1 / 1$

Color - mudstone - F - greyish red (5R 4/2), W - pale red (5R 6/2); silty shale - F

- moderate olive brown (5Y 4/4), W - pale red (5R 6/2)

Bedding - thin bedded

Sedimentary Structures - none

Paleocurrent Measurements - none

Fossils - none

Contact - none recorded

Strike/dip - none recorded

Thickness - $13 \mathrm{~m}(45 \mathrm{ft})$

UNIT 39: FOSSILIFEROUS LIMESTONE - GREENBRIER LIMESTONE

Grain Size and Texture - cherty packstone/grainstone

Color - none recorded

Bedding - none recorded

Sedimentary Structures - none

Paleocurrent Measurements - none

Fossils - none

Contact - none recorded

Strike/dip - none recorded

Thickness - none recorded 
END OF SECTION 
MEASURED SECTION: Scherr, West Virginia

DATE: 07/17/84

DESCRIBED BY: Tom Bjerste dt and Dr. Tom Kammer
QUADRANGLE: Greenland Gap 7.5' FORMATION: Price Formation

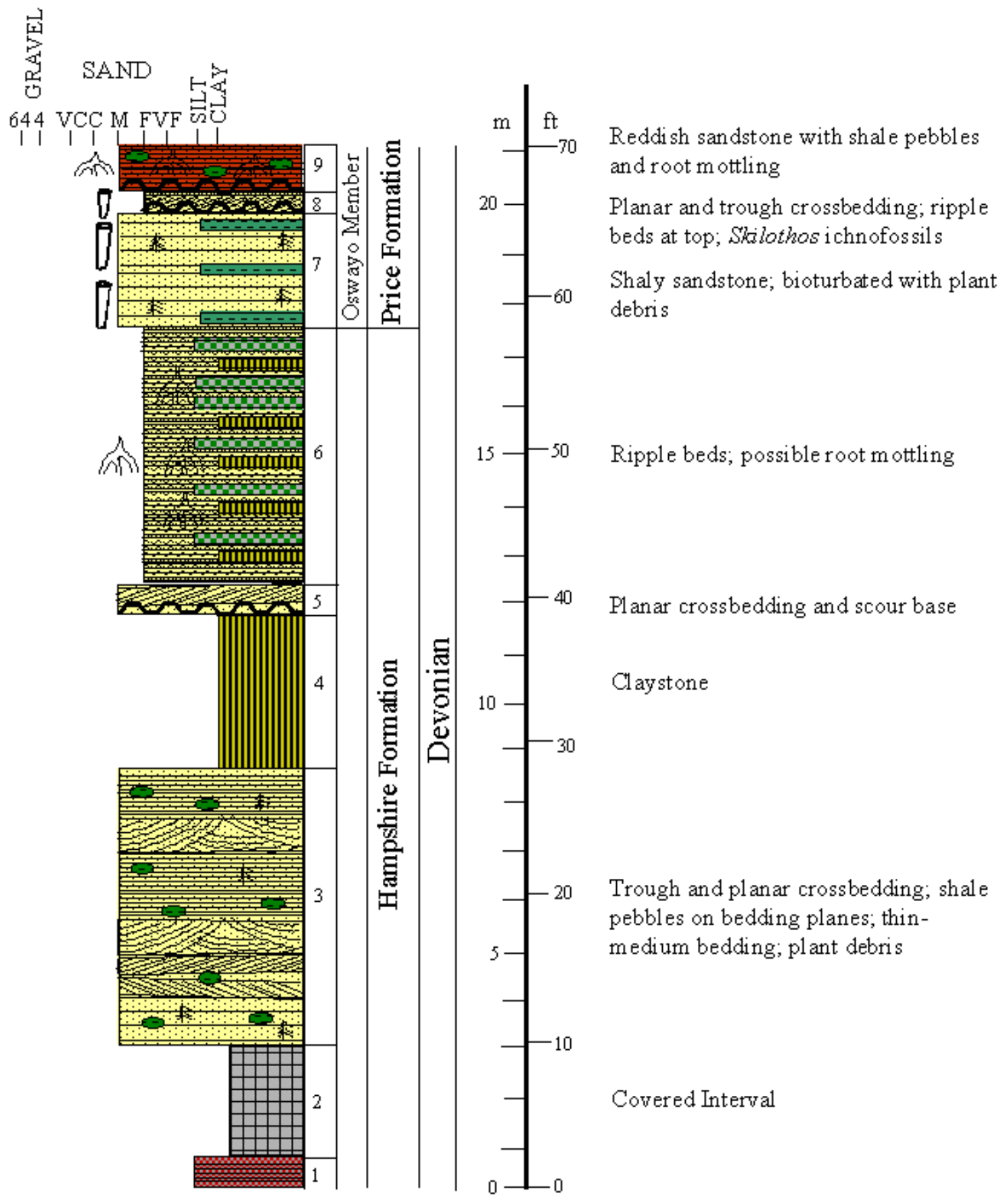

Figure 52. Units 1-9 from the Scherr stratigraphic section 
MEASURED SECTION: Scherr, West Virginia DATE: 07/17/84

DESCRIBED BY: Tom Bjerstedt and Dr. Tom Kammer
QUADRANGLE: Greenland Gap 7.5' FORMATION: Price Formation

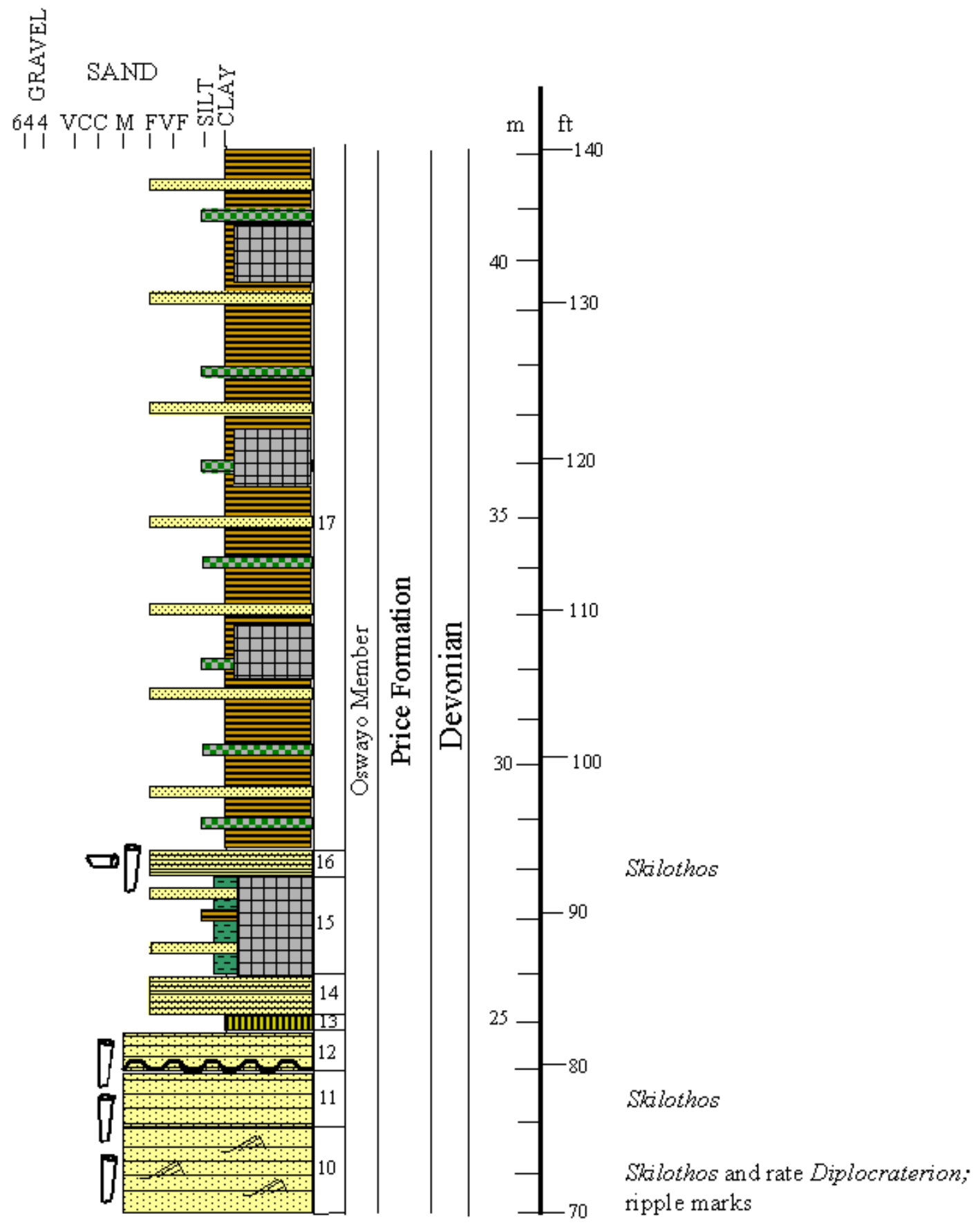

Figure 53. Units 10-17 from the Scherr stratigraphic section 
MEASURED SECTION: Scherr, West Virginia

DATE: 07/17/84

DESCRIBED BY: Tom Bjerstedt and Dr. Tom Kammer
QUADRANGLE: Greenland Gap 7.5'

FORMATION: Price Formation

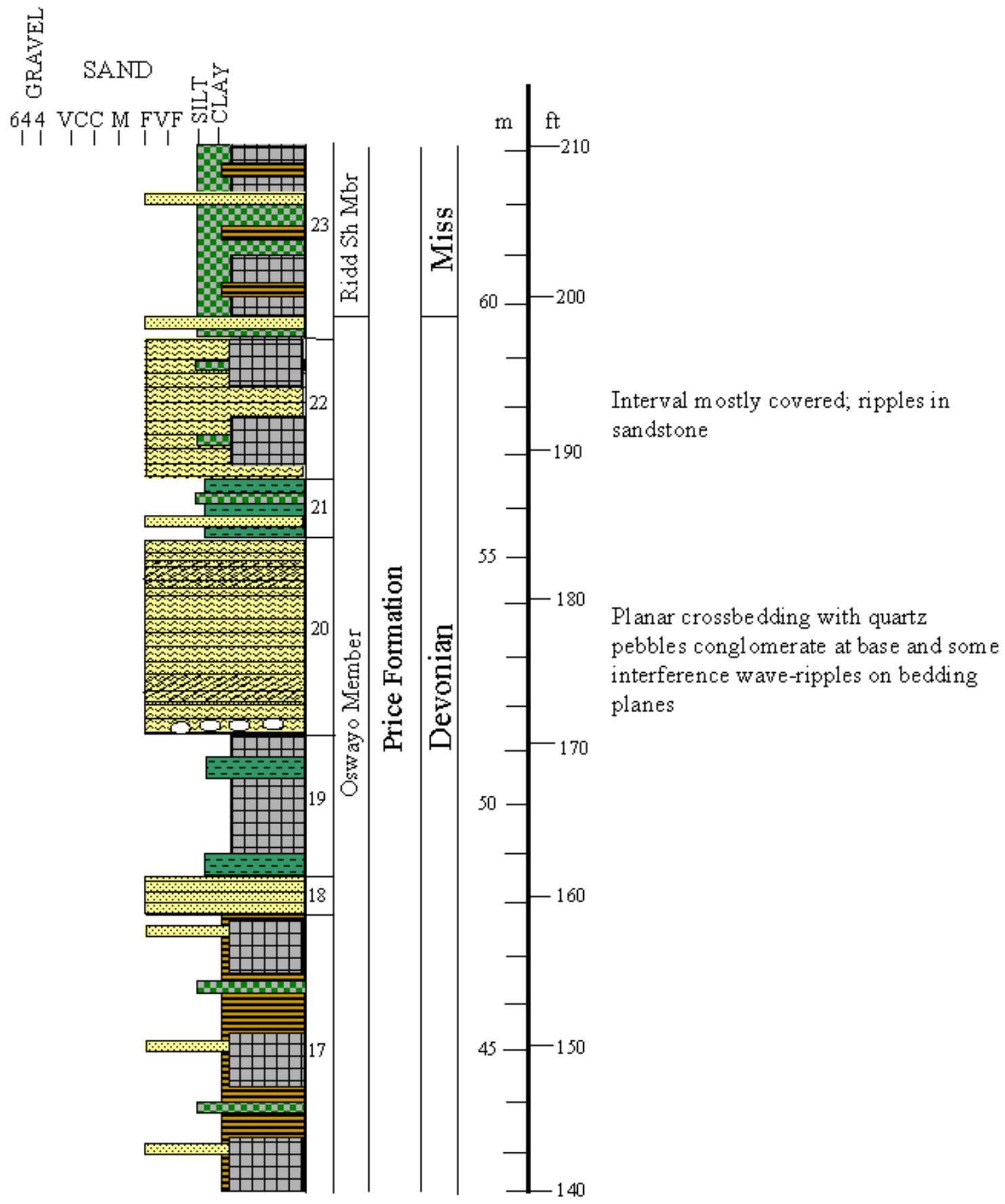

Figure 54: Units 17-23 from the Scherr stratigraphic section 
MEASURED SECTION: Scherr, West Virginia

DATE: 07/17/84

DESCRIBED BY: Tom Bjerstedt and Dr. Tom Kammer
QUADRANGLE: Greenland Gap 7.5'

FORMATION: Price Formation

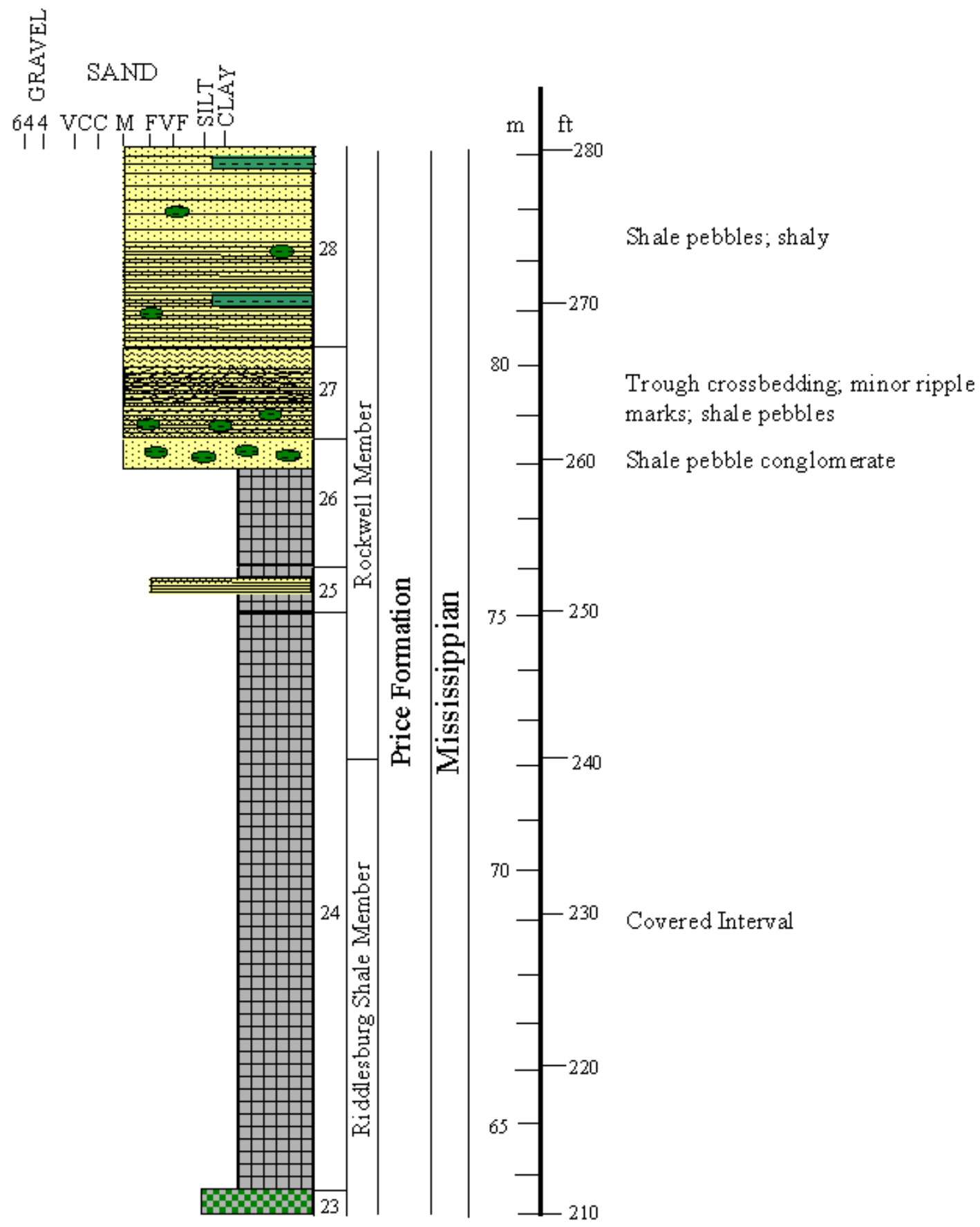

Figure 55. Units 23-28 from the Scherr stratigraphic section 
MEASURED SECTION: Scherr, West Virginia DATE: 07/17/84

DESCRIBED BY: Tom B jerstedt and Dr. Tom Kammer
QUADRANGLE: Greenland Gap 7.5' FORMATION: Price Formation

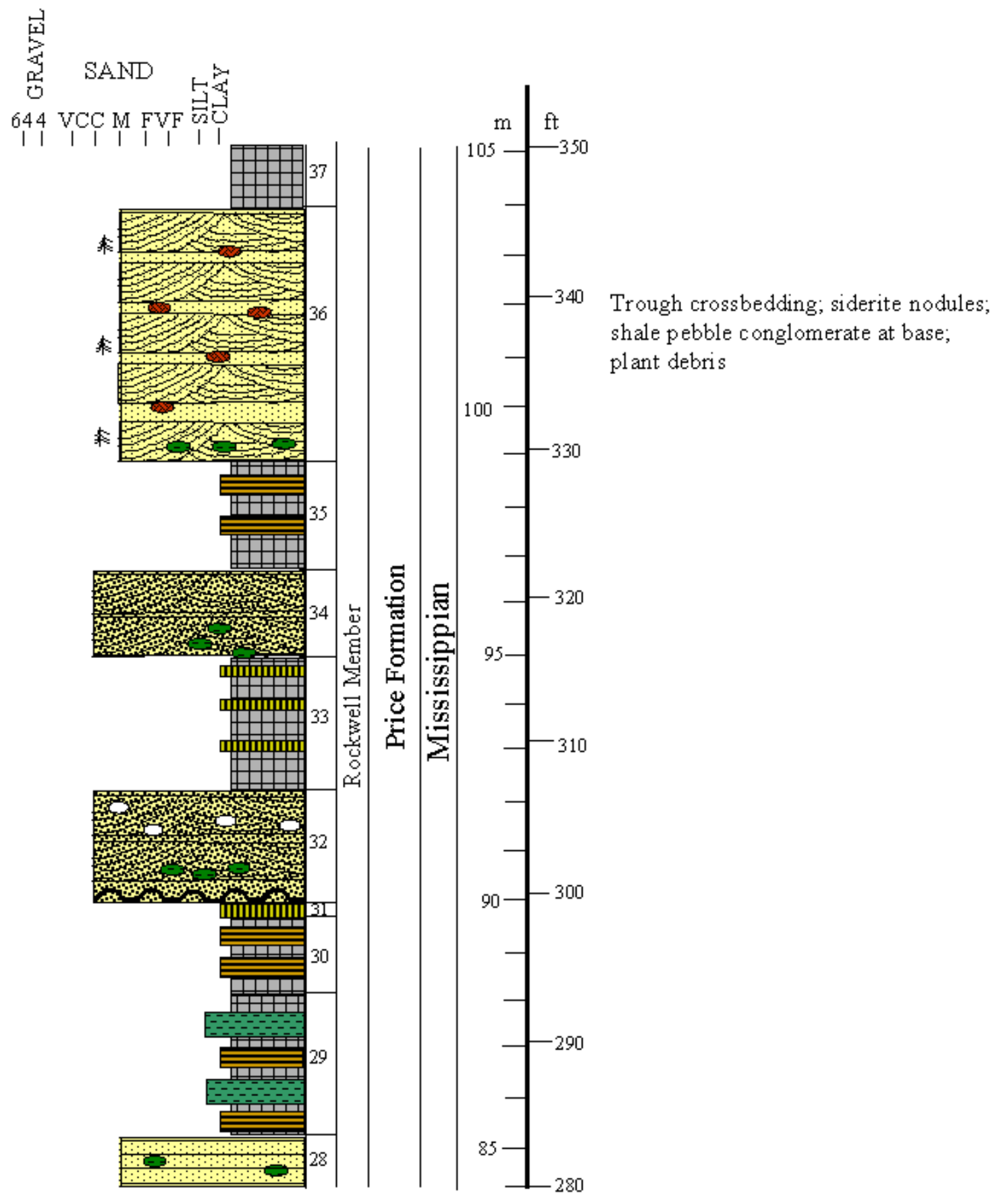

Figure 56. Units 28-37 from the Scherr stratigraphic section 
MEASURED SECTION: Scherr, West Virginia

DATE: 07/17/84

QUADRANGLE: Greenland Gap 7.5'

DESCRIBED BY: Tom Bjerstedt and Dr. Tom Kammer

FORMATION: Price Formation

644 VCCM FVF 至罗

届

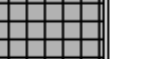

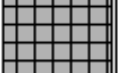

円田

38

$\prod^{38}$

$\Perp$

$\Perp^{+}$

H11

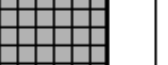

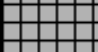

册

丹覀

П

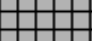

田

\#

\#

\# 37

+

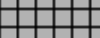

\#

\#助

\#舟

\#冓

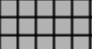

\#冓

П

\#

且

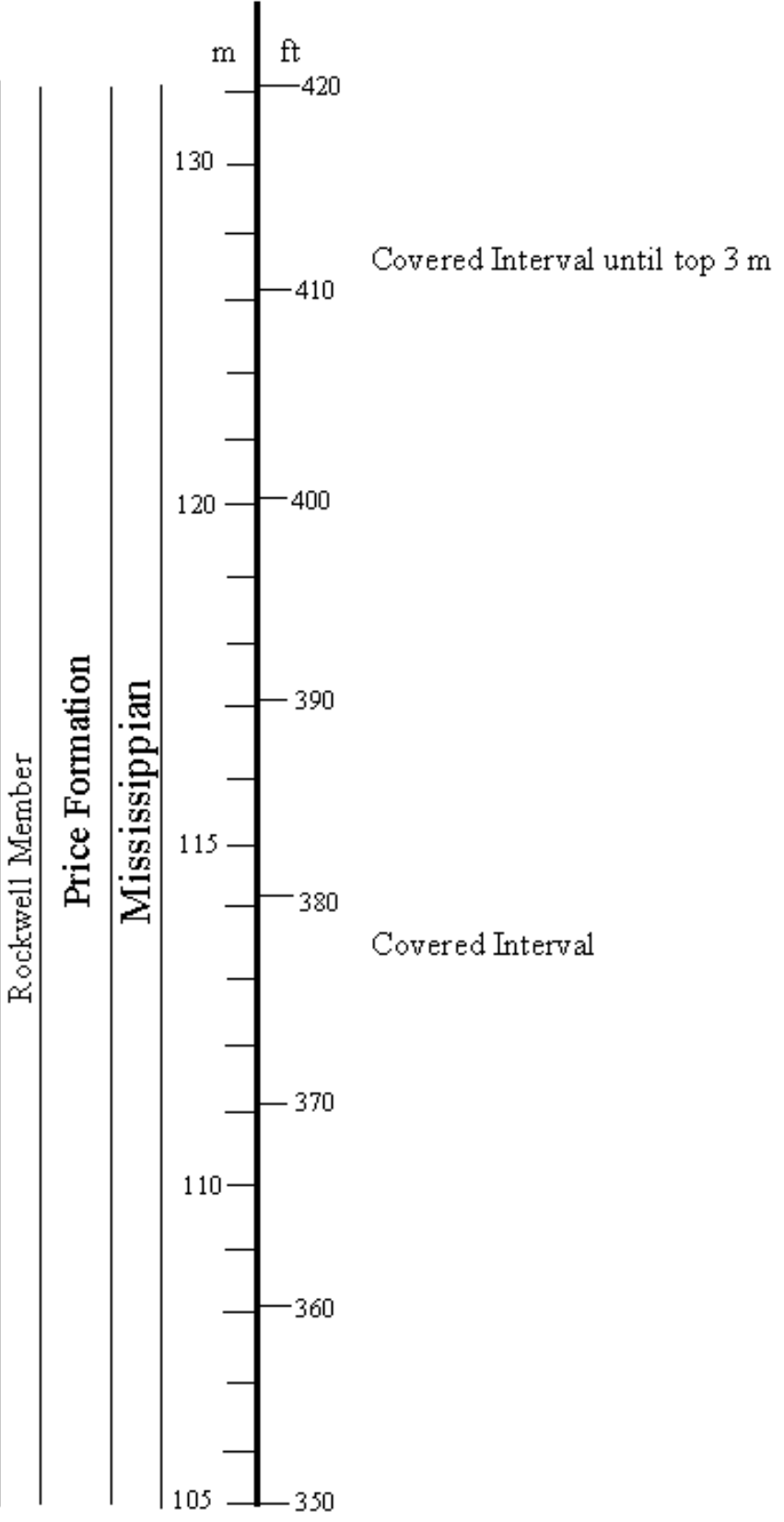

Figure 57. Units 37-38 from the Scherr stratigraphic section 
MEASURED SECTION: Scherr, West Virginia

DATE: $07 / 17 / 84$

DESCRIBED BY: Tom Bjerstedt and Dr. Tom Kammer
QUADRANGLE: Greenland Gap 7.5'

FORMATION: Price Formation
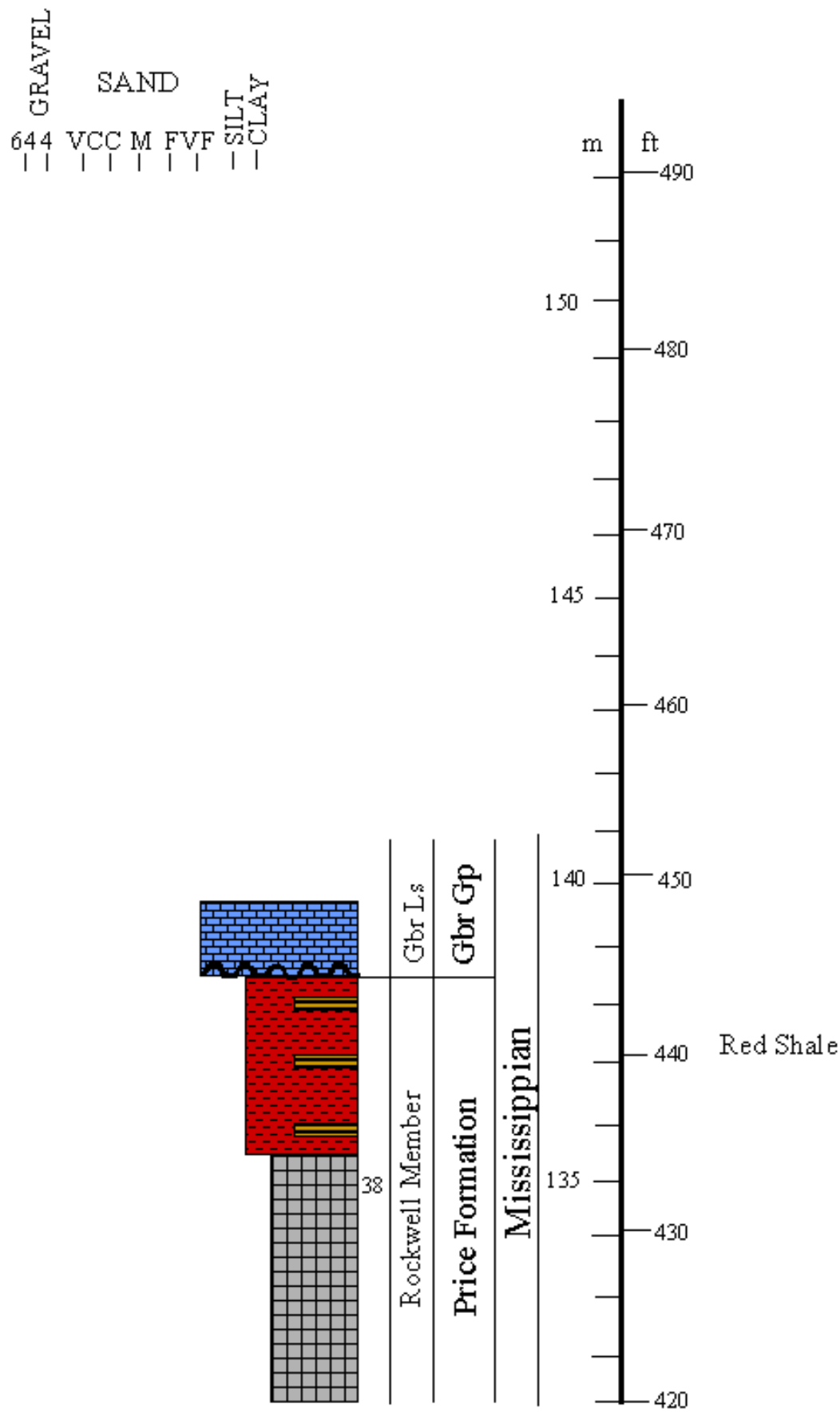

Figure 58. Unit 38 from the Scherr stratigraphic section 
Measured Section - Laurel Run, West Virginia

Measured by Sheldon Murphy and Barnes Nugent

Quadrangle - Blackbird Knob 7.5'

Date $-10 / 01 / 99$

Measured section of the Price Formation on southeast face of Fore Knobs at Laurel Run. Top of section at elevation $2640 \mathrm{ft}$. $(804 \mathrm{~m})$ located $5600 \mathrm{ft}$. (1707 m) southwest of bench mark 3378. Base of section at elevation $2300 \mathrm{ft}$. $(701 \mathrm{~m})$ located $5500 \mathrm{ft}$. $(1676 \mathrm{~m})$ southeast of bench mark 3378. Located in Union District within Grant County.

Hampshire Formation (Units 1-2)

Oswayo Member (Units 2-4)

Riddlesburg Member (Units 5)

Rockwell Member (Units 6-13

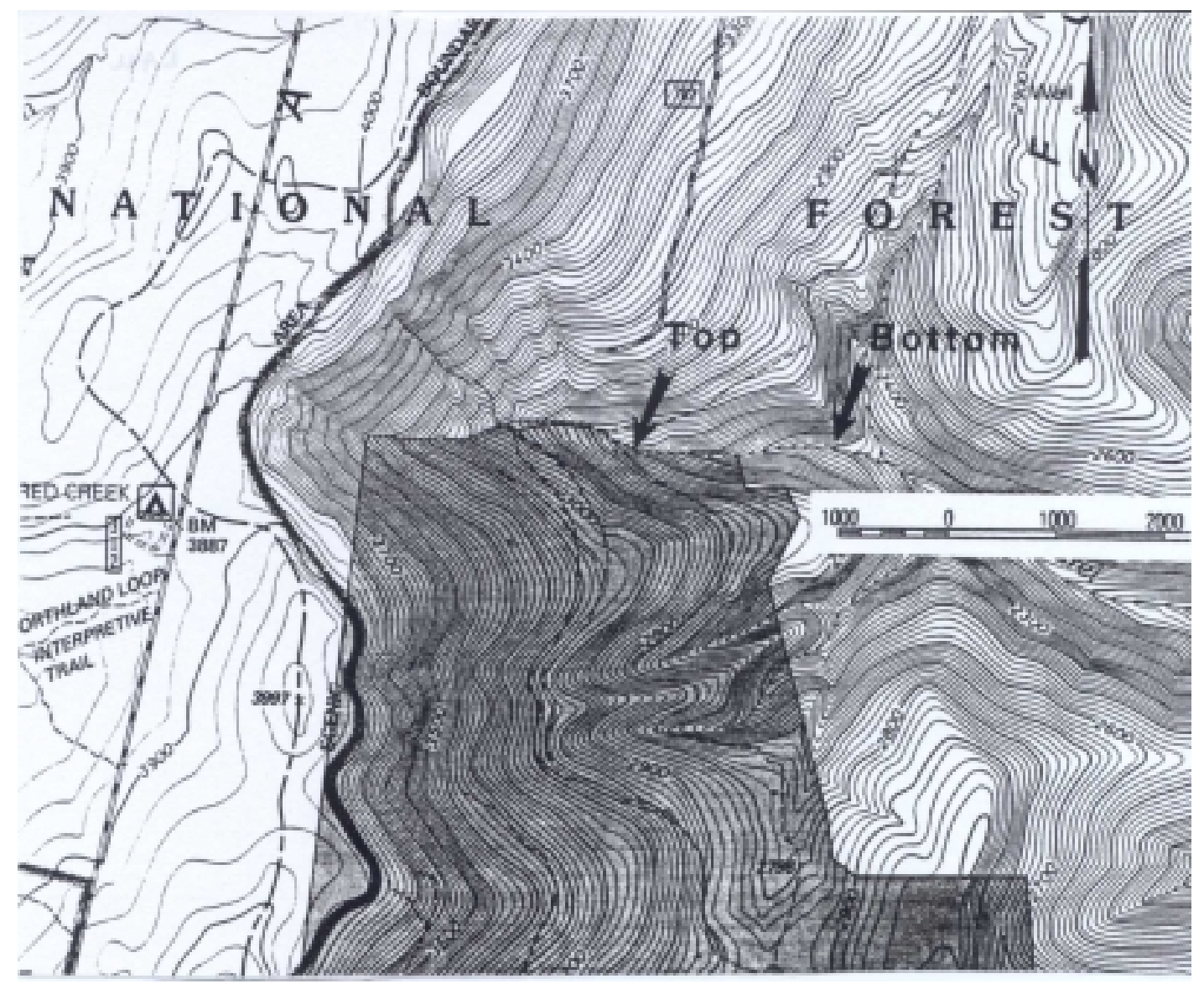

Figure 59. Location map for Laurel Run section taken from the Blackbird Knob 7.5' USGS topographic map 
Measured Section - Laurel Run

Measured by Sheldon Murphy and Barnes Nugent (WVGES)

Quadrangle - Blackbird Knob 7.5'

Date- 10/01/99

\section{UNIT 1: SANDSTONE WITH INTERBEDDED MUDSTONE AND \\ SHALE}

Grain Size and Texture - sandstone, very fine-grained, hard, subangular grains, quartz matrix, tightly packed grains, well sorted

Color- red

Bedding - planar beds from less than $0.025 \mathrm{~m}$ ( 1.0 inches) to $0.076 \mathrm{~m}$ ( 3.0 inches) throughout, mudstone in base and top, shale below mudstone near top, bed thickness increases up to $0.30 \mathrm{~m}(1.0 \mathrm{ft})$ at top

Sedimentary Structures - none observed

Paleocurrent Measurements - none

Fossils - none

Contact - covered at base and sharp at top

Strike/dip - 10 degrees/16 degree dip at 280 degrees

Thickness - $15.7 \mathrm{~m}(51.5 \mathrm{ft})$

\section{UNIT 2: SANDSTONE}

Grain Size and Texture - very fine-grained, hard, subrounded grains, tightly packed grains and well sorted, carbonaceous material in base

Color- buff

Bedding - contorted in basal $0.91 \mathrm{~m}(3.0 \mathrm{ft})$, epsilon crossbeds and planar crossbeds from right to left in base, basal beds are $0.015 \mathrm{~m}$ (0.6 inches) and thicken upwards to $0.30 \mathrm{~m}(1.0 \mathrm{ft})$ to $0.60 \mathrm{~m}(2.0 \mathrm{ft})$, middle of section beds are $0.030 \mathrm{~m}(0.10 \mathrm{ft})$, top of section is mottled with $0.45 \mathrm{~m}(1.5 \mathrm{ft})$ to $(0.60 \mathrm{~m} 2.0 \mathrm{ft})$ beds and bioturbated

Sedimentary Structures - bioturbated, planar crossbeds

Paleocurrent Measurements - none

Fossils - ichnofossils, Skilothos

Contact - sharp at top and base

Strike/dip - 25 degrees/14 degree dip at 295 degrees

Thickness $-11.5 \mathrm{~m}(38 \mathrm{ft})$

\section{UNIT 3: SILTSTONE WITH INTERBEDDED MUDSTONE}

Grain Size and Texture - shale soft, siltstone - fine-grained, semi hard, mottled Color- mudstone - dark grey, siltstone - grey

Bedding - planar siltstone beds

Sedimentary Structures - bioturbated with vertical worm tubes

Paleocurrent Measurements - none

Fossils - ichnofossils

Contact - sharp at top and base

Strike/dip - 25 degrees/14 degree dip at 295 degrees

Thickness $-1.8 \mathrm{~m}(6 \mathrm{ft})$ 


\section{UNIT 4: SANDSTONE}

Grain Size and Texture - very fine-grained, hard, subrounded grains, tightly packed and well sorted

Color- mudstone - grey-buff

Bedding - planar beds approximately $0.30 \mathrm{~m}(1.0 \mathrm{ft})$ to $0.45 \mathrm{~m}(1.5 \mathrm{ft})$ until top $1.5 \mathrm{~m}$ (5.0 ft) were beds are $0.001 \mathrm{~m}$ ( 0.05 inches) to $0.015 \mathrm{~m}$ ( 0.60 inches), some laminated beds at top, planar crossbeds at top accreting left to right then right to left

Sedimentary Structures - planar crossbeds

Paleocurrent Measurements - none

Fossils - none observed

Contact - sharp at base and gradational at top

Strike/dip - 26 degrees/14 degree dip at 296 degrees

Thickness $-13.4 \mathrm{~m}(44 \mathrm{ft})$

UNIT 5: SHALE WITH INTERBEDDED SILTSTONE, MUDSTONE AND SANSTONE AT BASE

Grain Size and Texture - very soft, hard and silty at top

Color- mudstone - dark grey-black

Bedding - none

Sedimentary Structures - none

Paleocurrent Measurements - none

Fossils - none observed

Contact - sharp at base and covered at top

Strike/dip - none taken

Thickness $-6.5 \mathrm{~m}(21.5 \mathrm{ft})$

\section{UNIT 6: COVERED INTERVAL}

Thickness $-7.1 \mathrm{~m}(23.5 \mathrm{ft})$

\section{UNIT 7: SANDSTONE WITH INTBEDDED QUARTZ PEBBLE} CONGLOMERATE

Grain Size and Texture - very fine-grained, very hard, subrounded grains, tightly packed and well sorted, $2-3 \mathrm{~cm}$ quartz pebbles

Color- mudstone - bottom brown-buff conglomerate - brown to reddish, top grey

Bedding - bottom beds are $0.30 \mathrm{~m}(1.0 \mathrm{ft})$ thick becoming thinner $0.25 \mathrm{~m}(1.0$ inches) with some right to left planar small scale crossbeds, middle of unit contains a conglomerate planar beds ( 2.0 inches) to ( 4.0 inches) consisting of quartz pebbles (up to $5 \mathrm{~cm}$ ) and iron nodules with a bottom scour surface, upper part of unit consists of planar and low angle right to left accreting planar crossbeds in base $(5.0 \mathrm{ft})$, beds are ( $0.6 \mathrm{ft})$ decreasing thickness to (2.0 inches) to laminated with some basal coarse zones near underlying conglomerate, very top beds get thicker $0.30 \mathrm{~m}(1.0 \mathrm{ft})$

Sedimentary Structures - planar crossbeds 
Paleocurrent Measurements (in top part of unit)

strike of bed -35 or 215 degrees

current direction azimuth - 305 degrees

type - planar crossbedding

width - N/A

height - N/A

strike of bed -45 or 225 degrees

current direction azimuth -315 degrees

type - planar crossbedding

width - N/A

height - N/A

Fossils - none observed

Contact - sharp at base and covered at top

Strike/dip - 17 degree/17 degree dip at 287 degrees

Thickness - $23 \mathrm{~m}(76 \mathrm{ft})$

\section{UNIT 8: SILTSTONE WITH INTERBEDDED SANDSTONE}

Grain Size and Texture - fine-grained, semi hard

Color - dark grey in base and mottled in top

Bedding - thin planar siltstone beds in base about $0.10 \mathrm{~m}$ (4.0 inches) and

sandstone at top is $0.60 \mathrm{~m}(2.0 \mathrm{ft})$, no bedding in top $0.91 \mathrm{~m}(3.0 \mathrm{ft})$, grades into

sandstone at top

Sedimentary Structures - bioturbated

Paleocurrent Measurements - none

Fossils - none

Contact - gradational at top and base

Strike/dip - none taken

Thickness - $3.5 \mathrm{~m}(11.5 \mathrm{ft})$

\section{UNIT 9: SANDSTONE}

Grain Size and Texture - very fine-grained, hard, subrounded grains, tightly packed and well sorted

Color - buff becoming grey toward top

Bedding - beds are planar, basal $0.60 \mathrm{~m}(2.0 \mathrm{ft})$ has $0.15 \mathrm{~m}$ (0.6 inches) beds becoming thinner $0.001 \mathrm{~m}$ ( 0.05 inches) to $0.05 \mathrm{~m}$ ( 2.0 inches) throughout, low angle planar crossbeds starting above basal $0.60 \mathrm{~m}(2.0 \mathrm{ft})$ and continue to top of section, crossbeds accrete left to right in base and right to left in top

Sedimentary Structures - planar crossbeds

Paleocurrent Measurements - none

Fossils - none

Contact - gradational at base and covered at top

Strike/dip - none taken

Thickness - $12 \mathrm{~m}$ (39.5 ft)

UNIT 10: COVERED INTERVAL 
Thickness - $11 \mathrm{~m}(39 \mathrm{ft})$

\section{UNIT 11: SANDSTONE}

Grain Size and Texture - very fine-grained, very hard, subangular grains, tightly packed and well sorted

Color - buff

Bedding - beds are planar and $0.06 \mathrm{~m}$ (2.5 inches) thick, low angle planar crossbeds accreting left to right and right to left

Sedimentary Structures - planar crossbeds

Paleocurrent Measurements - none

Fossils - none

Contact - gradational at base and covered at top

Strike/dip - none taken

Thickness $-2.7 \mathrm{~m}(9 \mathrm{ft})$

\section{UNIT 12: COVERED INTERVAL}

Thickness - $12 \mathrm{~m}(40 \mathrm{ft})$

\section{UNIT 13: SANDSTONE}

Grain Size and Texture - very fine-grained, very hard, subangular grains, tightly packed grains

Color - red

Bedding - planar basal beds $0.18 \mathrm{~m}(0.6 \mathrm{ft})$ thick becoming wavy and $0.025 \mathrm{~m}$

(1.0 inches) thick, low angle planar crossbeds accreting left to right and right to left in base

Sedimentary Structures - planar crossbeds

Paleocurrent Measurements - none

Fossils - none

Contact - covered at base and sharp to Mississippian Greenbrier Limestone at top

Strike/dip - none taken

Thickness - $3.6 \mathrm{~m}(12 \mathrm{ft})$

\section{END OF SECTION}


MEASURED SECTION: Laurel Run, West Virginia DATE: $11 / 05 / 99$

DESCRIBED B Y: Sheldon Murphy, Barnes Nugent

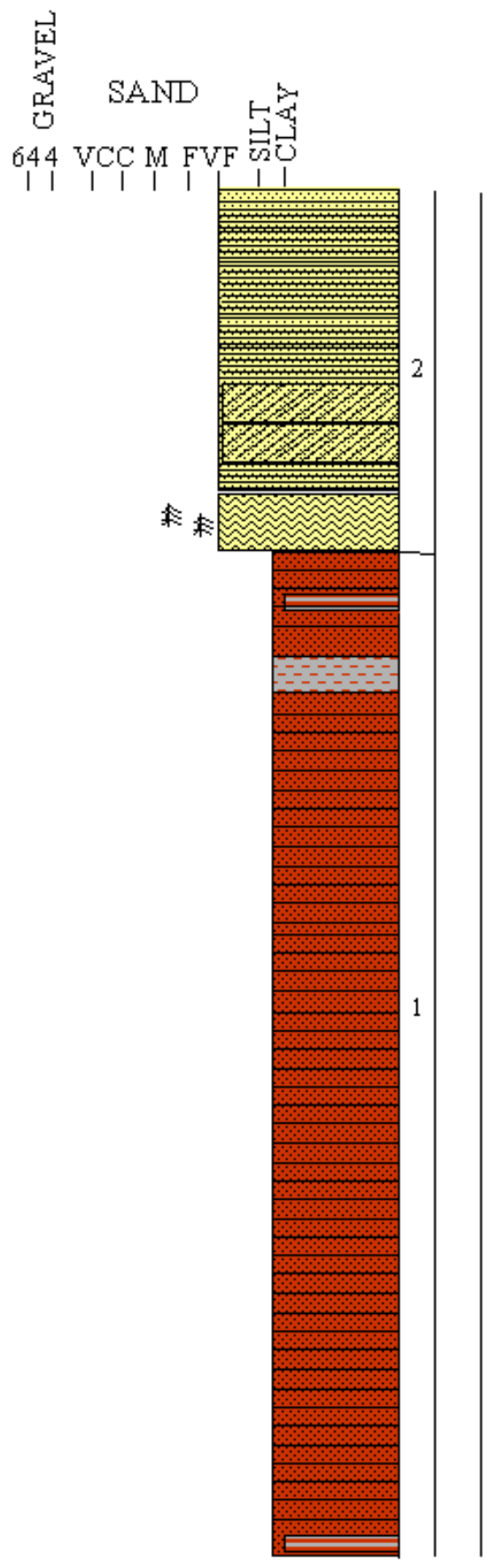

QUADRANGLE: Blackbird Know 7.5' FORMATION: Price Formation
Contorted bedding and carbonaceous material at the base with planar crossbeds above; middle of section is very thinly bedded; top of unit contains burrows

Red sandstone with thinly bedded planar beds

Figure 60. Units 1-2 from the Laurel Run stratigraphic section 
MEASURED SECTION: Laurel Run, West Virginia

DATE: $11 / 05 / 99$

DESCRIBED BY: Sheldon Murphy, Barnes Nugent

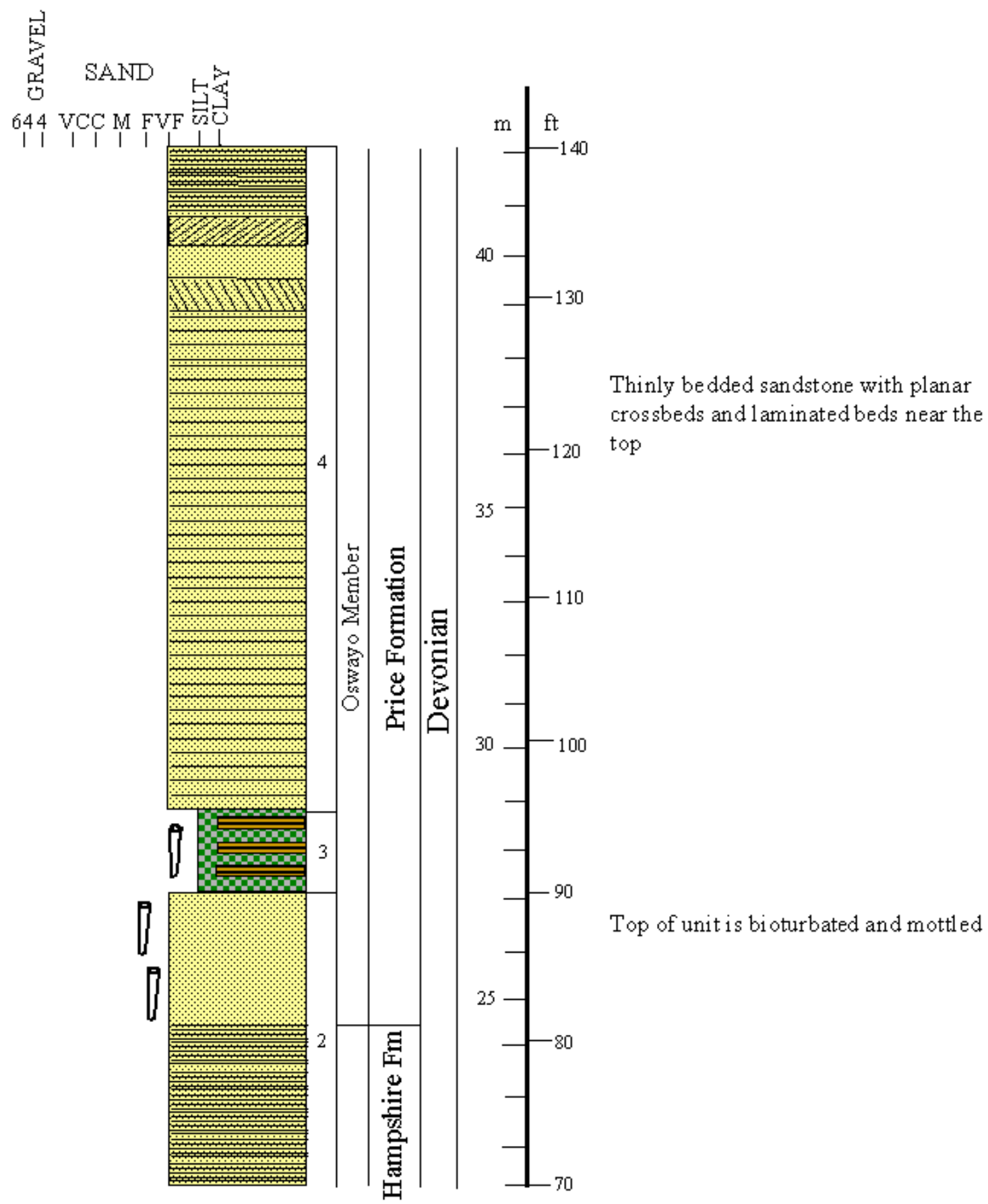

QUADRANGLE: Blackbird Knob 7.5' FORMATION: Price Formation 
MEASURED SECTION: Laurel Run, West Virginia DATE: $11 / 05 / 99$

DESCRIBED BY: Sheldon Murphy, Barnes Nugent
QUADRANGLE: Blackbird Knob 7.5' FORMATION: Price Formation

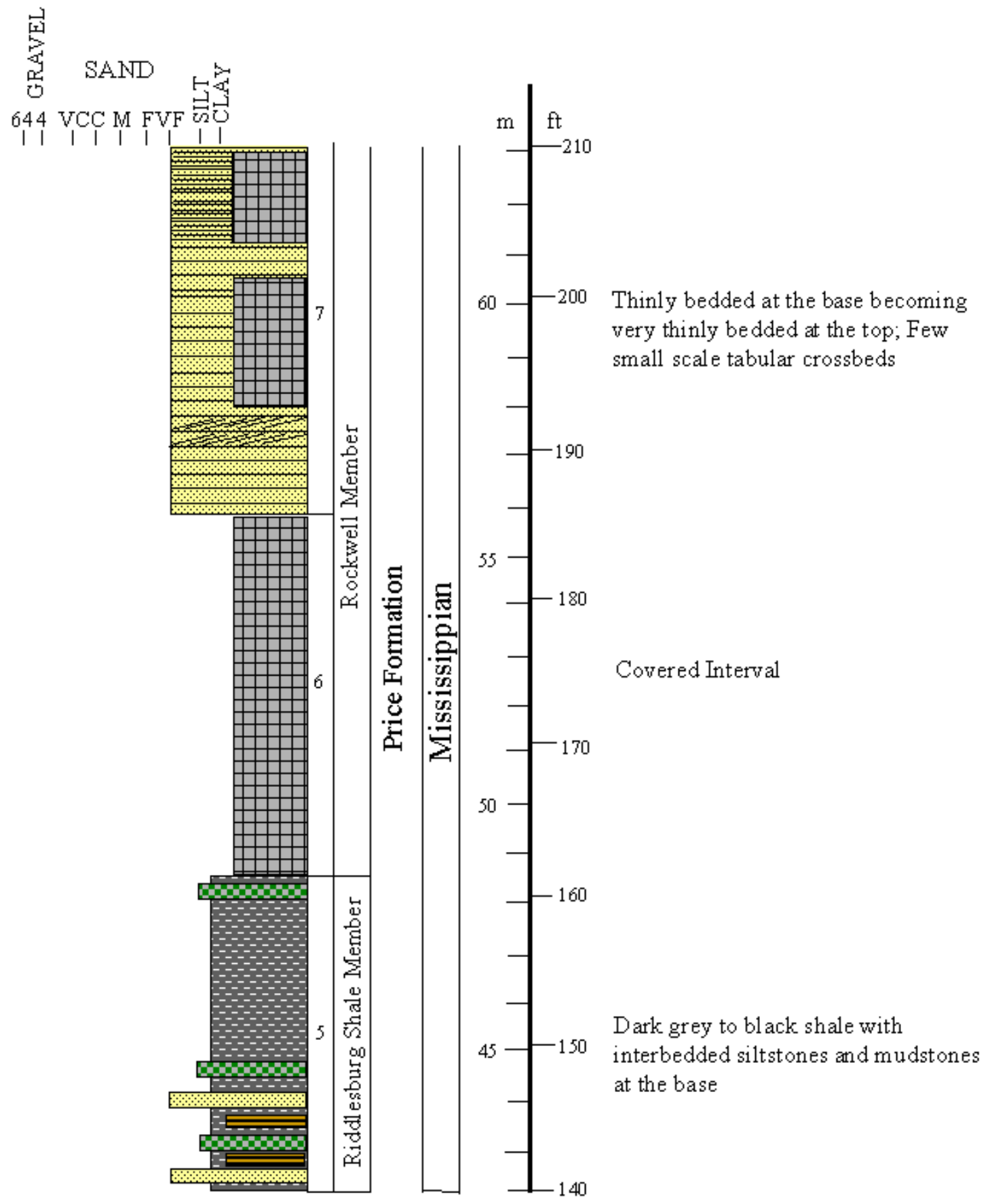

Figure 62. Units 5-7 from the Laurel Run stratigraphic section 
MEASURED SECTION: Laurel Run, West Virginia DATE: $11 / 05 / 99$

DESCRIED BY: Sheldon Murphy, Barnes Nugent
QUADRANGLE: Blackbird Knob 7.5' FORMATION: Price Formation

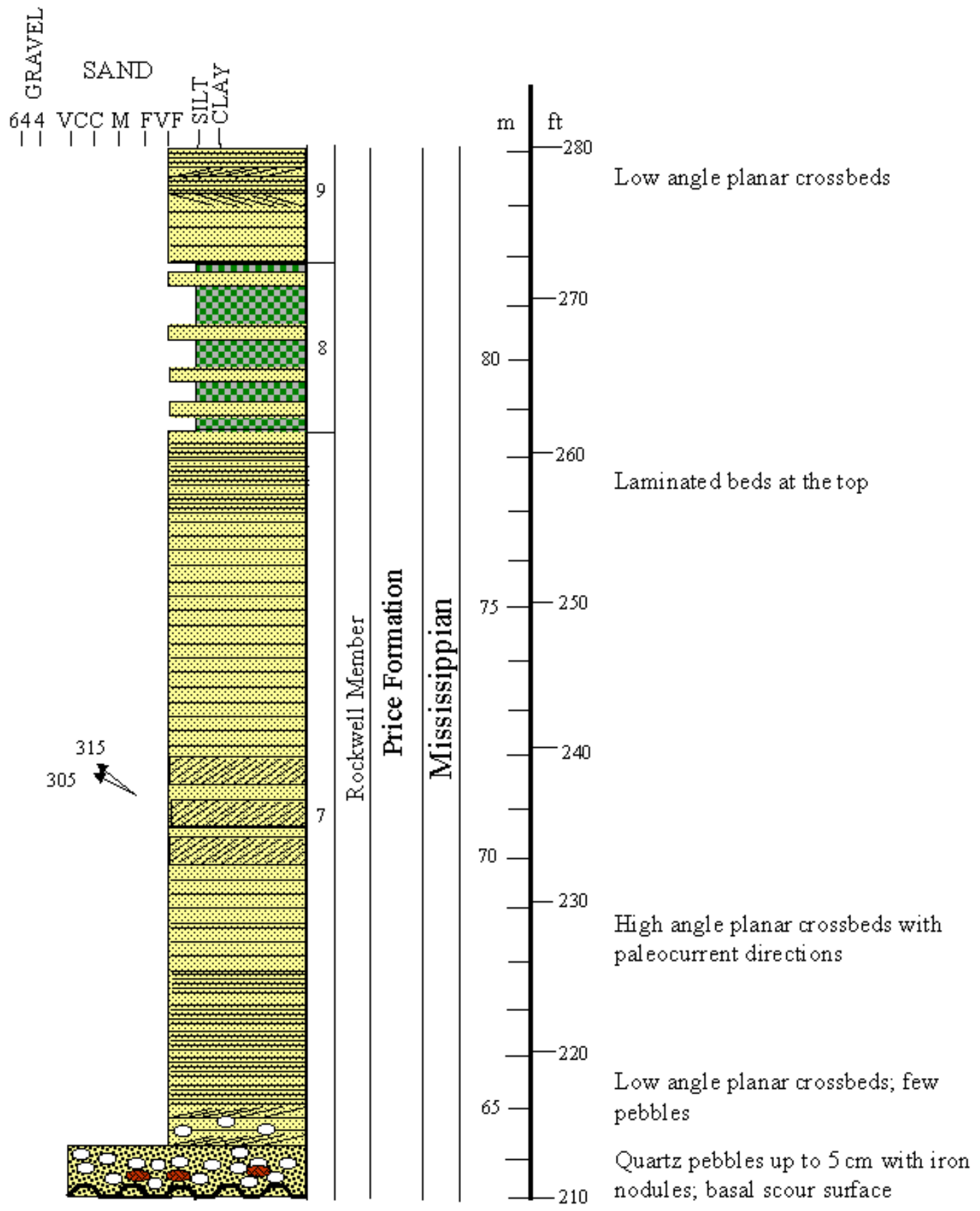

Figure 63. Units 7-9 from the Laurel Run stratigraphic section 
MEASURED SECTION: Laurel Run, West Virginia DATE: $11 / 05 / 99$

QUADRANGLE: Blackbird Knob 7.5' DESCRIBE BY: Sheldon Murphy, Barnes Nugent

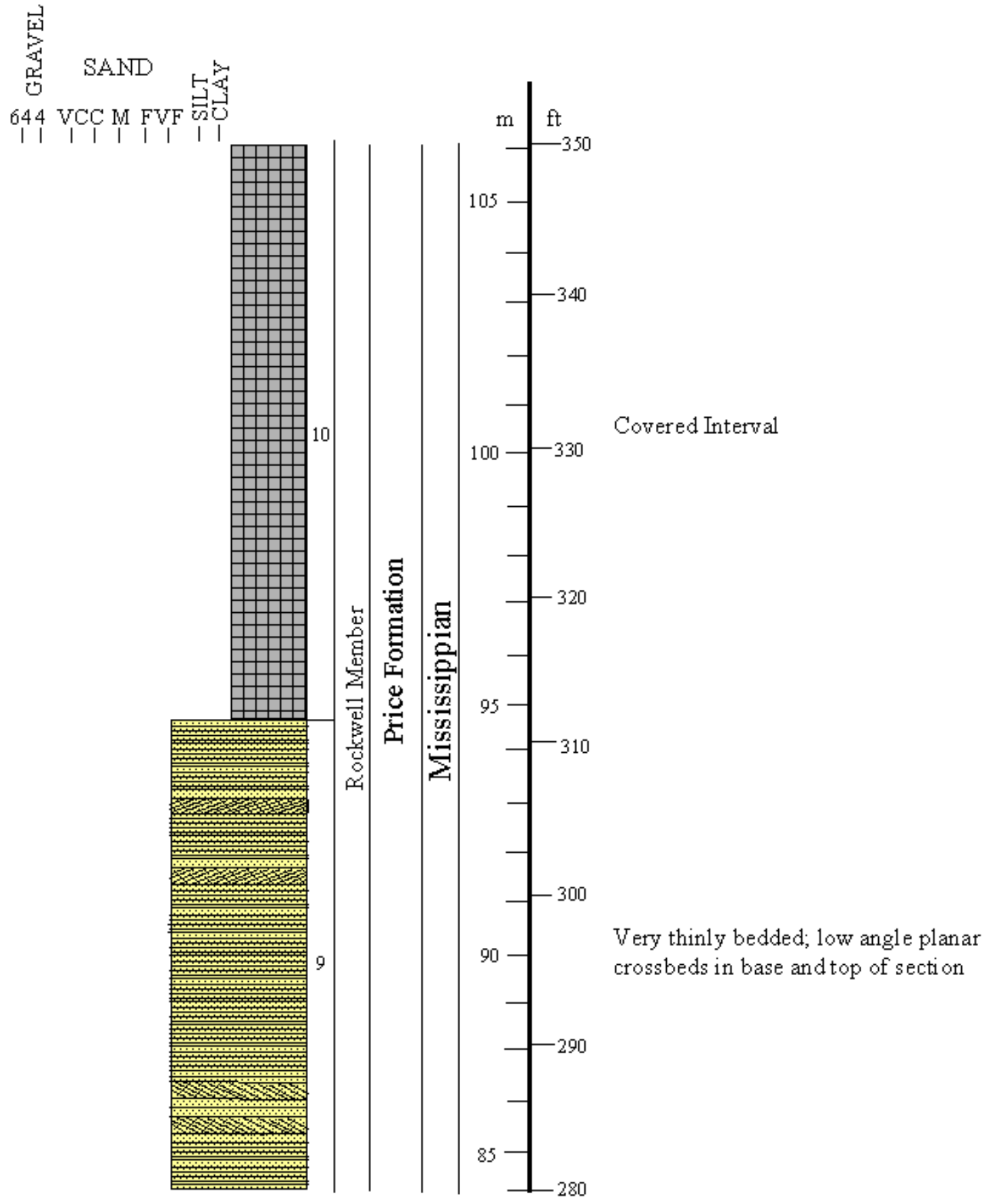

Figure 64. Units 9-10 from the Laurel Run stratigraphic section 
MEASURED SECTION: Laurel Run, West Virginia DATE: $11 / 05 / 99$

DESCRIBED BY: Sheldon Murphy, Barnes Nugent

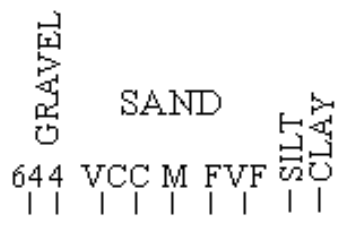

QUADRANGLE: Blackbird Knob 7.5' FORMATION: Price Formation

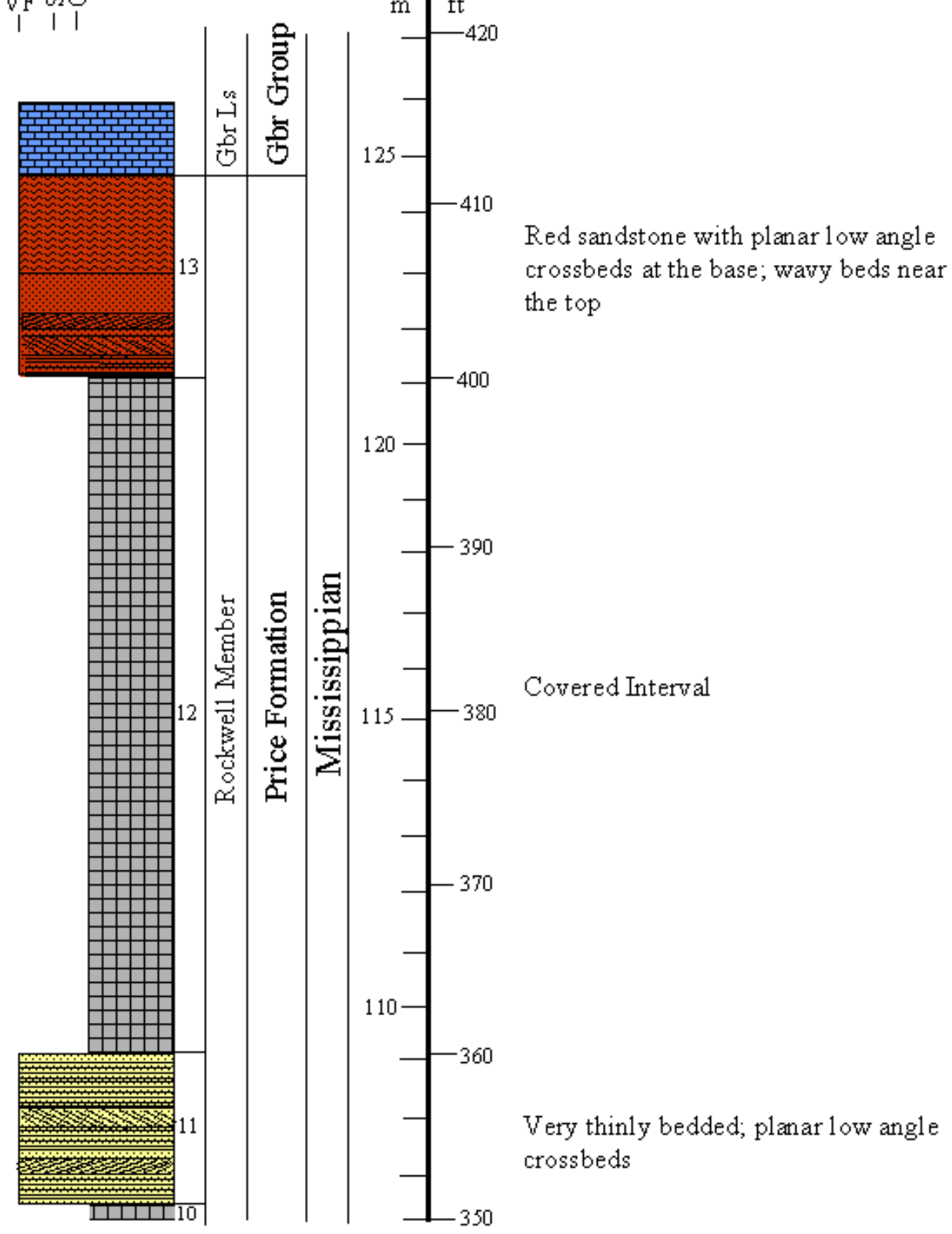

Figure 65. Units 10-13 from the Laurel Run stratigraphic section 


\section{Measured Section - Red Creek, West Virginia \\ Measured by Nick Fedorko (WVGES) \\ Quadrangle - Laneville 7.5' \\ Date - 06/07/94 - 06/09/94}

Measured section of the Price Formation along state route 32 on southeast slope of Pointy Knob at Red Creek. Section located at junction of route 32 and route 72 at elevation $2840 \mathrm{ft}$. $(865 \mathrm{~m})$ located $800 \mathrm{ft}$. (243 m) NNE of Wolford Church. Base of section at elevation $2600 \mathrm{ft}$. (792 m) located $2000 \mathrm{ft}$. (609 m) SSW of Wolford Church. Located in Dry Fork District within Tucker County.

Hampshire Formation (Units 1-25)

Oswayo Member (Units 26-31)

Riddlesburg Shale Member (Units 32-35)

Rockwell Member (35-38)

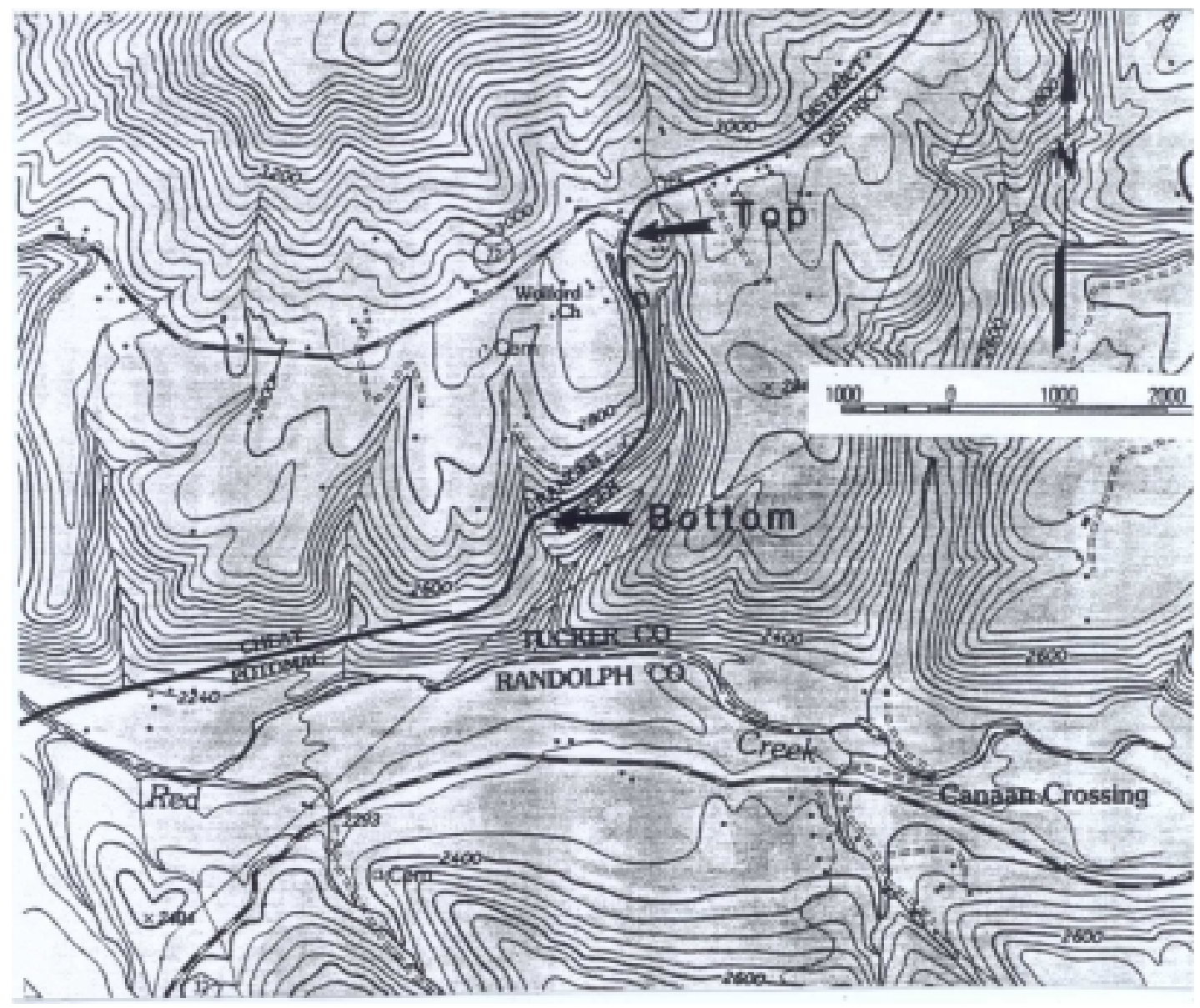

Figure 66. Location map for Red Creek section taken from the Laneville 7.5' USGS topographic map 
Measured Section - Red Creek

Measured by Nick Fedorko (WVGES - Vol. 174-49)

Quadrangle - Laneville 7.5'

Date - 06/07/94-06/09/94

Comment - thicknesses were not corrected for dip, only estimated

\section{UNIT 1: MUDSTONE}

Grain Size and Texture - fine to medium

Color - red

Bedding - blocky, shaly in base

Sedimentary Structures - none recorded

Fossils - none

Contact - none recorded

Strike/dip - none recorded

Thickness $-1.7 \mathrm{~m}(5.8 \mathrm{ft})$

UNIT 2: SILTY SANDSTONE

Grain Size and Texture - very fine-grained, silty

Color - red

Bedding - thin, less than $0.06 \mathrm{~m}(0.2 \mathrm{ft})$

Sedimentary Structures - none recorded

Fossils - none

Contact - top altered by unit 3

Strike/dip - none recorded

Thickness $-0.15 \mathrm{~m}(0.5 \mathrm{ft})$

\section{UNIT 3: SILTSTONE}

Grain Size and Texture - coarse

Color - red

Bedding - blocky

Sedimentary Structures - none recorded

Fossils - none

Contact - none recorded

Strike/dip - none recorded

Thickness $-1.1 \mathrm{~m}(3.9 \mathrm{ft})$

\section{UNIT 4: SILTY SANDSTONE}

Grain Size and Texture - very fine-grained, silty

Color - red

Bedding - thin, tabular bedding

Sedimentary Structures - none recorded

Fossils - none

Contact - none recorded

Strike/dip - none recorded

Thickness $-1.0 \mathrm{~m}(3.5 \mathrm{ft})$ 
UNIT 5: SANDY SILTSTONE

Grain Size and Texture - very fine-grained

Color - red

Bedding - blocky

Sedimentary Structures - none recorded

Fossils - none

Contact - sharp at base

Strike/dip - none recorded

Thickness - $1.4 \mathrm{~m}(4.6 \mathrm{ft})$

UNIT 6: SANDSTONE

Grain Size and Texture - fine-grained, hard

Color - red, light grey

Bedding - tabular

Sedimentary Structures - none recorded

Fossils - none

Contact - none recorded

Strike/dip - none recorded

Thickness - $2.2 \mathrm{~m}(7.4 \mathrm{ft})$

UNIT 7: SILTSTONE

Grain Size and Texture - coarse

Color - red

Bedding - blocky

Sedimentary Structures - slickensides

Fossils - none

Contact - sharp at base

Strike/dip - none recorded

Thickness $-0.5 \mathrm{~m}(1.8 \mathrm{ft})$

UNIT 8: SANDSTONE

Grain Size and Texture - fine-grained, hard

Color - light grey

Bedding - tabular

Sedimentary Structures - none recorded

Fossils - none

Contact - sharp at base

Strike/dip - none recorded

Thickness $-0.3 \mathrm{~m}(1.3 \mathrm{ft})$

\section{UNIT 9: SILTSTONE}

Grain Size and Texture - coarse

Color - grey-green, red

Bedding - blocky

Sedimentary Structures - slickensides

Fossils - none 
Contact - sharp at base

Strike/dip - none recorded

Thickness $-1.5 \mathrm{~m}(5.0 \mathrm{ft})$

\section{UNIT 10: SANDSTONE}

Grain Size and Texture - fine-grained, hard

Color - light grey

Bedding - tabular beds, basal channel

Sedimentary Structures - none recorded

Fossils - none

Contact - none recorded

Strike/dip - none recorded

Thickness $-0.1 \mathrm{~m}(0.6 \mathrm{ft})$

\section{UNIT 11: SILTSTONE}

Grain Size and Texture - fine-grained

Color - light grey

Bedding - tabular in top, blocky at base

Sedimentary Structures - none recorded

Fossils - root traces

Contact - none recorded

Strike/dip - none recorded

Thickness $-0.9 \mathrm{~m}(3.0 \mathrm{ft})$

\section{UNIT 12: SILTY SHALE}

Grain Size and Texture - fine-grained

Color - light grey

Bedding - poorly bedded

Sedimentary Structures - none recorded

Fossils - none recorded

Contact - none recorded

Strike/dip - none recorded

Thickness - $1.4 \mathrm{~m}$ (4.9ft)

\section{UNIT 13: SANDSTONE}

Grain Size and Texture - fine-grained, hard

Color - light grey

Bedding - none recorded, massive (?)

Sedimentary Structures - crossbedding, scour surfaces

Fossils - none

Contact - erosive base

Strike/dip - none recorded

Thickness - $6.2 \mathrm{~m}(20.4 \mathrm{ft})$

\section{UNIT 14: SANDY SILTSTONE}

Grain Size and Texture - fine-grained 
Color - red in top, light grey at base

Bedding - thinly bedded at top, massive at base

Sedimentary Structures - none recorded

Fossils - none recorded

Contact - none recorded

Strike/dip - none recorded

Thickness - $1.9 \mathrm{~m}(6.5 \mathrm{ft})$

UNIT 15: SILTY MUDSTONE

Grain Size and Texture - none recorded

Color - red

Bedding - none recorded

Sedimentary Structures - none recorded

Fossils - root traces

Contact - sharp base

Strike/dip - none recorded

Thickness $-0.3 \mathrm{~m}(1.1 \mathrm{ft})$

UNIT 16: SHALE

Grain Size and Texture - none recorded

Color - light grey-green

Bedding - blocky at base

Sedimentary Structures - none recorded

Fossils - root traces

Contact - sharp base

Strike/dip - none recorded

Thickness - $0.4 \mathrm{~m}$ (1.4ft)

UNIT 17: SILTY MUDSTONE

Grain Size and Texture - none recorded

Color - red

Bedding - blocky

Sedimentary Structures - none recorded

Fossils - none recorded

Contact - top poorly exposed

Strike/dip - none recorded

Thickness $-0.30 \mathrm{~m}(1.0 \mathrm{ft})$

UNIT 18: COVERED INTERVAL

Thickness $-1.0 \mathrm{~m}(3.6 \mathrm{ft})$

UNIT 19: SILTY MUDSTONE

Grain Size and Texture - none recorded

Color - red

Bedding - blocky

Sedimentary Structures - bioturbation 
Fossils - none

Contact - base well exposed, top poorly exposed

Strike/dip - none recorded

Thickness $-2.4 \mathrm{~m}(8.0 \mathrm{ft})$

\section{UNIT 20: SANDY SILTSTONE}

Grain Size and Texture - none recorded

Color - light grey-green

Bedding - poorly bedded

Sedimentary Structures - none recorded

Fossils - none

Contact - base concealed

Strike/dip - none recorded

Thickness - $1.4 \mathrm{~m}(4.6 \mathrm{ft})$

\section{UNIT 21: SANDSTONE (QUARTZ PEBBLES)}

Grain Size and Texture - fine to coarse-grained, hard, abundant quartz pebbles

Color - light grey

Bedding - none recorded

Sedimentary Structures - none recorded

Fossils - none

Contact - sharp, erosive lower contact

Strike/dip - none recorded

Thickness $-0.18 \mathrm{~m}(0.6 \mathrm{ft})$

\section{UNIT 22: SANDSTONE (BRACHIPOD IN FLOAT)}

Grain Size and Texture - very hard, fine-grained

Color - light grey

Bedding - tabular

Sedimentary Structures - none recorded

Fossils - brachiopods in float

Contact - none recorded

Strike/dip - none recorded

Thickness $-0.24 \mathrm{~m}(0.8 \mathrm{ft})$

\section{UNIT 23: SHALE}

Grain Size and Texture - none recorded

Color - light grey to light medium grey-green

Bedding - fissile, interbedded siltstone beds up to $0.09 \mathrm{~m}(0.3 \mathrm{ft})$, approximately $75 / 25$ shale/siltstone

Sedimentary Structures - none recorded

Fossils - none

Contact - none recorded

Strike/dip - none recorded

Thickness - $3.3 \mathrm{~m}$ (11 ft) 
UNIT 24: COVERED INTERVAL

Thickness - $6.7 \mathrm{~m}(22.1 \mathrm{ft})$

UNIT 25: SANDSTONE

Grain Size and Texture - fine-grained

Color - light grey-brown

Bedding - thick

Sedimentary Structures - none recording

Fossils - none

Contact - none recorded

Strike/dip - none recorded

Thickness - $2.5 \mathrm{~m}(8.2 \mathrm{ft})$

UNIT 26: SANDSTONE

Grain Size and Texture - fine-grained

Color - light grey

Bedding - some interbedded shaly zones

Sedimentary Structures - burrowed (?)

Fossils - none

Contact - none recorded

Strike/dip - none recorded

Thickness $-1.9 \mathrm{~m}(6.5 \mathrm{ft})$

UNIT 27: SANDSTONE

Grain Size and Texture - fine-grained

Color - light grey

Bedding - none recorded

Sedimentary Structures - burrowed

Fossils - none

Contact - none recorded

Strike/dip - none recorded

Thickness $-0.39 \mathrm{~m}(1.3 \mathrm{ft})$

UNTI 28: COVERED INTERVAL WITH SHALE

Thickness $-1.0 \mathrm{~m}(3.5 \mathrm{ft})$

UNIT 29: SANDSTONE

Grain Size and Texture - fine-grained

Color - light grey

Bedding - none recorded

Sedimentary Structures - bioturbation

Fossils - none

Contact - none recorded

Strike/dip - none recorded

Thickness $-0.27 \mathrm{~m}(0.9 \mathrm{ft})$ 


\section{UNIT 30: SHALE}

Grain Size and Texture - medium-grained zones in top $0.07 \mathrm{~m}$ (3.0 in), fine to medium-grained sandy siltstone beds up to $0.12 \mathrm{~m}(0.4 \mathrm{ft})$

Color - light grey-green

Bedding - fissile at base,

Sedimentary Structures - none recorded

Fossils - plant fossils (?)

Contact - none recorded

Strike/dip - none recorded

Thickness $-2.5 \mathrm{~m}(8.4 \mathrm{ft})$

\section{UNIT 31: SANDSTONE}

Grain Size and Texture - medium-grained, quartz pebbles in top $0.30 \mathrm{~m}$

Color - light grey-brown

Bedding - thick beds with internal thin planar laminations, erosive base

Sedimentary Structures - none recorded

Fossils - none

Contact - none recorded

Strike/dip - none recorded

Thickness $-6.3 \mathrm{~m}(20.7 \mathrm{ft})$

\section{UNIT 32: COVERED INTERVAL}

Thickness $-2.7 \mathrm{~m}(9.1 \mathrm{ft})$

\section{UNIT 33: SHALE (NOT WELL EXPOSED)}

Grain Size and Texture - silty

Color - medium grey

Bedding - fissile to slightly blocky, basal ( 5 in) interbedded with thin light grey silty-sandy beds up to $0.09 \mathrm{~m}(0.3 \mathrm{ft})$

Sedimentary Structures - none recorded

Fossils - lateral burrows and plant debris

Contact - none recorded

Strike/dip - none recorded

Thickness $-5.0 \mathrm{~m}(16.7 \mathrm{ft})$

\section{UNIT 34: SANDSTONE (QUARTZ PEBBLE CONGLOMERATE)}

Grain Size and Texture - fine - grained at top, quartz pebbles in basal $0.21 \mathrm{~m}(0.7$

$\mathrm{ft}$ )

Color - light grey brown

Bedding - none recorded

Sedimentary Structures - none recorded

Fossils - none

Contact - none recorded

Strike/dip - none recorded

Thickness $-0.67 \mathrm{~m}(2.2 \mathrm{ft})$ 
UNIT 35: SHALE AND SILTY SANDSTONE

Grain Size and Texture - sandstone - fine - grained

Color - light grey

Bedding $-0.60 \mathrm{~m}(0.2 \mathrm{ft})$ sandstone beds, lenticular

Sedimentary Structures - erosive top scour

Fossils - none

Contact - none recorded

Strike/dip - none recorded

Thickness $-1.8 \mathrm{~m}(6.0 \mathrm{ft})$

\section{UNIT 36: SANDSTONE (QUARTZ PEBBLES)}

Grain Size and Texture - upper sandstone - fine - grained, basal sandstone quartz pebbles, hard, fine-coarse-grained

Color - light grey brown

Bedding - upper sandstone $3.6 \mathrm{~m}(12 \mathrm{ft})$ - thin beds $0.06 \mathrm{~m}(0.2 \mathrm{ft})$, middle

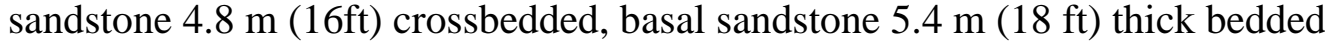

with crossbedding, quartz pebbles beds

Sedimentary Structures - crossbedding, undulating erosive base

Fossils - none

Contact - none recorded

Strike/dip - none recorded

Thickness - $14 \mathrm{~m}$ (46 ft)

\section{UNIT 37: SHALE}

Grain Size and Texture - sandstone - fine-grained

Color - shale - dark grey to black in upper $0.15 \mathrm{~m}(0.5 \mathrm{ft})$ with light grey shale

below, interbedded sandstone - light grey

Bedding - $0.60 \mathrm{~m}(2.0 \mathrm{ft})$ sandstone beds

Sedimentary Structures - none recorded

Fossils - none

Contact - none recorded

Strike/dip - none recorded

Thickness - $4.8 \mathrm{~m}(15.8 \mathrm{ft})$

\section{UNIT 38: SANDSTONE}

Grain Size and Texture - fine to medium-grained

Color - light grey brown to light grey green

Bedding - tabular ledge forming beds $0.12 \mathrm{~m}(0.4 \mathrm{ft})$ to $0.30 \mathrm{~m}(1.0 \mathrm{ft})$

Sedimentary Structures - none recorded

Fossils - none

Contact - none recorded

Strike/dip - none recorded

Thickness - $3.4 \mathrm{~m}(11.2 \mathrm{ft})$

UNIT 39: LIMESTONE

Grain Size and Texture - none recorded 
Color - light grey

Bedding - none recorded

Sedimentary Structures - none recorded

Paleocurrent Measurements - none

Fossils - none

Contact - contact of Greenbrier Limestone and Price Formation

Strike/dip - none recorded

Thickness - none recorded

\section{END OF SECTION}


MEASURED SECTION: Red Creek, West Virginia DATE: 06/09/94

DESCRIBED B Y: Nick Fe dorko

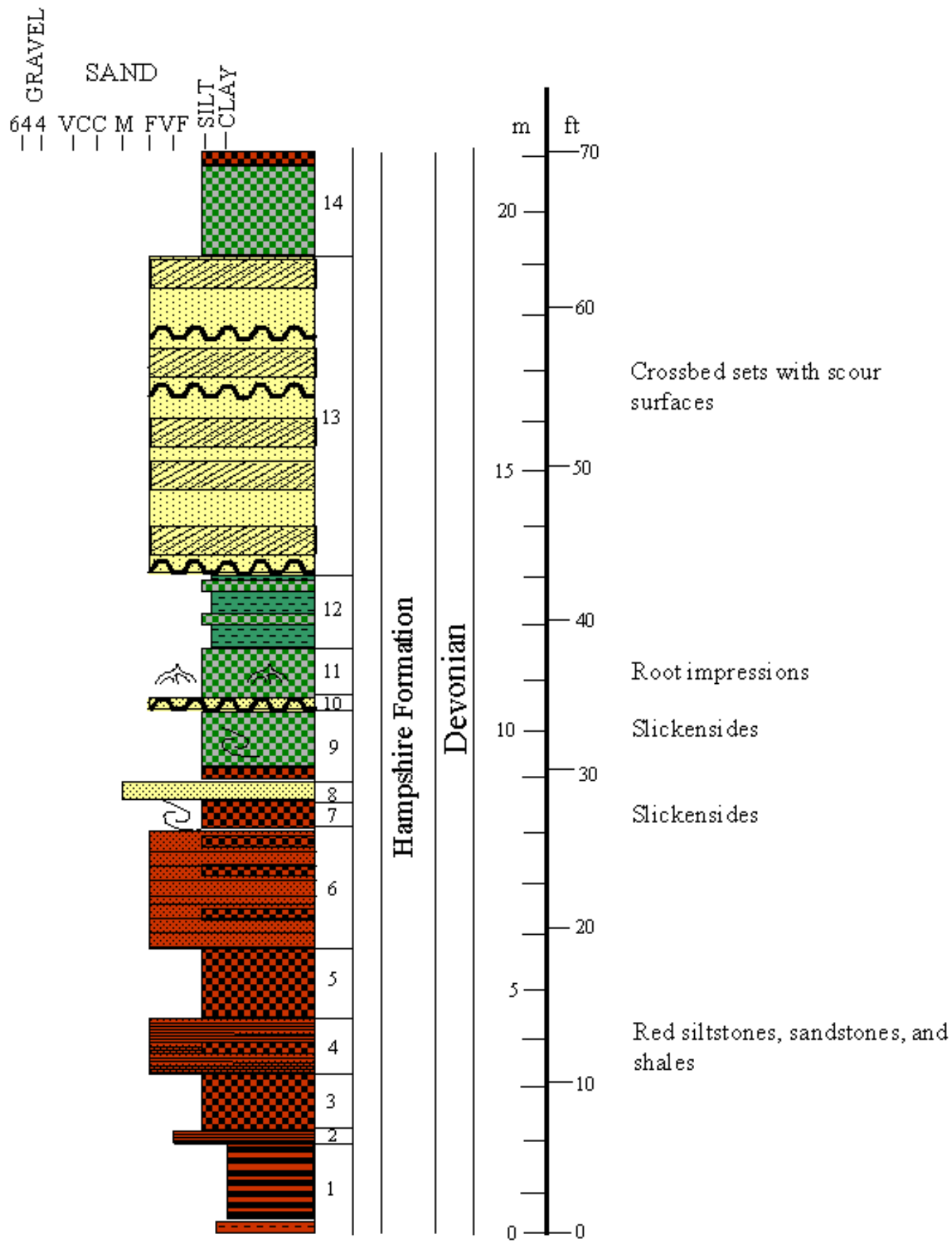

Figure 67. Units 1-14 from the Red Creek stratigraphic section 
MEASURED SECTION: Red Creek, West Virginia DATE: 06/07/94

DESCRIBED B Y: Nick Fedorko

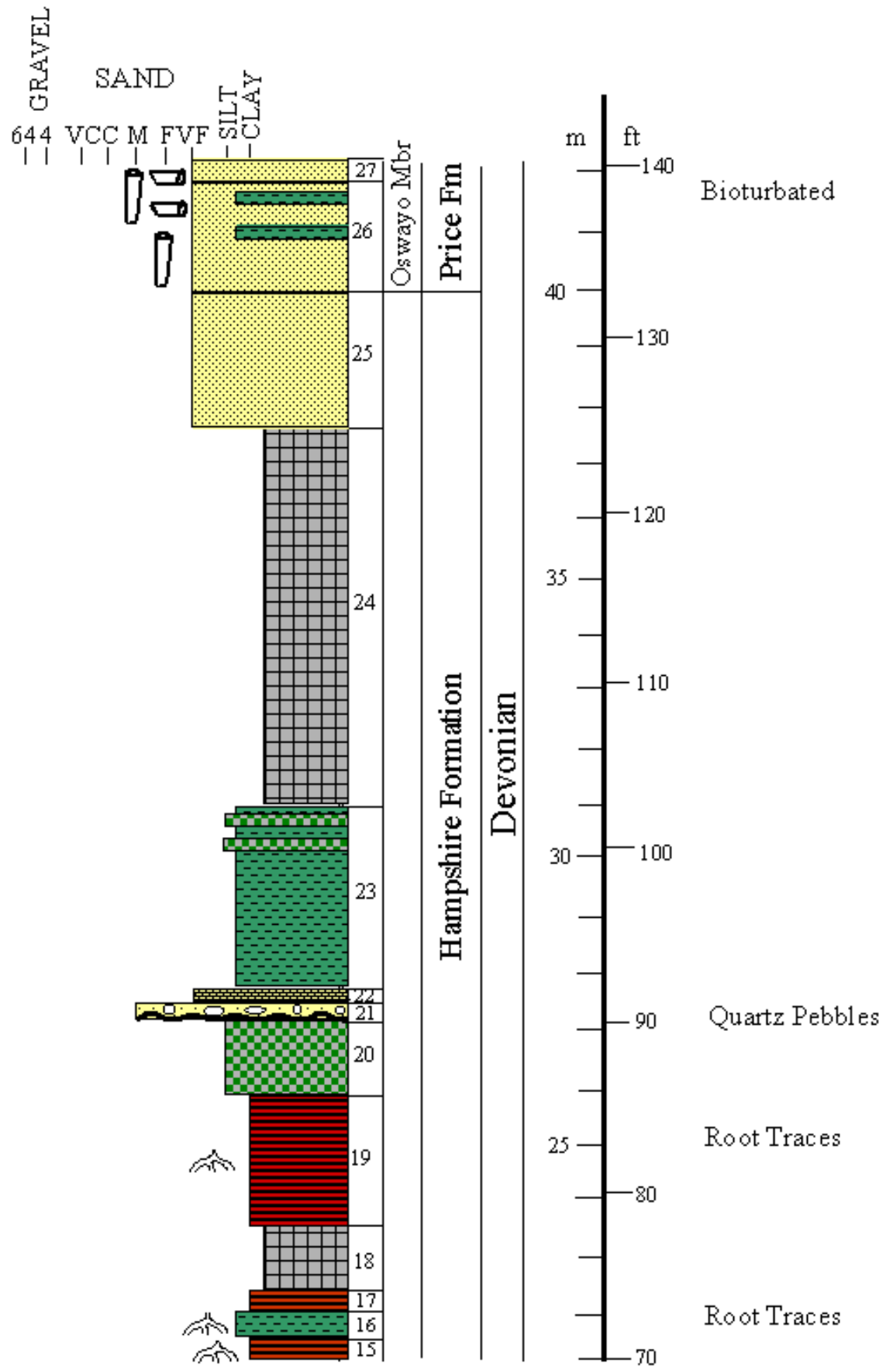

Figure 68. Units 15-27 from the Laurel Run stratigraphic section 
MEASURED SECTION: Red Creek, West Virginia DATE: 06/04/94

DESCRIBED B Y: Nick Fedorko

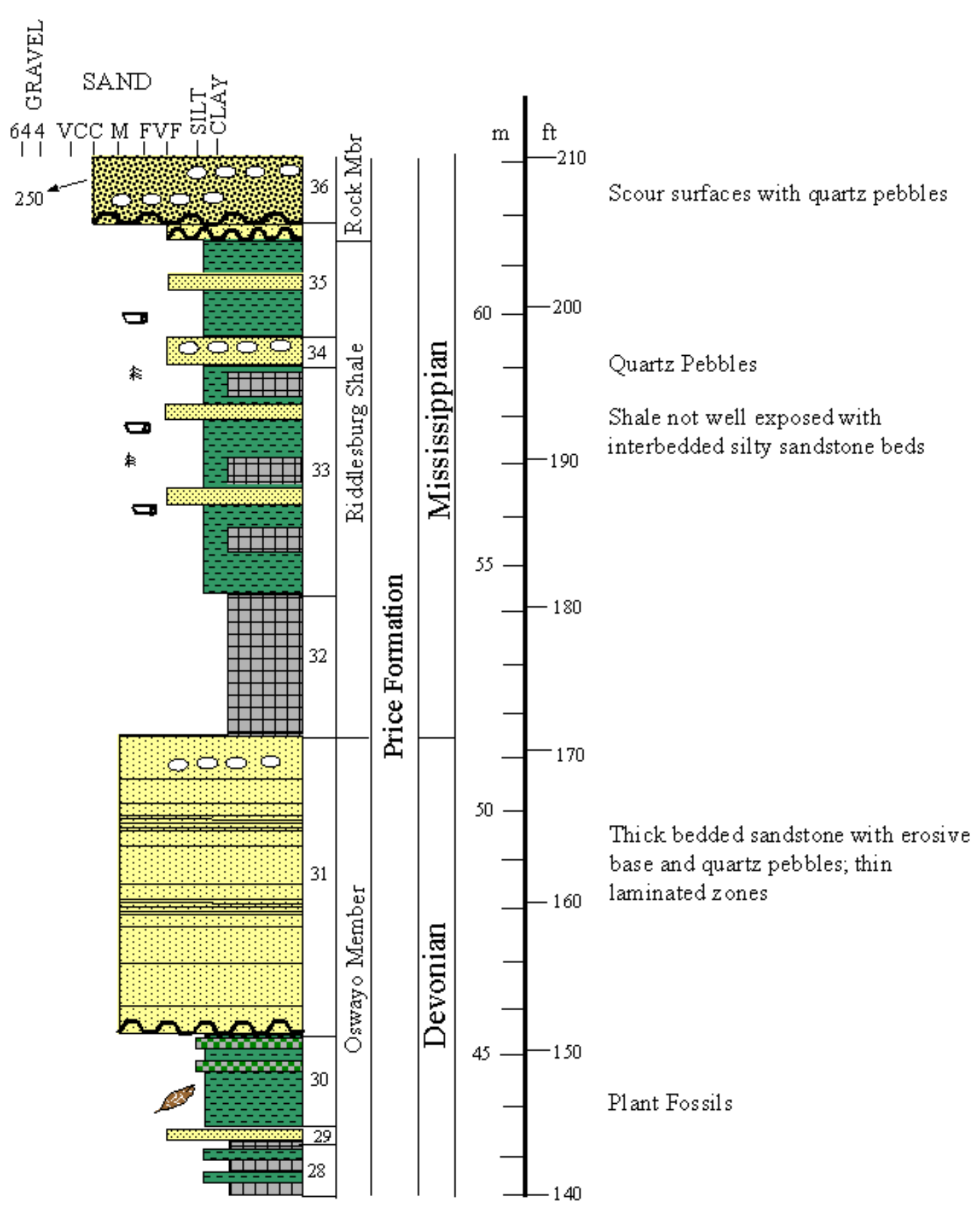

QUADRANGLE: Laneville 7.5'

FORMATION: Price Formation
.

Figure 69. Units 28-36 from the Laurel Run stratigraphic section 
MEASURED SECTION: Red Creek, West Virginia

DATE: 06/04/94

DESCRIBED BY:Nick Fe dorko

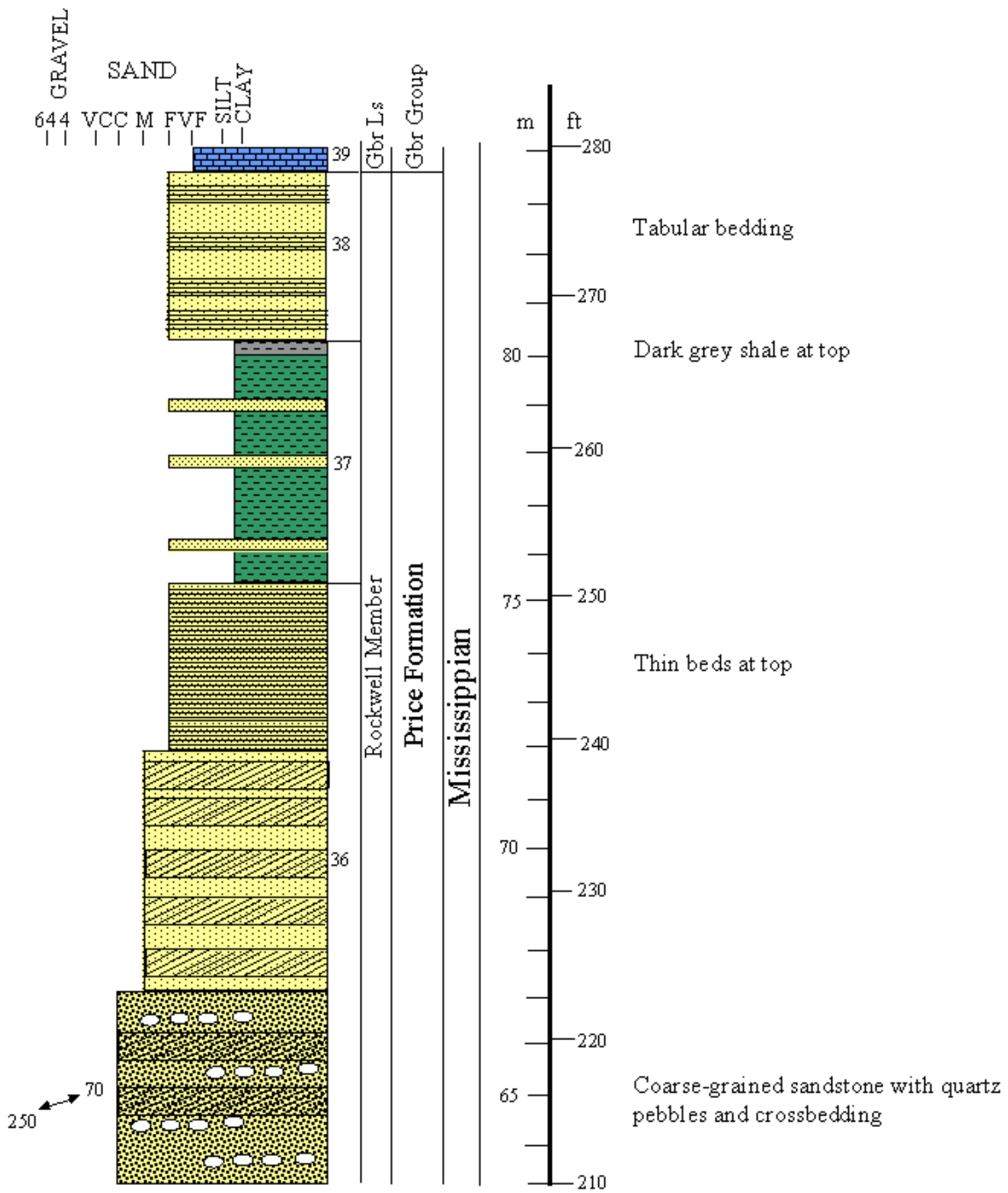

QUADRANGLE: Laneville 7.5' FORMATION: Price Formation 
Measured Section - Hendricks, West Virginia

Measured by Sheldon Murphy and David Jones

Quadrangle - Mozark Mountain 7.5'

Date $-05 / 17 / 01$

Measured section of the Price Formation along route WV route 72 at Hendricks. Top of section at elevation $1840 \mathrm{ft}$. $(560 \mathrm{~m})$ located $1000 \mathrm{ft}$. northeast of bench mark 1711. Base of section at elevation $1720 \mathrm{ft}$. $(524 \mathrm{~m})$ located $700 \mathrm{ft}$. $(213 \mathrm{~m})$ northeast of bench mark 1711. Located in Black Fork District within Tucker County.

Hampshire Formation (Units 1-7)

Oswayo Member (Unit 7)

Riddlesburg Shale Member (Units 8)

Rockwell Member (Units 9-10)

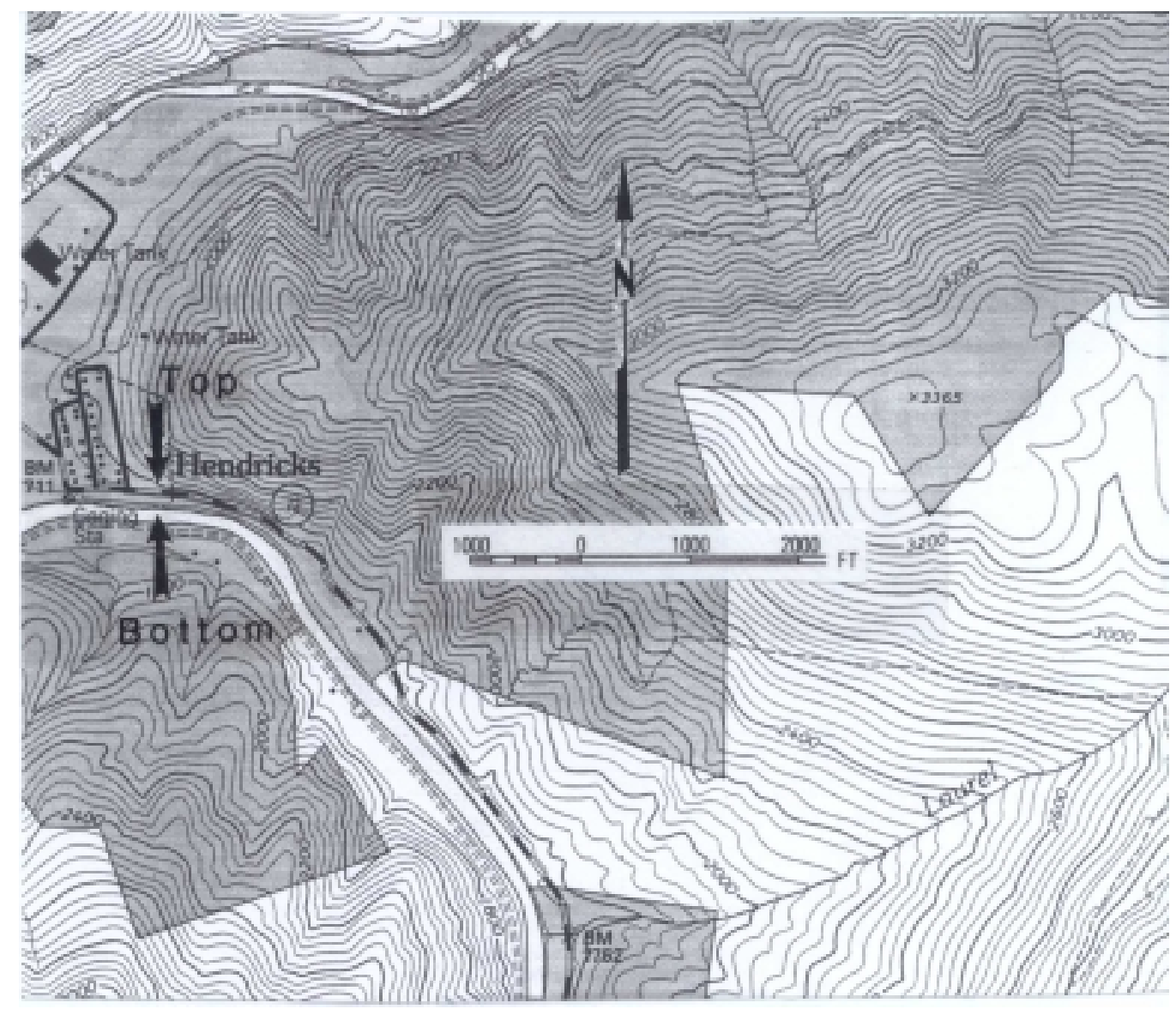

Figure 71. Location map for Hendricks section taken from the Mozark Mountain 7.5' USGS topographic map 
Measured Section - Hendricks

Measured by Sheldon Murphy and David Jones

Quadrangle - Laneville 7.5'

Date $-05 / 17 / 01$

\section{UNIT 1: MUDSTONE}

Grain Size and Texture - very fine-grained, soft, sandstone lense - hard, very fine-grained, well sorted, tightly packed with angular grains

Color - mudstone - red/olive mottled color, sandstone - buff with red/olive color weathered

Bedding - large basal paleosol bed $1.6 \mathrm{~m}$ (5.3 ft.), upper mudstone medium bedded $0.73 \mathrm{~m}(2.4 \mathrm{ft}$.), sandstone lense $-0.09 \mathrm{~m}(0.3 \mathrm{ft}$.) between mudstone beds

Sedimentary Structures - none recorded

Fossils - none

Contact - covered at base and sharp at top

Strike/dip - 5 degrees

Thickness $-2.3 \mathrm{~m}(7.7 \mathrm{ft})$

\section{UNIT 2: SANDSTONE}

Grain Size and Texture - hard, very fine-grained, well sorted, tightly packed with semi- angular grains

Color - buff

Bedding - large bed $0.91 \mathrm{~m}$ (3.0 ft.) containing possible shale clast voids or uneven surface due to underlying paleosol, undulating surface with variable thickness, continuous and parallel bedding with underlying and overlying lithologies.

Sedimentary Structures - none recorded

Fossils - none

Contact - sharp at base and top

Strike/dip - 5 degrees

Thickness $-0.91 \mathrm{~m}(3.0 \mathrm{ft})$

\section{UNIT 3: INTERBEDDED SANDSTONE AND MUDSTONE}

Grain Size and Texture - paleosols - very fine-grained, soft, sandstone - hard, very fine-grained, well sorted, tightly packed with angular grains

Color - mudstone - red/olive mottled color, sandstone - buff/tan

Bedding - thinly bedded lithologies parallel and continuous

Sedimentary Structures - none recorded

Fossils - none

Contact - sharp at base and semi-covered at top

Strike/dip -5 degrees

Thickness - $1.0 \mathrm{~m}(3.4 \mathrm{ft})$

UNIT 4: COVERED INTERVAL

Thickness $-1.5 \mathrm{~m}(5.0 \mathrm{ft}$.) 


\section{UNIT 5: MUDSTONE}

Grain Size and Texture - soft

Color - bright red/olive mottled color

Bedding - large bed

Sedimentary Structures - none recorded

Fossils - none

Contact - covered at base and sharp at top

Strike/dip -5 degrees

Thickness $-0.91 \mathrm{~m}(3.0 \mathrm{ft})$

\section{UNIT 6: SHALY SANDSTONE}

Grain Size and Texture - soft at base and top, hard in middle, very fine-grained, well sorted, tightly packed with angular grains

Color - shaly sandstone - red, hard sandstone - buff

Bedding - very thinly bedded shaly sandstones, thin bedded hard sandstone

Sedimentary Structures - very small scale trough crossbeds $0.07 \mathrm{~m}(0.3$ ") in upper shaly sandstone

Fossils - none

Contact - sharp at base and top covered

Strike/dip - 5 degrees

Thickness $-0.88 \mathrm{~m}(2.9 \mathrm{ft})$

\section{UNIT 7: COVERED INTERVAL}

Thickness - $12 \mathrm{~m}$ (40 ft.)

\section{UNIT 8: SHALE}

Grain Size and Texture - very fine-grained, fissile

Color - dark grey

Bedding - no bedding, mudcracks, soft sediment deformation due to overlying sandstone channel

Sedimentary Structures - none recorded

Fossils - Orbiculoid brachiopods

Contact - covered at base and sharp at top

Strike/dip - relatively flat lying

Thickness - $4.2 \mathrm{~m}$ (14.0 ft.)

\section{UNIT 9: CONGLOMERATIC SANDSTONE}

Grain Size and Texture - very hard, medium grained, fairly well sorted, tightly packed with rounded grains, quartz pebbles up to $6 \mathrm{~cm}$

Color - grey/white

Bedding - one large massive bed with basal scour surface becoming thinly bedded in top $1.52 \mathrm{~m}$ (5.0 ft.) containing scattered trough beds

Sedimentary Structures - trough beds

Fossils - none

Contact - sharp at base and top 
Strike/dip - relatively flat lying

Thickness - $7.6 \mathrm{~m}(25 \mathrm{ft})$

UNIT 10: SANDSTONE

Grain Size and Texture - hard, very fine-grained, well sorted, tightly packed Color - buff

Bedding - mostly thinly to thin bedded with some medium beds, parallel and continuous

Sedimentary Structures - some low angle crossbeds

Fossils - none

Contact - sharp at base and top

Strike/dip - relatively flat lying

Thickness - $3.6 \mathrm{~m}(12 \mathrm{ft})$

UNIT 11: LIMESTONE

Comment - not measured

END OF SECTION 
MEASURED SECTION: Hendricks, West Virginia DATE 05/17/01

DESCRIBED BY: Sheldon Murphy, David Jones

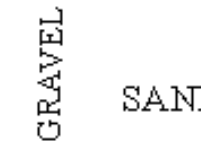

644 VCC M FVF

I । I I I I I I
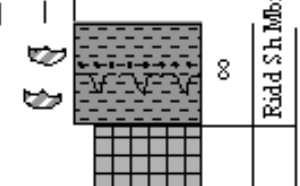

册

\#

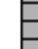

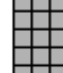

.

㟔

$+4$

$\bigoplus$ 田

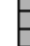
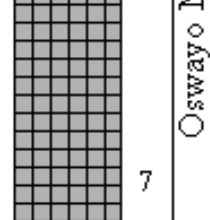

客

7

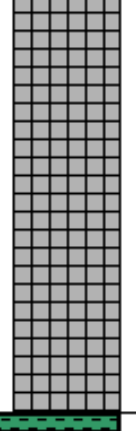

6

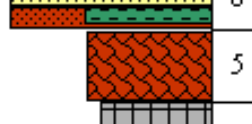

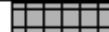

4

H

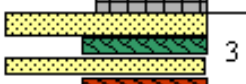

$\because 2$

isi
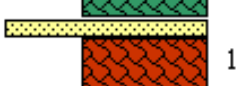

1

네네
D

:

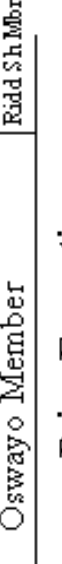

올

|

을

$-60$

$$
1
$$

$\mathrm{m}$ ft

$-70$

Orbiculoid Brachipods; mudcracks

Covered Interval

Shaly sandstone at top and base of unit; Upper sandstone contains small trough crossbeds

Covered Interval

Interbedded sandstone and pal eosols

Sandstone with undulating surface and shale clast voids

Red-Olive grey mottled paleosol with sandstone lense

Figure 72. Units 1-8 from the Hendricks stratigraphic section 
MEASURED SECTION: Hendricks, West Virginia DATE 05/17/01

DESCRIBED BY: Sheldon Murphy, David Jones

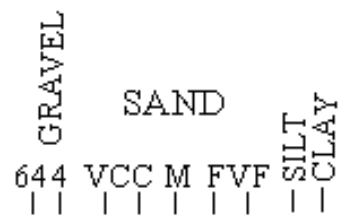

QUADRANGLE: Mozark Mtn. 7.5' FORMATION: Price Formation
Thinly to thin bedded sandstone with some medium beds and low angle crossbedding

Quartz Pebble conglomeratic sandstone with basal scour surface and scattered trough crossbeds; upper $1.5 \mathrm{~m}$ thinly bedded

Orbiculoid brachiopods; mudcracks

Figure 73. Units 8-11 from the Hendricks stratigraphic section 
Measured Section - Harman, West Virginia

Measured by Tom Bjerstedt and Dr. Tom Kammer

Quadrangle - Harman 7.5'

Date $-08 / 06 / 85$

Measured section of the Price Formation along route WV route 32 at Harman. Top of section at elevation $2390 \mathrm{ft}$. $(728 \mathrm{~m})$ located $2500 \mathrm{ft}$. (762 m) northwest of bench mark 2419. Base of section at $2303 \mathrm{ft}$. (702 m) located at bench mark 2303. Located in Union District within Grant County.

Riddlesburg Shale Member Units (1-2)

Rockwell Member (Units 3-9)

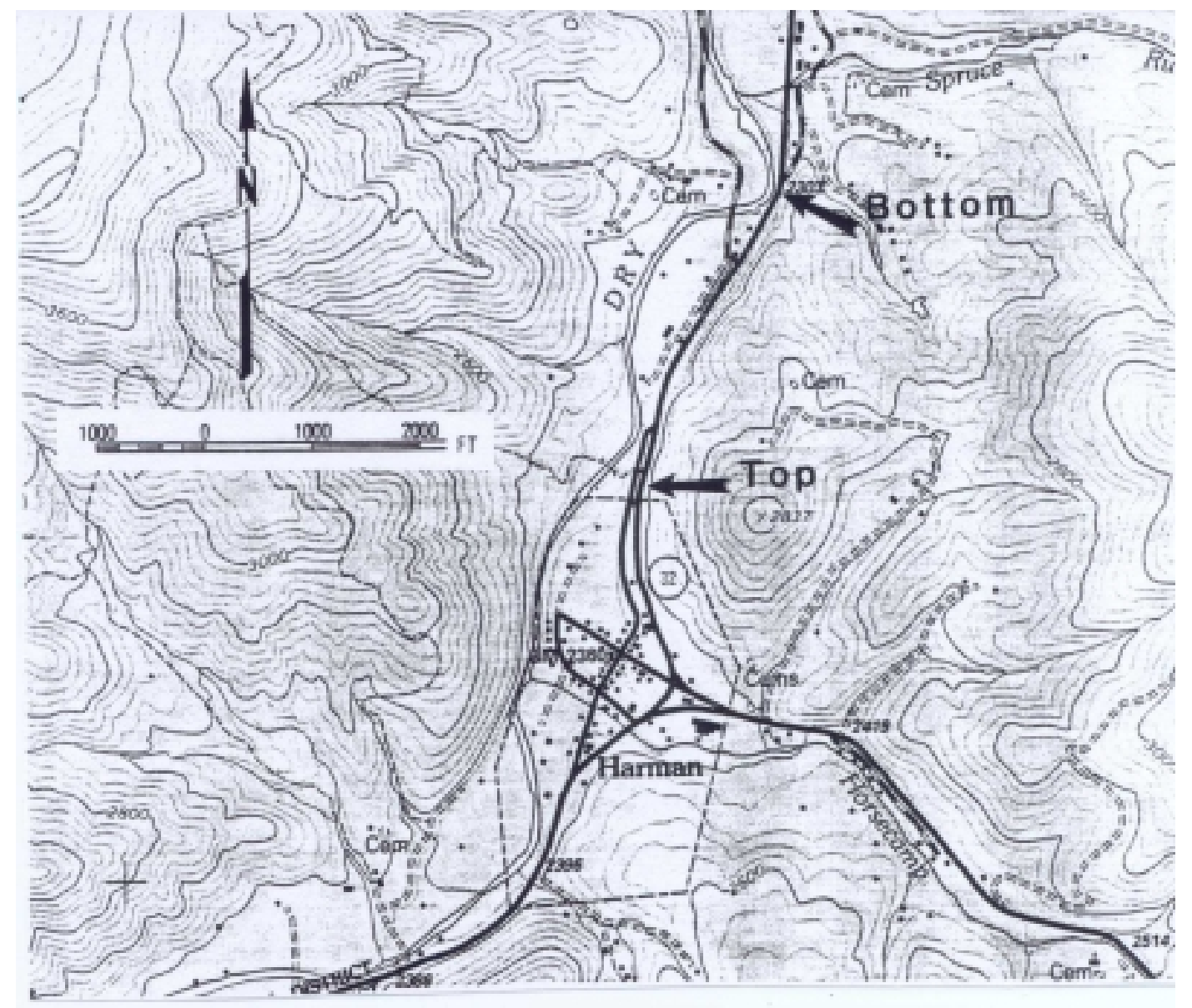

Figure 74. Location map for Harman section taken from the Harman 7.5' USGS topographic map 
Measured Section - Harman, West Virginia

Measured by Tom Bjerstedt and Dr. Tom Kammer

Quadrangle - Harman 7.5'

Date $-08 / 06 / 85$

\section{UNIT 1: MUDSTONE AND SILTSTONE}

Grain Size and Texture - none recorded

Color - F - dark grey (N3), W - medium dark grey (N4) and medium grey (N5)

Bedding - unbedded, weathers into irregularly shaped elongate pieces

Sedimentary Structures - unit becomes more fissile in upper $0.3 \mathrm{~m}$

Paleocurrent Measurements - none

Fossils - none

Contact - none recorded

Strike/dip - none recorded

Thickness - $1.8 \mathrm{~m}(6.0 \mathrm{ft})$

UNIT 2: SILSTONE AND SILTY SHALE WITH INTERBEDDED SANDSTONE

Grain Size and Texture - sandstone very fine-grained, silt/shale/sand - 3/2/1

Color - siltstone, sandstone - F - medium grey (N5), W - moderate brown (5YR

4/4); shale - F - olive black (5Y 2/1), W - dark grey 9N3)

Bedding - very thin to medium bedded

Sedimentary Structures - medium and thin bedded siltstones and very fine-

grained sandstones have wave-ripples with obvious wavy bedding, upper contact

gradational with unit 3 , load balls and load casts on the base of unit 3 give a

scoured appearance to the upper contact

Paleocurrent Measurements - none

Fossils - Scalarituba, Helminthopsis, Phycosiphon, Pelecypodichnus, and

Bifungites as hyporeliefs on soles of siltstones and sandstones

Contact - gradational upper contact

Strike/dip - none recorded

Thickness - $1.4 \mathrm{~m}(4.6 \mathrm{ft})$

\section{UNIT 3: SANDSTONE WITH INTERBEDDED SILTSTONE}

Grain Size and Texture - very fine-grained and fine-grained sandstones

Color - sandstone - F - medium grey (N5), W - moderate brownish (5YR 4/4);

siltstone - F - olive black (5Y 2/1), W - moderate brown (5YR 4/4)

Bedding - massive, spheroidal weathering

Sedimentary Structures - medium-grained, fine-grained sandstone at the top of

this unit is load-casted and contorted and above this beds are isolated load balls of

fine-grained sandstone in siltstone and very fine-grained sandstone

Paleocurrent Measurements - none

Fossils - none

Contact - none recorded

Strike/dip - none recorded

Thickness $-2.0 \mathrm{~m}(6.7 \mathrm{ft})$ 


\section{UNIT 4: SANDSTONE}

Grain Size and Texture - fine to medium-grained, well sorted, fine-grained sublitharenite in thin section

Color - F - medium dark grey (N4), W - dusky brown (5YR 2/2)

Bedding - one thick bed

Sedimentary Structures - horizontal laminations, slight scour base

Paleocurrent Measurements - none

Fossils - none

Contact - none recorded

Strike/dip - none recorded

Thickness $-0.6 \mathrm{~m}(2.0 \mathrm{ft})$

\section{UNIT 5: SANDSTONE}

Grain Size and Texture - fine-grained

Color - F - dark grey (N3), W - medium grey (N5)

Bedding - massive

Sedimentary Structures - load casting and apparent flowage structures in unit 3

but not nearly as pronounced, apparent scour base

Paleocurrent Measurements - none

Fossils - none

Contact - none recorded

Strike/dip - none recorded

Thickness - .5 m (5.0 ft)

\section{UNIT 6: CONGLOMERATIC SANDSTONE}

Grain Size and Texture - medium to coarse-grained, quartz pebbles up to $1.5 \mathrm{~cm}$

Color - F - medium grey (N5), W - light olive grey (5Y 6/1)

Bedding - medium to thick bedded

Sedimentary Structures - scour base, conglomeratic coarse-grained sandstones appear in lenses that pinch and swell, graded bedding, with unit 7, uppermost bedding plane shows wave-ripple marks, lenses of unit 6 lithology occur in lower $0.3 \mathrm{~m}$ of unit 7 nearly as pronounced, apparent scour base

Paleocurrent Measurements - none

Fossils - none

Contact - none recorded

Strike/dip - none recorded

Thickness $-0.7 \mathrm{~m}(2.3 \mathrm{ft})$

\section{UNIT 7: SILTY SHALE AND SILTSTONE}

Grain Size and Texture - none recorded

Color - F - dark grey (N3), W - medium grey (N5)

Bedding - thin bedded to laminated

Sedimentary Structures - load balls and casts of unit 8 in upper part

Paleocurrent Measurements - none

Fossils - none

Contact - none recorded 
Strike/dip - none recorded

Thickness $-0.8 \mathrm{~m}(2.8 \mathrm{ft})$

\section{UNIT 8: SANDSTONE AND SILTSTONE}

Grain Size and Texture - fine to medium-grained, basal quartz pebbles

Color - sandstone - F - light olive green (5Y 6/1), W - moderate brown (5YR

3/4); siltstone - F - olive black (5Y 6/1), W - olive grey (5Y 4/1)

Bedding - sandstone - medium to thick bedded, siltstone - very thin to thin bedded

Sedimentary Structures - unit is on fining-upward sequence from lowest; discontinuous, fine quartz pebble conglomerate at base, $1.5 \mathrm{~m}$ of medium to coarse-grained sandstone, $1.5 \mathrm{~m}$ a fine-grained sandstone, $1.2 \mathrm{~m}$ of thin-bedded siltstone; horizontal laminations, medium to small scale planar crossbed sets with tangential base

Paleocurrent Measurements - none

Fossils - none

Contact - none recorded

Strike/dip - none recorded

Thickness $-4.2 \mathrm{~m}(14 \mathrm{ft})$

\section{UNIT 9: SANDSTONE}

Grain Size and Texture - medium-grained, moderately sorted, medium to coarsegrained Subfeldsarenite in thin section, quartz pebbles in base

Color - F - light olive grey (5Y 6/1), W - brownish (5YR 4/1)

Bedding - thin to thick bedded, thick bedded at base grading to thin and medium bedded up section

Sedimentary Structures - very pronounced scour base cuts out $3 \mathrm{~m}$ of unit 8 , the following subunits are noted, from oldest; a $0.3 \mathrm{~m}$ fine quartz pebble conglomerate, $2.5 \mathrm{~m}$ of pebbly to medium to coarse-grained sandstone, and $13 \mathrm{~m}$ of thin to medium bedded, fine to medium bedded sandstone; the upper $3 \mathrm{~m}$ of the unit contains thin to very thin interbeds of olive grey siltstone (5Y 4/1) the thickest of which $0.3 \mathrm{~m}$; medium scale planar crossbed sets with tangential bases, large to medium scale trough crossbed sets some with a quartz pebble lag at base; discontinuous lenses of quartz pebble conglomerate up to $0.6 \mathrm{~m}$ thick and lenses of fine-grained sandstone and siltstone up to $0.3 \mathrm{~m}$ thick occur throughout unit; top of unit is marked by a $10 \mathrm{~cm}$ thick layer of pale yellowish green (10Y 8/2), crumbly claystone with sits on a $3 \mathrm{~cm}$ thick greyish black (N2) mudstone;

Upper $1.5 \mathrm{~m}$ of unit 9 , below claystone, is medium bedded, medium to coarse-

grained calcareous sandstone with up to $67 \%$ carbonate in thin section; bedding planes in the upper meter have a greenish-grey (5GY 6/1) color and have problematic trace fossil-like structures on bedding plane surfaces; layers of greenish-grey shale separate the medium bedded sandstone, the upper few $\mathrm{cm}$ of these sandstone have green shale pebbles and are color mottled greenish-grey and medium grey 
Paleocurrent Measurements - none

Fossils - ichnofossils (?)

Contact - none recorded

Strike/dip - 5/N74E

Thickness $-15.5 \mathrm{~m}(51 \mathrm{ft})$

UNIT 10: SANDY LIMESTONE AND CALCAREOUS SANDSTONE

Grain Size and Texture - sandstone - medium-grained, quartz pebbles in base

Color - F - greenish grey (5GY 6/1), W - moderate yellowish brown (10YR 5/4)

Bedding - thick to very thick bedded

Sedimentary Structures - basal $15 \mathrm{~cm}$ contains fine quartz pebbles

Paleocurrent Measurements - none

Fossils - none

Contact - none recorded

Strike/dip - none recorded

Thickness $-\sim 30 \mathrm{~m}(\sim 98 \mathrm{ft})$, entire unit not measured, estimate with roadside quarry

\section{END OF SECTION}


MEASURED SECTION: $\mathrm{H}$ arman, West V irginia

DATE: 08/0685

DESCRBED BY: Tom Bjerstedt and Dr. Tom Kammer

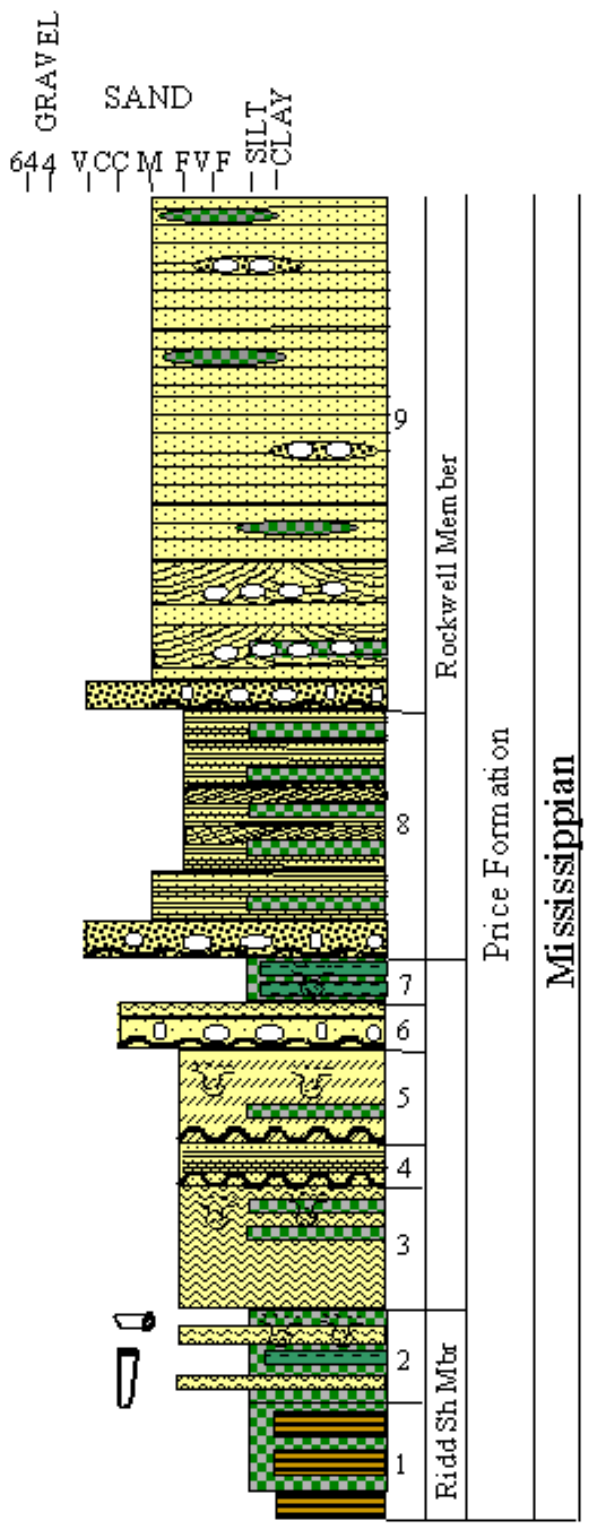

QUADRANGLE: Harm an 7.5' FORMATION: Price F ormation
Fining upward sequence with basal scour and quartz pebbles; laminated to thin bedding and planar crossbeds

Load balls and casts

Wave ripples with basal scour and quartz pebbles

Load balls and flow structures

Laminated beds with basal scour

Contorted bedding with load balls

Wavy bedding; bioturbated; load balls

Unbeddelbngate pieces

Figure 75. Units 1-9 from the Harman stratigraphic section 
MEASURED SECTION: Harman, West Virginia

DATE: 08/06/85

DESCRIBED BY:Tom Bjerstedt and Dr. Tom Kammer
QUADRANGLE: Harman 7.5'

FORMATION: Price Formation

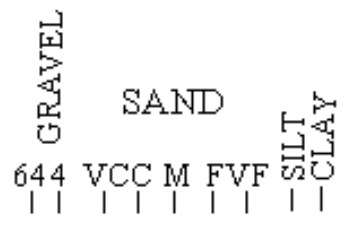

Dark grey mudstone at top; cal careous sandstone beneath mudstone and shale pebbles

Trough and planar crossbedding with scattered quartz and siltstone pebble lenses and lags; interbedded siltstone at top

Figure 76. Units 9-10 from the Harman stratigraphic section 


\section{Measured Section - Briery Gap, West Virginia Measured by Sheldon Murphy \\ Quadrangle - Circleville 7.5' \\ Date $-08 / 29 / 99$}

Measured section of the Price Formation along road to Spruce Knob at Briery Gap. Top of section at elevation $2760 \mathrm{ft}$. $(841 \mathrm{~m})$ located $8400 \mathrm{ft}$. $(2650 \mathrm{~m})$ northwest of bench mark 1936. Base of section at elevation $2560 \mathrm{ft} .(807 \mathrm{~m})$ located $6500 \mathrm{ft}$. $(1981 \mathrm{~m})$ northwest of bench mark 1936. Located in Circleville District within Pendleton County.

Hampshire Formation (Units 1-7)

Riddlesburg Member (Units 8-9)

Rockwell Member (Units 9-27)

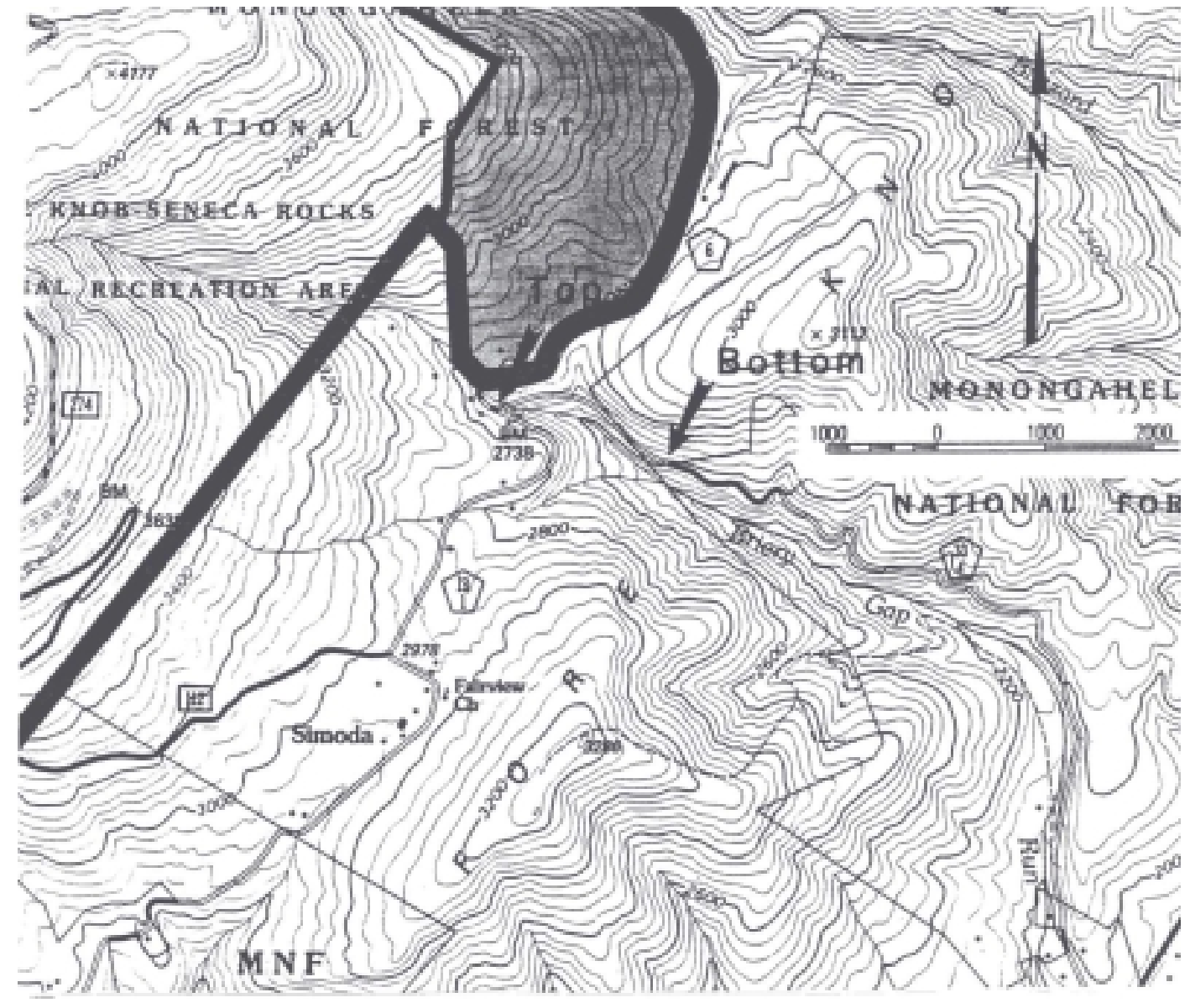

Figure 77. Location map for Briery Gap section taken from the Circleville 7.5' USGS topographic map 


\section{Measured Section - Briery Gap, West Virginia \\ Measured by Sheldon Murphy \\ Quadrangle - Circleville 7.5' \\ Date $-08 / 28 / 99$}

\section{UNIT 1: SANDSTONE}

Grain Size and Texture - very fine-grained, hard

Color - brown-tan

Bedding - planar beds with average thickness $0.025 \mathrm{~m}$ (1.0 inches) to $0.038 \mathrm{~m}$

(1.5 inches) at base with large scour surface from bottom $0.30 \mathrm{~m}(1.0 \mathrm{ft})$ to top

filled with right to left laterally accreting beds

Sedimentary Structures - right to left high angle crossbedding

Paleocurrent Measurements - none

Fossils - none observed

Contact - sharp at top and base

Strike/dip - 40 degrees/12 degree dip at 130 degrees

Thickness $-0.30 \mathrm{~m}(1.0 \mathrm{ft})$

\section{UNIT 2: SANDSTONE}

Grain Size and Texture - very fine-grained, hard

Color - red-tan

Bedding - thin beds approximately $0.025 \mathrm{~m}$ ( 1.0 inches) to $0.038 \mathrm{~m}$ ( 1.5 inches) becoming thinner toward the top

Sedimentary Structures - right to left accreting crossbeds, epsilon crossbedding

Paleocurrent Measurements - none

Fossils - none

Contact - sharp

Strike/dip - 40 degrees/12 degree dip at 130 degrees

Thickness $-1.5 \mathrm{~m}(5.0 \mathrm{ft})$

UNIT 3: SANDSTONE

Grain Size and Texture - very fine-grained, hard

Color - tan-brown

Bedding - planar beds $0.012 \mathrm{~m}$ or less ( 0.5 inches or less)

Sedimentary Structures - none observed

Paleocurrent Measurements - none

Fossils - none

Contact - sharp

Strike/dip - 40 degrees/12 degree dip at 130 degrees

Thickness $-0.60 \mathrm{~m}(2.0 \mathrm{ft})$

\section{UNIT 4: SANDSTONE}

Grain Size and Texture - very fine-grained, hard

Color - red

Bedding - mostly planar with some shale interbeds at base and top

Sedimentary Structures - none observed 
Paleocurrent Measurements - none

Fossils - none

Contact - sharp at base and covered above

Strike/dip - 40 degrees/12 degree dip at 130 degrees

Thickness $-1.7 \mathrm{~m}(5.7 \mathrm{ft})$, portions of rock disturbed or fallen therefore thickness is estimated

UNIT 5: SHALE WITH SANDSTONE AND MUDSTONE INTERBEDS AT TOP

Grain Size and Texture - sandstone, very fine-grained, hard

Color - red shale, buff sandstone

Bedding - thinly bedded sandstone

Sedimentary Structures - none observed

Paleocurrent Measurements - none

Fossils - trace fossils found in float

Contact - sharp at top, gradational at base

Strike/dip - 40 degrees/12 degree dip at 130 degrees

Thickness - $9.4 \mathrm{~m}(31 \mathrm{ft})$

\section{UNIT 6: SANDSTONE}

Grain Size and Texture - fine-grained, hard, well sorted, subangular grains

Color - grey, weathered brown-red

Bedding - medium bedded in top one-third, middle third thinly bedded, bottom one-third thickly bedded

Sedimentary Structures - none observed

Paleocurrent Measurements - none

Fossils - none

Contact - sharp at base into red beds below

Strike/dip - 40 degrees/12 degree dip at 130 degrees

Thickness $-1.8 \mathrm{~m}(6.0 \mathrm{ft})$

\section{UNIT 7: SANDSTONE}

Grain Size and Texture - fine-grained, hard, well sorted, subangular grains

Color - grey, weathered brown-red

Bedding - medium bedded in top one-third, thinly bedded in middle one-third and bottom one-third is medium to thickly bedded

Sedimentary Structures - none observed

Paleocurrent Measurements - none

Fossils - none observed

Contact - sharp into red beds below

Strike/dip - 40 degrees/12 degree dip at 130 degrees

Thickness - $14.9 \mathrm{~m}(49 \mathrm{ft})$

UNIT 8: INTERBEDDED SILTSTONE, SHALE, AND SANDSTONE

Grain Size and Texture - siltstone - hard, moderately sorted, subangular grains

Color - buff-grey, weathered reddish brown

Bedding - thin siltstone beds (1.0 inches) to (6.0 inches) 
Sedimentary Structures - none observed

Paleocurrent Measurements - none

Fossils - none

Contact - sharp at base and top

Strike/dip - 40 degrees/12 degree dip at 130 degrees

Thickness - $6.4 \mathrm{~m}(21 \mathrm{ft})$

UNIT 9: SANDSTONE (MOSTLY COVERED) WITH

INTERBEDDED SILTSTONE AND MUDSTONE AT BASE

Grain Size and Texture - fine-grained, hard, well sorted,

Color - grey

Bedding - medium

Sedimentary Structures - none observed

Paleocurrent Measurements - none

Fossils - lateral and vertical burrows in mudstone and siltstone at base

Contact - covered

Strike/dip - 40 degrees/12 degree dip at 130 degrees

Thickness - $25 \mathrm{~m}(82 \mathrm{ft})$

\section{UNIT 10: QUARTZ PEBBLE CONGLOMERATE}

Grain Size and Texture: coarse-grained, quartz pebbles up to $4.0 \mathrm{~cm}$, very hard, quartz arenite, rounded grains, clast supported

Color - White-buff

Bedding- massive

Sedimentary Structures - bottom scour surface

Paleocurrent Measurements - none

Fossils - none

Contact - covered at base sharp at top

Strike/dip - 40 degrees/12 degree dip at 130 degrees

Thickness $-0.91 \mathrm{~m}(3.0 \mathrm{ft})$

\section{UNIT 11: SANDSTONE}

Grain Size and Texture - very fine-grained, hard

Color - buff-tan

Bedding - planar beds $0.012 \mathrm{~m}(0.5$ inches $)$ to $0.76 \mathrm{~m}(2.5 \mathrm{ft})$ with overall unit thickness increasing from $0.020 \mathrm{~m}(0.8$ inches $)$ to $0.76 \mathrm{~m}(2.5 \mathrm{ft})$

Sedimentary Structures - left to right laterally accreting epsilon crossbedding Paleocurrent Measurements

Strike of bed -310 or 130 degrees

current direction azimuth -40 degrees

type - planar crossbedding

width - N/A

height $-\mathrm{N} / \mathrm{A}$

Fossils - none

Contact - relatively sharp contact to unit above

Strike/dip - 40 degrees/12 degree dip at 130 degrees 
Thickness $-0.91 \mathrm{~m}(3.0 \mathrm{ft})$

UNIT 12: SANDSTONE

Grain Size and Texture - very fine-grained, hard

Color- buff-tan

Bedding - planar beds ranging $0.011 \mathrm{~m}$ (0.5 inches) to $0.10 \mathrm{~m}$ (4.0 inches), beds pinch out to the right

Sedimentary Structures - Epsilon crossbedding right to left lateral accretion, high angle crossbeds up to 45 degrees

Paleocurrent Measurements - none

Fossils - none

Contact - sharp at bottom and top

Strike/dip - 40 degrees/12 degree dip at 130 degrees

Thickness $-0.60 \mathrm{~m}(2.0 \mathrm{ft})$

\section{UNIT 13: SANDSTONE}

Grain Size and Texture - very fine-grained, hard

Color- buff-tan

Bedding - planar beds $0.025 \mathrm{~m}$ (1.0 inches), covered at right

Sedimentary Structures - none observed

Paleocurrent Measurements - none

Fossils - none

Contact - sharp at bottom and top

Strike/dip - 40 degrees/12 degree dip at 130 degrees

Thickness $-0.30 \mathrm{~m}(1.0 \mathrm{ft})$

\section{UNIT 14: SANDSTONE}

Grain Size and Texture - very fine-grained, hard

Color- buff-tan-brown

Bedding - planar beds toward right and center with increasing bed inclination toward the left and epsilon crossbeds at far right where bed thickness decreases, average bed thickness $0.025 \mathrm{~m}$ ( 1.0 inches) to $0.050 \mathrm{~m}$ ( 2.0 inches), top is cut by channel scour

Sedimentary Structures - epsilon crossbedding

Paleocurrent Measurements - none

Fossils - none

Contact - sharp at bottom and top

Strike/dip - 40 degrees/12 degree dip at 130 degrees

Thickness $-0.30 \mathrm{~m}(1.0 \mathrm{ft})$

\section{UNIT 15: QUARTZ PEBBLE CONGLOMERATE}

Grain Size and Texture - quartz arenite, extremely hard, coarse-grained with quartz pebbles up to $2 \mathrm{~cm}$ in top and base, coarse-grained without quartz pebbles in center

Color- white at top and base, buff-tan in center

Bedding - medium, normal 
Sedimentary Structures - channel sandstone, channel lag

Paleocurrent Measurements

Strike of bed - 115 or 295 degrees

current direction azimuth - 205 degrees

type - trough crossbedding

width $-4.5 \mathrm{~m}(15 \mathrm{ft})$

height $-0.91 \mathrm{~m}(3.0 \mathrm{ft})$

Fossils - none

Contact - sharp at bottom and top

Strike/dip - 40 degrees/12 degree dip at 130 degrees

Thickness $-0.91 \mathrm{~m}(3.0 \mathrm{ft})$

\section{UNIT 16: QUARTZ PEBBLE CONGLOMERATE}

Grain Size and Texture - quartz arenite, extremely hard, coarse-grained with quartz pebbles up to 5 or $6 \mathrm{~cm}$ throughout

Color- white-buff-pink

Bedding - massive

Sedimentary Structures - large channel sandstone with basal scour

Paleocurrent Measurements

strike of bed - 145 or 325 degrees

current direction azimuth -235 degrees

type - trough crossbedding

width $-4.5 \mathrm{~m}(15 \mathrm{ft})$

height $-4.5 \mathrm{~m}(15 \mathrm{ft})$

Fossils - none

Contact - sharp at bottom

Strike/dip - 40 degrees/12 degree dip at 130 degrees

Thickness - $4.5 \mathrm{~m}$ (15 ft)

UNIT 17: COVERED INTERVAL

Thickness - $4.3 \mathrm{~m}(14.2 \mathrm{ft})$

\section{UNIT 18: SANDSTONE}

Grain Size and Texture - very fine-grained, very hard

Color- buff-tan

Bedding - one medium bed, somewhat broken at top

Sedimentary Structures - none

Paleocurrent Measurements - none

Fossils - none

Contact - fairly sharp at bottom and top

Strike/dip - 40 degrees/12 degree dip at 130 degrees

Thickness - $2.9 \mathrm{~m}$ (9.6 ft)

\section{UNIT 19: SANDSTONE}

Grain Size and Texture - very fine-grained, hard in basal $0.60 \mathrm{~m}(2.0 \mathrm{ft})$, not as 
hard in top $0.91 \mathrm{~m}(3.0 \mathrm{ft})$, possible silty in top

Color- buff-tan

Bedding - non-parallel discontinuous wavy bedding toward top and planar in basal $0.91 \mathrm{~m}(3.0 \mathrm{ft})$, thinly bedded $0.050 \mathrm{~m}$ ( 2.0 inches) to $0.15 \mathrm{~m}$ ( 6.0 inches $)$, very thin beds $.006 \mathrm{~m}$ ( 0.25 inches) to $0.012 \mathrm{~m}$ ( 0.50 inches) in upper $0.60 \mathrm{~m}(2.0$ $\mathrm{ft})$, top

$0.30 \mathrm{~m}(0.25 \mathrm{ft})$ are laminated

Sedimentary Structures - none

Paleocurrent Measurements - none

Fossils - none

Contact - covered at base of unit

Strike/dip - 40 degrees/12 degree dip at 130 degrees

Thickness $-2.9 \mathrm{~m}(9.6 \mathrm{ft})$

UNIT 20: INTERVAL

Thickness $-8.2 \mathrm{~m}(27 \mathrm{ft})$

\section{UNIT 21: SANDSTONE}

Grain Size and Texture - very fine-grained, hard, subangular grains, predominantly quartz with less than $10 \%$ matrix, tightly packed grains, well sorted, lots of $\mathrm{Fe}$

Color- buff-brown, dirty

Bedding - very thin planar beds less than $0.025 \mathrm{~m}$ (1.0 inches)

Sedimentary Structures - low angle right to left planar crossbeds

Paleocurrent Measurements - none

Fossils - none

Contact - covered at top and base

Strike/dip - 70 degrees/10 degree dip at 160 degrees

Thickness $-1.0 \mathrm{~m}(3.4 \mathrm{ft})$

UNIT 22: INTERVAL

Thickness $-13.7 \mathrm{~m}(45 \mathrm{ft})$

\section{UNIT 23: SANDSTONE}

Grain Size and Texture - very fine-grained, hard, subangular grains, predominantly quartz with less than $10 \%$ matrix, tightly packed grains, well sorted

Color- buff-brown, very little weathering

Bedding - small wavy beds $0.002 \mathrm{~m}$ ( 0.1 inches) to $0.010 \mathrm{~m}$ ( 0.4 inches) with overall bed thickness $0.36 \mathrm{~m}(1.2 \mathrm{ft})$

Sedimentary Structures - none

Paleocurrent Measurements - none

Fossils - none

Contact - covered at top and base

Strike/dip - 70 degrees/10 degree dip at 160 degrees

Thickness $-0.42 \mathrm{~m}(1.4 \mathrm{ft})$ 


\section{UNIT 24: COVERED INTERVAL}

Thickness - $22 \mathrm{~m}(72 \mathrm{ft})$

\section{UNIT 25: SANDSTONE}

Grain Size and Texture - fine-grained, hard, subangular grains, predominantly quartz with less than $10 \%$ matrix, tightly packed grains, well sorted Color- buff-brown, very little weathering

Bedding - wavy bedding in middle, planar beds at base, slightly crossbedded at top, beds range from $0.012 \mathrm{~m}$ ( 0.5 inches) to $0.050 \mathrm{~m}$ ( 2.0 inches), overall thickness $1.8 \mathrm{~m}(6.0 \mathrm{ft})$

Sedimentary Structures - none

Paleocurrent Measurements - none

Fossils - none

Contact - covered at base and sharp at top

Strike/dip - 70 degrees/10 degree dip at 160 degrees

Thickness $-0.45 \mathrm{~m}(1.50 \mathrm{ft})$

\section{UNIT 26: SANDSTONE}

Grain Size and Texture - fine-grained, hard, subangular grains, predominantly quartz with less than $10 \%$ matrix, tightly packed grains, well sorted

Color- buff-tan in basal $0.76 \mathrm{~m}(2.5 \mathrm{ft})$ then turns red

Bedding - low angle planar crossbeds $0.025 \mathrm{~m}$ (1.0 inches) in basal $0.30 \mathrm{~m}$ (1.0

$\mathrm{ft}$ ), planar beds $0.012 \mathrm{~m}$ ( 0.5 inches) to $0.025 \mathrm{~m}$ ( 1.0 inches) above with some small scale planar crossbeds $0.60 \mathrm{~m}(2.0 \mathrm{ft})$ down from the top

Sedimentary Structures - planar crossbedding

Paleocurrent Measurements

strike of bed - 165 or 345 degrees

current direction azimuth -75 degrees

type - planar crossbedding

width - N/A

height $-\mathrm{N} / \mathrm{A}$

Fossils - none

Contact - sharp at base and top

Strike/dip - 70 degrees/10 degree dip at 160 degrees

Thickness $-0.45 \mathrm{~m}(1.5 \mathrm{ft})$

\section{UNIT 27: SANDSTONE}

Grain Size and Texture - coarse-grained, hard, subrounded grains, predominantly quartz with less than 5-10\% matrix, tightly packed grains, well sorted

Color- White-reddish-pink, weathered red

Bedding - outcrop extends along ridge indicating large-scale lateral accretion, scours, and crossbedding, Individual beds range from $0.006 \mathrm{~m}$ ( 0.25 inches), only in small intervals, to $0.012 \mathrm{~m}$ ( 0.5 inches)

Sedimentary Structures - planar crossbedding

Paleocurrent Measurements 
strike of bed - 145 degrees or 325 degrees

current direction azimuth - 50 degrees

type - planar crossbedding

width - N/A

height $-\mathrm{N} / \mathrm{A}$

Fossils - none

Contact - base covered

Strike/dip - 70 degrees/14 degree dip at 97 degrees

Thickness - $11.8 \mathrm{~m}(39 \mathrm{ft})$

\section{END OF SECTION}


MEASURED SECTION: Briery Gap, West Virginia DATE: 08/28/99

DESCRIBED BY: Sheldon Murphy
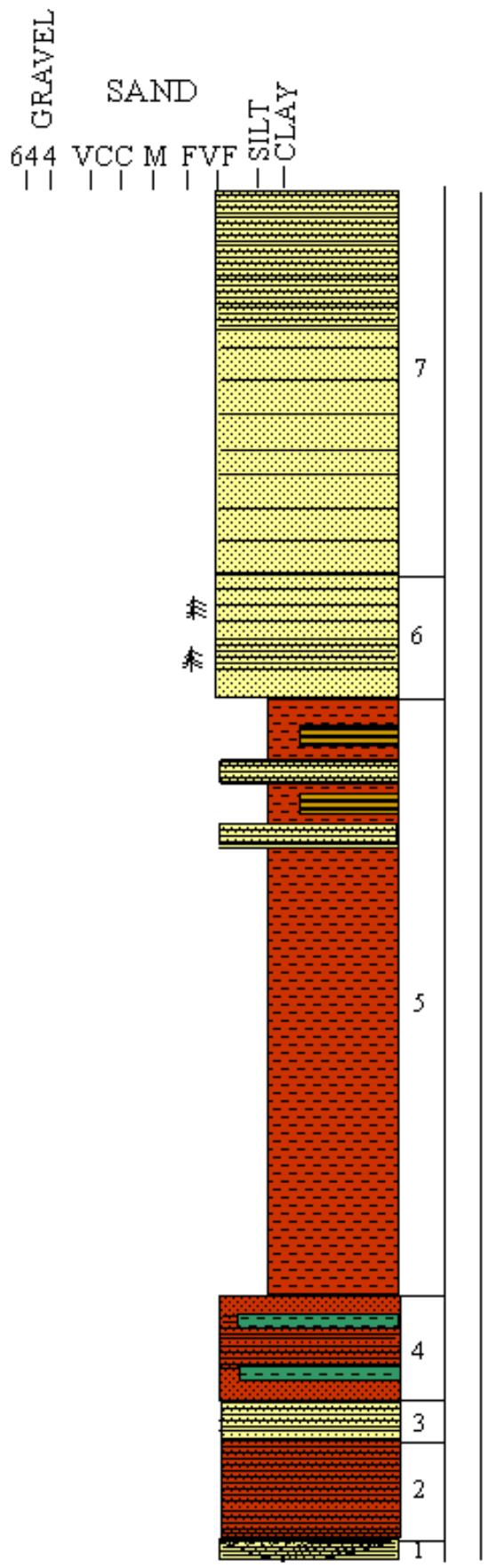

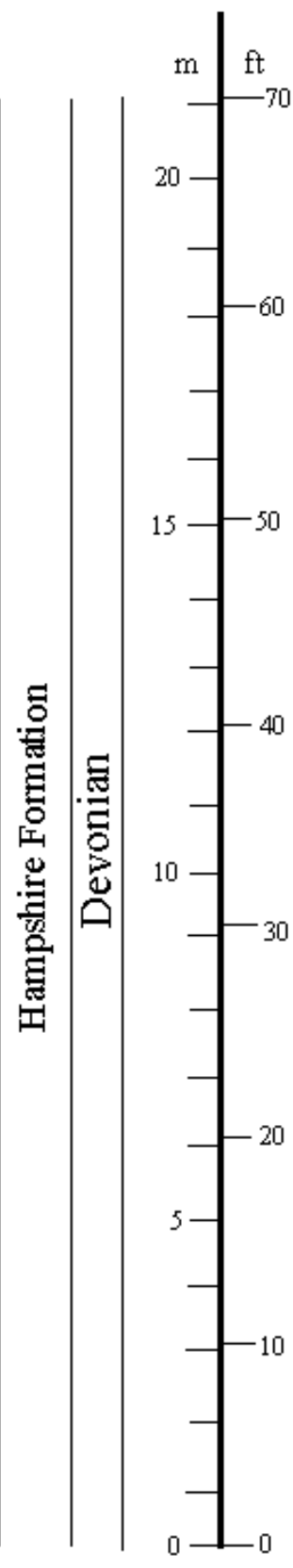

QUADRANGLE: Circleville 7.5' FORMATION: Price Formation

Thickly bedded becoming thinly bedded

Plant debris and carbonaceous material at base

Trough crossbedding filled with planar crossbeds

Figure 78. Units 1-7 from the Briery Gap stratigraphic section 
MEASURED SECTION: Briery Gap, West Virginia DATE: 08/28/99

DESCRIBED BY: Sheldon Murphy

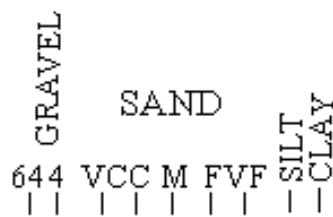
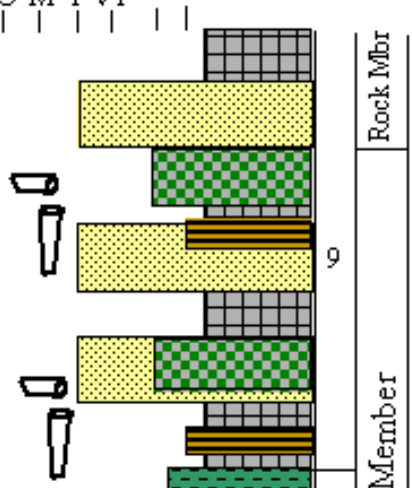
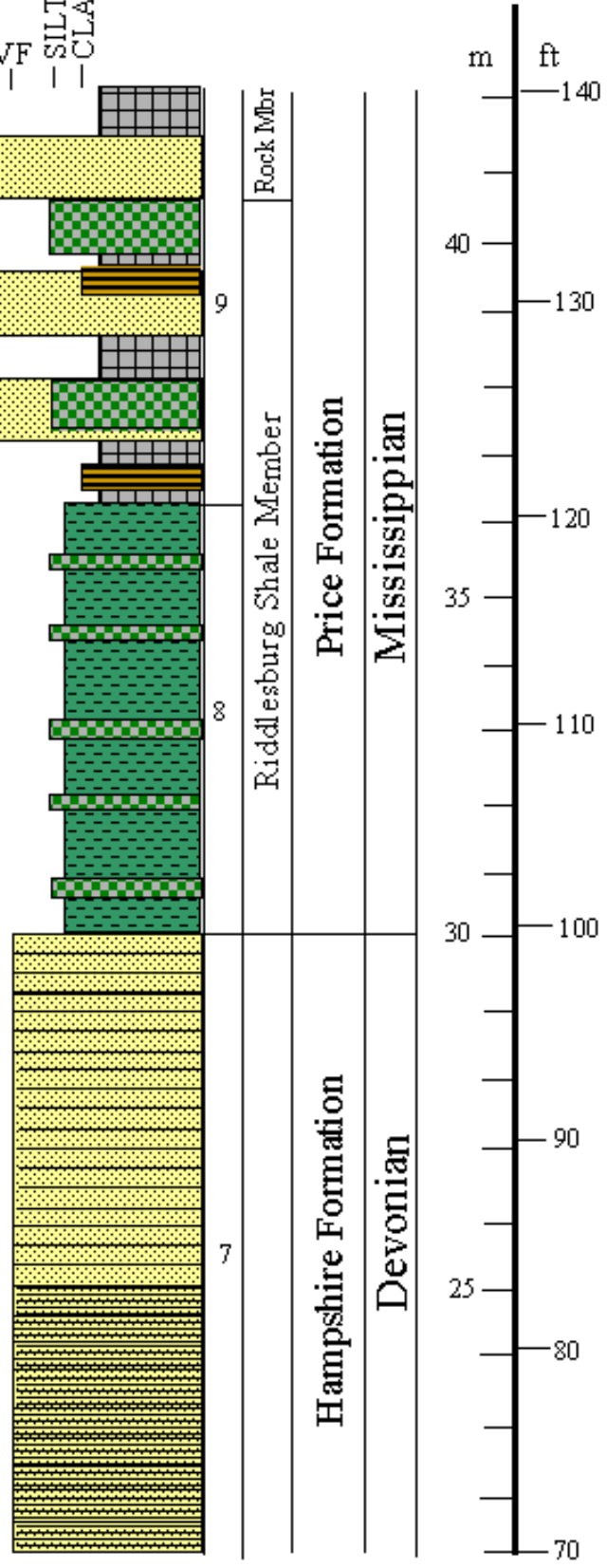

Thinly bedded in middle becoming medium bedded at top

Figure 79. Units 7-9 from the Briery Gap stratigraphic section 
MEASURED SECTION: Briery Gap, West Virginia DATE: 08/28/99

DESCRIBED BY: Sheldon Murphy$$
5
$$

SAND

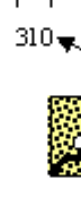

然

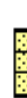
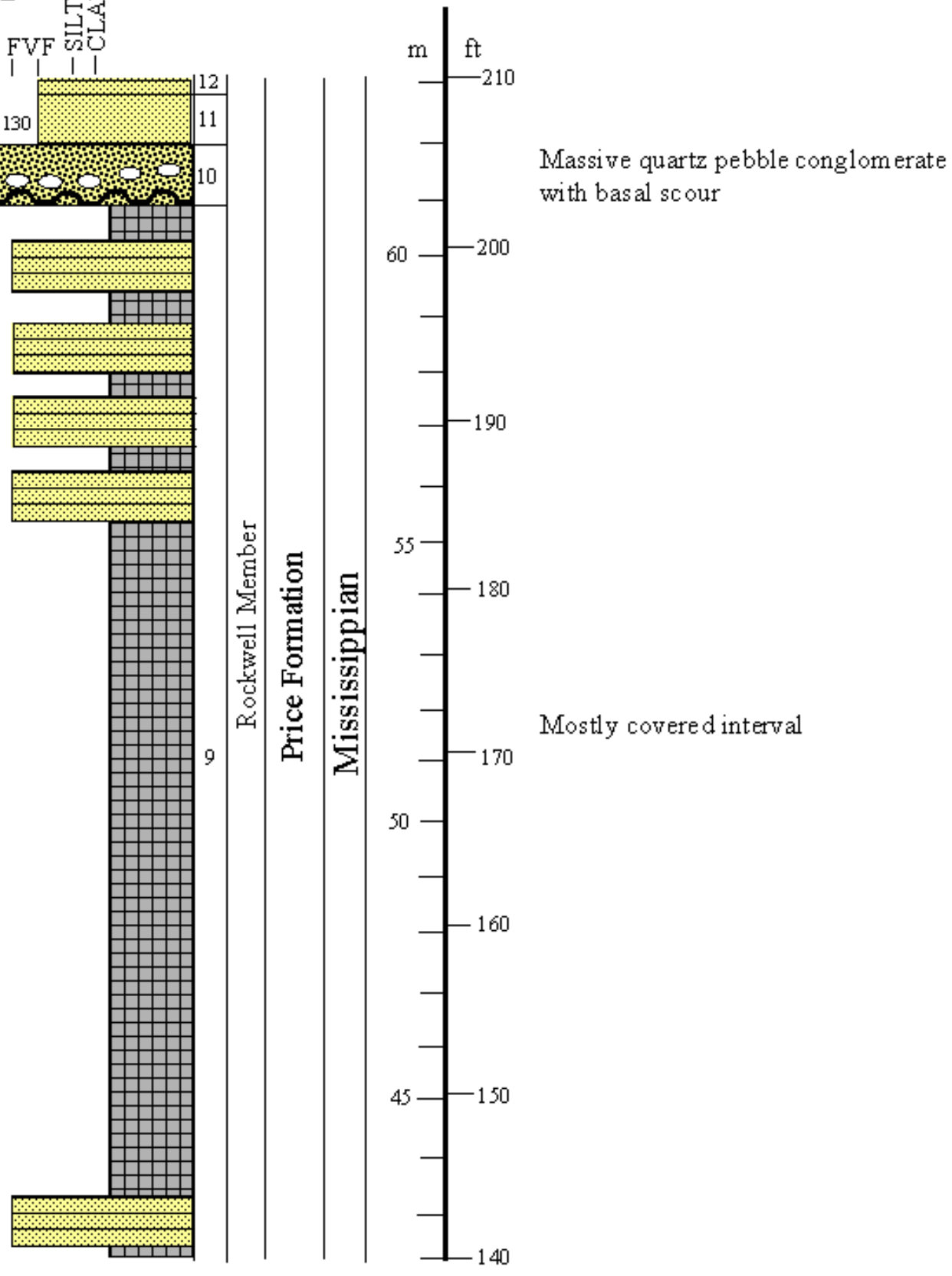

Figure 80. Units 9-12 from the Briery Gap stratigraphic section
QUADRANGLE: Circleville 7.5' FORMATION: Price Formation 
MEASURED SECTION: Briery Gap, West Virginia DATE: 08/28/99

DESCRIBED BY: Sheldon Murphy
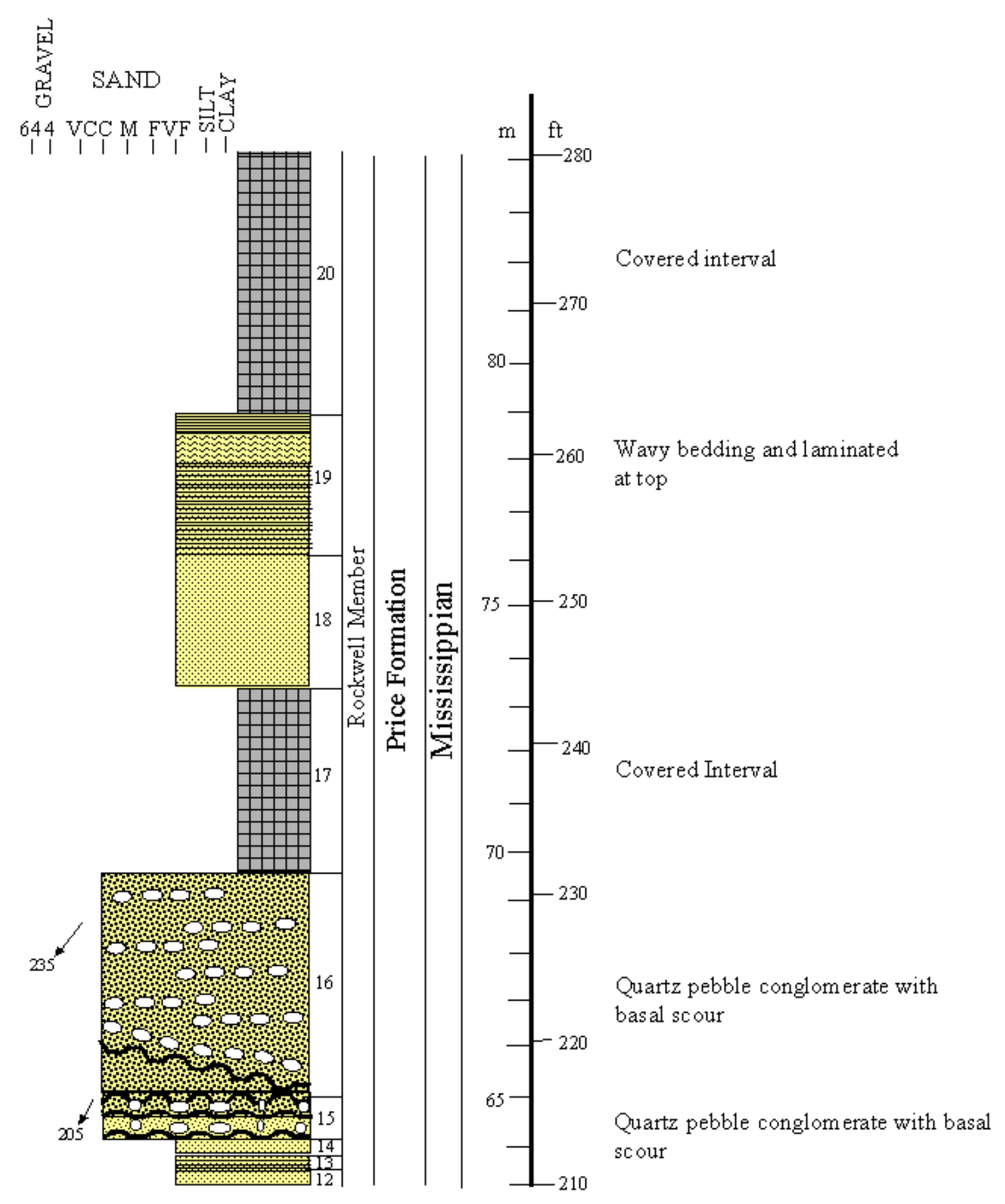

QUADRANGLE: Circleville 7.5'

FORMATION: Price Formation

Figure 81. Units 12-20 from the Briery Gap stratigraphic section 
MEASURED SECTION: Briery Gap, West Virginia DATE: 08/28/99

DESCRIBED B Y: Sheldon Murphy

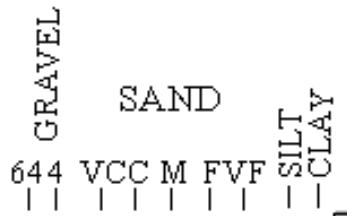

644 VCC M FVF

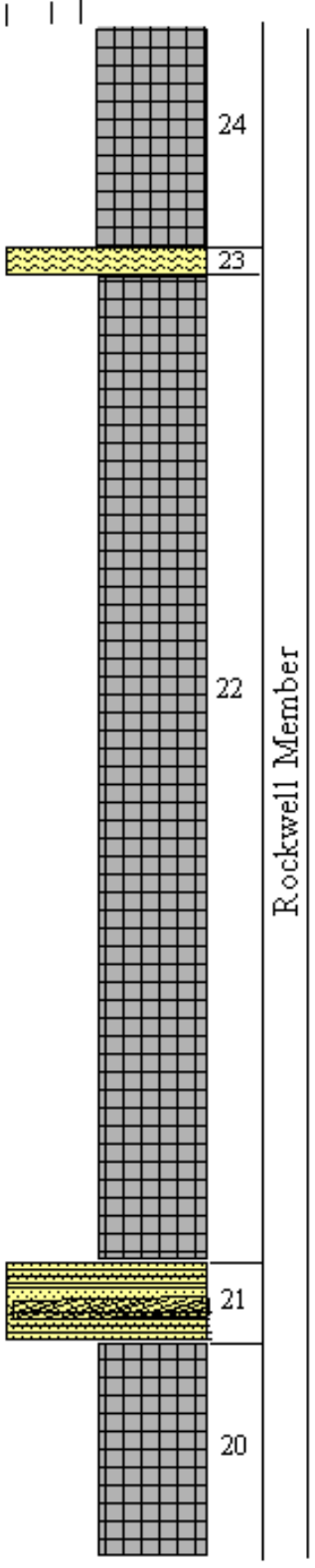

$$
\text { । }
$$

QUADRANGLE: Circleville 7.5'

FORMATION: Price Formation 
MEASURED SECTION: Briery Gap, West Virginia DATE: 08/28/99

DESCRIBED BY: Sheldon Murphy

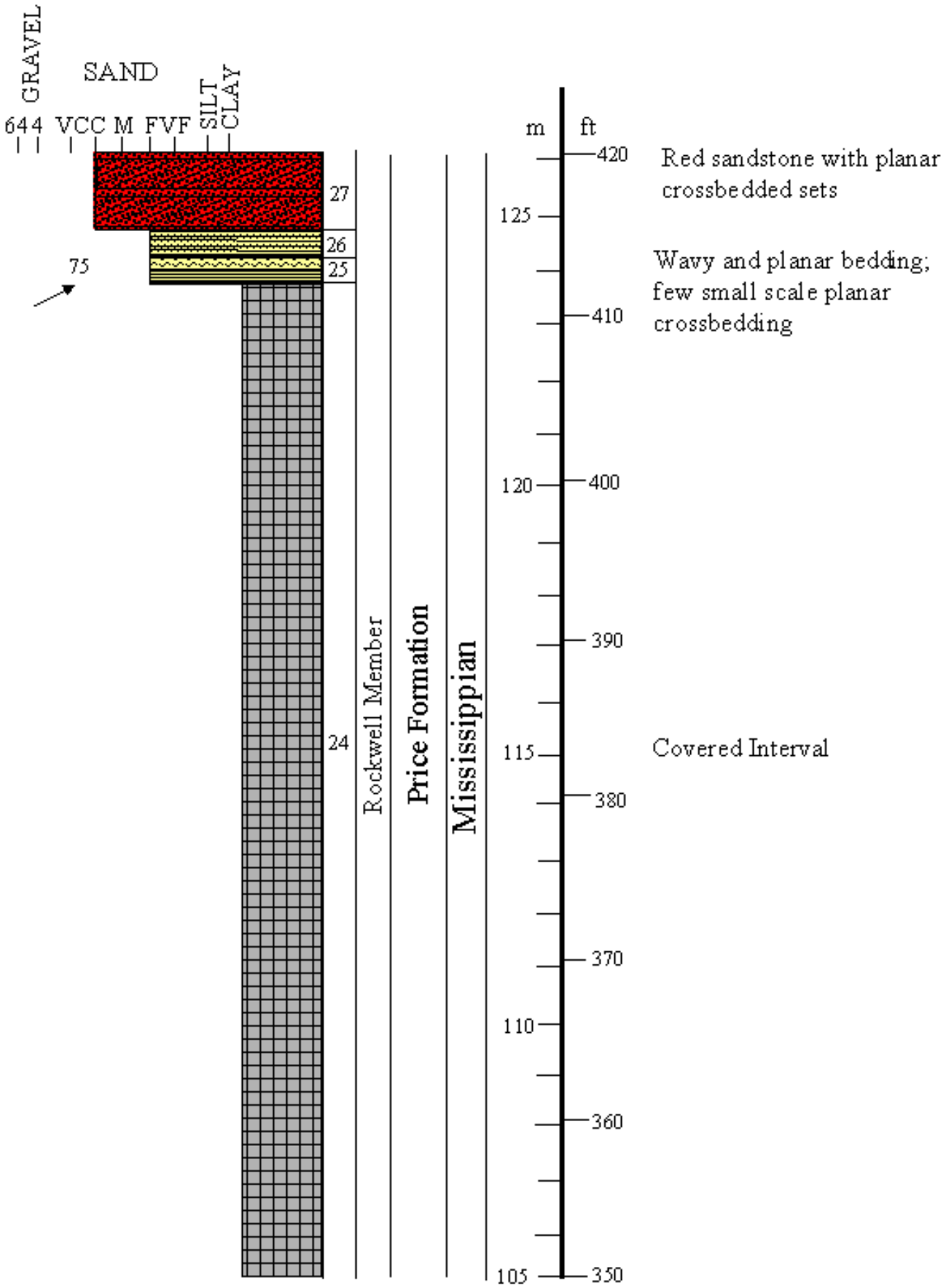

Figure 83. Units 24-27 from the Briery Gap stratigraphic section 
MEASURED SECTION: Briery Gap, West Virginia DATE: 08/28/99

DESCRIBED BY: Sheldon Murphy

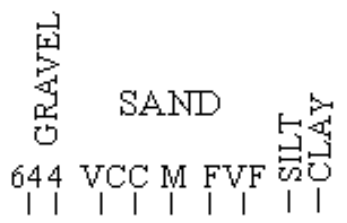

QUADRANGLE: Circleville 7.5' FORMATION: Price Formation

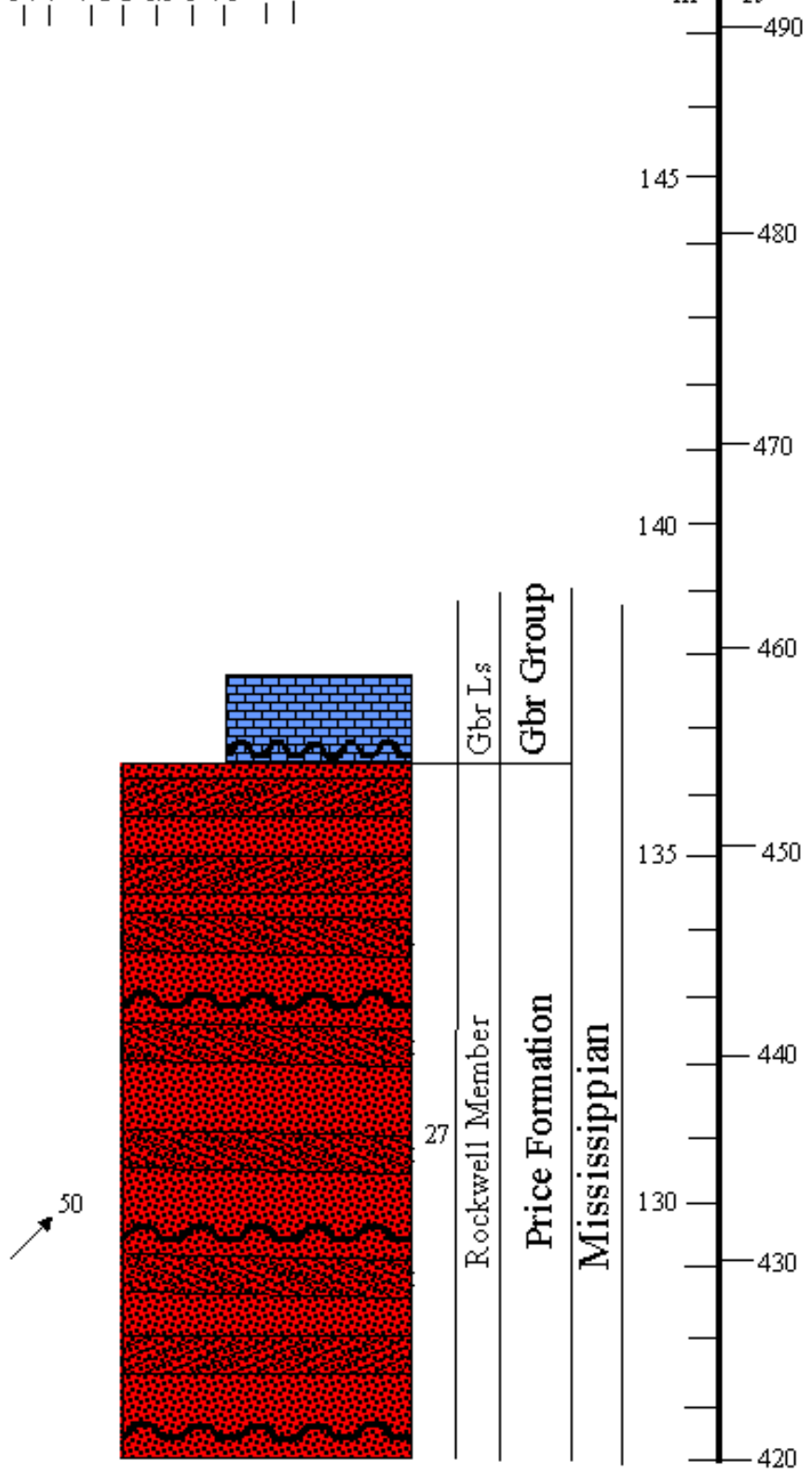

Figure 84. Unit 27 from the Briery Gap stratigraphic section 
Measured Section - Durbin, West Virginia

Measured by Sheldon Murphy and Barnes Nugent (WVGES)

Quadrangle - Durbin 7.5,

Date $-11 / 05 / 99$

Measured section of the Price Formation along state route 250 and 92 on southwest slope of Back Allegheny Mountain at Durbin. Top of section at elevation $3200 \mathrm{ft}$. $(975 \mathrm{~m})$ located 2200 $\mathrm{ft} .(670 \mathrm{~m})$ northeast of bench mark 3262. Base of section at elevation $3000 \mathrm{ft} .(914 \mathrm{~m})$ located $3500 \mathrm{ft}$. $(1067 \mathrm{~m})$ northeast of bench mark 3114. Located in Greenbank District within Pocahontas County.

Oswayo Member (Units 1-2)

Riddlesburg Shale Member (Unit 2-4)

Rockwell Member (Units 4-5)

Unnamed Upper Member (Unit 5-6)

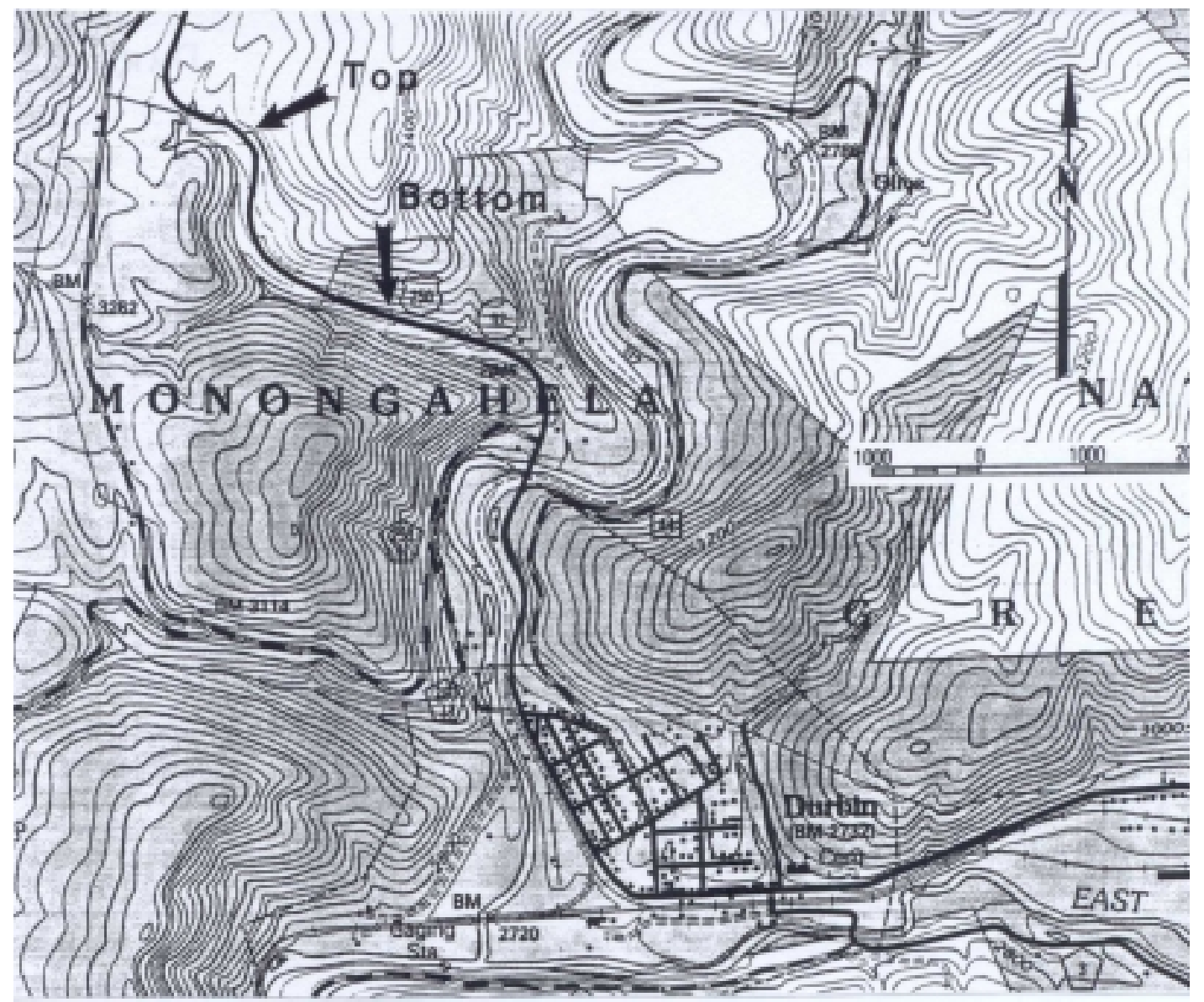

Figure 85. Location map for Durbin section taken from the Durbin 7.5' USGS topographic map 
Measured Section - Durbin, West Virginia

Measured by Sheldon Murphy and Barnes Nugent

Quadrangle - Durbin 7.5'

Date $-08 / 28 / 99$

\section{UNIT 1: MUDSTONE}

Grain Size and Texture - very fine-grained, hard, sandy throughout paleosol becoming less sandy at top, concretions

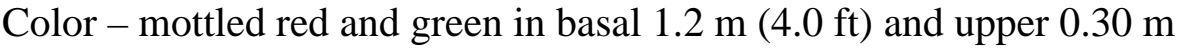

$(1.0 \mathrm{ft})$ mostly green

Bedding - medium bed

Sedimentary Structures - root mottling

Paleocurrent Measurements- none

Fossils - none observed

Contact - gradational at top and concealed into red shale beneath

Strike/dip - 25 degrees/12 degree dip

Thickness $-1.5 \mathrm{~m}(5.01 \mathrm{ft})$

\section{UNIT 2: SANDSTONE WITH INTERBEDDED SILSTONE AND MUDSTONE}

Grain Size and Texture - fine-grained, hard, subangular grains, moderately sorted, quartz pebbles less than $1 \mathrm{~cm}$ about $0.91 \mathrm{~m}(3 \mathrm{ft}$ ) from top of unit, shaly at bottom

Color - buff-brown sandstone at base and grey-brown toward top, siltstone and mudstones are mottled red and green

Bedding - planar continuous parallel beds approximately $0.60 \mathrm{~m}(2.0 \mathrm{ft})$ thick from base to upper $3.0 \mathrm{~m}(10 \mathrm{ft})$ were beds are laminated crossbeds, few interbedded shale beds in top $1.5 \mathrm{~m}(5.0 \mathrm{ft})$ and base

Sedimentary Structures - base contains large scour surface and another scour surface approximately $1.5 \mathrm{~m}(5.0 \mathrm{ft})$ from top, dip angle of beds is less in the middle and predominately flat lying then dip angle of beds increases, very bottom scour contains rip-up clasts, some beds are contorted in upper part of section due to scouring, bioturbated

Paleocurrent Measurements strike of bed -310 or 130 degrees

current direction azimuth -220 or 40 degrees

type - trough crossbedding

width $-6.0 \mathrm{~m}(20 \mathrm{ft})$

height $-1.5 \mathrm{~m}(5.0 \mathrm{ft})$

strike of bed -315 or 135 degrees

current direction azimuth -225 or 45 degrees

type - trough crossbedding

width $-18 \mathrm{~m}(60 \mathrm{ft})$

height $-1.2 \mathrm{~m}(4.0 \mathrm{ft})$

Fossils - plant debris in middle of section, horizontal and vertical bioturbation (top) 
Contact - gradational at top and bottom

Strike/dip - 60 degrees/12 degree dip at 330 degrees

Thickness $-9.4 \mathrm{~m}(31 \mathrm{ft})$

\section{UNIT 3: SILTSTONE AND INTERBEDDED MUDSTONE}

Grain Size and Texture - very fine-grained and hard

Color - brown-buff in base and grey toward top

Bedding - relatively no bedding except for small shale beds at top, bioturbated, possible iron concretions

Sedimentary Structures - bioturbation

Paleocurrent Measurements- none

Fossils - bioturbated, trace fossils-Diplocraterion (?) in middle of unit, small Ushaped lateral burrows, some vertical tubes with ichnofossils in concretions

Contact - sharp at top and gradational at base

Strike/dip - 60 degrees/12 degree dip at 330 degrees

Thickness $-4.1 \mathrm{~m}(13.5 \mathrm{ft})$

\section{UNIT 4: SANDSTONE WITH QUARTZ PEBBLES}

Grain Size and Texture - basal part of sandstone is very hard, dirty, fine-grained with 1-2 cm quartz pebbles, pebbles are well rounded and sand grains are subrounded and well sorted, upper part of sandstone is coarse-grained, clean and white

Color - White (top) to buff-brown (base)

Bedding - Beds are mostly parallel and continuous, bed thickness is from $0.10 \mathrm{~m}$ (4.0 inches) to $0.30 \mathrm{~m}(1.0 \mathrm{ft})$ in basal two-thirds then beds are mostly $0.30 \mathrm{~m}(1.0$ $\mathrm{ft}$ ), some beds are broken up due to weathering, some small laminated zones occur near the base, basal concoidal fractures

Sedimentary Structures - none observed

Paleocurrent Measurements- none

Fossils - Arenocolites, horizontal and vertical bioturbation about $2.1 \mathrm{~m} \mathrm{(7ft)}$ above underlying shale

Contact - bottom is sharp although partially covered and top is covered

Stike/dip - 53 degrees/13 degree dip at 323 degrees

Thickness $-9.4 \mathrm{~m}(31 \mathrm{ft})$

\section{UNIT 5: COVERED INTERVAL - SITLSTONE WITH INTERBEDDED SHALE}

AND MUDSTONE IN TOP $1.5 \mathrm{~m}(5.0 \mathrm{ft})$

Grain Size and Texture - very fine-grained, clean, medium hard, hard sandstone at base, quartz granules in lenses

Color - grey

Bedding - parallel continuous planar beds with beds thinning from $0.12 \mathrm{~m}(5.0$ inches) to almost laminated at top, top $0.45 \mathrm{~m}$ (1.5 ft) is interbedded with shale and mudstone

Sedimentary Structures - none observed 
Paleocurrent Measurements- none

Fossils - none observed

Contact - covered at base and sharp at top

Strike/dip - 53 degrees/13 degree dip at 323 degrees

Thickness - $12.1 \mathrm{~m}(40 \mathrm{ft})$

\section{UNIT 6: FOSSILIFEROUS SANDSTONE}

Grain Size and Texture - very fine-grained, hard, sub-rounded grains and wellsorted, tightly packed and clast supported, weathered brown

Color- grey, weathers brown

Bedding $-2.1 \mathrm{~m}(7.0 \mathrm{ft})$ large bed at base becoming medium to very thinly bedded ranging from $0.30 \mathrm{~m}(1.0 \mathrm{ft})$ to $0.025 \mathrm{~m}$ ( 1.0 inches $)$, overall bed thickness decreases up section, laminated beds at top, and some concoidal fracturing at top

Sedimentary Structures - trough crossbeds

Paleocurrent Measurements

Strike of bed - 260 or 80 degrees

current direction azimuth -350 or 170 degrees

type - trough crossbedding (channel)

width $-30 \mathrm{~m}(100 \mathrm{ft})$

height $-8.3 \mathrm{~m}(27.5 \mathrm{ft})$

Fossils - abundant fossils in medium to thinly bedded sandstones except in basal

$2.1 \mathrm{~m}(7.0 \mathrm{ft})$, brachiopods, top of crinoid stems, bryozoans

Contact - sharp at base and covered at top (top of hill slope)

Strike/dip - 60 degrees/12 degree dip at 330 degrees

Thickness $-8.3 \mathrm{~m}(27.5 \mathrm{ft})$

\section{END OF SECTION}


MEASURED SECTION: Durbin, West Virginia

DATE: $11 / 05 / 99$

DESCRIBED BY: Sheldon Murphy, Barnes Nugent

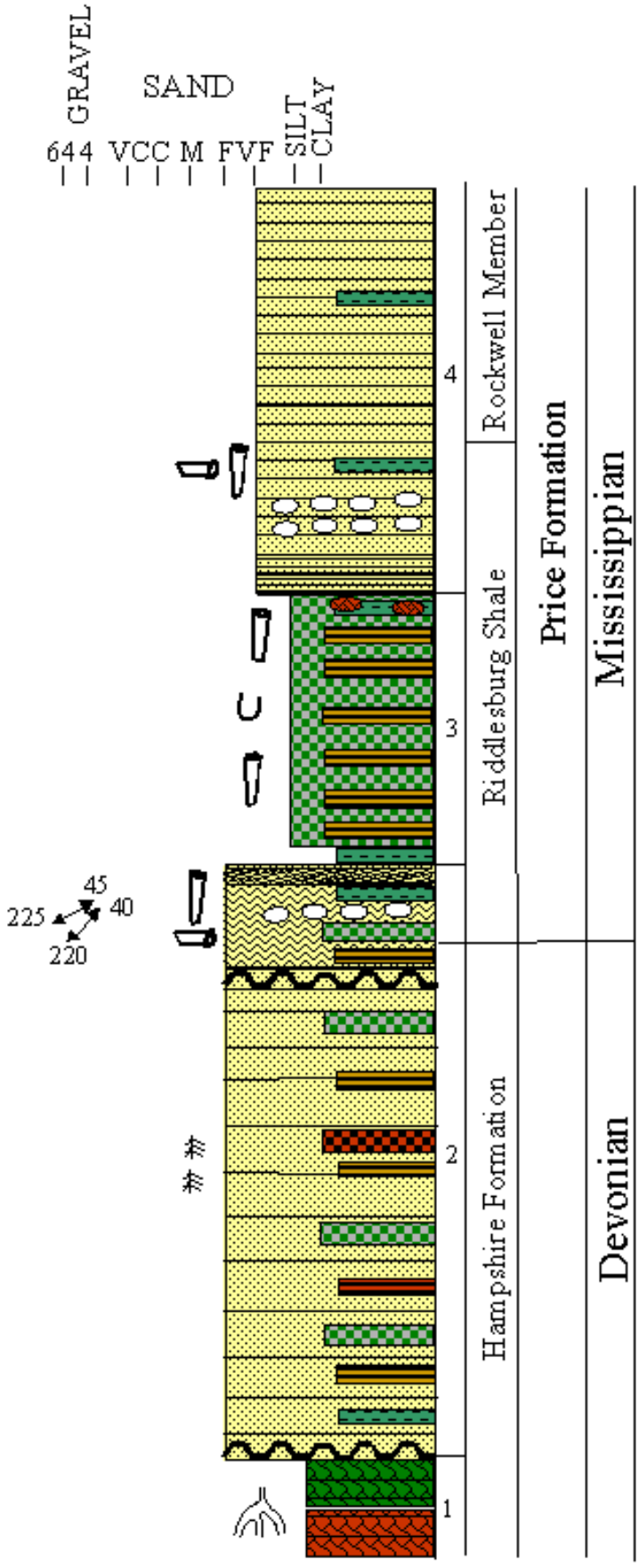

QUADRANGLE: Durbin 7.5'

FORMATION: Price Formation
Coarsening upward sandstone with scattered $1-2 \mathrm{~cm}$ quartz pebbles; laminated zones near the base

Vertical and u-shaped burrows; concretions
Planar bedded sandstone containing laminated crossbeds near the top; scour surfaces with rip-up clasts in the base; interbedded mottled red and green siltstones and mudstones

Paleosol with root mottling

Figure 86. Units 1-4 from the Durbin stratigraphic section 
MEASURED SECTION: Durbin, West Virginia

DATE: $11 / 05 / 99$

DESCRIBED B Y: Sheldon Murphy, Barnes Nugent
QUADRANGLE: Durbin 7.5'

FORMATION: Price Formation

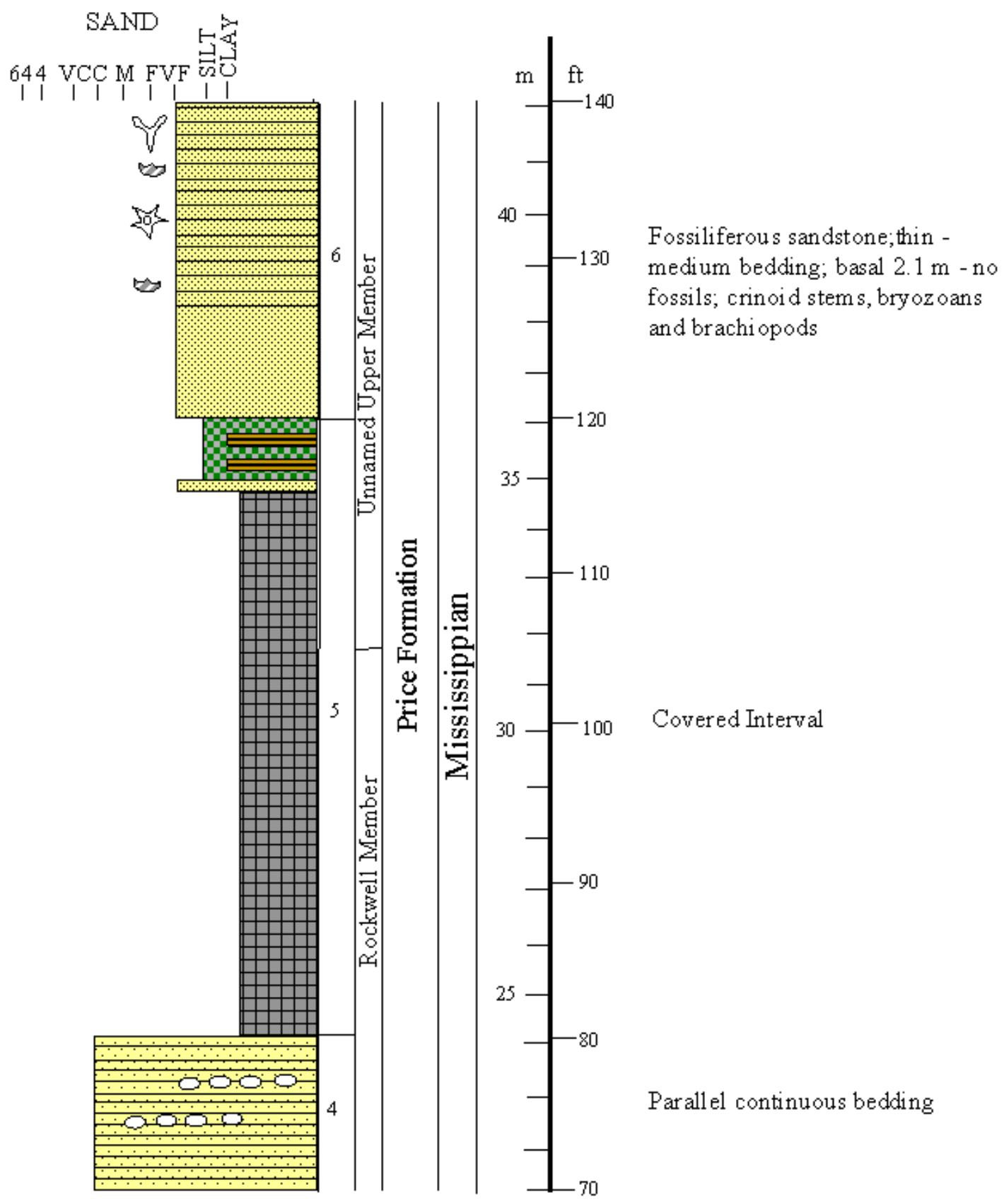

Figure 87. Units 4-6 from the Durbin stratigraphic section 
MEASURED SECTION: Durbin, West Virginia DATE: $11 / 05 / 99$

DESCRIBD B Y: Sheldon Murphy, Barnes Nugent

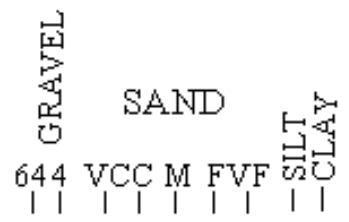

QUADRANGLE: Durbin 7.5'

FORMATION: Price Formation
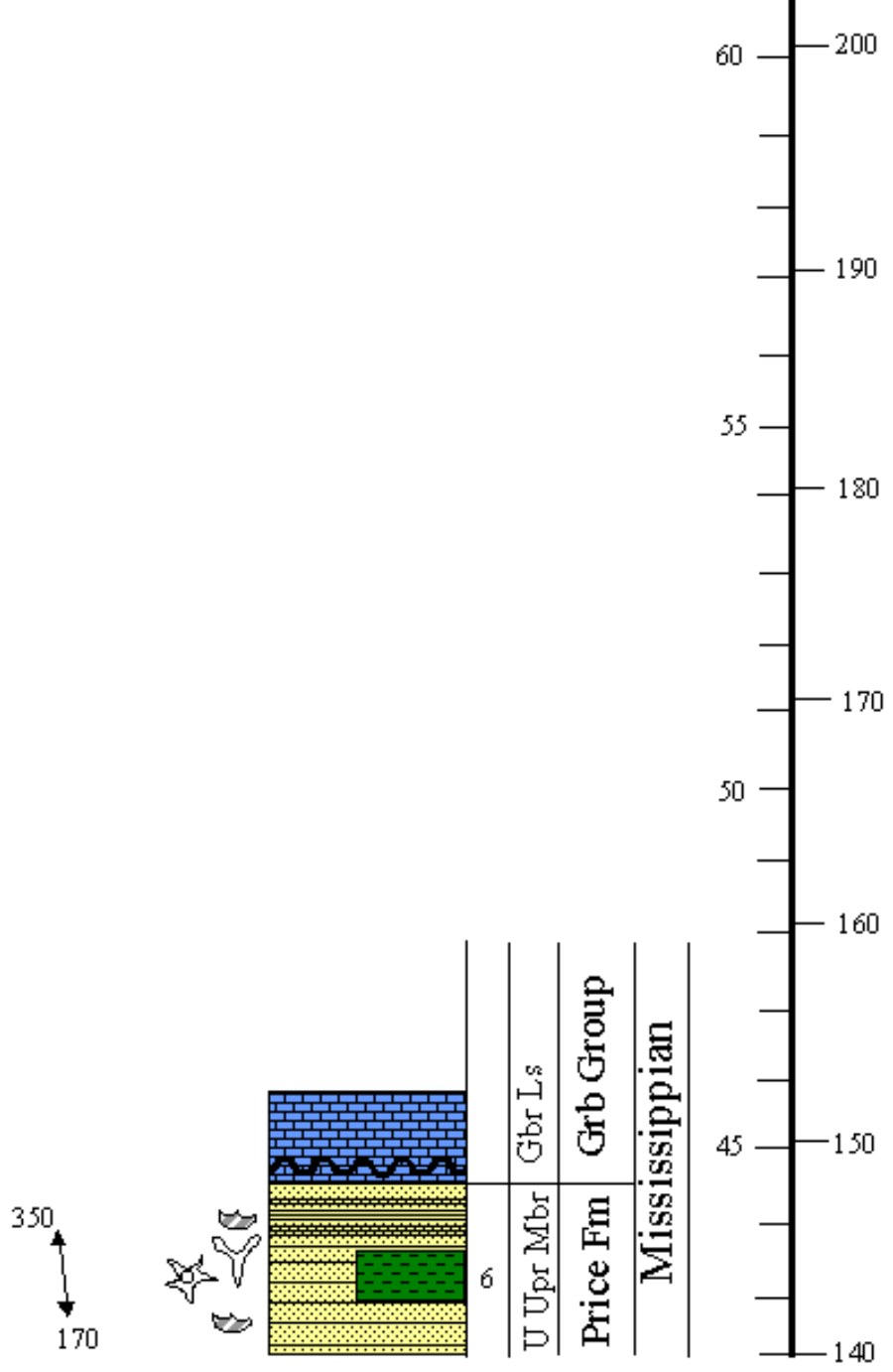

Laminated

Figure 88. Unit 6 from the Durbin stratigraphic section 
Measured Section - Mace, West Virginia

Measured by Tom Bjerstedt and Dr. Tom Kammer

Quadrangle - Mingo 7.5'

Date $-06 / 26 / 84$

Measured section of the Price Formation along WV route 219 at Mace. Top of section at elevation $3080 \mathrm{ft}$. $(939 \mathrm{~m})$ located $1000 \mathrm{ft}$. $(304 \mathrm{~m})$ north of benchmark 3192. Base of section at elevation $2880 \mathrm{ft}$. $(878 \mathrm{~m})$ located $1000 \mathrm{ft}$. (304 m) northwest of benchmark 2882. Located in Mingo District within Randolph County.

Hampshire Formation (Units 1-10)

Riddlesburg Shale Member (Units 11-13)

Unnamed Upper Member (Units 14-19)

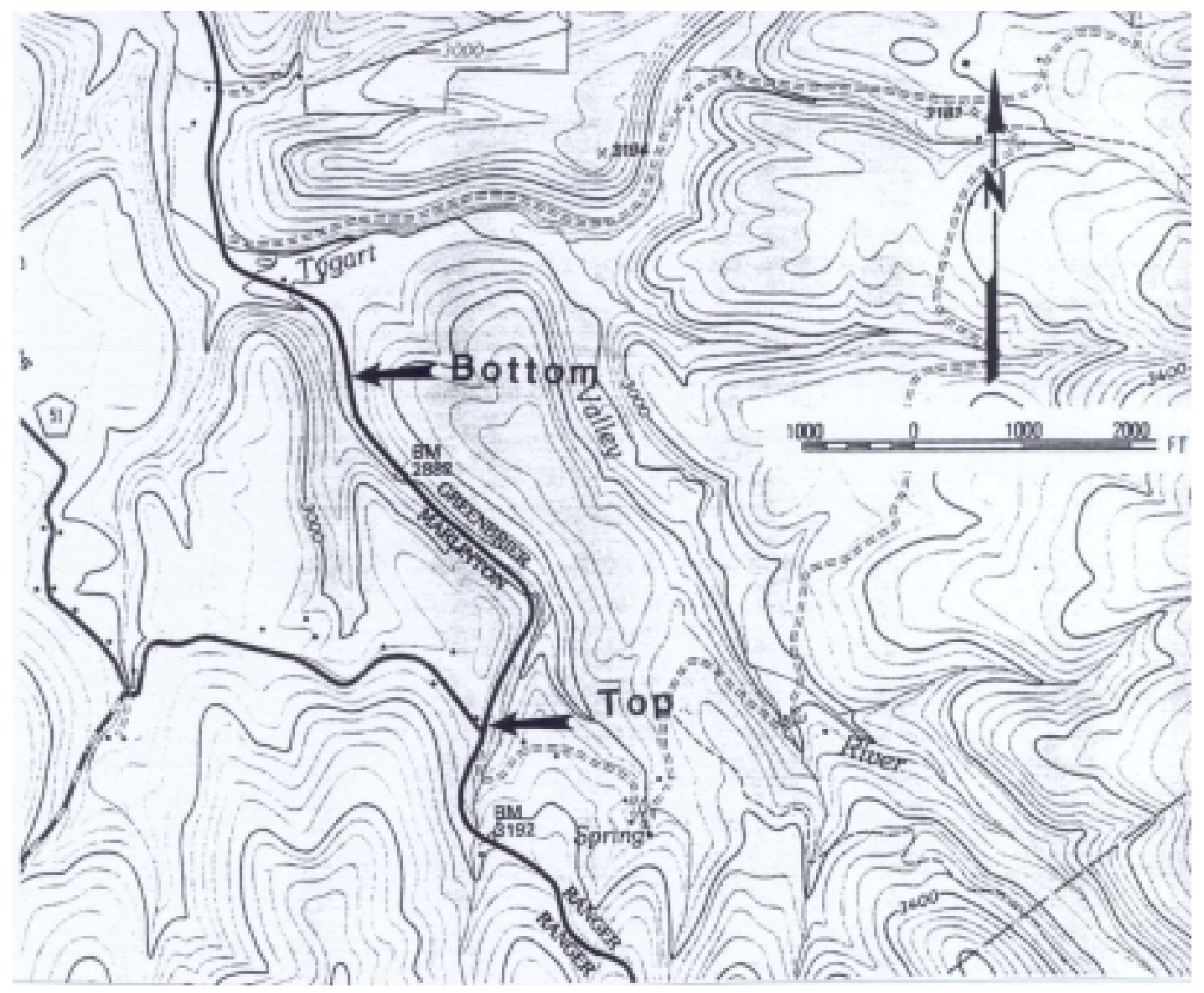

Figure 89. Location map for Mace section taken from the Mingo 7.5' USGS topographic map 


\author{
Measured Section - Mace \\ Measured by Tom Bjerstedt and Dr. Tom Kammer \\ Quadrangle - Mingo 7.5' \\ Date - 06126184
}

\title{
UNIT 1: SANDSTONE
}

Grain Size and Texture - fine-grained

Color - F - greyish red (10R 4/2), W - pale red (5R 6/2)

Bedding - none recorded

Sedimentary Structures - none recorded

Fossils - none recorded

Contact - none recorded

Strike/dip - none recorded

Thickness - $1.5 \mathrm{~m}(5.0 \mathrm{ft})$ - unit not entirely measured

\section{UNIT 2: COVERED INTERVAL}

Thickness $-1.5 \mathrm{~m}(5.0 \mathrm{ft})$

\section{UNIT 3: SANDSTONE}

Grain Size and Texture - fine-grained

Color - F - olive grey (5Y 6/1), W - moderate brown (5Y 4/4)

Bedding - thin to thick bedded, bedding thins upward in unit

Sedimentary Structures - medium scale trough crossbed sets, trough bottoms have lags or larger plant debris and light grey shale pebbles

Fossils - none recorded

Contact - none recorded

Strike/dip - none recorded

Thickness - $3.5 \mathrm{~m}(11.6 \mathrm{ft})$

\section{UNIT 4: COVERED INTERVAL (SANDSTONE IN FLOAT)}

Grain Size and Texture - fine-grained and conglomeratic sandstone float

Color - none recorded

Bedding - thin bedding

Sedimentary Structures - none recorded

Fossils - none recorded

Contact - none recorded

Strike/dip - none recorded

Thickness - $8.8 \mathrm{~m}(29 \mathrm{ft})$

\section{UNIT 5: SANDSTONE}

Grain Size and Texture - fine to medium- grained

Color - F - greenish grey (5GY 6/1), W - light olive grey (5Y 5/2)

Bedding - thin to medium bedded

Sedimentary Structures - very prominent trough and planar crossbed sets, lower 
part of unit shows trough crossbeds which grade upward to planar crossbeds with tangential bases, these bedsets are separated by thin beds of horizontally-laminated sandstone

Fossils - none recorded

Contact - none recorded

Strike/dip - none recorded

Thickness - $8.8 \mathrm{~m}(29 \mathrm{ft})$

UNIT 6: COVERED INTERVAL

Thickness - $3.6 \mathrm{~m}(12 \mathrm{ft})$

UNIT 7: COVERED INTERVAL (INTERBEDDED SANDSTONE)

Grain Size and Texture - fine-grained, shale clasts

Color - F - light olive grey (5Y 6/1), W - light brown (5YR 5/6)

Bedding - thick bedded

Sedimentary Structures - none observed

Fossils - none observed

Contact - none recorded

Strike/dip - none recorded

Thickness - $8.2 \mathrm{~m}(27 \mathrm{ft})$

UNIT 8: COVERED INTERVAL (INTERBEDDED SANDSTONE AND SHALE)

Grain Size and Texture - fine-grained sandstones, silty shales

Color - none recorded

Bedding - medium bedded sandstone, laminated silty shale

Sedimentary Structures - none recorded

Fossils - none recorded

Contact - none recorded

Strike/dip - none recorded

Thickness $-5.3 \mathrm{~m}(17.5 \mathrm{ft})$

UNIT 9: QUARTZ PEBBLE CONGLOMERATE

Grain Size and Texture - fine to medium sized quartz pebbles and shale pebbles

Color - none recorded

Bedding - none recorded

Sedimentary Structures - none recorded

Fossils - none recorded

Contact - none recorded

Strike/dip - none recorded

Thickness $-0.3 \mathrm{~m}(1.0 \mathrm{ft})$

UNIT 10: COVERED INTERVAL (INTERBEDDED SANDSTONE AND SILTSTONE)

Grain Size and Texture - fine-grained sandstone

Color - F - light olive grey (5Y 5/2), W - moderate brown (5YR 4/4)

Bedding - thin to medium bedded 
Sedimentary Structures - none observed

Fossils - none recorded

Contact - none recorded

Strike/dip - none recorded

Thickness $-3.0 \mathrm{~m}(10 \mathrm{ft})$

\section{UNIT 11: SANDSTONE WITH INTERBEDDED SILTSTONE AND SILTY}

\section{SHALE}

Grain Size and Texture - fine-grained sandstone, sand/silt/shale $=3 / 2 / 1$

Color - sandstone - F - light olive grey (5Y 5/2), W - moderate brown (5YR 3/4), siltstone and silty shale $-\mathrm{F}$ - light olive grey (5Y $3 / 4), \mathrm{W}$ - moderate brown (5YR 3/4)

Bedding - very thin to medium bedded dependent upon lithology

Sedimentary Structures - a series of at least 15 fining-upward sequences or graded rythmites, medium-bedded sandstone grading up to siltstones and very thin-bedded silty shales

Fossils - Helminthopsis

Contact - none recorded

Strike/dip - none recorded

Thickness $-3.0 \mathrm{~m}(10 \mathrm{ft})$

\section{UNIT 12: SANDSTONE WITH INTERBEDDED SILTSTONE AND SILTY}

SHALE

Grain Size and Texture - fine-grained sandstone, sand/silt/shale $=1 / 2 / 1$

Color - sandstone - F - light olive grey (5Y 5/2), W - moderate brown (5YR 3/4), siltstone and silty shale $-\mathrm{F}$ - light olive grey (5Y $3 / 4), \mathrm{W}$ - moderate brown (5YR 3/4)

Bedding - medium to thick bedded

Sedimentary Structures - minor low angle cross stratification and probable hummocky stratification, trough crossbed sets

Fossils - Helminthopsis

Contact - none recorded

Strike/dip - none recorded

Thickness $-3.0 \mathrm{~m}(10 \mathrm{ft})$

\section{UNIT 13: SANDSTONE}

Grain Size and Texture - fine-grained, sublitharenite, well sorted in thin section

Color - F - light olive grey (5Y 5/2), W - moderate brown (5YR 4/4)

Bedding - thick bedded to massive

Sedimentary Structures - horizontally laminated and apparent hummocky cross stratification sandstone, abundant discontinuous shelly lags up to $10 \mathrm{~cm}$ thick, basal contact sharp but apparently non-erosional

Fossils - Syringothyrsis angulata, bivalves, planispiral gastropods and crinozoan columnals

Contact - sharp at base

Strike/dip - none recorded 
Thickness - $3.3 \mathrm{~m}(11 \mathrm{ft})$

UNIT 14: COVERED INTERVAL (INTERBEDDED SILTSTONE AND SANDSTONE)

Grain Size and Texture - fine-grained sandstone

Color - F - olive grey (5Y 3/2), W - moderate brown (5YR 4/4)

Bedding - very thin to medium bedded

Sedimentary Structures - none observed

Fossils - Planolites and horizontal burrows as hyporeliefs on the few exposed sandstones

Contact - none recorded

Strike/dip - none recorded

Thickness $-4.7 \mathrm{~m}(15 \mathrm{ft})$

\section{UNIT 15: SANDSTONE}

Grain Size and Texture - fine-grained

Color - F - medium grey (N5), W - moderate brown (5YR 4/4)

Bedding - one very thick bed, silty interbeds

Sedimentary Structures - none recorded

Fossils - Planolites and Phycodes as hyporeliefs

Contact - none recorded

Strike/dip - none recorded

Thickness - $1.2 \mathrm{~m}(4.0 \mathrm{ft})$

\section{UNIT 16: COVERED INTERVAL (INTERBEDDED SILTSTONE AND} SANDSTONE)

Grain Size and Texture - fine-grained sandstone

Color - F - light olive grey (5Y 3/4), W - moderate brown (5YR 3/4)

Bedding - very thin to medium bedded

Sedimentary Structures - none recorded

Fossils - Orbiculoidea in float

Contact - none recorded

Strike/dip - none recorded

Thickness $-6.4 \mathrm{~m}(21.0 \mathrm{ft})$

\section{UNIT 17: SANDSTONE (PARTIALLY COVERED)}

Grain Size and Texture - very fine-grained

Color - F - greyish red (5R 4/2), W - pale brown (5YR 5/2)

Bedding - thin to medium bedded

Sedimentary Structures - horizontal laminations

Fossils - very small to medium horizontal burrows

Contact - none recorded

Strike/dip - none recorded

Thickness $-2.1 \mathrm{~m}(7.0 \mathrm{ft})$ 


\section{UNIT 18: SANDSTONE WITH INTERBEDDED SILTSTONE (PARTIALLY COVERED)}

Grain Size and Texture - fine-grained

Color - F - olive grey (5Y 3/2), W - light olive grey (5Y 5/2)

Bedding - thin bedded

Sedimentary Structures - none observed

Fossils - none observed

Contact - none recorded

Strike/dip - none recorded

Thickness $-1.5 \mathrm{~m}(5.0 \mathrm{ft})$

\section{UNIT 19: SANDSTONE}

Grain Size and Texture - fine-grained

Color - F - light olive grey (5Y 5/2), W - moderate brown (5YR 3/4)

Bedding - thick bedded

Sedimentary Structures - a few flute casts, scattered shale pebbles

Fossils - Scalarituba and Isopodichnus, pellet-lined burrows, woody debris

Contact - none recorded

Strike/dip - none recorded

Thickness $-0.8 \mathrm{~m}(2.7 \mathrm{ft})$

UNIT 20: LIMESTONE (GREENBRIER LIMESTONE)

END OF SECTION 
MEASURED SECTION: Mace, We st Virginia

DATE: 06/26/84

DESCRIBED BY: Tom Bjerstedt and Dr. Tom Kammer
QUADRANGLE: Mingo 7.5,

FORMATION: Price Formation

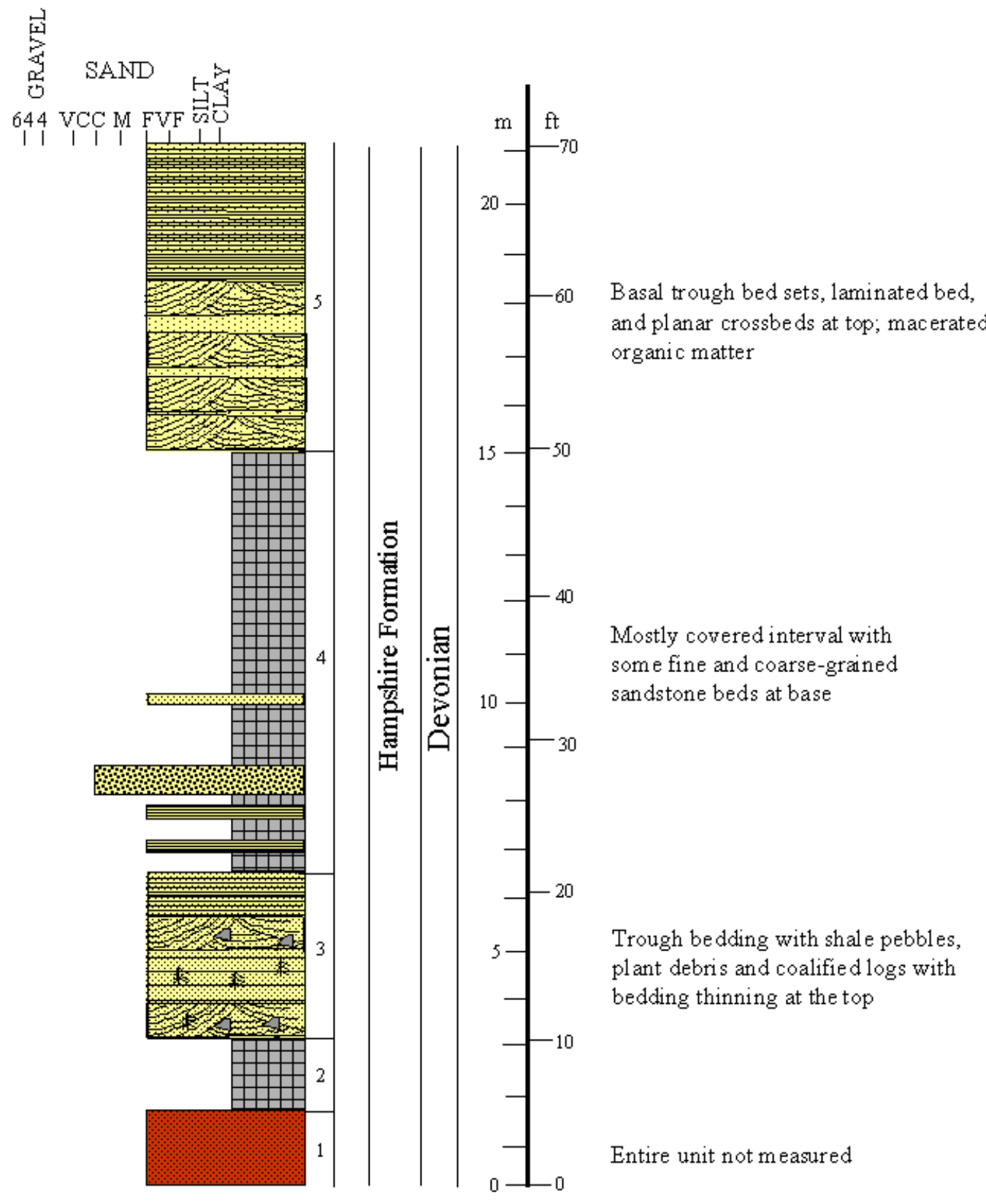

Figure 90. Units 1-5 from the Mace stratigraphic section 
MEASURED SECTION: Mace, West Virginia

DATE: 06/26/84

DESCRIBED BY: Tom Bjerstedt and Dr. Tom Kammer
QUADRANGLE: Mingo 7.5'

FORMATION: Price Formation

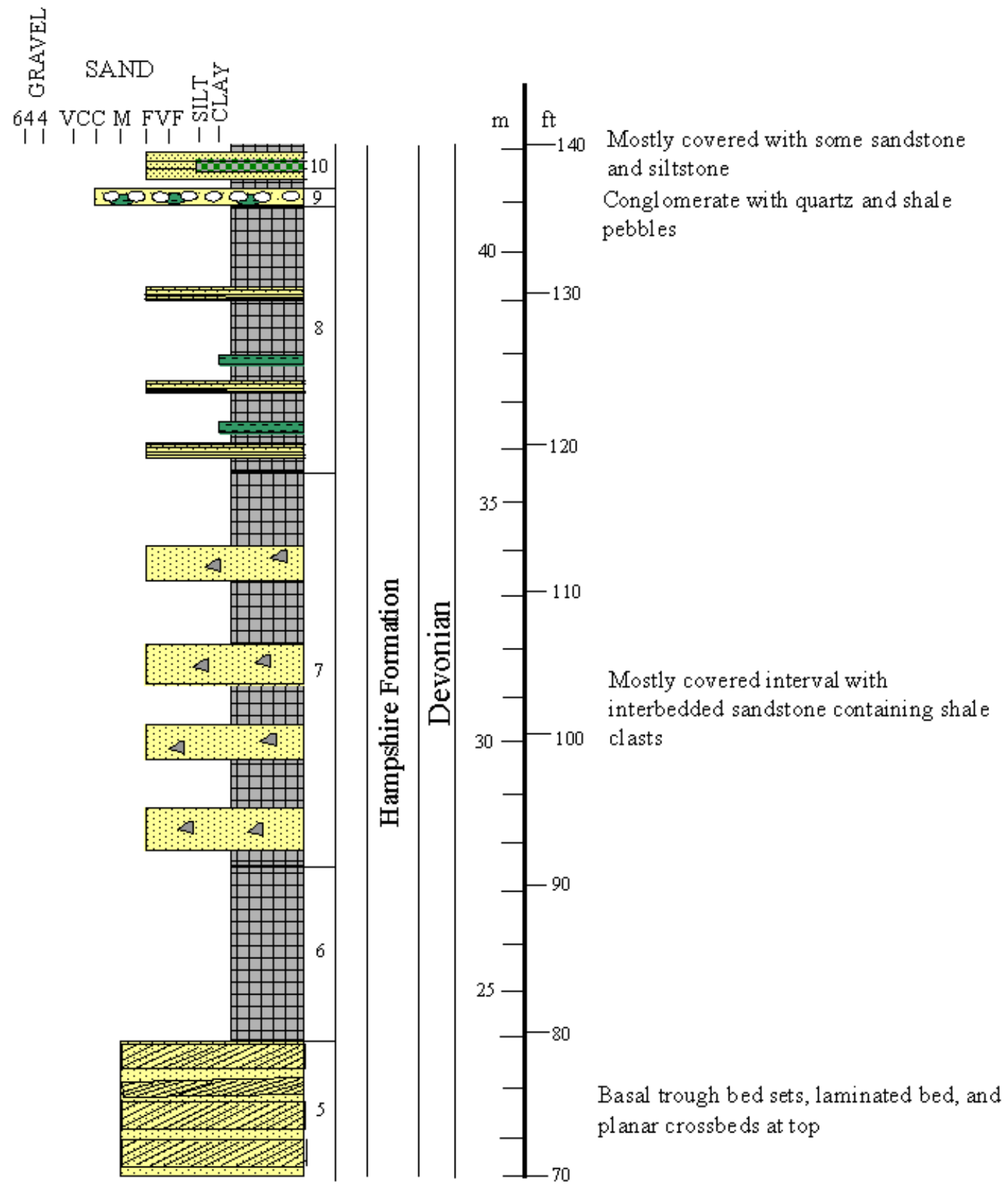

Figure 91. Units 5-10 from the Mace stratigraphic section 
MEASURED SECTION: Mace, West Virginia

DATE: 06/26/84

DESCRIBED BY: Tom Bjerstedt and Dr. Tom Kammer

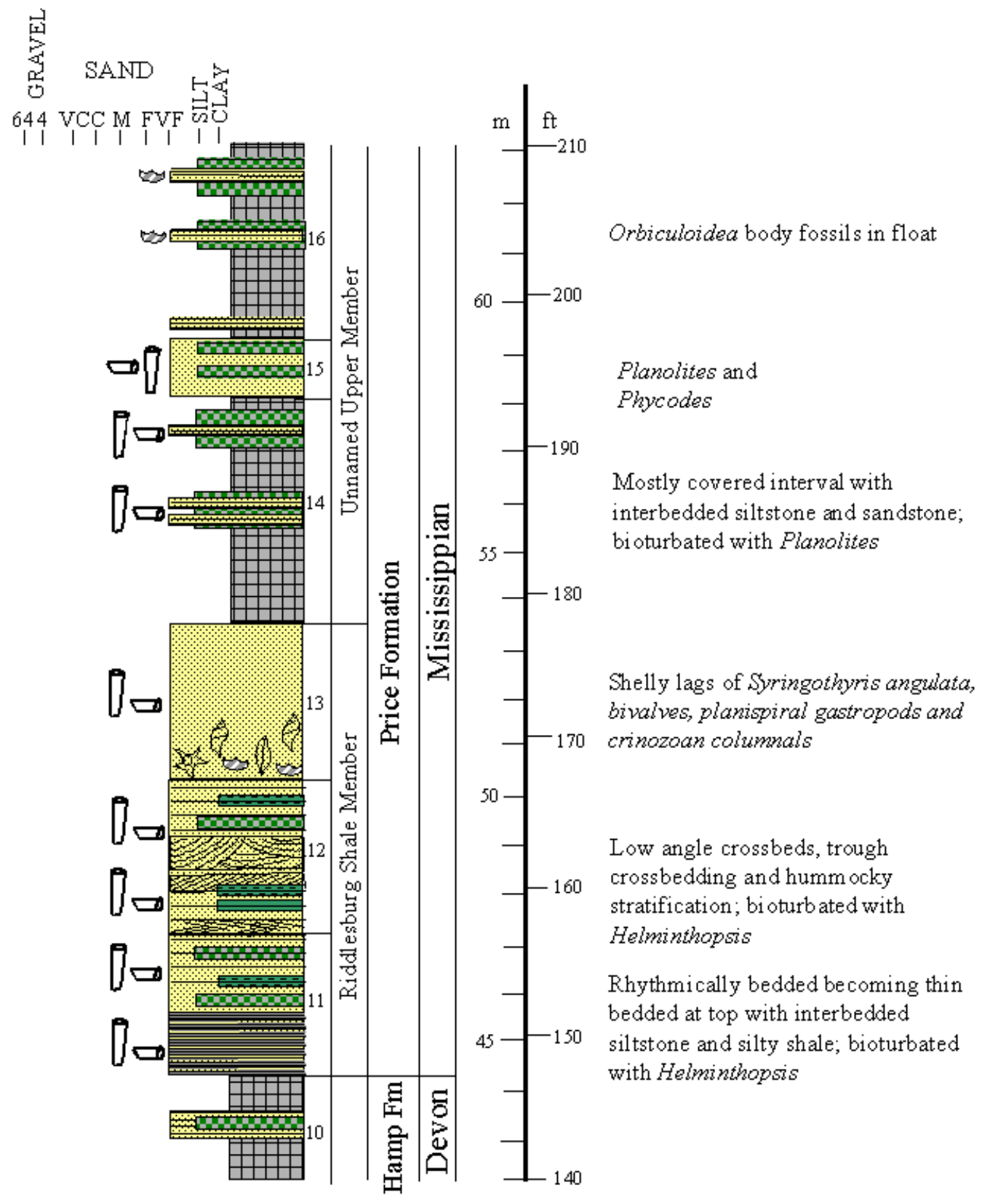

QUADRANGLE: Mingo 7.5,

FORMATION: Price Formation 
MEASURED SECTION: Mace, West Virginia

DATE: 06/26/84

DESCRIBED BY: Tom B jerstedt and Dr. Tom Kammer

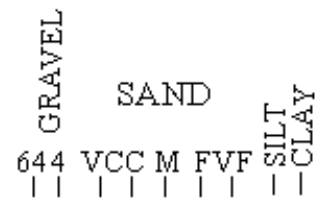

QUADRANGLE: Mingo 7.5'

FORMATION: Price Formation
Bioturbated with Scalarituba and Isopodichnus, shale pebbles; wood debris

Partially concealed sandstone with interbedded siltstone

Thin to medium bedded with horizontal burrows; partially coveredinterval with a few laminated beds

Figure 93. Units 16-19 from the Mace stratigraphic section 
Appendix II - Secondary Localities

\begin{tabular}{|c|c|c|c|c|c|c|c|}
\hline Primary and Secondary & & & & Sedimentary & Strike(s)/ & Paleocurrent & Paleoflow \\
\hline Localities & $7.5^{\prime}$ Quadrangle & Fomation & Member & Structure & $\operatorname{Dip}(d)$ & Strike & Directions \\
\hline & & & & & (degrees) & (degrees) & (degrees) \\
\hline Briery Gap (unit 10) & Circleville & $\mathrm{Mp}$ & Lower Rockwell & planar crossbeds & 40s/12d@130 & 40 or 220 & 310 \\
\hline Briery Gap (unit 14) & Circleville & $\mathrm{Mp}$ & Lower Rockwell & channel & 40s/12d@130 & 145 or 325 & 235 \\
\hline Briery Gap (unit 15) & Circleville & $\mathrm{Mp}$ & LowerRockwell & channel & 40s/12d@130 & 115 or 295 & 205 \\
\hline Briery Gap (unit 26) & Circleville & $\mathrm{Mp}$ & Upper Rockwell & planar crossbeds & 70s/10d@160 & 165 or 345 & 75 \\
\hline Briery Gap (unit 27) & Circleville & $\mathrm{Mp}$ & Upper Rockwell & planar crossbeds & 70s/14d@97 & 145 or 325 & 50 \\
\hline Laurel Run (unit 7) & Blackbird Knob & $\mathrm{Mp}$ & LowerRockwell & planar crossbeds & 17s/17d@287 & 35 or 215 & 305 \\
\hline Laurel Run (unit 7) & Blackbird Knob & $\mathrm{Mp}$ & LowerRockwell & planar crossbeds & 17s/17d@287 & 45 or 225 & 315 \\
\hline Durbin (unit2) & Durbin & $\mathrm{Mp}$ & Riddlesburg & trough & 60s/12d@330 & 130 or 310 & 40 or 220 \\
\hline Durbin (unit2) & Durbin & $\mathrm{Mp}$ & Riddlesburg & trough & 60s/12d@330 & 135 or 315 & 45 or 225 \\
\hline Durbin (unit 6) & Durbin & $\mathrm{Mp}$ & Riddlesburg & channel & 60s/12d@330 & 80 or 260 & 170 or 350 \\
\hline Rowlesburg (Bjerstedt-25) & Rowlesburg & $\mathrm{Mp}$ & Oswayo & trough axis & * & 150 or 330 & 240 \\
\hline Rowlesburg (Bjerstedt-30) & Rowlesburg & $\mathrm{Mp}$ & Cussewago & tool marks & * & 95 or 275 & 185 \\
\hline Rowlesburg (Bjerstedt-30) & Rowlesburg & $\mathrm{Mp}$ & Cussewago & tool marks & * & 115 or 295 & 205 \\
\hline Rowlesburg (Bjerstedt-31) & Rowlesburg & $\mathrm{Mp}$ & Riddlesburg & gutter casts & * & 20 or 200 & 290 \\
\hline Wamsley Run (Bjerstedt-7) & Laneville & $\mathrm{Mp}$ & Riddlesburg & flute casts & * & 115 or 295 & 205 \\
\hline Marlinton (Bjerstedt-7) & Marlinton & $\mathrm{Mp}$ & Riddlesburg & tool and flute marks & * & 158 or 338 & 248 \\
\hline Fairview Church (Bjerstedt) & Edray & $\mathrm{Mp}$ & Cloyd & planar bedsets & * & 122 or 302 & 32 \\
\hline Fairview Church (Bjerstedt) & Edray & $\mathrm{Mp}$ & Cloyd & planar bedsets & * & 30 or 210 & 300 \\
\hline Caldwell (Bjerstedt-41) & Lewisburg & $\mathrm{Mp}$ & Cloyd & planar bedsets & * & 28 or 208 & 298 \\
\hline Caldwell (Bjerstedt-44) & Lewisburg & $\mathrm{Mp}$ & Cloyd & tool marks & * & 170 or 350 & 260 \\
\hline Caldwell (Bjerstedt-46) & Lewisburg & $\mathrm{Mp}$ & Cloyd & trough axis & * & 162 or 342 & 252 \\
\hline Caldwell (Bjerstedt-52) & Lewisburg & $\mathrm{Mp}$ & Sunbury & trough axis & * & 130 or 310 & 220 \\
\hline Caldwell (Bjerstedt-57) & Lewisburg & $\mathrm{Mp}$ & Upper Price & tool marks & * & 30 or 210 & 330 \\
\hline Caldwell (Bjerstedt-60) & Lewisburg & $\mathrm{Mp}$ & Upper Price & wave-ripple trends & * & 160 or 340 & 70 \\
\hline Caldwell (Bjerstedt-71) & Lewisburg & $\mathrm{Mp}$ & Upper Price & planar bedsets & * & 36 or 216 & 306 \\
\hline Alta (Bjerstedt-14) & Asbury & $\mathrm{Mp}$ & Upper Price & trough axis & * & 165 or 345 & 255 \\
\hline Alta Highwall (Bjerstedt-17) & Asbury & $\mathrm{Mp}$ & Upper Price & planar bedsets & * & 180 or 360 & 270 \\
\hline Sherwood Lake (Bjer-19) & Rucker Gap & $\mathrm{Mp}$ & Upper Price & trough axis & * & 55 or 235 & 335 \\
\hline Bluefield (Bjerstedt-1) & Princeton & $\mathrm{Mp}$ & Sunbury & tool marks & * & 166 or 346 & 256 \\
\hline Bluefield (Bjerstedt-3) & Princeton & $\mathrm{Mp}$ & Sunbury & tool marks & * & 10 or 190 & 280 \\
\hline Bluefield (Bjerstedt-11) & Princeton & $\mathrm{Mp}$ & Upper Price & current-ripple trends & * & 70 or 250 & 340 \\
\hline
\end{tabular}




\begin{tabular}{|c|c|c|c|c|c|c|c|}
\hline Bluefield (Bjerstedt-12) & Princeton & $\mathrm{Mp}$ & Upper Price & current-ripple trends & * & 23 or 203 & 293 \\
\hline Bluefield (Bjerstedt-12) & Princeton & $\mathrm{Mp}$ & Upper Price & tool marks & * & 142 or 322 & 232 \\
\hline Bluefield (Bjerstedt-19) & Princeton & $\mathrm{Mp}$ & Upper Price & wave-ripple trends & * & 127 or 307 & 37 \\
\hline Bluefield (Bjerstedt-20) & Princeton & $\mathrm{Mp}$ & Upper Price & flute casts & * & 156 or 336 & 246 \\
\hline Bluefield (Bjerstedt-37) & Princeton & $\mathrm{Mp}$ & Upper Price & trough axis & * & 6 or 186 & 276 \\
\hline $\mathrm{pc}-1$ & Onego & $\mathrm{Mp}$ & Upper Rockwell & planar crossbeds & 15s/4d@285 & 10 or 190 & 280 \\
\hline $\mathrm{pc}-1$ & Onego & $\mathrm{Mp}$ & Upper Rockwell & trough crossbeds & 15s/4d@285 & 70 or 250 & 160 or 340 \\
\hline pc-1 & Onego & $\mathrm{Mp}$ & Upper Rockwell & trough crossbeds & 15s/4d@285 & 70 or 250 & 160 or 340 \\
\hline pc-2 & Onego & $\mathrm{Mp}$ & Lower Rockwell & planar crossbeds & 40s/5d@310 & 140 or 320 & 230 \\
\hline pc-2 & Onego & $\mathrm{Mp}$ & Lower Rockwell & trough crossbeds & 40s/5d@310 & 125 or 305 & 215 \\
\hline pc-2 & Onego & $\mathrm{Mp}$ & Lower Rockwell & flute mark (channel) & 40s/5d@310 & 120 or 300 & 210 \\
\hline $\mathrm{pc}-2$ & Onego & $\mathrm{Mp}$ & Lower Rockwell & trough crossbeds & 40s/5d@310 & 125 or 305 & 35 \\
\hline $\mathrm{pc}-3$ & Onego & $\mathrm{Mp}$ & Upper Rockwell & planar crossbeds & * & 120 or 300 & 210 \\
\hline $\mathrm{pc}-4$ & Onego & $\mathrm{Mp}$ & Upper Rockwell & planar crossbeds & * & 10 or 190 & 280 \\
\hline $\mathrm{pc}-5$ & Onego & $\mathrm{Mp}$ & Upper Rockwell & planar crossbeds & * & 130 or 310 & 40 \\
\hline pc-6 & Onego & $\mathrm{Mp}$ & Upper Rockwell & planar crossbeds & 20s/13d@290 & 170 or 350 & 80 \\
\hline pc-7 & Cass & $\mathrm{Mp}$ & Lower Rockwell (?) & trough crossbeds & * & 115 or 295 & 25 or 205 \\
\hline pc-7 & Cass & $\mathrm{Mp}$ & Lower Rockwell (?) & planar crossbeds & * & 130 or 310 & 220 \\
\hline pc-8 & Cass & $\mathrm{Mp}$ & Riddlesburg (?) & planar crossbeds & * & 180 or 360 & 270 \\
\hline pc-9 & Mingo & Dhs & Hampshire & planar crossbeds & * & 355 or 175 & 265 \\
\hline pc-9 & Mingo & Dhs & Hampshire & planar crossbeds & * & 20 or 200 & 290 \\
\hline pc-9 & Mingo & Dhs & Hampshire & planar crossbeds & * & 10 or 190 & 280 \\
\hline pc-10 & Harman & $\mathrm{Mp}$ & Lower Rockwell & trough crossbeds & * & 90 or 270 & 180 or 360 \\
\hline $\mathrm{pc}-10$ & Harman & $\mathrm{Mp}$ & Lower Rockwell & planar crossbeds & * & 50 or 230 & 140 \\
\hline pc-10 & Harman & $\mathrm{Mp}$ & Lower Rockwell & trough crossbeds & * & 90 or 270 & 360 \\
\hline pc-11 & Laneville & $\mathrm{Mp}$ & Cussewago & trough crossbeds & * & 50 or 230 & 140 \\
\hline $\mathrm{pc}-11$ & Laneville & $\mathrm{Mp}$ & Cussewago & trough crossbeds & * & 50 or 230 & 140 or 320 \\
\hline pc-12 & Onego & $\mathrm{Mp}$ & Lower Rockwell & assymetrical ripples & * & 25 or 205 & 115 \\
\hline pc-12 & Onego & $\mathrm{Mp}$ & Lower Rockwell & trough crossbeds & * & 180 or 360 & 270 \\
\hline pc-12 & Onego & $\mathrm{Mp}$ & Lower Rockwell & trough crossbeds & * & 120 or 300 & 210 \\
\hline pc-12 & Onego & $\mathrm{Mp}$ & Lower Rockwell & trough crossbeds & * & 140 or 320 & 230 \\
\hline pc-12 & Onego & $\mathrm{Mp}$ & Upper Rockwell & trough crossbeds & * & 170 or 350 & 260 \\
\hline pc-12 & Onego & $\mathrm{Mp}$ & Upper Rockwell & trough crossbeds & * & 150 or 330 & 240 \\
\hline pc-13 & Onego & $\mathrm{Mp}$ & Upper Rockwell & trough crossbeds & * & 70 or 250 & 160 or 340 \\
\hline pc-14 & Cass & $\mathrm{Mp}$ & Hampshire & trough crossbeds & * & 125 or 305 & 215 \\
\hline pc-15 & Cass & $\mathrm{Mp}$ & Hampshire & trough crossbeds & * & 130 or 310 & 220 \\
\hline
\end{tabular}




\begin{tabular}{|c|c|c|c|c|c|c|c|}
\hline $\mathrm{pc}-15$ & Cass & $\mathrm{Mp}$ & Hampshire & trough crossbeds & * & 100 or 280 & 190 \\
\hline pc-15 & Cass & $\mathrm{Mp}$ & Hampshire & trough crossbeds & * & 90 or 270 & 180 or 360 \\
\hline $\mathrm{pc}-16$ & Rowlesburg & $\mathrm{Mp}$ & Lower Rockwell & planar crossbeds & * & 40 or 220 & 310 \\
\hline $\mathrm{pc}-16$ & Rowlesburg & $\mathrm{Mp}$ & Lower Rockwell & planar crossbeds & * & 20 or 200 & 290 \\
\hline pc-16 & Rowlesburg & $\mathrm{Mp}$ & Upper Rockwell & trough crossbeds & * & 180 or 360 & 270 \\
\hline pc-16 & Rowlesburg & $\mathrm{Mp}$ & Upper Rockwell & trough crossbeds & * & 30 or 210 & 300 \\
\hline pc-17 & Table Rock & $\mathrm{Mp}$ & Upper Rockwell & assymetrical ripples & * & 145 or 325 & 235 \\
\hline pc-17 & Table Rock & $\mathrm{Mp}$ & Upper Rockwell & trough crossbeds & * & 20 or 200 & 110 or 290 \\
\hline $\mathrm{pc}-17$ & Table Rock & $\mathrm{Mp}$ & Upper Rockwell & trough crossbeds & * & 115 or 295 & 25 or 205 \\
\hline pc-18 (Harman Section) & Harman & $\mathrm{Mp}$ & Lower Rockwell & trough crossbeds & * & 70 or 250 & 160 \\
\hline pc-18 (Harman Section) & Harman & $\mathrm{Mp}$ & Lower Rockwell & trough crossbeds & * & 70 or 250 & 160 or 340 \\
\hline pc-18 (Harman Section) & Harman & $\mathrm{Mp}$ & Lower Rockwell & trough crossbeds & * & 45 or 225 & 135 \\
\hline pc-19 (Red Creek-WGES) & Laneville & $\mathrm{Mp}$ & Lower Rockwell & trough crossbeds & * & 160 or 340 & 70 or 250 \\
\hline pc-19 (Red Creek-WGES) & Laneville & $\mathrm{Mp}$ & Lower Rockwell & trough crossbeds & * & 160 or 340 & 250 \\
\hline pc-19 (Red Creek-WGES) & Laneville & $\mathrm{Mp}$ & Lower Rockwell & trough crossbeds & * & 160 or 340 & 70 or 250 \\
\hline $\mathrm{pc}-20$ & Laneville & Dhs & Hampshire & trough crossbeds & * & 50 or 230 & 140 or 320 \\
\hline pc-20 & Laneville & Dhs & Hampshire & trough crossbeds & * & 70 or 250 & 160 or 340 \\
\hline $\mathrm{pc}-21$ & Harman & $\mathrm{Mp}$ & Upper Rockwell & trough crossbeds & * & 150 or 330 & 60 or 240 \\
\hline $\mathrm{pc}-21$ & Harman & $\mathrm{Mp}$ & Upper Rockwell & trough crossbeds & * & 20 or 200 & 290 \\
\hline pc-21 & Harman & $\mathrm{Mp}$ & Upper Rockwell & trough crossbeds & * & 180 or 360 & 270 \\
\hline $\mathrm{pc}-21$ & Harman & $\mathrm{Mp}$ & Upper Rockwell & trough crossbeds & * & 20 or 200 & 290 \\
\hline $\mathrm{pc}-21$ & Harman & $\mathrm{Mp}$ & Upper Rockwell & trough crossbeds & * & 180 or 360 & 270 \\
\hline pc-21 & Harman & $\mathrm{Mp}$ & Upper Rockwell & trough crossbeds & * & 30 or 210 & 300 \\
\hline $\mathrm{pc}-22$ & Harman & $\mathrm{Mp}$ & Riddlesburg & trough crossbeds & * & 120 or 300 & 30 or 210 \\
\hline pc-22 & Harman & $\mathrm{Mp}$ & Lower Rockwell & symmetrical ripples & * & 70 or 250 & 160 \\
\hline pc-22 & Harman & $\mathrm{Mp}$ & Lower Rockwell & planar crossbeds & * & 160 or 340 & 70 \\
\hline pc-22 & Harman & $\mathrm{Mp}$ & Lower Rockwell & planar crossbeds & * & 150 or 330 & 60 \\
\hline pc-22 & Harman & $\mathrm{Mp}$ & Lower Rockwell & trough crossbeds & * & 120 or 300 & 30 \\
\hline pc-23 & Harman & $\mathrm{Mp}$ & Upper Rockwell & trough crossbeds & * & 135 or 315 & 225 \\
\hline $\mathrm{pc}-23$ & Harman & $\mathrm{Mp}$ & Upper Rockwell & trough crossbeds & * & 130 or 310 & 220 \\
\hline pc-24 & Laneville & $\mathrm{Mp}$ & Upper Rockwell & trough crossbeds & * & 150 or 330 & 60 or 240 \\
\hline $\mathrm{pc}-24$ & Laneville & $\mathrm{Mp}$ & Upper Rockwell & trough crossbeds & * & 130 or 310 & 40 or 220 \\
\hline $\mathrm{pc}-25$ & Laneville & $\mathrm{Mp}$ & Upper Rockwell & trough crossbeds & * & 25 or 205 & 115 or 295 \\
\hline $\mathrm{pc}-26$ & Laneville & $\mathrm{Mp}$ & Upper Rockwell & planar crossbeds & * & 20 or 200 & $290(?)$ \\
\hline pc-26 & Laneville & $\mathrm{Mp}$ & Upper Rockwell & trough crossbeds & * & 175 or 355 & 265 \\
\hline $\mathrm{pc}-26$ & Laneville & $\mathrm{Mp}$ & Upper Rockwell & trough crossbeds & * & 175 or 355 & 265 \\
\hline
\end{tabular}




\begin{tabular}{|c|c|c|c|c|c|c|c|}
\hline pc-27 & Harman & $\mathrm{Mp}$ & Riddlesburg & trough crossbeds & * & 15 or 195 & 105 or 285 \\
\hline pc-27 & Harman & $\mathrm{Mp}$ & Riddlesburg & trough crossbeds & * & 10 or 190 & 100 or 280 \\
\hline pc-27 & Harman & $\mathrm{Mp}$ & Riddlesburg & symmetrical ripples & * & 110 or 290 & 20 or 200 \\
\hline pc-28 & Harman & Dhs & Hampshire & trough crossbeds & * & 105 or 285 & 15 or 195 \\
\hline pc-28 & Harman & Dhs & Hampshire & trough crossbeds & * & 100 or 280 & 10 or 190 \\
\hline pc-29 & Harman & $\mathrm{Mp}$ & Upper Rockwell & planar crossbeds & * & 25 or 205 & 115 \\
\hline pc-30 & Harman & $\mathrm{Mp}$ & Lower Rockwell & trough crossbeds & * & 155 or 335 & 245 \\
\hline pc-30 & Harman & $\mathrm{Mp}$ & Lower Rockwell & trough crossbeds & * & 175 or 355 & 265 \\
\hline pc-30 & Harman & $\mathrm{Mp}$ & Lower Rockwell & trough crossbeds & * & 155 or 335 & 245 \\
\hline pc-31 & Onego & $\mathrm{Mp}$ & Lower Rockwell & trough crossbeds & * & 15 or 195 & 285 \\
\hline pc-31 & Onego & $\mathrm{Mp}$ & Lower Rockwell & trough crossbeds & * & 10 or 190 & 100 or 280 \\
\hline pc-32 & Onego & $\mathrm{Mp}$ & Lower Rockwell & planar crossbeds & * & 165 or 345 & 255 \\
\hline pc-32 & Onego & $\mathrm{Mp}$ & Lower Rockwell & planar crossbeds & * & 130 or 310 & 130 \\
\hline $\mathrm{pc}-32$ & Onego & $\mathrm{Mp}$ & Lower Rockwell & trough crossbeds & * & 30 or 210 & 120 or 300 \\
\hline pc-33 & Spruce Knob & $\mathrm{Mp}$ & Lower Rockwell & planar crossbeds & ${ }^{*}$ & 180 or 360 & 90 \\
\hline pc-34 & Spruce Knob & $\mathrm{Mp}$ & Upper Rockwell & trough crossbeds & 30s/26d@300 & 142 or 322 & 52 \\
\hline pc-34 & Spruce Knob & $\mathrm{Mp}$ & Upper Rockwell & trough crossbeds & 30s/26d@300 & 150 or 330 & 60 \\
\hline pc-34 & Spruce Knob & $\mathrm{Mp}$ & Upper Rockwell & trough crossbeds & 30s/26d@300 & 75 or 255 & 345 \\
\hline pc-35 & Glady & $\mathrm{Mp}$ & Lower Rockwell (?) & planar crossbeds & ${ }^{*}$ & 130 or 310 & 220 \\
\hline pc-35 & Glady & $\mathrm{Mp}$ & Lower Rockwell (?) & trough crossbeds & * & 95 or 275 & 185 \\
\hline pc-35 & Glady & $\mathrm{Mp}$ & Lower Rockwell (?) & trough crossbeds & * & 175 or 355 & 265 \\
\hline pc-35 & Glady & $\mathrm{Mp}$ & Lower Rockwell (?) & trough crossbeds & * & 165 or 345 & 255 \\
\hline pc-35 & Glady & $\mathrm{Mp}$ & Lower Rockwell (?) & trough crossbeds & * & 165 or 345 & 255 \\
\hline $\mathrm{pc}-35$ & Glady & $\mathrm{Mp}$ & Lower Rockwell (?) & trough crossbeds & * & 180 or 360 & 270 \\
\hline pc-36 & Onego & $\mathrm{Mp}$ & Upper Rockwell & trough crossbeds & * & 75 or 255 & 165 or 345 \\
\hline pc-36 & Onego & $\mathrm{Mp}$ & Upper Rockwell & trough crossbeds & * & 60 or 240 & 150 or 330 \\
\hline pc-36 & Onego & $\mathrm{Mp}$ & Upper Rockwell & trough crossbeds & * & 100 or 280 & 10 or 190 \\
\hline pc-36 & Onego & $\mathrm{Mp}$ & Upper Rockwell & planar crossbeds & * & 35 or 215 & 295 \\
\hline pc-36 & Onego & $\mathrm{Mp}$ & Upper Rockwell & trough crossbeds & * & 70 or 250 & 160 or 340 \\
\hline pc-37 & Onego & $\mathrm{Mp}$ & Lower Rockwell & trough crossbeds & * & 60 or 240 & 150 or 330 \\
\hline pc-37 & Onego & $\mathrm{Mp}$ & Lower Rockwell & trough crossbeds & * & 80 or 260 & 170 or 350 \\
\hline pc-38 & Onego & $\mathrm{Mp}$ & Upper Rockwell & planar crossbeds & * & 60 or 240 & 330 \\
\hline pc-38 & Onego & $\mathrm{Mp}$ & Upper Rockwell & trough crossbeds & * & 20 or 200 & 110 or 290 \\
\hline pc-38 & Onego & $\mathrm{Mp}$ & Upper Rockwell & planar crossbeds & * & 50 or 230 & 320 \\
\hline pc-38 & Onego & $\mathrm{Mp}$ & Upper Rockwell & planar crossbeds & * & 30 or 210 & 300 \\
\hline pc-39 & Onego & $\mathrm{Mp}$ & Upper Rockwell & trough crossbeds & * & 140 or 320 & 50 or 230 \\
\hline
\end{tabular}




\begin{tabular}{|c|c|c|c|c|c|c|c|}
\hline pc-39 & Onego & $\mathrm{Mp}$ & Upper Rockwell & trough crossbeds & * & 155 or 335 & 65 or 235 \\
\hline pc-39 & Onego & $\mathrm{Mp}$ & Upper Rockwell & trough crossbeds & * & 120 or 300 & 30 or 210 \\
\hline pc-40 & Laneville & $\mathrm{Mp}$ & Riddlesburg & trough crossbeds & * & 150 or 330 & 60 or 240 \\
\hline pc-43 & Elkins & $\mathrm{Mp}$ & Upper Rockwell & trough crossbeds & * & 130 or 310 & 40 or 220 \\
\hline pc-43 & Elkins & $\mathrm{Mp}$ & Upper Rockwell & trough crossbeds & * & 155 or 335 & 65 or 235 \\
\hline pc-44 & Spruce Knob & $\mathrm{Mp}$ & Lower Rockwell & symmetrical ripples & * & 40 or 220 & 130 or 310 \\
\hline pc-44 & Spruce Knob & $\mathrm{Mp}$ & Lower Rockwell & planar crossbeds & * & 10 or 190 & 280 \\
\hline pc-44 & Spruce Knob & $\mathrm{Mp}$ & Lower Rockwell & planar crossbeds & * & 10 or 190 & 280 \\
\hline pc-45 & Hopeville & $\mathrm{Mp}$ & Lower Rockwell & trough crossbeds & 183s/6d@275 & 105 or 285 & 15 or 195 \\
\hline pc-45 & Hopeville & $\mathrm{Mp}$ & Lower Rockwell & planar crossbeds & 183s/6d@275 & 10 or 190 & 280 \\
\hline pc-45 & Hopeville & $\mathrm{Mp}$ & Lower Rockwell & planar crossbeds & 183s/6d@275 & 20 or 200 & 290 \\
\hline pc-45 & Hopeville & $\mathrm{Mp}$ & Lower Rockwell & trough crossbeds & 183s/6d@275 & 120 or 300 & 30 or 210 \\
\hline $\mathrm{pc}-45$ & Hopeville & $\mathrm{Mp}$ & Lower Rockwell & trough crossbeds & 183s/6d@275 & 115 or 295 & 25 or 205 \\
\hline $\mathrm{pc}-46$ & Hopeville & $\mathrm{Mp}$ & Upper Rockwell & planar crossbeds & ${ }^{*}$ & 180 or 360 & 270 \\
\hline pc-46 & Hopeville & $\mathrm{Mp}$ & Upper Rockwell & planar crossbeds & * & 160 or 340 & 250 \\
\hline pc-46 & Hopeville & $\mathrm{Mp}$ & Upper Rockwell & planar crossbeds & * & 30 or 210 & 300 \\
\hline pc-46 & Hopeville & $\mathrm{Mp}$ & Upper Rockwell & planar crossbeds & * & 150 or 330 & 240 \\
\hline pc-46 & Hopeville & $\mathrm{Mp}$ & Upper Rockwell & trough crossbeds & ${ }^{*}$ & 25 or 205 & 115 or 295 \\
\hline pc-47 & Onego & $\mathrm{Mp}$ & Lower Rockwell & trough crossbeds & 330s/18d@280 & 10 or 190 & 280 \\
\hline pc-48 & Onego & $\mathrm{Mp}$ & Upper Rockwell & trough crossbeds & 250s/8d@340 & 140 or 320 & 50 or 230 \\
\hline pc-48 & Onego & $\mathrm{Mp}$ & Upper Rockwell & trough crossbeds & 250s/8d@340 & 115 or 295 & 25 or 205 \\
\hline pc-49 & Snowy Mountain & $\mathrm{Mp}$ & Upper Rockwell & trough crossbeds & ${ }^{*}$ & 130 or 310 & 40 or 220 \\
\hline pc-49 & Snowy Mountain & $\mathrm{Mp}$ & Upper Rockwell & trough crossbeds & * & 145 or 325 & 55 or 235 \\
\hline $\mathrm{pc}-49$ & Snowy Mountain & $\mathrm{Mp}$ & Upper Rockwell & trough crossbeds & * & 145 or 325 & 55 or 235 \\
\hline pc-50 & Spruce Knob & $\mathrm{Mp}$ & Lower Rockwell & trough crossbeds & * & 80 or 260 & 170 or 350 \\
\hline pc-50 & Spruce Knob & $\mathrm{Mp}$ & Lower Rockwell & trough crossbeds & * & 90 or 270 & 180 or 360 \\
\hline $\mathrm{pc}-51$ & Spruce Knob & $\mathrm{Mp}$ & Lower Rockwell & trough crossbeds & * & 145 or 325 & 55 or 235 \\
\hline pc-51 & Spruce Knob & $\mathrm{Mp}$ & Lower Rockwell & trough crossbeds & * & 135 or 315 & 225 \\
\hline pc-52 & Spruce Knob & $\mathrm{Mp}$ & Lower Rockwell & planar crossbeds & * & 45 or 225 & 315 \\
\hline pc-52 & Spruce Knob & $\mathrm{Mp}$ & Lower Rockwell & trough crossbeds & * & 80 or 260 & 350 \\
\hline pc-52 & Spruce Knob & $\mathrm{Mp}$ & Lower Rockwell & trough crossbeds & * & 175 or 355 & 265 \\
\hline pc-52 & Spruce Knob & $\mathrm{Mp}$ & Lower Rockwell & trough crossbeds & * & 180 or 360 & 270 \\
\hline pc-52 & Spruce Knob & $\mathrm{Mp}$ & Lower Rockwell & trough crossbeds & * & 175 or 355 & 265 \\
\hline pc-52 & Spruce Knob & $\mathrm{Mp}$ & Lower Rockwell & trough crossbeds & * & 45 or 225 & 315 \\
\hline pc-52 & Spruce Knob & $\mathrm{Mp}$ & Lower Rockwell & trough crossbeds & * & 50 or 230 & 320 \\
\hline pc-52 & Spruce Knob & $\mathrm{Mp}$ & Lower Rockwell & planar crossbeds & * & 15 or 195 & 285 \\
\hline
\end{tabular}




\begin{tabular}{|c|c|c|c|c|c|c|c|}
\hline pc-53 & Spruce Knob & $\mathrm{Mp}$ & Lower Rockwell & trough crossbeds & * & 95 or 275 & 5 \\
\hline pc-53 & Spruce Knob & $\mathrm{Mp}$ & Lower Rockwell & trough crossbeds & * & 135 or 315 & 45 \\
\hline pc-53 & Spruce Knob & $\mathrm{Mp}$ & Lower Rockwell & trough crossbeds & * & 120 or 300 & 30 \\
\hline pc-53 & Spruce Knob & $\mathrm{Mp}$ & Lower Rockwell & trough crossbeds & * & 120 or 300 & 30 \\
\hline pc-53 & Spruce Knob & $\mathrm{Mp}$ & Lower Rockwell & trough crossbeds & * & 95 or 275 & 5 \\
\hline pc-54 & Spruce Knob & $\mathrm{Mp}$ & Lower Rockwell & symmetrical ripples & * & 105 or 285 & 15 or 195 \\
\hline pc-54 & Spruce Knob & $\mathrm{Mp}$ & Lower Rockwell & trough crossbeds & * & 45 or 225 & 135 \\
\hline pc-54 & Spruce Knob & $\mathrm{Mp}$ & Lower Rockwell & trough crossbeds & * & 90 or 270 & 180 \\
\hline pc-54 & Spruce Knob & $\mathrm{Mp}$ & Lower Rockwell & trough crossbeds & * & 125 or 305 & 215 \\
\hline pc-54 & Spruce Knob & $\mathrm{Mp}$ & Lower Rockwell & trough crossbeds & * & 100 or 280 & 190 \\
\hline pc-54 & Spruce Knob & $\mathrm{Mp}$ & Lower Rockwell & trough crossbeds & * & 55 or 235 & 145 \\
\hline pc-55 & Palo Alto & Dhs & Hampshire & trough crossbeds & * & 25 or 205 & 115 or 295 \\
\hline pc-55 & Palo Alto & Dhs & Hampshire & trough crossbeds & * & 30 or 210 & 300 \\
\hline $\mathrm{pc}-55$ & Palo Alto & Dhs & Hampshire & trough crossbeds & * & 50 or 230 & 140 or 320 \\
\hline pc-56 (in Durbin Section) & & * & * & * & * & * & * \\
\hline
\end{tabular}




\section{Paleocurrent Stop \# 14 - Hampshire Formation}

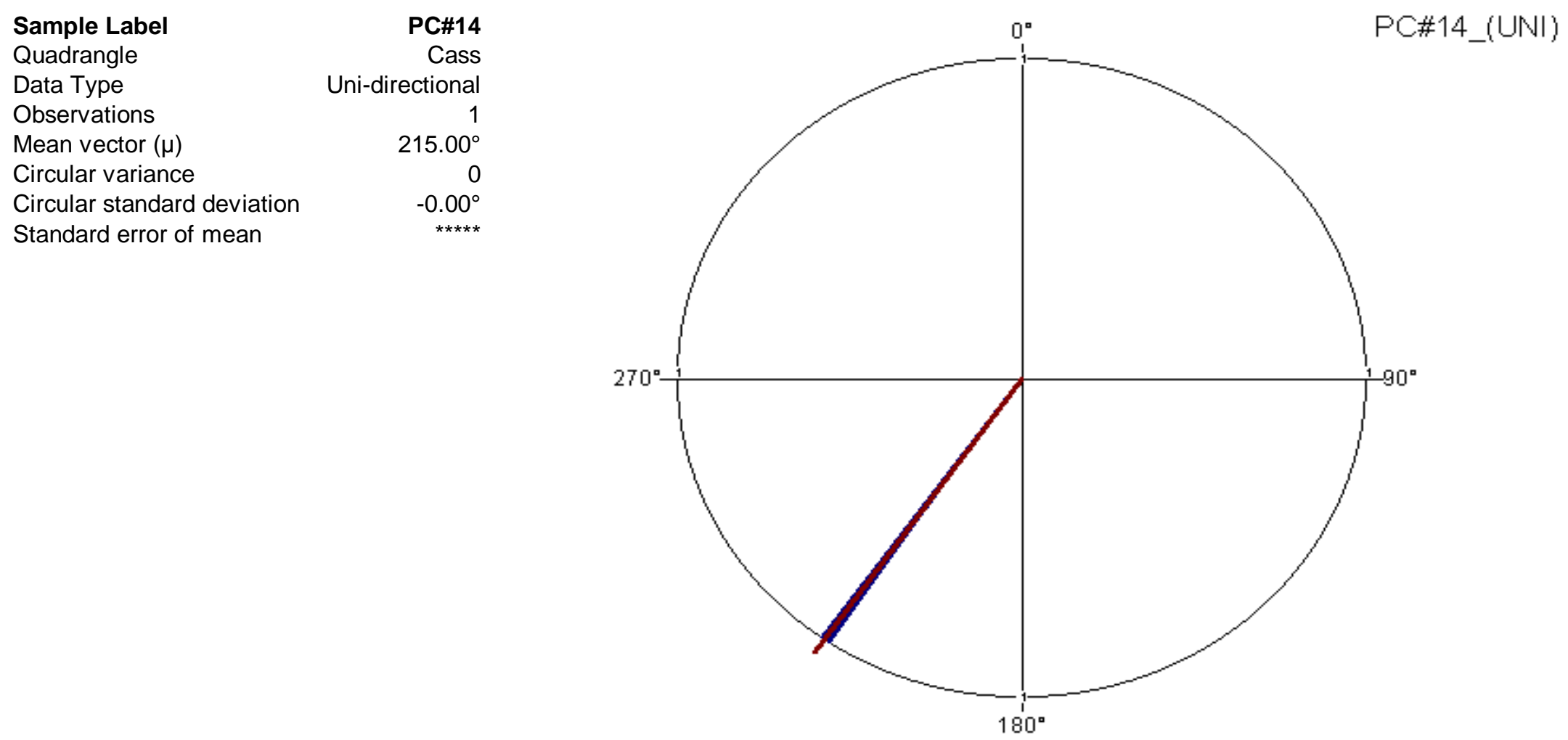

Figure 94. Uni-directional rose diagram for secondary locality 14 in the Hampshire Formation 


\section{Paleocurrent Stop \# 15 - Hampshire Formation}

Sample Label

Quadrangle

Data Type

Observations

Mean vector $(\mu)$

Circular variance

Circular standard deviation

Standard error of mean
PC\#15
Cass
Uni-directional
$205.00^{\circ}$
0.03
$15.09^{\circ}$
$33.73^{\circ} *$

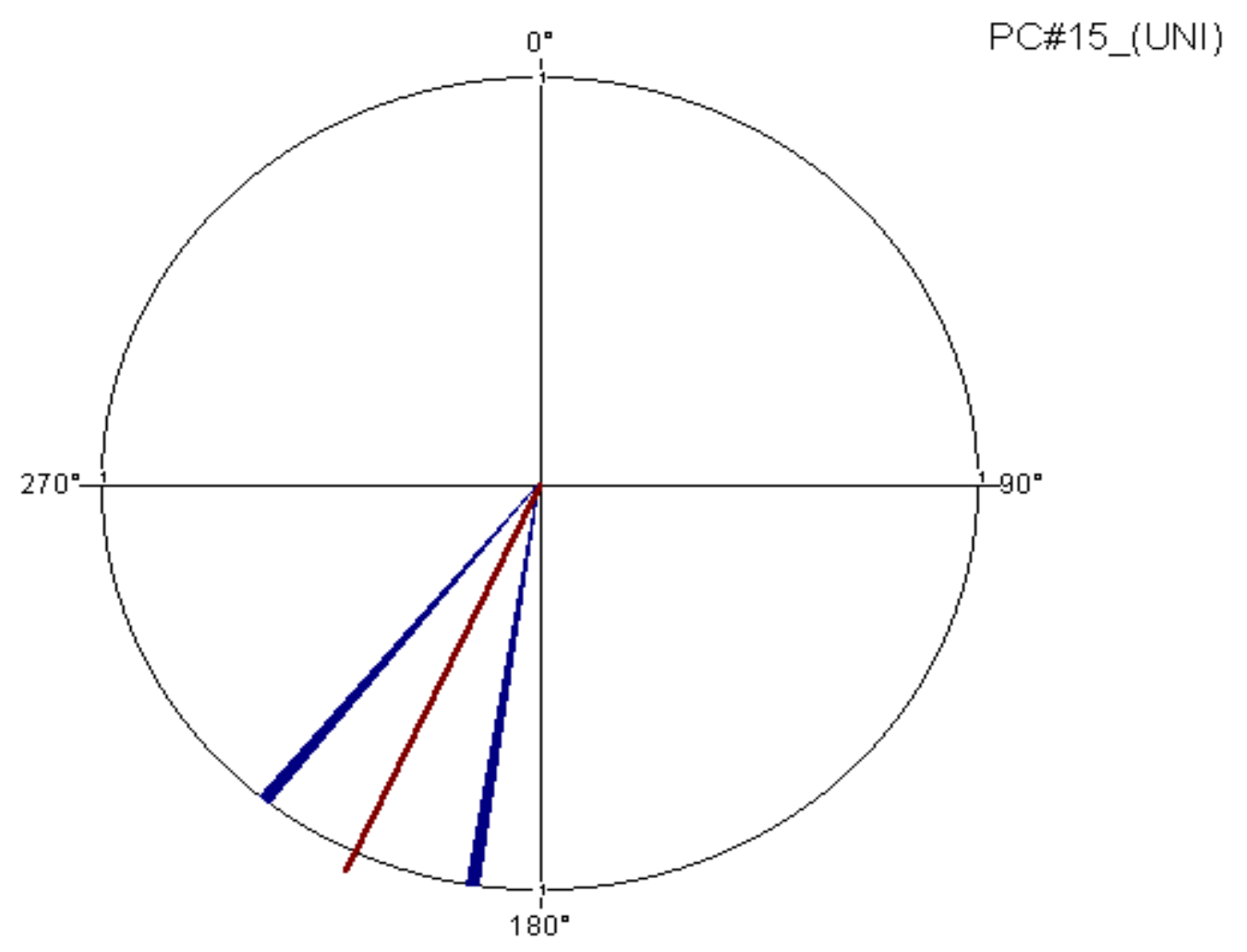

Figure 95. Uni-directional rose diagram for secondary locality 15 in the Hampshire Formation 


\section{Paleocurrent Stop \# 15 - Hampshire Formation}

Sample Label
Quadrangle
Data Type
Observations
Mean vector $(\mu)$
Circular variance
Circular standard deviation
Standard error of mean

PC\#15
Cass
Bi-directional
1
$180.00^{\circ}$
0
$-0.00^{\circ}$
$\star \star \star * *$

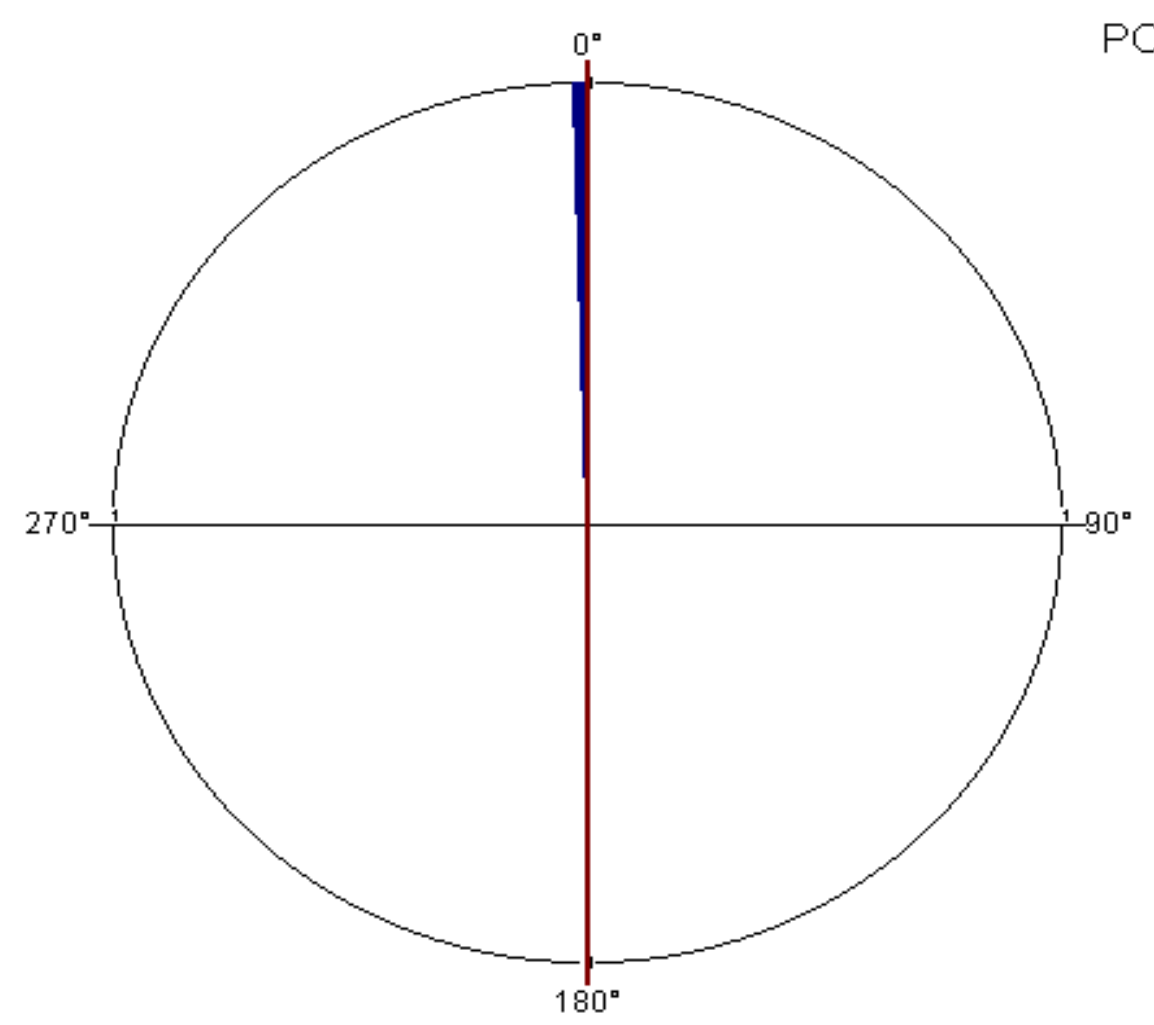

PC\#15_(BI)

Figure 96. Bi-directional rose diagram for secondary locality 15 in the Hampshire Formation 


\section{Paleocurrent Stop \# 20 - Hampshire Formation}

$\begin{array}{lr}\text { Sample Label } & \text { PC\#20 } \\ \text { Quadrangle } & \begin{array}{r}\text { Laneville } \\ \text { Data Type }\end{array} \\ \text { Observations } & 2 \\ \text { Mean vector }(\mu) & 150.00^{\circ} \\ \text { Circular variance } & 0.06 \\ \text { Circular standard deviation } & 20.21^{\circ} \\ \text { Standard error of mean } & 45.16^{\circ} \text { * }\end{array}$

Standard error of mean

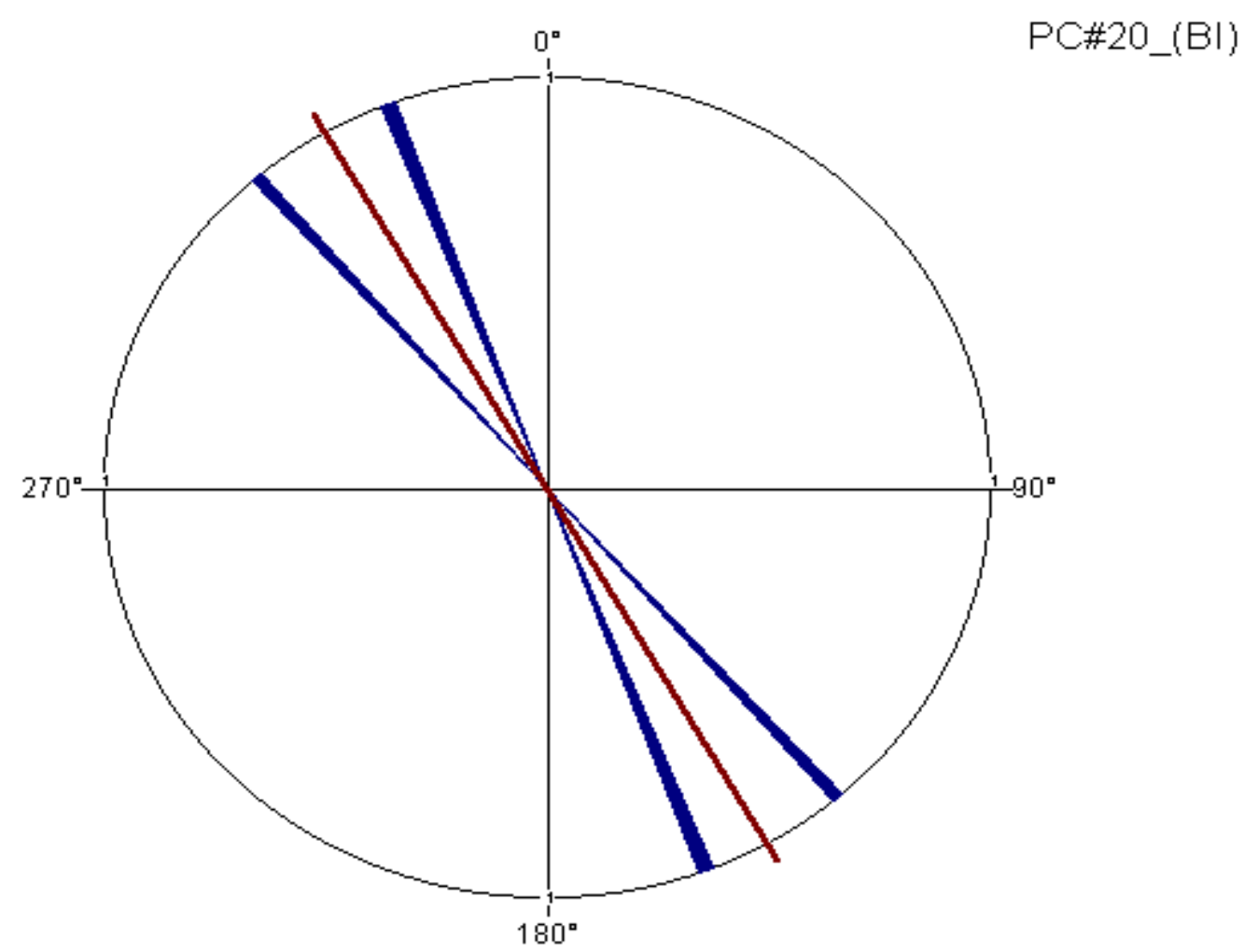

Figure 97. Bi-directional rose diagram for secondary locality 20 in the Hampshire Formation 


\section{Paleocurrent Stop \# 28 - Hampshire Formation}

$\begin{array}{lr}\text { Sample Label } & \text { PC\#28 } \\ \text { Quadrangle } & \text { Harman } \\ \text { Data Type } & \text { Bi-directional } \\ \text { Observations } & 2 \\ \text { Mean vector }(\mu) & 12.50^{\circ} \\ \text { Circular variance } & 0 \\ \text { Circular standard deviation } & 5.00^{\circ} \\ \text { Standard error of mean } & 11.19^{\circ}\end{array}$

Sample Label

Circular variance

Standard error of mean

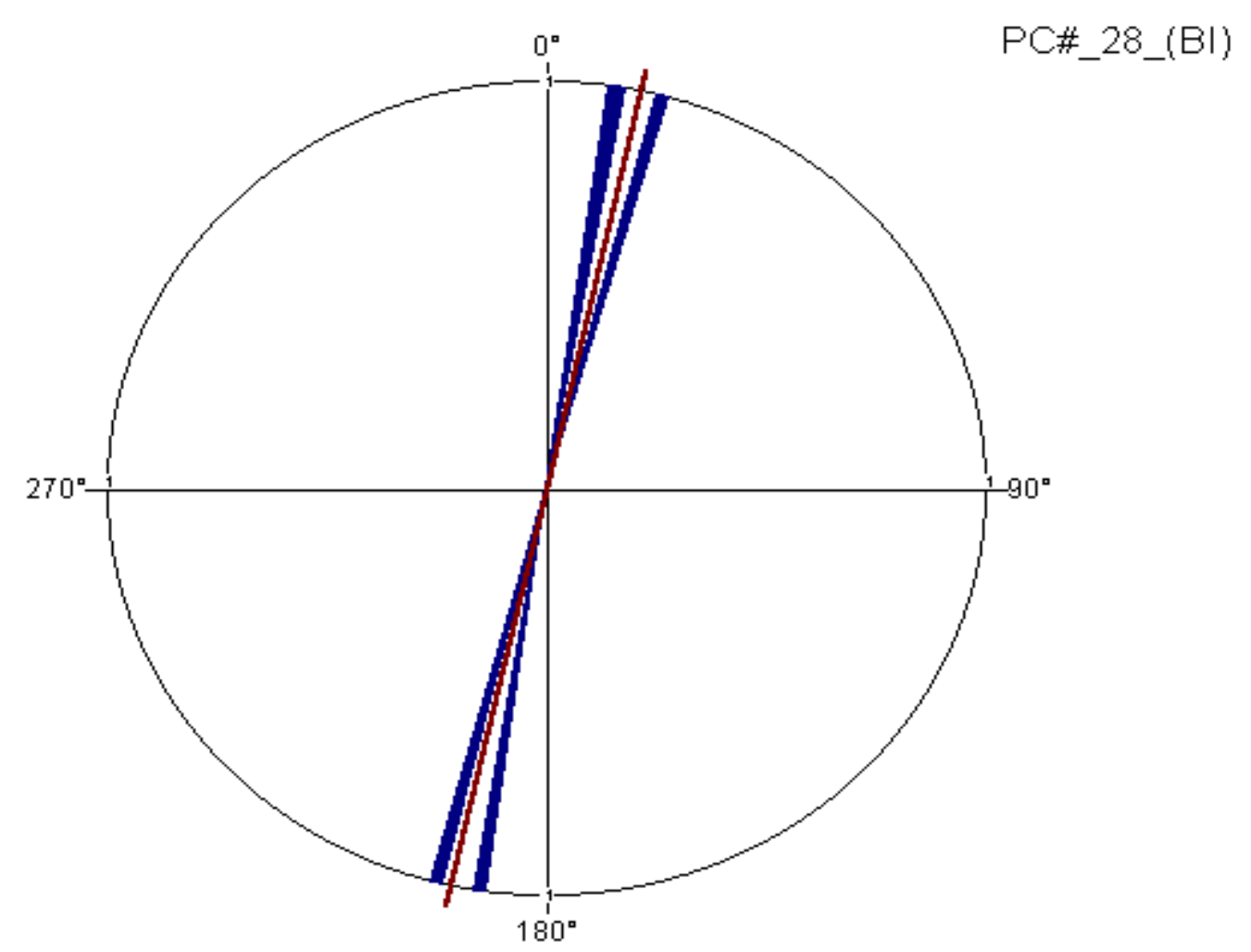

Figure 98. Bi-directional rose diagram for secondary locality 28 in the Hampshire Formation 


\section{Paleocurrent Stop \# 9 - Hampshire Formation}

Sample Label

Quadrangle

Data Type

Observations

Mean vector $(\mu)$

Circular variance

Circular standard deviation

Standard error of mean

PC\#9
Mingo
Uni-directional
3
$278.35^{\circ}$
$0.02^{\circ}$
$10.29^{\circ}$
$11.51^{\circ}$

Figure 99. Uni-directional rose diagram for secondary locality 9 in the Hampshire Formation 


\section{Rowlesburg - Oswayo Member}

Sample Label

Quadrangle

Data Type

Observations

Mean vector $(\mu)$

Circular variance

Circular standard deviation

Standard error of mean

$$
\begin{array}{r}
\text { Rowlesburg } \\
\text { Rowlesburg } \\
\text { Uni-directional } \\
1 \\
240.00^{\circ} \\
0 \\
-0.00^{\circ} \\
* \star \star * *
\end{array}
$$

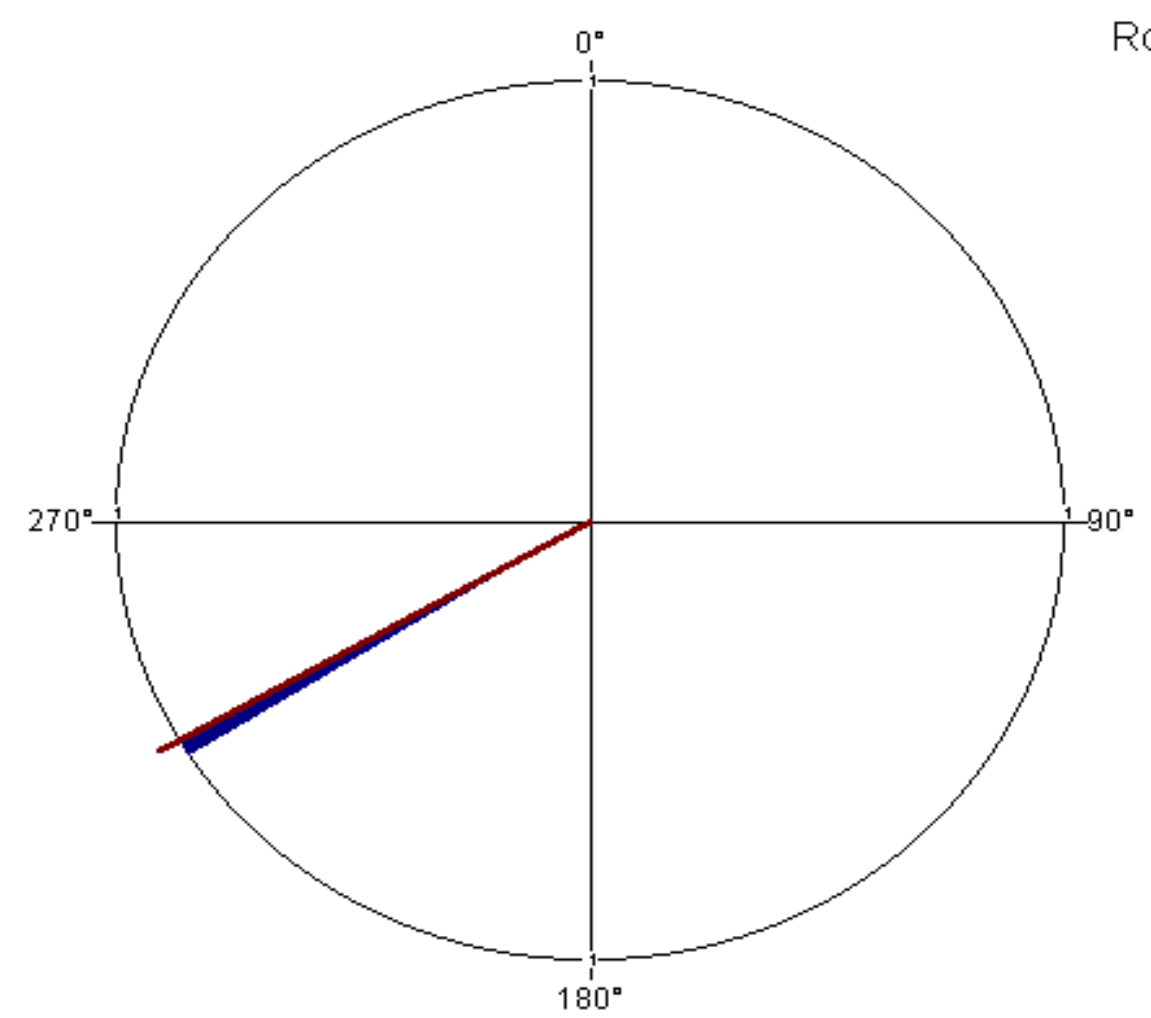

Rowlesburg

Figure 100. Uni-directional rose diagram for secondary locality at Rowlesburg in the Oswayo Member 


\section{Durbin - Ridddlesburg Shale Member}

\section{Sample Label}

Quadrangle

Data Type

Observations

Mean vector $(\mu)$

Circular variance

Circular standard deviation

Standard error of mean

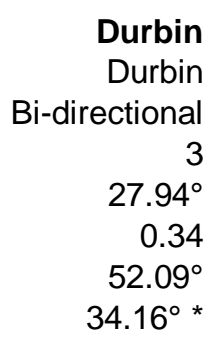

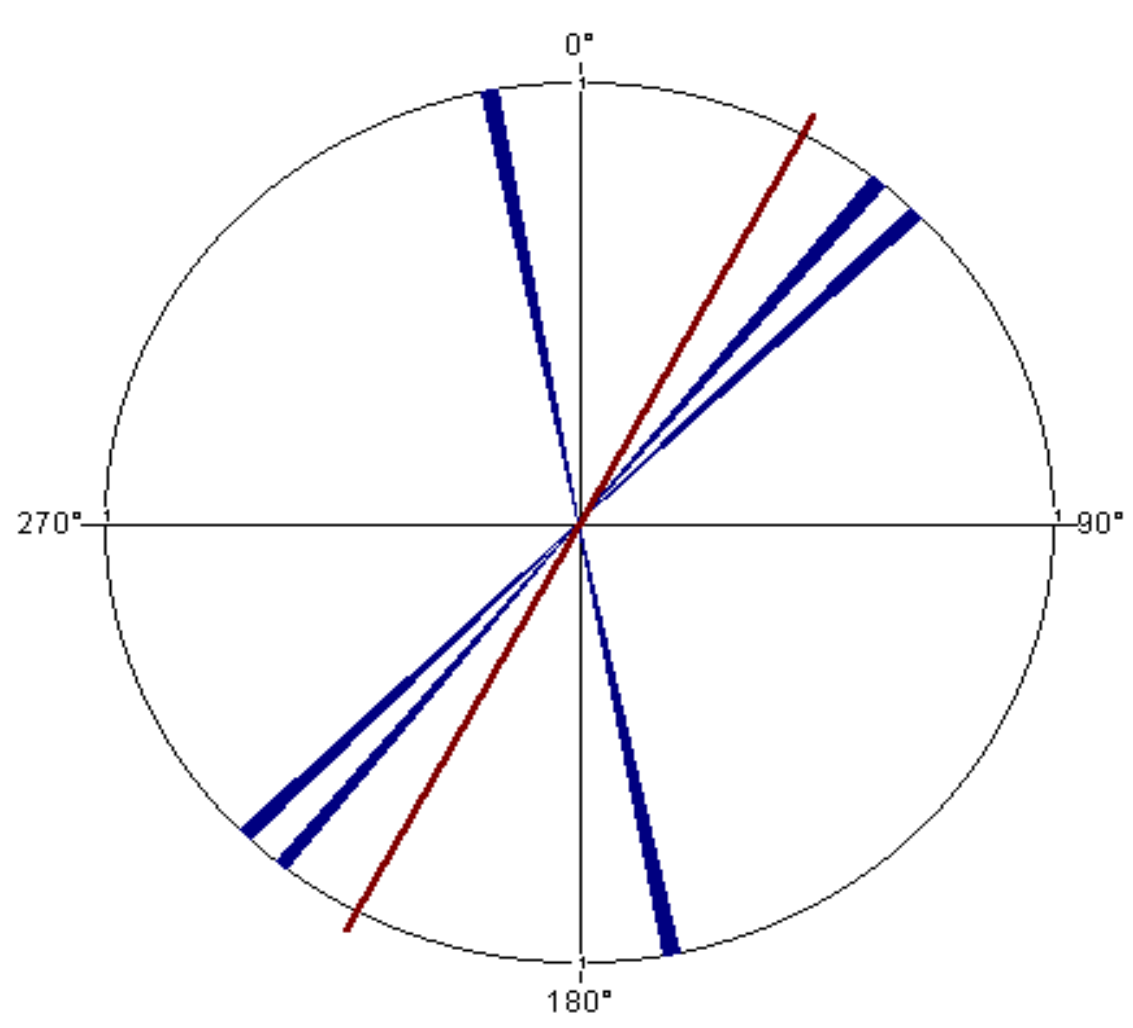

Figure 101. Bi-directional rose diagram for secondary locality at Durbin in the Riddlesburg Shale Member 


\section{Rowlesburg - Riddlesburg Shale Member}

\section{Sample Label}

Quadrangle

Data Type

Observations

Mean vector $(\mu)$

Circular variance

Circular standard deviation

Standard error of mean

$$
\begin{array}{r}
\text { Rowlesburg } \\
\text { Rowlesburg } \\
\text { Uni-directional } \\
1 \\
290.00^{\circ} \\
0 \\
-0.00^{\circ} \\
\star \star \star \star *
\end{array}
$$

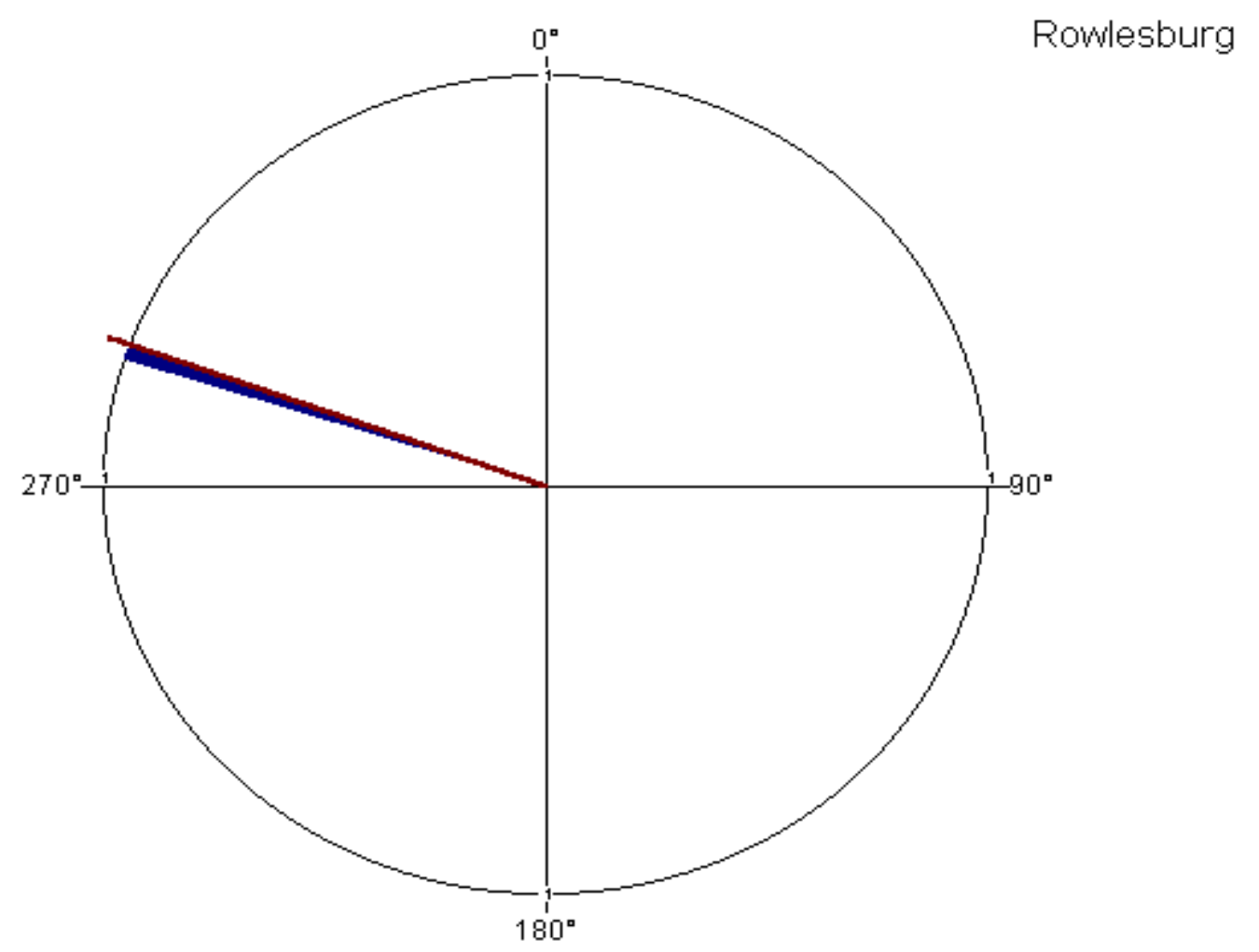

Figure 102. Uni-directional rose diagram for secondary locality at Rowlesburg in the Riddlesburg Shale Member 


\section{Paleocurrent Stop \# 8 - Riddlesburg Shale Member}

Sample Label

Quadrangle

Data Type

Observations

Mean vector $(\mu)$

Circular variance

Circular standard deviation

Standard error of mean

PC\#8
Cass
Uni-directional
1
$270.00^{\circ}$
0
$-0.00^{\circ}$
$\star * * *$

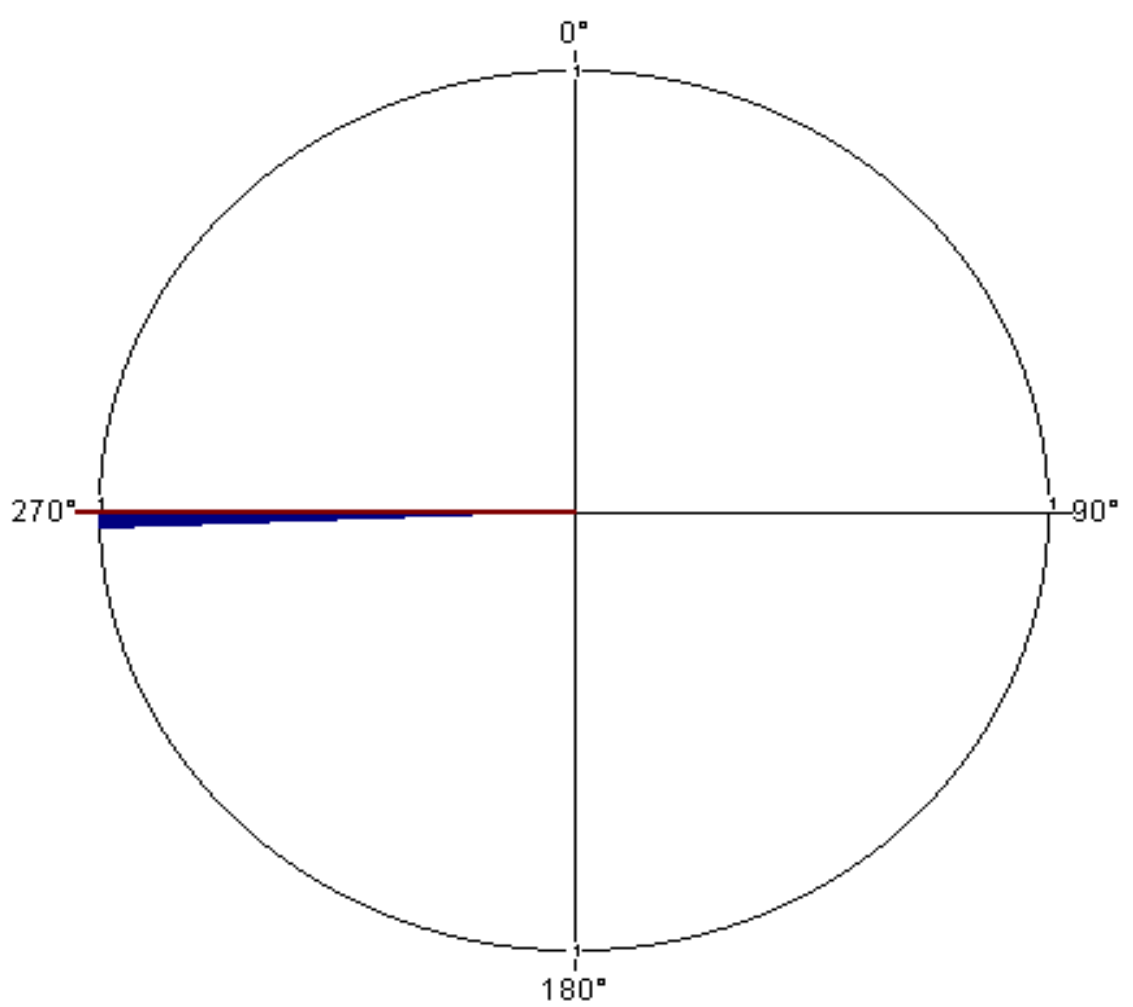

Figure 103. Uni-directional rose diagram for secondary locality 8 in the Riddlesburg Shale Member 


\section{PC \#11 - Riddlesburg Shale Member}

Sample Label
Quadrangle
Data Type
Observations
Mean vector $(\mu)$
Circular variance
Circular standard deviation
Standard error of mean

PC\#11

Laneville

Uni-directional

$140.00^{\circ}$

$140.00^{\circ}$

$-0.00^{\circ}$

Standard error of mean

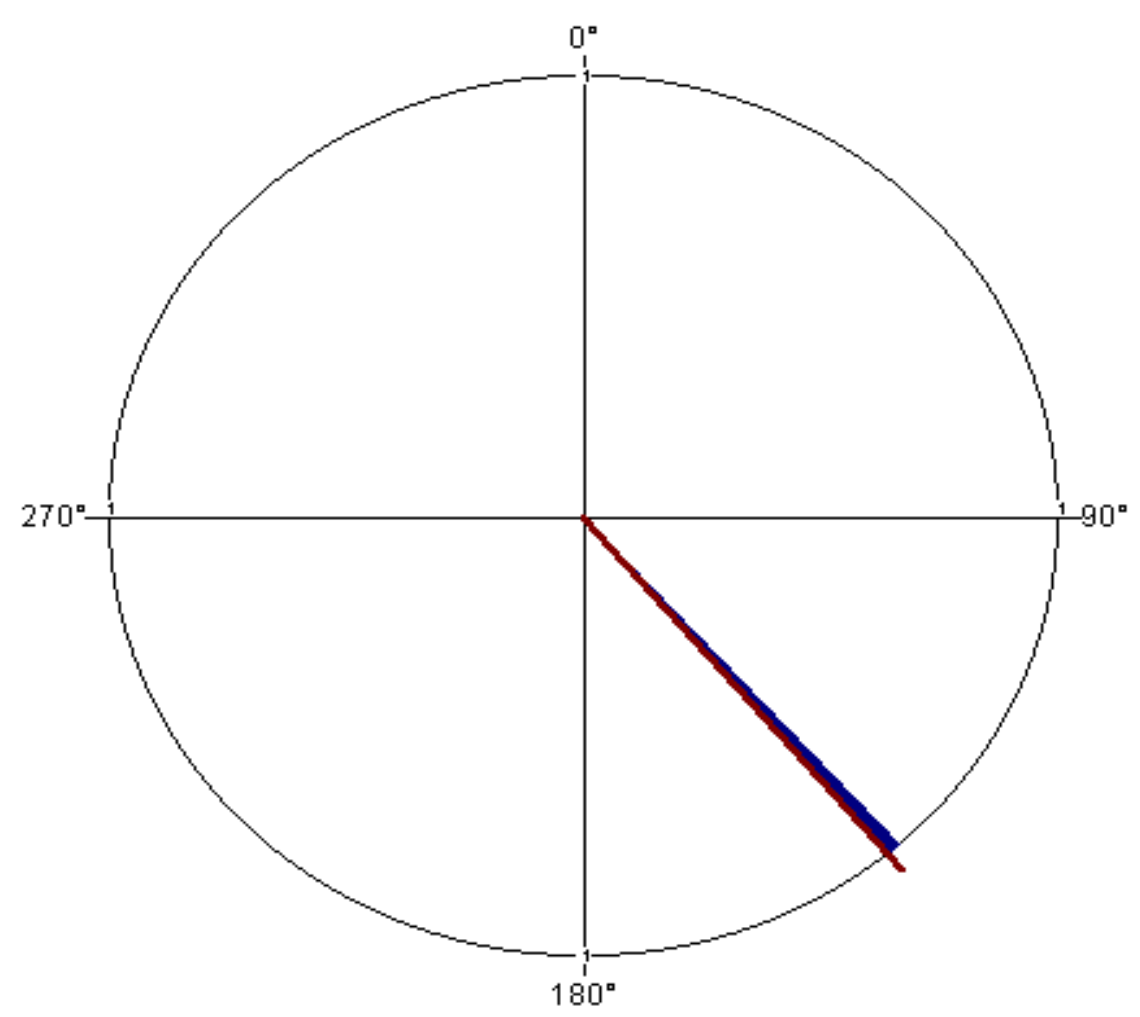

PC\#11

Figure 104. Uni-directional rose diagram for secondary locality 11 in the Riddlesburg Shale Member 


\section{PC \#11 - Riddlesburg Shale Member}

$\begin{array}{lr}\text { Sample Label } & \text { PC\#11 } \\ \text { Quadrangle } & \text { Laneville } \\ \text { Data Type } & \text { Bi-directional } \\ \text { Observations } & 1 \\ \text { Mean vector }(\mu) & 140.00^{\circ} \\ \text { Circular variance } & 0 \\ \text { Circular standard deviation } & -0.00^{\circ} \\ \text { Standard error of mean } & \star \star \star \star \star\end{array}$

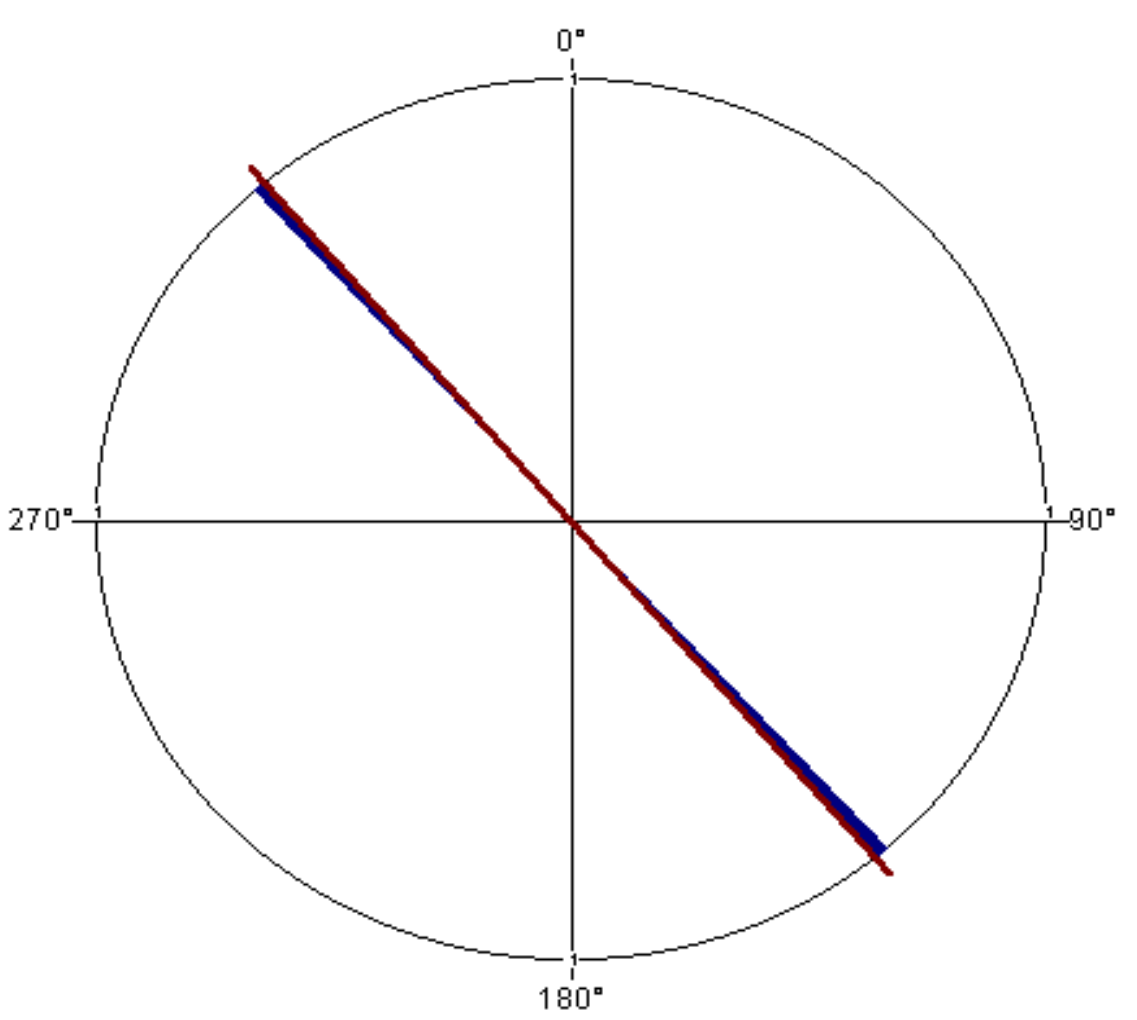

PC\#11

Figure 105. Bi-directional rose diagram for secondary locality 11 in the Riddlesburg Shale Member 


\section{Paleocurrent Stop \# 22 - Riddlesburg Shale Member}

Sample Label

Quadrangle

Data Type

Observations

Mean vector $(\mu)$

Circular variance

Circular standard deviation

Standard error of mean

PC\#22
Harman
Bi-directional
1
$30.00^{\circ}$
0
$-0.00^{\circ}$
$* * * * *$

3

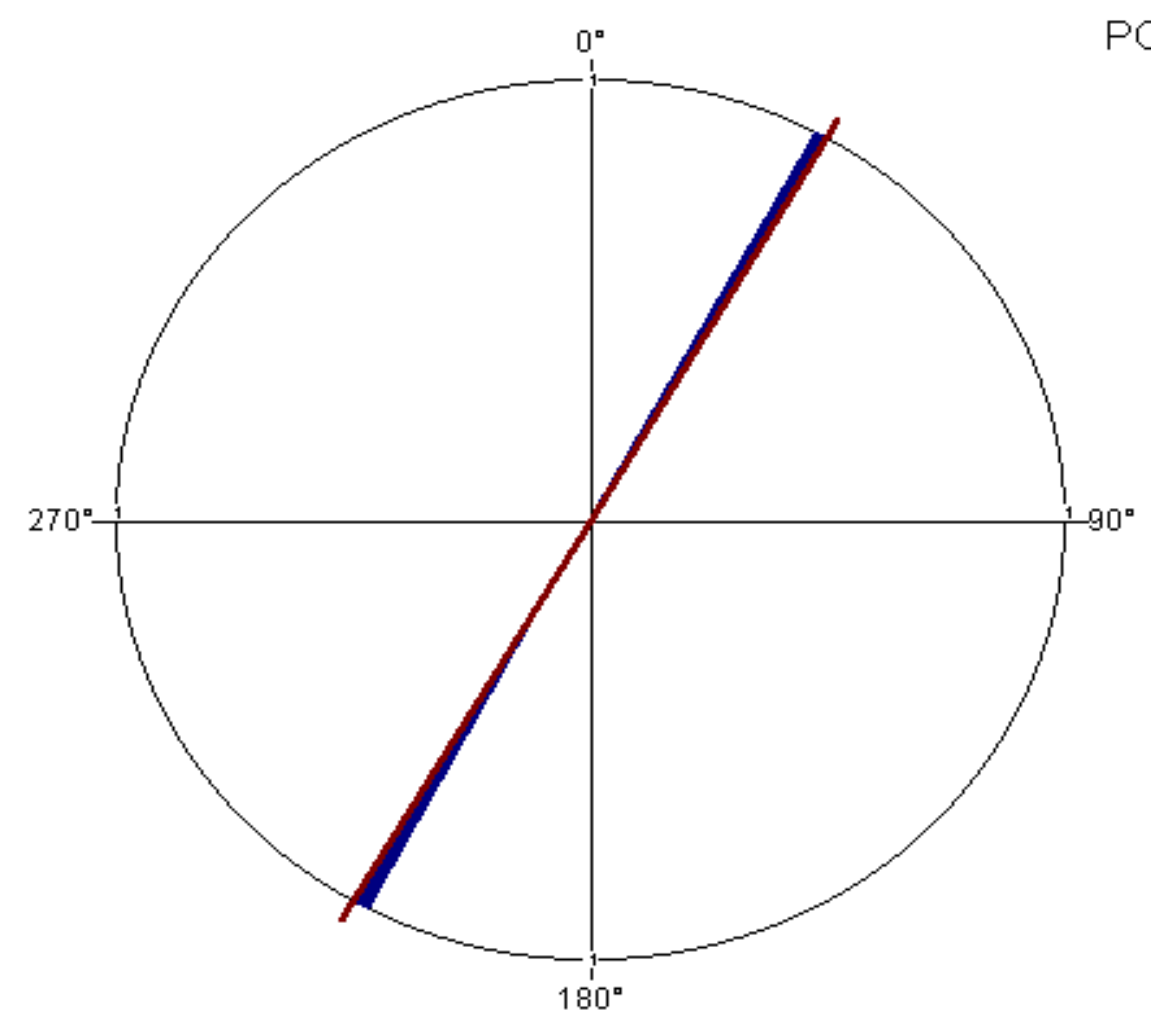

Figure 106. Bi-directional rose diagram for secondary locality 22 in the Riddlesburg Shale Member 


\section{Paleocurrent Stop \# 27 - Riddlesburg Shale Member}

Sample Label

Quadrangle

Data Type

Observations

Mean vector $(\mu)$

Circular variance

Circular standard deviation

Standard error of mean
PC\#27

Harman

Bi-directional

$95.42^{\circ}$

0.65

$82.70^{\circ}$

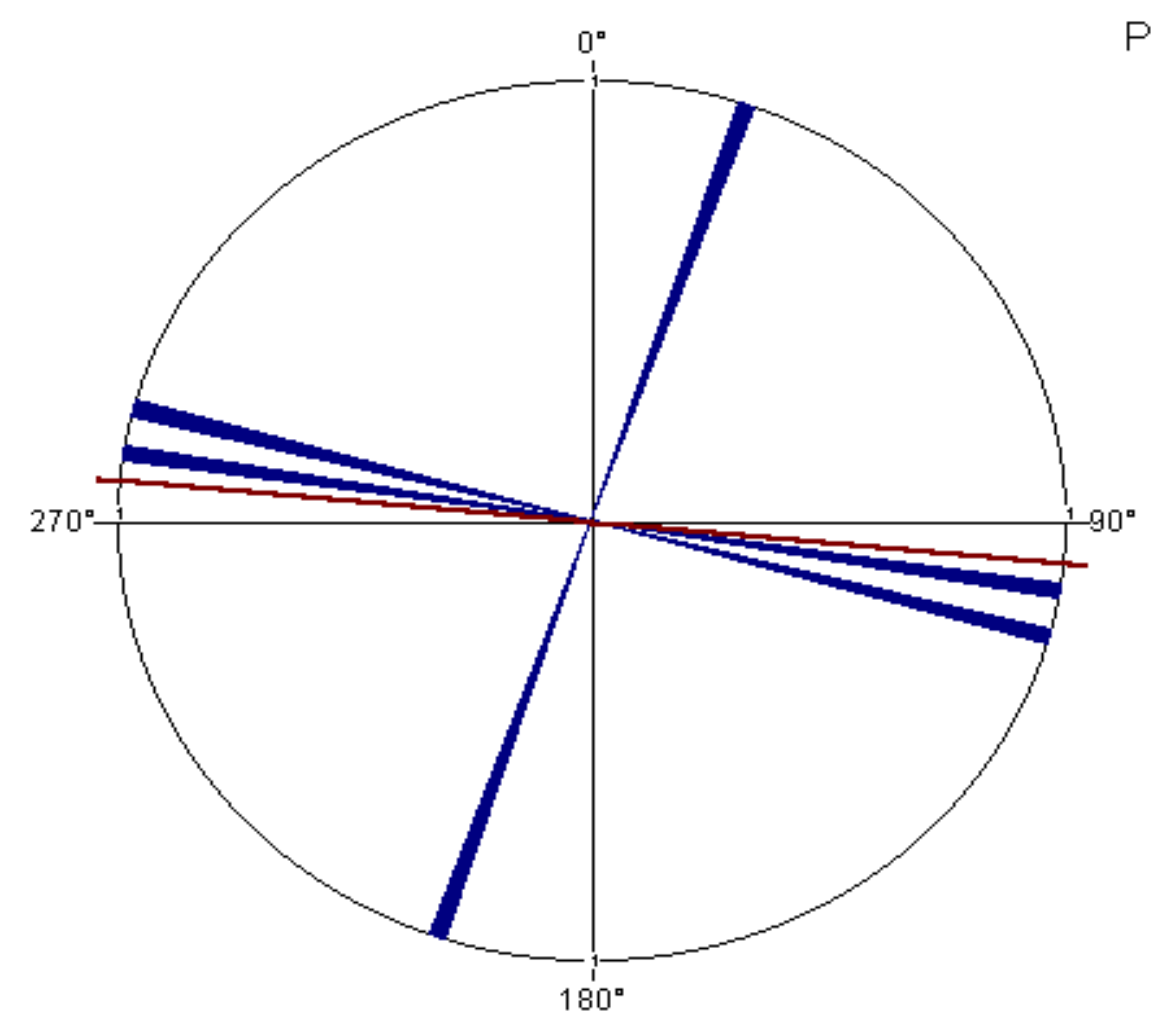

PC\#27_(2)

Figure 107. Bi-directional rose diagram for secondary locality 27 in the Riddlesburg Shale Member 


\section{Paleocurrent Stop \# 40 - Riddlesburg Shale Member}

Sample Label

Quadrangle

Data Type

Observations

Mean vector $(\mu)$

Circular variance

Circular standard deviation

Standard error of mean

$\mathbf{P C \# 4 0}$
Laneville
Bi-directional
1
$60.00^{\circ}$
0
$-0.00^{\circ}$
$\star * \star * *$

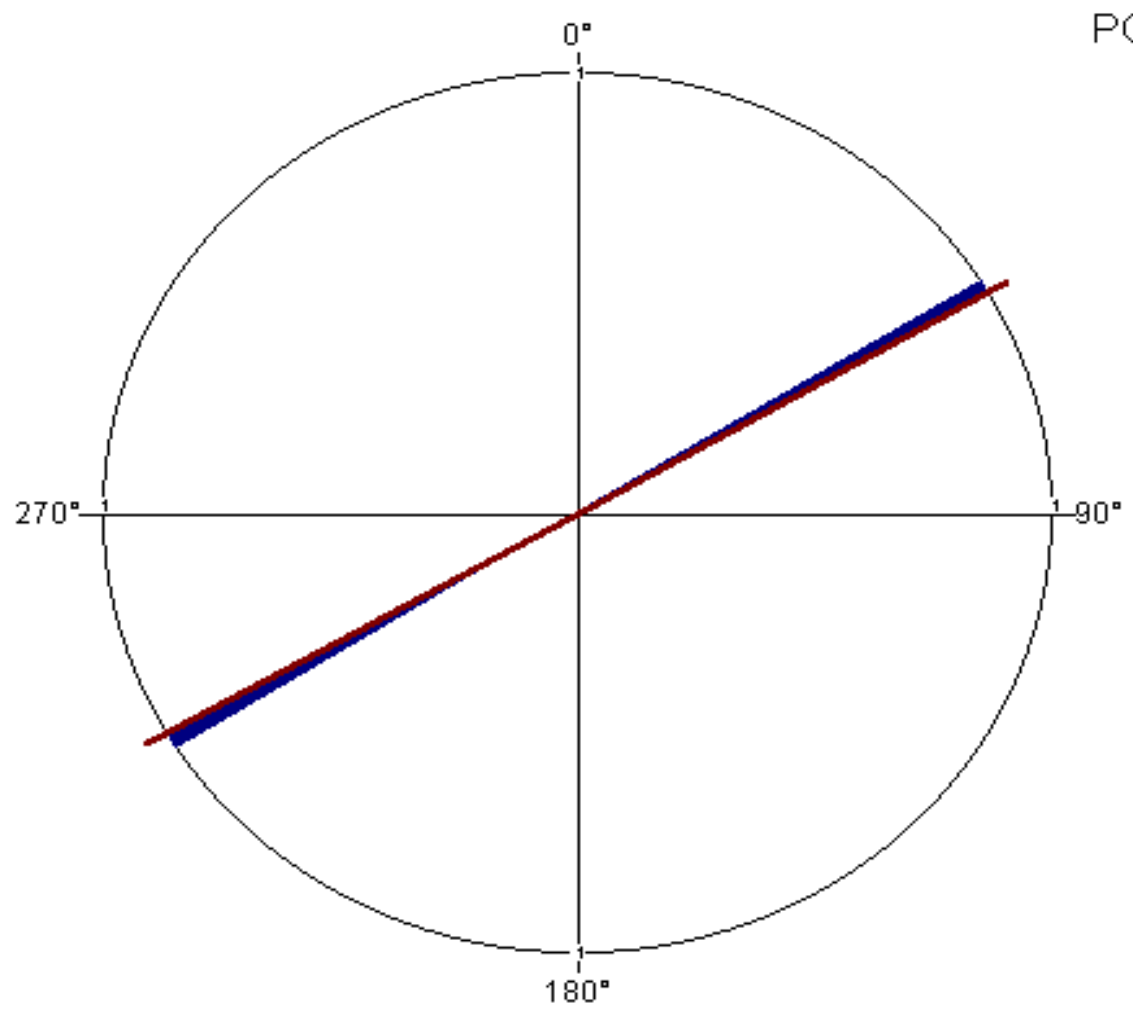

PC\#40_(BI)

Figure 108. Bi-directional rose diagram for secondary locality 40 in the Riddlesburg Shale Member 


\section{Briery Gap - Lower Rockwell Member}

\section{Sample Label}

Quadrangle

Data Type

Observations

Mean vector $(\mu)$

Circular variance

Circular standard deviation

Standard error of mean

$$
\begin{array}{r}
\text { Briery Gap } \\
\text { Circleville } \\
\text { Uni-directional } \\
3 \\
220.00^{\circ} \\
0.69 \\
87.62^{\circ} \\
* \star * \star *
\end{array}
$$

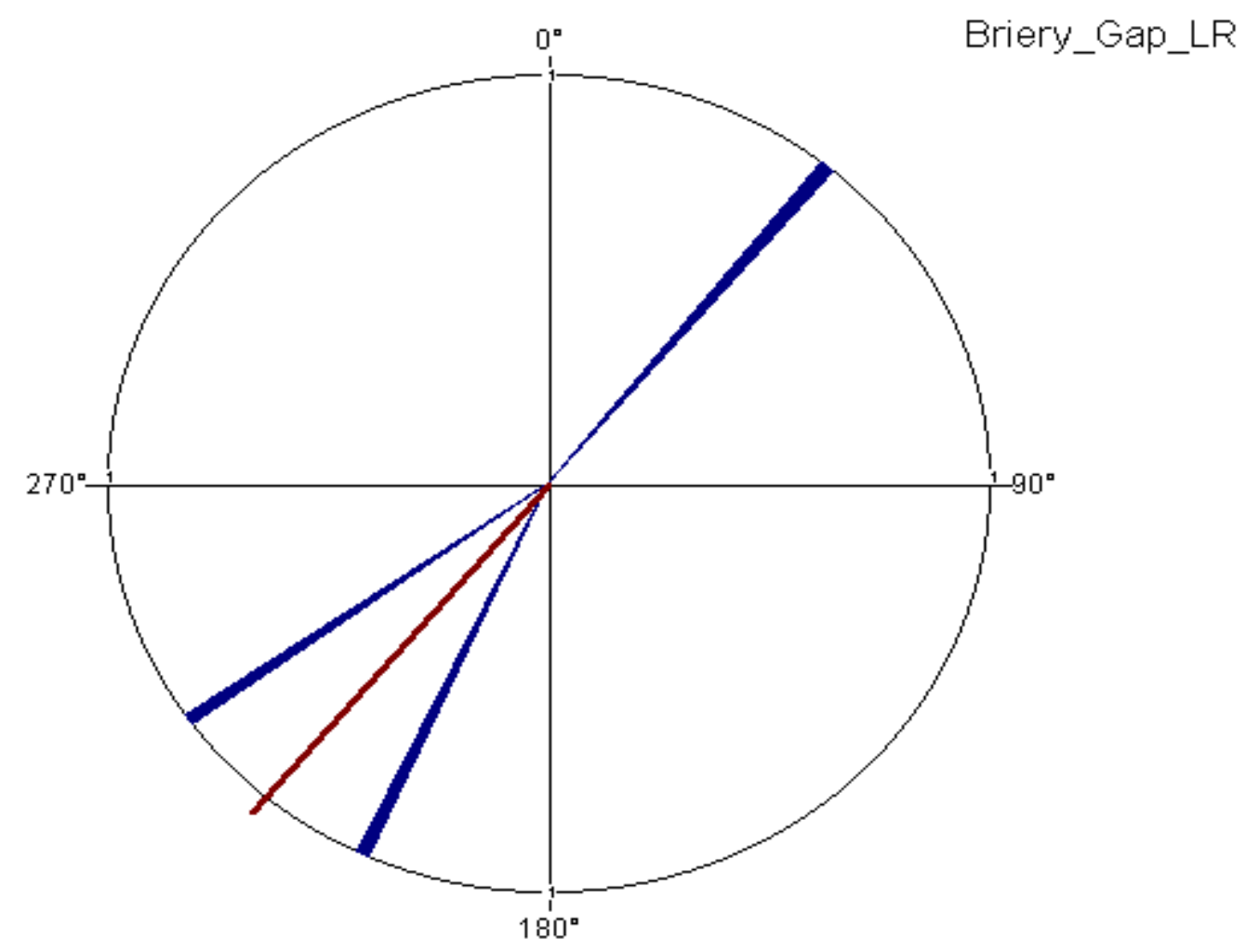

Figure 109. Uni-directional rose diagram for secondary locality at Briery Gap in the lower Rockwell Member 


\section{Briery Gap - Upper Rockwell Member}

\section{Sample Label}

Quadrangle

Data Type

Observations

Mean vector $(\mu)$

Circular variance

Circular standard deviation

Standard error of mean

\section{Briery Gap}

Circleville

Uni-directional

$$
\begin{array}{r}
2 \\
62.50^{\circ} \\
0.02 \\
12.55^{\circ} \\
28.06^{\circ}
\end{array}
$$

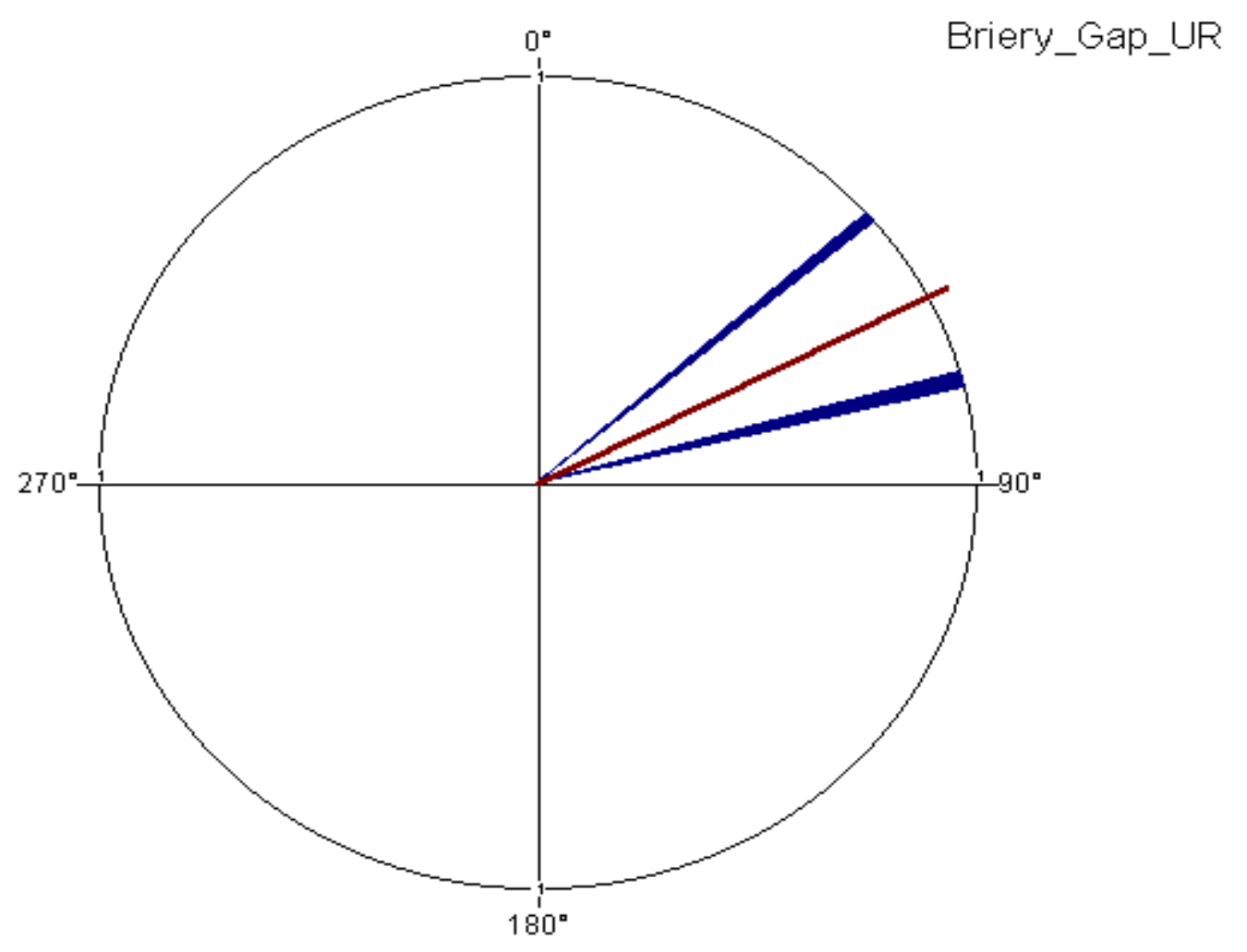

Figure 110. Uni-directional rose diagram for secondary locality at Briery Gap in the upper Rockwell Member 


\section{Paleocurrent Stop \# 1 - Upper Rockwell Member}

Sample Label

Quadrangle

Data Type

Observations

Mean vector $(\mu)$

Circular variance

Circular standard deviation

Standard error of mean
PC\#1

Onego

Uni-directional

$280.00^{\circ}$

0

$-0.00^{\circ}$

$* * * * *$

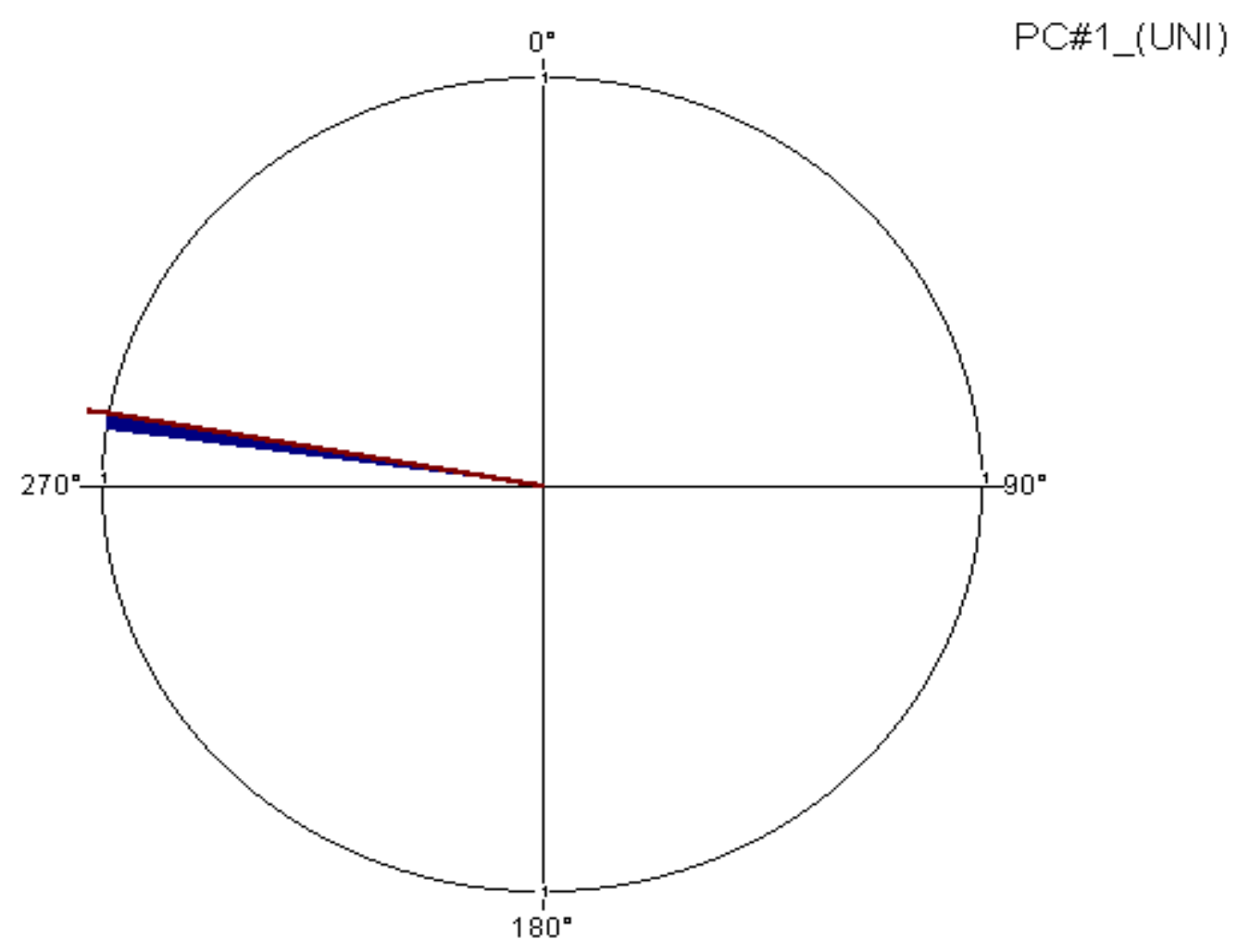

Figure 111. Uni-directional rose diagram for secondary locality 1 in the upper Rockwell Member 


\section{Paleocurrent Stop \# 1 - Upper Rockwell Member}

Sample Label

Quadrangle

Data Type

Observations

Mean vector $(\mu)$

Circular variance

Circular standard deviation

Standard error of mean

PC\#1
Onego
Bi-directional
2
$160.00^{\circ}$
0
$-0.00^{\circ}$
$\star * * * *$

Figure 112. Bi-directional rose diagram for secondary locality 1 in the upper Rockwell Member 


\section{Paleocurrent Stop \# 2 - Lower Rockwell Member}

Sample Label

Quadrangle

Data Type

Observations

Mean vector $(\mu)$

Circular variance

Circular standard deviation

Standard error of mean
PC\#2

Onego

Uni-directioanl

$220.00^{\circ}$

0.51

$68.20^{\circ}$

$49.32^{\circ}$ *

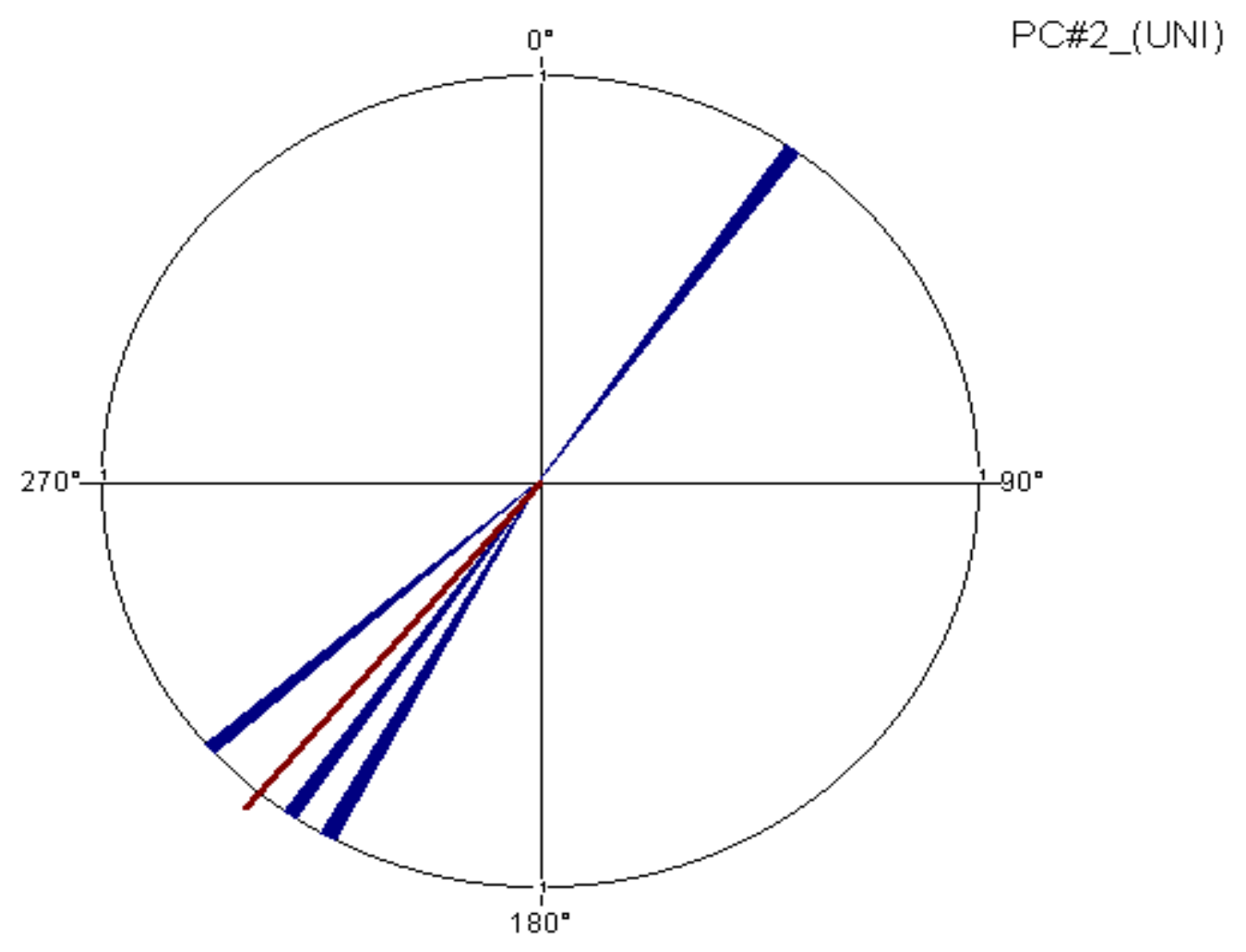

Figure 113. Uni-directional rose diagram for secondary locality 2 in the lower Rockwell Member 


\section{Paleocurrent Stop \# 3 - Upper Rockwell Member}

Sample Label

Quadrangle

Data Type

Observations

Mean vector $(\mu)$

Circular variance

Circular standard deviation

Standard error of mean

PC\#3
Onego
Uni-directional
1
$210.00^{\circ}$
0
$-0.00^{\circ}$
$* * * * *$

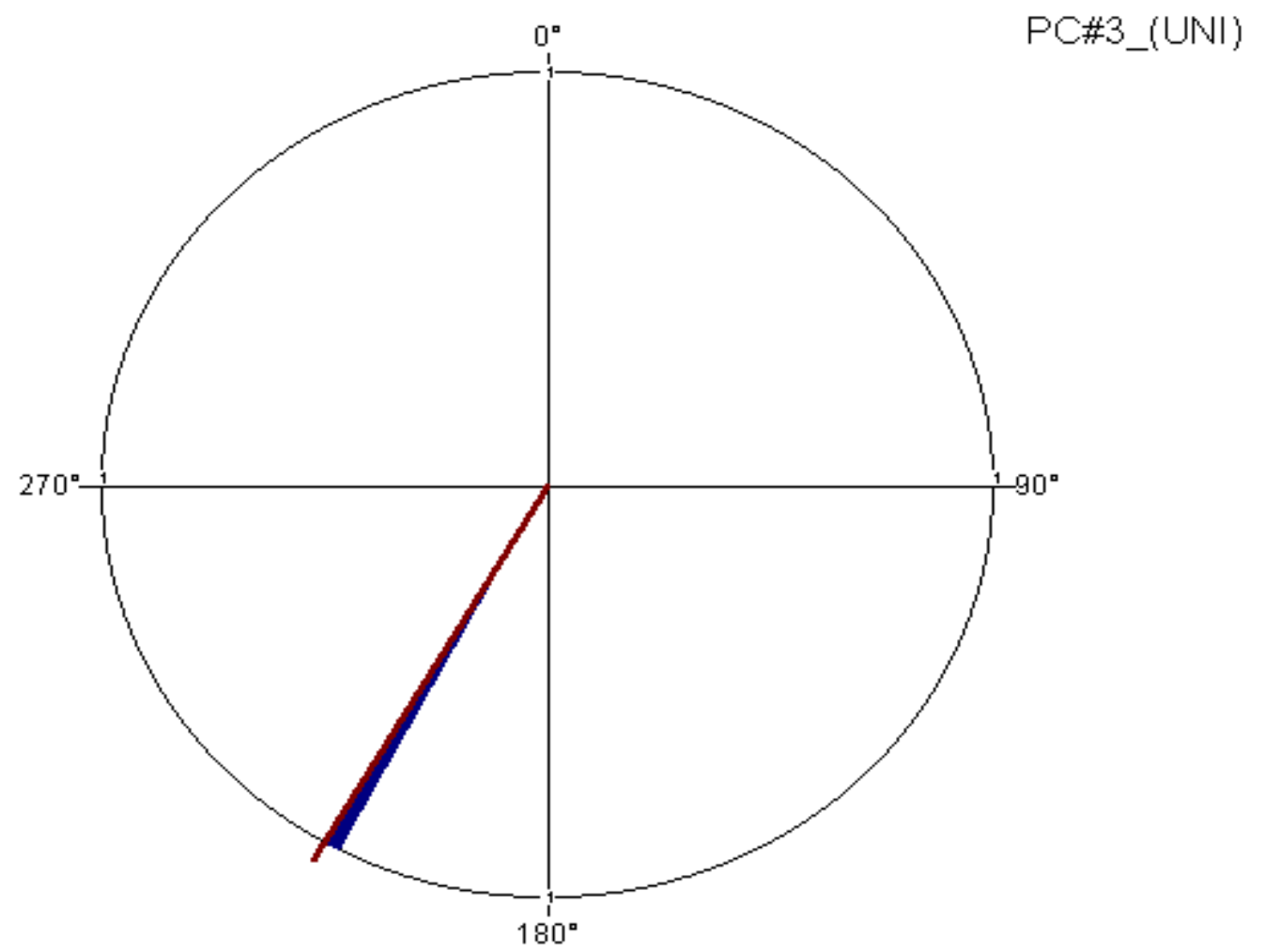

Figure 114. Uni-directional rose diagram for secondary locality 3 in the upper Rockwell Member 


\section{Paleocurrent Stop \# 4 - Upper Rockwell Member}

$\begin{array}{lr}\text { Sample Label } & \text { PC\#4 } \\ \text { Quadrangle } & \text { Onego } \\ \text { Data Type } & \text { Uni-directional } \\ \text { Observations } & 1 \\ \text { Mean vector }(\mu) & 280.00^{\circ} \\ \text { Circular variance } & 0 \\ \text { Circular standard deviation } & -0.00^{\circ} \\ \text { Standard error of mean } & * * * * *\end{array}$

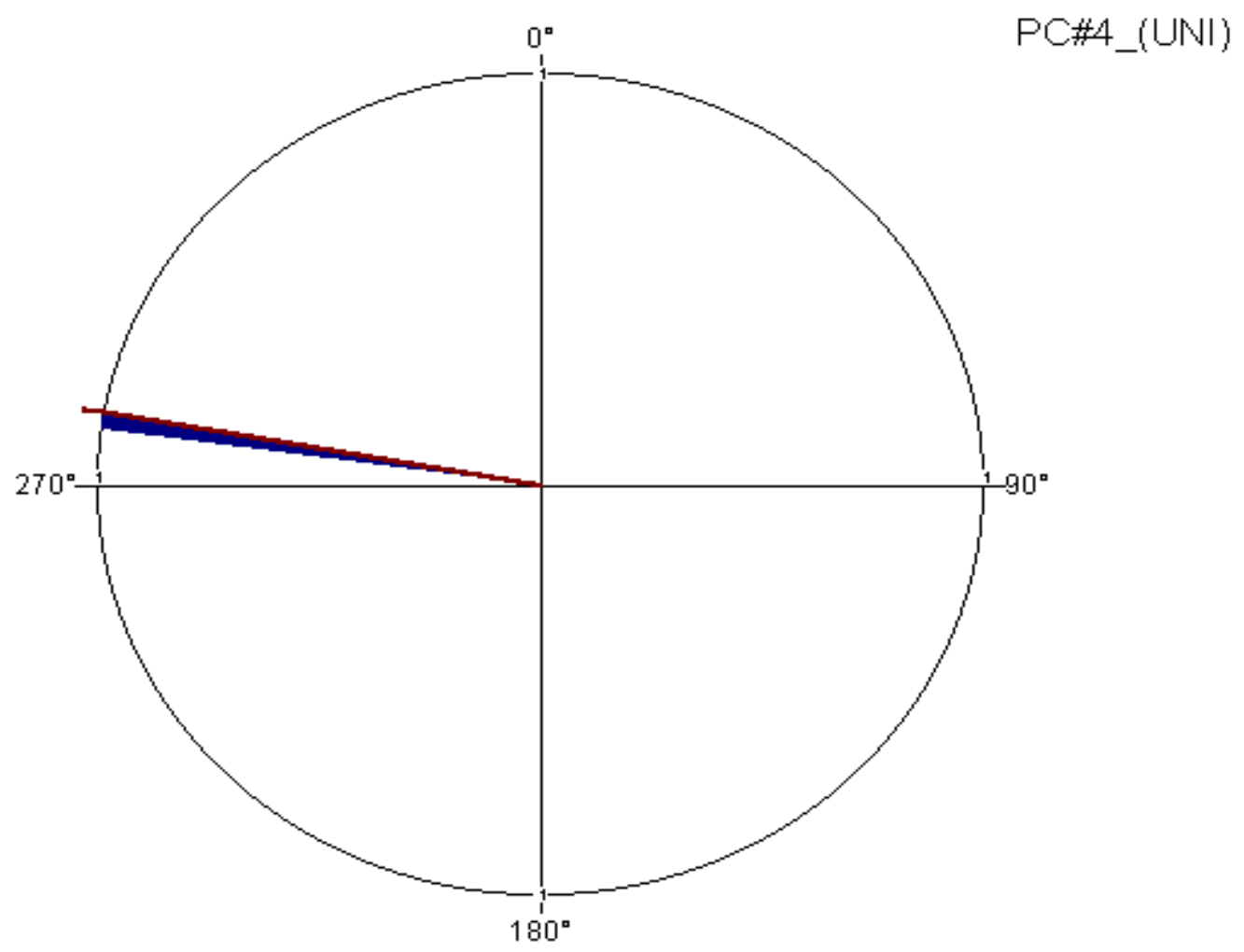

Figure 115. Uni-directional rose diagram for secondary locality 4 in the upper Rockwell Member 


\section{Paleocurrent Stop \# 5 - Upper Rockwell Member}

$\begin{array}{lr}\text { Sample Label } & \text { PC\#5 } \\ \text { Quadrangle } & \text { Onego } \\ \text { Data Type } & \text { Uni-directional } \\ \text { Observations } & 1 \\ \text { Mean vector }(\mu) & 40.00^{\circ} \\ \text { Circular variance } & 0 \\ \text { Circular standard deviation } & 0.00^{\circ} \\ \text { Standard error of mean } & \star \star \star \star \star \star\end{array}$

Standard error of mean

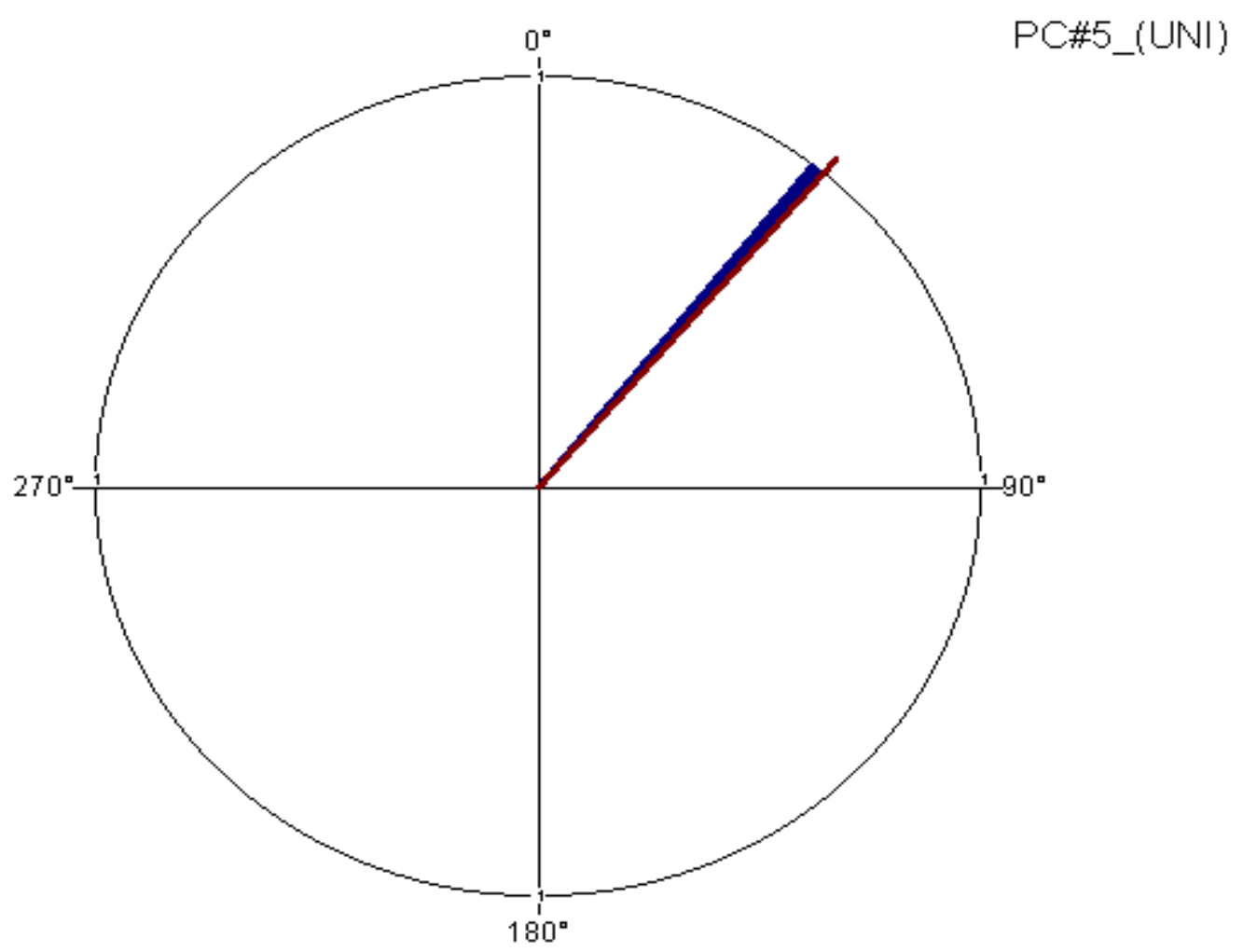

Figure 116. Uni-directional rose diagram for secondary locality 5 in the upper Rockwell Member 


\section{Paleocurrent Stop \# 6 - Upper Rockwell Member}

\section{Sample Label}

Quadrangle

Data Type

Observations

Mean vector $(\mu)$

Circular variance

Circular standard deviation

Standard error of mean

PC\#6
Onego
Uni-direcitonal
1
$80.00^{\circ}$
0
$-0.00^{\circ}$
$\star * \star \star *$

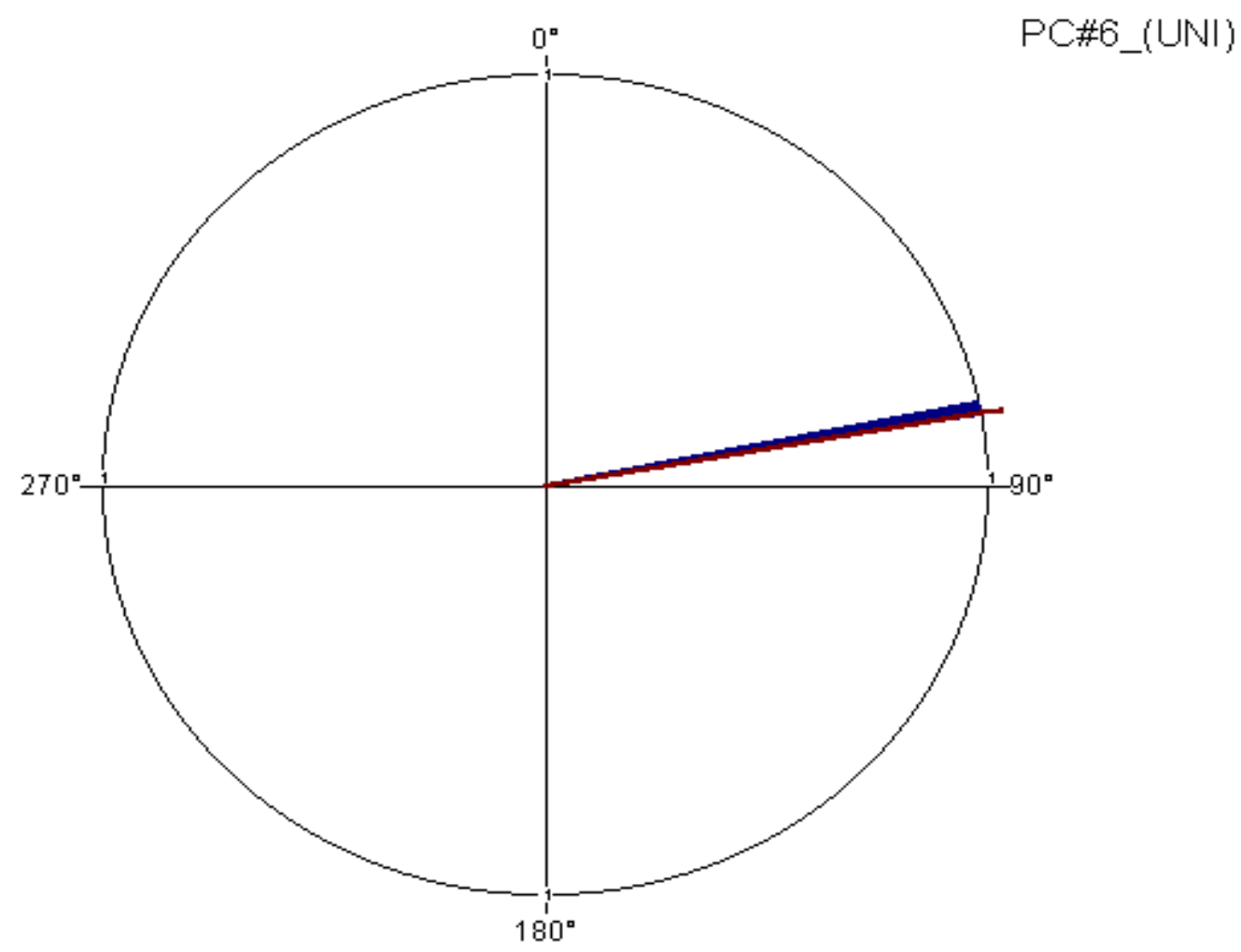

Figure 117. Uni-directional rose diagram for secondary locality 6 in the upper Rockwell Member 


\section{Paleocurrent Stop \# 7 - Lower Rockwell Member}

Sample Label

Quadrangle

Data Type

Observations

Mean vector $(\mu)$

Circular variance

Circular standard deviation

Standard error of mean

PC\#7
Cass
Uni-directional
1
$220.00^{\circ}$
0
$0.00^{\circ}$
$\star \star \star \star$

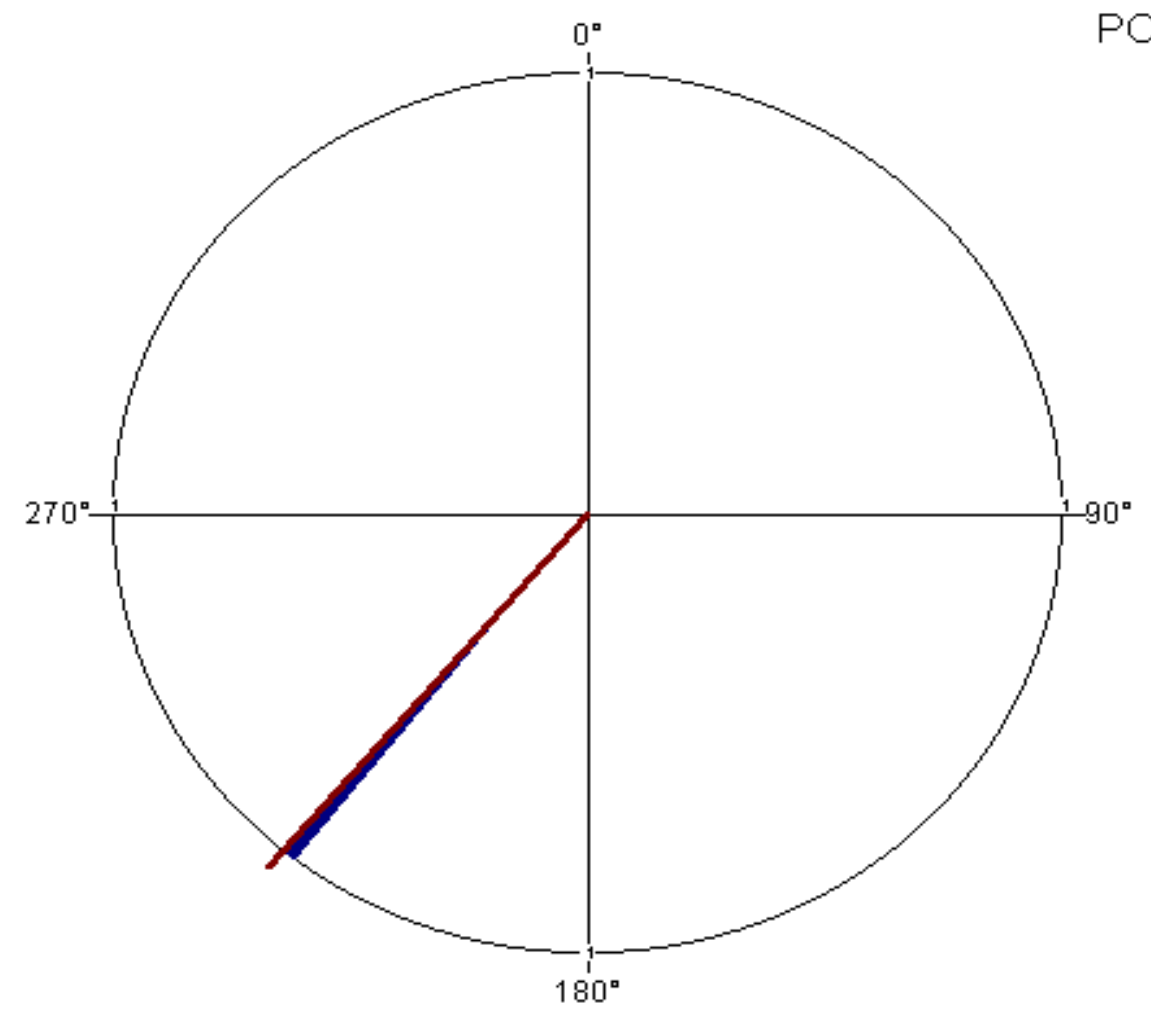

Figure 118. Uni-directional rose diagram for secondary locality 7 in the lower Rockwell Member 


\section{Paleocurrent Stop \# 7 - Lower Rockwell Member}

Sample Label

Quadrangle

Data Type

Observations

Mean vector $(\mu)$

Circular variance

Circular standard deviation

Standard error of mean

PC\#7
Cass
Bi-directional
1
$25.00^{\circ}$
0
$-0.00^{\circ}$
$\star \star \star \star \star$

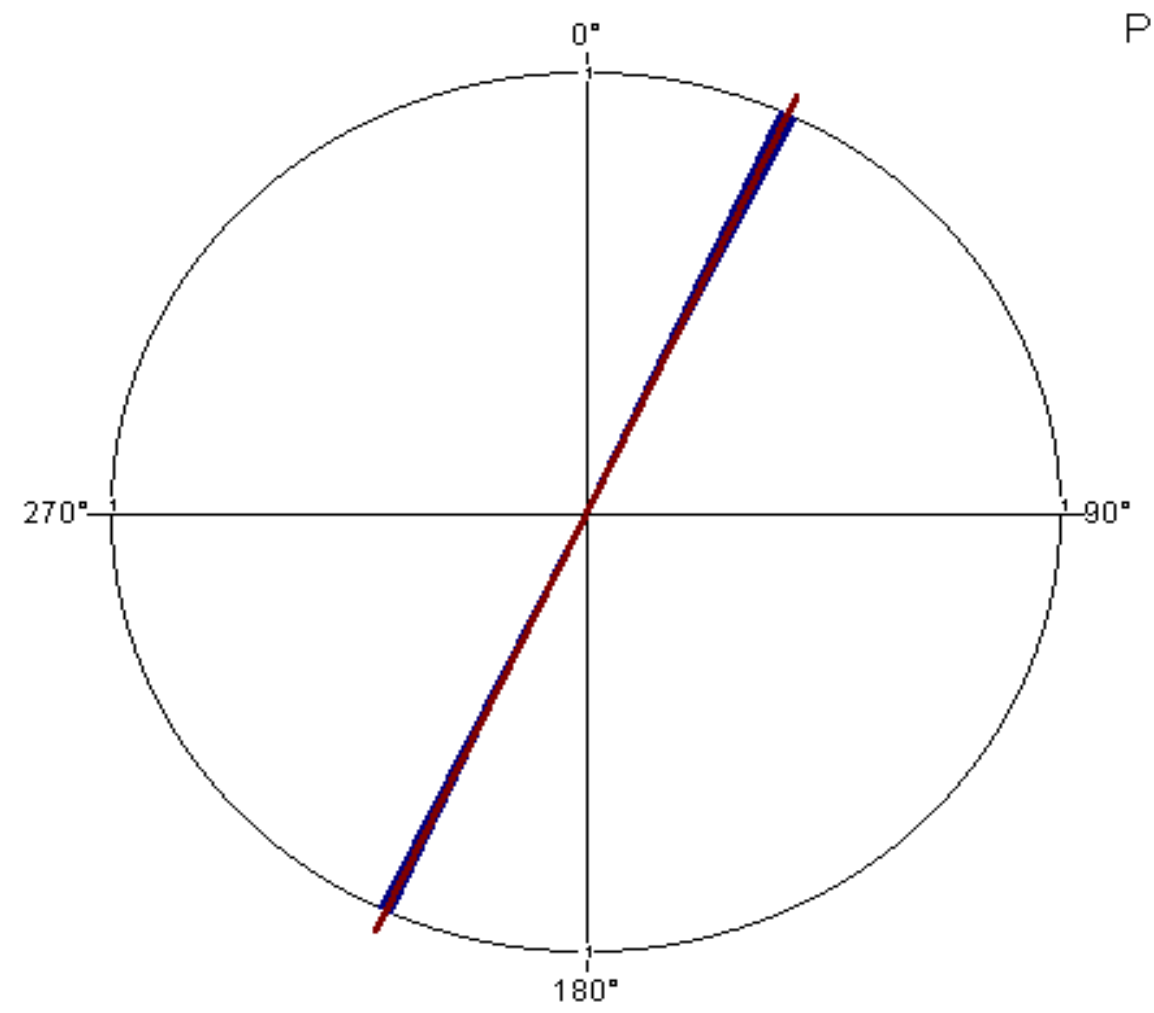

PC\#7_(BI)

Figure 119. Bi-directional rose diagram for secondary locality 7 in the lower Rockwell Member 


\section{Paleocurrent Stop \# 10 - Lower Rockwell Member}

\section{Sample Label}

Quadrangle

Data Type

Observations

Mean vector $(\mu)$

Circular variance

Circular standard deviation

Standard error of mean
PC\#10

Harman

Uni-directional

$70.00^{\circ}$

0.66

$83.93^{\circ}$

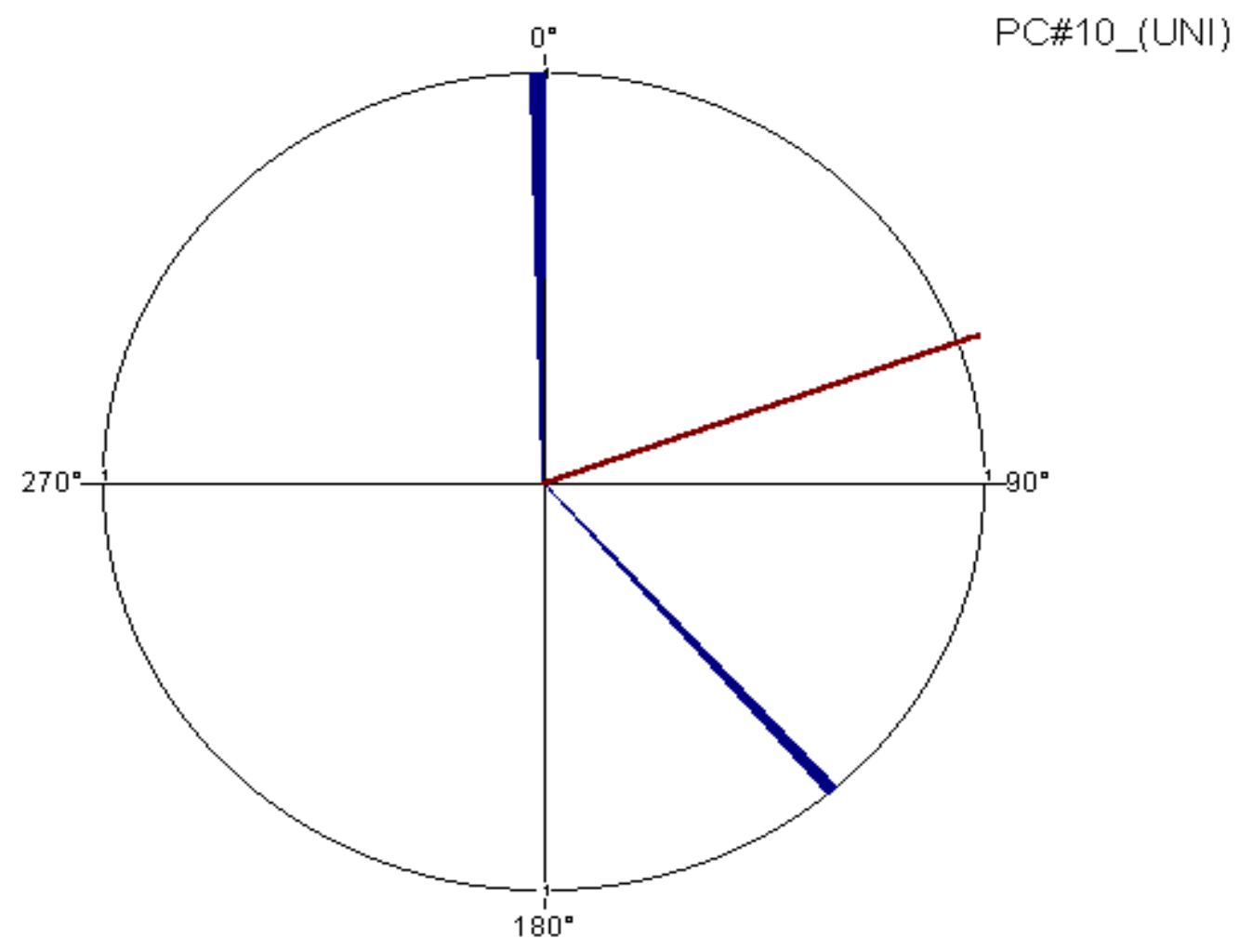

Figure 120. Uni-directional rose diagram for secondary locality 10 in the lower Rockwell Member 


\section{Paleocurrent Stop \# 10 - Lower Rockwell Member}

Sample Label

Quadrangle

Data Type

Observations

Mean vector $(\mu)$

Circular variance

Circular standard deviation

Standard error of mean

PC\#10
Harman
Bi-directional
2
$160.00^{\circ}$
0.23
$41.83^{\circ}$
$92.53^{\circ}$ *

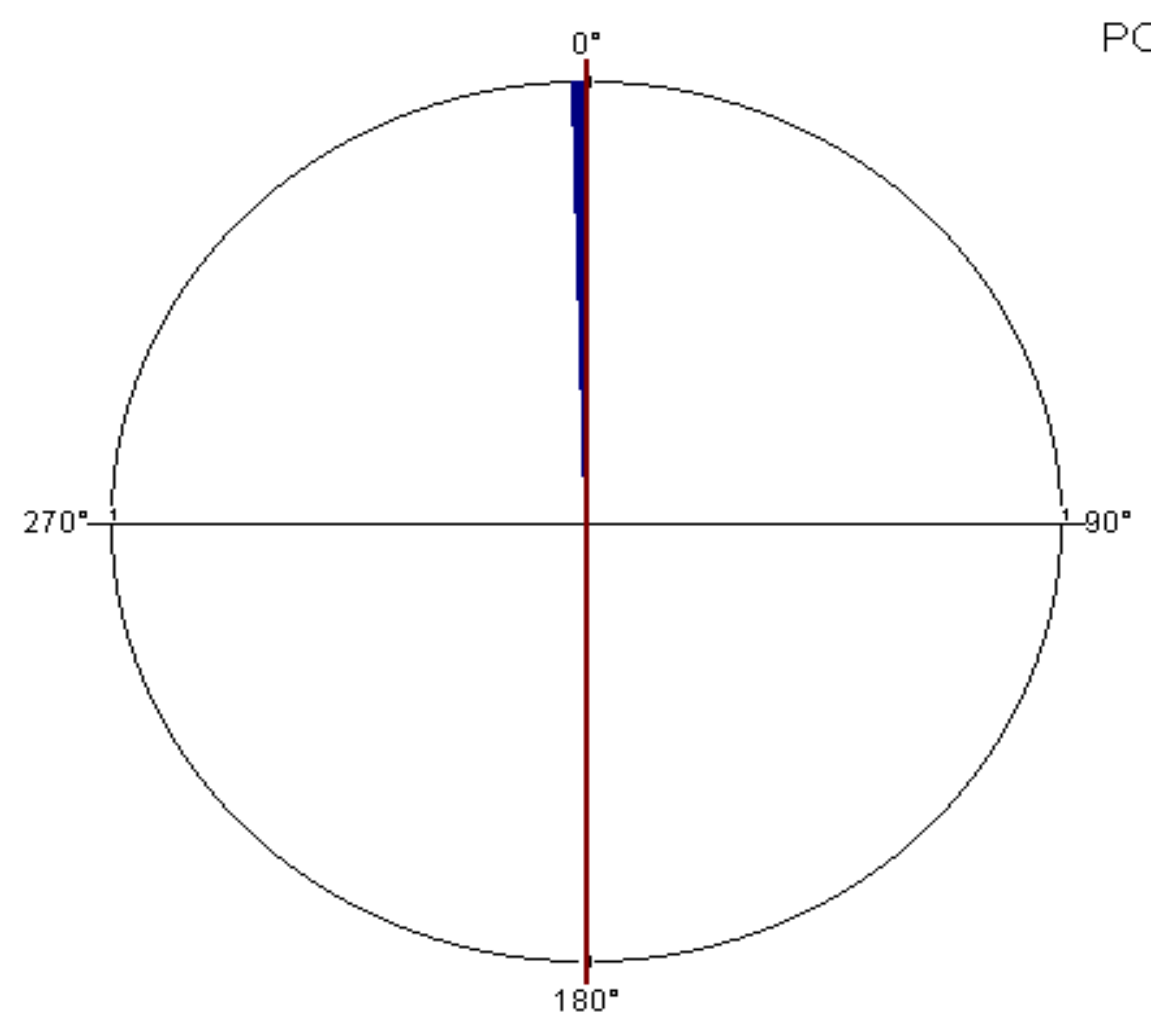

PC\#10_(BI)

Figure 121. Bi-directional rose diagram for secondary locality 10 in the lower Rockwell Member 


\section{Paleocurrent Stop \# 12 - Lower Rockwell Member}

Sample Label

Quadrangle

Data Type

Observations

Mean vector $(\mu)$

Circular variance

Circular standard deviation

Standard error of mean
PC\#12

Onego

Uni-directional

$215.15^{\circ}$

0.41

$58.81^{\circ}$

$35.05^{\circ}$ *

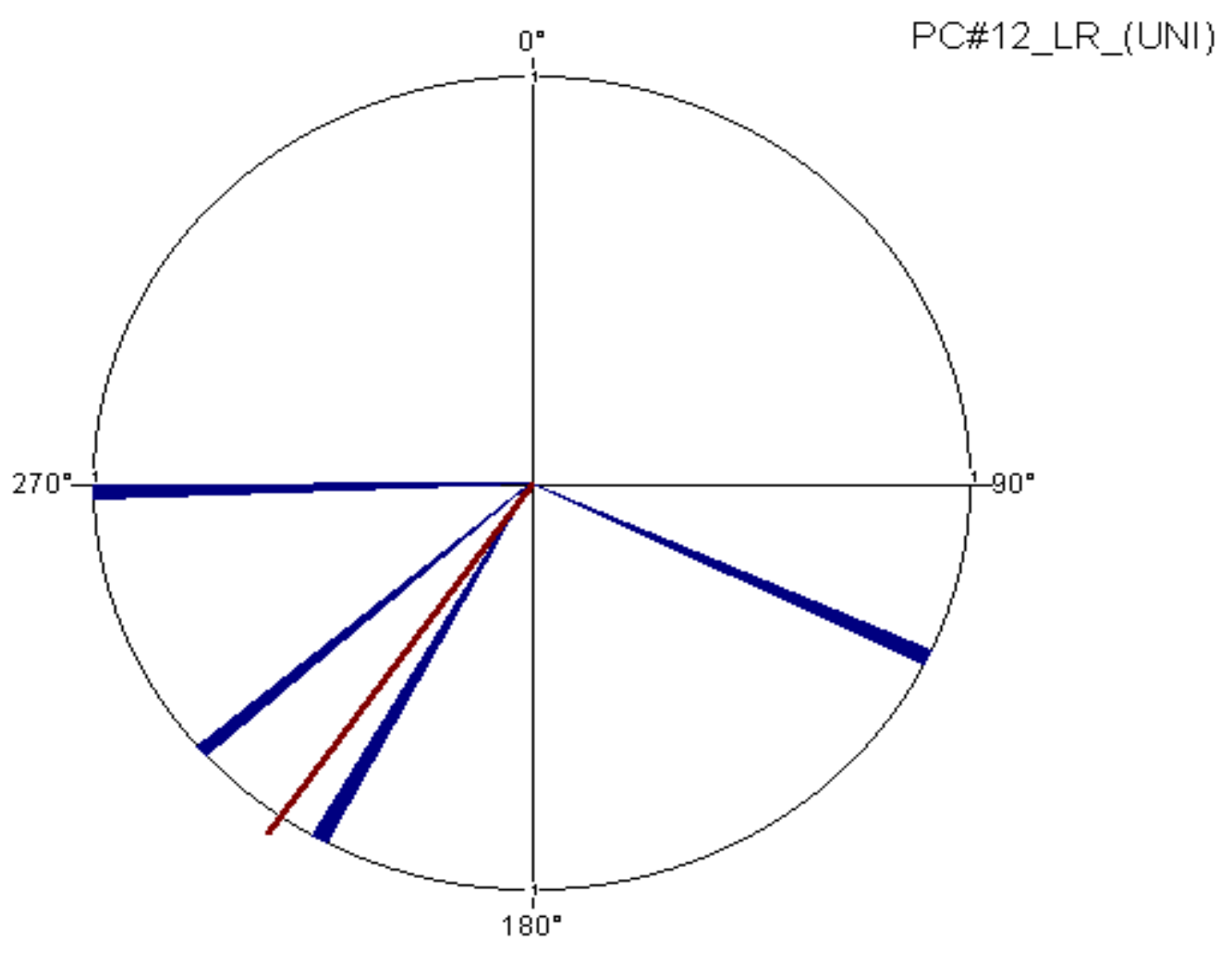

Figure 122. Uni-directional rose diagram for secondary locality 12 in the lower Rockwell Member 


\section{Paleocurrent Stop \# 12 - Upper Rockwell Member}

Sample Label

Quadrangle

Data Type

Observations

Mean vector $(\mu)$

Circular variance

Circular standard deviation

Standard error of mean

PC\#12
Onego
Uni-directional
2
$250.00^{\circ}$
0.02
$10.03^{\circ}$
$22.42^{\circ}$

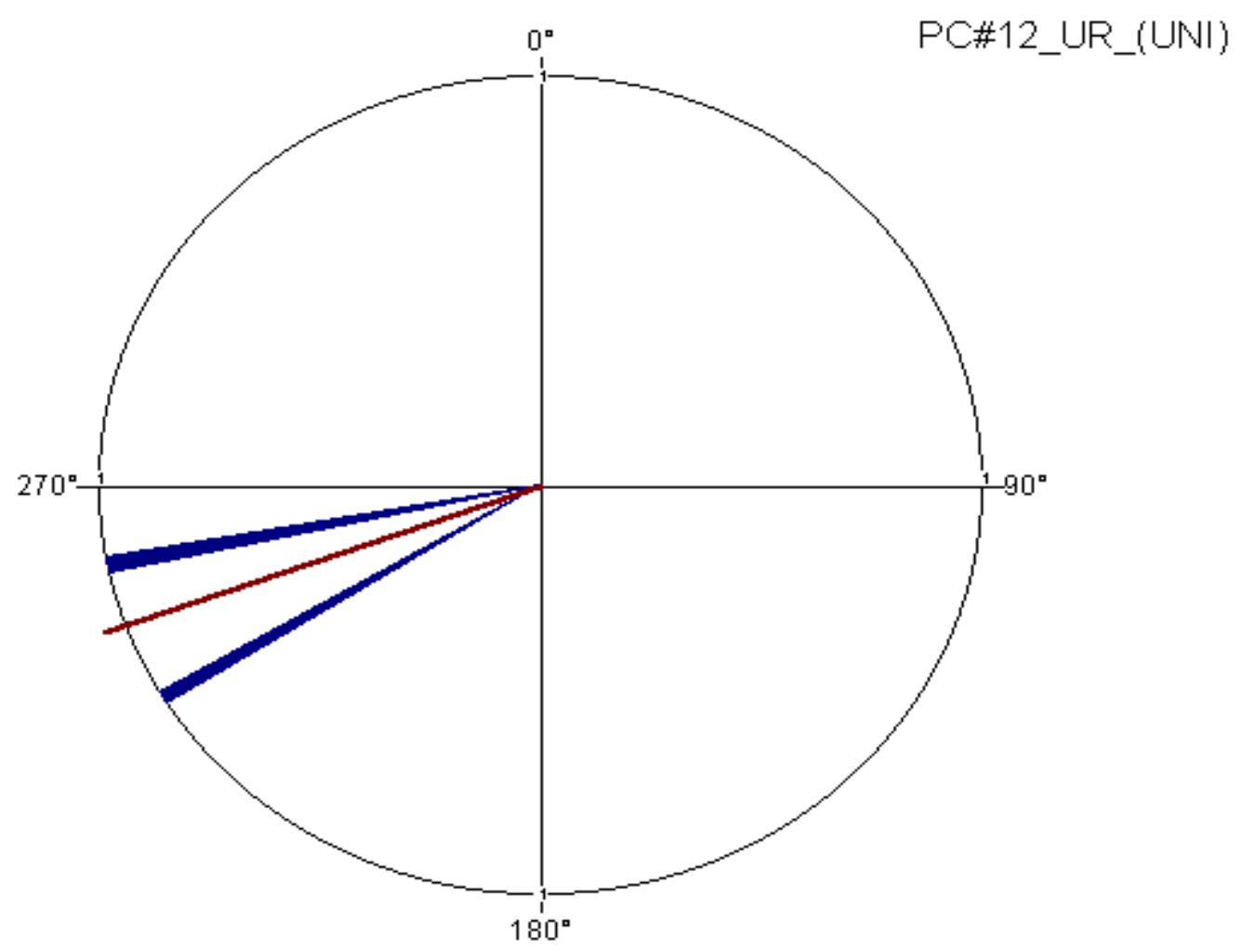

Figure 123. Uni-directional rose diagram for secondary locality 12 in the upper Rockwell Member 


\section{Paleocurrent Stop \# 13 - Upper Rockwell Member}

$\begin{array}{lr}\text { Sample Label } & \text { PC\#13 } \\ \text { Quadrangle } & \text { Onego } \\ \text { Data Type } & \text { Bi-directional } \\ \text { Observations } & 1 \\ \text { Mean vector }(\mu) & 160.00^{\circ} \\ \text { Circular variance } & 0 \\ \text { Circular standard deviation } & -0.00^{\circ} \\ \text { Standard error of mean } & * * * * *\end{array}$

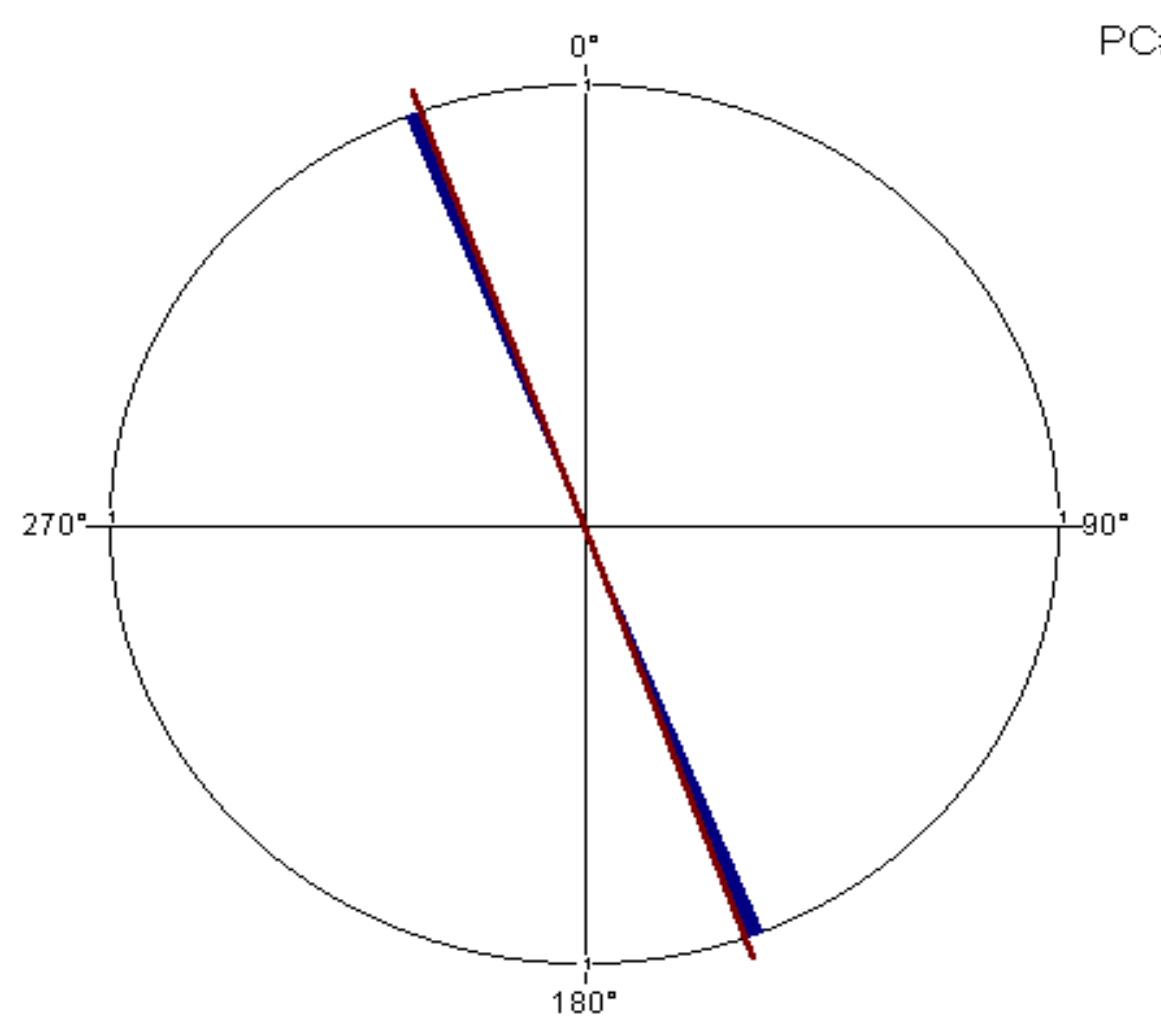

Figure 124. Bi-directional rose diagram for secondary locality 13 in the upper Rockwell Member 


\section{Paleocurrent Stop \# 16 - Lower Rockwell Member}

Sample Label

Quadrangle

Data Type

Observations

Mean vector $(\mu)$

Circular variance

Circular standard deviation

Standard error of mean
PC\#16

Rowlesburg

Uni-directional

$300.00^{\circ}$

0.02

$10.03^{\circ}$

$22.42^{\circ}$

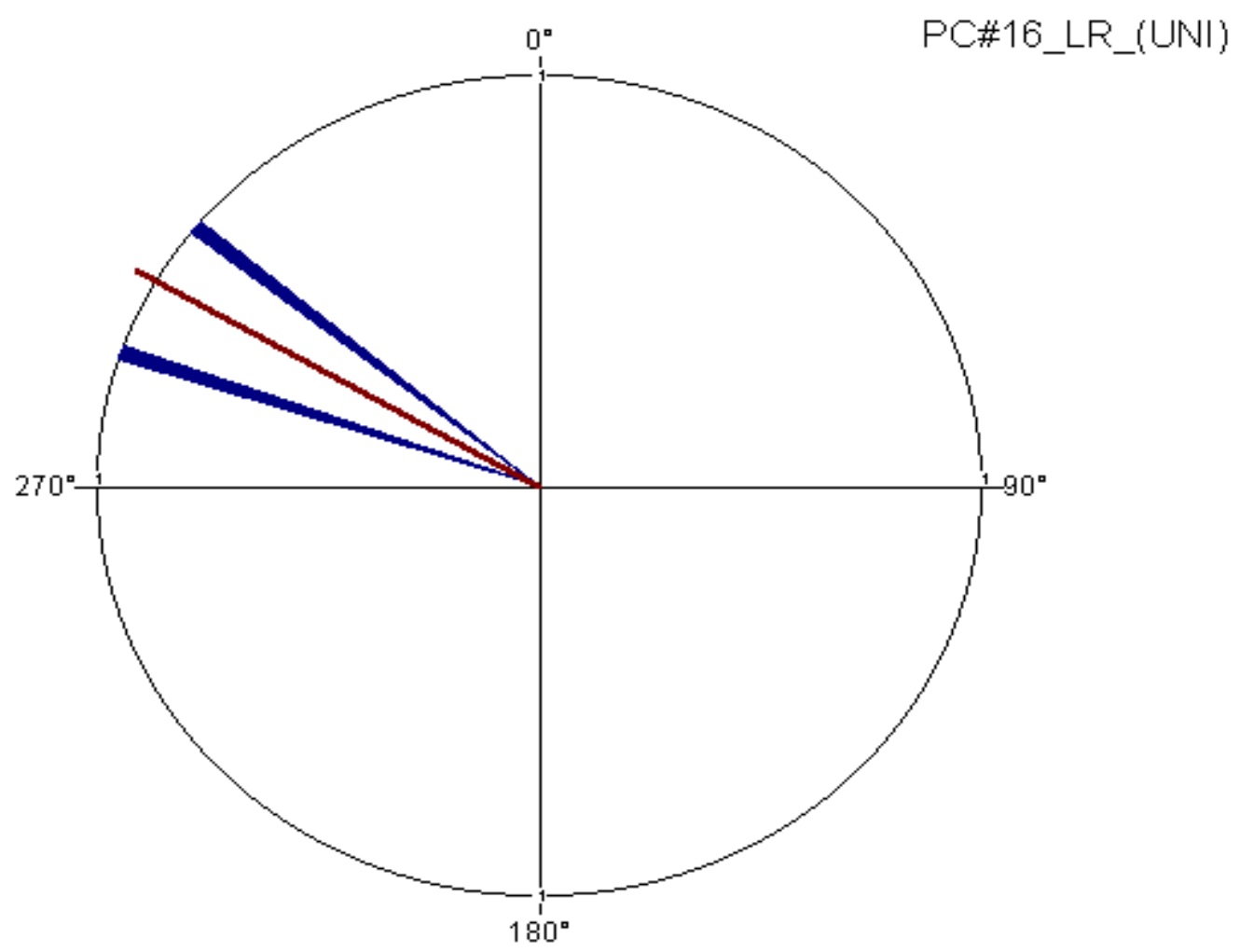

Figure 125. Uni-directional rose diagram for secondary locality 16 in the lower Rockwell Member 


\section{Paleocurrent Stop \# 16 - Upper Rockwell Member}

$\begin{array}{lr}\text { Sample Label } & \text { PC\#16 } \\ \text { Quadrangle } & \text { Rowlesburg } \\ \text { Data Type } & \text { Uni-directional } \\ \text { Observations } & 2 \\ \text { Mean vector }(\mu) & 285.00^{\circ} \\ \text { Circular variance } & 0.03 \\ \text { Circular standard deviation } & 15.09^{\circ} \\ \text { Standard error of mean } & 33.73^{\circ} \text { * }\end{array}$

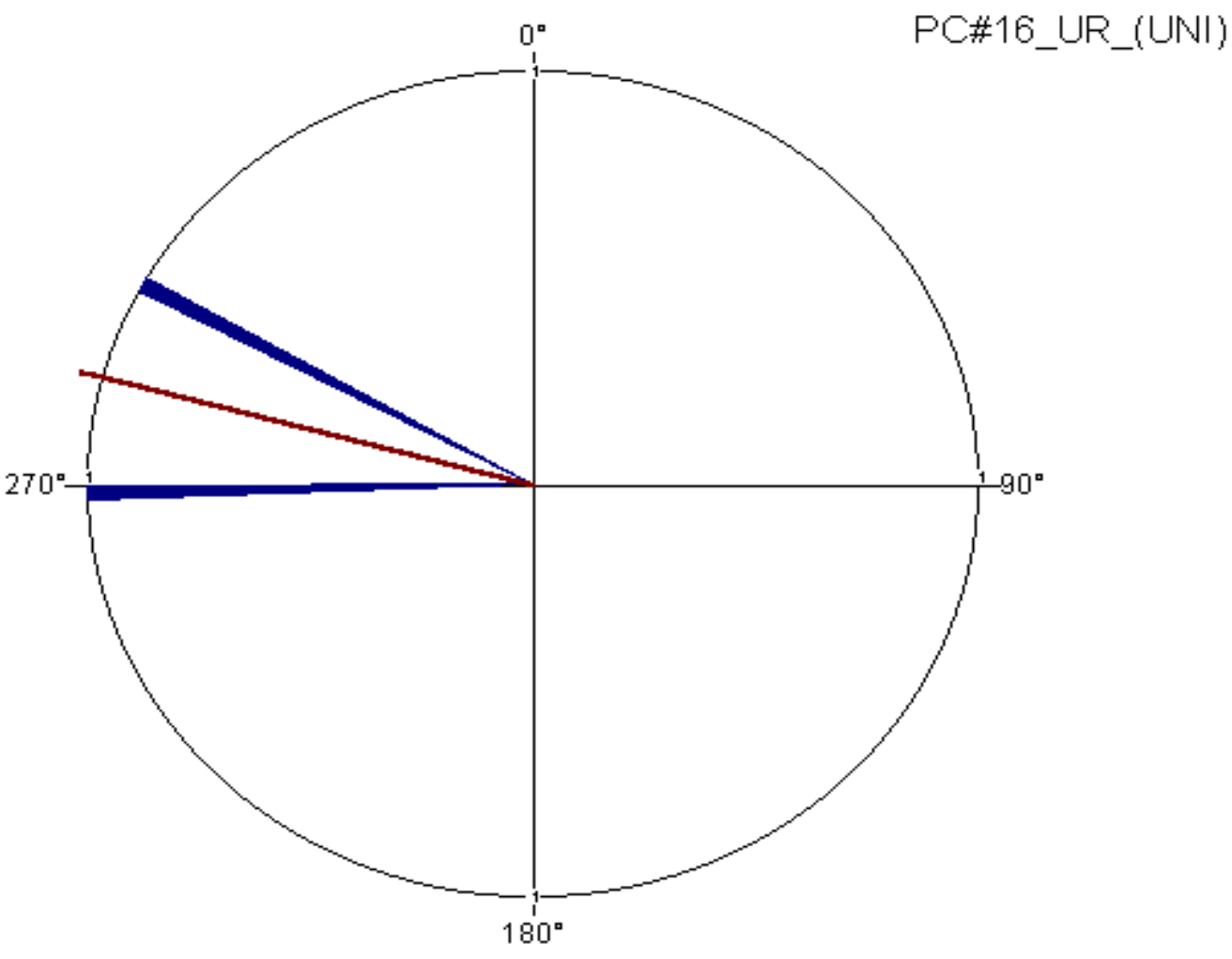

Figure 126. Uni-directional rose diagram for secondary locality 16 in the upper Rockwell Member 


\section{Paleocurrent Stop \# 17 - Upper Rockwell Member}

\section{Sample Label}

Quadrangle

Data Type

Observations

Mean vector $(\mu)$

Circular variance

Circular standard deviation

Standard error of mean
PC\#17

Table Rock

Uni-directional

$235.00^{\circ}$

0

$-0.00^{\circ}$

$* * * * *$

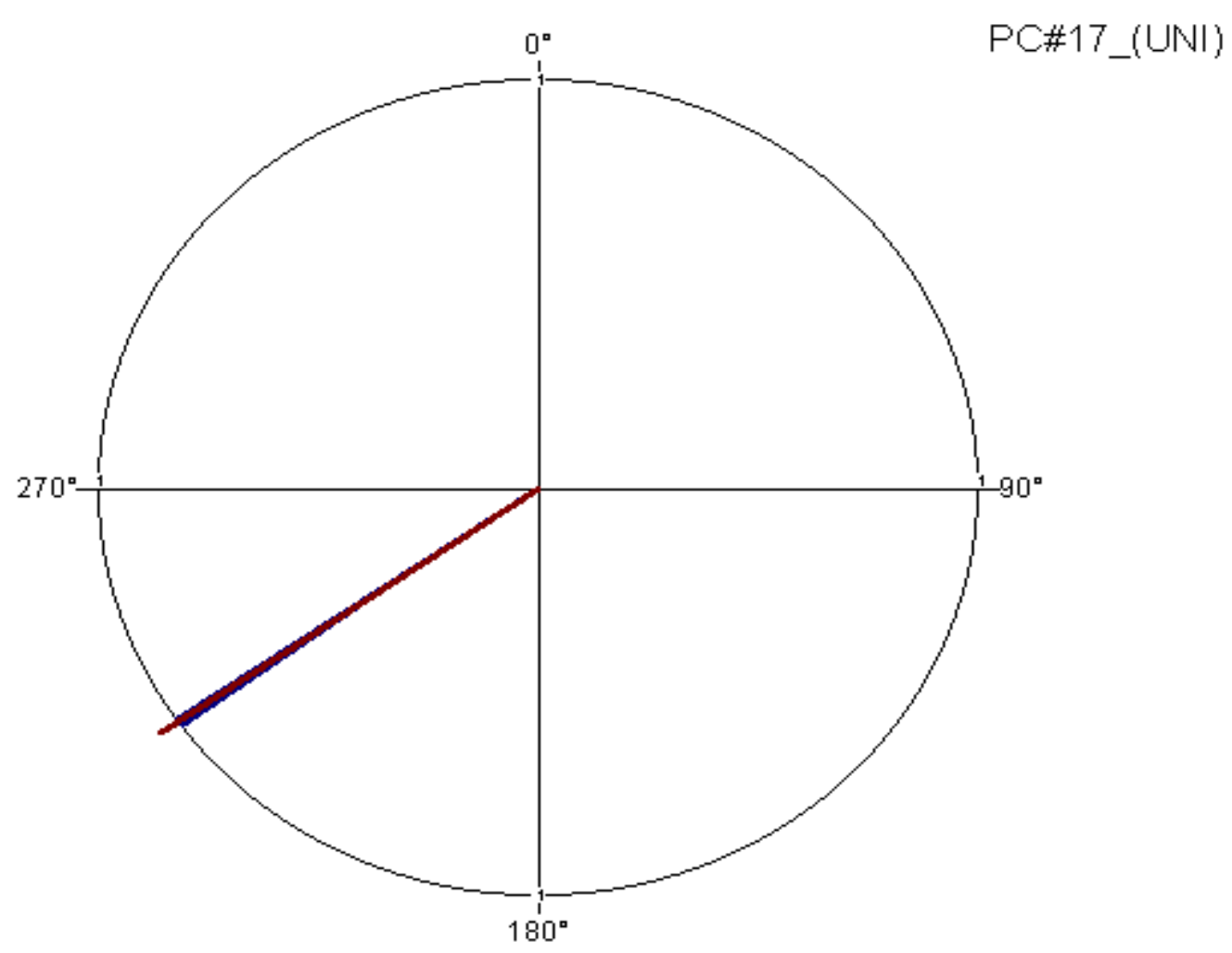

Figure 127. Uni-directional rose diagram for secondary locality 17 in the upper Rockwell Member 


\section{Paleocurrent Stop \# 17 - Upper Rockwell Member}

Sample Label

Quadrangle

Data Type

Observations

Mean vector $(\mu)$

Circular variance

Circular standard deviation

Standard error of mean
PC\#17

Table Rock

Bi-directional

$67.50^{\circ}$

0.91

$126.57^{\circ}$

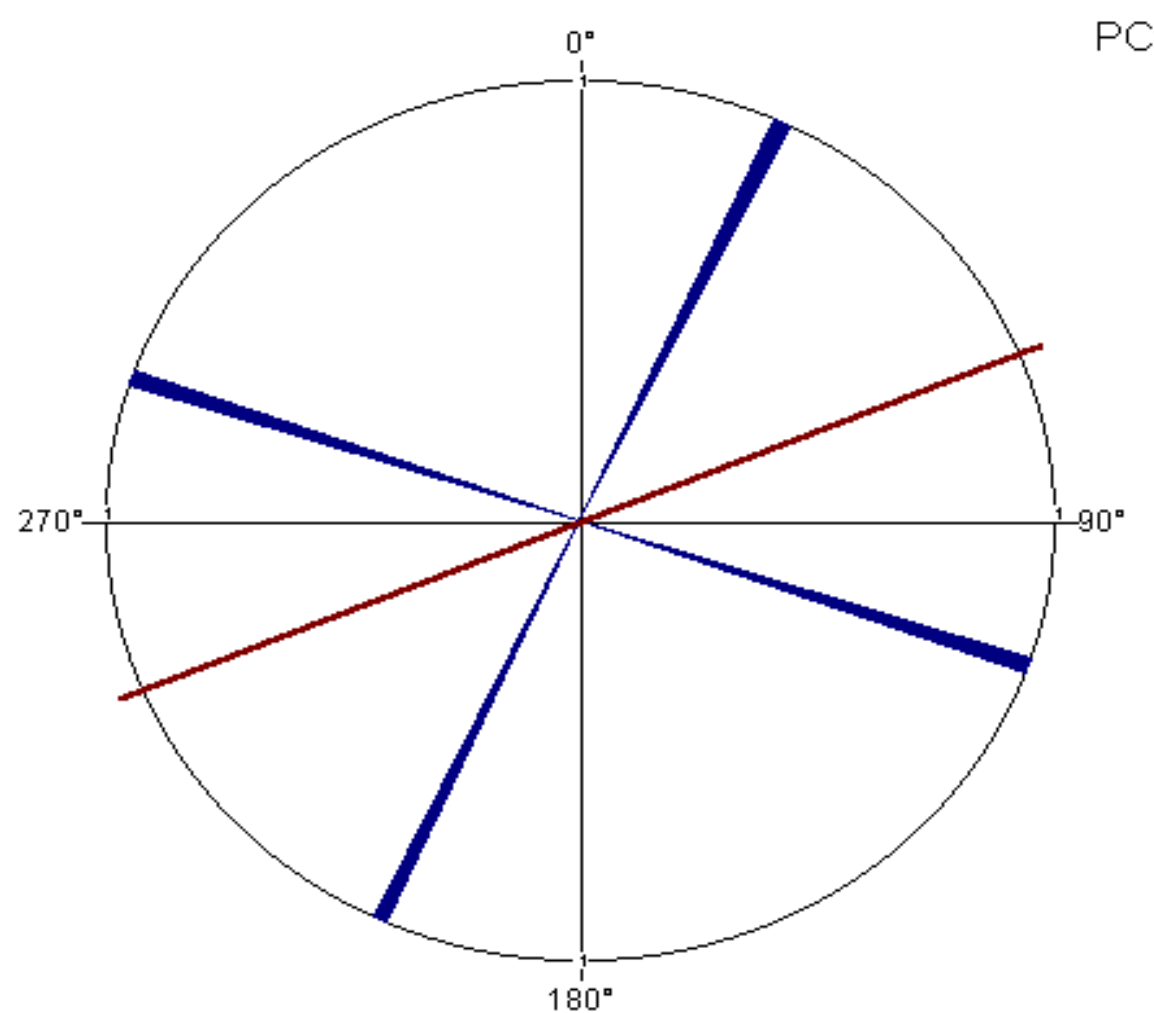

PC\#17_(BI)

Figure 128. Bi-directional rose diagram for secondary locality 17 in the upper Rockwell Member 


\section{Paleocurrent Stop \# 18 - Lower Rockwell Member}

$\begin{array}{lr}\text { Sample Label } & \text { PC\#18 } \\ \text { Quadrangle } & \text { Harman } \\ \text { Data Type } & \text { Uni-directional } \\ \text { Observations } & 2 \\ \text { Mean vector }(\mu) & 147.50^{\circ} \\ \text { Circular variance } & 0.02 \\ \text { Circular standard deviation } & 12.55^{\circ} \\ \text { Standard error of mean } & 28.06^{\circ}\end{array}$

Standard error of mean

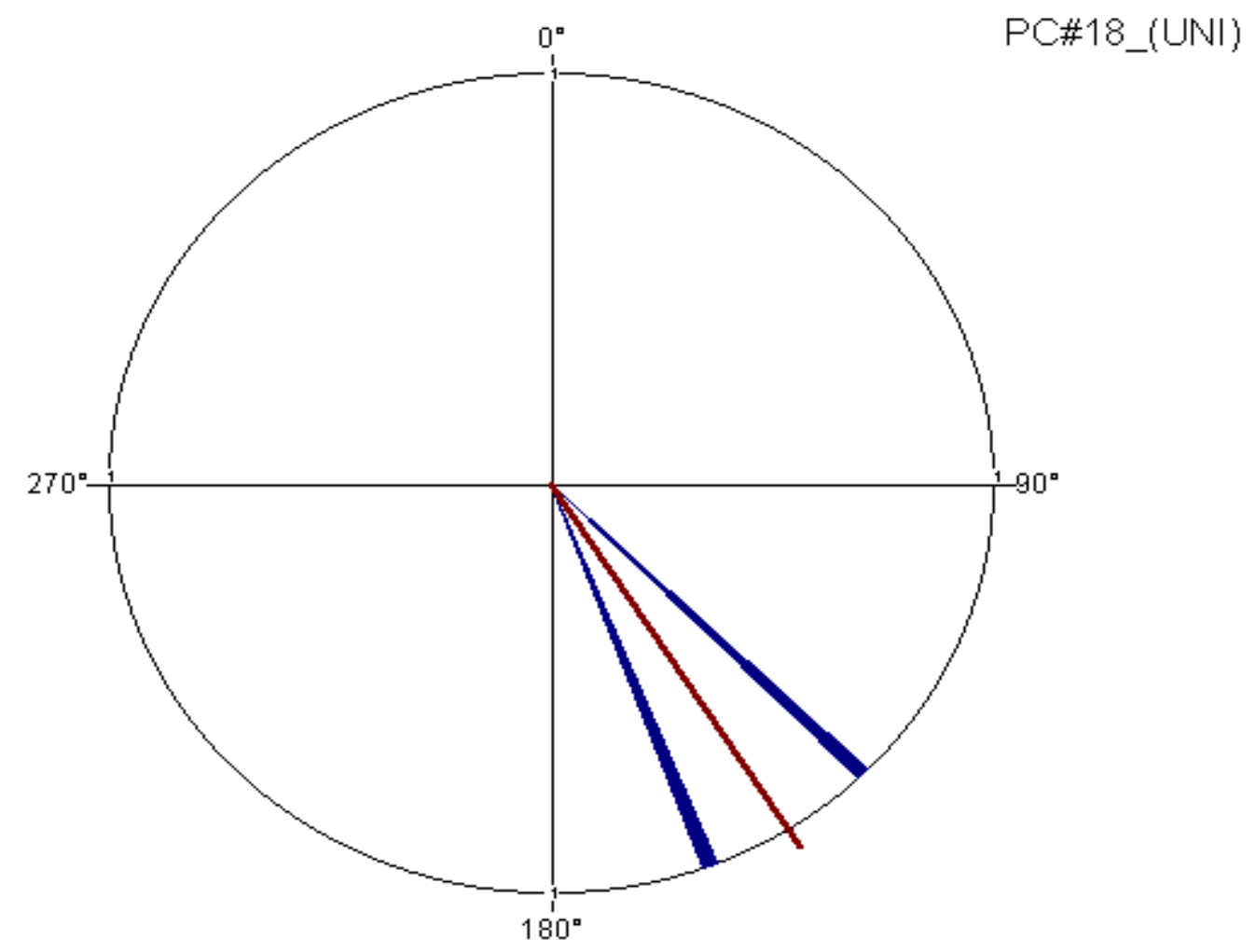

Figure 129. Uni-directional rose diagram for secondary locality 18 in the lower Rockwell Member 


\section{Paleocurrent Stop \# 18 - Lower Rockwell Member}

\section{Sample Label}

Quadrangle

Data Type

Observations

Mean vector $(\mu)$

Circular variance

Circular standard deviation

Standard error of mean
PC\#18

Harman

Bi-directional

$160.00^{\circ}$

$160.00^{\circ}$

$-0.00^{\circ}$

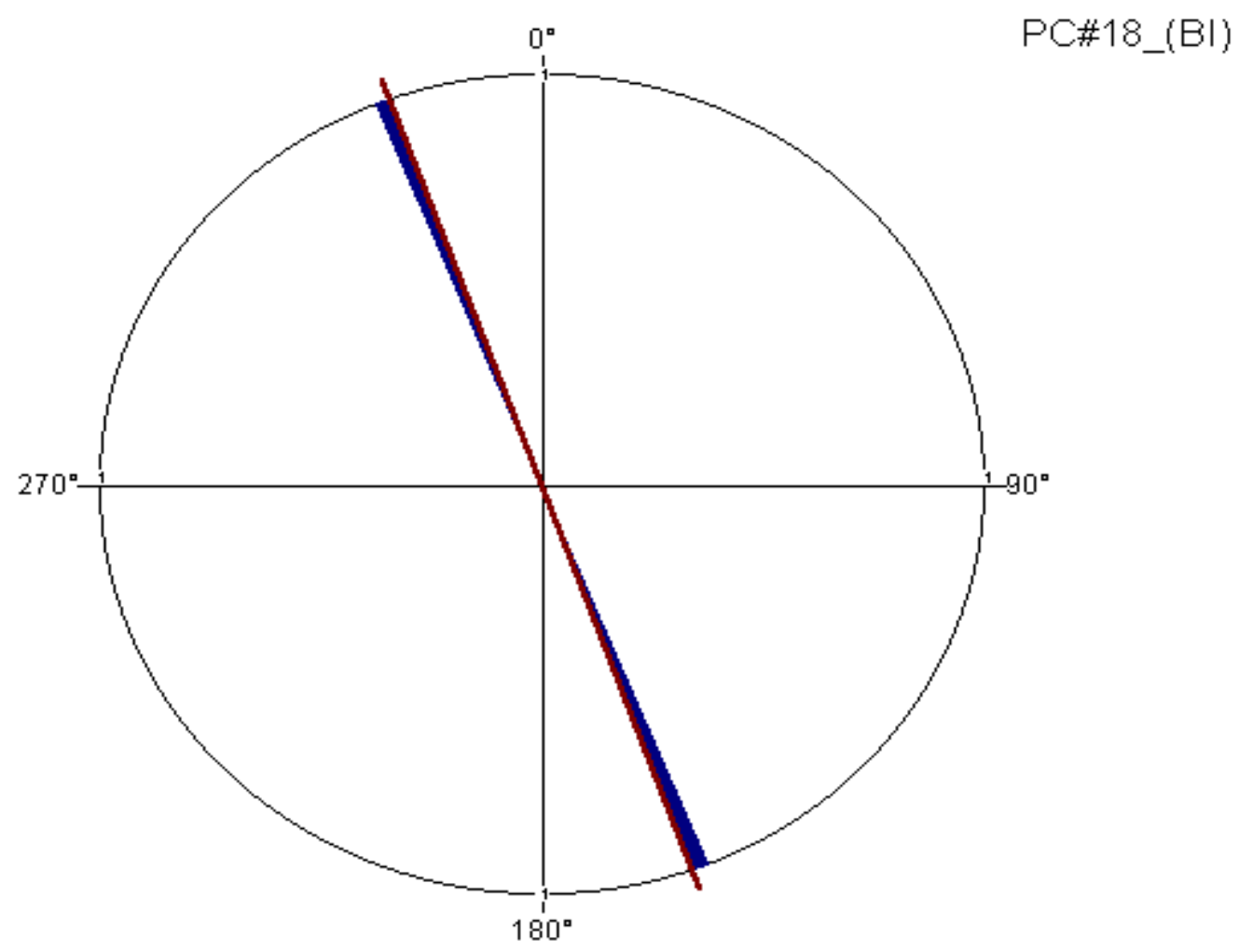

Figure 130. Bi-directional rose diagram for secondary locality 18 in the lower Rockwell Member 


\section{Paleocurrent Stop \# 19 - Lower Rockwell Member}

Sample Label

Quadrangle

Data Type

Observations

Mean vector $(\mu)$

Circular variance

Circular standard deviation

Standard error of mean

PC\#19
Laneville
Uni-directional
1
$250.00^{\circ}$
0
$-0.00^{\circ}$
$* * * * *$

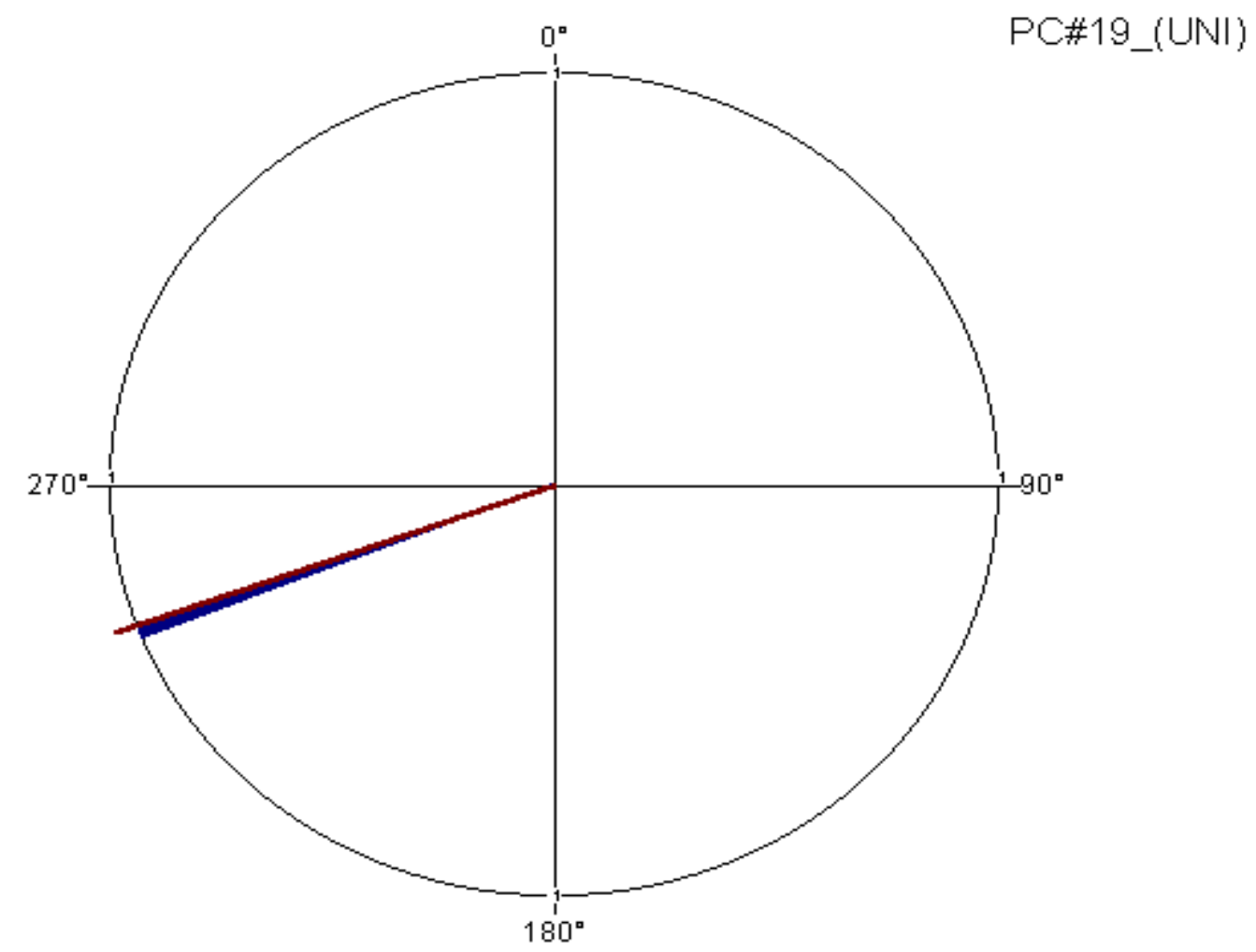

Figure 131. Uni-directional rose diagram for secondary locality 19 in the lower Rockwell Member 


\section{Paleocurrent Stop \# 19 - Lower Rockwell Member}

Sample Label

Quadrangle

Data Type

Observations

Mean vector $(\mu)$

Circular variance

Circular standard deviation

Standard error of mean

PC\#19
Laneville
Bi-directional
2
$70.00^{\circ}$
0
$-0.00^{\circ}$
$\star * * * *$

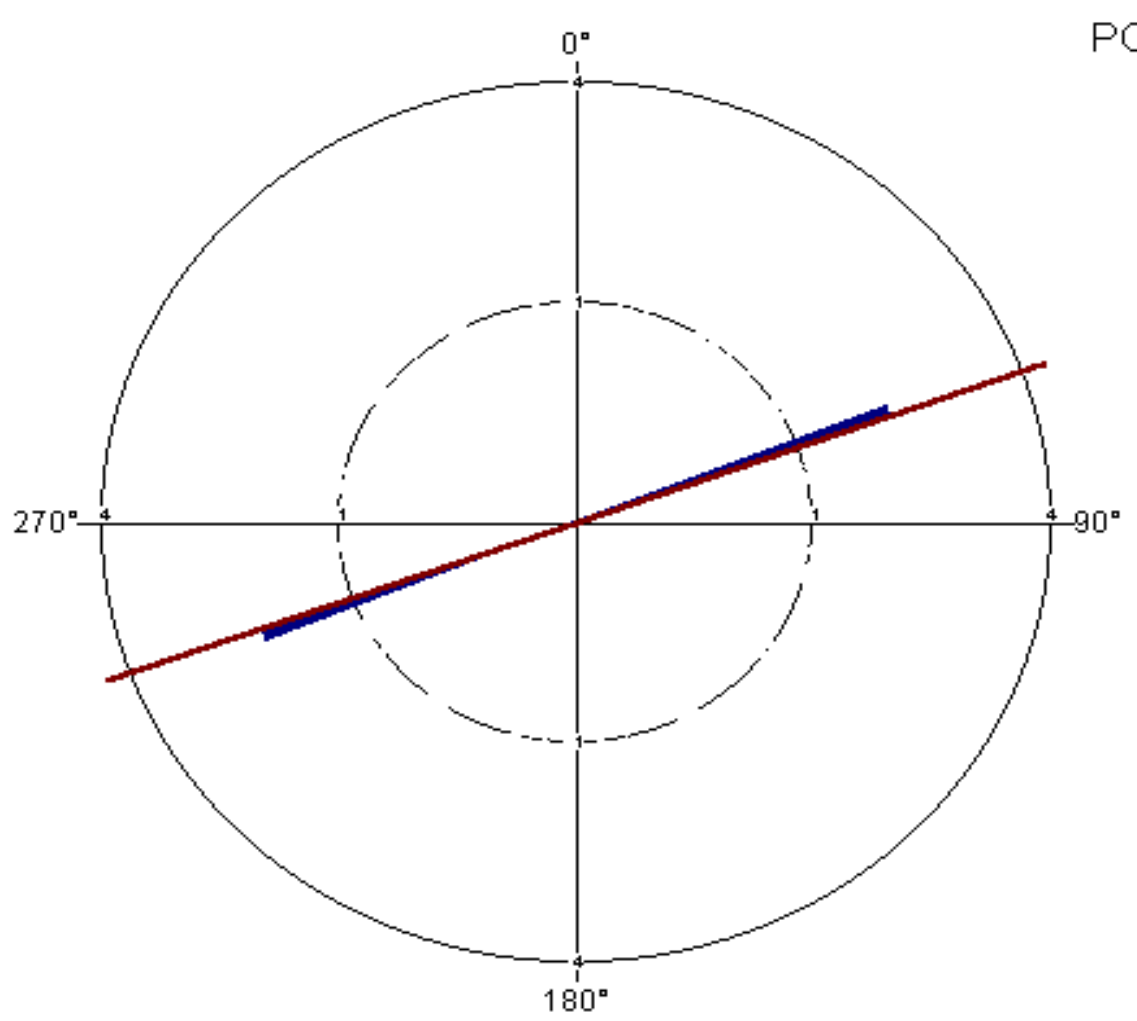

Figure 132. Bi-directional rose diagram for secondary locality 19 in the lower Rockwell Member 


\section{Paleocurrent Stop \# 21 - Upper Rockwell Member}

Sample Label

Quadrangle

Data Type

Observations

Mean vector $(\mu)$

Circular variance

Circular standard deviation

Standard error of mean

PC\#21
Harman
Uni-directional
5
$284.01^{\circ}$
0.02
$12.04^{\circ}$
$7.67^{\circ}$

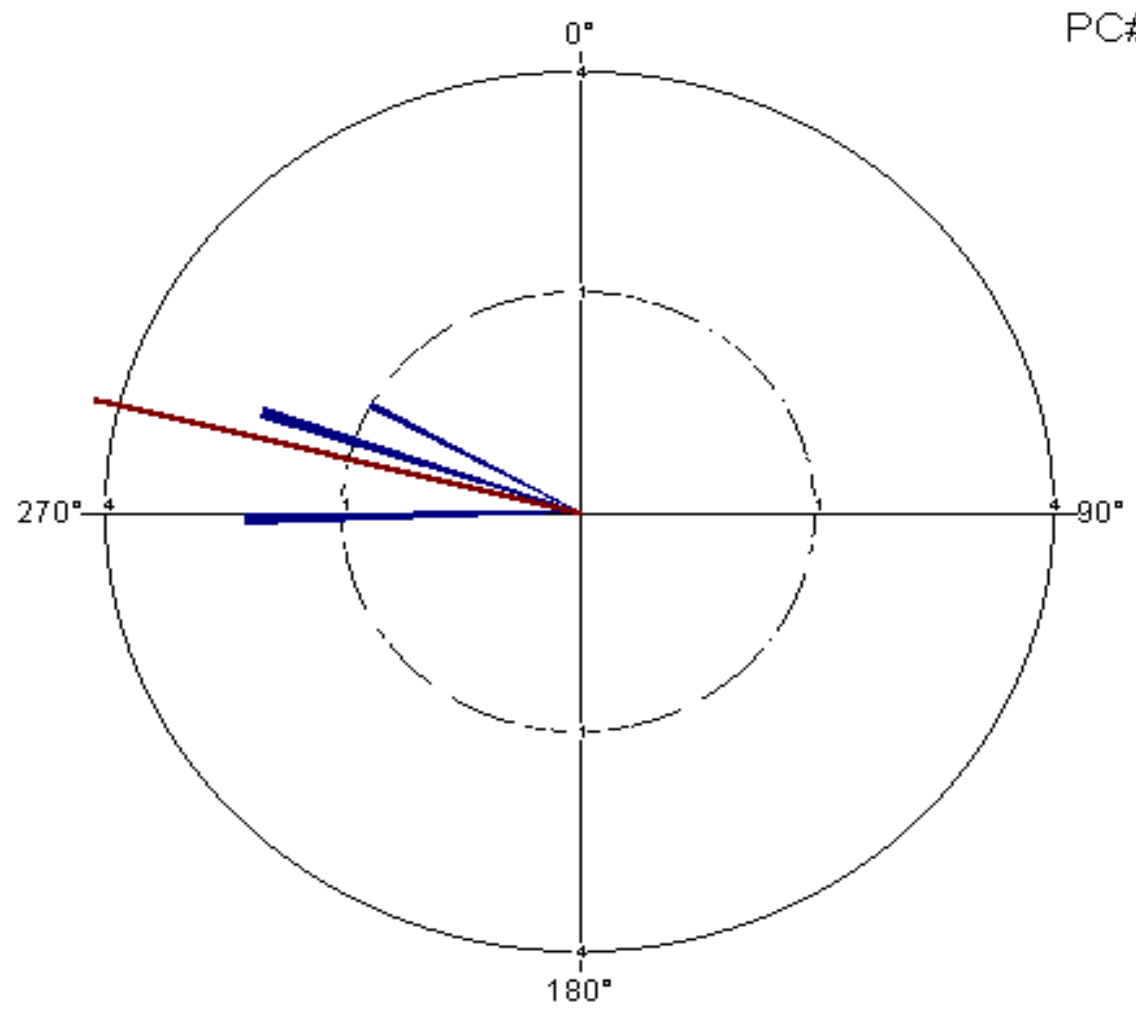

Figure 133. Uni-directional rose diagram for secondary locality 21 in the upper Rockwell Member 


\section{Paleocurrent Stop \# 21 - Upper Rockwell Member}

\section{Sample Label}

Quadrangle

Data Type

Observations

Mean vector $(\mu)$

Circular variance

Circular standard deviation

Standard error of mean
PC\#21

Harman

Bi-directional

1
$60.00^{\circ}$

0

$-0.00^{\circ}$

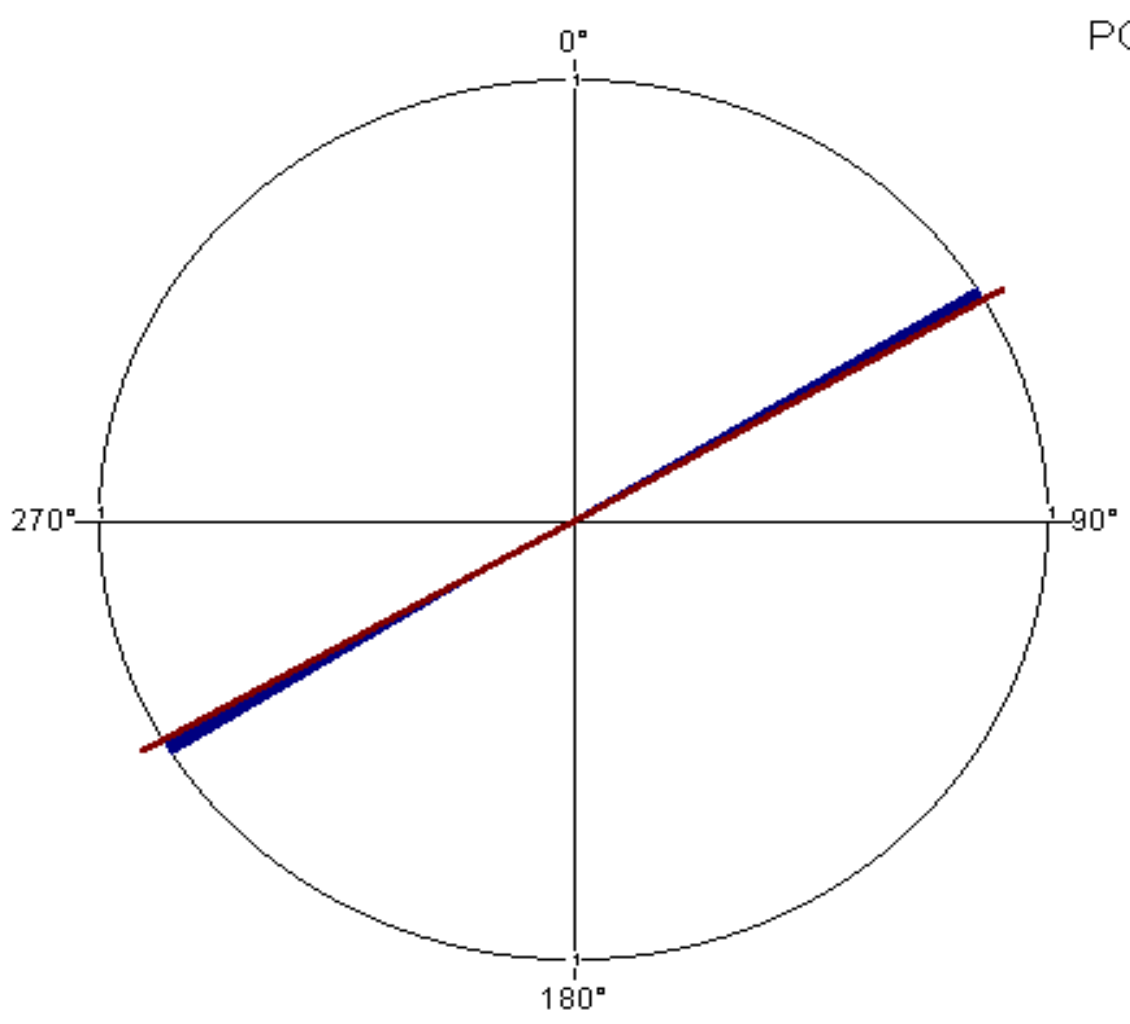

PC\#21_(BI)

Figure 134. Bi-directional rose diagram for secondary locality 21 in the upper Rockwell Member 


\section{Paleocurrent Stop \# 22 - Lower Rockwell Member}

Sample Label

Quadrangle

Data Type

Observations

Mean vector $(\mu)$

Circular variance

Circular standard deviation

Standard error of mean
PC\#22

Harman

Uni-directional

$73.82^{\circ}$

0.31

$49.43^{\circ}$

$26.59^{\circ}$ *

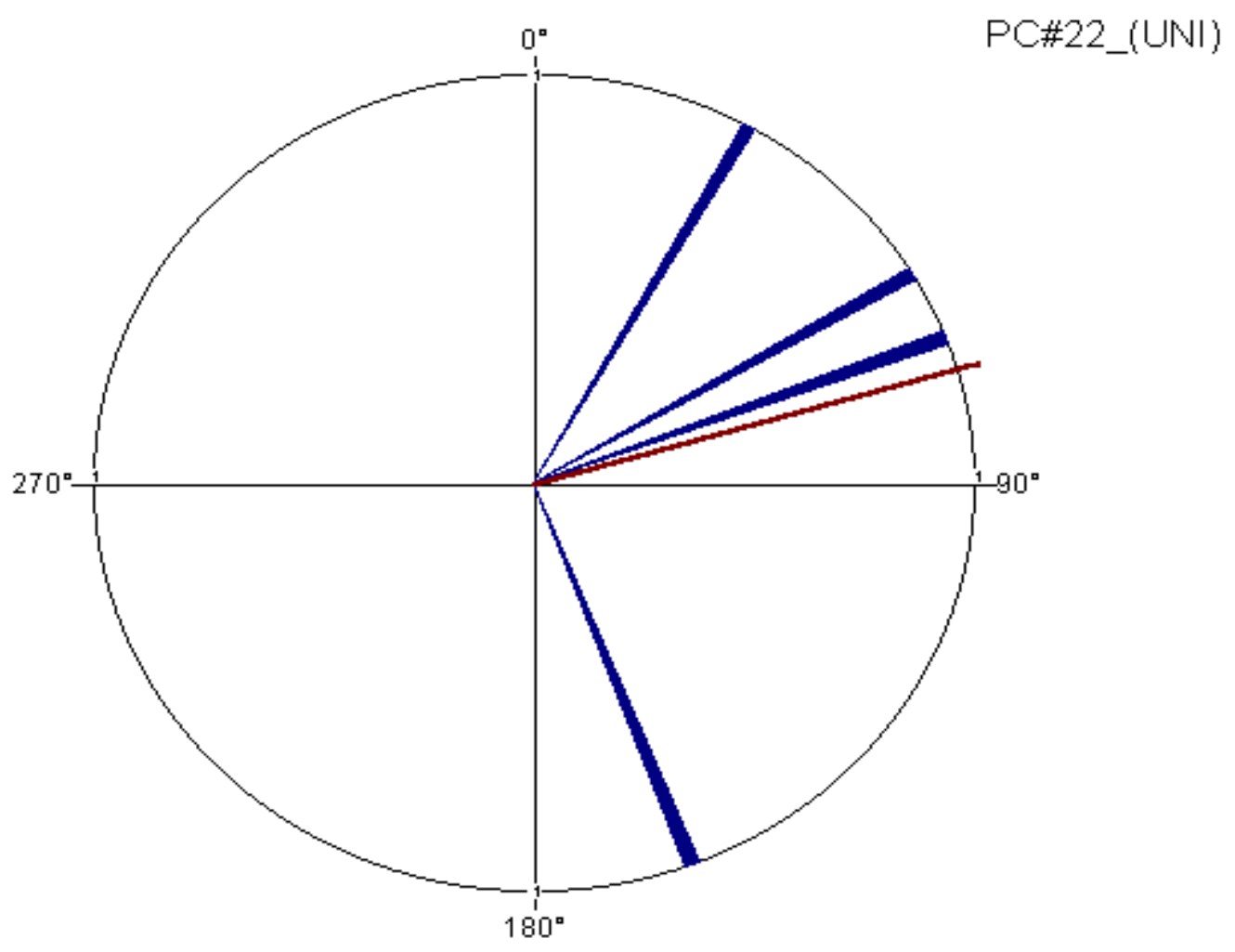

Figure 135. Uni-directional rose diagram for secondary locality 22 in the lower Rockwell Member 


\section{Paleocurrent Stop \# 23 - Upper Rockwell Member}

\section{Sample Label}

Quadrangle

Data Type

Observations

Mean vector $(\mu)$

Circular variance

Circular standard deviation

Standard error of mean

PC\#23
Harman
Uni-directional
2
$222.50^{\circ}$
0
$2.50^{\circ}$
$5.59^{\circ}$

Figure 136. Uni-directional rose diagram for secondary locality 23 in the upper Rockwell Member 


\section{Paleocurrent Stop \# 24 - Upper Rockwell Member}

Sample Label

Quadrangle

Data Type

Observations

Mean vector $(\mu)$

Circular variance

Circular standard deviation

Standard error of mean

PC\#24
Laneville
Bi-directional
2
$50.00^{\circ}$
0.06
$20.21^{\circ}$
$45.16^{\circ}$ *

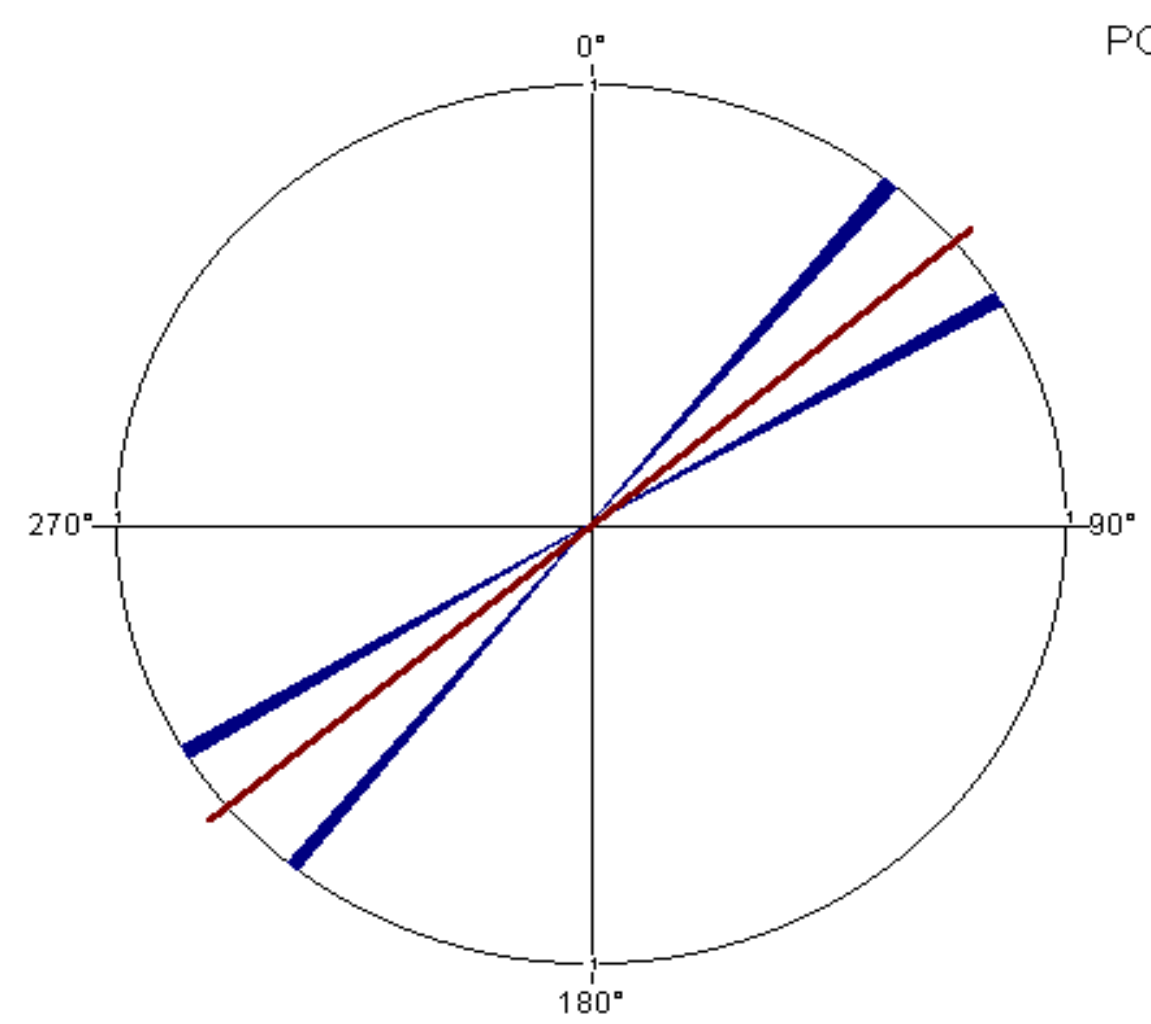

PC\#24_(BI)

Figure 137. Bi-directional rose diagram for secondary locality 24 in the upper Rockwell Member 


\section{Paleocurrent Stop \# 25 - Upper Rockwell Member}

Sample Label

Quadrangle

Data Type

Observations

Mean vector $(\mu)$

Circular variance

Circular standard deviation

Standard error of mean

PC\#25
Laneville
Bi-directional
1
$115.00^{\circ}$
0
$-0.00^{\circ}$
$\star \star \star \star \star$

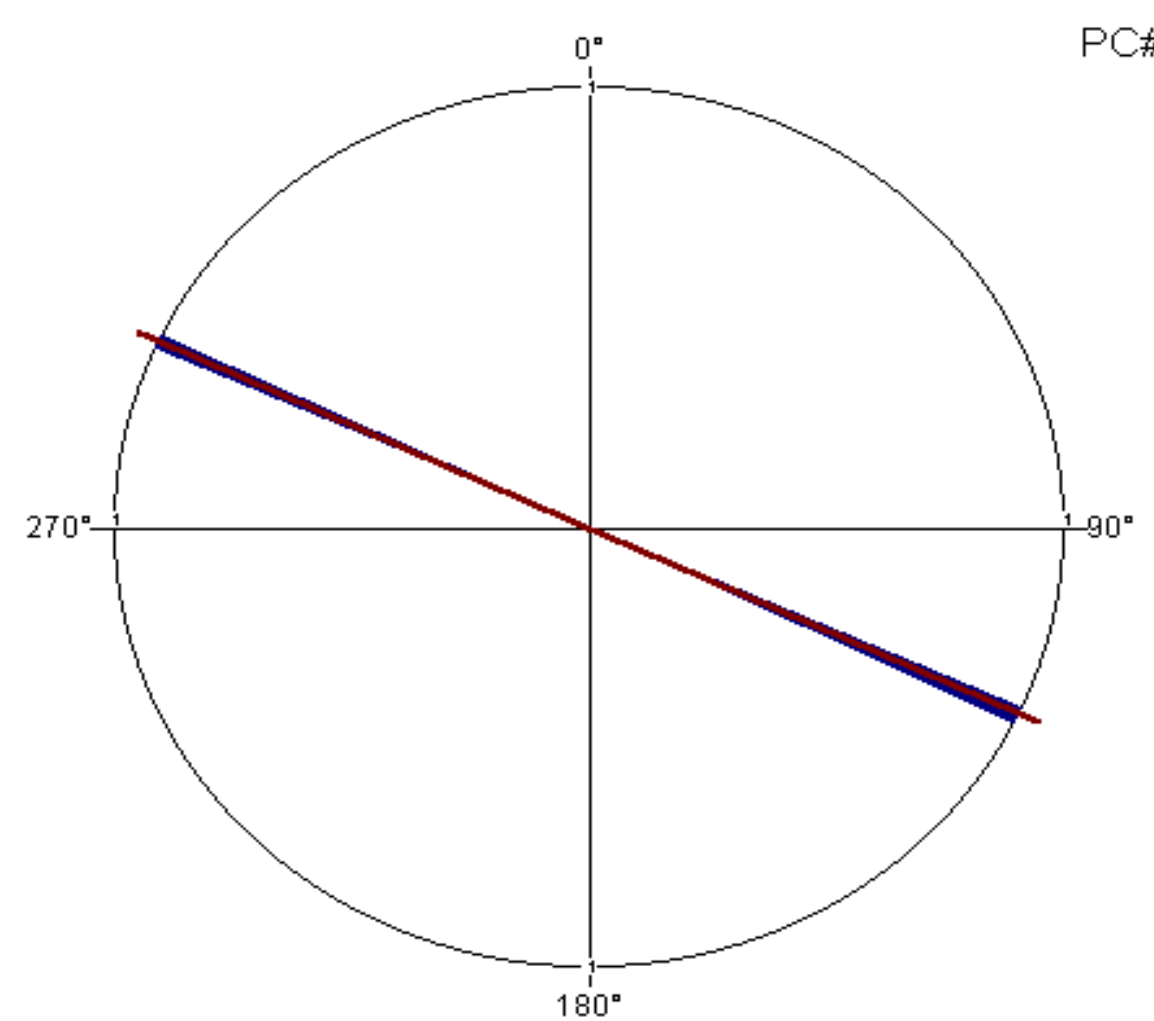

Figure 138. Bi-directional rose diagram for secondary locality 25 in the upper Rockwell Member 


\section{Paleocurrent Stop \# 26 - Upper Rockwell Member}

$\begin{array}{lr}\text { Sample Label } & \text { PC\#26 } \\ \text { Quadrangle } & \text { Laneville } \\ \text { Data Type } & \text { Uni-directional } \\ \text { Observations } & 3 \\ \text { Mean vector }(\mu) & 273.27^{\circ} \\ \text { Circular variance } & 0.02 \\ \text { Circular standard deviation } & 11.82^{\circ} \\ \text { Standard error of mean } & 13.21^{\circ}\end{array}$

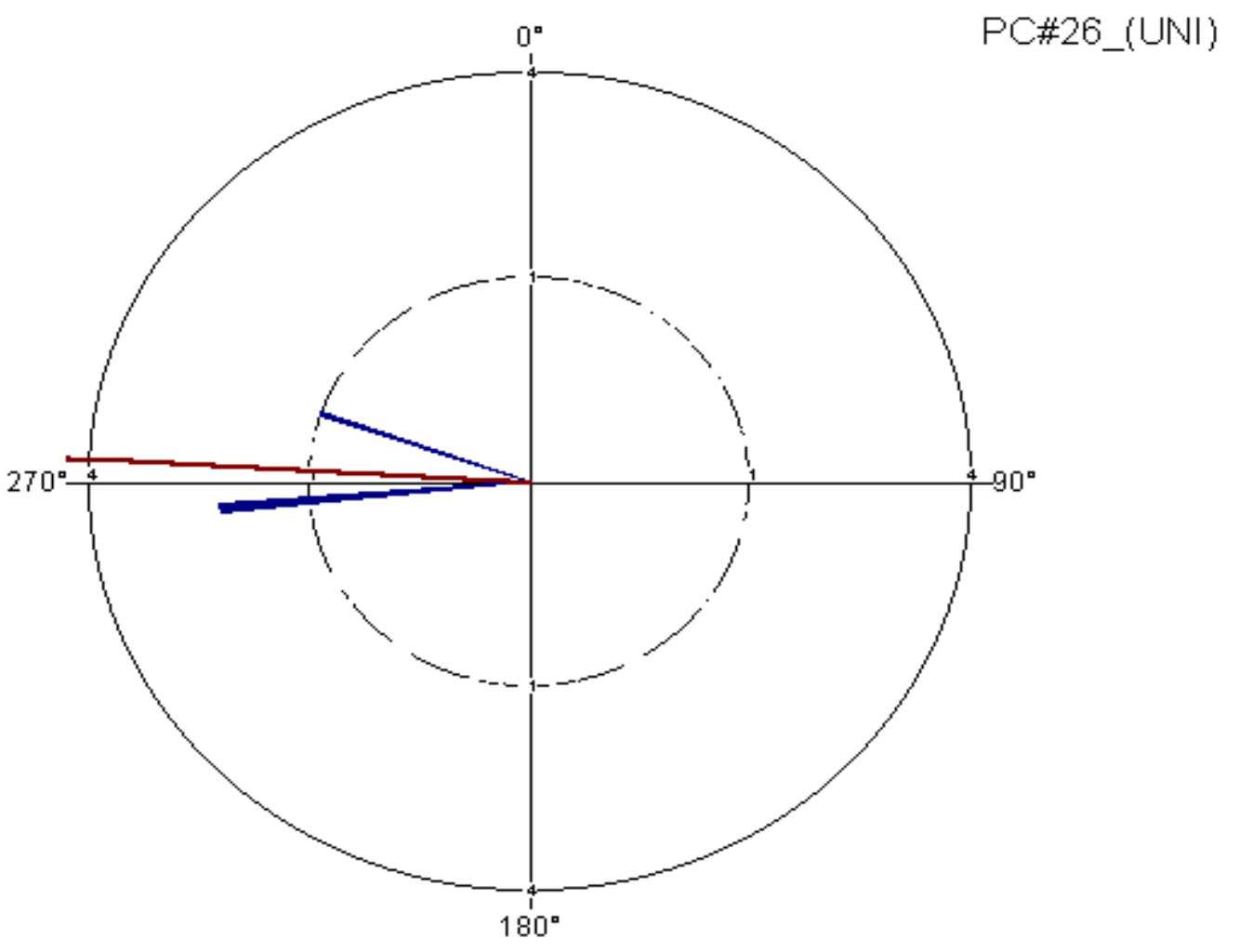

Figure 139. Uni-directional rose diagram for secondary locality 26 in the upper Rockwell Member 


\section{Paleocurrent Stop \# 29 - Upper Rockwell Member}

$\begin{array}{lr}\text { Sample Label } & \begin{array}{r}\text { PC\#29 } \\ \text { Harman }\end{array} \\ \text { Quadrangle } & \text { Uni-directional } \\ \text { Data Type } & 1 \\ \text { Observations } & 115.00^{\circ} \\ \text { Mean vector }(\mu) & 0 \\ \text { Circular variance } & -0.00^{\circ} \\ \text { Circular standard deviation } & * \star \star \star * \\ \text { Standard error of mean } & \end{array}$

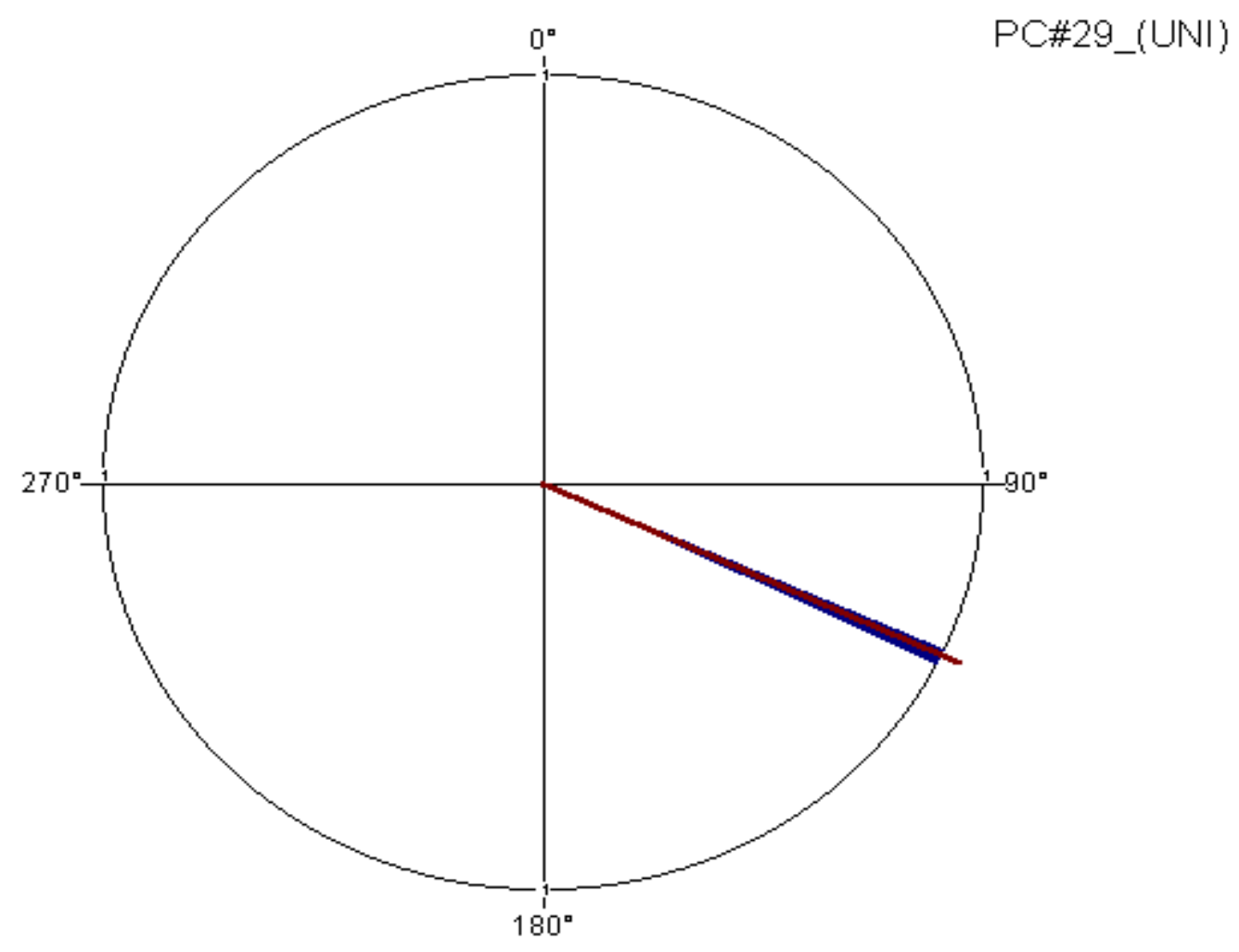

Figure 140. Uni-directional rose diagram for secondary locality 29 in the upper Rockwell Member 


\section{Paleocurrent Stop \# 30 - Lower Rockwell Member}

Sample Label

Quadrangle

Data Type

Observations

Mean vector $(\mu)$

Circular variance

Circular standard deviation

Standard error of mean

PC\#30
Harman
Uni-directional
3
$251.64^{\circ}$
0.01
$9.44^{\circ}$
$10.56^{\circ}$

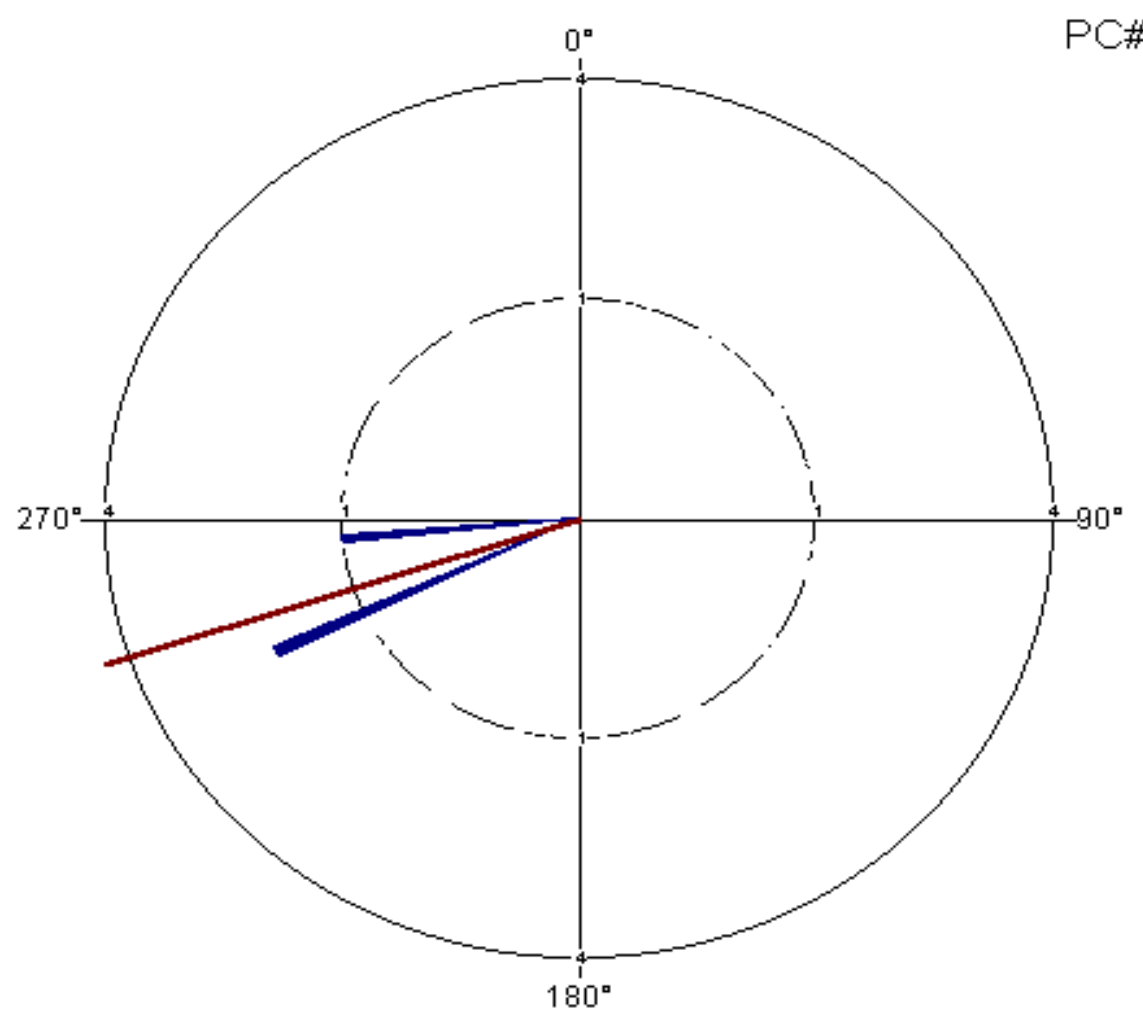

Figure 141. Uni-directional rose diagram for secondary locality 30 in the lower Rockwell Member 


\section{Paleocurrent Stop \# 31 - Lower Rockwell Member}

Sample Label

Quadrangle

Data Type

Observations

Mean vector $(\mu)$

Circular variance

Circular standard deviation

Standard error of mean

PC\#31
Onego
Uni-directional
1
$285.00^{\circ}$
0
$-0.00^{\circ}$
$\star \star \star \star *$

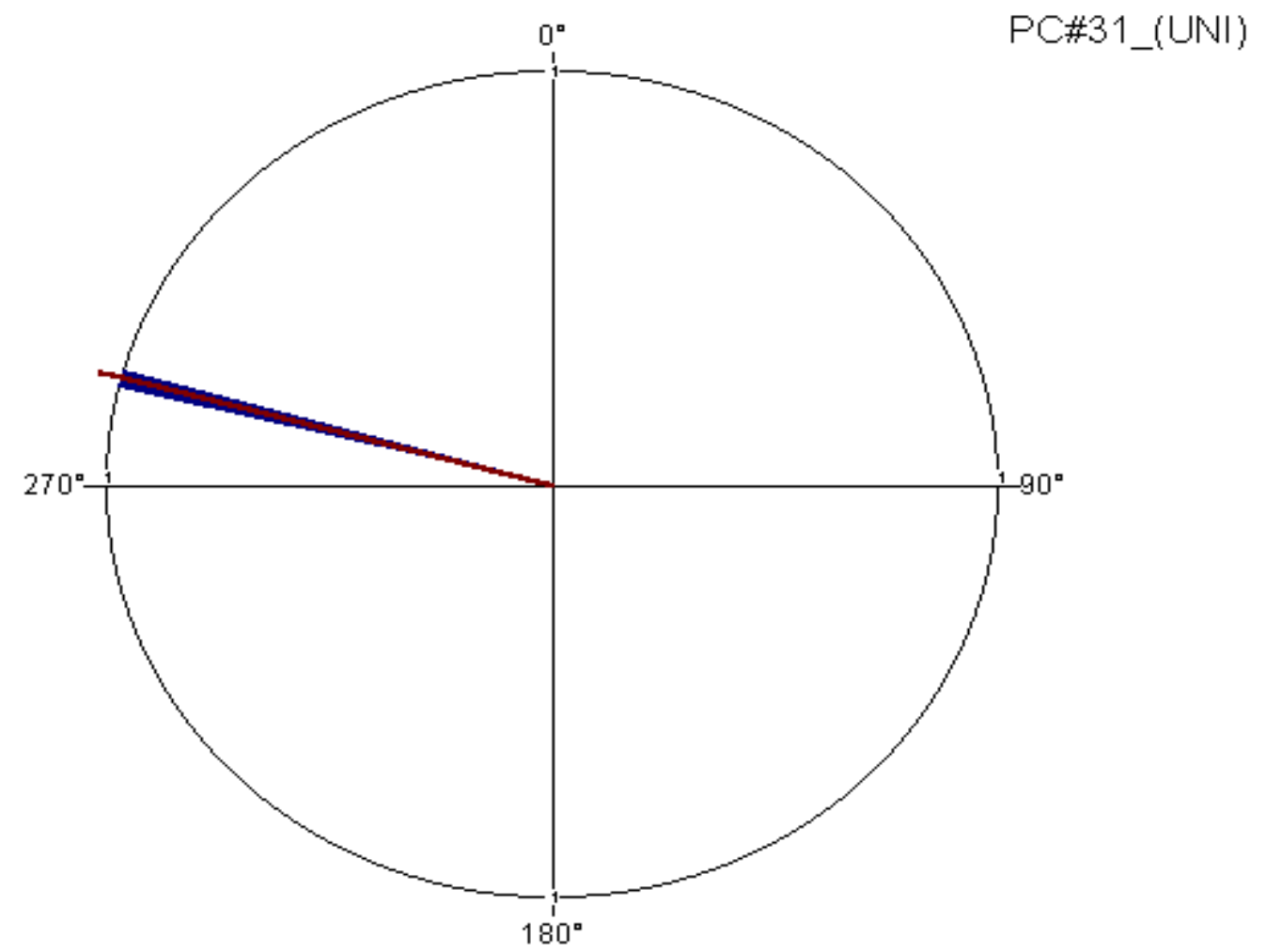

Figure 142. Uni-directional rose diagram for secondary locality 31 in the lower Rockwell Member 


\section{Paleocurrent Stop \# 31 - Lower Rockwell Member}

Sample Label

Quadrangle

Data Type

Observations

Mean vector $(\mu)$

Circular variance

Circular standard deviation

Standard error of mean

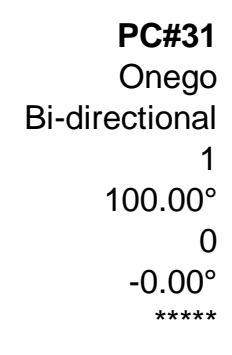

PC\#31_(BI)

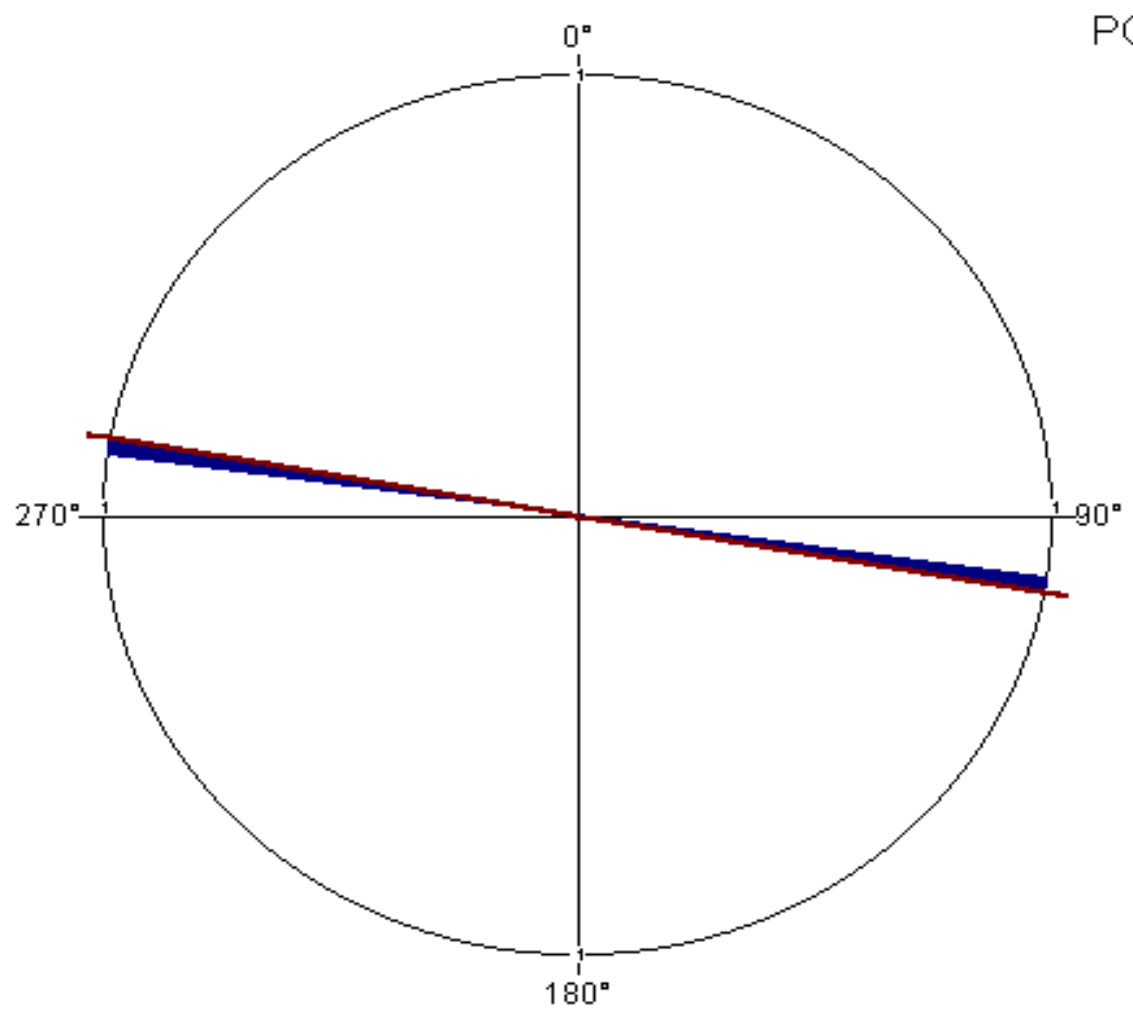

Figure 143. Bi-directional rose diagram for secondary locality 31 in the lower Rockwell Member 


\section{Paleocurrent Stop \# 32 - Lower Rockwell Member}

$\begin{array}{lr}\text { Sample Label } & \text { PC\#32 } \\ \text { Quadrangle } & \text { Onego } \\ \text { Data Type } & \text { Uni-directional } \\ \text { Observations } & 2 \\ \text { Mean vector }(\mu) & 192.50^{\circ} \\ \text { Circular variance } & 0.54 \\ \text { Circular standard deviation } & 71.23^{\circ} \\ \text { Standard error of mean } & * \star \star \star *\end{array}$

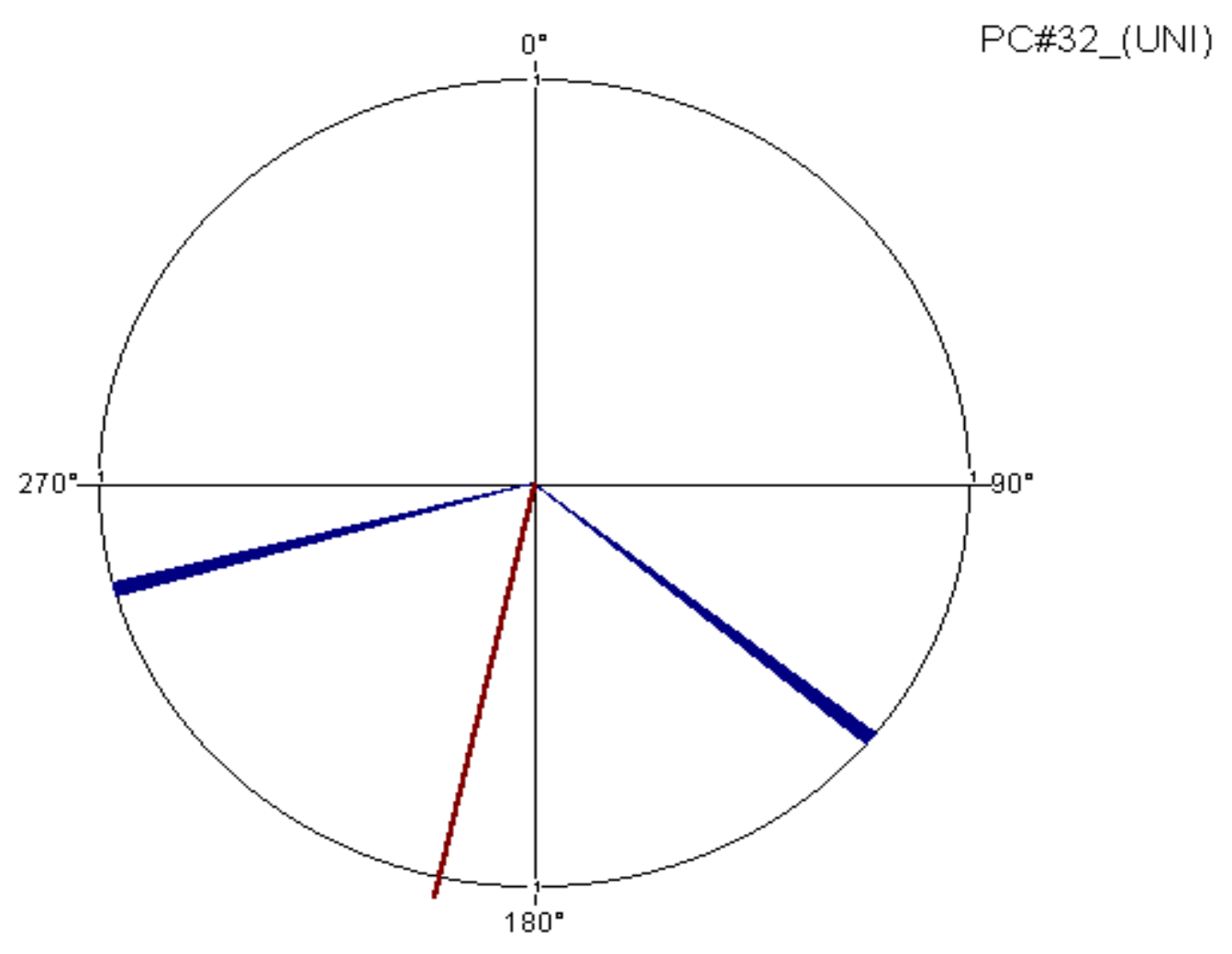

Figure 144. Uni-directional rose diagram for secondary locality 32 in the lower Rockwell Member 


\section{Paleocurrent Stop \# 32 - Lower Rockwell Member}

Sample Label

Quadrangle

Data Type

Observations

Mean vector $(\mu)$

Circular variance

Circular standard deviation

Standard error of mean

PC\#32
Onego
Bi-directional
1
$120.00^{\circ}$
0
$-0.00^{\circ}$
$* * * *$

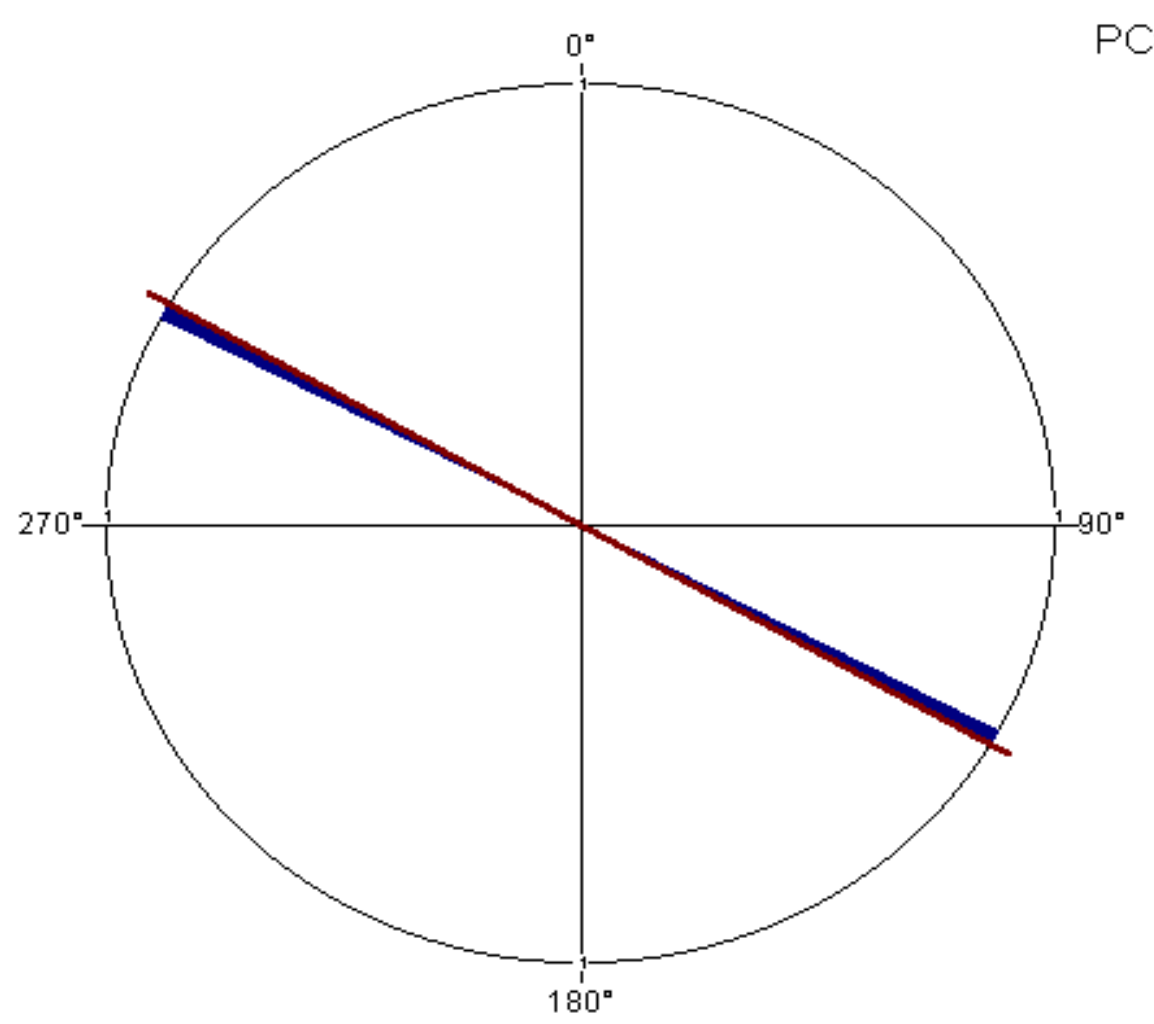

Figure 145. Bi-directional rose diagram for secondary locality 32 in the lower Rockwell Member 


\section{Paleocurrent Stop \# 33 - Lower Rockwell Member}

\section{Sample Label}

Quadrangle

Data Type

Observations

Mean vector $(\mu)$

Circular variance

Circular standard deviation

Standard error of mean
PC\#33

Spruce Knob

Uni-directional

$90.00^{\circ}$

0

$-0.00^{\circ}$

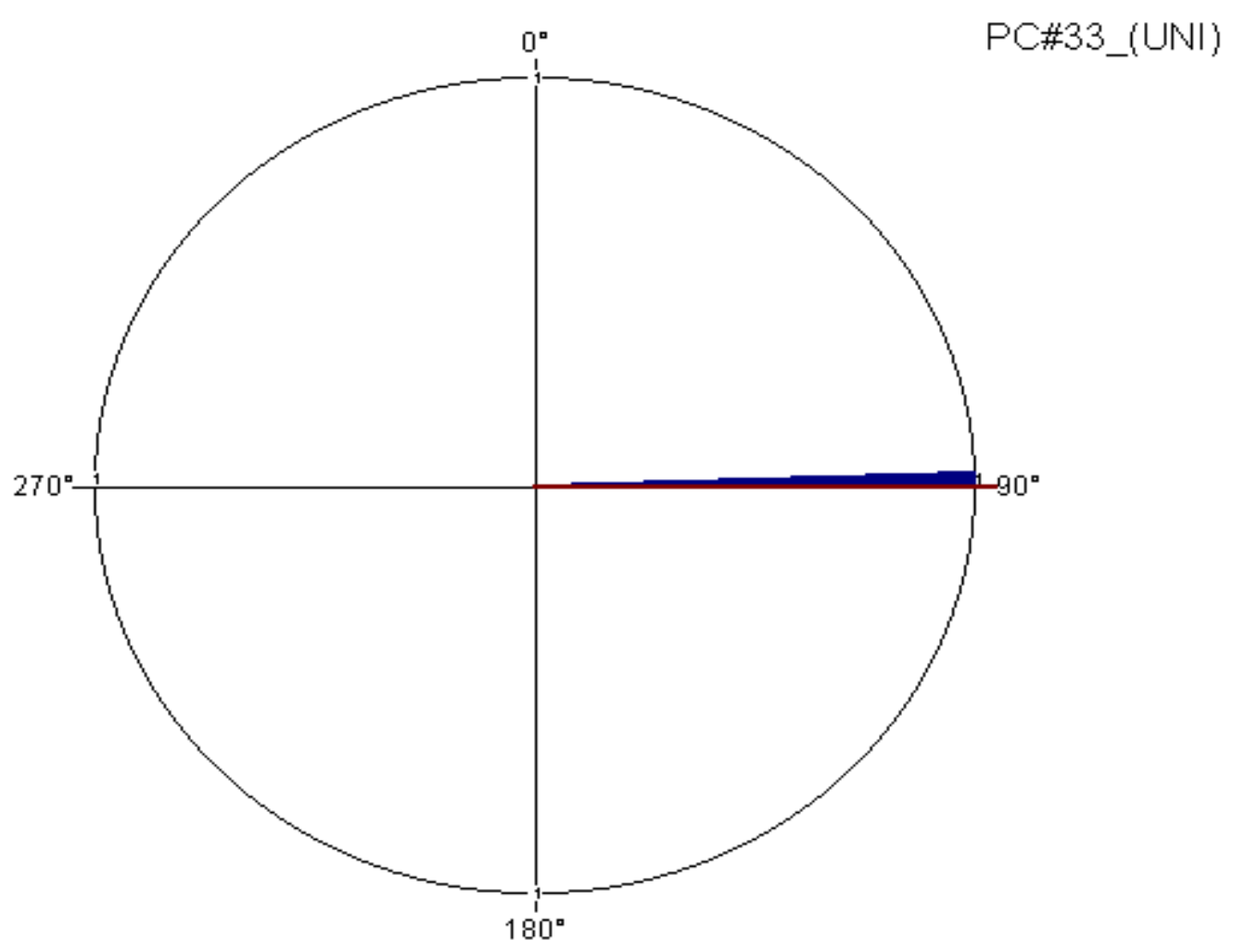

Figure 146. Uni-directional rose diagram for secondary locality 33 in the lower Rockwell Member 


\section{Paleocurrent Stop \# 34 - Upper Rockwell Member}

Sample Label

Quadrangle

Data Type

Observations

Mean vector $(\mu)$

Circular variance

Circular standard deviation

Standard error of mean
PC\#34

Spruce Knob

Uni-directional

3
$83^{\circ}$

$33.83^{\circ}$

0.16

$34.37^{\circ}$

$38.17^{\circ}$ *

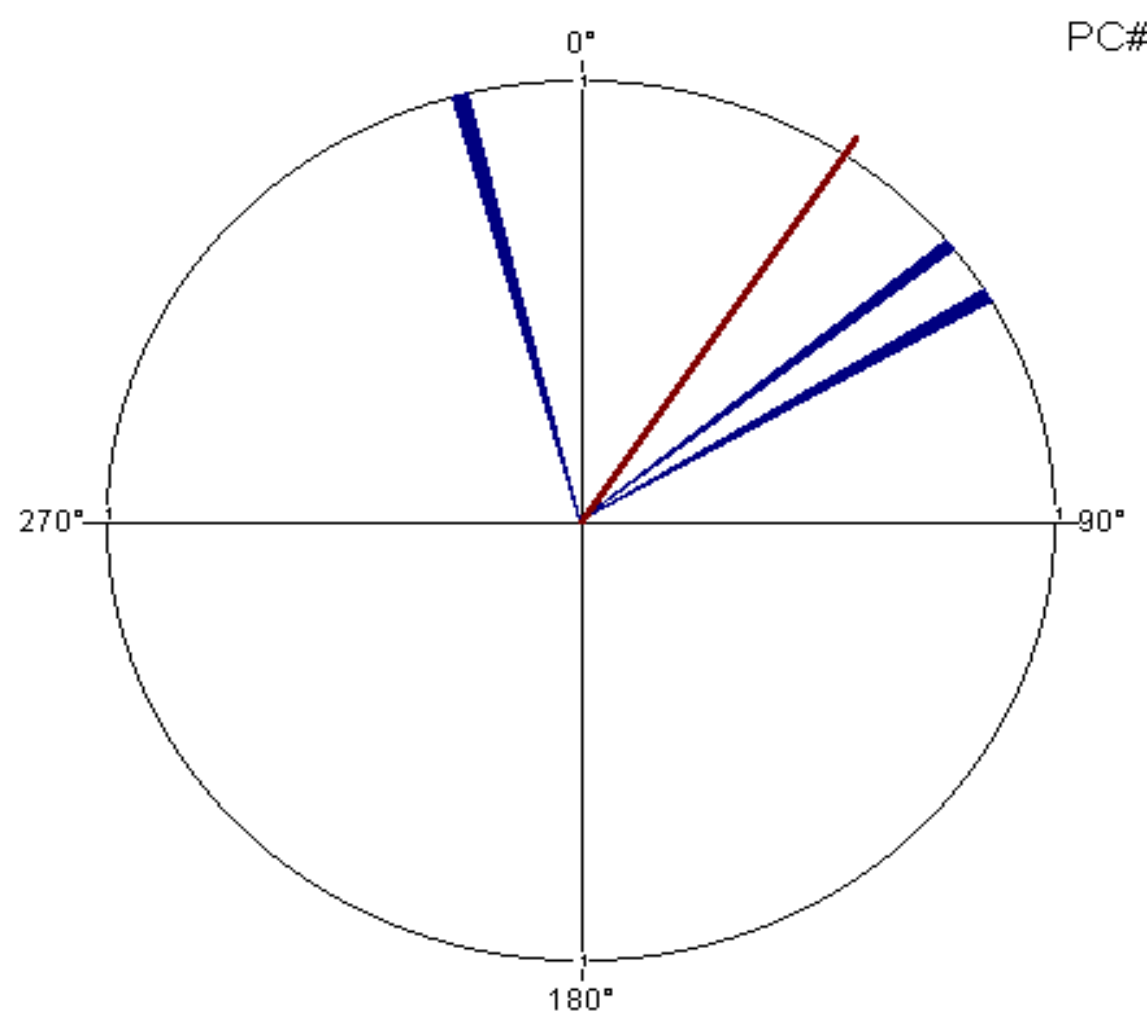

Figure 147. Uni-directional rose diagram for secondary locality 34 in the upper Rockwell Member 


\section{Paleocurrent Stop \# 35 - Lower Rockwell Member}

\section{Sample Label}

Quadrangle

Data Type

Observations

Mean vector $(\mu)$

Circular variance

Circular standard deviation

Standard error of mean

PC\#35
Glady
Uni-directional
6
$243.06^{\circ}$
0.13
$30.14^{\circ}$
$16.35^{\circ}$

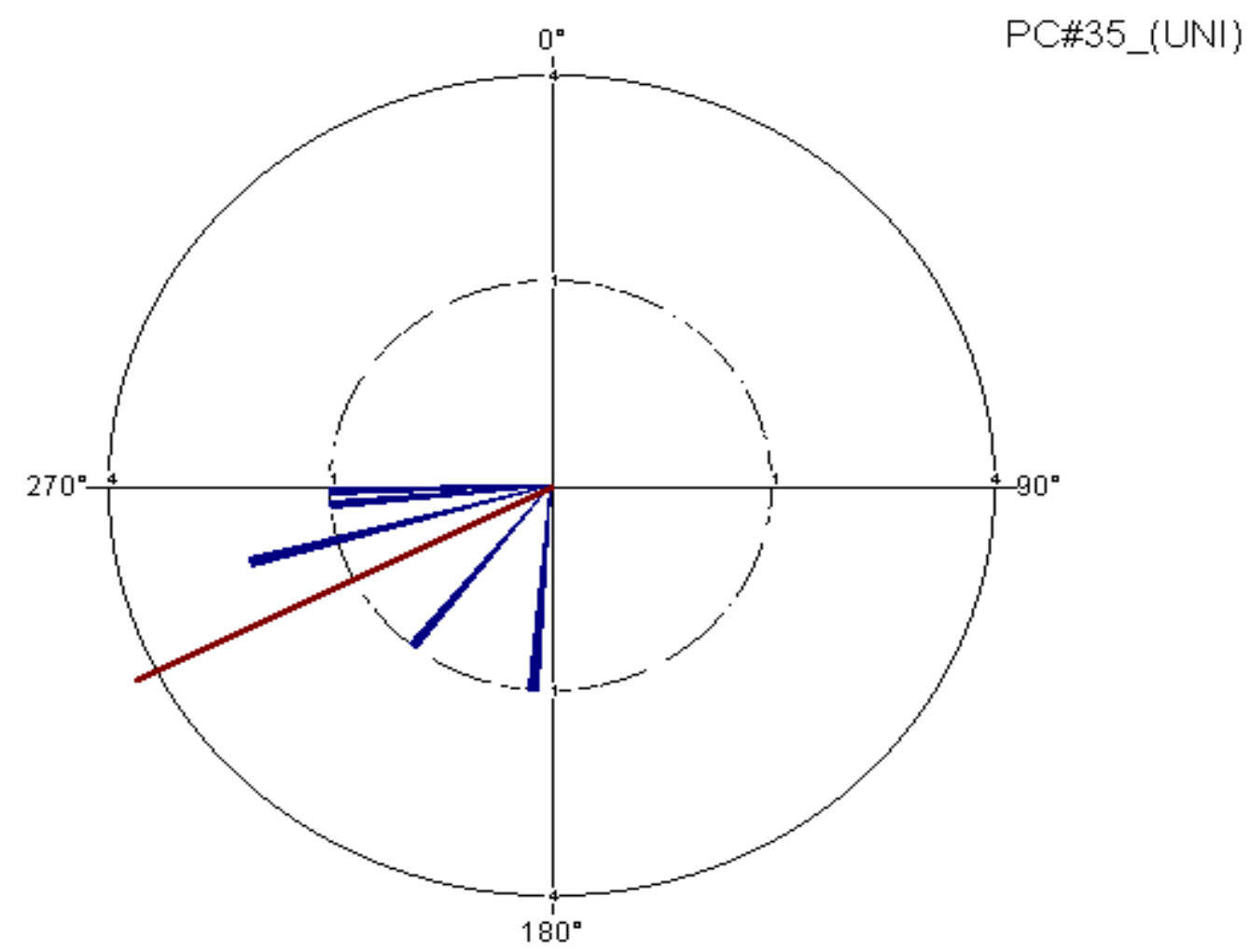

Figure 148. Uni-directional rose diagram for secondary locality 35 in the lower Rockwell Member 


\section{Paleocurrent Stop \# 36 - Upper Rockwell Member}

Sample Label

Quadrangle

Data Type

Observations

Mean vector $(\mu)$

Circular variance

Circular standard deviation

Standard error of mean

PC\#36
Onego
Uni-directional
1
$295.00^{\circ}$
0
$-0.00^{\circ}$
$\star \star \star \star \star$

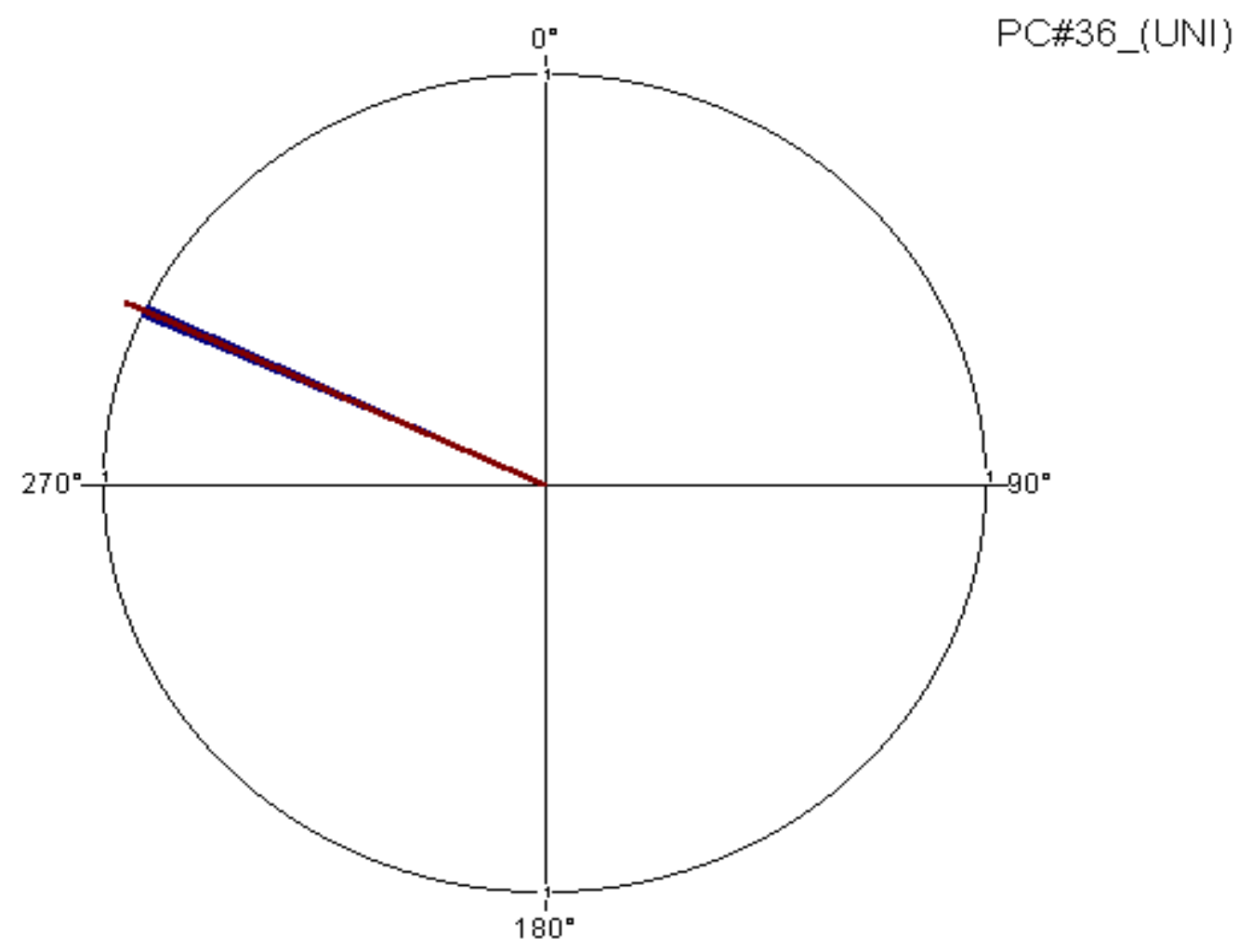

Figure 149. Uni-directional rose diagram for secondary locality 36 in the upper Rockwell Member 


\section{Paleocurrent Stop \# 36 - Upper Rockwell Member}

$\begin{array}{lr}\text { Sample Label } & \text { PC\#36 } \\ \text { Quadrangle } & \text { Onego } \\ \text { Data Type } & \text { Bi-directional } \\ \text { Observations } & 4 \\ \text { Mean vector }(\mu) & 165.76^{\circ} \\ \text { Circular variance } & 0.13 \\ \text { Circular standard deviation } & 29.77^{\circ} \\ \text { Standard error of mean } & 23.56^{\circ} \text { * }\end{array}$

Standard error of mean

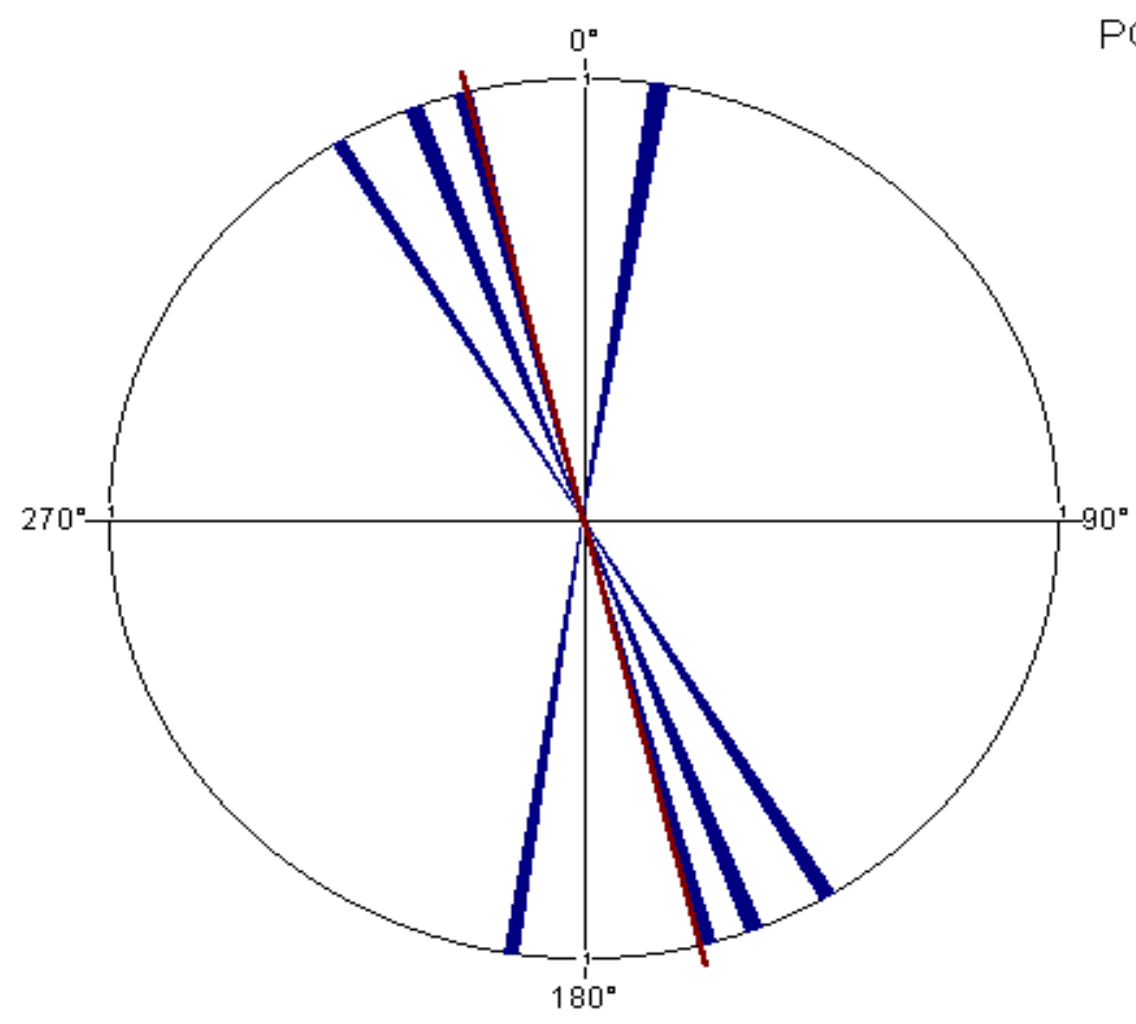

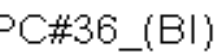

Figure 150. Bi-directional rose diagram for secondary locality 36 in the upper Rockwell Member 


\section{Paleocurrent Stop \# 37 - Lower Rockwell Member}

Sample Label

Quadrangle

Data Type

Observations

Mean vector $(\mu)$

Circular variance

Circular standard deviation

Standard error of mean

PC\#37
Onego
Bi-directional
2
$160.00^{\circ}$
0.06
$20.21^{\circ}$
$45.16^{\circ}$ *

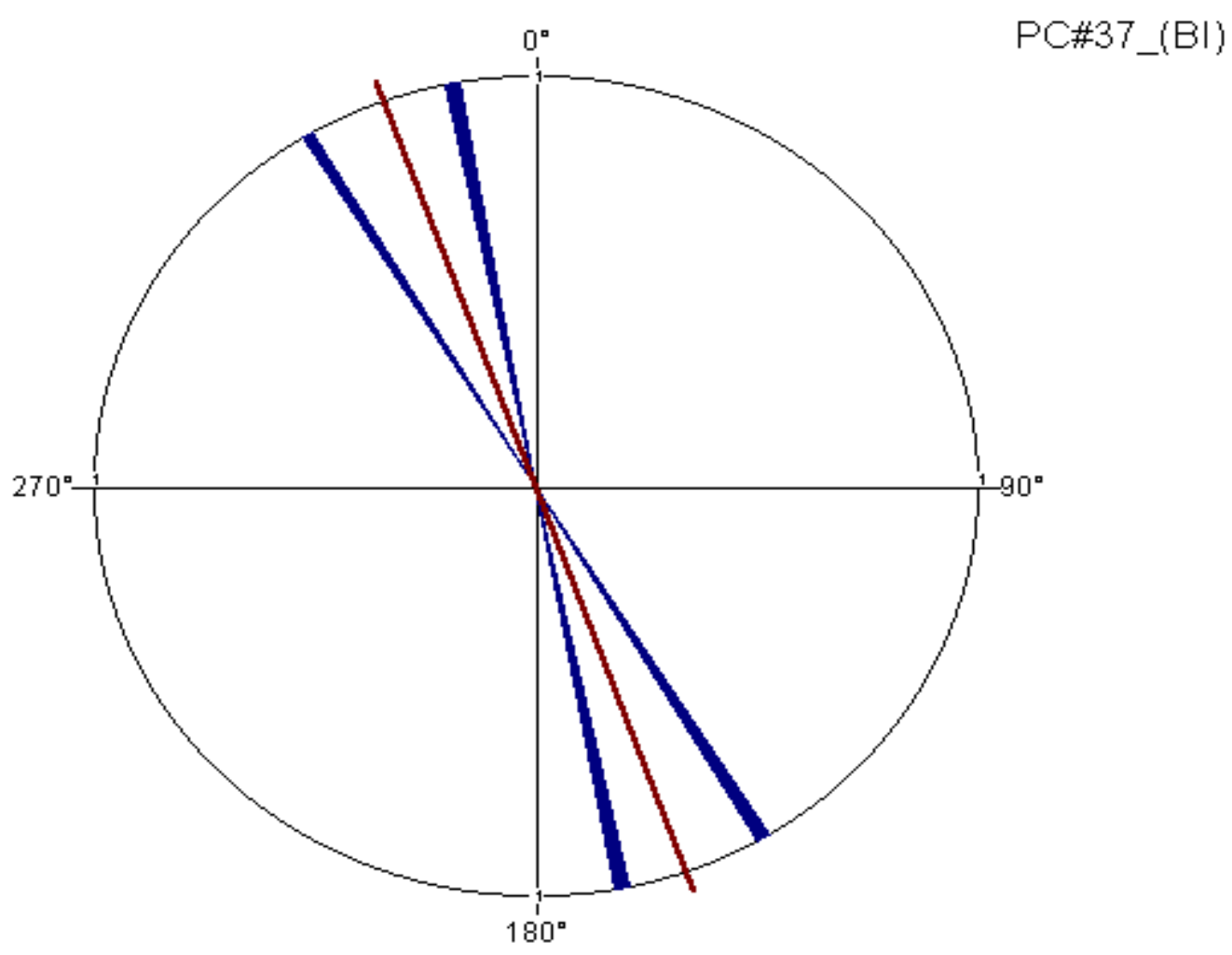

Figure 151. Bi-directional rose diagram for secondary locality 37 in the lower Rockwell Member 


\section{Paleocurrent Stop \# 38 - Upper Rockwell Member}

Sample Label

Quadrangle

Data Type

Observations

Mean vector $(\mu)$

Circular variance

Circular standard deviation

Standard error of mean
PC\#38

Onego

Uni-directional

$316.70^{\circ}$

0.02

$12.51^{\circ}$

$13.98^{\circ}$

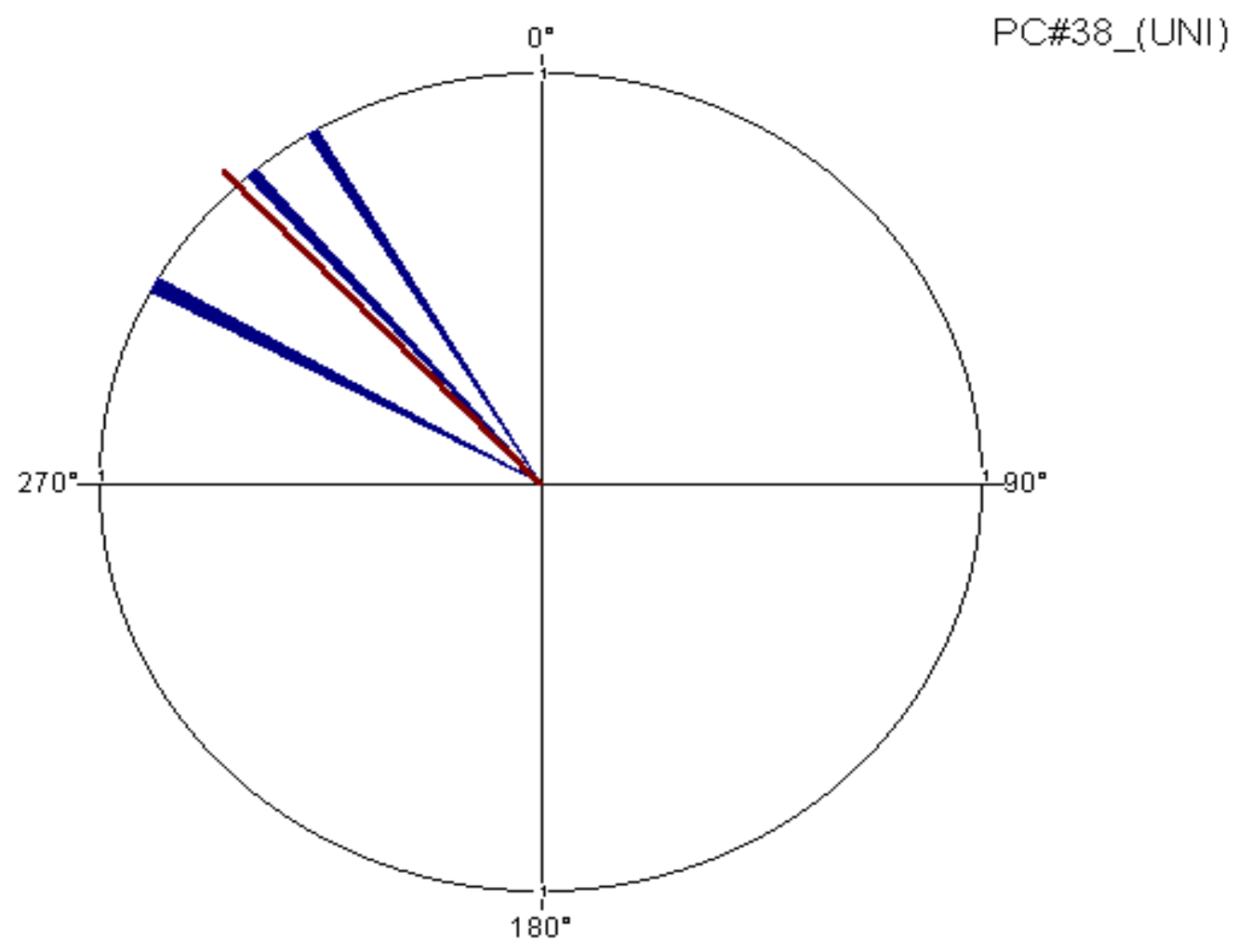

Figure 152. Uni-directional rose diagram for secondary locality 38 in the upper Rockwell Member 


\section{Paleocurrent Stop \# 38 - Upper Rockwell Member}

Sample Label

Quadrangle

Data Type

Observations

Mean vector $(\mu)$

Circular variance

Circular standard deviation

Standard error of mean

PC\#38
Onego
Bi-directional
1
$110.00^{\circ}$
0
$0.00^{\circ}$
$* \star \star * *$

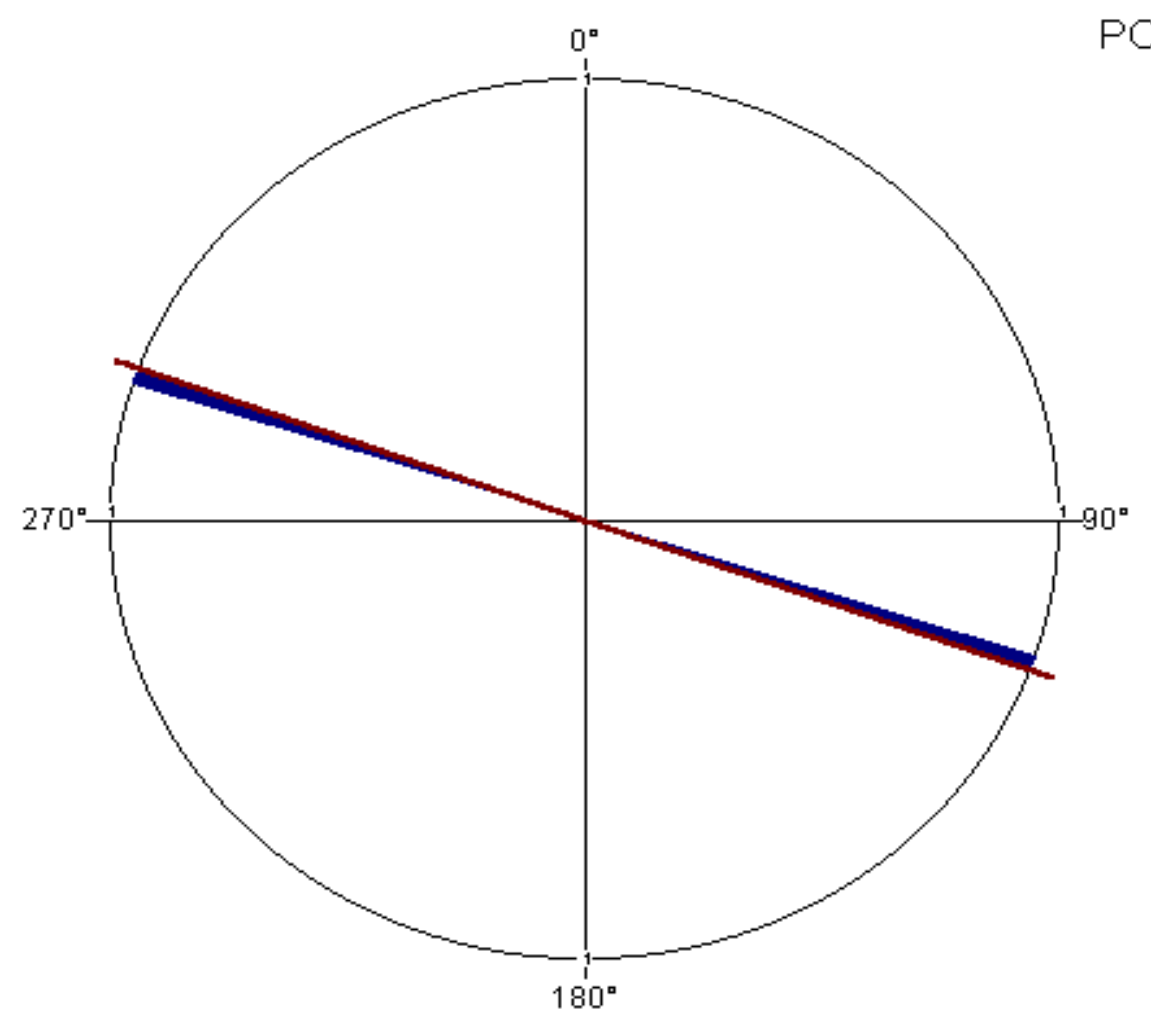

PC\#38_(Bl)

Figure 153. Bi-directional rose diagram for secondary locality 38 in the upper Rockwell Member 


\section{Paleocurrent Stop \# 39 - Upper Rockwell Member}

Sample Label

Quadrangle

Data Type

Observations

Mean vector $(\mu)$

Circular variance

Circular standard deviation

Standard error of mean

PC\#39
Onego
Bi-directional
3
$48.45^{\circ}$
0.12
$29.14^{\circ}$
$32.50^{\circ}$ *

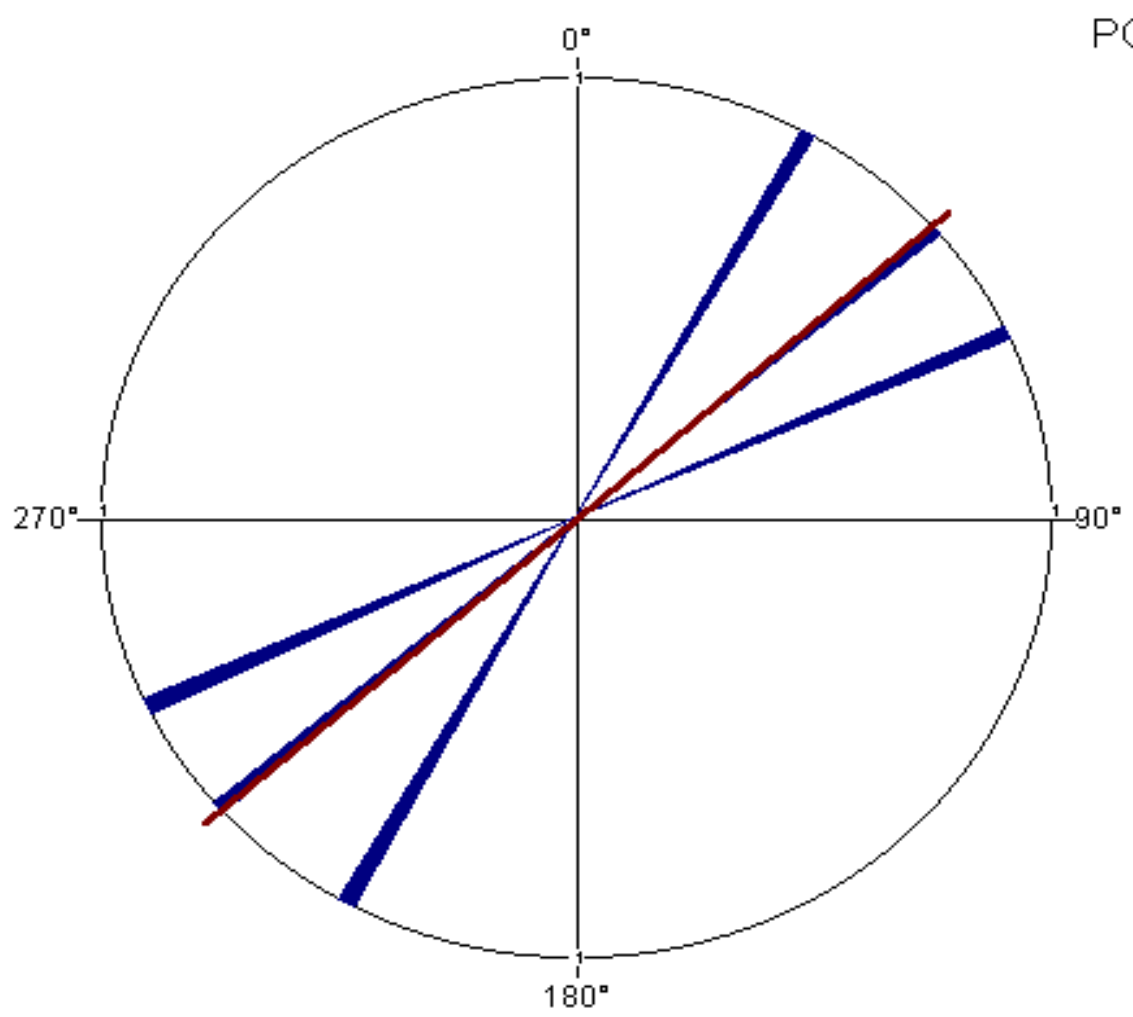

Figure 154. Bi-directional rose diagram for secondary locality 39 in the upper Rockwell Member 


\section{Paleocurrent Stop \# 43 - Upper Rockwell Member}

Sample Label

Quadrangle

Data Type

Observations

Mean vector $(\mu)$

Circular variance

Circular standard deviation

Standard error of mean

PC\#43
Elkins
Bi-directional
2
$52.50^{\circ}$
0.09
$25.41^{\circ}$
$56.74^{\circ}$ *

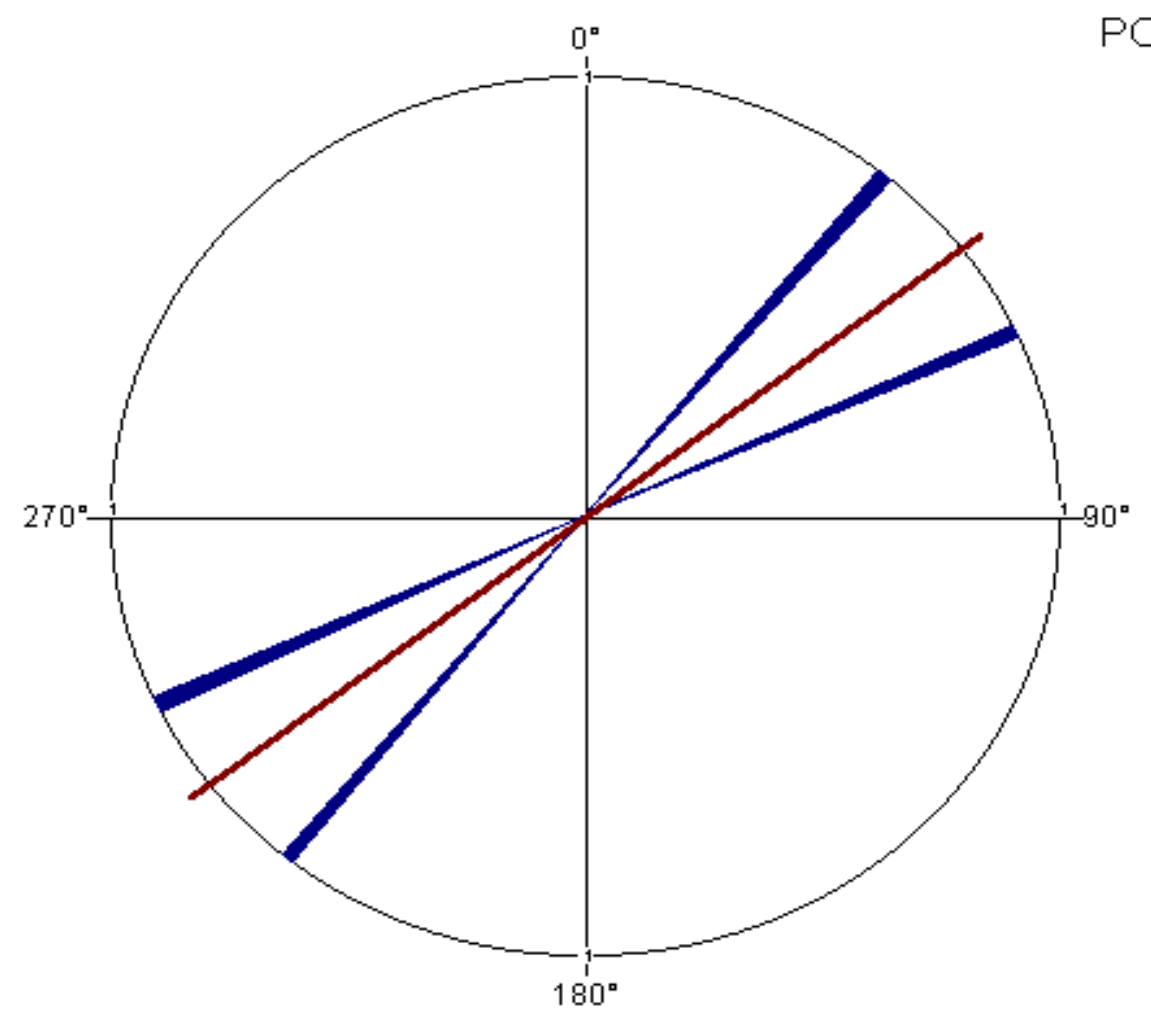

PC\#43_(BI)

Figure 155. Bi-directional rose diagram for secondary locality 43 in the upper Rockwell Member 


\section{Paleocurrent Stop \# 44 - Lower Rockwell Member}

\section{Sample Label}

Quadrangle

Data Type

Observations

Mean vector $(\mu)$

Circular variance

Circular standard deviation

Standard error of mean
PC\#44

Spruce Knob

Uni-directional

$$
\begin{array}{r}
2 \\
280.00^{\circ} \\
0 \\
-0.00^{\circ} \\
* * * *
\end{array}
$$

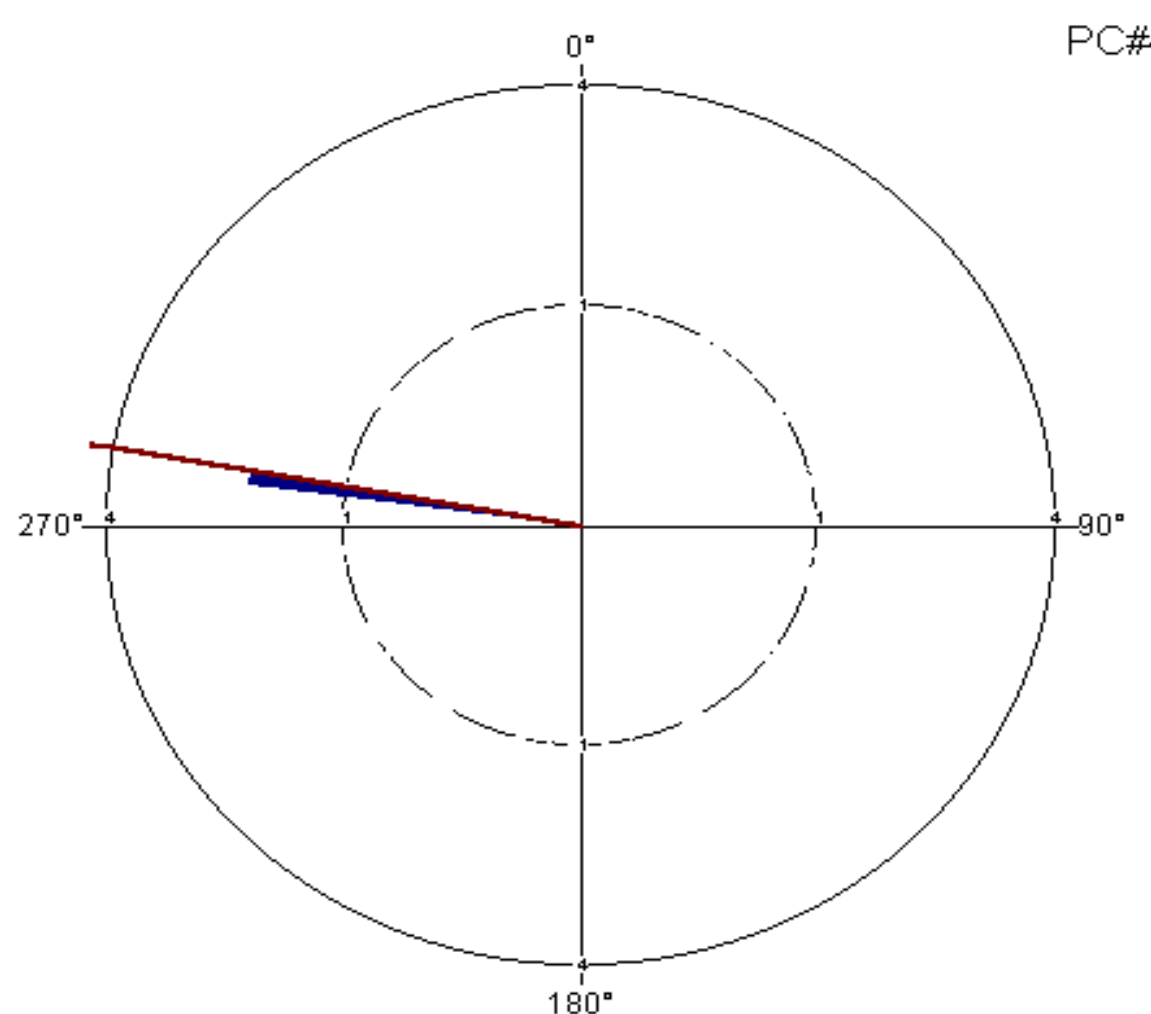

Figure 156. Uni-directional rose diagram for secondary locality 44 in the lower Rockwell Member 


\section{Paleocurrent Stop \# 44 - Lower Rockwell Member}

\section{Sample Label}

Quadrangle

Data Type

Observations

Mean vector $(\mu)$

Circular variance

Circular standard deviation

Standard error of mean
PC\#44

Spruce Knob

Bi-directional

$$
\begin{array}{r}
1 \\
130.00^{\circ} \\
0 \\
-0.00^{\circ} \\
* * * \star
\end{array}
$$

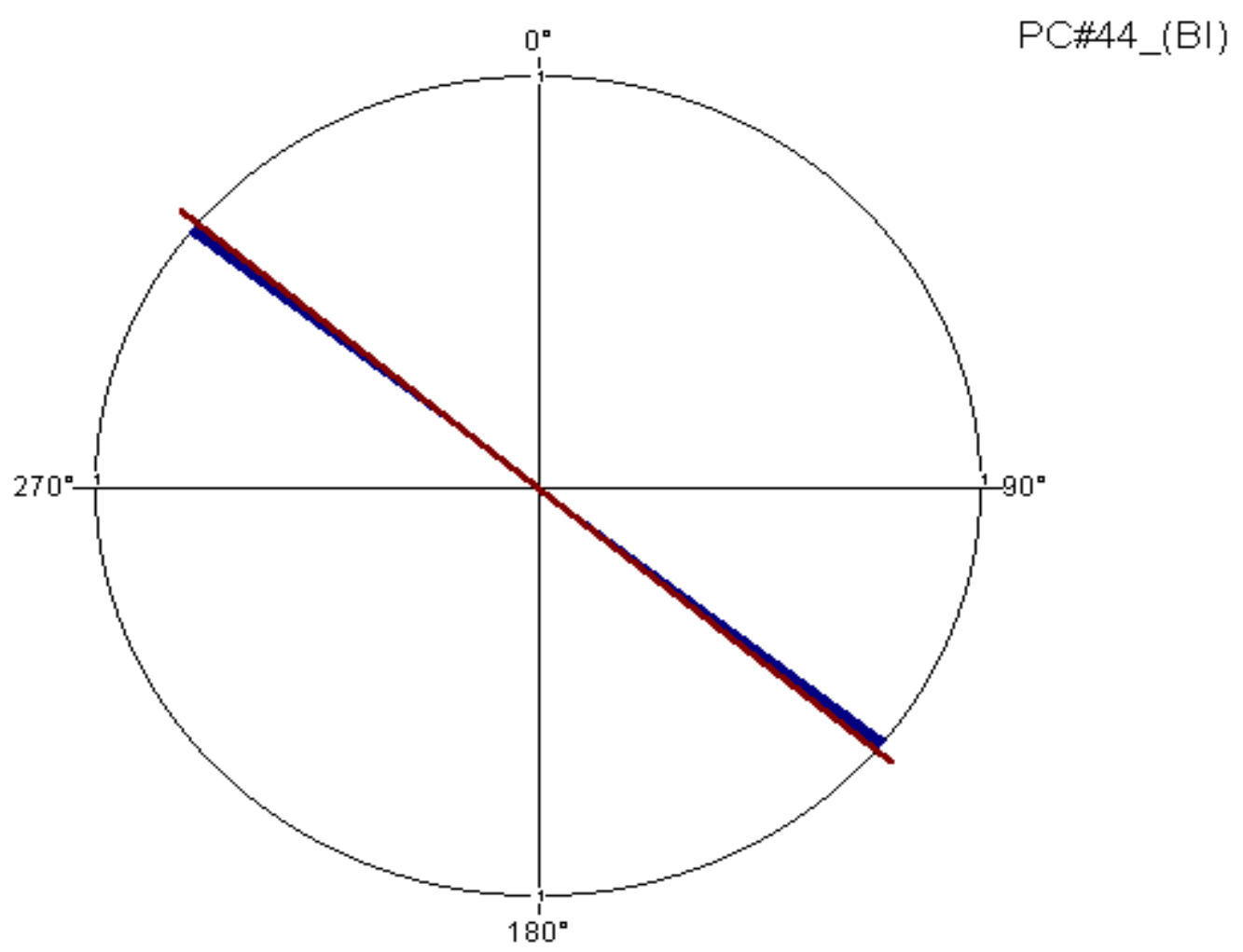

Figure 157. Bi-directional rose diagram for secondary locality 44 in the lower Rockwell Member 


\section{Paleocurrent Stop \# 45 - Lower Rockwell Member}

Sample Label

Quadrangle

Data Type

Observations

Mean vector $(\mu)$

Circular variance

Circular standard deviation

Standard error of mean

PC\#45
Hopeville
Uni-directional
2
$285.00^{\circ}$
0
$5.00^{\circ}$
$11.19^{\circ}$

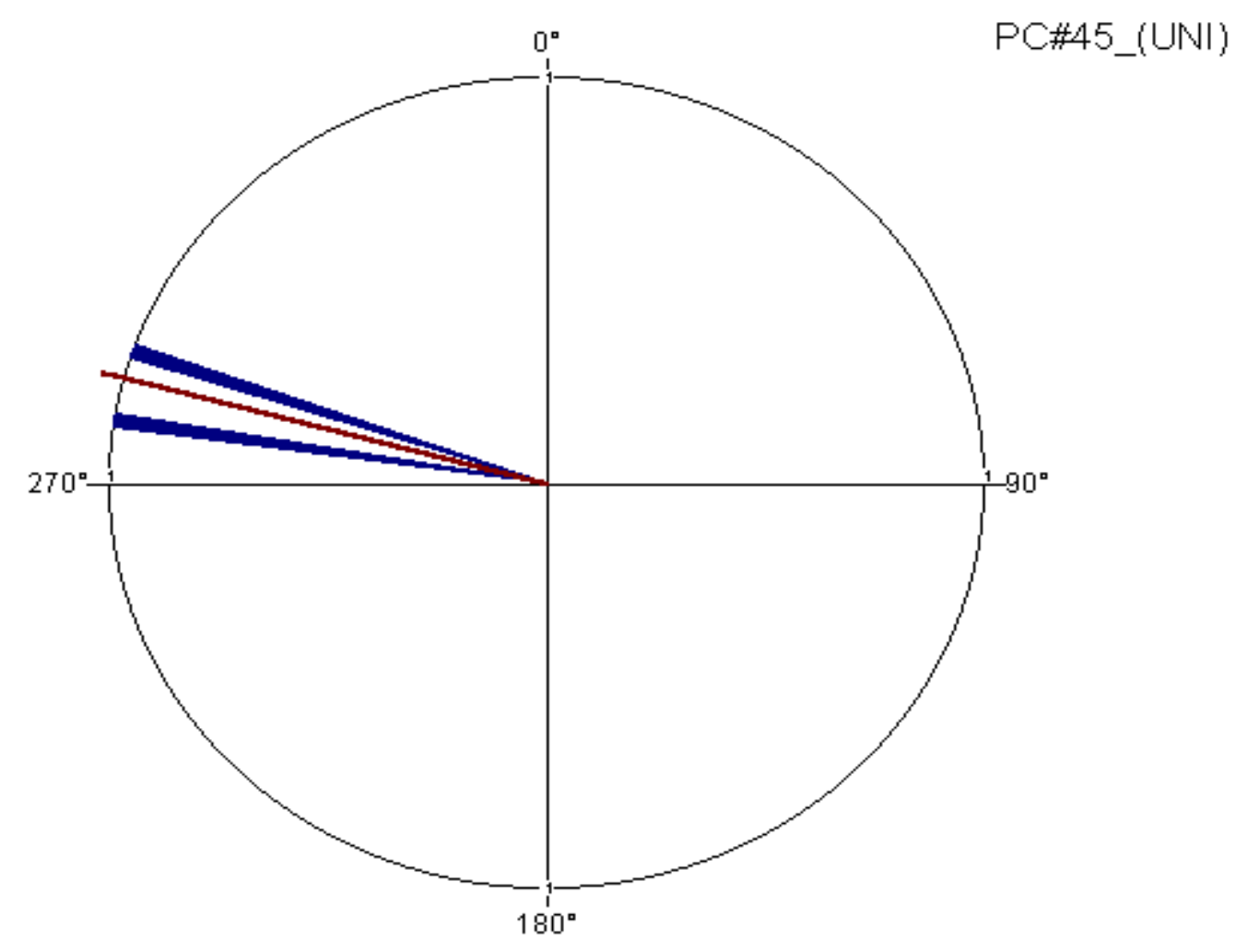

Figure 158. Uni-directional rose diagram for secondary locality 45 in the lower Rockwell Member 


\section{Paleocurrent Stop \# 45 - Lower Rockwell Member}

Sample Label

Quadrangle

Data Type

Observations

Mean vector $(\mu)$

Circular variance

Circular standard deviation

Standard error of mean
PC\#45

Hopeville

Bi-directional

3

$23.35^{\circ}$

0.02

$12.51^{\circ}$

$13.98^{\circ}$

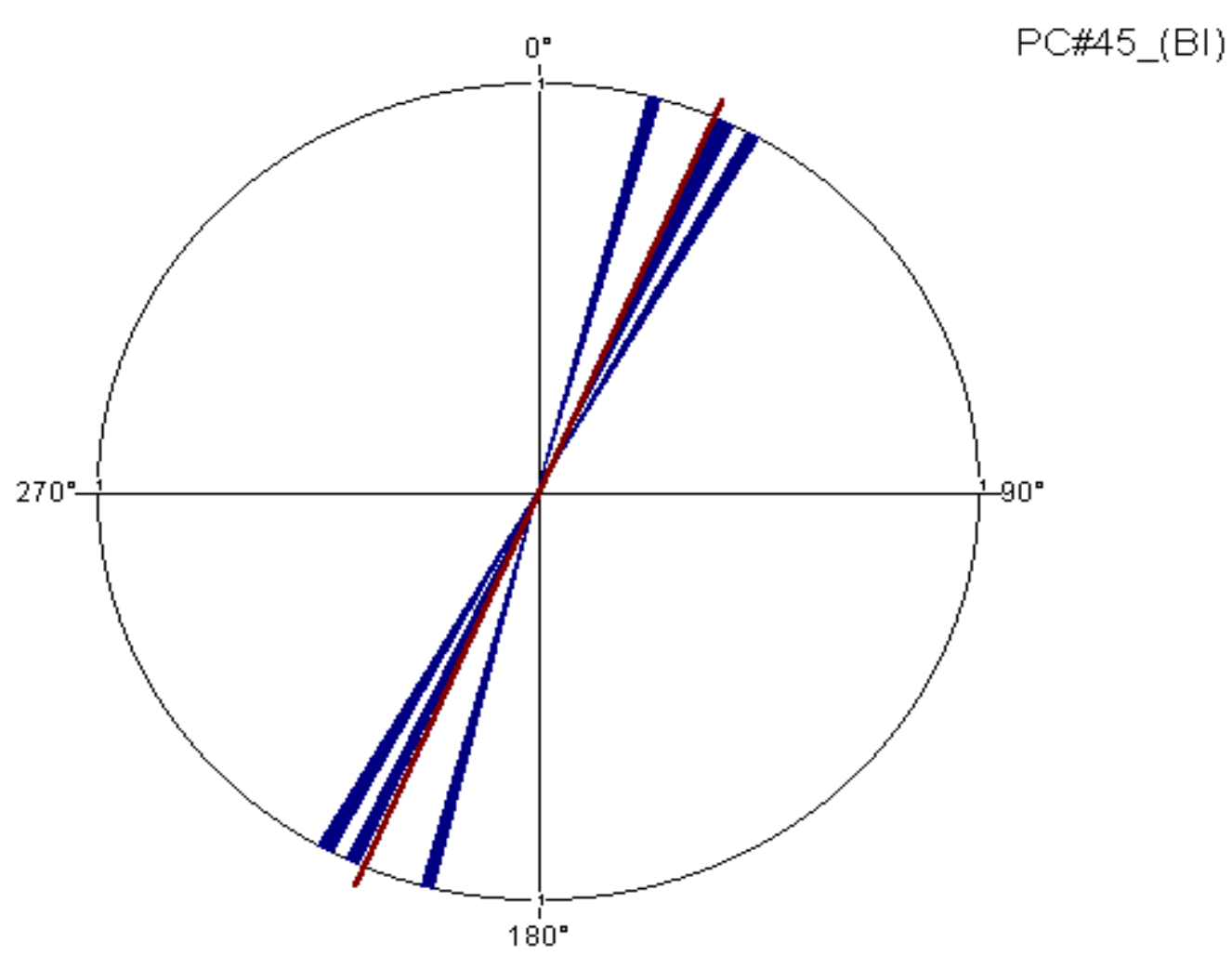

Figure 159. Bi-directional rose diagram for secondary locality 45 in the lower Rockwell Member 


\section{Paleocurrent Stop \# 46 - Upper Rockwell Member}

Sample Label

Quadrangle

Data Type

Observations

Mean vector $(\mu)$

Circular variance

Circular standard deviation

Standard error of mean
PC\#46

Hopeville

Uni-directional

4
$264.68^{\circ}$

0.08

$23.10^{\circ}$

$18.31^{\circ}$

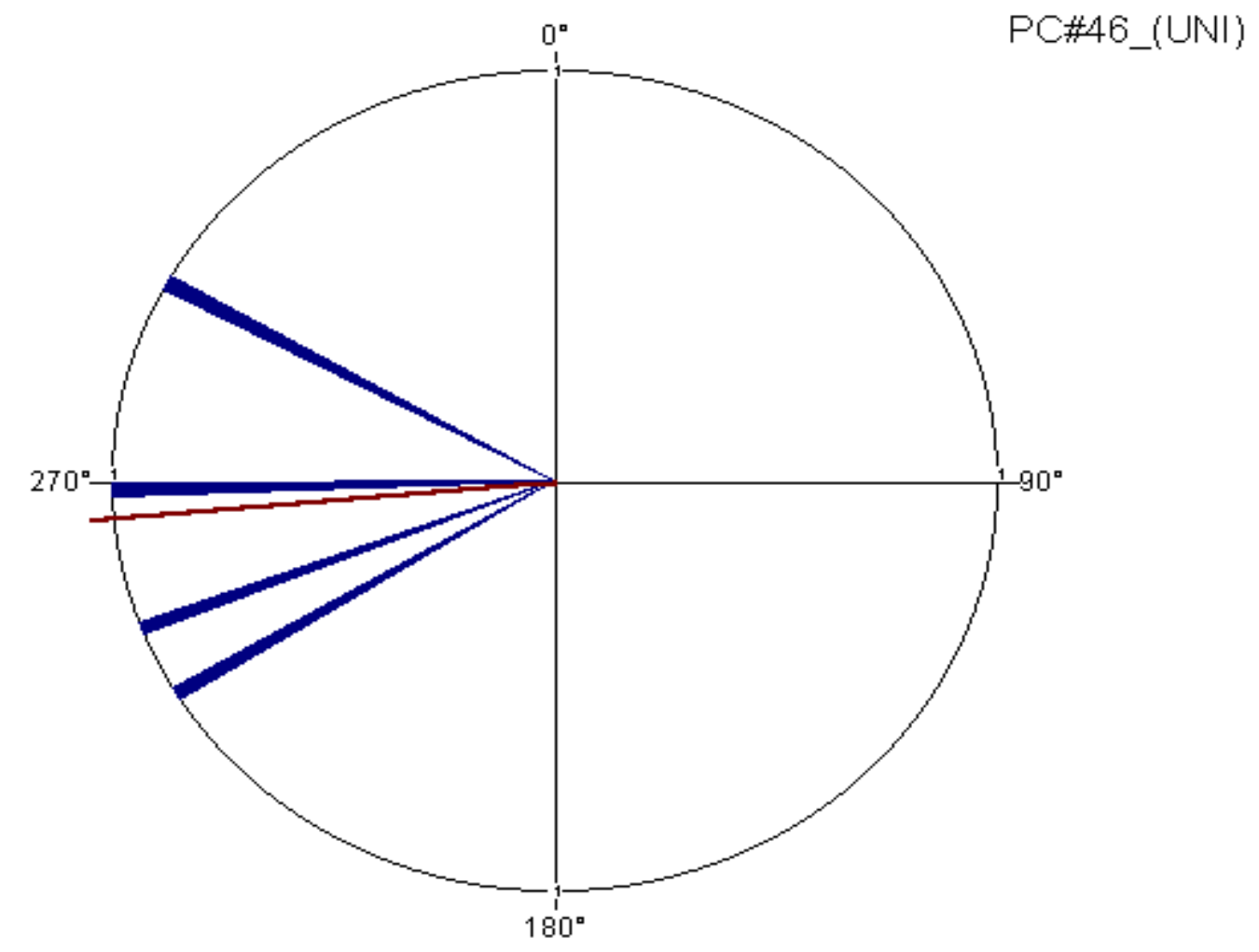

Figure 160. Uni-directional rose diagram for secondary locality 46 in the upper Rockwell Member 


\section{Paleocurrent Stop \# 46 - Upper Rockwell Member}

Sample Label

Quadrangle

Data Type

Observations

Mean vector $(\mu)$

Circular variance

Circular standard deviation

Standard error of mean
PC\#46

Hopeville

Bi-directional

$115.00^{\circ}$

0

$-0.00^{\circ}$

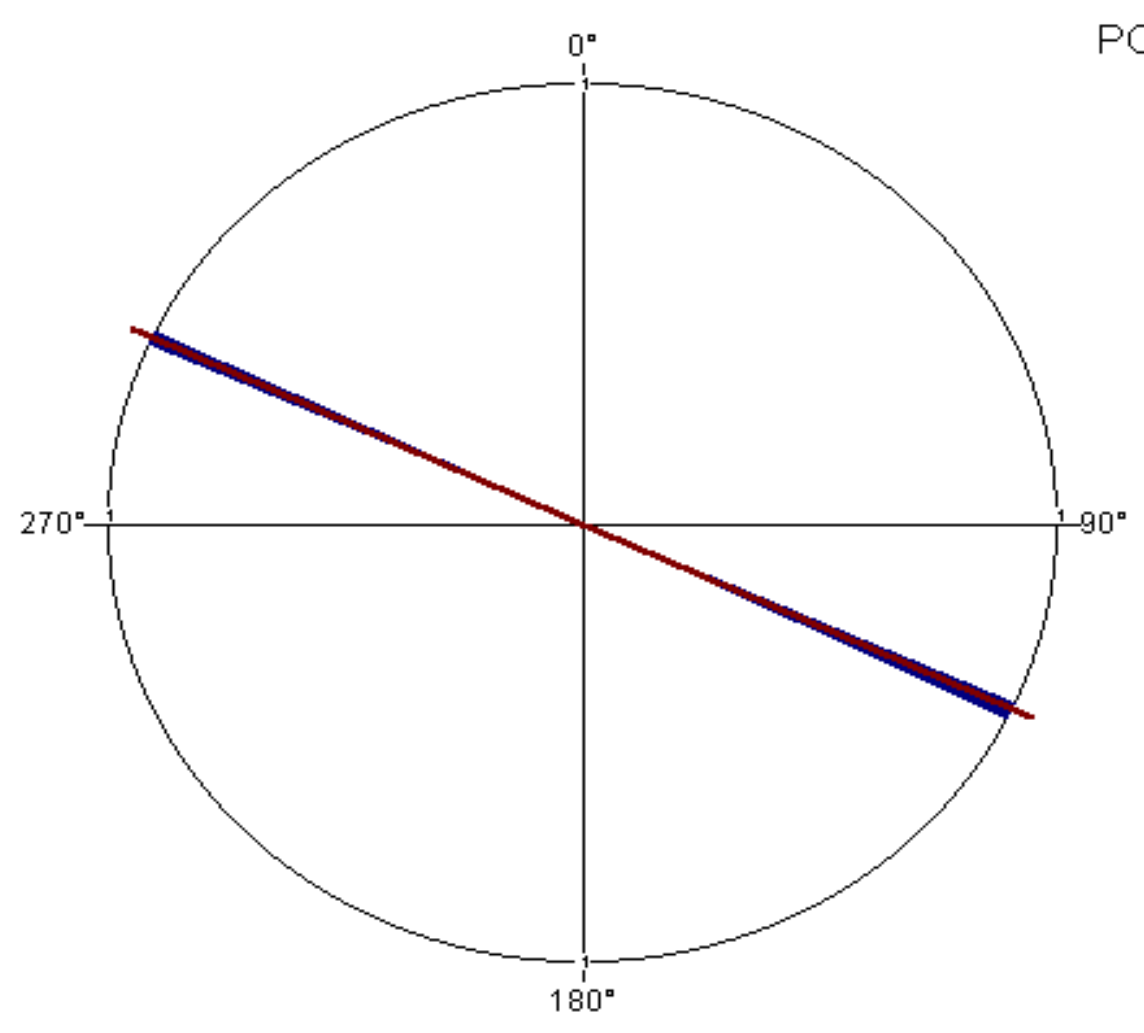

PC\#46_(BI)

Figure 161. Bi-directional rose diagram for secondary locality 46 in the upper Rockwell Member 


\section{Paleocurrent Stop \# 47- Lower Rockwell Member}

$\begin{array}{lr}\text { Sample Label } & \text { PC\#47 } \\ \text { Quadrangle } & \text { Onego } \\ \text { Data Type } & \text { Uni-directional } \\ \text { Observations } & 1 \\ \text { Mean vector }(\mu) & 280.00^{\circ} \\ \text { Circular variance } & 0 \\ \text { Circular standard deviation } & -0.00^{\circ} \\ \text { Standard error of mean } & \star \star \star * *\end{array}$

Standard error of mean

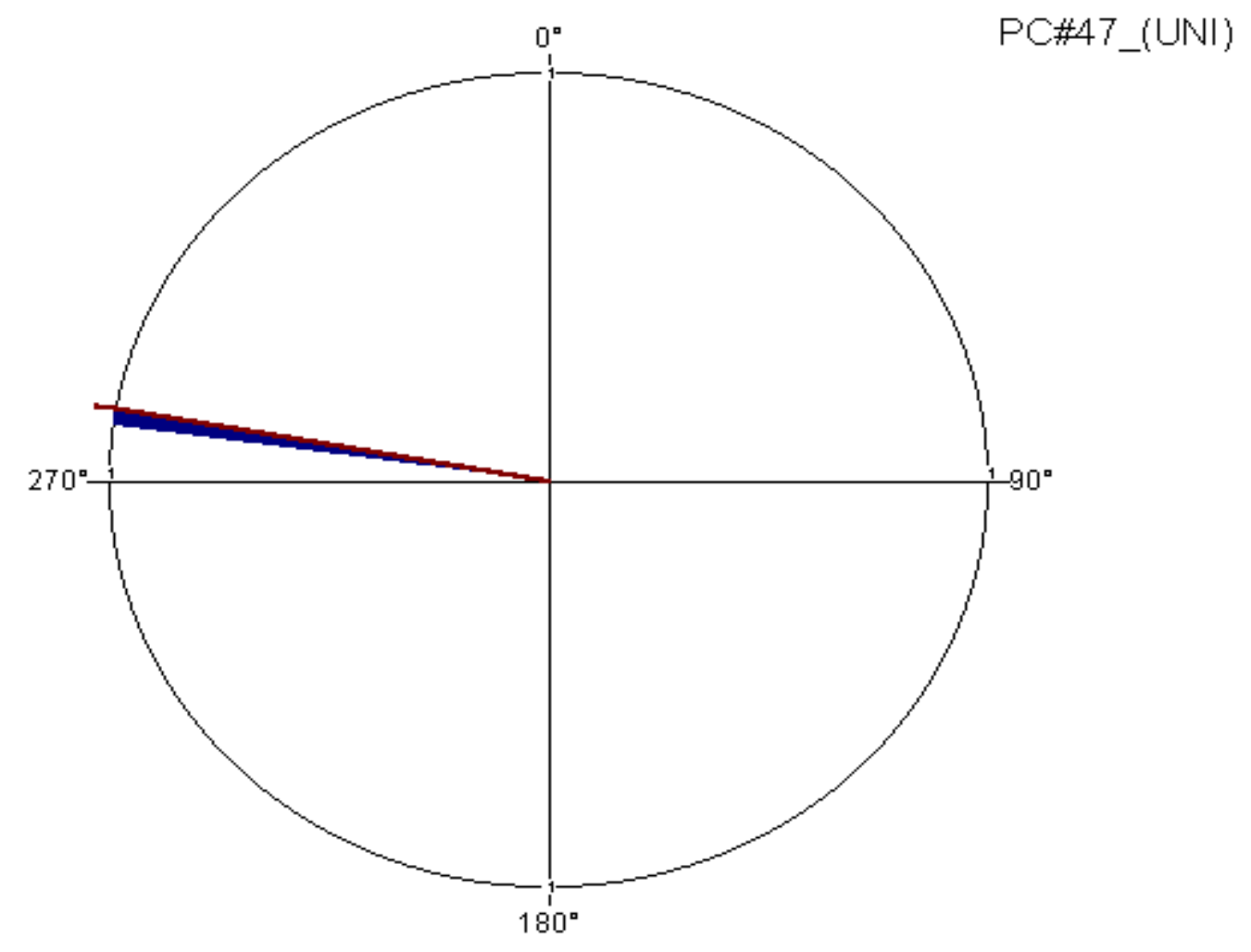

Figure 162. Uni-directional rose diagram for secondary locality 47 in the lower Rockwell Member 


\section{Paleocurrent Stop \# 48 - Upper Rockwell Member}

$\begin{array}{lr}\text { Sample Label } & \text { PC\#48 } \\ \text { Quadrangle } & \text { Onego } \\ \text { Data Type } & \text { Bi-directional } \\ \text { Observations } & 2 \\ \text { Mean vector }(\mu) & 37.50^{\circ} \\ \text { Circular variance } & 0.09 \\ \text { Circular standard deviation } & 25.41^{\circ} \\ \text { Standard error of mean } & 56.74^{\circ} \text { * }\end{array}$

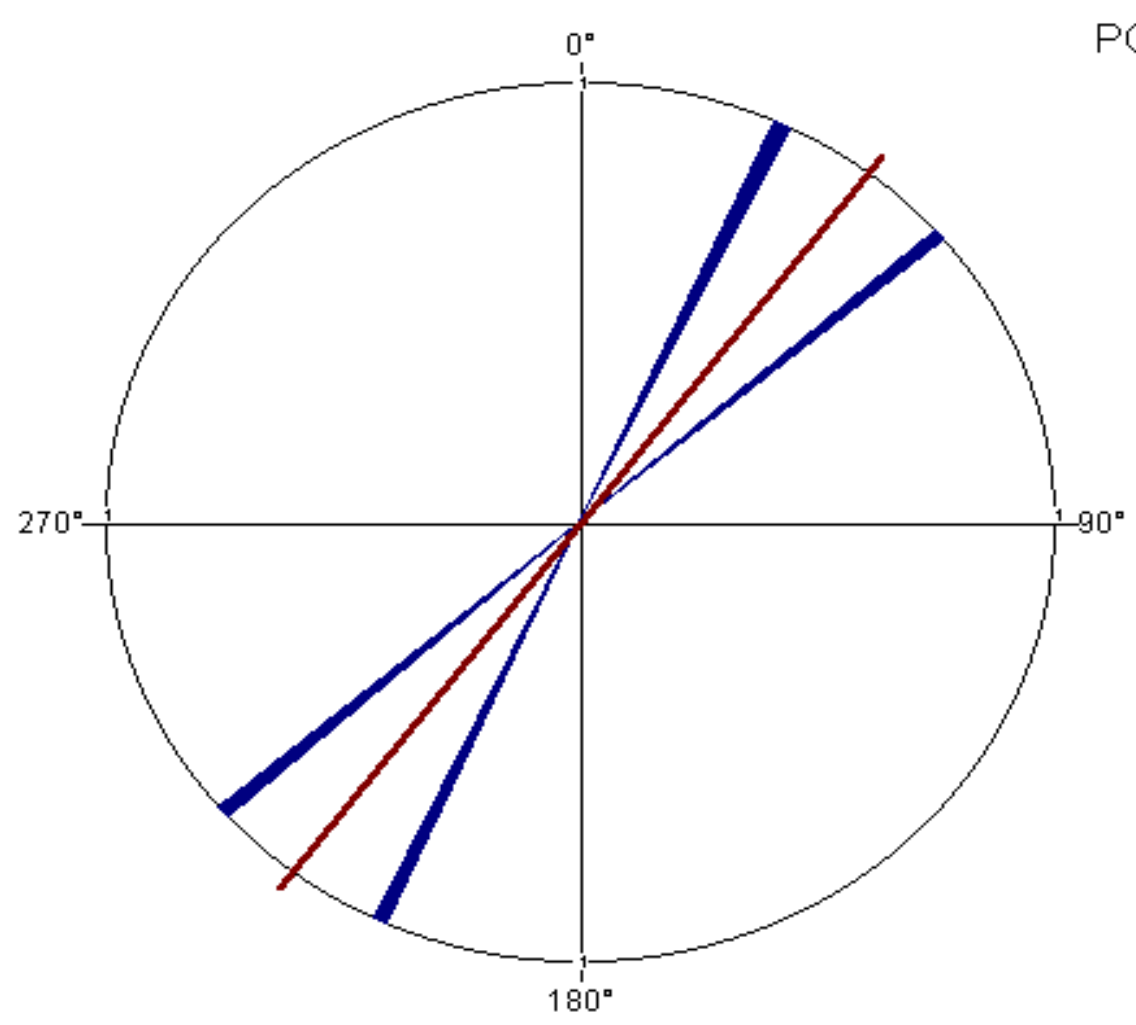

Figure 163. Bi-directional rose diagram for secondary locality 48 in the upper Rockwell Member 


\section{Paleocurrent Stop \# 49 - Upper Rockwell Member}

Sample Label

Quadrangle

Data Type

Observations

Mean vector $(\mu)$

Circular variance

Circular standard deviation

Standard error of mean

PC\#49
Snowy Mtn
Bi-directional
3
$50.05^{\circ}$
0.03
$14.20^{\circ}$
$15.87^{\circ}$

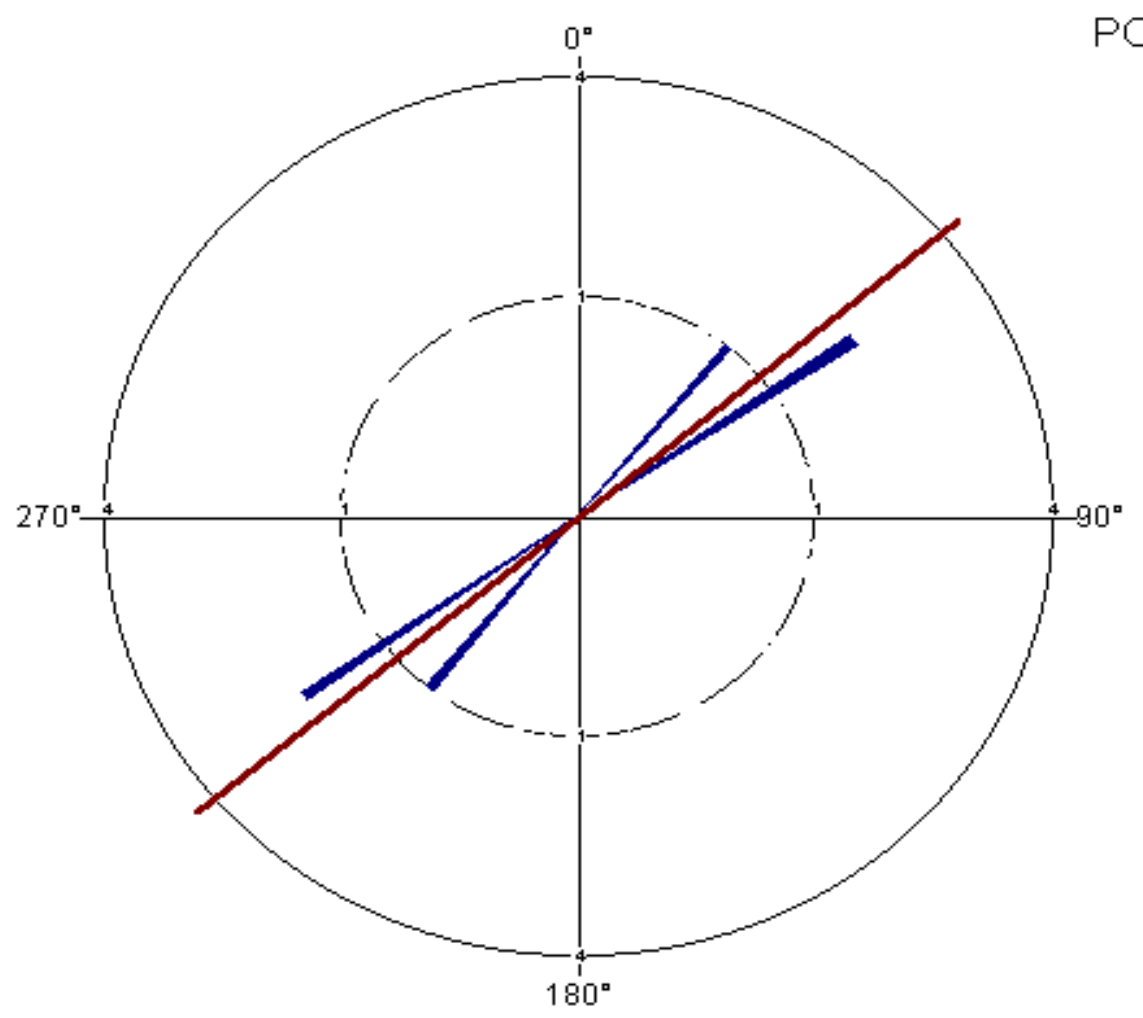

PC\#49_(BI)

Figure 164. Bi-directional rose diagram for secondary locality 49 in the upper Rockwell Member 


\section{Paleocurrent Stop \# 50 - Lower Rockwell Member}

Sample Label

Quadrangle

Data Type

Observations

Mean vector $(\mu)$

Circular variance

Circular standard deviation

Standard error of mean
PC\#50

Spruce Knob

Bi-directional

$175.00^{\circ}$

0.02

$10.03^{\circ}$

$22.42^{\circ}$

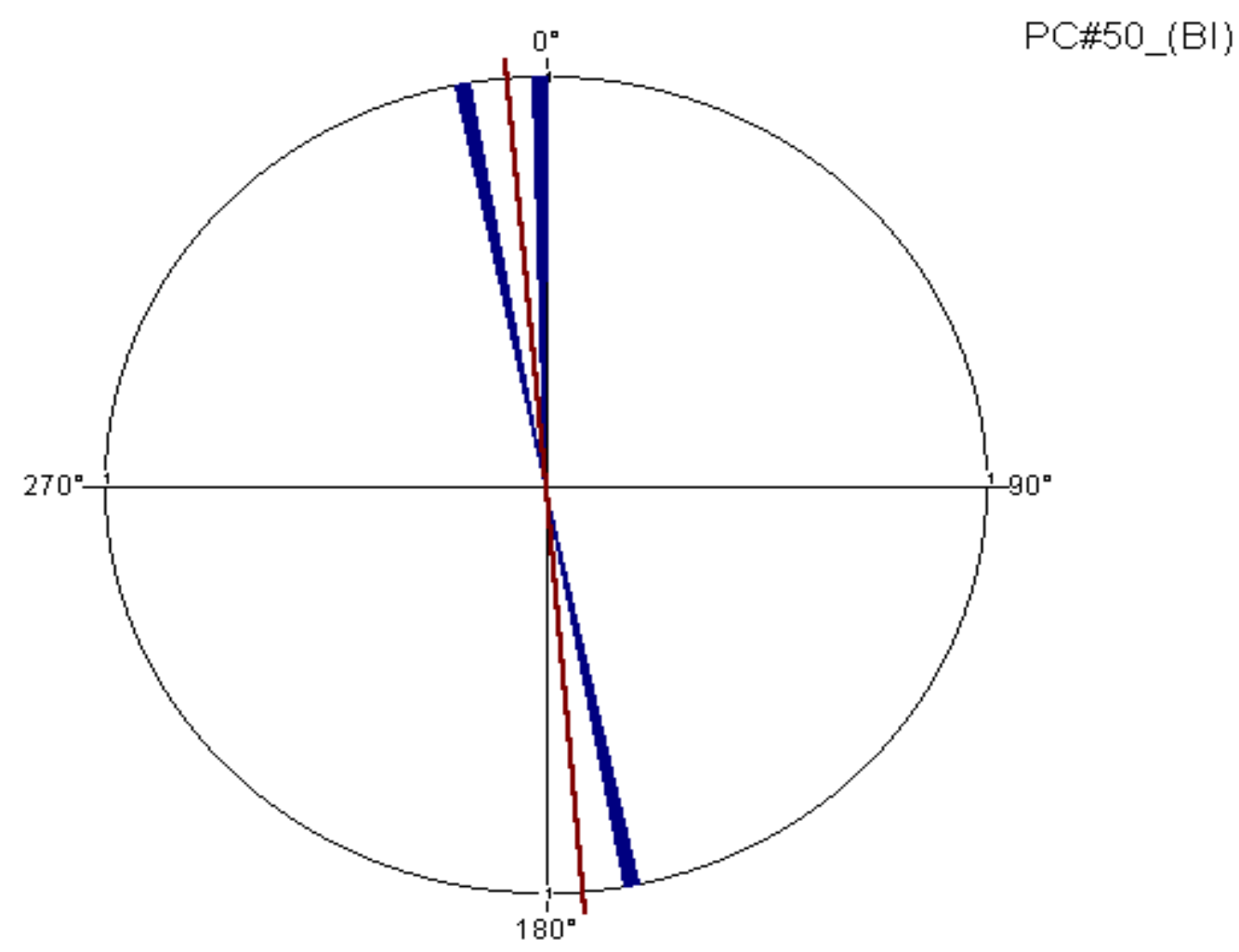

Figure 165. Bi-directional rose diagram for secondary locality 50 in the lower Rockwell Member 


\section{Paleocurrent Stop \# 51 - Lower Rockwell Member}

\section{Sample Label}

Quadrangle

Data Type

Observations

Mean vector $(\mu)$

Circular variance

Circular standard deviation

Standard error of mean
PC\#51

Spruce Knob

Uni-directional

$225.00^{\circ}$

0

$-0.00^{\circ}$

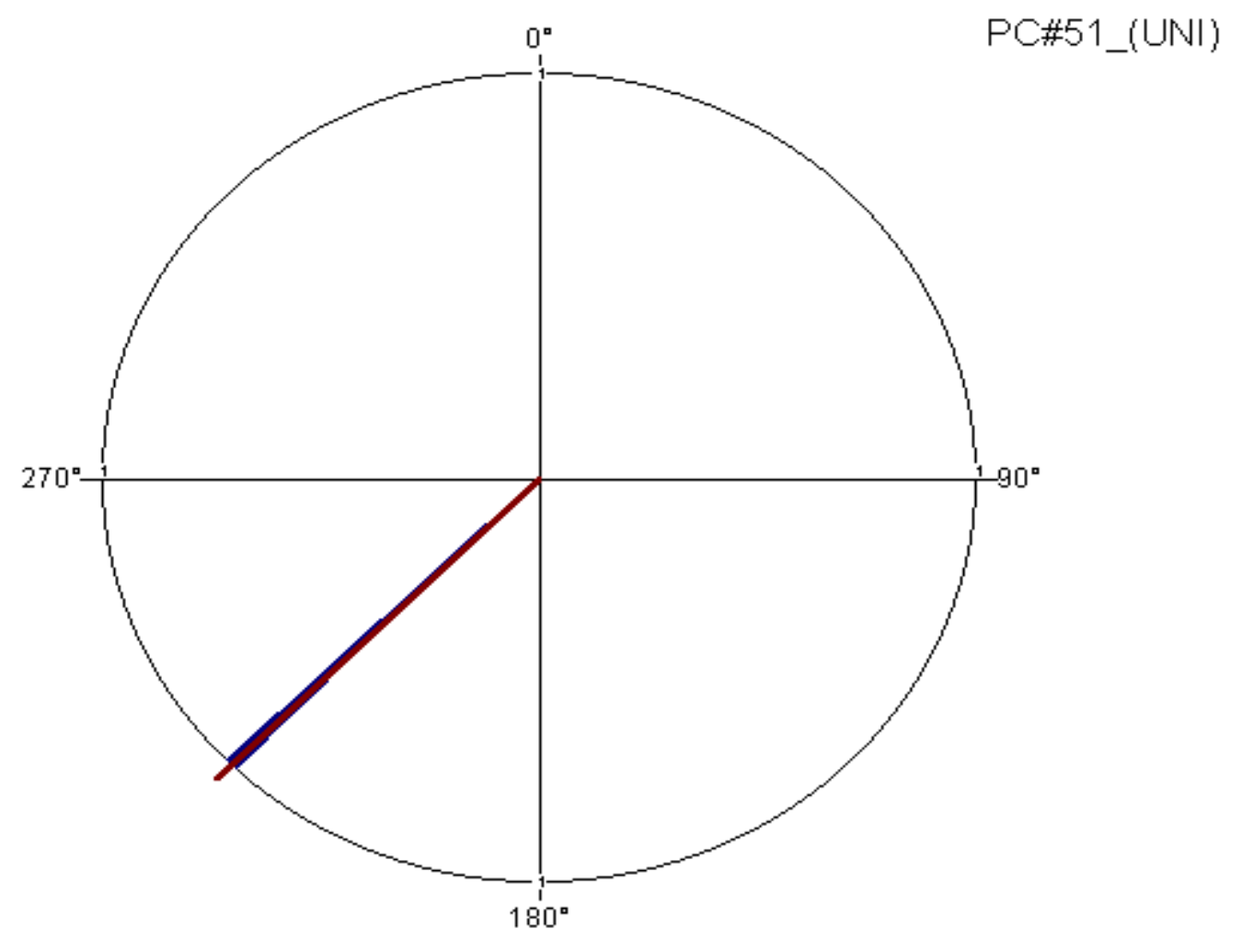

Figure 166. Uni-directional rose diagram for secondary locality 51 in the lower Rockwell Member 


\section{Paleocurrent Stop \# 51 - Lower Rockwell Member}

Sample Label

Quadrangle

Data Type

Observations

Mean vector $(\mu)$

Circular variance

Circular standard deviation

Standard error of mean

PC\#51
Spruce Knob
Bi-directional
1
$55.00^{\circ}$
0
$-0.00^{\circ}$
$* * * * *$

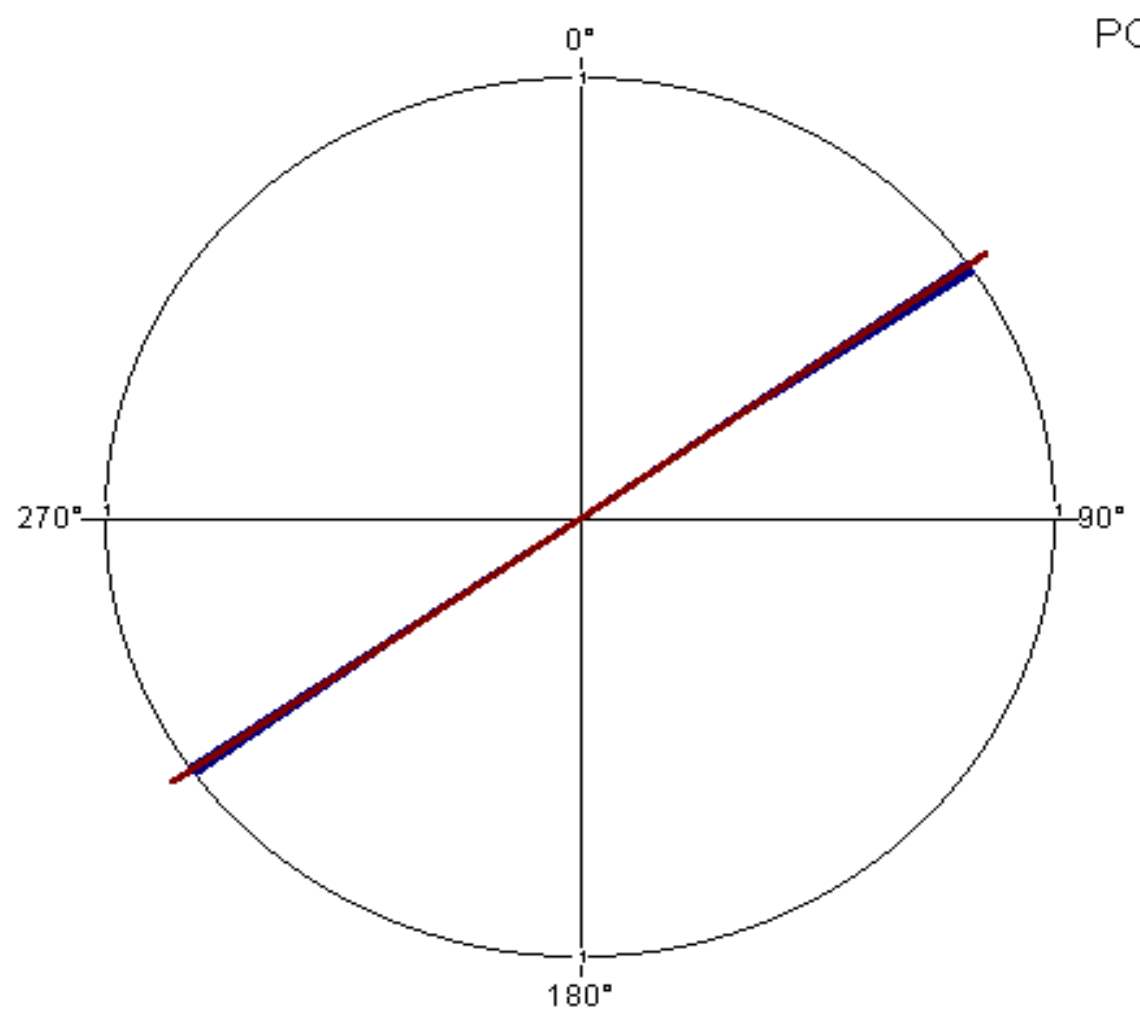

Figure 167. Bi-directional rose diagram for secondary locality 51 in the lower Rockwell Member 


\section{Paleocurrent Stop \# 52 - Lower Rockwell Member}

Sample Label

Quadrangle

Data Type

Observations

Mean vector $(\mu)$

Circular variance

Circular standard deviation

Standard error of mean
PC\#52

Spruce Knob

Uni-directional

$$
\begin{array}{r}
8 \\
297.70^{\circ}
\end{array}
$$

0.13

$29.76^{\circ}$

$12.92^{\circ}$

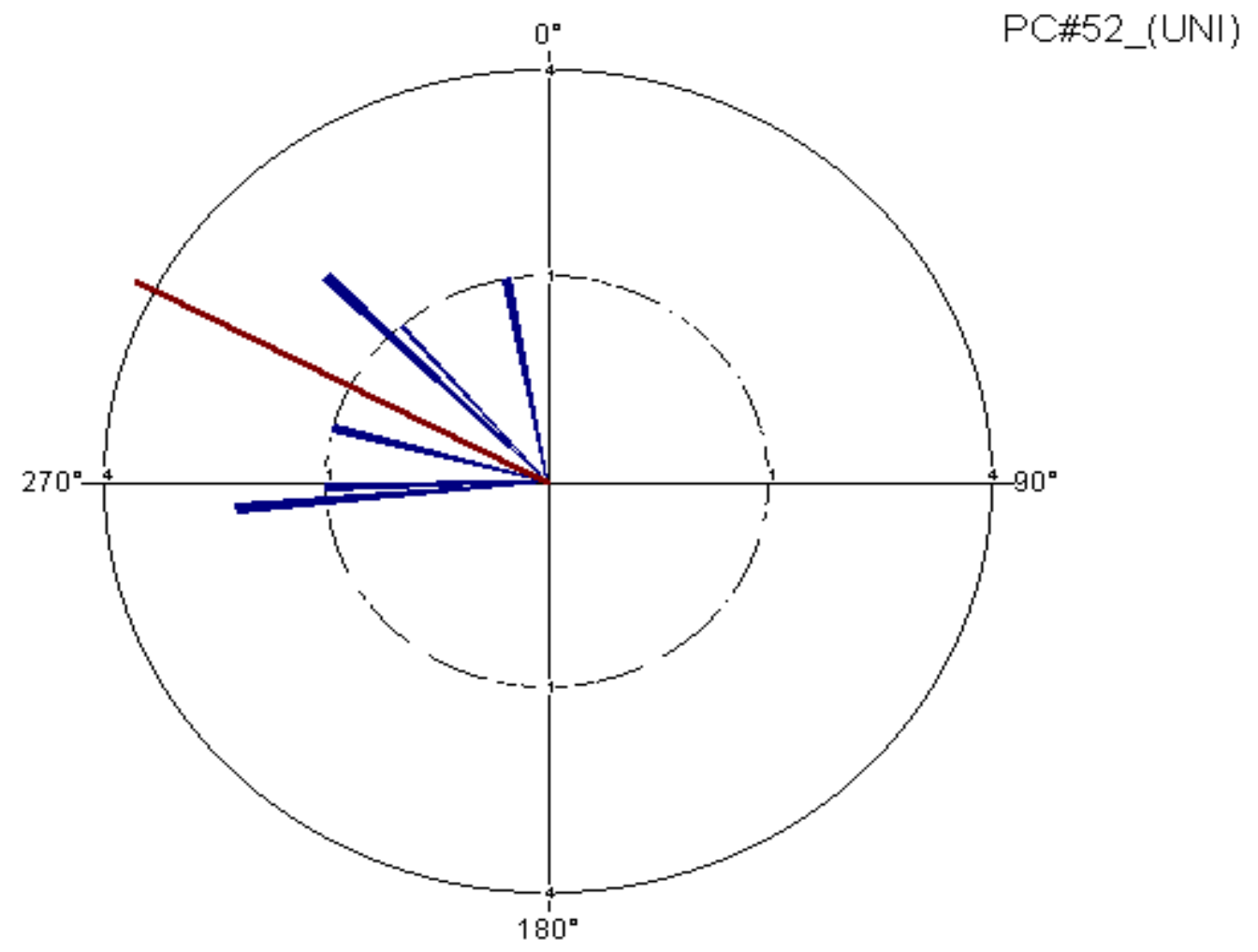

Figure 168. Uni-directional rose diagram for secondary locality 52 in the lower Rockwell Member 


\section{Paleocurrent Stop \# 53 - Lower Rockwell Member}

Sample Label

Quadrangle

Data Type

Observations

Mean vector $(\mu)$

Circular variance

Circular standard deviation

Standard error of mean
PC\#53

Spruce Knob

Uni-directional

$$
\begin{array}{r}
5 \\
23.00^{\circ} \\
0.04 \\
15.76^{\circ} \\
10.04^{\circ}
\end{array}
$$

Figure 169. Uni-directional rose diagram for secondary locality 53 in the lower Rockwell Member 


\section{Paleocurrent Stop \# 54 - Lower Rockwell Member}

Sample Label

Quadrangle

Data Type

Observations

Mean vector $(\mu)$

Circular variance

Circular standard deviation

Standard error of mean
PC\#54

Spruce Knob Uni-directional

$172.98^{\circ}$

0.13

$29.91^{\circ}$

$19.01^{\circ}$

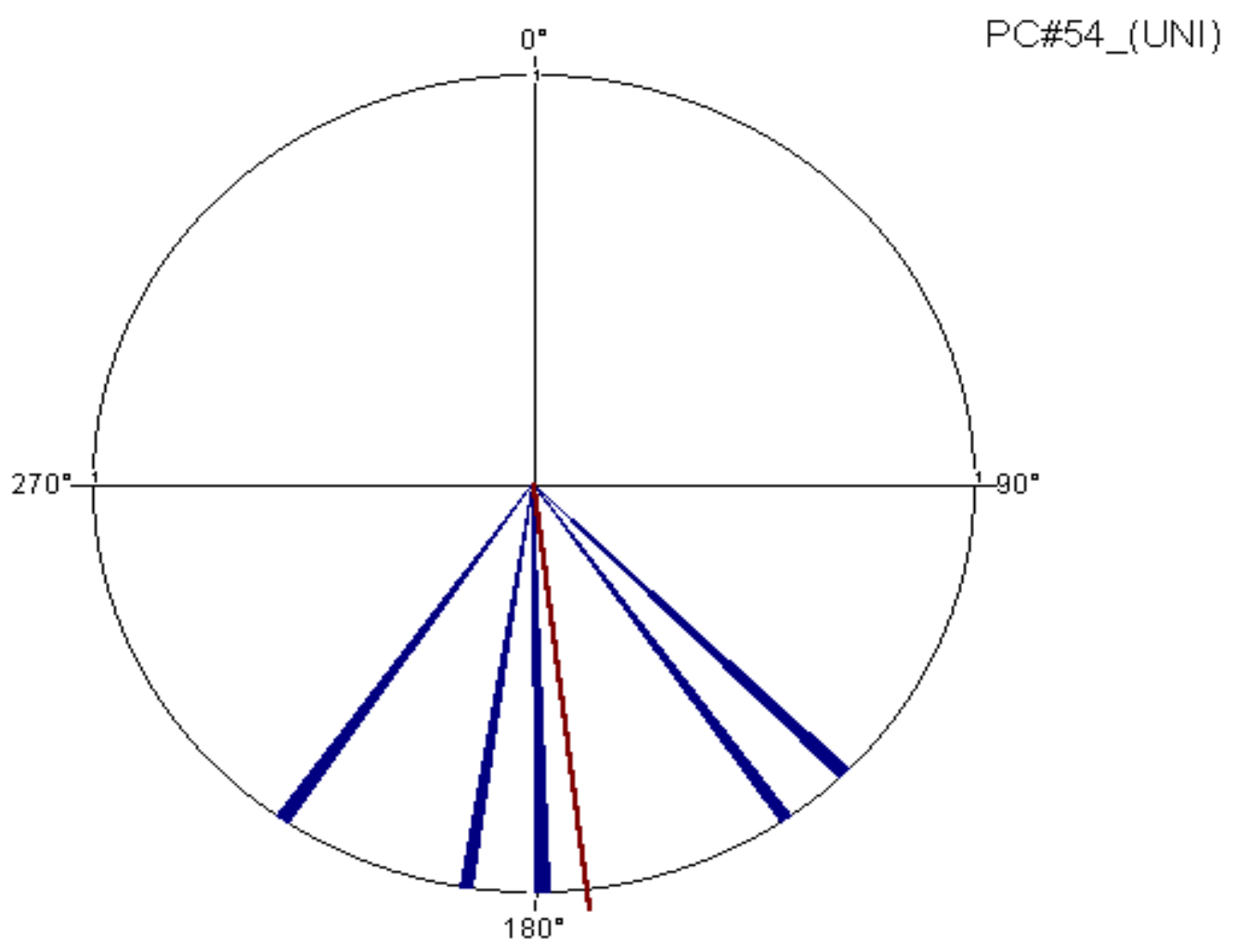

Figure 170. Uni-directional rose diagram for secondary locality 54 in the lower Rockwell Member 


\section{Paleocurrent Stop \# 54 - Lower Rockwell Member}

\section{Sample Label}

Quadrangle

Data Type

Observations

Mean vector $(\mu)$

Circular variance

Circular standard deviation

Standard error of mean
PC\#54

Spruce Knob

Bi-directional

$15.00^{\circ}$

0

$-0.00^{\circ}$

$* * * * *$

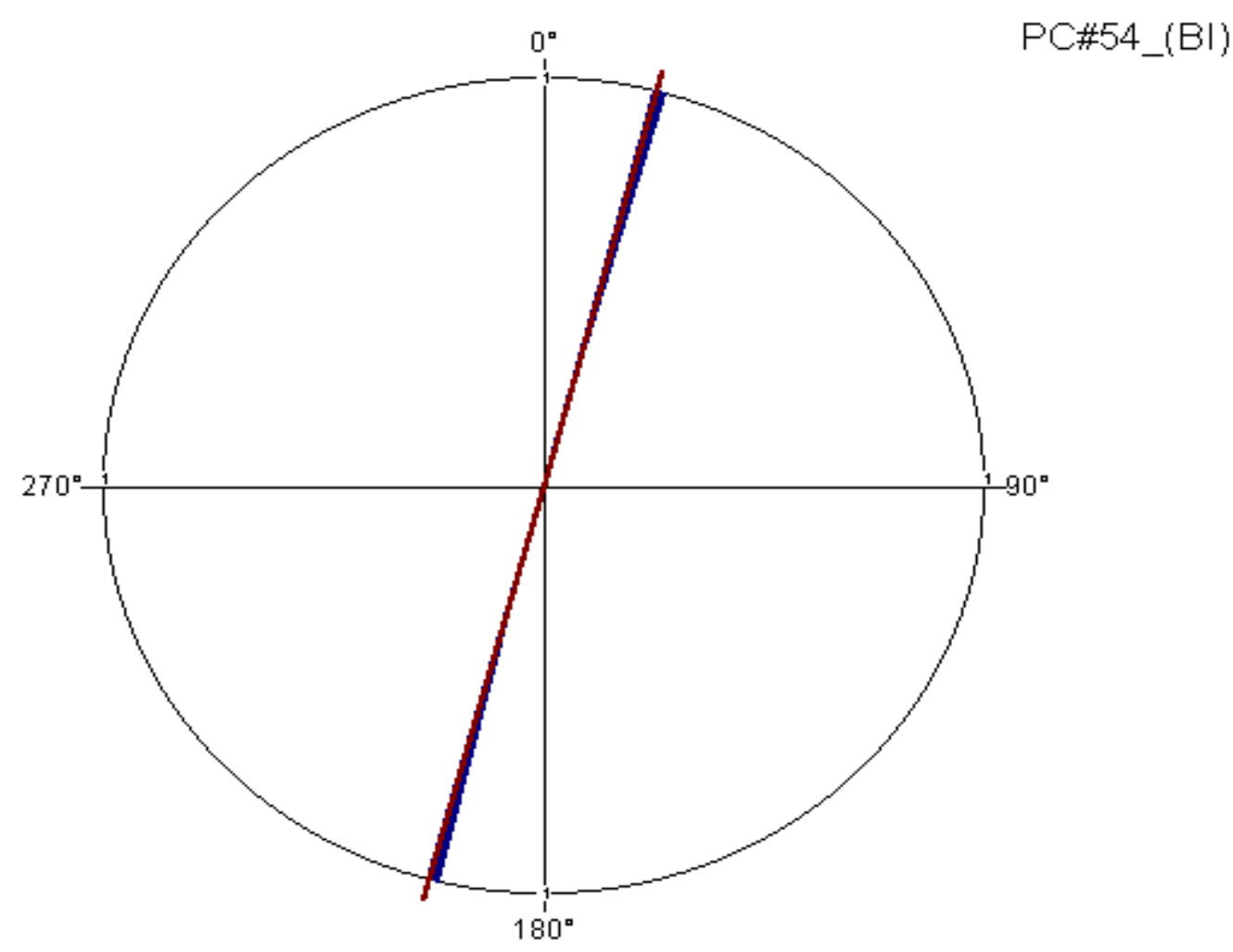

Figure 171. Bi-directional rose diagram for secondary locality 54 in the lower Rockwell Member 


\section{Appendix IV - Grouped paleocurrent data from the lower Rockwell Member}

\section{Area 1 - Lower Rockwell Member}

Sample Label

Data Type

Observations

Mean vector $(\mu)$

Circular variance

Circular standard deviation

Standard error of mean
Area 1

Uni-directional

22

$298.76^{\circ}$

0.72

$91.09^{\circ}$

$29.93^{\circ}$ *

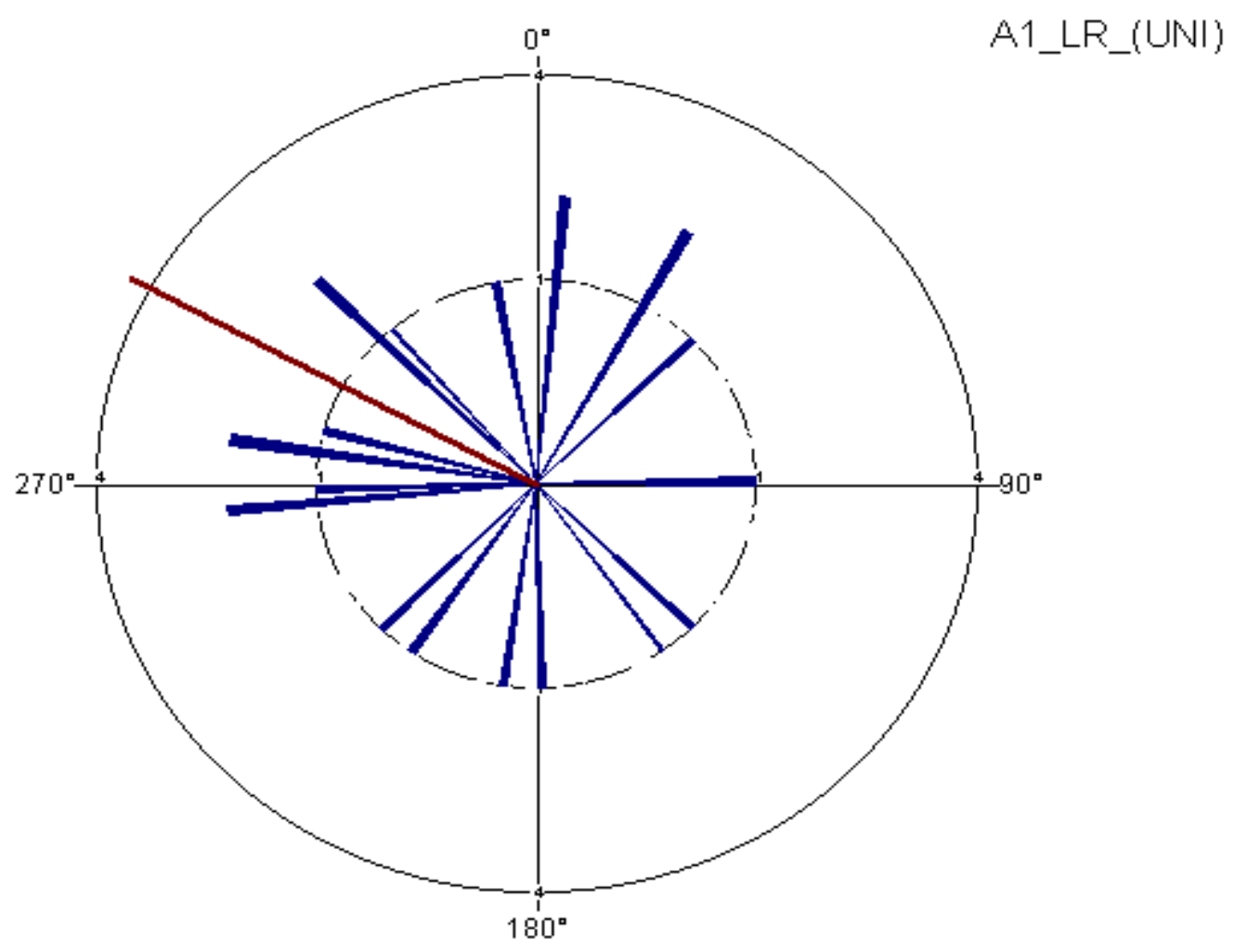

Figure 172. Uni-directional rose diagram from area 1 in the lower Rockwell Member 


\section{Area 1 - Lower Rockwell Member}

Sample Label

Data Type

Observations

Mean vector $(\mu)$

Circular variance

Circular standard deviation

Standard error of mean

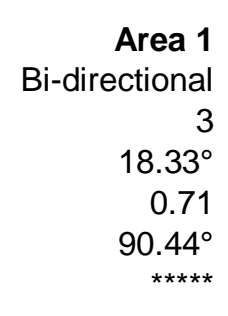

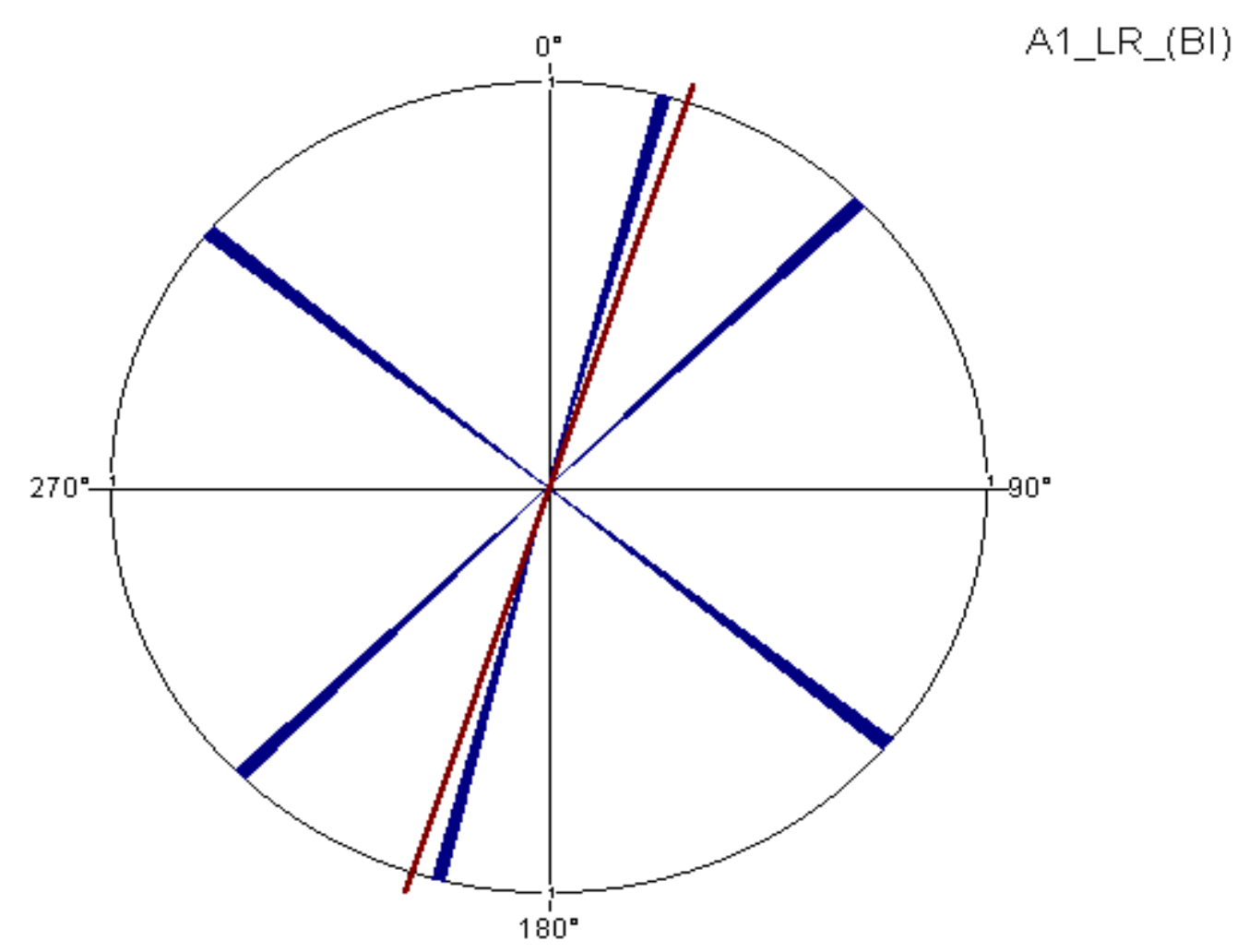

Figure 173. Bi-directional rose diagram from area 1 in the lower Rockwell Member 


\section{Area 2 - Lower Rockwell Member}

Sample Label

Data Type

Observations

Mean vector $(\mu)$

Circular variance

Circular standard deviation

Standard error of mean
Area 2

Uni-directional

$$
\begin{array}{r}
7 \\
220.00^{\circ} \\
0.59 \\
76.04^{\circ} \\
43.55^{\circ} \text { * }
\end{array}
$$

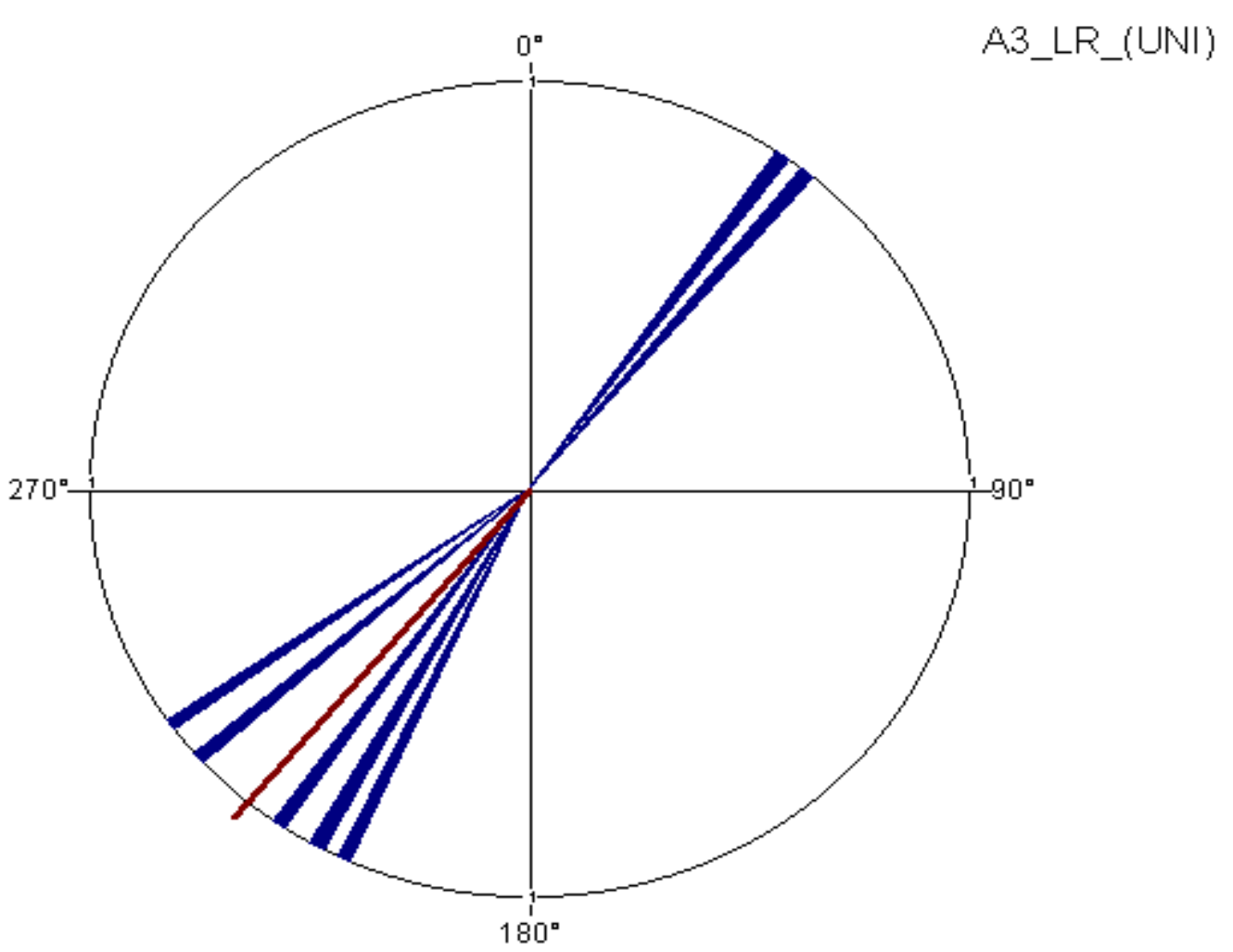

Figure 174. Uni-directional rose diagram from area 2 in the lower Rockwell Member 


\section{Area 3- Lower Rockwell Member}

Sample Label

Data Types

Observations

Mean vector $(\mu)$

Circular variance

Circular standard deviation

Standard error of mean
Area 3

Uni-directional

8
$235.63^{\circ}$
0.47

0.47

$64.41^{\circ}$

$27.01^{\circ}$ *

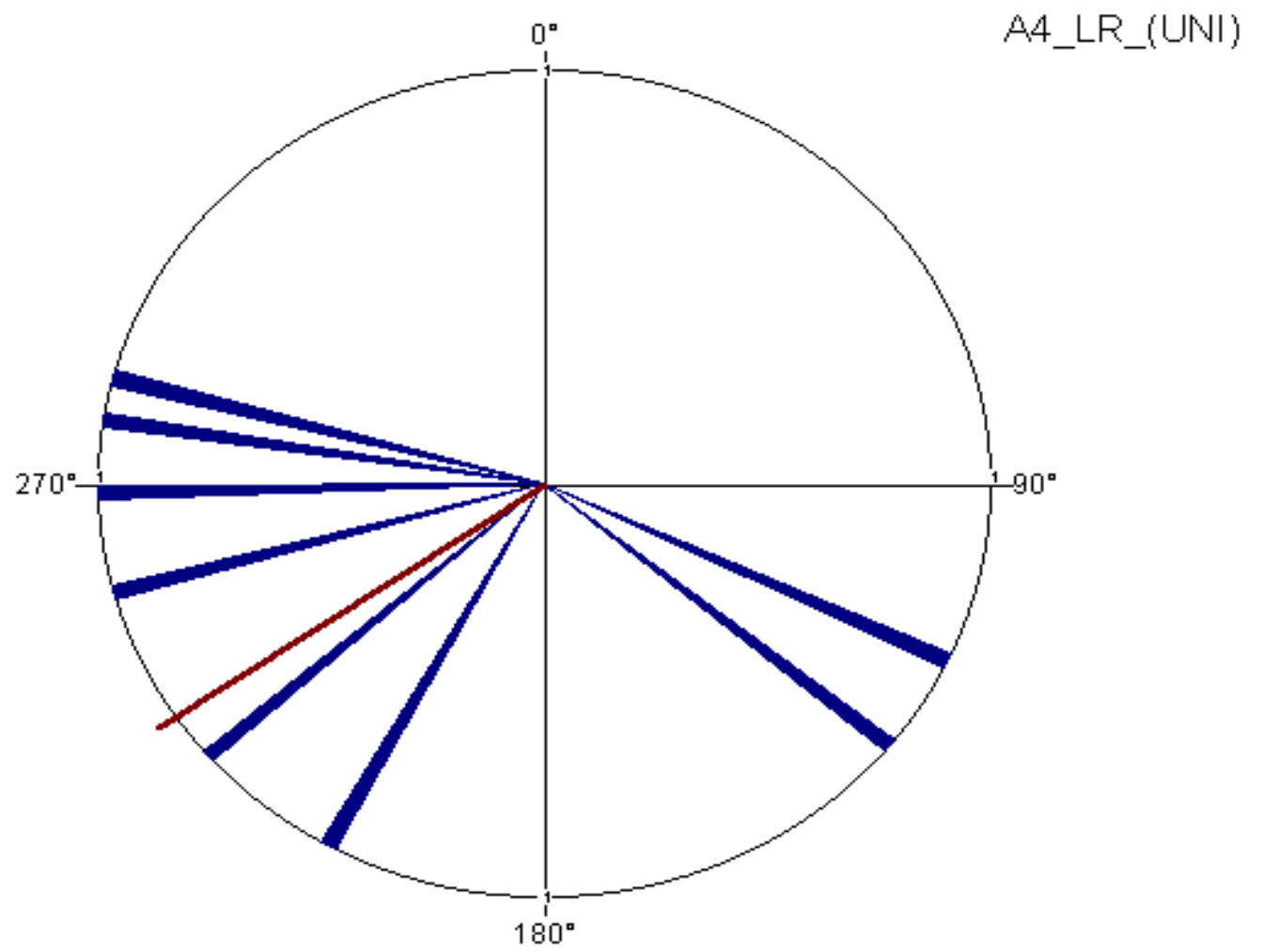

Figure 175. Uni-directional rose diagram from area 3 in the lower Rockwell Member 


\section{Area 3 - Lower Rockwell Member}

Sample Label Data Type

Observations

Mean vector $(\mu)$

Circular variance

Circular standard deviation

Standard error of mean
Area 3

Bi-directional

$$
\begin{array}{r}
4 \\
135.00^{\circ} \\
0.4 \\
57.53^{\circ} \\
33.68^{\circ} \text { * }
\end{array}
$$

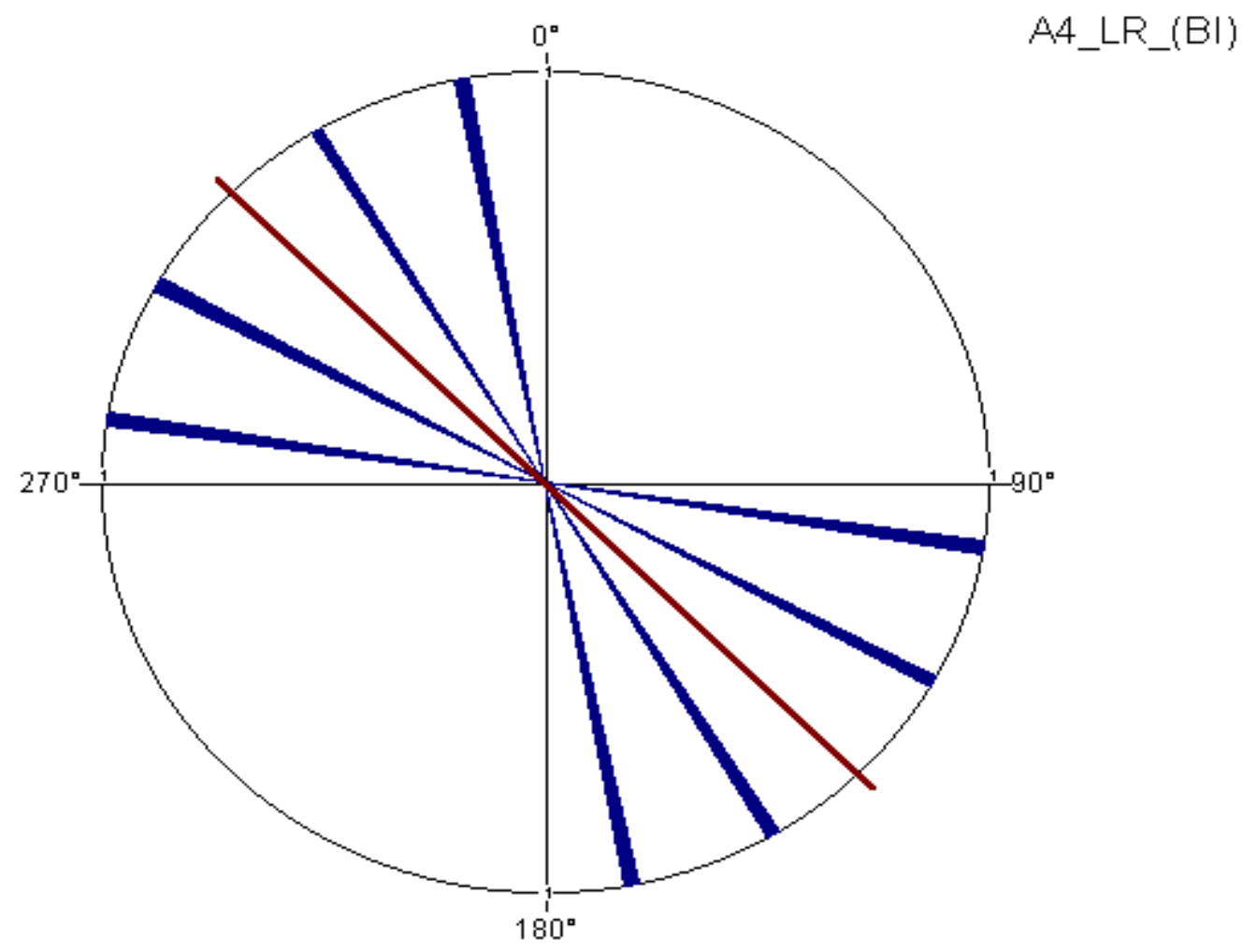

Figure 176. Bi-directional rose diagram from area 3 in the lower Rockwell Member 


\section{Area 4 - Lower Rockwell Member}

Sample Label

Data Type

Observations

Mean vector $(\mu)$

Circular variance

Circular standard deviation

Standard error of mean
Area 4

Uni-directional

11

$134.98^{\circ}$

0.81

$104.02^{\circ}$

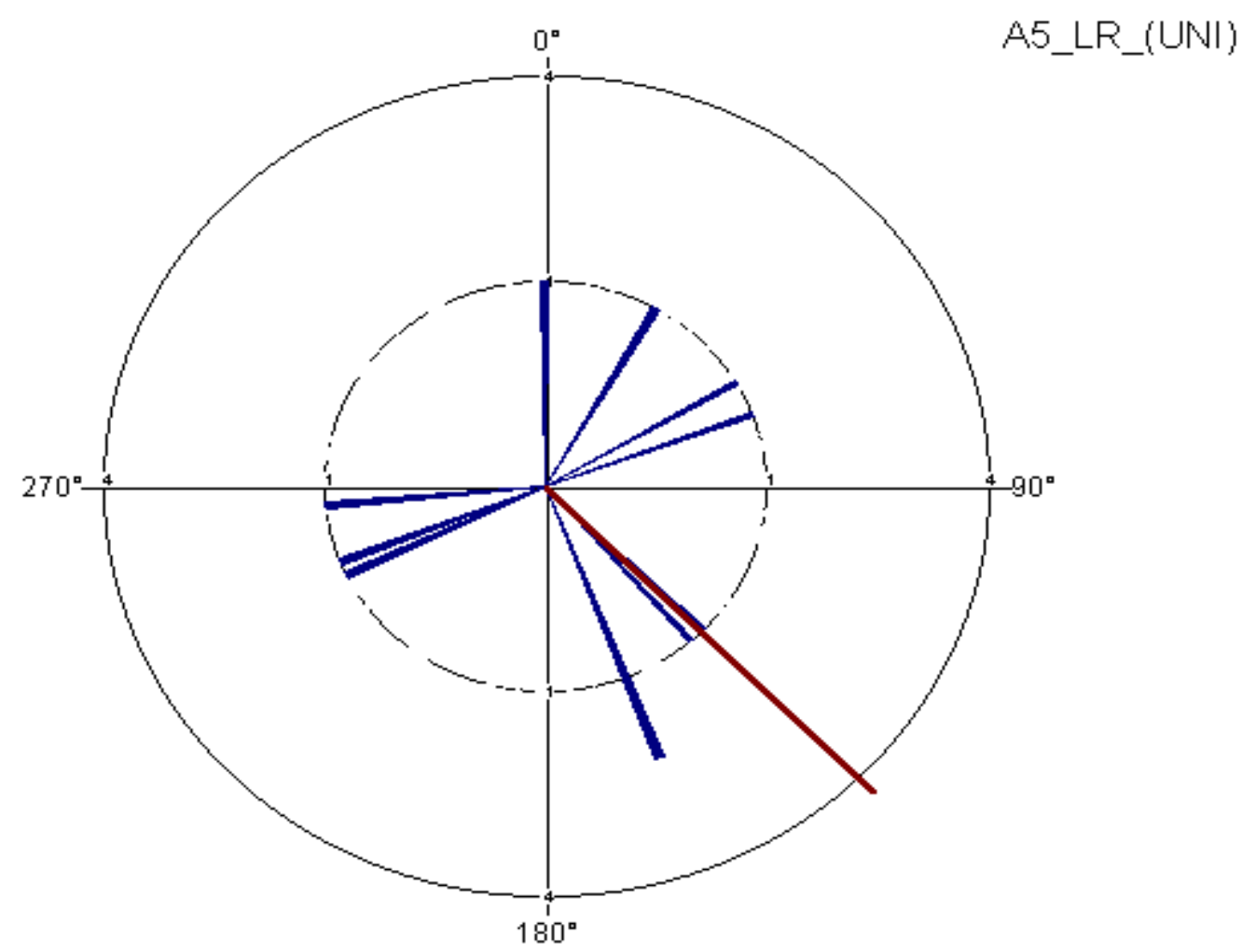

Figure 177. Uni-directional rose diagram from area 4 in the lower Rockwell Member 


\section{Area 4 - Lower Rockwell Member}

Sample Label

Data Type

Observations

Mean vector $(\mu)$

Circular variance

Circular standard deviation

Standard error of mean
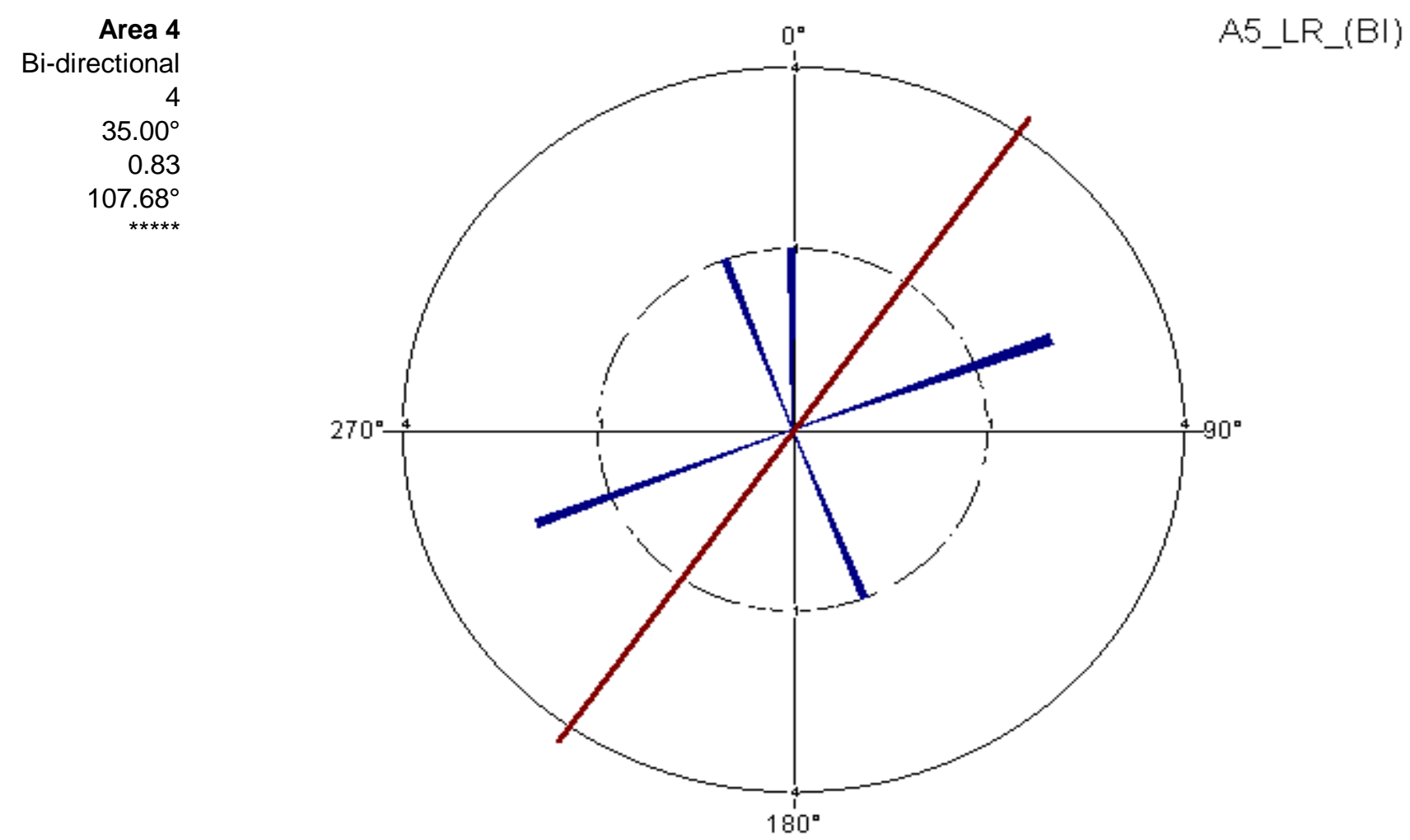

Figure 178. Bi-directional rose diagram from area 4 in the lower Rockwell Member 


\section{Area 5 - Lower Rockwell Member}

\section{Sample Label}

Data Type

Observations

Mean vector $(\mu)$

Circular variance

Circular standard deviation

Standard error of mean

Area 5
Uni-directional
4
$297.50^{\circ}$
0.03
$13.51^{\circ}$
$10.72^{\circ}$

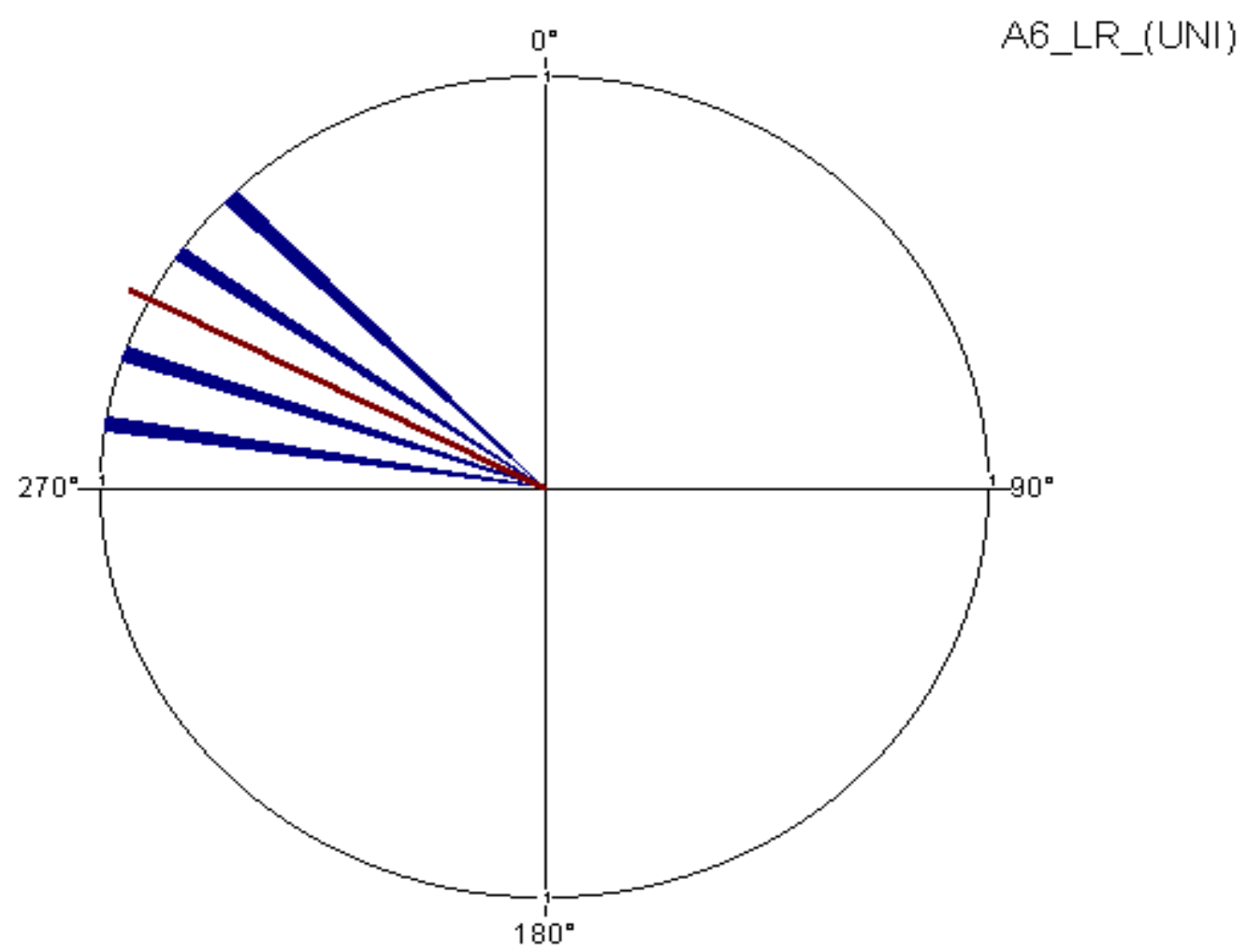

Figure 179. Uni-directional rose diagram from area 5 in the lower Rockwell Member 


\section{Area 5 - Lower Rockwell Member}

$\begin{array}{lr}\text { Sample Label } & \text { Area 5 } \\ \text { Data Type } & \text { Bi-directional } \\ \text { Observations } & 3 \\ \text { Mean vector }(\mu) & 23.35^{\circ} \\ \text { Circular variance } & 0.02 \\ \text { Circular standard deviation } & 12.51^{\circ} \\ \text { Standard error of mean } & 13.98^{\circ}\end{array}$

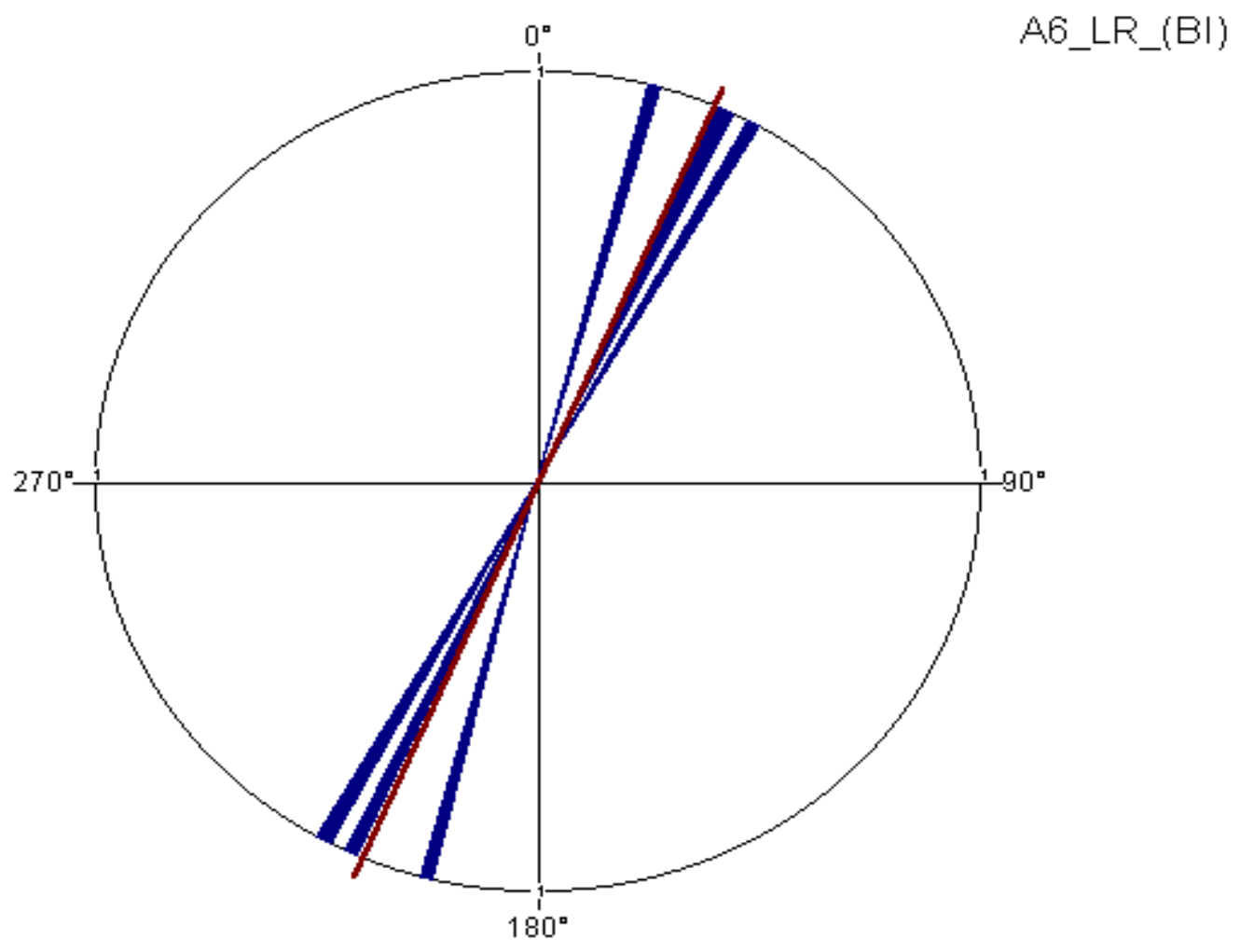

Figure 180. Bi-directional rose diagram from area 5 in the lower Rockwell Member 


\section{Area 6 - Lower Rockwell Member}

Sample Label

Data Type

Observations

Mean vector $(\mu)$

Circular variance

Circular standard deviation

Standard error of mean
Area 6

Uni-directional

$$
\begin{array}{r}
2 \\
300.00^{\circ} \\
0.02 \\
10.03^{\circ} \\
22.42^{\circ}
\end{array}
$$

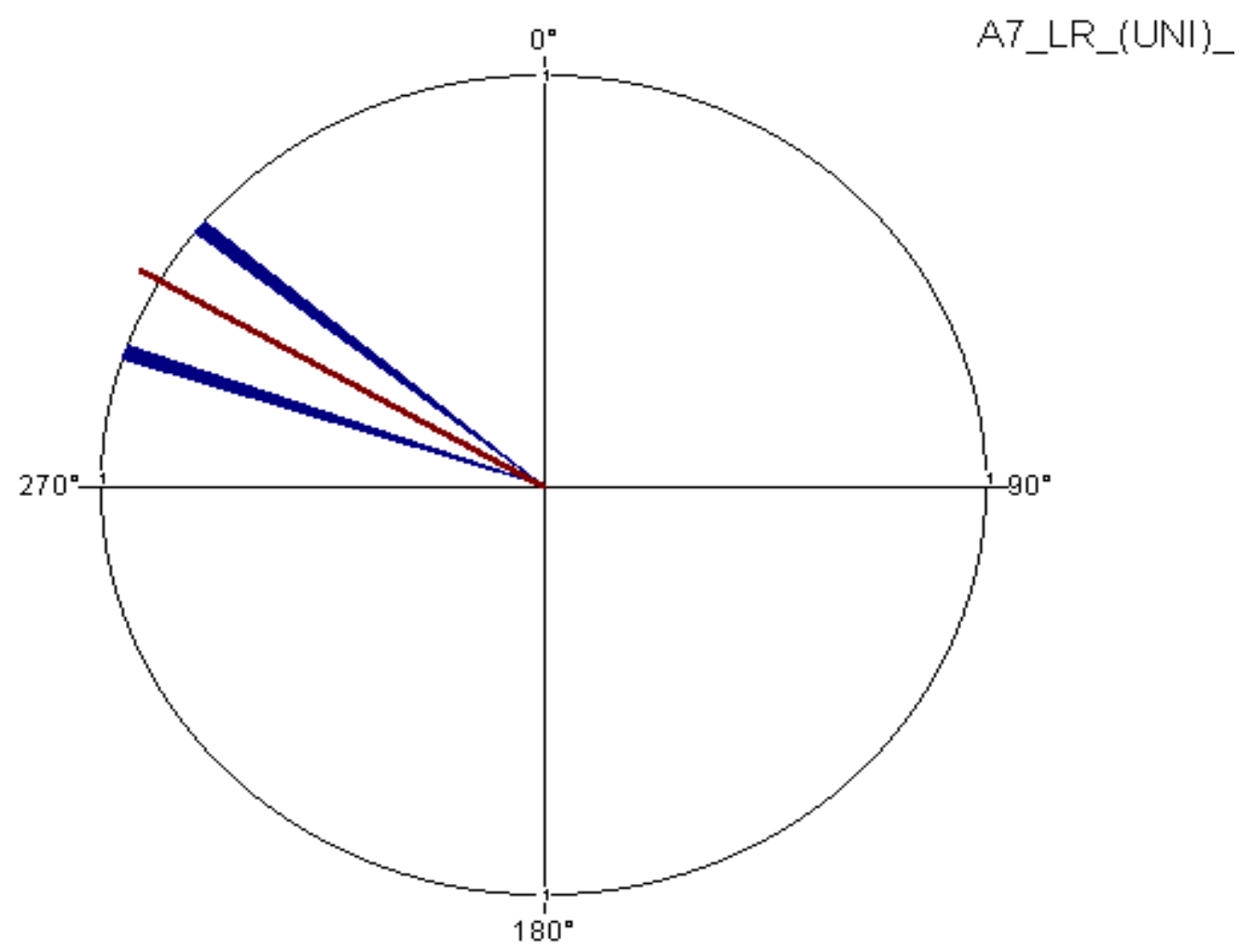

Figure 181. Uni-directional rose diagram from area 6 in the lower Rockwell Member 


\section{Area 7 - Lower Rockwell Member}

Sample Label

Data Type

Observations

Mean vector $(\mu)$

Circular variance

Circular standard deviation

Standard error of mean

Area 7
Uni-directional
6
$243.06^{\circ}$
0.13
$30.14^{\circ}$
$16.35^{\circ}$

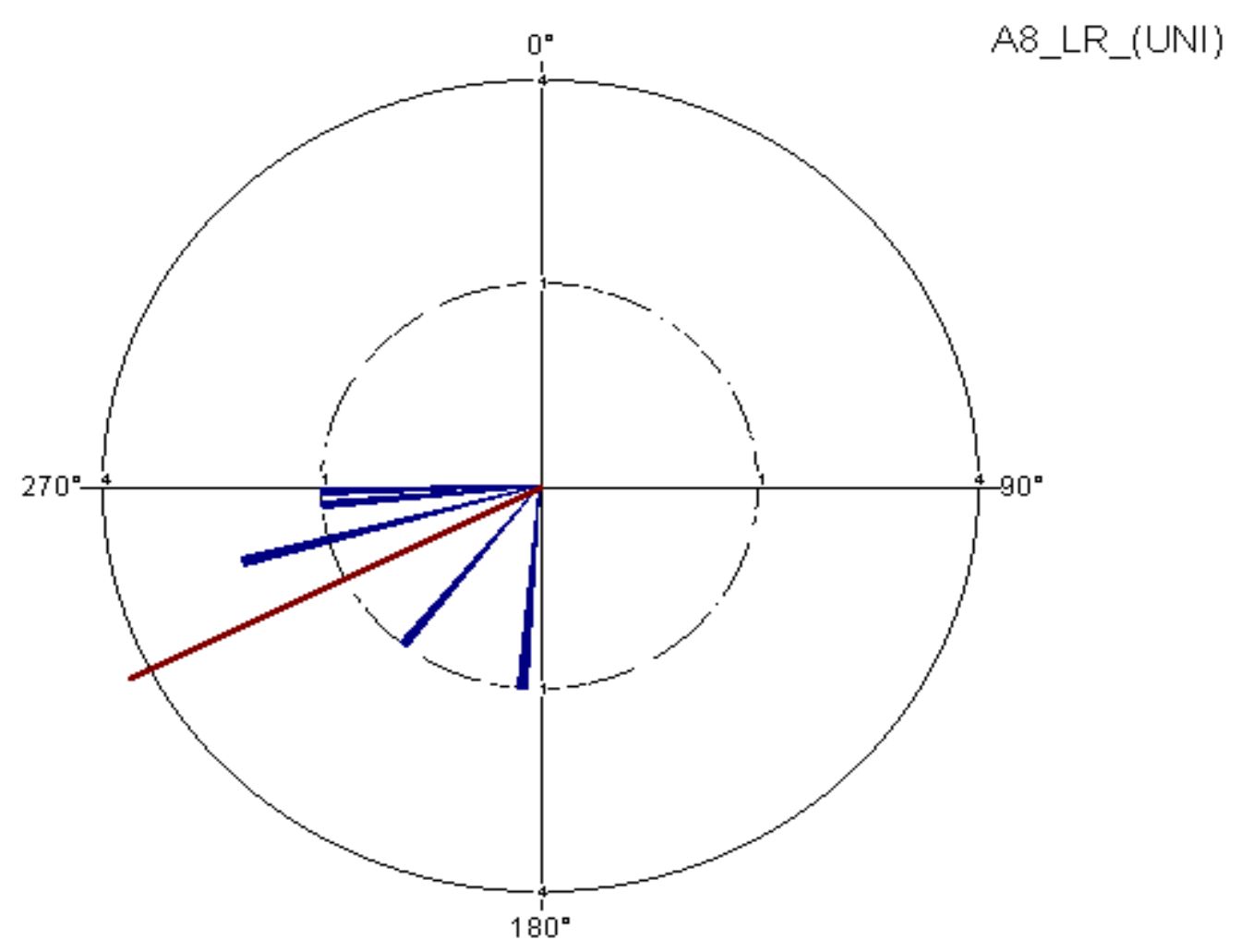

Figure 182. Uni-directional rose diagram from area 7 in the lower Rockwell Member 


\section{Appendix V - Grouped data from the upper Rockwell Member}

\section{Area 1 - Upper Rockwell Member}

\section{Sample Label}

Data Type

Observations

Mean vector $(\mu)$

Circular variance

Circular standard deviation

Standard error of mean

Area 1
Uni-directional
3
$33.83^{\circ}$
0.16
$34.37^{\circ}$
$38.17^{\circ}$ *

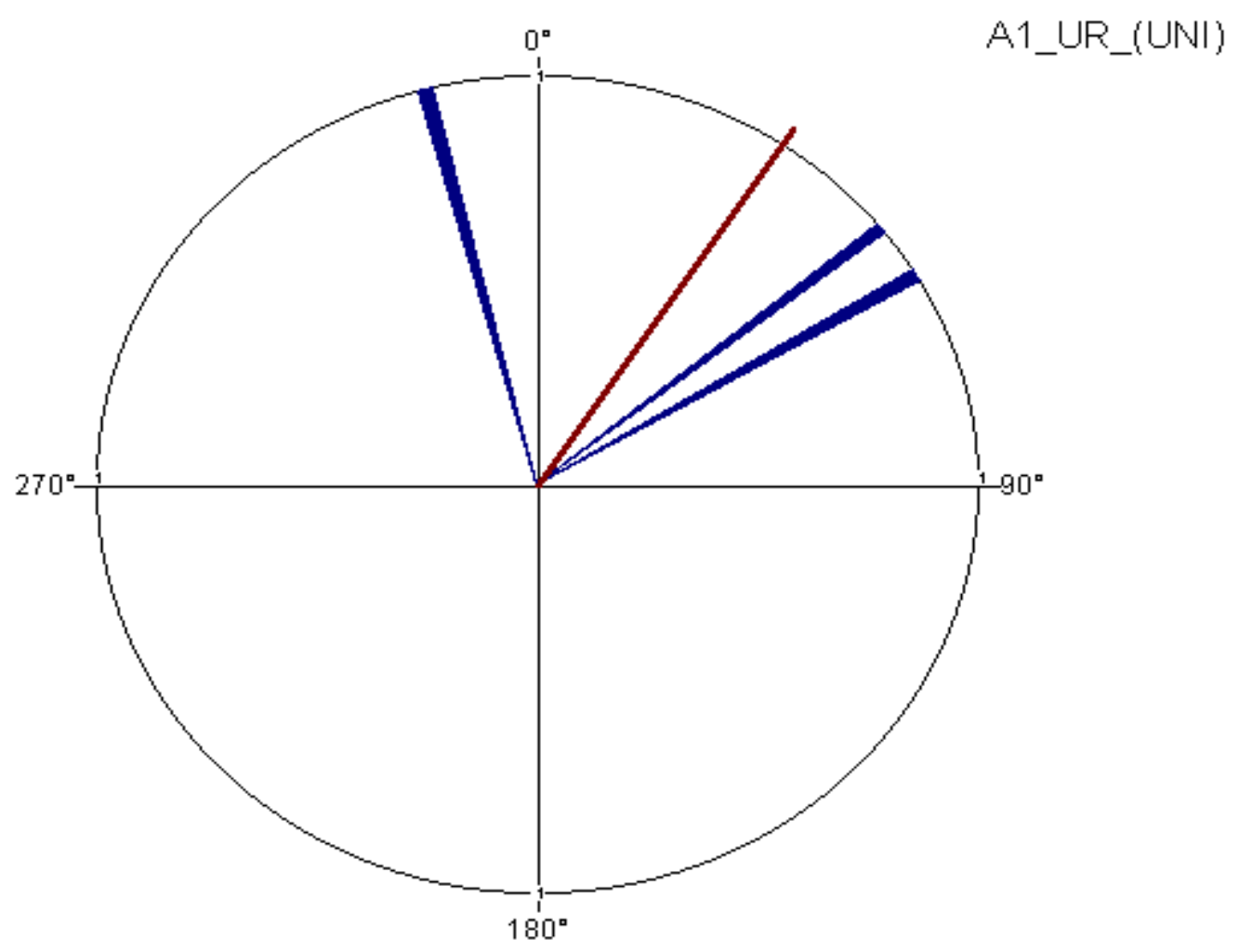

Figure 183. Uni-directional rose diagram from area 1 in the upper Rockwell Member 


\section{Area 2 - Upper Rockwell Member}

Sample Label

Data Type

Observations

Mean vector $(\mu)$

Circular variance

Circular standard deviation

Standard error of mean
Area 2

Uni-directional

7
$3.94^{\circ}$

0.77

$98.56^{\circ}$

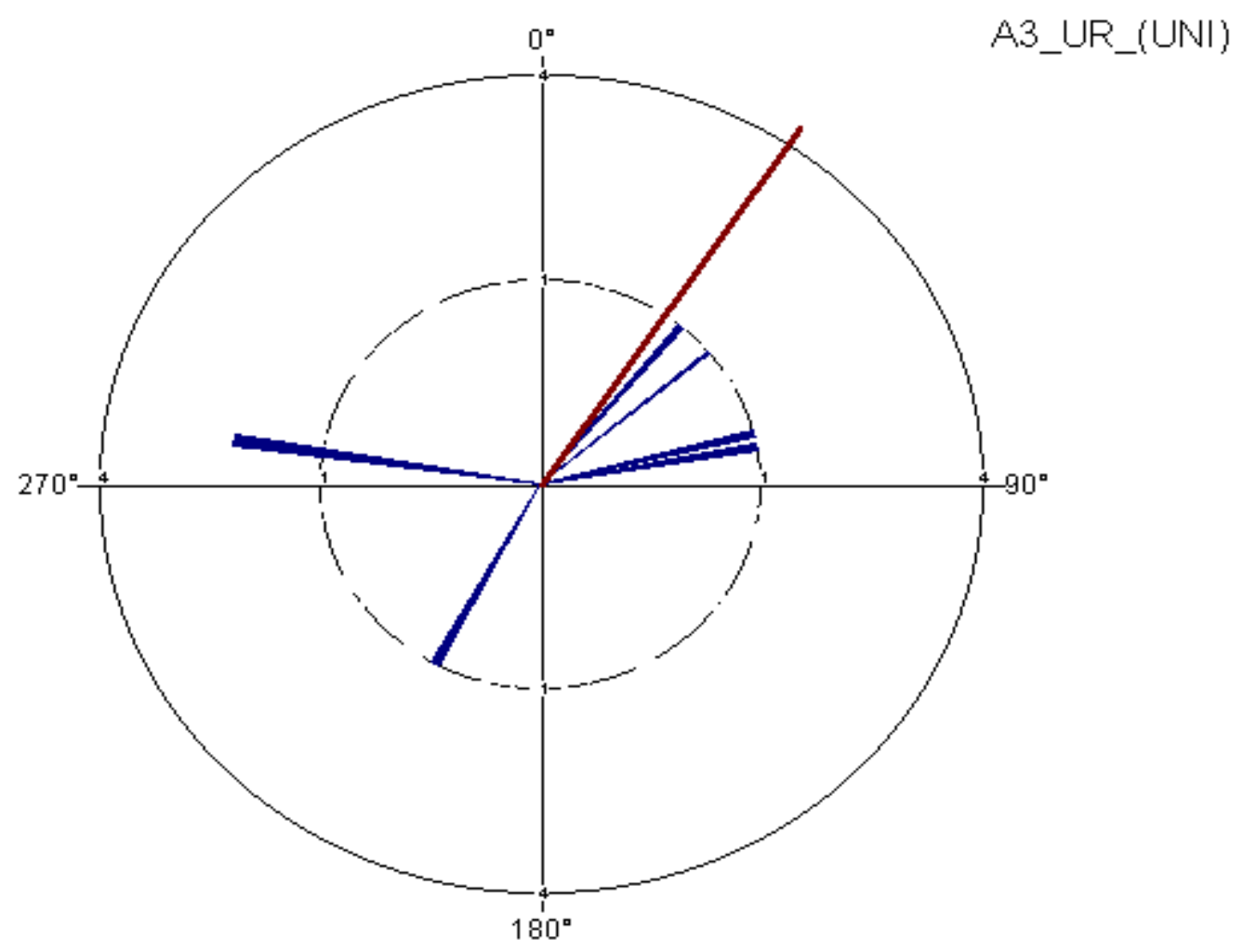

Figure 184. Uni-directional rose diagram from area 2 in the upper Rockwell Member 


\section{Area 2 - Upper Rockwell Member}

Sample Label

Data Type

Observations

Mean vector $(\mu)$

Circular variance

Circular standard deviation

Standard error of mean
Area 2

Bi-directional

$1600^{3}$

0

$-0.00^{\circ}$

$* * * * *$

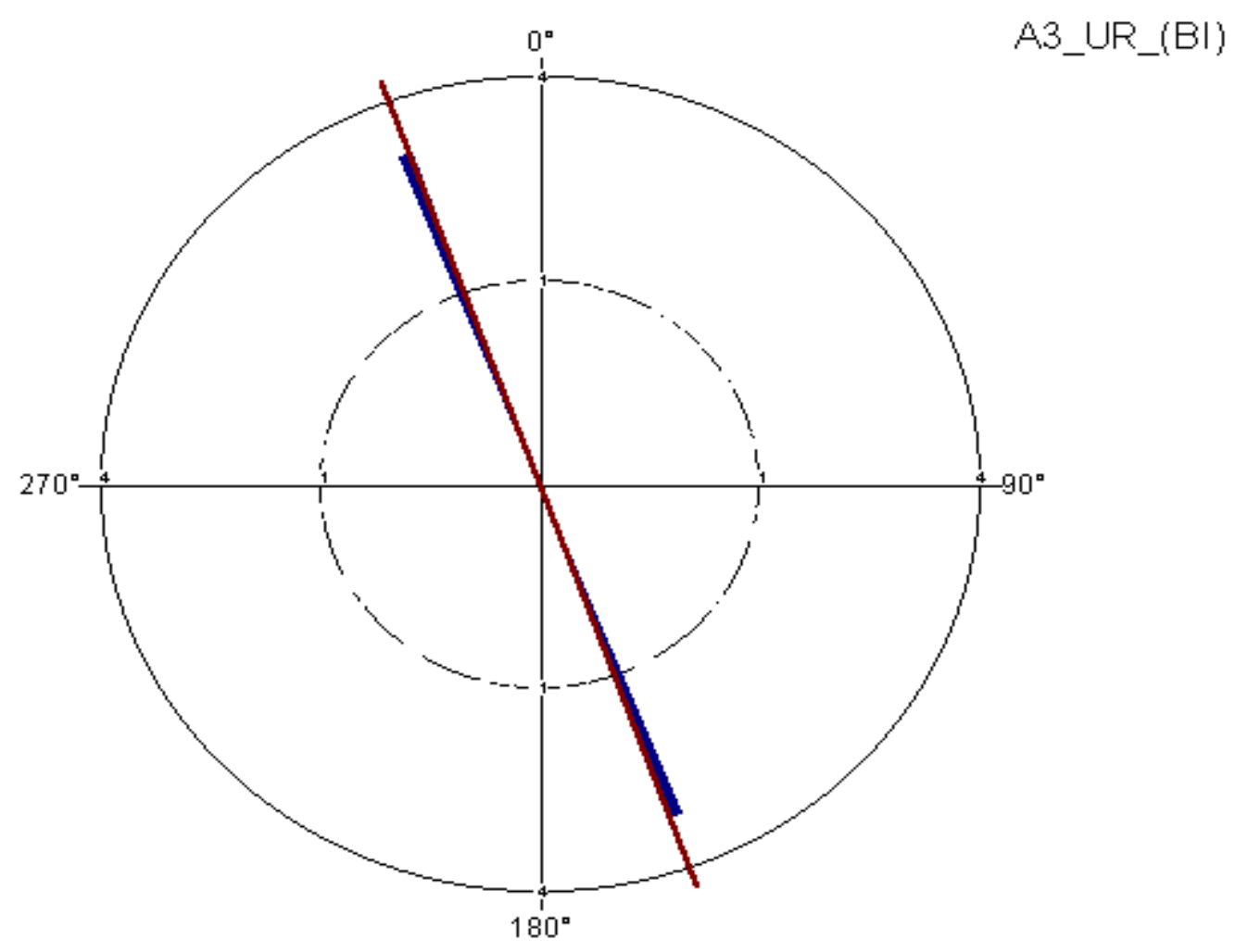

Figure 185: Bi-directional rose diagram from area 2 in the upper Rockwell Member 


\section{Area 3 - Upper Rockwell Member}

Sample Label

Data Type

Observations

Mean vector $(\mu)$

Circular variance

Circular standard deviation

Standard error of mean

Area 3
Uni-directional
6
$291.54^{\circ}$
0.15
$32.20^{\circ}$
$17.45^{\circ}$

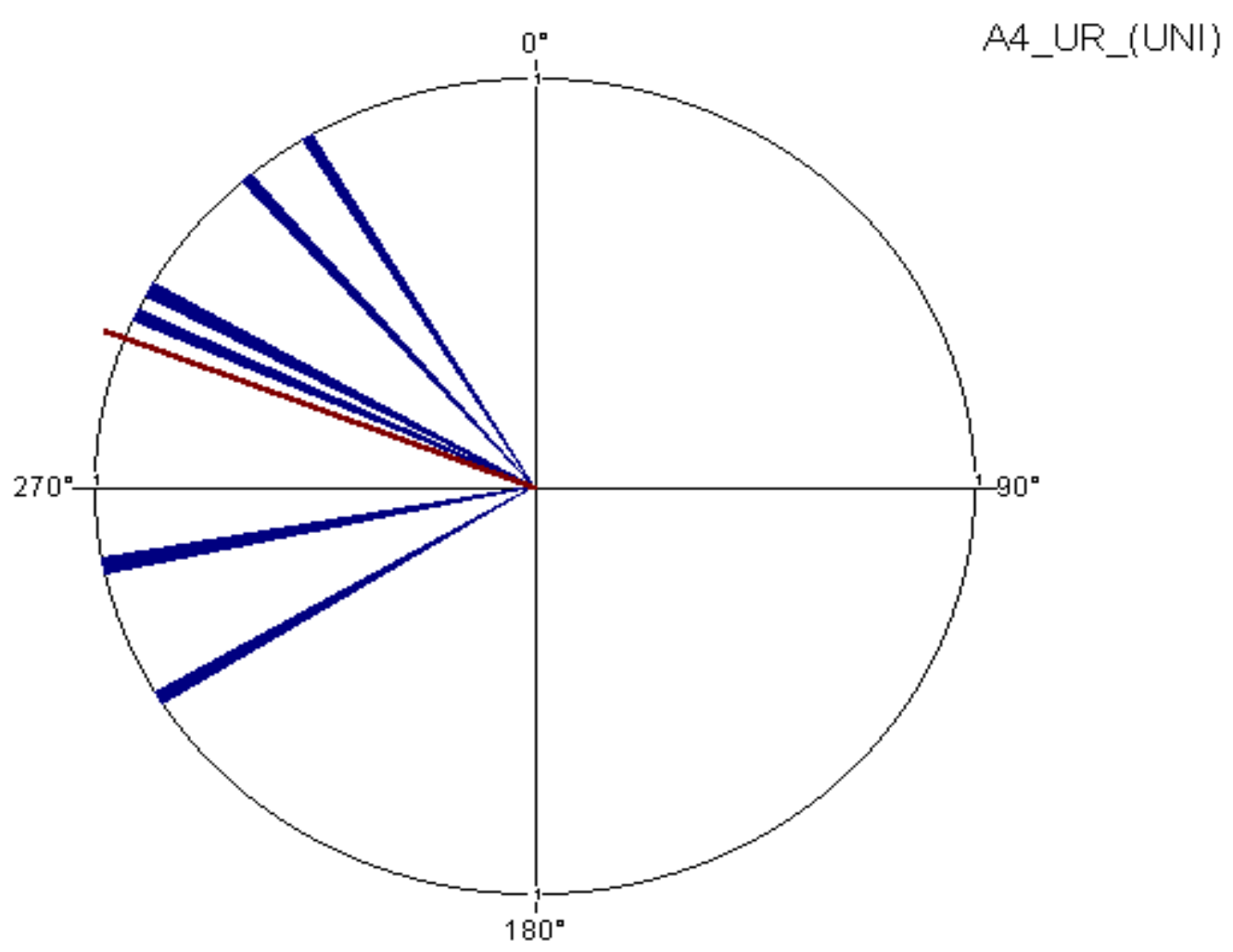

Figure 186. Uni-directional rose diagram from area 3 in the upper Rockwell Member 


\section{Area 3 - Upper Rockwell Member}

Sample Label

Data Type

Observations

Mean vector $(\mu)$

Circular variance

Circular standard deviation

Standard error of mean
Area 3

Bi-directional

8
$4.39^{\circ}$

0.75

$95.18^{\circ}$

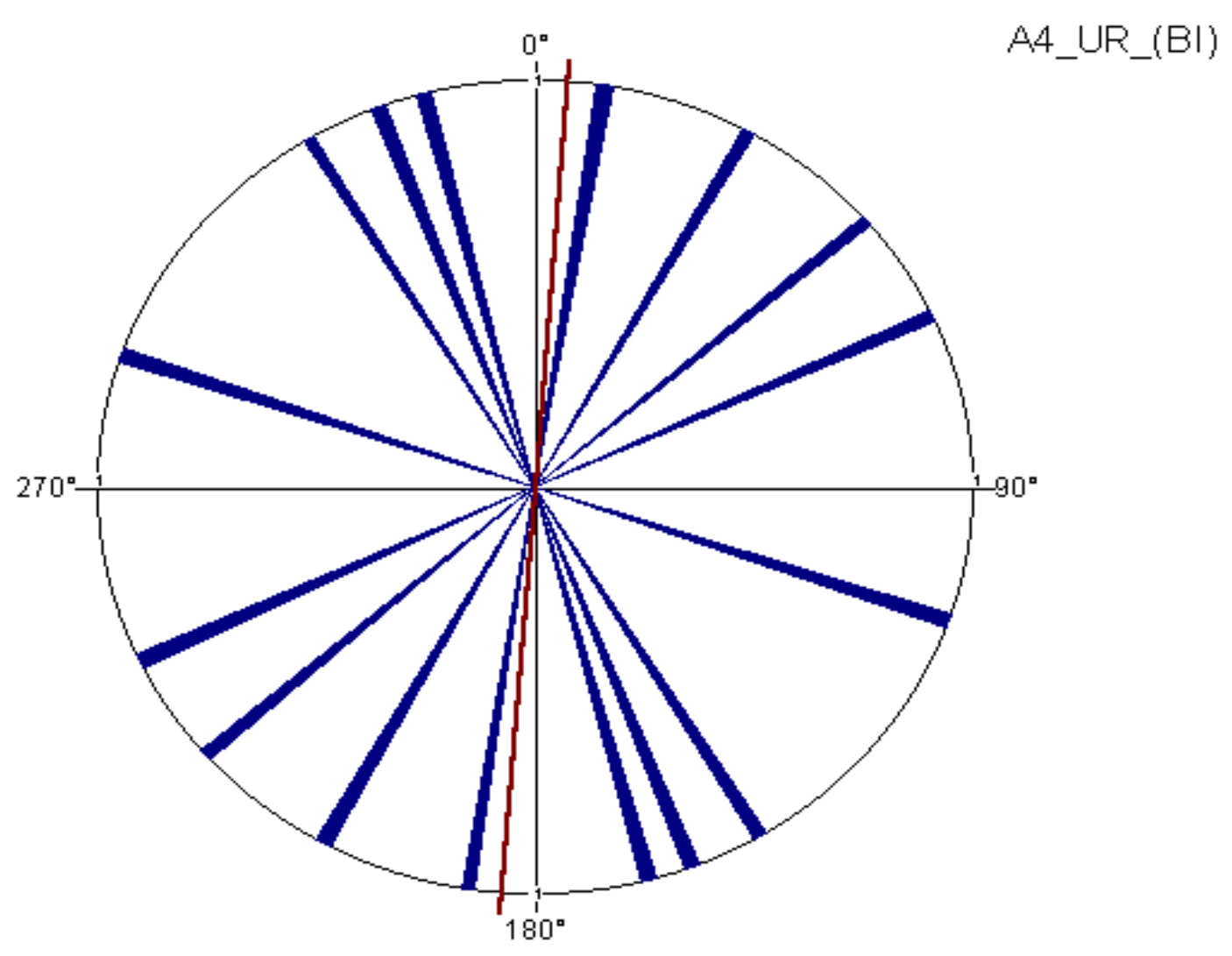

Figure 187. Bi-directional rose diagram from area 3 in the upper Rockwell Member 


\section{Area 4 - Upper Rockwell Member}

Sample Label

Data Type

Observations

Mean vector $(\mu)$

Circular variance

Circular standard deviation

Standard error of mean
Area 4

Uni-directional

11
$266.17^{\circ}$

0.26

$44.47^{\circ}$

$15.40^{\circ}$

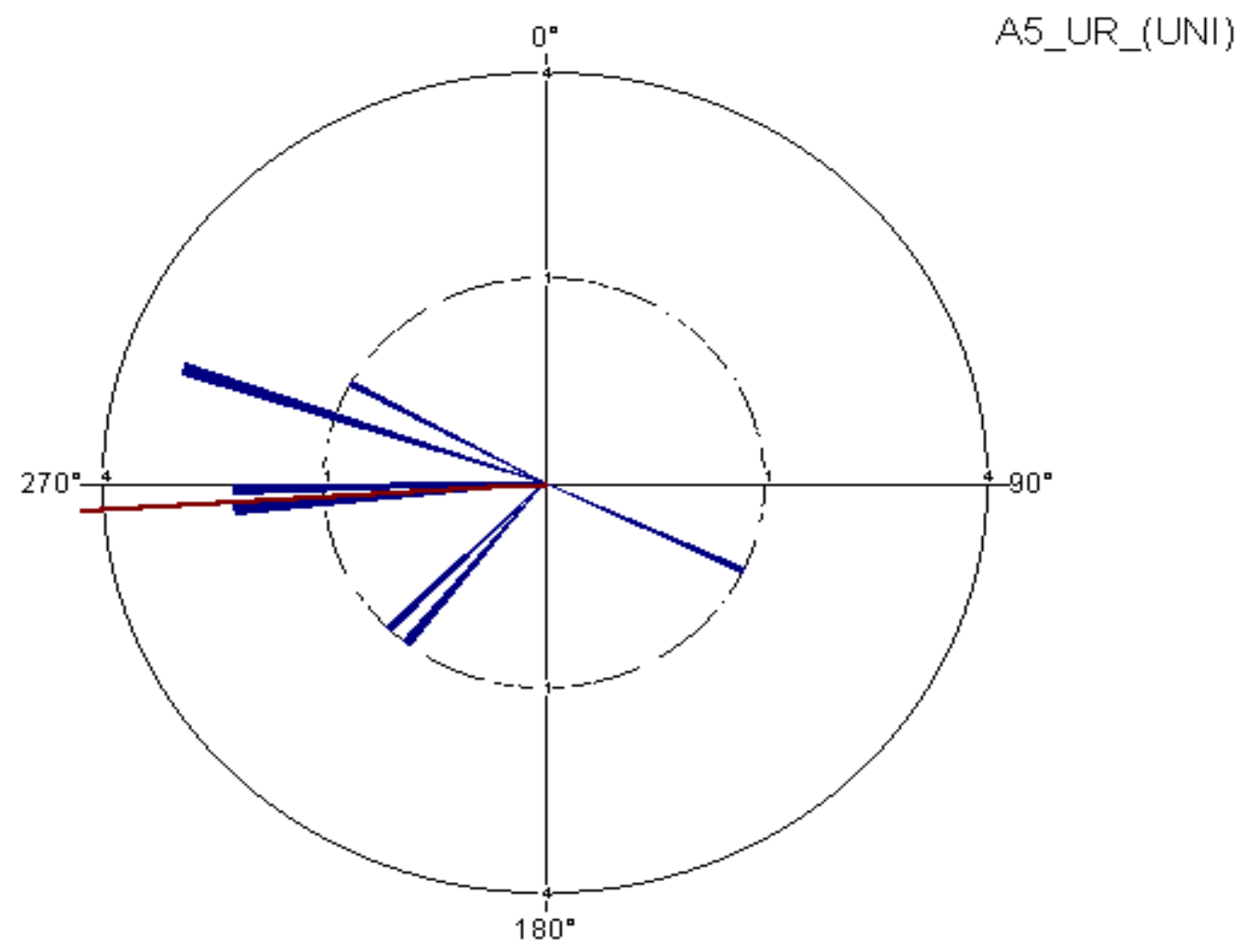

Figure 188. Uni-directional rose diagram from area 4 in the upper Rockwell Member 


\section{Area 4 - Upper Rockwell Member}

\section{Sample Label}

Data Type

Observations

Mean vector $(\mu)$

Circular variance

Circular standard deviation

Standard error of mean
Area 4

Bi-directional

4
$49^{\circ}$

$63.49^{\circ}$
0.39

$56.92^{\circ}$

$33.05^{\circ}$ *

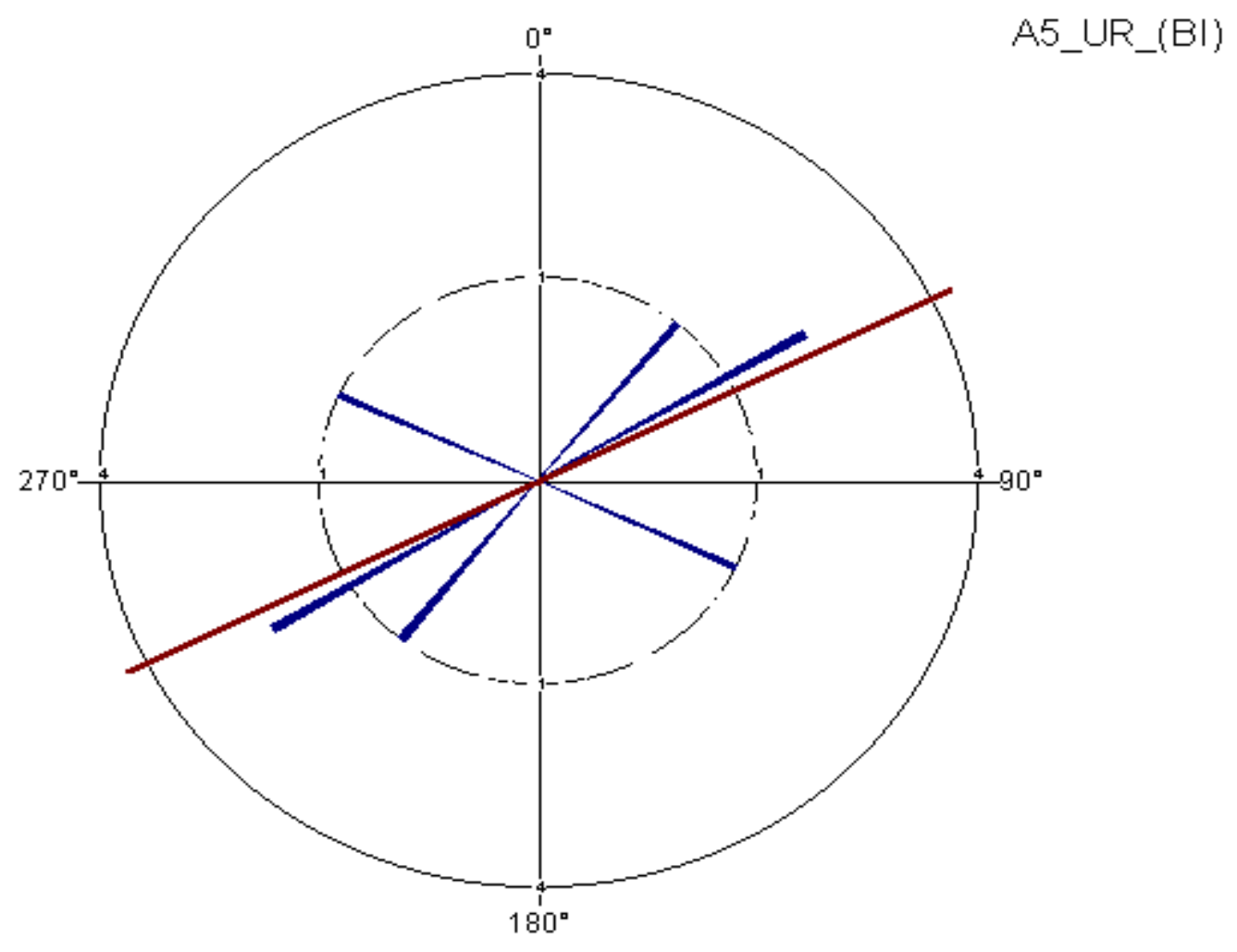

Figure 189. Bi-directional rose diagram from area 4 in the upper Rockwell Member 


\section{Area 5 - Upper Rockwell Member}

$\begin{array}{lr}\text { Sample Label } & \text { Area 5 } \\ \text { Data Type } & \text { Uni-directional } \\ \text { Observations } & 4 \\ \text { Mean vector }(\mu) & 264.68^{\circ} \\ \text { Circular variance } & 0.08 \\ \text { Circular standard deviation } & 23.10^{\circ} \\ \text { Standard error of mean } & 18.31^{\circ}\end{array}$

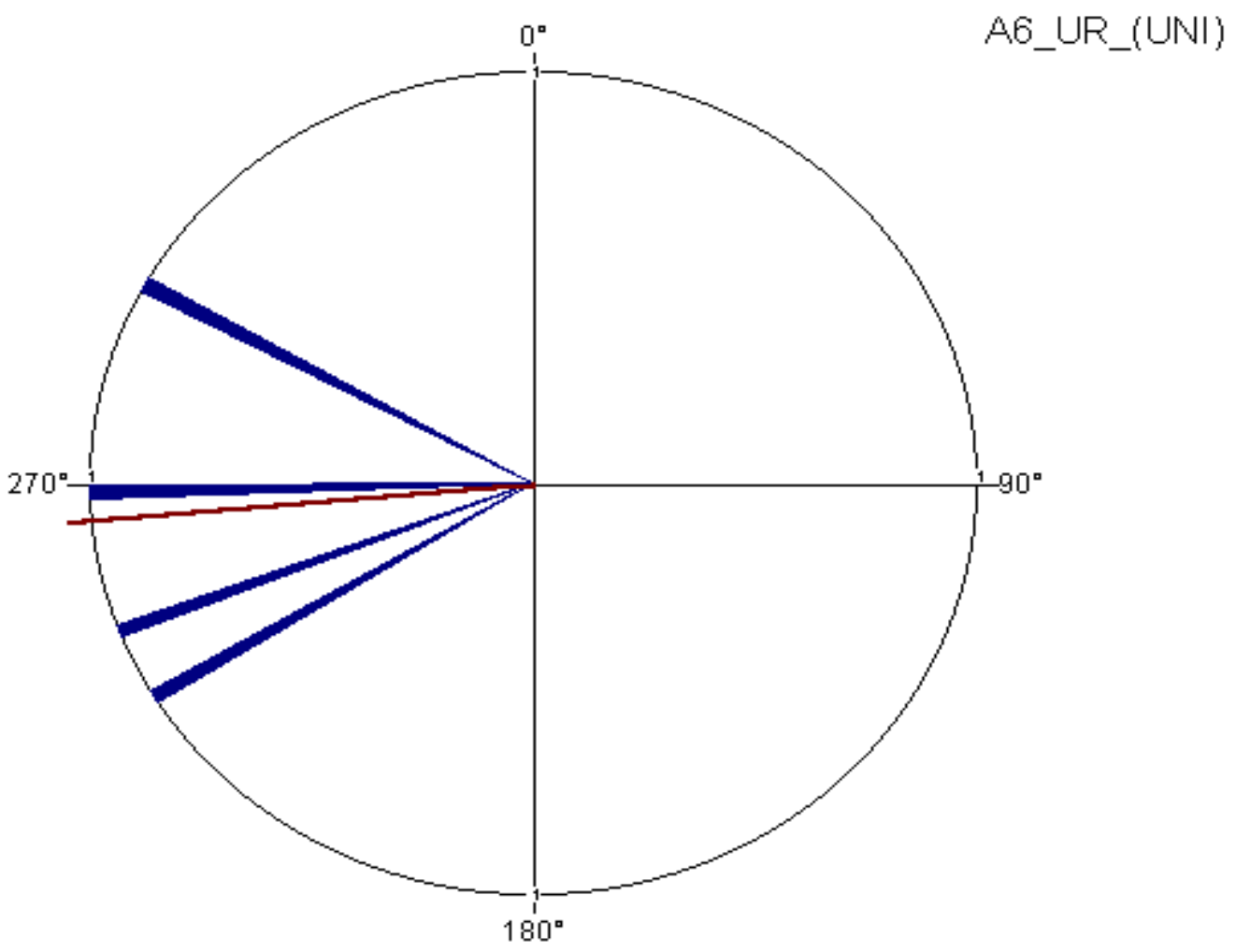

Figure 190. Uni-directional rose diagram from area 5 in the upper Rockwell Member 


\section{Area 5 - Upper Rockwell Member}

\section{Sample Label}

Data Type

Observations

Mean vector $(\mu)$

Circular variance

Circular standard deviation

Standard error of mean
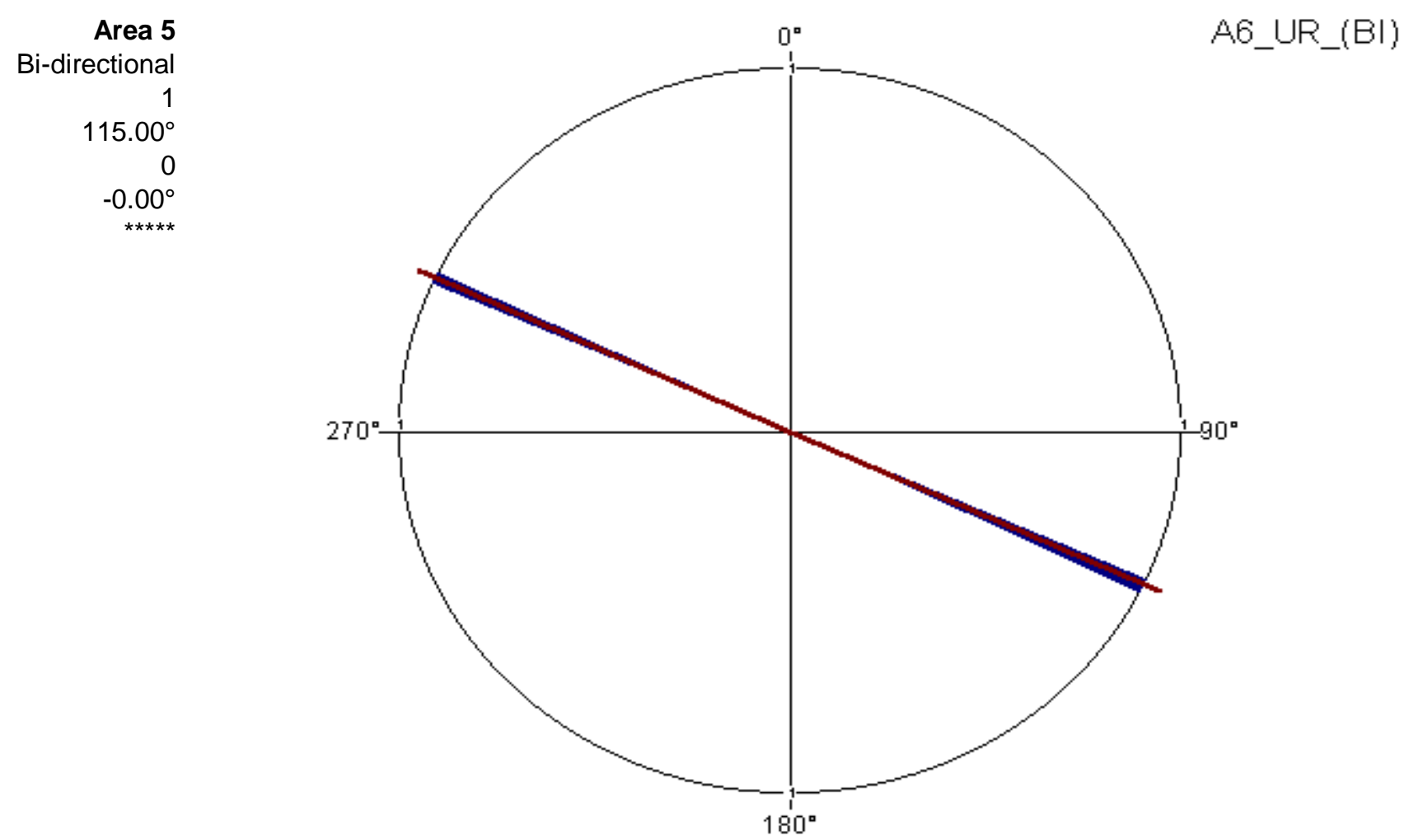

Figure 191. Bi-directional rose diagram from area 5 in the upper Rockwell Member 


\section{Area 6 - Upper Rockwell Member}

Sample Label

Data Type

Observations

Mean vector $(\mu)$

Circular variance

Circular standard deviation

Standard error of mean
Area 6

Uni-directional

$268.43^{\circ}$

0.1

$26.93^{\circ}$

$30.06^{\circ}$ *

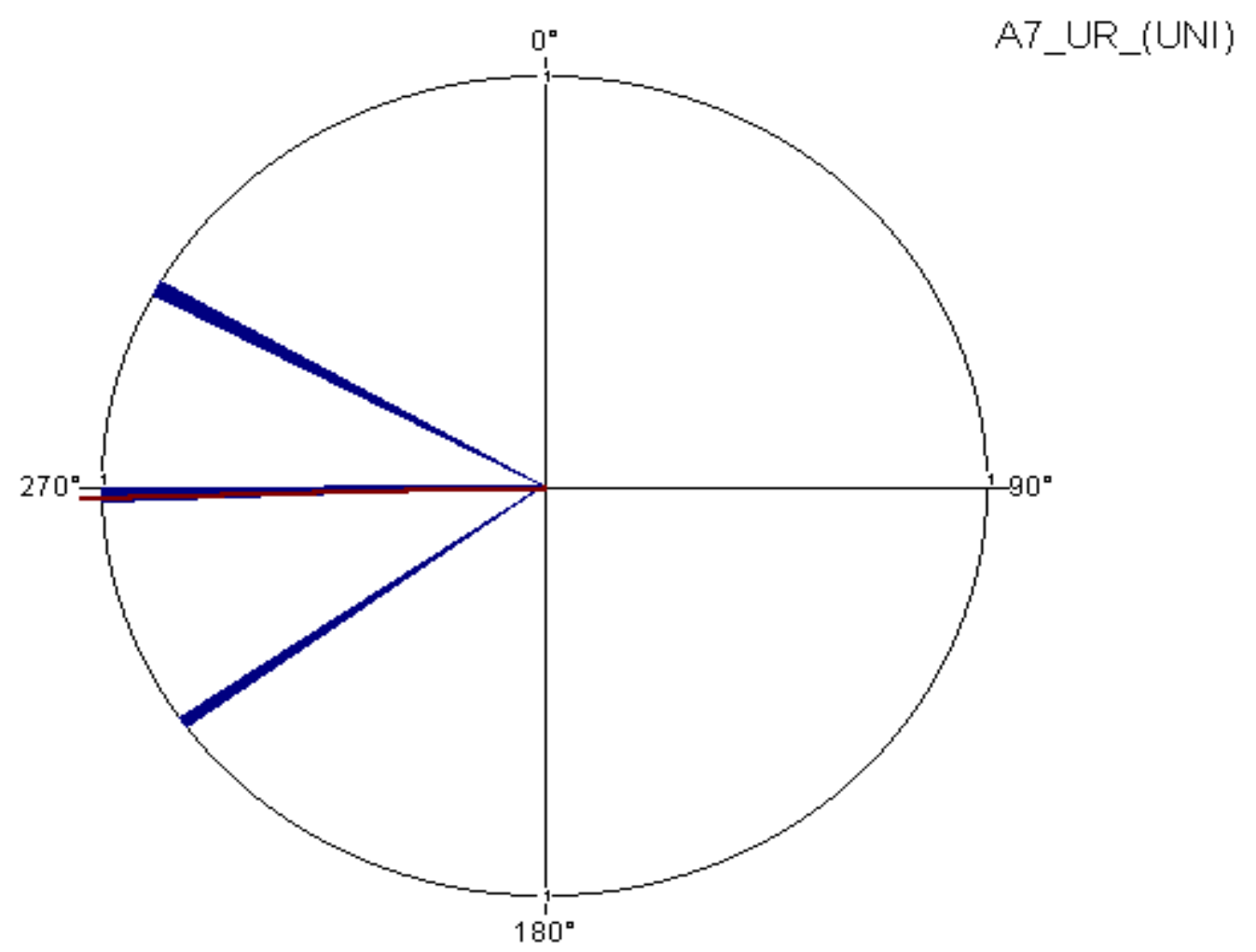

Figure 192. Uni-directional rose diagram from area 6 in the upper Rockwell Member 


\section{Area 6 - Upper Rockwell Member}

Sample Label

Data Type

Observations

Mean vector $(\mu)$

Circular variance

Circular standard deviation

Standard error of mean
Area 6

Bi-directional

2

$67.50^{\circ}$

0.91

$126.57^{\circ}$

$* \star * \star *$

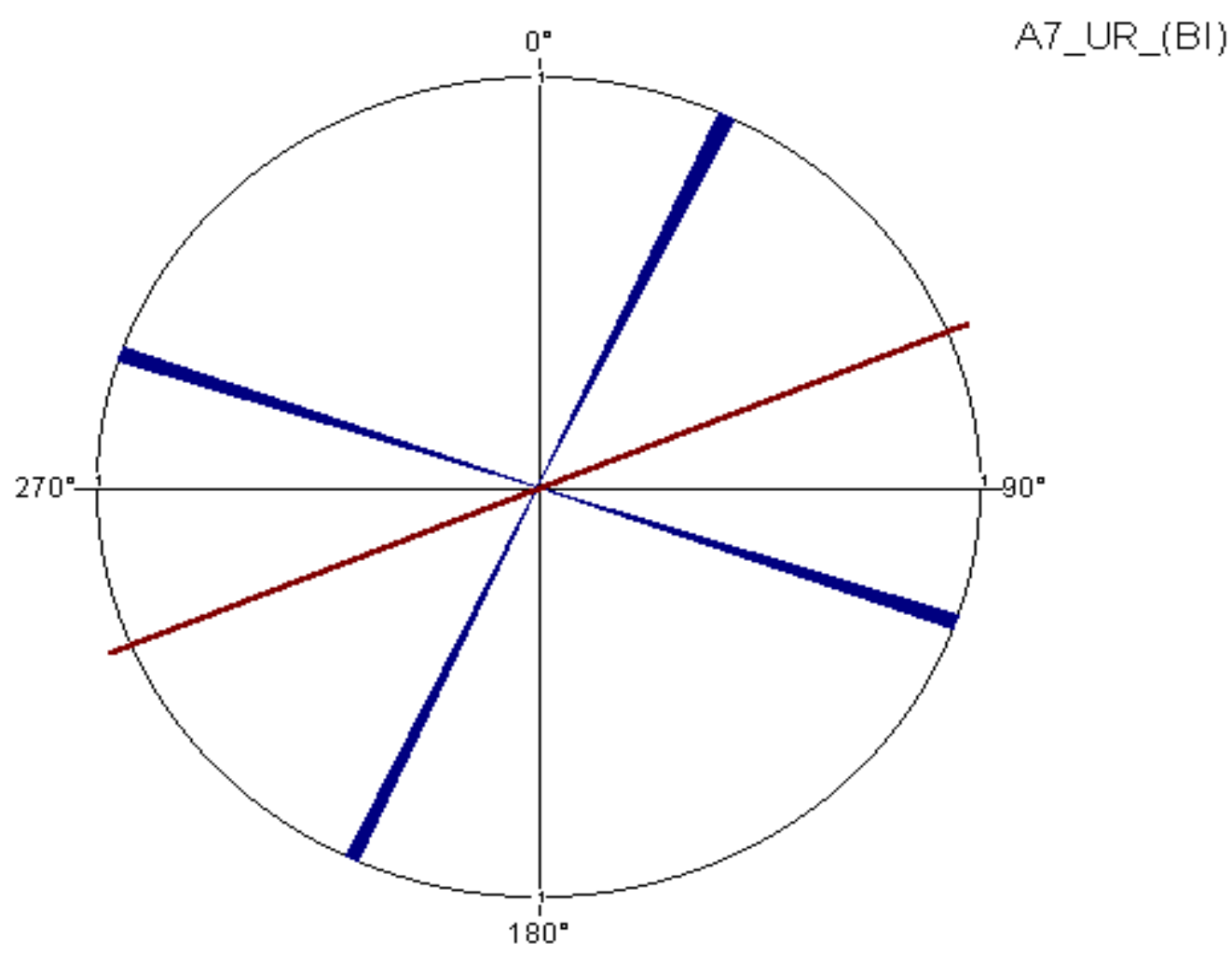

Figure 193. Bi-directional rose diagram from area 6 in the upper Rockwell Member 


\section{Area 7 - Upper Rockwell Member}

Sample Label

Data Type

Observations

Mean vector $(\mu)$

Circular variance

Circular standard deviation

Standard error of mean
Area 7

Bi-directional

$52.50^{\circ}$

0.09

$25.41^{\circ}$

$56.74^{\circ} *$

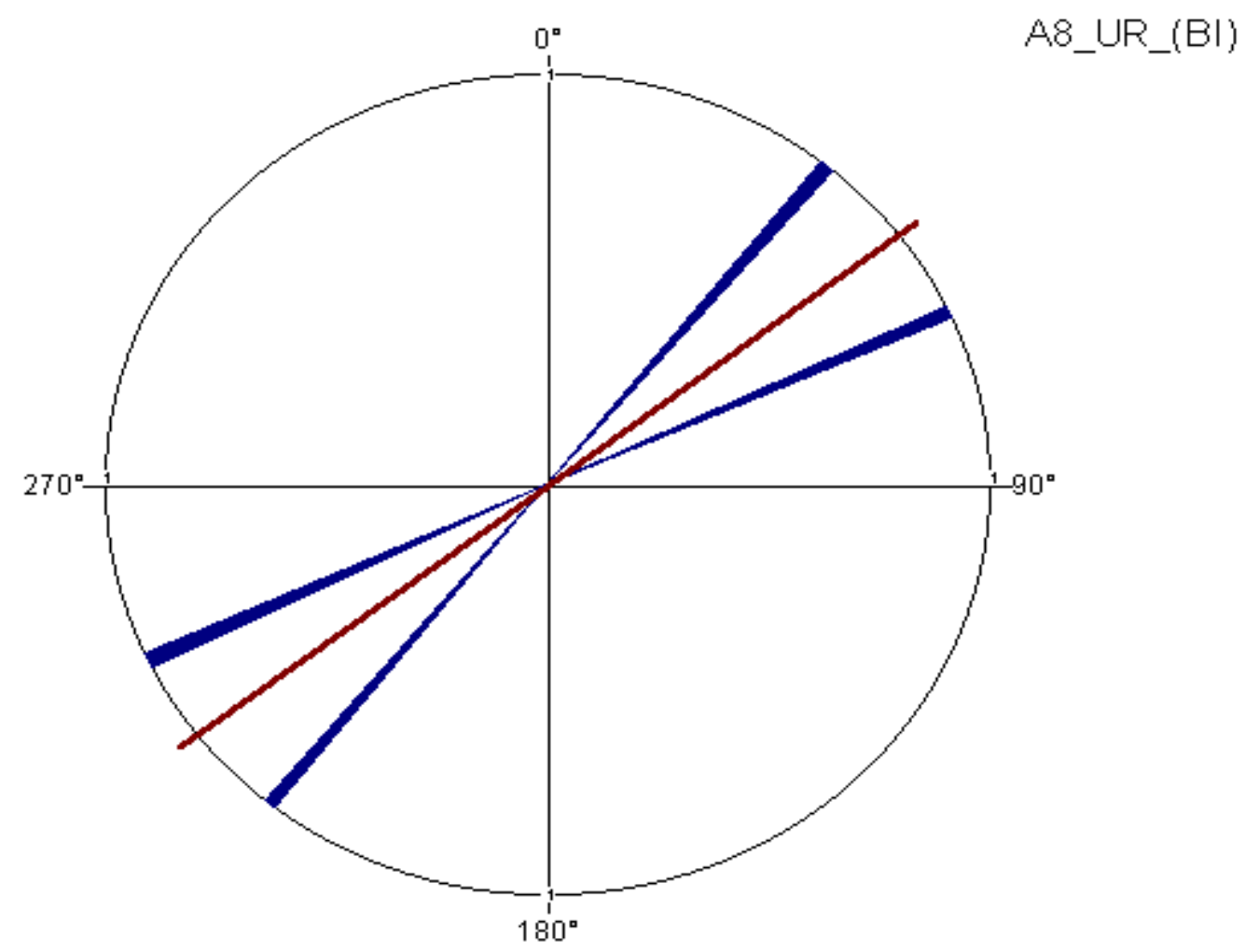

Figure 194. Bi-directional rose diagram from area 7 in the upper Rockwell Member 
Appendix VI

Randomly generated standard deviation for observations ranging 0-360 degrees

\begin{tabular}{|c|c|c|c|c|c|c|c|c|}
\hline & 22 obs & $11 \mathrm{obs}$ & $\underline{8 \text { obs }}$ & 7 obs & $\underline{6 \text { obs }}$ & 4 obs & 3 obs & $2 \mathrm{obs}$ \\
\hline 1.00 & 63.81 & 41.12 & 43.18 & $\overline{34.75}$ & $\overline{23.64}$ & 8.69 & 2.89 & 0.00 \\
\hline 2.00 & 66.49 & 41.24 & 45.20 & 36.01 & 26.58 & 13.05 & 5.51 & 0.00 \\
\hline 3.00 & 69.34 & 48.14 & 45.36 & 37.34 & 28.17 & 14.64 & 5.69 & 0.00 \\
\hline 4.00 & 71.53 & 50.52 & 45.47 & 39.57 & 32.39 & 17.23 & 7.94 & 0.71 \\
\hline 5.00 & 71.58 & 50.76 & 47.00 & 44.78 & 39.03 & 17.86 & 8.08 & 0.71 \\
\hline 6.00 & 76.07 & 55.41 & 47.46 & 44.81 & 39.37 & 17.87 & 10.39 & 0.71 \\
\hline 7.00 & 78.01 & 56.82 & 48.50 & 44.87 & 39.42 & 18.87 & 12.10 & 0.71 \\
\hline 8.00 & 78.62 & 57.68 & 49.83 & 45.00 & 39.75 & 19.30 & 12.17 & 0.71 \\
\hline 9.00 & 78.63 & 58.48 & 52.10 & 46.61 & 39.78 & 23.14 & 12.17 & 0.71 \\
\hline 10.00 & 78.91 & 58.50 & 53.30 & 47.01 & 41.06 & 23.56 & 12.66 & 1.41 \\
\hline 11.00 & 79.47 & 58.58 & 53.82 & 47.78 & 41.29 & 25.67 & 13.43 & 1.41 \\
\hline 12.00 & 79.79 & 61.02 & 54.31 & 48.18 & 41.63 & 25.75 & 13.50 & 1.41 \\
\hline 13.00 & 79.93 & 61.05 & 54.99 & 48.64 & 42.83 & 25.89 & 13.75 & 1.41 \\
\hline 14.00 & 80.33 & 62.85 & 56.26 & 50.74 & 43.94 & 25.89 & 14.01 & 1.41 \\
\hline 15.00 & 80.34 & 63.91 & 56.60 & 51.09 & 44.09 & 25.97 & 14.01 & 1.41 \\
\hline 16.00 & 80.73 & 64.33 & 56.63 & 51.78 & 44.41 & 26.08 & 14.36 & 1.41 \\
\hline 17.00 & 80.76 & 64.46 & 57.52 & 52.52 & 44.51 & 26.25 & 15.10 & 1.41 \\
\hline 18.00 & 81.02 & 64.52 & 57.99 & 52.71 & 44.84 & 27.33 & 15.18 & 1.41 \\
\hline & 81.21 & 65.21 & 58. & 53.03 & 45.77 & & 15.52 & 2.12 \\
\hline 20.00 & 81.61 & 65.39 & 58.28 & 53.15 & 46.08 & 28.39 & 15.95 & 2.12 \\
\hline 21.00 & 81.75 & 65.51 & 58.29 & 53.33 & 46.77 & 28.90 & 16.50 & 2.12 \\
\hline 22.00 & 82.01 & 65.59 & 58.60 & 53.48 & 46.93 & 29.07 & 16.62 & 2.12 \\
\hline 23.00 & 82.03 & 66.25 & 58.96 & 53.93 & 47.18 & 29.13 & 17.21 & 2.12 \\
\hline 24.00 & 82.07 & 66.71 & 59.00 & 54.07 & 48.81 & 29.18 & 17.21 & 2.12 \\
\hline 25.00 & 82.13 & 67.03 & 59.02 & 54.08 & 49.59 & 29.26 & 17.24 & 2.83 \\
\hline 26.00 & 82.15 & 67.64 & 59.13 & 55.34 & 49.64 & 29.54 & 17.39 & 2.83 \\
\hline 27.00 & 82.32 & 68.35 & 60.58 & 56.80 & 49.77 & 30.00 & 18.72 & 2.83 \\
\hline 28.00 & 82.64 & 68.43 & 60.70 & 56.82 & 49.89 & 31.14 & 19.01 & 2.83 \\
\hline 29.00 & 82.79 & 68.44 & 60.93 & 56.84 & 50.32 & 32.03 & 19.73 & 2.83 \\
\hline 30.00 & 82.88 & 68.71 & 61.09 & 56.84 & 50.82 & 32.08 & 19.98 & 3.54 \\
\hline 31.00 & 83.05 & 68.88 & 61.37 & 56.88 & 51.46 & 32.31 & 20.01 & 3.54 \\
\hline 32.00 & 83.66 & 69.37 & 61.38 & 57.39 & 51.56 & 32.82 & 20.03 & 3.54 \\
\hline 33.00 & 83.67 & 69.59 & 61.44 & 57.44 & 51.60 & 33.02 & 20.66 & 3.54 \\
\hline 34.00 & 83.80 & 69.77 & 61.52 & 57.55 & 51.61 & 33.74 & 20.74 & 3.54 \\
\hline 35.00 & 83.88 & 69.84 & 62.47 & 57.71 & 52.09 & 34.74 & 20.81 & 4.24 \\
\hline 36.00 & 83.93 & 70.11 & 62.63 & 58.57 & 52.34 & 34.81 & 21.08 & 4.24 \\
\hline 37.00 & 84.03 & 70.17 & 62.86 & 59.08 & 52.79 & 34.86 & 21.13 & 4.24 \\
\hline 38.00 & 84.17 & 70.79 & 63.52 & 59.80 & 52.92 & 35.89 & 21.22 & 4.24 \\
\hline
\end{tabular}




\begin{tabular}{|c|c|c|c|c|c|c|c|c|}
\hline 0 & 84.21 & 70.85 & 63.75 & 59.97 & 53.61 & 35.97 & 21. & 4.24 \\
\hline 40.00 & 4.37 & 70.86 & 64.00 & & 53.63 & & & \\
\hline .00 & 4.3 & & & & & & & \\
\hline .00 & & & & & & & & \\
\hline .00 & & & & & & & & \\
\hline & & & & & & & & \\
\hline & & & .09 & & & & & \\
\hline & & & .24 & & & & & \\
\hline 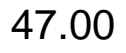 & & 72. & .20 & 2.91 & & & & \\
\hline 48.0 & .25 & 72.68 & .00 & 62.94 & & 9.27 & & \\
\hline 9.0 & .26 & 72.82 & 66.19 & 63.01 & & 9.30 & P4 & \\
\hline .0 & .48 & 72.92 & 66.21 & 63.1 & 56.08 & 39.37 & 5.42 & \\
\hline 1.00 & .53 & 73.43 & 66.30 & 63.37 & 56.98 & 40.07 & 25.81 & \\
\hline 2.00 & 61 & 73.82 & 66.6 & 63. & & 40.09 & 26.58 & \\
\hline 3.0 & 5.68 & 73.9 & 66.7 & 63. & & 40.61 & 63 & \\
\hline 10 & .79 & 74.0 & 67.07 & 63. & & 90 & 76 & \\
\hline J & 68 & 4.29 & 67. & & & & & \\
\hline & & 7 & & & & & & \\
\hline & & & & & & & & \\
\hline & & & & & & & & \\
\hline & & & & & & & & \\
\hline & & & & & & & & \\
\hline & & & & & & & & \\
\hline & & & & & & & & \\
\hline & & & & & & & & \\
\hline 10 & 87.29 & $76 .($ & & & & & & \\
\hline & .34 & 76.4 & & 66. & & 44 & & \\
\hline 0 & 7.57 & 76.4 & 70. & 66. & & & & \\
\hline 67.0 & 7.67 & 76.52 & 71. & 66.41 & & 39 & 30.66 & ( \\
\hline 68.0 & 7.68 & 66 & 71. & 66.52 & & 44. & 30. & . \\
\hline 69.0 & .74 & 0.70 & & 66. & & 44.87 & 8 & \\
\hline 70.0 & $\varepsilon$ & 7 & & 67. & & & & \\
\hline 71.0 & & 7 & & & & & 0 & \\
\hline 72.0 & 8 & 77 & & & & $4 !$ & 32. & \\
\hline 73.0 & 88. & 77 & 72. & 67. & & & 32. & \\
\hline 74.0 & 8 & 77 & 72. & & & & & \\
\hline 75.0 & 88. & & & & & & & \\
\hline 76.00 & 88. & & 72. & & & & & \\
\hline 77.00 & & & & & & 46.27 & & 7.78 \\
\hline & & & 72.75 & & & & 33.20 & 7.78 \\
\hline & 88.61 & 78.0 & 72.99 & & & & & \\
\hline & & & & & & & & \\
\hline & & & & & & & & \\
\hline & 89.2 & 78.94 & 73.29 & 69.62 & 61.85 & 47.72 & 35.22 & 0.4 \\
\hline
\end{tabular}




\begin{tabular}{|c|c|c|c|c|c|c|c|c|}
\hline 83.00 & 9.30 & 78.97 & 73.37 & 69.65 & 61.99 & 47.93 & & 8.49 \\
\hline 84.00 & .35 & 8.99 & 73.40 & 69.67 & & & & \\
\hline 35. & .36 & 9. & 0 & & & & & \\
\hline 36. & & & & & & & 5.06 & \\
\hline & & & & & & & & \\
\hline & & & & & & & & \\
\hline & & & & & & & & \\
\hline & & & & & & & & \\
\hline .00 & .62 & 4 & 9 & & & & & $\pi$ \\
\hline & 3 & 3 & . & & & & & 90 \\
\hline & & & & & & & & 90 \\
\hline & & & & & & & & 90 \\
\hline & & & & & & & & .90 \\
\hline & & & . & 0 & & & & \\
\hline & 90 & & D. & 8 & & & & 0.1 \\
\hline 00 & .04 & .27 & 75. & 2.26 & & & 1.86 & . \\
\hline & & & 5. & 2.41 & & & .90 & U. \\
\hline & & & ). & 4 & & & & U. \\
\hline & & & & 5 & & & & \\
\hline & & & & & & & & \\
\hline & & & & & & & & \\
\hline & & & & & & & & \\
\hline & & & & & & & & \\
\hline & & & & & & & & \\
\hline & & & & & & & & \\
\hline & & & & & & & & \\
\hline & & & & & & & & \\
\hline & & & & & & & & \\
\hline & & & & & & & & \\
\hline & & & & & & & & .0 \\
\hline & & & & 5 & & & & 2.7 \\
\hline & & & & 4 & & & & |2.7 \\
\hline & & 8 & 7 & 2 & & & & 12.7 \\
\hline & 0 & 82.72 & 6. & 74.93 & & & & 12.7 \\
\hline & 0 & 2.80 & 6. & 74.9 & & & & 12.7 \\
\hline & & 2.86 & & & & & & 12.7 \\
\hline & & 2.90 & & & & & & 12.7 \\
\hline & & & 7 & & & & & 34 \\
\hline & & & 76. & & & & & 3.4 \\
\hline & & & & & & & & 34 \\
\hline & & & & & & & & \\
\hline & & & & & & & & \\
\hline 25.00 & & & 77. & & & & 44.24 & 14.1 \\
\hline 26.00 & 91. & 83.29 & 77.59 & 75.84 & 68.90 & 56.12 & 44.66 & \\
\hline
\end{tabular}




\begin{tabular}{|c|c|c|c|c|c|c|c|c|}
\hline & 175 & 83.32 & 77.73 & 76.08 & $69 .($ & 56.45 & 44.75 & \\
\hline 28.00 & & 83.41 & 77.89 & & & & & \\
\hline 9 & 91.82 & & 77.90 & & & & & \\
\hline 0. & & & & & & & & \\
\hline 1.5 & & & 78.21 & & & & & \\
\hline & 99 & & 3.26 & & & & & \\
\hline & & & 78.57 & 76.25 & & & & \\
\hline & & & 7 & j.28 & & & & \\
\hline & & & 78.72 & & & & & \\
\hline & 13 & . 27 & 78.78 & 76.73 & & & & \\
\hline 7.00 & .15 & 31 & 78.87 & 76.93 & 70.75 & & 4 & \\
\hline .00 & 2.21 & 51 & 78.93 & 76.94 & 70.78 & 8.68 & & \\
\hline .00 & 92.27 & .57 & 78.97 & 77.02 & & 8.80 & 46.3 & \\
\hline & 92.40 & 71 & 78.97 & 77. & & & & \\
\hline & 2.44 & 4.80 & 78. & 77. & & & & \\
\hline & 2.44 & 5.12 & 79.08 & 77.09 & & & & \\
\hline & 2.44 & 8 & 79.27 & 77. & & & & \\
\hline & 2.46 & & 79.42 & & & & & \\
\hline & & & & & & & & \\
\hline & & & & & & & & \\
\hline & & & & & & & & \\
\hline & & & & & & & & \\
\hline & & & & & & & & \\
\hline & & & & & & & & \\
\hline & & & & & & & & \\
\hline .00 & & & & & & & & \\
\hline & 9 & & 7 & $78 . \varepsilon$ & 72. & & & \\
\hline & .95 & & $\varepsilon$ & 78.84 & & & & \\
\hline & .98 & & $\varepsilon$ & 78.88 & & & & \\
\hline & & & & 78. & & & & \\
\hline & .02 & & $\varepsilon$ & 79. & & & & \\
\hline & & & & 7 & & & & \\
\hline & & & & & & & & \\
\hline & & & & & & & & \\
\hline & & & & & & & & \\
\hline & & & & & & & & \\
\hline & & & & & & & & \\
\hline & & & & & & & & \\
\hline & & & & & & & 1.10 & \\
\hline & 93.45 & & & 80.22 & & 62.16 & 1.68 & \\
\hline & & & & & & & & \\
\hline & & & & & & & & \\
\hline & & & & & & & & \\
\hline & & & & 00.00 & 74.05 & .07 & 52.83 & \\
\hline
\end{tabular}




\begin{tabular}{|c|c|c|c|c|c|c|c|c|}
\hline & 376 & 87.29 & 81. & 81.1 & 74.23 & 62. & 52. & \\
\hline 72.00 & 3.80 & 87.34 & & & & & & \\
\hline 3.00 & 3.85 & 87.50 & & & & & & \\
\hline 4 & 3.85 & 7.55 & & & & & & \\
\hline & .07 & 87.84 & & & & & & \\
\hline & & 96 & & & & & & \\
\hline & & .11 & .46 & & & & & \\
\hline & & & & & & & & \\
\hline & & & .52 & .64 & & & & \\
\hline & & & 82.60 & .74 & 4.93 & & & \\
\hline & 32 & & 82.83 & .85 & 4.97 & & & \\
\hline & .33 & 88.60 & 82.83 & 89 & 5.01 &.$\angle 0$ & & \\
\hline & 4.39 & 88.62 & 82.85 & 82.00 & .03 & 5.38 & & \\
\hline & 4.49 & 88.64 & 82.86 & 66 & & & & \\
\hline & 4.52 & 88.85 & 0 & 25 & & & & \\
\hline & 4.56 & 4 & 3.22 & 27 & & & & \\
\hline & 4.67 & 88.5 & & & & & & \\
\hline & 4.69 & & & & & & & \\
\hline & 17 & & & & & & & \\
\hline & 4 & & & & & & & \\
\hline & 94. & & & & & & & \\
\hline & & & & & & & & \\
\hline & & & & & & & & \\
\hline & & & & & & & & \\
\hline & & & & & & & & \\
\hline & & & & & & & & \\
\hline & 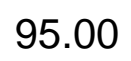 & & & $\varepsilon$ & 0.93 & & & \\
\hline & 01 & & $\varepsilon$ & 2 & 7.13 & & & \\
\hline & .06 & & 8 & & & & & \\
\hline 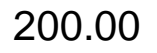 & & & & & .20 & & & \\
\hline & & 8 & & & & & & \\
\hline & & 9 & & & & & & \\
\hline & & & & & & & & \\
\hline & & & & & & & & \\
\hline & & & & & & & & \\
\hline & & & & & & & & \\
\hline & & & & & & & & \\
\hline & & & & & & & & \\
\hline & 95.47 & & & & & 69.60 & & \\
\hline & 95.51 & & & & & 69.65 & 3.14 & \\
\hline & 95.52 & & & & & & & \\
\hline & & & & & & & & \\
\hline & & & & & & & & \\
\hline & & & 1.10 & 0.4 & r. & 10.01 & 0.40 & \\
\hline
\end{tabular}




\begin{tabular}{|c|c|c|c|c|c|c|c|c|}
\hline & 567 & 90.8 & 84. & 84.58 & 78.48 & 70.24 & & \\
\hline & 5.69 & 90.89 & & & & & & \\
\hline & 572 & & & & & & & \\
\hline & 5.79 & & & & & & & \\
\hline & 5.81 & & & & & & & \\
\hline & 83 & & & & & & & \\
\hline & 85 & 8 & & & 9.29 & 11 & & \\
\hline & .85 & 9 & & & 9.29 & & & \\
\hline & 85 & & & & 9.33 & & & \\
\hline & .87 & & & & 9.49 & & & \\
\hline 5.00 & .88 & & 85. & & 9.57 & 11.30 & & \\
\hline 6.00 & 5.97 & 3 & 85. & & 9.68 & 71.60 & & \\
\hline 7.00 & .99 & 4 & 85. & & 9.95 & 71.64 & & \\
\hline 8.00 & 6.00 & 5 & & & 12 & 71. & & \\
\hline 9.00 & 6.00 & & & & & & & \\
\hline 0.00 & 6.05 & & 7 & & & 72.08 & & \\
\hline & 6.08 & & & & & 72. & & \\
\hline & 6 & & & & & & & \\
\hline & 6' & & & & & & & \\
\hline & J & & & & & & & \\
\hline & & & & & & & & \\
\hline & & & & & & & & \\
\hline & & & & & & & & \\
\hline & & & & & & & & \\
\hline & & & & & & & & \\
\hline & & & & & & & & \\
\hline & & 92. & & & & & & \\
\hline & 6 & 92. & & & & & & \\
\hline 3.0 & .64 & 9 & 6. & 86 & & 73.65 & & \\
\hline 40 & .67 & 9 & & 86 & & & & \\
\hline & 6 & & 8 & 86 & & & & \\
\hline & 5.7 & & & & & & & \\
\hline & 6.75 & & & & & & & \\
\hline & $\varsigma$ & & & & & & & \\
\hline & 96.8 & & & & & & & \\
\hline & & & & & & & & \\
\hline & & & & & & & & \\
\hline & & & & & & & & \\
\hline & & & & & & 75.21 & & \\
\hline & 97.0 & 92.86 & & & 82.09 & 75.40 & & \\
\hline & & 92.86 & & & & & & \\
\hline & & & & & & & & \\
\hline & & & & & & & & \\
\hline & & 92.97 & . & 01.55 & & & & \\
\hline
\end{tabular}




\begin{tabular}{|c|c|c|c|c|c|c|c|c|}
\hline & 7.22 & 92.9 & 88.25 & 87.67 & 82.59 & 75.71 & & \\
\hline 60.00 & 97.24 & 93.03 & 88.25 & 87.83 & & 75.74 & & \\
\hline & 7.27 & & & & & & & \\
\hline & & & & & & & & \\
\hline & & 3 & & & & & & \\
\hline & & & & & & & & \\
\hline & 40 & 99 & .77 & & & & & \\
\hline & & & 81 & & & & & \\
\hline & & & 88.83 & & & & & \\
\hline & .59 & 7 & 88.83 & 88.67 & 3.39 & & & \\
\hline & .59 & 3.6 & 88.90 & 88.75 & 3.50 & & & \\
\hline .00 & .66 & 3.6 & 88.90 & 88.78 & 3.55 & & .73 & \\
\hline .00 & 7.72 & 3.6 & 88.92 & 88.80 & 3.63 & & .98 & \\
\hline 2.00 & 7.73 & 3. & 88.95 & 88.87 & 3.78 & & & \\
\hline & 5 & 8 & 88.96 & 88.87 & 3.87 & & & \\
\hline & 7.76 & 7 & 89.03 & 8.95 & 3.91 & & & \\
\hline & .88 & 7 & 89.09 & 8.96 & 3.91 & & & \\
\hline & & & & & & & & \\
\hline & & & & & & & & \\
\hline & & & & & & & & \\
\hline & & & & & & & & \\
\hline & & & & & & & & \\
\hline & & & & & & & & \\
\hline & & & & & & & & \\
\hline & & & & & & & & \\
\hline & 98 & & 89.8 & & & & & \\
\hline & 9 & 94. & 89.99 & & .42 & & 8.02 & \\
\hline & & 9 & 90.1 & & & & 3.13 & \\
\hline & .21 & & 15 & 9.86 & & & .24 & \\
\hline & 3.22 & 9 & 90.31 & & & 1 & 44 & \\
\hline & 9 & 9 & 90.32 & & & & & \\
\hline & & 9 & & & & & & \\
\hline & & & 90. & & & & & \\
\hline & & & & & & & & \\
\hline & & & & & & & & \\
\hline & & & & & & & & \\
\hline & & & & & & & & \\
\hline & & & & & & & .16 & \\
\hline & & & 90.80 & & & 79.49 & 0.32 & \\
\hline & & 94. & 90.80 & & & 79.59 & 70.45 & 1 \\
\hline & & & & & & & 70.55 & \\
\hline & & & & & & & 70.85 & \\
\hline & & & & & & & 71.11 & \\
\hline & & & 91.22 & 30.04 & & & 71.14 & \\
\hline
\end{tabular}




\begin{tabular}{|c|c|c|c|c|c|c|c|c|}
\hline & 8.72 & 95.30 & 91.24 & 90.7 & 85. & & & \\
\hline م04 & 98.74 & 95.32 & 1.27 & & & & & \\
\hline & 98.78 & & & & & & & \\
\hline & 98.78 & & & & & & & \\
\hline & 8.88 & 5 & & & & & & \\
\hline & & & & & & & & \\
\hline & 98.90 & 1 & 49 & & & & & \\
\hline & 98.91 & & & & & & & \\
\hline & 98.93 & & 66 & & & & & \\
\hline & 98.93 & 5.61 & 0 & & & & & \\
\hline & 98.94 & 5.63 & 91.73 & & & & & \\
\hline & 99.03 & 5.65 & 91.86 & & & & 2.20 & \\
\hline & 99.05 & 5.66 & 91.90 & & & & 2.23 & \\
\hline & 99.06 & 5.75 & 91. & & & & & \\
\hline & 99.06 & 6 & 9 & & & & & \\
\hline & 99.07 & 5.77 & 92. & & & & & \\
\hline & 99.1 & 5.90 & & & & & & \\
\hline & 99.2 & & & & & & & \\
\hline & & & & & & & & \\
\hline & & & & & & & & \\
\hline & & & & & & & & \\
\hline & & & & & & & & \\
\hline & & & & & & & & \\
\hline & & & & & & & & \\
\hline & & & & & & & & \\
\hline & & & & & & & & \\
\hline & & & 92.80 & 2.75 & & & & \\
\hline & & & 92.82 & & & & & \\
\hline & 99 & & 2.84 & & & 7 & & \\
\hline & 99.72 & 9 & 2.93 & & & & & \\
\hline & 99.79 & 0.73 & 9 & & & & & \\
\hline & 99. & 9 & & & & & & \\
\hline & & & & & & & & \\
\hline & & & & & & & & \\
\hline & & & & & & & & \\
\hline & & & & & & & & \\
\hline & & & & & & & & \\
\hline & & & & & & & & \\
\hline & & & & & & & & . \\
\hline o. & & 97.10 & 78 & & & & 5.74 & . \\
\hline & & & & & & & & \\
\hline & & & & & & & & \\
\hline & & & & & & & & \\
\hline & & & ד. & 0.14 & & 84.37 & 76.27 & \\
\hline
\end{tabular}




\begin{tabular}{|c|c|c|c|c|c|c|c|c|}
\hline 70 & 100. & 97.38 & 94.05 & 94.04 & 89. & 84.40 & & \\
\hline 48.00 & 0.28 & 97.39 & & & & & & \\
\hline & & 97.4 & & & & & & \\
\hline 0.00 & & & & & & & & \\
\hline & 0.29 & & & & & & & \\
\hline & & .70 & & & & & & \\
\hline & & 7.75 & 20 & & & & 31 & \\
\hline & & .76 & & & & & & \\
\hline & & .85 & 4.32 & & & & & \\
\hline & & 7.85 & 4.34 & & & & & \\
\hline & & 7.86 & 4.43 & & & & & \\
\hline .00 & 52 & 7.89 & 4.46 & & 2 & & 7. & \\
\hline .00 & 0.56 & 7.90 & 94.48 & 66 & & & 0.2 & \\
\hline & & 7.5 & 94. & 76 & & & & \\
\hline & & 7.5 & & & & & & \\
\hline & & 7.9 & & & & & & \\
\hline & & 7 & & & & & & \\
\hline & & & & & & & & \\
\hline & & & & & & & & \\
\hline & & & & & & & & \\
\hline & & & & & & & & \\
\hline & & & & & & & & \\
\hline & & & & & & & & \\
\hline & & & & & & & & \\
\hline & & & & & & & & \\
\hline & & 9 & & & & & & \\
\hline & & & & & & & & \\
\hline & & 9 & & & & & & \\
\hline & & 9 & & & & & & \\
\hline & & 9 & & & & & & \\
\hline & & 9 & & & & & & \\
\hline & & 9 & & & & & & \\
\hline & & & & & & & & \\
\hline & & & & & & & & \\
\hline & & 9 & & & & & & \\
\hline & & 9 & & & & & & \\
\hline & & & & & & & & \\
\hline & & & & & & & & \\
\hline 35.00 & 101.21 & 98.94 & & & & & 81.65 & \\
\hline & 101.22 & 98.96 & & & & & 81.85 & \\
\hline & & & & & & & & \\
\hline & & & & & & & & \\
\hline & & & & & & & 82.24 & \\
\hline & & & 96. & 91.25 & וע. & 38.37 & 82.31 & \\
\hline
\end{tabular}




\begin{tabular}{|c|c|c|c|c|c|c|c|c|}
\hline & 013 & 99.24 & 96.6 & 97.2 & 93. & 88. & 82. & \\
\hline 2.00 & & 99.27 & & & & & & \\
\hline & & & & & & & & \\
\hline & & & & & & & & \\
\hline & & 9.47 & & & & & & \\
\hline & & 49 & & & & & & \\
\hline & & 9.62 & & & & & & \\
\hline & & & & & & & & \\
\hline & & 9.67 & & & & & & \\
\hline & & 9.81 & & & & & .81 & \\
\hline & & 9.82 & & & & & 3.87 & \\
\hline & & 9.89 & & & & 42 & 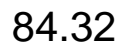 & \\
\hline & 01.62 & 0.01 & & & & 9.44 & 3 & \\
\hline & & & 97. & & & & & \\
\hline & & & & & & & & \\
\hline & & & & & & & & \\
\hline & & & & & & & & \\
\hline & & & & & & & & \\
\hline & & & & & & & & \\
\hline & & & & & & & & \\
\hline & & & & & & & & \\
\hline & & & & & & & & \\
\hline & & & & & & & & \\
\hline & & & & & & & & \\
\hline & & & & & & & & \\
\hline & & & & & & & & \\
\hline & & & & & & & 5.85 & \\
\hline & & & & & & & & \\
\hline & 1 & & 97. & & & & & \\
\hline & 7 & & & & & & & \\
\hline & & & & & & & & \\
\hline & & & & & & & & \\
\hline & & & & & & & & \\
\hline & & & & & & & & \\
\hline & & & & & & & & \\
\hline & & & & & & & & \\
\hline & & & & & & & & \\
\hline & & & & & & & & \\
\hline & & & & & & & 87.50 & \\
\hline 100.00 & 102.44 & & & & & & 87.54 & \\
\hline . & & & & & & & 87.62 & \\
\hline & & & & & & & & \\
\hline & & & & & & & & \\
\hline & & & & & & 2.00 & 01.00 & \\
\hline
\end{tabular}




\begin{tabular}{|c|c|c|c|c|c|c|c|c|}
\hline & & & & & & & & \\
\hline & 02.56 & 101.32 & 98.60 & 99.48 & & & & \\
\hline & & & & & & & & \\
\hline & & & & & & & & \\
\hline 9.1 & 2.62 & & & & & & & \\
\hline & 4 & & & & & & & \\
\hline & & & & & & & & \\
\hline & & & & & & & & \\
\hline & 69 & & & & & & & \\
\hline & 2.71 & & 98. & & & & & \\
\hline & 2.81 & & & & & & & \\
\hline & 2.86 & & 99. & & 7.27 & & & \\
\hline & 02.87 & & 99. & & 7.32 & .58 & & \\
\hline & 02.87 & & 99. & & & & & \\
\hline & 02.91 & & & & & & & \\
\hline & 02.94 & & & & & & & \\
\hline & & & & & & & & \\
\hline & & & & & & & & \\
\hline & & & & & & & & \\
\hline & & & & & & & & \\
\hline & & & & & & & & \\
\hline & & & & & & & & \\
\hline & & & & & & & & \\
\hline & & & & & & & & \\
\hline & & & & & & & & \\
\hline & .23 & & & & & & & \\
\hline & .26 & & & & & & & \\
\hline & .27 & & & & & & & \\
\hline & 3.28 & & & & & & & \\
\hline & & & & & & & & \\
\hline & & & & & & & & \\
\hline & & & & & & & & \\
\hline & & & & & & & & \\
\hline & & & & & & & & \\
\hline & & & & & & & & \\
\hline & & & & & & & & \\
\hline & & & & & & & & \\
\hline & & & & & & & & \\
\hline & & & & & & & 93.18 & \\
\hline & & & & & & & & \\
\hline & & & & & & & & \\
\hline & & & & & & & & \\
\hline & & & & & & & & \\
\hline & & & & & & & & \\
\hline
\end{tabular}




\begin{tabular}{|c|c|c|c|c|c|c|c|c|}
\hline & & & & & & & & \\
\hline & 3.88 & 103.14 & & & & & & \\
\hline & & & & & & & & \\
\hline & & & & & & & & \\
\hline & & & & 2.20 & & & & \\
\hline & & & & & & & & \\
\hline & & & & .25 & & & & \\
\hline & & & & & & & & \\
\hline & & & & & & & & \\
\hline & & & & & & & & \\
\hline & & & & .49 & & & & \\
\hline & & & & 2.63 & & 97. & & \\
\hline & & & & 02.65 & & 97. & & \\
\hline & & & & & & & & \\
\hline & & & & & & & & \\
\hline & & & & 02.93 & & & & \\
\hline & & & & & & & & \\
\hline & & & & & & & & \\
\hline & & & & & & & & \\
\hline & & & & & & & & \\
\hline & & & & & & & & \\
\hline & & & & & & & & \\
\hline & & & & & & & & \\
\hline & & & & & & & & \\
\hline & & & & & & & & \\
\hline & & & & .22 & & & & \\
\hline & & & & .26 & & & & \\
\hline & & & & 36 & & & & \\
\hline & & & & 38 & & & & \\
\hline & & & & & & & & \\
\hline & & & & & & & & \\
\hline & & & & & & & & \\
\hline & & & & & & & & \\
\hline & & & & & & & & \\
\hline & & & & & & & & \\
\hline & & & & & & & & \\
\hline & & & & & & & & \\
\hline & & & & & & & & \\
\hline & & & & & & & & \\
\hline & & & & 104.08 & & & & \\
\hline & & & & & & & & \\
\hline & & & & & & & & \\
\hline & & & & & & & & \\
\hline & & & & & & & T1.4 & \\
\hline
\end{tabular}




\begin{tabular}{|c|c|c|c|c|c|c|c|c|}
\hline & & & & & & & & \\
\hline & 04.86 & 105.10 & & & 102.90 & & & \\
\hline & & & & & & & & \\
\hline & & & & & & & & \\
\hline & & & & & & & & \\
\hline & & & & & & & & \\
\hline & & & & & & & & \\
\hline & & & & & & & & \\
\hline & & & & & & & & \\
\hline & & & & & & & & \\
\hline & & & & & & & & \\
\hline & & & & & & & & \\
\hline & & & & & & & & \\
\hline & & & & & & & & \\
\hline & & & & & & & & \\
\hline & & & & & & & & \\
\hline & & & & & & & & \\
\hline & & & & & & & & \\
\hline & & & & & & & & \\
\hline & & & & & & & & \\
\hline & & & & & & & & \\
\hline & & & & & & & & \\
\hline & & & & & & & & \\
\hline & & & & & & & & \\
\hline & & & & & & & & \\
\hline & & & & & & & & \\
\hline & & & & & & & & \\
\hline & & & & & & & & \\
\hline & & & & & & & & \\
\hline & & & & & & & & \\
\hline & & & & & & & & \\
\hline & & & & & & & & \\
\hline & & & & & & & & \\
\hline & & & & & & & & \\
\hline & & & & & & & & \\
\hline & & & & & & & & \\
\hline & & & & & & & & \\
\hline & & & & & & & & \\
\hline & & & & & & & & \\
\hline & & & & & & & & \\
\hline & & & & & & & & \\
\hline & & & & & & & & \\
\hline & & & & & & & & \\
\hline & & 100. & & 100.40 & & & . & \\
\hline
\end{tabular}




\begin{tabular}{|c|c|c|c|c|c|c|c|c|}
\hline & & & & & & & & \\
\hline & & & 5.24 & & & & & \\
\hline & & & & & & & & \\
\hline & & & & & & & & \\
\hline & & & & & & & & \\
\hline & & & & & & & & \\
\hline & & & & & & & & \\
\hline & & & & & & & & \\
\hline & & & & & & & & \\
\hline & & & & & & & & \\
\hline & & & & & & & & \\
\hline & & & & & & & & \\
\hline & & & & & & & & \\
\hline & & & & & & & & \\
\hline & & & & & & & & \\
\hline & & & & & & & & \\
\hline & & & & & & & & \\
\hline & & & & & & & & \\
\hline & & & & & & & & \\
\hline & & & & & & & & \\
\hline & & & & & & & & \\
\hline & & & & & & & & \\
\hline & & & & & & & & \\
\hline & & & & & & & & \\
\hline & & & & & & & & \\
\hline & & & & & & & & \\
\hline & & & & & & & & \\
\hline & & & & & & & & \\
\hline & & & & & & & & \\
\hline & & & & & & & & \\
\hline & & & & & & & & \\
\hline & & & & & & & & \\
\hline & & & & & & & & \\
\hline & & & & & & & & \\
\hline & & & & & & & & \\
\hline & & & & & & & & \\
\hline & & & & & & & & \\
\hline & & & & & & & & \\
\hline & & & & & & & & \\
\hline & 107.25 & & & & & & & \\
\hline & & & & & & & & \\
\hline & & & & & & & & \\
\hline & & & & & & & & \\
\hline & & 100. & & & & & & \\
\hline
\end{tabular}




\begin{tabular}{|c|c|c|c|c|c|c|c|c|}
\hline & & & & & & & & \\
\hline & & 8.37 & & & & & & \\
\hline & & & & & & & & \\
\hline & & & & & & & & \\
\hline & & & & & & & & \\
\hline & & & & & & & & \\
\hline & & & & & & & & \\
\hline & & & & & & & & \\
\hline & & & & & & & & \\
\hline & & & & & & & & \\
\hline & & & & & & & & \\
\hline & & & & & & & & \\
\hline & & & & & & & & \\
\hline & & & & & & & & \\
\hline & & & & & & & & \\
\hline & & & & & & & & \\
\hline & & & & & & & & \\
\hline & & & & & & & & \\
\hline & & & & & & & & \\
\hline & & & & & & & & \\
\hline & & & & & & & & \\
\hline & & & & & & & & \\
\hline & & & & & & & & \\
\hline & & & & & & & & \\
\hline & & & & & & & & \\
\hline & & & & & & & & \\
\hline & & & & & & & & .1 \\
\hline & & & & & & & & 1 \\
\hline & & & & & & & & .1 \\
\hline & & & & & & & & .1 \\
\hline & & & & & & & & \\
\hline & & & & & & & & \\
\hline & & & & & & & & \\
\hline & & & & & & & & \\
\hline & & & & & & & & \\
\hline & & & & & & & & \\
\hline & & & & & & & & \\
\hline & & & & & & & & 1 \\
\hline & & & & & & & & 3.2 \\
\hline & & 110.26 & & & & & & 3.2 \\
\hline & & & & & & & & \\
\hline & & & & & & & & \\
\hline & & & & & & & & \\
\hline & & & & & & & & \\
\hline
\end{tabular}




\begin{tabular}{|c|c|c|c|c|c|c|c|c|}
\hline & & & & & & & & \\
\hline 60 & & & & & & & & \\
\hline & & & & & & & & \\
\hline & & & & & & & & \\
\hline & & & & & & & & \\
\hline & & & & & & & & \\
\hline & & & & & & & & \\
\hline & & & & & & & & \\
\hline & & & & & & & & \\
\hline & & & & & & & & \\
\hline & & & & & & & & \\
\hline & & & & & & & & \\
\hline & & & & & & & & \\
\hline & & & & & & & & \\
\hline & & & & & & & & \\
\hline & & & & & & & & \\
\hline & & & & & & & & \\
\hline & & & & & & & & \\
\hline & & & & & & & & \\
\hline & & & & & & & & \\
\hline & & & & & & & & \\
\hline & & & & & & & & \\
\hline & & & & & & & & \\
\hline & & & & & & & & \\
\hline & & & & & & & & \\
\hline & & & & & & & & \\
\hline & & & & & & & & \\
\hline & & & & & & & & \\
\hline & & & & & & & & \\
\hline & & & & & & & & \\
\hline & & & & & & & & \\
\hline & & & & & & & & \\
\hline & & & & & & & & \\
\hline & & & & & & & & \\
\hline & & & & & & & & \\
\hline & & & & & & & & \\
\hline & & & & & & & & \\
\hline & & & & & & & & \\
\hline & & & & & & & & \\
\hline & & & & & & 17.60 & & \\
\hline & & & & & & & & \\
\hline & & & & & & & & \\
\hline & & & & & & & & \\
\hline & & & & & 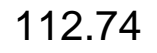 & & & \\
\hline
\end{tabular}




\begin{tabular}{|c|c|c|c|c|c|c|c|c|}
\hline & & & & & & & & \\
\hline & & & 12.29 & & & & & \\
\hline & & & & & & & & \\
\hline & & & & & & & & \\
\hline & & & & & & & & \\
\hline & & & & & & & & \\
\hline & & & & & & & & \\
\hline & & & & & & & & \\
\hline & & & & & & & & \\
\hline & & & & & & & & \\
\hline & & & & & & & & \\
\hline & & & & & & & & \\
\hline & & & & & & & & \\
\hline & & & & & & & & \\
\hline & & & & & & & & \\
\hline & & & & & & & & \\
\hline & & & & & & & & \\
\hline & & & & & & & & \\
\hline & & & & & & & & \\
\hline & & & & & & & & \\
\hline & & & & & & & & \\
\hline & & & & & & & & \\
\hline & & & & & & & & \\
\hline & & & & & & & & \\
\hline & & & & & & & & \\
\hline & & & & & & & & \\
\hline & & & & & & & & \\
\hline & & & & & & & & \\
\hline & & & & & & & & \\
\hline & & & & & & & & \\
\hline & & & & & & & & \\
\hline & & & & & & & & \\
\hline & & & & & & & & \\
\hline & & & & & & & & \\
\hline & & & & & & & & \\
\hline & & & & & & & & \\
\hline & & & & & & & & \\
\hline & & & & & & & & \\
\hline & & & & & & & 127.85 & \\
\hline & & & & & & .70 & 127.99 & \\
\hline & & & & & & & & \\
\hline & & & & & & & & \\
\hline & & & & & & & & \\
\hline & & & & & & & & \\
\hline
\end{tabular}




\begin{tabular}{|c|c|c|c|c|c|c|c|c|}
\hline & & & & & & & & \\
\hline 400 & & & & & & & & \\
\hline & & & & & & & & \\
\hline & & & & & & & & \\
\hline & & & & & & & & \\
\hline & & & & & & & & \\
\hline & & & & & & & & \\
\hline & & & & & & & & \\
\hline & & & & & & & & \\
\hline & & & & & & & & \\
\hline & & & & & & & & \\
\hline & & & & & & & & \\
\hline & & & & & & & & \\
\hline & & & & & & & & \\
\hline & & & & & & & & \\
\hline & & & & & & & & \\
\hline & & & & & & & & \\
\hline & & & & & & & & \\
\hline & & & & & & & & \\
\hline & & & & & & & & \\
\hline & & & & & & & & \\
\hline & & & & & & & & \\
\hline & & & & & & & & \\
\hline & & & & & & & & \\
\hline & & & & & & & & \\
\hline & & & & & & & & \\
\hline & & & & & & & 2.20 & \\
\hline & & & & & & & .58 & \\
\hline & & & & & & & & \\
\hline & & & & & & & & \\
\hline & & & & & & & & \\
\hline & & & & & & & & \\
\hline & & & & & & & & \\
\hline & & & & & & & & \\
\hline & & & & & & & & \\
\hline & & & & & & & & \\
\hline & & & & & & & & \\
\hline & & & & & & & & \\
\hline & & & & & & & 34.52 & \\
\hline 102.0 & & & & & & & 34.80 & \\
\hline . & & & & & & & & \\
\hline & & & & & & & & \\
\hline & & & & & & & & \\
\hline & & & & & & & & \\
\hline
\end{tabular}




\begin{tabular}{|c|c|c|c|c|c|c|c|c|}
\hline & & & & & & & & \\
\hline & & & & & & & & \\
\hline & & & & & & & & \\
\hline & & & & & & & & \\
\hline & 2.61 & & & & & & & \\
\hline & & & & & & & & \\
\hline & & & & & & & & \\
\hline & & & & & & & & \\
\hline & & & & & & & & \\
\hline & & & & & & & & \\
\hline & & & & & & & & \\
\hline & & & & & & & & \\
\hline & & & & & & & & \\
\hline & & & & & & & & \\
\hline & & & & & & & & \\
\hline & & & & & & & & \\
\hline & & & & & & & & \\
\hline & & & & & & & & \\
\hline & & & & & & & & \\
\hline & & & & & & & & \\
\hline & & & & & & & & \\
\hline & & & & & & & & \\
\hline & & & & & & & & \\
\hline & & & & & & & & \\
\hline & & & & & & & & \\
\hline & & & & & & & & \\
\hline & & & & & & & & \\
\hline & & & & & & & & 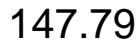 \\
\hline & & & & & 22.43 & & & \\
\hline & & & & &. .44 & & & \\
\hline & & & & & & & & \\
\hline & & & & & & & & \\
\hline & & & & & & & & \\
\hline & & & & & & & & \\
\hline & & & & & 76 & & & \\
\hline & & & & & & & & \\
\hline & & & & & & & & \\
\hline & & & & & 122.91 & & & \\
\hline & & & & & 122.94 & 33.71 & & 0.6 \\
\hline & 114.14 & & & & 122.99 & 133.81 & & 0.6 \\
\hline & 114.15 & & & & 122.99 & & & 0.6 \\
\hline & & & & & & & & \\
\hline & & & & & & & & \\
\hline & & & & & & & & \\
\hline
\end{tabular}




\begin{tabular}{|c|c|c|c|c|c|c|c|c|}
\hline & & & & & & & & \\
\hline & & & & 122.68 & & & & \\
\hline & & & & & & & & \\
\hline & & & & & & & & \\
\hline & & & & 2.76 & & & & \\
\hline & & & &. .77 & & & & \\
\hline & & & & 84 & & & & \\
\hline & & & & & & & & \\
\hline & & & & & & & & \\
\hline & & & & & & & & \\
\hline & & & & & & & & \\
\hline & & & & 23.11 & & & & \\
\hline & & & & 23.14 & & & & \\
\hline & & & & & & & & \\
\hline & & & & & & & & \\
\hline & & & & & & & & \\
\hline & & & & & & & & \\
\hline & & & & & & & & \\
\hline & & & & & & & & \\
\hline & & & & & & & & \\
\hline & & & & & & & & \\
\hline & & & & & & & & \\
\hline & & & & & & & & \\
\hline & & & & & & & & \\
\hline & & & & & & & & \\
\hline & & & & & & & & \\
\hline & & & & & & & & \\
\hline & & & & & & & & \\
\hline & & & & 18 & 6.27 & & & \\
\hline & & & & .26 & 6.29 & & & \\
\hline & & & & & & & & \\
\hline & & & & & & & & \\
\hline & & & & & & & & \\
\hline & & & & & & & & \\
\hline & & & & & & & & \\
\hline & & & & & & & & \\
\hline & & & & & & & & \\
\hline & & & & & & & & \\
\hline & & & & & 126.71 & & & 100. \\
\hline & & & & & 126.73 & & & 169.7 \\
\hline & & & & & & & & 0.4 \\
\hline & & & & & & & & \\
\hline & & & & & & & & \\
\hline & & 120 & & & & & & \\
\hline
\end{tabular}




\begin{tabular}{|c|c|c|c|c|c|c|c|c|}
\hline & & & & & & & & \\
\hline & & & & & & & & \\
\hline & & & & & & & & \\
\hline & & & & & & & & \\
\hline & & & & & & & & \\
\hline & & & & & & & & \\
\hline & & & & & & & & \\
\hline & & & & & & & & \\
\hline & & & & & & & & \\
\hline & & & & & & & & \\
\hline & & & & & & & & \\
\hline & & & & & & & & \\
\hline & & & & & & & & \\
\hline & & & & & & & & \\
\hline & & & & & & & & \\
\hline & & & & & & & & \\
\hline & & & & & & & & \\
\hline & & & & & & & & \\
\hline & & & & & & & & \\
\hline & & & & & & & & \\
\hline & & & & & & & & \\
\hline & & & & & & & & \\
\hline & & & & & & & & \\
\hline & & & & & & & & \\
\hline & & & & & & & & \\
\hline & & & & & & & & \\
\hline & & & & .78 & & & & \\
\hline & & & & 83 & & & & \\
\hline & & 123 & & 8.96 & & & & \\
\hline & & 123. & & .22 & & & & \\
\hline & & & & & & & & \\
\hline & & & & & & & & \\
\hline & & & & & & & & \\
\hline & & & & & & & & \\
\hline & & & & & & & & \\
\hline & & & & & & & & \\
\hline & & & & & & & & \\
\hline & & & & & & & & 185. \\
\hline & & 123 & & & & & & 185.9 \\
\hline & & 123 & & & & & & 100. \\
\hline & & 124. & & & & & & \\
\hline & & & & & & & & \\
\hline & & & & & & & & \\
\hline & & & & & & & & \\
\hline
\end{tabular}




\begin{tabular}{|c|c|c|c|c|c|c|c|c|}
\hline & & & & & & & & \\
\hline & & 124.48 & & & & & & \\
\hline & & & & & & & & \\
\hline & & & & & & & & \\
\hline & & & & & & & & \\
\hline & & & & & & & & \\
\hline & & & & & & & & \\
\hline & & & & & & & & \\
\hline & & & & & & & & \\
\hline & & & & & & & & \\
\hline & & & & & & & & \\
\hline & & & & & & & & \\
\hline & & & & & & & & \\
\hline & & & & & & & & \\
\hline & & & & & & & & \\
\hline & & & & & & & & \\
\hline & & & & & & & & \\
\hline & & & & & & & & \\
\hline & & & & & & & & \\
\hline & & & & & & & & \\
\hline & & & & & & & & \\
\hline & & & & & & & & \\
\hline & & & & & & & & \\
\hline & & & & & & & & \\
\hline & & & & & & & & \\
\hline & & & & & & & & \\
\hline & & & & & & & & \\
\hline & & & & & & & & \\
\hline & & & & & & & & \\
\hline & & & & & & & & \\
\hline & & & & & & & & \\
\hline & & & & & & & & \\
\hline & & & & & & & & \\
\hline & & & & & & & & \\
\hline & & & & & & & & \\
\hline & & & & & & & & \\
\hline & & & & & & & & \\
\hline & & & & & & & & $7 . \varepsilon$ \\
\hline & & 128.64 & & & & & & 208.6 \\
\hline & 121. & 128.73 & & & & 151.52 & & 209.3 \\
\hline & & & & & & & & \\
\hline & & & & & & & & \\
\hline & & & & & & & & \\
\hline & 15 & & & & & & & \\
\hline
\end{tabular}




\begin{tabular}{|c|c|c|c|c|c|c|c|c|}
\hline & 12186 & & & & & & & \\
\hline 964.00 & 21.99 & 129.63 & 135.42 & 137.17 & 139.24 & 153.72 & .70 & \\
\hline 500 & & & & & & & & \\
\hline & .24 & & & & & & & \\
\hline & 2.24 & 129.94 & 5.68 & 138.35 & 24 & 155.02 & & \\
\hline & & & & & & & & \\
\hline & 2.27 & & & & & & & \\
\hline & 2.40 & & & 38.97 & & & & \\
\hline & 2.52 & & & & & & & \\
\hline & 2.56 & & & & & & & \\
\hline & 2.66 & & & & & .69 & & \\
\hline & 2.88 & & & .33 & & 9.42 & & \\
\hline & 22.90 & 1.44 & 7.68 & 140.54 & 142.86 & 9.92 & & \\
\hline & 23.12 & 131.84 & 3.83 & 0.97 & & & & \\
\hline & 3.18 & & & & & & & \\
\hline & 23.23 & & & & & & & \\
\hline & & & & & & & & \\
\hline & & & & & & & & \\
\hline & & & & & & & & \\
\hline & & 133 & & & & & & \\
\hline & & & & & & & & \\
\hline & & 133 & & & & & & \\
\hline & & 133 & & .85 & & & & \\
\hline & & & & & & & & \\
\hline & & & & & & & & \\
\hline & & & & & & & & \\
\hline & 5.27 & & & & & & & \\
\hline & 125.38 & & & & & 7.83 & & \\
\hline & 125.58 & 135. & & 146.27 & & 169.43 & & \\
\hline & 125.88 & 136.01 & & 146.55 & 150.63 & 170.21 & 176 & \\
\hline 3.00 & 126.38 & 136.65 & 145.50 & 146.84 & 151.22 & 171.94 & $17 \varepsilon$ & \\
\hline & 126.55 & 136.72 & 145.82 & 147.40 & 151.79 & 175.98 & 180.27 & 2 \\
\hline & 126.57 & 137.11 & 146.19 & 147.41 & 152.06 & 177.82 & 180.44 & 0. \\
\hline & 127.59 & 137.72 & 146.77 & 148.09 & 154.63 & 179.04 & 181.36 & \\
\hline & 127.80 & 137.74 & 148.68 & 148.65 & 155.08 & 179.16 & 181.73 & \\
\hline & 127.99 & 141.51 & & 148.91 & 157.07 & 179.49 & 182.08 & \\
\hline & & & & 154.39 & & & & \\
\hline & & & & & 161.46 & & & \\
\hline
\end{tabular}


North-South cross-section of the Price Formation along the West Virginia Dome

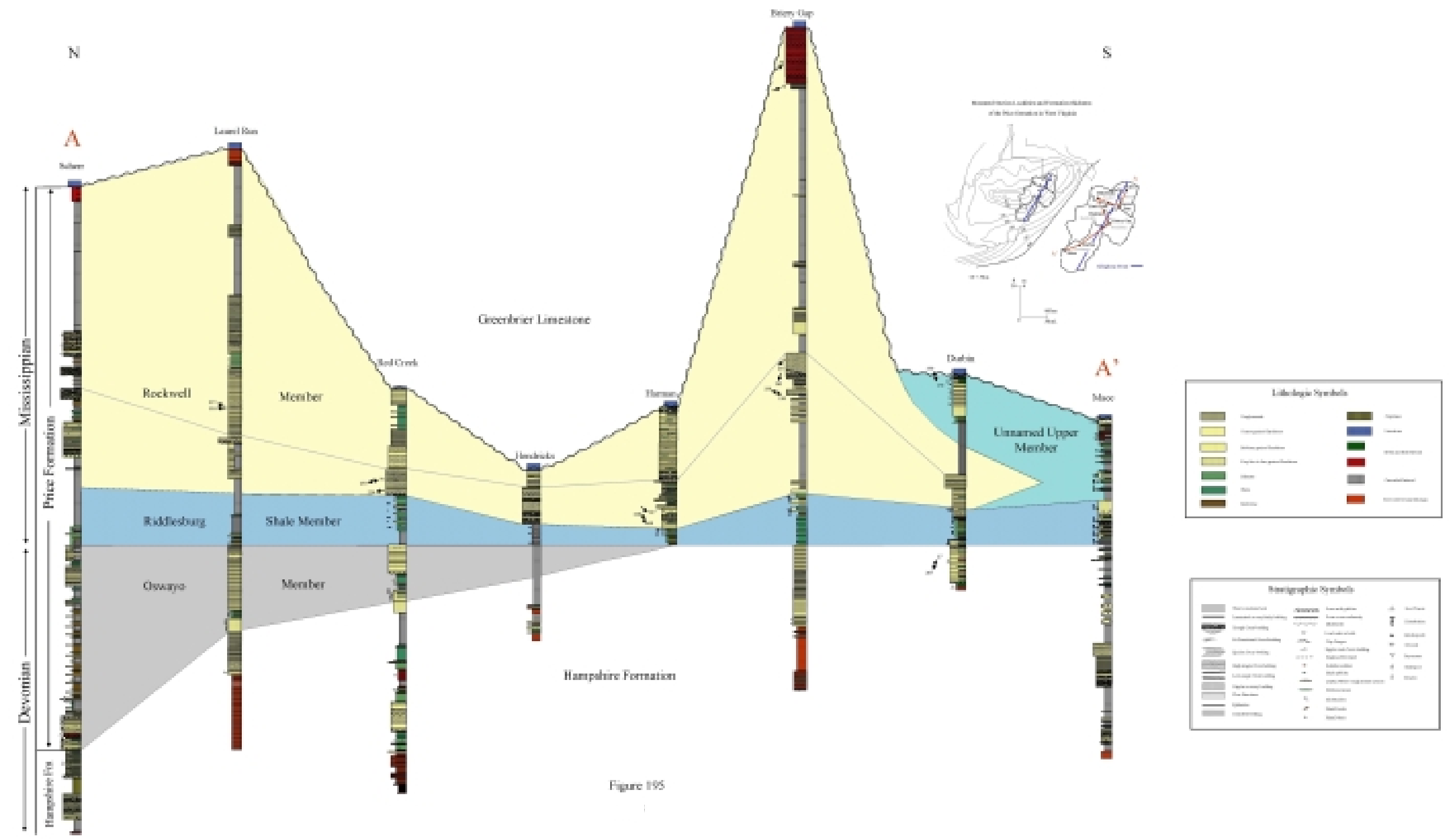

